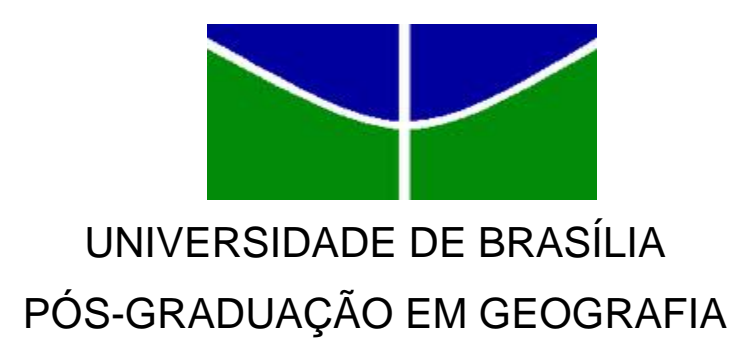

Saimon Freitas Cajado Lima

A Judicialização do Território: O Caso de Planaltina -DF

Brasília - DF

Outubro / 2014 
SAIMON FREITAS CAJADO LIMA

A Judicialização do Território: O Caso de Planaltina -DF

Dissertação de Mestrado submetida ao

Departamento de Geografia da Universidade de Brasília, como parte dos requisitos necessários para a obtenção do Grau de Mestre em Geografia.

Área de concentração - Gestão Ambiental e Territorial,

Orientador: Prof. Dr. Fernando Luiz Araújo Sobrinho

Brasília - DF Outubro / 2014 
Nome - LIMA, Saimon Freitas Cajado

Título - A Judicialização do Território: O Caso de Planaltina -DF

Dissertação de Mestrado submetida ao

Departamento de Geografia da Universidade de Brasília, como parte dos requisitos necessários para a obtenção do Grau de Mestre em Geografia, área de concentração Gestão Ambiental e Territorial.

Aprovado em:

Banca Examinadora

Fernando Luiz Araújo Sobrinho, Doutor (UnB)

(Orientador)

João Mendes da Rocha Neto, Pós-Doutor (UnB)

(Examinador Interno)

Beatriz Ribeiro Soares, Doutora (UFU)

(Examinador Externo)

Everaldo Batista da Costa, Doutor (UnB)

(Suplente) 


\section{Ficha catalográfica elaborada pela Biblioteca Central da Universidade de Brasília.}

É concedida à Universidade de Brasília permissão para reproduzir cópias desta dissertação, emprestar, vender, somente para propósitos acadêmicos e científicos. Reservo-me outros direitos de publicação; nenhuma parte desta dissertação de mestrado pode ser reproduzida sem a autorização de minha parte. Autorizo a reprodução e divulgação total ou parcial deste trabalho, por qualquer meio convencional ou eletrônico, para fins de estudo e pesquisa, desde que citada à fonte.

$$
\text { Catalogação da Publicação }
$$

Departamento de Geografia. Curso de Pós-Graduação

Universidade de Brasília

Lima, Saimon Freitas Cajado.

A judicialização do Terriório: O caso de Planaltina-DF/

Saimon Freitas Cajado Lima;

Orientador Fernando Luiz Araújo Sobrinho. - Brasília-DF, 2014.

$458 \mathrm{f}$. : il.

Dissertação (Mestrado)--Universidade de Brasília, 2014.

1. Planaltina-DF. 2. Setor Tradicional. 3. formação socioespacial. 4. território usado.

5. Judicialização.

I. Sobrinho, Fernando Luiz Araújo. II. Título. A Judicialização do Território. III. Título: O caso de Planaltina. 


\section{DEDICATÓRIA}

A Deus, minha família e familiares, sustentáculos nesta longa jornada. 


\section{AGRADECIMENTOS}

Primeiramente a Deus, pelas graças e conquistas concedidas ao longo de toda a minha vida;

À minha esposa Letícia Campos Mota Cajado, pela paciência, incentivo, carinho, compreensão e por estar ao meu lado todos os dias;

Aos meus filhos, Lara Campos Cajado e Rafael Campos Cajado, pela força que me impulsiona a ir além das minhas capacidades, motivos de todo esforço empregado no desenvolvimento das atividades acadêmicas;

A meus pais, Antônio Cajado de Lima e Arleny Freitas Cardoso Lima, pela educação recebida e apoios material, emocional, que me conduziram a este momento;

À minha irmã, Cynthia Freitas Cardoso Lima e sobrinha, Ana Júlia Cajado Urcino, pelo carinho e auxílio na labuta diária;

Às minhas avós, Amélia e Francisca, pelo aconchego e ternura;

Aos meus segundos pais, Lindinalva Rubem Campos e José Cirilo Mota, por me acolherem e me apoiarem, no caminho trilhado, como um filho;

A Jezér Campos Mota, Laice Campos Mota e minha afilhada Ana Beatriz, por estarem presentes em todos os momentos;

Ao amigo e irmão João Mendes da Rocha Neto, pela paciência, incentivo e tempo despendido para a materialização desta dissertação;

Ao amigo Fernando Luiz Araújo Sobrinho, pela confiança quanto à concretização desta pesquisa, pela solicitude e parceria;

Aos novos amigos do Curso de Mestrado em Geografia do ano de 2012, o qual me possibilitou ampliar minha visão sobre a Ciência Geografia;

A todos os meus colegas de trabalho pelas palavras de encorajamento;

Aos movimentos pastorais das paróquias São Sebastião e Santa Luzia - Planaltina-DF, pelas orações e auxílio espiritual;

Aos irmãos do Ministério Voz do Mestre, por todos os momentos de batalhas ao longo deste ano;

A todos que, de maneira direta ou indireta, contribuíram para a conclusão desta pesquisa. 


\section{RESUMO}

LIMA, Saimon Freitas Cajado. A Judicialização do Território: O Caso de Planaltina DF. 2014. (páginas - 458). Dissertação de Mestrado- Departamento de Geografia da Universidade de Brasília, Brasília - DF, 2014.

A proposta dessa pesquisa tem por finalidade expor as questões atinentes a precariedade jurídica dos imóveis que compõem o espaço urbano em Planaltina-DF. Este estado de precariedade, que impacta no pleno exercício do direito de propriedade por parte de seus habitantes, é explicitado, mediante periodização, cuja categoria formação socioespacial é apropriada metodologicamente enquanto ferramenta para descrever os três ciclos de expansão da cidade em relevo. Neste percurso que conduz ao plano atual, território usado, verifica-se a acumulação de omissões condizentes a regularização do espaço urbano da cidade, cuja sua gênese se dá na Praça de São Sebastião, atual núcleo urbano localizado no Setor Tradicional. Tais omissões, quanto às questões correlatas a ilegalidade ou clandestinidade atinentes à produção do espaço urbano, implicam na judicialização do território, cujos fatores associados à inércia do Poder Executivo local, nos distintos ciclos de produção do espaço urbano e somados às práticas culturais atreladas à posse da terra, se acumulam desde um contexto pré-máquina (Santos, 2002) até os dias atuais. Nessa perspectiva, tomando como referencial a ótica dialética, objetiva-se demonstrar os impactos da multiplicidade dos processos, eventos, e omissões presentes no percurso da construção do território em uso que acabaram por demandar a atuação do Poder Judiciário nas lides que se ampliaram, enquanto resultado das ações ou omissões dos múltiplos agentes responsáveis pelo movimento do território de Planaltina. Além disto, almeja-se compreender os impactos das decisões/ações do Poder Judiciário, oriundos de tais conflitos, que transitaram ou ainda transitam nos tribunais e os desdobramentos destes em relação aos sistemas de objetos espaciais, assim como no movimento do território.

Palavras-chave: Planaltina-DF, Setor Tradicional, formação socioespacial, território usado, judicialização. 


\begin{abstract}
LIMA, Saimon Freitas Cajado. The Territory Judicialization: The Case of Planaltina DF. 2014. (pages - 458). Dissertação (Mestrado) - Departamento da Universidade de Brasília, Brasília - DF, 2014.
\end{abstract}

The research proposal aims to expose vague issues pertaining to legal precariousness of the properties that make up the urban space in Planaltina-DF. This state of insecurity that impacts on the full exercise of ownership right from part of its inhabitants is fully explained by periodization, whose category socio-spatial is methodologically appropriated as a tool to describe the three cycles of expansion of the city with emphasis. In this pathway leading to the current plan used territory, there is the accumulation of omissions related to the regularization of urban space in the city, which takes its genesis in Praça de Sao Sebastiao, current urban center located in Setor Tradicional. Such omissions face the related issues pertaining to illegal or clandestine production of urban space, cause the legalization of the territory, whose factors are associated to the inertia of the local Executive in distinct cycles of production of the urban space, plus cultural practices linked to possession earth and accumulate from a pre-machine context (Santos, 2002) up to the present days. In this perspective, via dialectical gaze, the objective is to demonstrate the impact of the processes multiplicity, events, and omissions in the course of construction of the territory in use that demanded the performance of the Judiciary in labors that extend as a result of actions or omissions of multiple agents responsible for movement of Planaltina territory. Furthermore, we aimed to understand the impact of decisions / actions of the Judiciary arising from such conflicts that eventually passed or still pass through the courts, and the ramifications for these systems with spatial objects as well as the movement of the territory.

Keywords: Planaltina-DF, Setor Tradicional, socio-spatial formation, territory used, judicialization. 


\section{SUMÁRIO}

\section{LISTA DE FIGURAS}

LISTA DE TABELAS

LISTA DE MAPAS

LISTA DE FOTOGRAFIAS

LISTA DE ABREVIAÇÕES E SIGLAS

Introdução.

Capítulo 1 - A formação socioespacial de Planaltina-DF: A gênese das lógicas do uso e ocupação do solo

1.1 A categoria território usado no contexto da situação

da Região Administrativa IV

1.2 - Planaltina Pré-Brasília: a vigência de um meio pré-máquina

1.2.1 - Entradas e Bandeiras e a lógica de produção do espaço em

meio ao modo de produção colonial.

1.3 - Planaltina 1811: marco inicial da formação da cidade goiana. 100

1.3.1 - O surgimento do Largo de São Sebastião de

Mestre D'Ármas

1.4 - Comissão Cruls e o discurso mudancista: primeiros estudos quanto

a transferência da capital para o Planalto Central.

1.5 - 1922: A Pedra Fundamental e o prenúncio da especulação

imobiliária

Capítulo 2 - A construção de Brasília e a sua utopia: um embate dialético entre o velho e o novo e suas repercussões na metamorfose da cidade de Planaltina (1950-1960).

2.1 - O marco da atual problemática fundiária: A Comissão de Cooperação para a mudança da Nova Capital (1955-1958). .160 
2.2 - Os ranços do processo de desapropriação

2.3 - Planaltina-GO x Planaltina-DF: a perca da sede municipal, especulação imobiliária e a ampliação do espaço urbano irregular

Capítulo 3 - Planaltina-DF: da autonomia à perifeira precarizada em processo de expansão (1961- 1980). .225

3.1 - Da autonomia à perifeira precarizada .237

3.2 - O processo de expansão da cidade face a rigidez normativa. .245

3.3- A continuidade da precariedade jurídica do

Setor Tradicional (1961-1980) 271

Capítulo 4-O território usado e os seus múltiplos agentes: A judicialização em Planaltina-DF (1980 aos dias atuais)

4.1 - Judicialização: do que se trata?

4.2 - O terceiro ciclo de expansão de Planaltina: da rigidez a privatização

e a ampliação das demandas sociais/judicial. .303

4.3 - A judicialização do Setor Tradicional. .360

Considerações Finais. .395

Referencial Bibliográfico. 408

Anexos .416 


\section{LISTA DE FIGURAS}

Figura 01 - Planaltina e demais RA's do Distrito Federal.

Figura 02 - Cidades consolidadas sem regularização fundiária, por quantidade

de unidades habitacionais.

Figura 03 - Capitanias Hereditárias: economia e território no século $\mathrm{XVI}$. .89

Figura 04 - Reestruturação do sistema produtivo (séculos XVIII/XIX) 110

Figura 05 - Comissão Polli Coelho: propostas de sítio para a nova capital. 148

Figura 06 - Relatório Belcher: Sítio Castanho e a implementação de Brasília 150

Figura 07 - Planta índice Cadastral. 169

Figura 08 - Mapa da situação fundiária do Distrito Federal. 211

Figura 09 - RIDE: Atual divisão política do Distrito Federal e Planaltina de Goiás. .228

Figura 10 - Planta urbana de Planaltina (1983). .276 


\section{LISTA DE TABELAS}

Tabela 01 - Planaltina-DF: População conforme o ano de chegada ao Distrito Federal, 2013.

Tabela 02 - Planaltina-DF: População segundo a naturalidade, 2013 .52

Tabela 03 - Planaltina-DF: Domicílios ocupados conforme posse de documento do Imóvel, 2013 .70

Tabela 04 - Distrito Federal: Núcleo Habitacionais de Interesse Social com processo de regularização em andamento, 2012

Tabela 05 - Distrito Federal: Migração para o Distrito Federal por local de nascimento, migração direta ou indireta e região da última residência, 1959.........255

Tabela 06 - Distrito Federal: População por tipo de povoamento, 1959. 256 


\section{LISTA DE MAPAS}

Mapa 01 - Localização de Planaltina-DF .45

Mapa 02 - Área Urbana de Planaltina - PDOT 2012 ........................................49

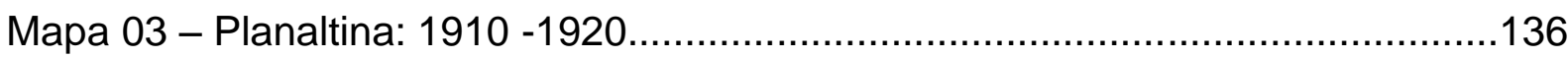

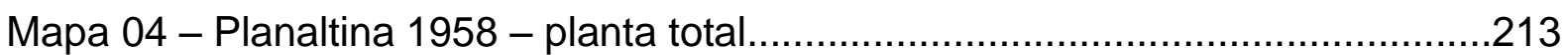

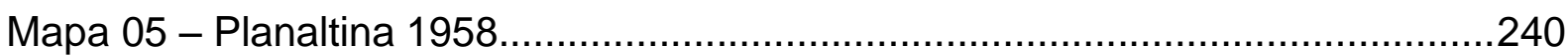

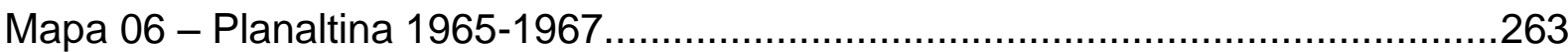

Mapa 07 - Sobreposição das plantas de Planaltina em 1958 e 1965-1967 .274

Mapa 08 - Os três ciclos de ocupação urbana em Planaltina: 1958; 1965-1967; 1980-2012 337

Mapa 09 - Quadras com matrículas trancadas - Estratégia de Regularização Fundiária PDOT 2012 338 


\section{LISTA DE FOTOGRAFIAS}

Fotografia 01 - Praça de São Sebastião..........................................................113

Fotografia 02 - Pedra Fundamental: 1922 ........................................................132

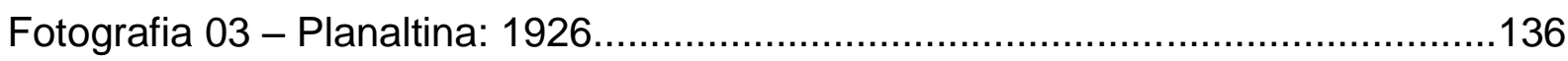

Fotografia 04 - Atual Bairro Nossa Senhora de Fátima........................................207

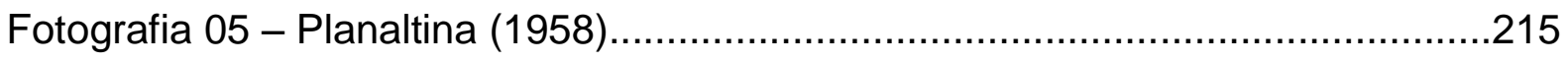

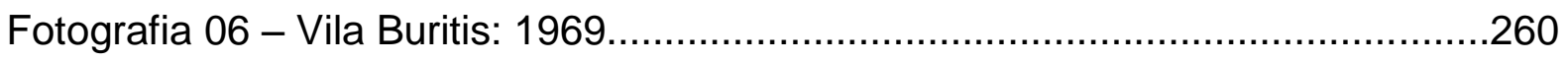

Fotografia 07 - Padrão de endereços dos parcelamentos de terras rurais, após decisão judicial favorável aos adquirentes do Quintas da Alvorada em

Planaltina.

Fotografia 08 - Expansão da rede de comércio sobre parcelamentos

clandestinos e o encarecimento da terra - Mestre D'Ármas.

Fotografia 09 - Expansão da rede de comércio sobre parcelamentos

clandestinos e o encarecimento da terra - Arapoanga.

Fotografia 10 - Expansão da rede de comércio sobre parcelamentos clandestinos e o encarecimento da terra, em virtude da construção de shopping entre o

Setor Tradicional e Instância Mestre D’Ármas.........................................................353

Fotografia 11 - Habitações de padrão socioeconômico elevado em loteamentos

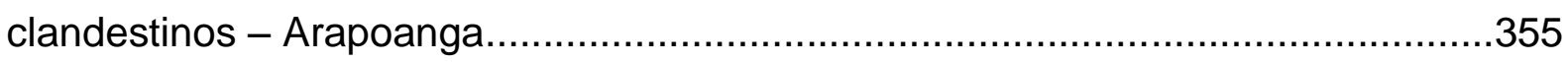

Fotografia 12 - Habitações de padrão socioeconômico elevado em

loteamentos clandestinos - Mestre D'Ármas......................................................356

Fotografia 13 - Quadra 07 do Setor Tradicional Residencial Norte.........................378 


\section{LISTA DE ABREVIAÇÕES E SIGLAS}

ADI's - Ação Direta de Inconstitucionalidade

AGEFIZ - Agência de Fiscalização do Distrito Federal

AMSPA - Associação dos Mutuários de São Paulo e Adjacências

ARIS - Áreas de Regularização de Interesse Social

CAESB (Companhia de Saneamento Ambiental do Distrito Federal)

CEB - Companhia Elétrica de Brasília

CIAM - Congresso Internacional de Arquitetura Moderna

CODEPLAN - Companhia de Planejamento do Distrito Federal

COOHAPLAN - Cooperativa Habitacional dos Trabalhadores e Servidores de Baixa Renda do Planalto

GDF - Governo do Distrito Federal

GENOR - Unidade de Planejamento Territorial Norte

IBGE - Instituto Brasileiro de Geografia e Estatística

LUOS - Lei de Usos e Ocupação do Solo

MDE 74/85 - Memorial Descritivo 1985

MPDFT - Ministério Público do Distrito Federal e Territórios

NGB 74/85 - Normas de Edificação e Gabarito 1985

NOVACAP - Companhia Urbanizadora da Nova Capital do Brasil

PDOT - Plano Diretor de Ordenamento Territorial

PIC - Planta Índice Cadastral

PDAD - Pesquisa Distrital por Amostra de Domicílio

RA VI - Região Administrativa VI (Planaltina)

RA VIII - Região Administrativa VIII (Jardim)

STF - Supremo Tribunal Federal

STJ - Superior Tribunal de Justiça

SEDUH - Secretaria de Estado de Desenvolvimento Urbano e Habitação

SEDHAB - Secretaria de Estado de Habitação Regularização e Desenvolvimento Urbano

SICAD - Sistema Cartográfico do Distrito Federal

TAC - Termo de Ajuste de Conduta

TERRACAP - Companhia Imobiliária de Brasília

TJDFT - Tribunal de Justiça do Distrito Federal e Territórios

URB 74/85 - Área Histórica e Faixa de Proteção Ambiental 


\section{Introdução}

A proposta de desenvolvimento da dissertação encontra-se pautada no processo de judicialização do território, tendo como objeto material a Região Administrativa de Planaltina-DF, com destaque para o Setor Tradicional, núcleo urbano vernacular anterior à construção da capital federal.

A escolha deste tema e objeto de estudo ocorreu em função da demanda expansiva relativas às intervenções nas últimas décadas do Poder Judiciário, face às lides relacionadas ao aspecto legal concernente ao uso e ocupação solo, assim como das questões jurídicas de seu disciplinamento.

Nesse contexto, é de suma importância buscar entendimento quanto ao acúmulo de ações, processos e eventos ao longo da construção, movimento da área urbana da Região Administrativa de Planaltina-DF, que resultam nas formas mais recentes de atuação do Poder Judiciário e sua repercussão na lógica de produção do espaço urbano.

Assim, a priori, identifica-se que o ativismo judicial efetiva-se, principalmente, em detrimento da inércia do Poder Executivo (inicialmente enquanto Município Goiano e depois enquanto Governo do Distrito Federal) para com a tomada de ações, que viessem a repercutir na regularização fundiária do espaço urbano nos distintos períodos de seu processo de totalização desdobrando-se, atualmente, na situação de uso precário dos imóveis por parte de seus moradores.

Além da inércia atrelada à referida instância de poder, também identifica-se o desconhecimento da população quanto às questões jurídicas, atinentes a efetivação do domínio de suas respectivas posses, fato este que resultam em situação de fragilidade, tendo em vista o direito à moradia.

Nessa perspectiva, cabe ao geógrafo compreender e espacializar, através do uso de seu arcabouço teórico-metodológico, o desvelar de tais ações, decisões proferidas pela instância judicial (Tribunal de Justiça do Distrito Federal e Territórios, Superior Tribunal de Justiça e Supremo Tribunal Federal) sobre as questões atinentes às lides territoriais, objetivando, desta maneira, captar os possíveis impactos gerados sobre o movimento espacial da cidade. 
Assim, por meio da cognição do processo de formação sócioespacial de Planaltina-DF, que, espaço-temporalmente, compreende aos seus ciclos de expansão pré e pós-Brasília, almeja-se captar as contradições dessa dinâmica de construção que resultam no território usado do presente, utilizando-se de olhar dialético.

Para tal, tem-se, enquanto proposta para o desenvolvimento do estudo, uma análise espaço-temporal da evolução da cidade de Planaltina-DF, que é produto das intervenções dos múltiplos agentes que incidiram na composição de seus objetos geográficos, em associação às questões atreladas à precariedade jurídica dos imóveis e setores ao longo de sua composição, resultando no quadro atual de litígios judiciais.

Assim, a relação do sistema de ações e sua imbricação no sistema de objetos proposto por Milton Santos (2002), também auxiliam na cognição do movimento do espaço urbano da Região Administrativa de Planaltina-DF, que atualmente encontra-se judicializado.

As intencionalidades advindas das ações provenientes dos distintos agentes sociais (população, poder público, segmento imobiliário, dentre outros), ao longo desse processo de formação sócioespacial, em específico, repercutem no posicionamento tomado pelos magistrados na produção das decisões judiciais atuais, das contradições históricas de uso do território que se acumulam desde o período colonial e que reverberam negativamente no exercício do direito de propriedade no presente contexto (território usado).

Denota-se que essas decisões judiciais repercutem no modo de produção do espaço, tornando-se desta maneira uma ação que implica na dinâmica e na configuração dos objetos espaciais, uma vez que se estabelecem novas possibilidades 'regulamentadas', que viabilizam novas práticas e ações sociais.

Pode-se observar que, embora dois terços da área urbana da Região Administrativa de Planaltina necessite de intervenções para a promoção do processo de regularização dos imóveis, o cerne da complexidade jurídica, que impacta no pleno exercício do direito de propriedade de seus moradores, espacialmente, concentra-se no atual Setor Tradicional (núcleo vernacular). 
Tomando por base o método dialético, a análise do processo de formação sócioespacial da cidade de Planaltina-DF vale-se da perspectiva interescalar que parte de uma totalidade ampla para uma escala local, particular, singular, permitindo visualizar, no plano do presente, o desdobramento de sucessivos eventos atinentes à construção do objeto de estudo, por meio do viés teórico-conceitual denominado território usado.

Na perspectiva do processo de totalização - movimento dos eventos que se inscrevem nas formas, conteúdos e nas dinâmicas que dão vida ao espaço a Região Administrativa de Planaltina congrega em sua forma e função atuais, o desencadeamento dos eventos que permeiam a própria constituição das sucessivas configurações territoriais, bem como, sua inserção na divisão territorial do trabalho que ganha em intensidade com a construção de Brasília. Este fato aflora a situação jurídica das terras locais.

Essa exposição da precariedade jurídica das propriedades rurais e também urbanas, explicitam a lógica de formação sócioespacial local pautada na posse irregular dos imóveis, uma vez que estes, em variadas situações, não dispunhem de documentação. Este aspecto também influencia no suposto planejamento do espaço urbano da cidade, atual Setor Tradicional, assim como nas tentativas de sua regularização.

$\mathrm{Na}$ execução das desapropriações dos imóveis contidos no quadrilátero, observa-se a sobreposição da lógica estabelecida nas convenções sociais para com as normas formais, que regulamentavam o uso e ocupação do solo. Estes aspectos são expostos por Magalhães (2011) que retrata as características socioculturais do Sertão de Planaltina, além de Castro (1986), Farias (2006) e Oliveira (2008). Tais autores relatam os muitos casos locais em que a desconsideração dos aspectos jurídicos, legais, irão refletir no efetivo domínio sobre a terra.

Objetiva-se, dessa forma, o entendimento do movimento dialético entre o velho (Planaltina oitocentista) e o novo (Brasília), onde o velho remonta o uso do território segundo uma dinâmica pré-máquina (SANTOS, 2003), cuja sua forma, função e estrutura eram regidas pelos tempos lentos, que ao se chocarem com o novo que se impunha, geraram, enquanto rugosidades, as questões atinentes à 
legitimidade do domínio das terras e, no caso em questão, dos imóveis urbanos, na difícil realização da escrituração e registro cartorial dos mesmos que se contrapunham ao arcabouço normativos que disciplinavam tais práticas.

Nesse contexto, observa-se que o estabelecimento das primeiras ocupações de terras e instalação das primeiras propriedades ocorreu segundo a lógica do Brasil Colônia (pré-máquina), via concessão de Sesmarias e ocupação de posseiros, tendo nos registros paroquiais e no valor do acordo oral os instrumentos de legitimação da posse da terra. Contudo, não sendo efetivado o seu domínio.

O desenrolar deste processo que está atrelado à precariedade jurídica das terras e até mesmo com a formulação e regularização das plantas urbanas da cidade em seu contexto pré-Brasília, resultam em um plano posterior de dificuldade na efetivação das desapropriações das terras, necessárias ao cumprimento do Art. $2^{\circ}$, alínea "e" da Lei $n^{\circ}$ 2874/56, como premissa a efetivação do Art. 4ํ das Disposições Transitórias contidas na Constituição de 1946, assim como do Art. $3^{\circ}$ da Carta Magna de 1891, que vislumbravam a consolidação da nova sede do Poder Central do Estado Brasileiro no Planalto Central.

Atualmente, como resultado da lógica atinente a inconclusa desapropriação das terras que constituem o atual quadrilátero do Distrito Federal, observa-se a facilitação do parcelamento irregular do solo e sua ocupação ilegal por distintas classes socioeconômicas, oriundos das crescentes demandas sociais pósBrasília, via relações de compra e venda não aprovadas pela legislação vigente, colocando em uma situação de clandestinidade os habitantes de tais setores que também se consubstancia via grilagem de terras.

A ação mencionada é consequência da fragilidade na condução do processo de desapropriação e transferência da titularidade dos imóveis rurais e até mesmo da área urbana já consolidada pré-Brasília, que corresponde à antiga sede do Município de Planaltina de Goiás - Setor Tradicional - e que atualmente, em uma perspectiva legal, inexistem, muito embora se encontrem cristalizadas espacialmente em uma dinâmica que remonta a pelo menos dois séculos.

Tais situações, somadas a uma série de obstáculos de âmbito normativo, dificultam à acessibilidade da população em risco social aos serviços e 
equipamentos públicos essenciais ao seu bem-estar, situação essa vinculada à regularização da terra.

O processo de regularização dos setores urbanos que culmina na emissão dos registros cartoriais, acaba por constituir o elemento central da discussão, haja vista que este fato, além de propiciar a condição de acessibilidade aos equipamentos públicos, proporciona, principalmente, o pleno gozo do direito de propriedade que juridicamente resguarda o morador quanto ao efetivo domínio sobre o bem imóvel.

Quanto ao aspecto legal dos imóveis urbanos, esta condição de precariedade legal, tendo em vista o pleno exercício do direito de propriedade, expõe uma dinâmica de conformação urbana, cuja produção permeia o estado de ilegalidade, descumprindo os aspectos legais previstos desde a vigência do Decreto Lei 58/1937, que trata da implementação de loteamentos e venda de terrenos

No caso atual da Região Administrativa de Planaltina-DF, a condição de ilegalidade, irregularidade, clandestinidade, corresponde, socialmente e em sua maioria, à situação de segregação socioespacial, cuja busca da regularização fundiária objetiva o reconhecimento de seus habitantes enquanto cidadãos.

Desde a materialização da nova capital, verifica-se a expansão do processo de polinucleamento do Distrito Federal que também incide em Planaltina, cujo motor é o exclusão social daqueles que construíram Brasília, sendo que boa parcela destes trabalhadores são removidos pelo Estado em direção à cidade vernacular, resultando na materialização da atual Vila Buritis.

Entretanto, observa-se também, nas últimas décadas, o aumento das demandas habitacionais, que desvela-se na irregularidade da ocupação ou do parcelamento das terras rurais, o que caracteriza na possibilidades de geração de lucros para os diversos agentes contidos no território, desde o proprietário particular da terra ao grileiro, já que a precariedade jurídica das terras somado ao inconcluso processo de desapropriação das antigas fazendas abrem precedentes para as ações especulativas.

Em face de tais fatos atinentes à questão jurídica das terras cabe citar a atuação do Poder Judiciário nas ultimas década, tendo em vista a materialização 
dos parcelamentos clandestinos, onde Malagutti (1997) explicita que o impulsionamento desta dinâmica de espraiamento dos condomínios dá-se em consonância com a decisão proferida pelo Tribunal de Justiça do Distrito Federal e Territórios (TJDF).

Tal decisão decorrente da Ação Cível de número № 4.890 dispõe sobre a possibilidade de registro das primeiras glebas, advindas de parcelamentos particulares que corresponde ao condomínio Quintas da Alvorada. Esta decisão/ação desdobra-se na composição de novos objetos espaciais condomínios clandestinos - que também acabam por influenciar na atual constituição do espaço urbano da Região Administrativa de Planaltina-DF, haja vista que o precedente judicial que se abre.

Para Ferreira e Steinberger (2006), atualmente vive-se o conflito entre a rigidez e a flexibilização das normas reguladoras do território, no qual averigua-se os resultados, em termos espaciais, desta flexibilização na expansão dos loteamentos e condomínios no Distrito Federal e, consequentemente, em PlanaltinaDF.

Tendo em vista a conjuntura exposta, são pertinente os seguintes questionamentos: Em que medida as questões fundiárias têm sido impactadas pelas decisões do Poder Judiciário? Até que ponto o caráter das decisões judiciais são resultantes, respectivamente, da inércia e ineficácia da atuação dos demais Poderes do Distrito Federal? Quais os desdobramentos das ações, decisões do Poder Judiciário no tecido urbano da Região Administrativa de Planaltina?

Tendo em vista o problema exposto, o objetivo central da presente proposta de estudo é:

- Analisar a atuação do Poder Judiciário (TJDFT, STJ e STF) quanto às lides de ordem territorial e normativas e os impactos no tecido urbano da Região Administrativa de Planaltina-DF.

Com relação aos objetivos específicos propõe-se:

- Descrever o processo de formação socioespacial da cidade de Planaltina-DF e os desdobramentos nas questões atuais de litígio territorial; 
- Compreender o uso do território de Planaltina-DF mediante a ação de múltiplos agentes e suas lógicas ao longo do tempo;

- Identificar qual o papel e de que forma o Poder Judiciário atua quanto às lides condizentes com a irregularidade, clandestinidade das habitações e áreas na Região Administrativa de Planaltina;

- Discutir de que maneira tais problemas político-jurídicos condizentes, ao uso e ocupação do solo, se manifestam na Região Administrativa de Planaltina;

- Verificar o desdobramento das decisões proferidas pelo Poder Judiciário no plano territorial, sobre a forma, função e a estrutura da cidade objeto.

Atualmente, só em Planaltina-DF, estima-se a existência de mais de 80 parcelamentos clandestinos, os quais, somados a outros litígios territoriais que remontam aos processos anteriores de formação socioespacial da cidade em questão, como o caso do Setor Tradicional, expressam o quadro de precariedade jurídica da cidade e a amplitude da questão relacionada a efetivação dominial dos imóveis.

Em tal contexto, verifica-se na Região Administrativa de Planaltina uma mudança abrupta de sua conformação territorial em detrimento da expansão horizontal sofrida, associada ao crescimento populacional resultante da permissividade referente à ocupação do solo.

Bairros como Arapoangas, Instâncias Mestre D'Armas de I a VI, Aprodarmas, bem como o surgimento de condomínios fechados, são residuais deste ultimo ciclo, encontrando-se ainda em situação de clandestinidade. Estes constituem frações do todo, que somados ao acúmulo complexo verificado no Setor Tradicional, resultam em uma nova totalidade que vincula-se a precariedade jurídica dos imóveis e o pleno exercício do direito de propriedade.

Considerando o cenário apresentado, observa-se que, de maneira ostensiva, o Poder Judiciário junto com o Ministério Público se fazem presentes, nas últimas décadas pós-Brasília, no tocante a intervenção ou legitimação das políticas de ordenamento territoriais propostas, somados também as lides que extrapolam tal temporalidade e até mesmo os limites político-administrativos do Distrito Federal.

Nesse viés, em que a instância judicial (TJDFT, STJ, STF) se apresenta como o mais curto e rápido caminho para a resolução dos conflitos condizentes à obtenção dos direitos e garantias sociais, propõe-se analisar, na 
Região Administrativa de Planaltina-DF, os impactos de tais ações, decisões judiciais e a impressão em alto relevo dos sistemas de objetos nele contidos a lógica que rege tal construção.

É nesse raciocínio delineado que tem-se a seguinte hipótese que norteará a investigação: as decisões proferidas pelo Poder Judiciário relativas às lides condizentes ao ordenamento territorial, vinculadas às sucessivas tentativas de regularização da cidade ao longo das décadas, impactam na dinâmica de produção das formas espaciais, podendo ser observando no tecido urbano da Região Administrativa de Planaltina-DF.

Quanto ao esforço de operacionalização das categorias formação socioespacial, território usado, sistema de ações e objetos e judicialização do território, estes encontrar-se-ão presentes ao longo da discussão mediante a composição dos capítulos.

A organização dos capítulos, por si só, remetem-se à tentativa de periodização dos processos associados à formação socioespacial de Planaltina-DF, à evolução de sua espacialidade até chegar no presente momento, cujo o acúmulo de ações resultam nas lógicas de uso do território.

Nessa perspectiva, o primeiro capítulo, "A formação sócio-espacial de Planaltina-DF: a gênese da lógica do uso e ocupação do solo", tem-se o início desta operacionalização das referidas categorias acima citadas, trazendo o contexto espaço-temporal das relações de produção que originam a cidade objeto em processo de totalização, em movimento, desde um contexto pré-máquina, abarcando todo o primeiro ciclo de expansão da cidade.

Os subtítulos "A categoria território usado no contexto da situação da Região Administrativa IV", "Planaltina Pré-Brasília: a vigência de um meio prémáquina", "Planaltina 1811: marco inicial da formação urbana da cidade goiana", "A Comissão Cruls e a chama mudancista: primeiros estudos para a transferência da capital para o Planalto Central" e "1922: A Pedra Fundamental e prenuncio da especulação fundiária", objetivam demonstrar justamente os agentes contidos no território em um contexto que antecede a construção de Brasília, em associação as lógicas que remontam a formação socioespacial da cidade que desdobra-se na gênese da precariedade jurídica dos imóveis rurais e, principalmente, urbanos, impactando no pleno exercício do direito de propriedade, ilegalidade de seus moradores. 
Busca-se desta maneira compreender a função desempenhada por Planaltina, que era chamada de Arraial de São Sebastião de Mestre D'armas, quanto à lógica existente no Sertão Planaltino que se materializou, fruto do bandeirantismo incentivado pela Coroa Portuguesa e que resultou na interiorização e expansão das malhas territoriais, embora de maneira incipiente no contexto colonial.

Propõe-se também caracterizar os primeiros processos de uso e ocupação do solo local, as lógicas atreladas à posse da terra e a repercussão da possível materialização da capital no Planalto Central Brasileiro em virtude da dinâmica de uso do território em construção.

Neste sentido, constata-se a existência do movimento mudancista, desde muito antes da Constituição de 1891, articulando-se politicamente para a promoção da transferência da sede administrativa do território para o Brasil Central.

Os marcos legais como a Constituição 1891, somado à Carta Magna de 1946 e tendo como intervalo o lançamento da Pedra Fundamental, foram eventos que impulsionam transformações socioespaciais da cidade objeto desta pesquisa, prenunciando, inclusive, a futura lógica especulativa para com uso do território em função da proximidade para com a nova sede da máquina burocrática nacional.

O segundo capítulo: "A construção de Brasília e a sua utopia: um embate dialético entre o velho e o novo e suas repercussões na metamorfose da cidade de Planaltina (1950-1960)", trata de um momento chave no processo de formação socioespacial que resulta na reconfiguração do espaço urbano em relevo e de suas cercanias, tendo em vista a problemática relacionada à condução das desapropriações das terras, fator este que resultará já em disputas judiciais que perduram até o momento presente.

O período em relevo abarca, temporalmente, toda a década de 1950 até a inauguração da cidade de Brasília no dia 21 de abril de 1960, tendo como subtítulos que tratam deste período os seguintes: "O marco da atual problemática fundiária: A Comissão de Cooperação para a Mudança da Nova Capital (19551958)", "Os ranços do processo de desapropriação" e "Planaltina-GO X PlanaltinaDF: a perca da sede municipal, especulação imobiliária e a ampliação do espaço urbano irregular".

A forma, função e estruturas de Planaltina-DF começaram a sofrer profundas alterações, tendo no novo que se impõe (Brasília), o rompimento com as 
práticas socioespaciais ainda atreladas à Planaltina oitocentista. As estruturas de poder que giravam em torno da posse e propriedade da terra inicia um movimento de ruptura.

O sonho das elites locais de conquistar um espaço no centro do poder nacional, enquanto finalidade do movimento mudancista, também se desfaz com o prenúncio da vinda dos burocratas do alto escalão do governo federal para o Planalto Central, resultando em profundas contradições no cenário político local.

A queda da primazia política, enquanto feridas abertas sobre as estruturas oligárquicas locais, acima de tudo, remetem-se a perda da terra (propriedades rurais) pela execução das desapropriações a preços irrisórios, objeto de lides posteriores em detrimento da valorização das mesmas por estarem contidas no quadrilátero do DF.

A ideologia do completo domínio das terras do quadrilátero pela nova estrutura do Poder Público que se instalava, resultou na escassez do acesso a erra nos anos subsequentes, fruto dos mecanismos impostos pelo planejamento territorial, cuja finalidade era a manutenção incólume do plano urbanístico de Brasília.

Enquanto resposta a tal imposição oriunda da construção da nova capital, contraditoriamente tão sonhada, teve-se a promoção da especulação fundiária deflagrada pela Prefeitura de Planaltina, ainda pertencente a Goiás, sobre as terras em processo de desapropriação, gerando uma das grandes questões controvertidas até o presente momento - planta no 58 - quanto à legalidade jurídica das propriedades urbanas contidas no centro consolidado da cidade objeto de análise.

Tal fato já citado, vincula-se a inconclusa questão da desapropriação das terras pertencentes ao município de Planaltina de Goiás e, que nas últimas três décadas tem sido frequentemente objeto de discussão nos tribunais em suas três instâncias (TJDFT, STJ e STF), podendo ser caracterizado enquanto rugosidade (SANTOS, 2002) no processo de formação socioespacial de Planaltina.

O terceiro capítulo - "Planaltina-DF: da autonomia à periferia precarizada em processo de expansão (1961-1980)" - apresenta, em sua proposta analítica, o desdobramento da formação socioespacial da cidade em um novo contexto, que retrata a nova função e os novos contornos de Planaltina dentro das lógicas territoriais impostas pelo recém instalado Poder Público do Distrito Federal. 
Enquanto subtítulos que compõem a proposta de reflexão contida no capítulo, tem-se os respectivos tópicos: "Da autonomia à perifeira precarizada"; "O processo de expansão da cidade face à rigidez normativa" e "A continuidade da precariedade jurídica do Setor Tradicional (1961-1980)".

É nesse momento, dentro da proposta de periodização, que o espaço urbano de Planaltina sofre suas primeiras alterações com a velocidade na expansão do seu sítio urbano nunca anteriormente ocorrido, passando a partir do final da década de 1960 a receber as famílias oriundas das invasões alocadas em Brasília, dando origem a novos bairros como a Vila Buritis e suas quadras. Portanto, será discutido a utopia de Brasília enquanto cidade modernista que postulava um modelo urbano inclusivo, mas que na prática já nasce impondo um processo segregador.

Assim, Planaltina torna-se receptáculo de tal dinâmica cujo resultado do embate dialético entre o velho e o novo na construção de uma nova síntese, reflete-se no contraste social também segregador entre os antigos habitantes (Setor Tradicional) com suas tradições face ao uso do território, e os novos moradores situados na Vila Buritis, cuja lógica do 'planejamento', em função destes, modificam a forma, a função e a estrutura social da cidade vernacular.

A partir deste planejamento resultante do embate dialético que se estabelece entre o velho e o novo, outro confronto é gerado pela multiplicidade de plantas urbanas não regularizadas tais como a de 1941, 1958 e a PR4/1(1965/1967), as quais resultam na ampliação da precariedade jurídica dos imóveis, o que repercute no acúmulo de problemas para a efetiva legalização do Setor Tradicional, impactando no exercício do direito de propriedade dos posteriores adquirentes dos respectivos lotes.

Já o território usado enquanto faceta do processo de totalização e materialização da respectiva formação socioespacial que culmina no presente, é explicitado no quarto capítulo, cujo título é: O território usado e os múltiplos agentes: A judicialização territorial em Planaltina-DF (1980 aos dias atuais).

Os subtítulos contidos em tal delimitação reflexiva englobam os seguintes temas: "Judicialização: do que se trata?", "O terceiro ciclo de expansão de Planaltina: da rigidez à privatização e à ampliação das demandas sócio/judiciais" e "A judicialização do Setor Tradicional".

O território usado enquanto materialidade do presente face à lógica de atuação dos agentes nele contidos, confronta novos nexos em virtude da luta pela 
posse da terra, como o crescimento de loteamentos clandestinos (Arapoangas, Mestre D’Ármas, Instâncias, Vale do Amanhecer) de baixa renda e assentamentos irregulares implementados pelo estado (Jardim Roriz, Vila Nossa Senhora de Fátima, Buritis II, III e IV), bem como as rugosidades que correspondem ao núcleo consolidado mais antigo da cidade de Planaltina: o Setor Tradicional.

É neste período que se observa, além da expansão dos objetos geográficos da cidade em questão, o aumento da demanda para o Poder Judiciário em resposta às diversas lides que se ampliam junto a expansão clandestina atrelada ao movimento do território.

O produto da sobreposição dos processos correlatos à formação socioespacial de Planaltina-DF tem por resultado um intrincado mosaico quanto à precariedade jurídica dos lotes, cuja problemática resume-se na difícil condição de exercer o direito de propriedade, o domínio dos imóveis, além das garantias oriundas destas condições.

Então, será exposto neste capítulo o espraiamento dos loteamentos clandestinos da cidade, em somatória aos conflitos frente à inconclusa desapropriação das terras, que correspondem ao atual Setor Tradicional de Planaltina-DF, desdobrando-se, desta maneira, em embates judiciais entre o Poder Executivo do Distrito Federal e o Município de Planaltina-GO e os respectivos ocupantes deste setor.

Este embate travado entre ambos, busca o reconhecimento do domínio das áreas públicas e de setores residenciais, fato este que irá repercutir também na relação de domínio dos imóveis a ser exercido por seus moradores do atual Setor Tradicional.

Nesse prisma, ao reconhecer a Região Administrativa de Planaltina-DF enquanto totalidade e fração de uma totalidade maior, assim como o Setor Tradicional, tem-se por pretensão que o estudo sirva de embasamento para a compreensão dos demais eventos que abarcam os temas condizentes com a dinâmica evolutiva do espaço em questão, sendo este interpretado enquanto estudo de caso.

Para Gil (1991, p. 78) o "estudo de caso é caracterizado pelo estudo aprofundado e exaustivo de um ou de poucos objetos, de maneira a permitir conhecimento amplo e detalhado do mesmo; tarefa praticamente impossível mediante a outros delineamentos considerados". Neste prisma, essa investigação 
exaustiva tivera enquanto resultado a espacialização da judicialização do território que corresponde ao espaço urbano de Planaltina-DF, assim como as lógicas que repercutem em seu processo de totalização.

Assim, Gil (1991, p.79) atesta que "esse delineamento se fundamenta na ideia de que a análise de uma unidade de determinação universal possibilita a compreensão da generalidade do mesmo ou, pelo menos, o estabelecimento de bases para uma investigação posterior, mais sistemática e precisa”.

Severino (2007, p. 121), define estudo de caso como sendo o "estudo de um caso em particular, considerando representativo de um conjunto de casos análogos, por ele significativamente representativo. A coleta de dados e sua análise se dão da mesma forma que as pesquisas de campo, em geral".

Ainda sobre o estudo de caso, Severino (2007, p.121) assevera que "o caso escolhido para a pesquisa deve ser significativo e bem representativo, de modo a ser apto a fundamentar uma generalização para situações análogas, autorizando inferências".

Segundo Gil (1991), dado o baixo custo orçamentário e a relativa facilidade quanto à execução da pesquisa, podendo ser desenvolvida de forma individual ou por um pequeno grupo de pesquisa demandada pela modalidade estudo de caso, tem-se a opção pela mesma enquanto procedimento estrutural da construção da referia proposta de dissertação.

Para Gil (1991) o estudo de caso é diretamente vinculado à pesquisa exploratória. A pesquisa exploratória, segundo o autor, é caracterizada enquanto uma tipologia de pesquisa que tem por principais virtudes propiciar um olhar aproximado do objeto de estudo, além de seu uso ser apropriado para o desenvolvimento de temas pouco explorados, ou seja, se remete a proposta em apreciação.

Sobre a pesquisa exploratória, Gil (1991, p. 44) expõe que esta tem como principal finalidade "desenvolver, esclarecer, e modificar conceitos e ideias, com vistas na formulação de problemas mais precisos ou hipóteses pesquisáveis para estudos posteriores". 
Quanto à pesquisa exploratória, Gil (1991, p. 44) afirma ainda que, de "todos os tipos de pesquisa, estas são as que apresentam menor rigidez no planejamento. Habitualmente envolvem levantamento bibliográfico e documental, entrevistas não padronizadas e estudos de caso".

Severino (2007, p.123) caracteriza a pesquisa exploratória pela "busca apenas por levantar informações sobre um determinado objeto, delimitando assim um campo de trabalho, mapeando as condições de manifestações desse objeto".

O campo delimitado para a pesquisa que se propõe é a Região Administrativa de Planaltina-DF, e em especial do Setor Tradicional, visando a compreensão do movimento do espaço urbano atrelado às questões que implicam na precariedade jurídica dos imóveis, impactando no pleno exercício do direito de propriedade de seus moradores.

Tendo em vistas essas situações, a instância do Poder Judicial, através de suas decisões, constituirá um dos motores de tal processo de produção das dinâmicas espaciais por meio da judicialização.

Quanto aos demais procedimentos necessários para a construção do presente estudo, tem-se, no levantamento de dados, um passo importante para o entendimento do território usado do presente, o qual está judicializado, que é a área urbana da Região Administrativa de Planaltina-DF.

Para a confecção da teorização e conclusão da mesma, foram utilizados, enquanto elementos que integram a pesquisa exploratória, as técnicas de levantamento documental e entrevistas abertas. Tais metodologias dão suporte para verificação dos fenômenos espaciais em sua concretude, cujas categorias: formação socioespacial; território usado; sistemas de ações e objetos e judicialização compõem o sistema metodológico (exercício de abstração) que norteiam o desenvolvimento do presente estudo.

Vale enfatizar quer o presente estudo dispõe de um viés multidisciplinar, uma vez que envolve não apenas uma perspectiva teóricometodológico restrito a ciência Geografia, mas também pesquisas históricas, além da exposição de conceitos e levantamentos processuais e documentais acerca da questão jurídica dos imóveis contidos em Planaltina-DF. 
Assim, o levantamento de informações através das pesquisas bibliográficas e documentais, objetivam a operacionalização das categorias e conceitos direcionada ao esforço de teorização do tema proposto, assim como, da visualização dos desdobramentos dos processos vinculados à formação socioespacial de Planaltina-DF em totalização, que acaba por culminar no atual território usado judicializado.

A realização da pesquisa bibliográfica, relativa a essa dissertação, ocorreu mediante a aquisição de livros (livrarias virtuais, convencionais), cujas temáticas abordadas contemplaram o tema em discussão; bibliotecas virtuais tendo como exemplo, a Universidade de Brasília e Universidade de São Paulo com os respectivos bancos de dados que disponibilizam teses, dissertações e artigos produzidos.

Severino (2007, p. 122) define pesquisa bibliográfica como "aquela que se realiza a partir do registro disponível, decorrente de pesquisas anteriores, em documentos impressos, como livros, artigos, teses, etc.".

Ele destaca que a pesquisa bibliográfica trata-se, enquanto práxis, da "utilização dos dados ou categorias teóricas já trabalhadas por outros pesquisadores e devidamente registrados. Os textos tornam-se fontes dos temas a serem pesquisados. $O$ pesquisador trabalha a partir das contribuições dos autores dos estudos analítico constantes dos textos".

Nesta prática, buscou-se o aporte teórico e o desenvolvimento das ideias atinentes as categorias em exposto, assim como todo o processo de totalização da cidade objeto de investigação, que no exercício de abstração quanto à dinâmica de produção conduz à sua materialidade atual.

Já os textos legais como sentenças, acórdãos, procedimentos de dúvidas, promessas de compra e venda dentre outras fontes a serem apreciadas, visam expor a real situação de litígio territorial que se acumula ao longo do processo de produção da cidade, cujo resultado, de tais análises, resulta na produção de uma cartografia da judicialização de Planaltina-DF, e em especial, do Setor Tradicional, fração do território que goza de maior complexidade jurídica. 
A busca de tais documentos ocorreu por meio de pesquisa virtual nos sites das autarquias do Poder Executivo do Distrito Federal como Codeplan, Sedhab e Terracap, assim como nas diversas esferas e estruturas que compõem o Poder Judiciário como o MPDFT, TJDFT, STJ, STF, dentre outros. O acesso às fontes de papel dos documentos citados também ocorreu através de visitações aos referidos estabelecimentos, cujo resultado fora a retirada de cópias de relatórios, processos, sentenças e acórdãos.

Severino (2007, p. 122-123) define pesquisa documental em um sentido amplo, ou seja, não só de documentos impressos, "mas sobretudo de outros tipos de documentos, tais como jornais, fotos, filmes, gravações, documentos legais. Nesses casos, os conteúdos dos textos ainda não tiveram nenhum tratamento analítico, são ainda matéria-prima, a partir da qual o pesquisador vai desenvolver sua investigação e análise".

A coleta e análise dos documentos serão expressos, enquanto resultado, em uma perspectiva quantitativa, já que os fenômenos espaciais identificados e expostos trarão em seu signo a representação cartográfica, onde as ação oriundas dos múltiplos agentes contidos no território somados às decisões/ações do Poder Judiciário, repercutirão na produção, no movimento territorial, no processo de judicialização, e os seus efeitos no plano espacial.

Assim, a pesquisa bibliográfica, somado aos textos legais, decisões judiciais via sentenças, acórdãos e procedimentos de dúvidas, ações movidas pelo Ministério Público, pareceres de órgãos do Poder Público sobre a dinâmica que remete a precariedade jurídica dos imóveis e desapropriações de terras e entrevistas, resulta na elaboração de mapas cuja finalidade é compreender o processo de formação socioespacial de Planaltina-DF, em associação à ampliação dos problemas jurídicos dos imóveis e à sua complexidade face ao pleno exercício do direito de propriedade no presente.

Essas informações são confrontadas com as plantas urbanas de 1958 e a PR-4/1 que ilustram esse contínuo processo de precarização da área vernacular da cidade que concentra a complexa situação referente ao domínio dos imóveis.

Todavia, embora o Setor Tradicional seja a fração em maior evidência na descrição do processo de formação socioespacial que culmina no atual território 
usado, será explicitado, cartograficamente, também os bairros passíveis de regularização e obtenção do domínio por seus usuários, bem com os bairros clandestinos cuja situação dominial se revela igualmente precária.

Com esta dissertação será possível compreender os fatores que resultaram na situação de posse precária dos imóveis ou na situação de clandestinidade, além de ser possível identificar os ciclos de expansão da área urbana em relevo, atrelado aos fatores e eventos que desvelam-se no território usado do presente, o qual encontra-se judicializado. 


\section{Capítulo 1 - A formação socioespacial de Planaltina-DF: A gênese da lógica do uso e ocupação do solo.}

A sua ação, decisão quanto às questões de cunho material e formal (produção jurídica condizente as políticas de ordenamento territorial e lides relativas à titularidade da posse da terra), se desdobram, enquanto efeito, no movimento da configuração urbana da Região Administrativa de Planaltina-DF, objeto territorial da proposta do estudo.

É de suma importância ressaltar que a judicialização do território ocorre em múltiplas escalas, ou seja, em todo território nacional e em suas frações, haja vista que a própria questão registral recai ao âmbito do Poder Judiciário, uma vez que esse procedimento administrativo é tutelado pelo Poder em apreciação. Somase a isso os conflitos atinentes ao reconhecimento do direito à propriedade, direito de propriedade, desapropriações, dentre outros fatores correlatos, que gravitam no resguardo das garantias expressas na Constituição e que envolvem os inúmeros agentes contidos no território em uso e que acabam por recorrer aos tribunais.

Tem-se como evento, que inicia tal desencadeamento de intervenções judiciais sobre as questões de litígio fundiário, assim como na produção do arcabouço normativo que regula a dinâmica do uso do território, a construção da Capital Federal, cujos efeitos políticos-jurídicos e sociais resignificam a produção do espaço urbano em questão.

É perceptível a ocorrência do embate dialético entre o velho e o novo. Há uma imposição de uma nova geografização das formas e normas que sobrepõem à dinâmica territorial que se estabelecera em detrimento a processos pretéritos, característicos do meio geográfico pré-máquina (SANTOS, SILVEIRA, 2003), ou seja, em um contexto colonial e que se complexifica com a sucessão dos períodos em meio ao processo de formação socioespacial da cidade objeto analisado.

Associado às constantes intervenções normativas quando da produção de políticas de ordenamento territorial (Plano Diretor de Ordenamento Territorial, 
dentre outros), somado as questões correlatas ao reconhecimento da titularidade da terra, fica explícito a participação do Poder Judiciário (Tribunal de Justiça do Distrito Federal e Territórios, Superior Tribunal de Justiça e Supremo Tribunal Federal) e os desdobramentos de suas decisões na conformação do território.

Essa atuação ocorre mediante arguições no transcorrer das décadas pós-construção de Brasília, realizadas pelo Ministério Público local junto à instância judicial, somando-se a outros segmentos sociais e institucionais que se vinculam as disputas presentes no território em uso.

Tais litígios abarcam tanto os conflitos entre particulares e o Poder Público, ou entre entes federados que vislumbram a titularidade e a propriedade da terra, assim como as demandas direcionadas a proposições das políticas urbanas referentes ao uso e ocupação do solo, tendo nestas políticas, em muitos outros casos, a expressão da intencionalidade de grupos proeminentes da sociedade e as necessidades corporativas.

Em ambos os contextos rasamente expostos, tem-se como resultado a materialização em um plano espacial das decisões/ações do Poder Judiciário em suas diversas instâncias - favoráveis ou contrárias ao Ministério Público e demais segmentos sociais - que repercutem no próprio movimento da cidade de Planaltina, enquanto subespaço ${ }^{1}$.

Tal materialização das ações/decisões judiciais é oriunda da morosidade quanto ao desempenho das funções das demais instâncias de Poder (Executivo e Legislativo), no que tange às questões de regularização fundiária e do uso e ocupação do solo urbano.

\footnotetext{
${ }^{1}$ Santos (1985, p.14) define subespaço mediante um olhar sistêmico atrelada ao modo de produção capitalista, tendo em vista a relação do todo e suas partes, assim como das partes que compõem o todo em suas respectivas singularidades, segundo a seguinte perspectiva:

Tal sistema é comandado pelo modo de produção dominante nas suas manifestações à escala do espaço em questão. Isso coloca de imediato o problema histórico.

(...) O sistema é comandado por regra próprias ao modo de produção dominante em sua adaptação ao meio local. Estaremos, então, diante de um sistema menor ou correspondente a um subespaço e de um sistema maior que o abrange, correspondente ao espaço. Cada sistema funciona em relação ao sistema maior como um elemento, enquanto ele próprio, em si mesmo é um sistema. Caso o subsistema a que referimos seja desdobrado em subsistemas, a mesma relação se repete (...) E cada sistema ou subsistema é formado de variáveis que, todas, dispõem de força própria na estruturação do espaço, mas cuja ação é de fato combinada com a ação das demais variáveis.
} 
Em alguns casos, a problemática fundiária da cidade de Planaltina remonta a um período da formação do território anterior (Planaltina oitocentista) a construção da cidade de Brasília e a todo aparato jurídico que viabilizou tal projeto urbanístico e geopolítico.

O Poder Judiciário, pós-Brasília, face às situações apresentadas brevemente, profere decisões que também impactam na dinâmica do modo de produção da cidade (Planaltina-DF), tendo como meio de produção a terra.

Por conseguinte, o decisum ${ }^{2}$ constitui uma nova possibilidade normativa de intervenção, movimento do espaço, muito embora, às vezes, utilizada de maneira controvertida pelos diversos segmentos sociais contidos na base territorial em uso.

Nesta dinâmica, que remonta a perspectiva dos processos mais recentes, observa-se a necessidade premente da regularização das terras que remonta quase que a totalidade da área urbana de Planaltina-DF, tanto para a população que se encontra em risco social, como também para as camadas sociais mais abastadas que exercem pressão sobre o Poder Público.

Da mesma forma, verifica-se a existência de lides que vinculam-se ao processo de desapropriação das terras anteriormente pertencentes à Planaltina-GO e às famílias tradicionais locais, cuja atual suposta propriedade ${ }^{3}$ do solo está associada, espaço-temporalmente, às dinâmicas espaciais originárias dos séculos

\footnotetext{
${ }^{2}$ Em Latim, decisão.

${ }^{3}$ Sobre a questão do procedimento administrativo atrelado ao registro de imóveis e que juridicamente garante o exercício do direito de propriedade face ao direito a propriedade, Santana de Melo (2006, p. 12-13) assim define a importância do primeiro:

(...) O título gera direitos obrigacionais entre as partes, contudo, somente seu registro lhe confere eficácia erga omnes (...) no direito brasileiro onde a presunção é relativa (juris tantum) nos termos do $\S 2^{0}$ do artigo 1.245, "enquanto não se promover, por meio de ação própria, a decretação de invalidade do registro, e o respectivo cancelamento, o adquirente continua a ser havido como dono do imóvel".

Em síntese, para a aquisição da propriedade do imóvel não basta o simples acordo de vontades entre adquirente e transmitente. O contrato de compra e venda, por exemplo, não é suficiente, por si só, para transmitir o domínio. Essa transferência somente se opera com o registro do título no registro imobiliário, antes deste somente existirá o direito pessoal.

É cediço que o registro no Registro de Imóveis não é a única forma de aquisição da propriedade imóvel, já que nos termos do Código Civil também se adquire a propriedade pela acessão, usucapião, desapropriação e pelo direito hereditário, porém, mesmo nesses casos é imprescindível o acesso ao Registro de Imóveis para ser preservada a continuidade registrária e eficácia erga omnes, possuindo 0 ato praticado somente efeito declaratório.

Desenvolve-se, outrossim, a ideia da utilização do Registro de Imóveis como meio para se combater e evitar burla às leis de parcelamento do solo e condomínio horizontal (...)
} 
XVIII, XIX e primeira metade do século XX (contexto pré-Brasília) vinculadas a um sistema de posse da terra, cujas cicatrizes deixadas perpassam pelos tribunais em suas diversas instâncias decisórias (TJDFT, STJ e STF).

Cabe ressaltar que, atualmente, tanto as ocupações clandestinas como as que se encontram em situação irregular na cidade de Planaltina-DF, são resultantes da rigidez normativa (em um primeiro momento pós-concepção de Brasília), da ausência de efetiva fiscalização quanto ao uso e ocupação do solo e, até mesmo, por omissão (caso da desapropriação do Setor Tradicional) frente a questões que perduram por décadas.

Neste cenário, no qual o Poder Judiciário é partícipe, é importante deixar claro que o que se busca não é a defesa ou a censura de tal instância, mas compreender a atuação deste na produção da materialidade urbana em consonância com o posicionamento frente a tais questões.

O título gera direitos obrigacionais entre as partes, contudo, somente seu registro Ihe confere eficácia erga omnes. A grande diferença entre os sistemas germânico e brasileiro funda-se na presunção que é dada à propriedade, no alemão, uma vez inscrito o título a presunção é absoluta (juris et de jure) da propriedade, diferentemente do que ocorre no direito brasileiro, no qual a presunção é relativa (juris tantum) nos termos do $\S 2^{\circ}$ do artigo 1.245, "enquanto não se promover, por meio de ação própria, a decretação de invalidade do registro, e o respectivo cancelamento, o adquirente continua a ser havido como dono do imóvel" .

Para a aquisição da propriedade do imóvel não basta o simples acordo de vontades entre adquirente e transmitente. O contrato de compra e venda, por exemplo, não é suficiente, por si só, para transmitir o domínio. Essa transferência somente opera-se com o registro do título no registro imobiliário, antes deste somente existirá o direito pessoal.

É notório que o registro no Registro de Imóveis não é a única forma de aquisição da propriedade imóvel, já que nos termos do Código Civil também se adquire a propriedade pela acessão, usucapião, desapropriação e pelo direito hereditário, porém, mesmo nesses casos, é imprescindível o acesso ao Registro de Imóveis para ser preservada a continuidade registrarial e eficácia erga omnes, possuindo, o ato praticado, somente efeito declaratório. 
Almeja-se, do mesmo modo, identificar nas ações/decisões do Poder Judiciário, as contradições da produção espacial em meio à perspectiva dialética, que permeia o entendimento das lógicas que se desdobram na formação do tecido urbano de Planaltina-DF.

Para dar suporte a tal estudo, tem-se, enquanto subsídio teórico em uso na construção do presente tema, os conceitos "território usado", "formação socioespacial", "sistemas de ações e objetos" cunhados por Milton Santos, enquanto sistematização e sustentação aos argumentos da investigação em proposição, ao longo do trabalho.

Buscar-se-á também o aprofundamento cognitivo quanto ao conceito de "judicialização", uma vez que a argumentação central baseia-se no entendimento da dinâmica de atuação da instância judiciária em associação à produção do movimento territorial, assim como dos objetos geográficos nele contidos resultantes de suas ações/decisões.

Apreende-se que os conceitos relacionados à formação socioespacial, território usado, sistema de ações e objetos e judicialização constituem as categorias centrais no processo de teorização dos fenômenos espaciais em análise, cuja finalidade repousa na espacialização de ocupações irregulares e clandestinas existentes e dos conflitos judiciais contidos no território.

Objetiva-se a promoção de uma leitura mais aprofundada do movimento do território, em consonância a atuação da instância de Poder em específico, pouco estudado e explorado pelos estudos desenvolvidos pela Geografia: o Poder Judiciário.

Nesse viés, vê-se uma interdependência entre as categorias formação socioespacial, território usado e sistema de ações e objetos, uma vez que a formação socioespacial propõe um entendimento sobre o desenvolvimento histórico das sociedades face ao modo de produção capitalista, cujo impacto repercute no movimento do espaço e na composição de suas estruturas.

Planaltina-DF, enquanto totalidade cindida, encontra-se em constante movimento de totalização junto ao todo em sua próprio dinâmica produção espacial. 
Tal reciprocidade espaço-temporal em suas múltiplas escalas de inter-relação culminam no plano do presente - território usado.

O território usado é o território dos diversos objetos espaciais e dos agentes que os herdam em um contexto de uma nova totalidade, dando prosseguimento à dinâmica de (re)produção do espaço mediante à sua (re)construção, dando novos usos ou implementando novas materialidades no plano do presente, cujo Poder Judiciário também o compõe.

A Lei, norma - razão de ser do Poder Judiciário - em seu processo evolutivo enquanto técnica, ao ser aplicada, constitui-se em uma ação que, na presente proposta, terá os seus efeitos no espaço impactando a lógica de uso do território, tendo desdobramentos na dinâmica de (re)produção dos objetos geográficos e no uso dos mesmos pela sociedade em seus distintos segmentos corporativos.

Sobre o processo de teorização e justificativa para com o uso das categorias adotadas neste constructo teórico, tendo como finalidade correlacioná-las à compreensão da produção do espaço geográfico, assim como nas dinâmicas sociais que the conferem sua vida, Santos (2012) ressalta a importância da escolha e operacionalização das categorias.

Tal seletividade tem por intenção a produção de um conhecimento sistêmico elucidativo dos fenômenos espaciais e proposição de leis que deem conta da interpretação dos fatos. Santos (2012) assevera tal raciocínio delineando a seguinte afirmação:

Um sistema de realidades, ou seja, um sistema formado pelas coisas e a vida que as anima, supõem uma legalidade: uma estruturação e uma lei de funcionamento. Uma teoria, isto é, sua explicação, é um sistema construído no espírito, cujas categorias de pensamento reproduzem a estrutura que garante o encadeamento dos fatos. (SANTOS, 2012, p.29).

A busca por essa leitura da atual composição do espaço, sinônimo de sociedade, cujas normas e instância judicial estão contidas enquanto estruturas, se constitui em uma tentativa de apreender o próprio objeto da geografia, que neste 
caso, traduz-se enquanto território usado e que, por final, se estabelece através do processo de totalização.

Neste entendimento, Sposito (2004) ao citar Santos, propõe o encorajamento de tal exercício para com o desenvolvimento de novas teorias, na busca pelo esforço interpretativo dos conceitos e categorias que fazem parte do corpo teórico da geografia, tendo por finalidade a cognição do seu objeto de estudo:

(...) o corpus de uma disciplina é subordinado ao objeto e não o contrário, sendo indispensável uma preocupação ontológica, um esforço interpretativo de dentro, o que tanto contribui para identificar a natureza do espaço, como para encontrar as categorias de estudo que permitam corretamente analisá-lo. (SANTOS apud SPOSITO, 2004, p. 90).

Ainda sobre esse lançar-se ao entendimento e proposição de novas percepções quanto ao desenrolar dos processos sociais - a razão de ser da ciência - que neste caso se trata de uma abordagem vinculada a uma perspectiva da geografia, Sposito (2004) cita Deleuze e Guattari para expressar tal pensamento:

(...) não há conceito simples (...) o conceito importa algumas características: todo conceito tem componente e se define por eles (...) todo conceito tem um contorno irregular, conceito é uma questão de articulação, corte e superposição. É um todo, porque totaliza seus componentes, mas um todo fragmentário...todo conceito remete a um problema. (DELEUZE e GUATTARI apud, SPOSITO, 2004, p. 60).

É nesse esforço de análise da judicialização do território e suas repercussões sobre a Região Administrativa de Planaltina-DF, que o presente estudo respalda-se nos posicionamentos acima expostos por Sposito (2004), incorporando desta maneira um espírito empreendedor.

O entendimento do que seja essa judicialização do território, tendo como enfoque a questão do ordenamento territorial e dos litígios nele presentes, será melhor aprofundado no transcorrer dos tópicos que se seguem.

Todavia, é importante expor brevemente que a Judicialização, segundo Valle (2012, p.17), trata-se de "um processo de expansão decisória do Poder Judiciário em direção às áreas de competência tradicionalmente exercidas pelos demais poderes", em detrimento a ineficácia quanto ao cumprimento das políticas 
públicas em seus diversos segmentos ou quanto à ineficácia da produção de normas que contemplem as demandas sociais.

Vale salientar que as quatro categorias anteriormente expostas, mesmo descritas enquanto vigas mestras para o exercício do processo de abstração e entendimento do movimento do real, necessitam de conceitos que possibilitem o complemento quanto à construção de uma teorização e análise dos processos em seu devido grau de complexidade.

Assim, ao se deparar com as questões urbanas, tendo como plano central os fatores político-jurídicos, bem como a análise o movimento do espaço urbano, torna-se de extrema importância a abordagem de elementos conceituais condizentes ao processo de urbanização, segregação socioespacial, legal e ilegal, política pública, uso e ocupação do solo, precariedade jurídica imobiliária e direito de propriedade para a elucidação da relação dialética espaço-sociedade que repercutem na estruturação do espaço urbano da Região Administrativa de Planaltina-DF, foco da discussão.

Nos próximos subtítulos e capítulos, a finalidade é a exposição, elucidação, operacionalização das categorias citadas em páginas anteriores, cujo objetivo vincula-se ao entendimento da atuação do Poder Judiciário enquanto instância de Poder que, ao agir, responde na dinâmica de construção do espaço urbano.

1.1 A categoria território usado no contexto da situação da Região Administrativa IV.

Santos \& Silveira (2003) ao discutirem a definição de território, territorialidade e espaço buscam promover o esclarecimento vocabular sobre essas três definições.

O território seria a "extensão apropriada e usada". Já o termo territorialidade é posto como "sinônimo de pertencer àquilo que nos pertence", logo, na expressão exposta pelos autores, o sentido de pertencer está vinculado à existência de um ente que promove o direcionamento, o regulamento e "se preocupa 
com o destino, com a construção do futuro" da sociedade, que seria o Estado (Santos, Silveira, 2003, p. 19).

Nesse raciocínio, o termo território também se remete a "um nome político para o espaço de um país" que supõe a existência de uma base material para a presença de um Estado, podendo abrigar no mesmo, uma ou mais nações. Dessa forma, a noção de "espaço território", expressa a sujeição do mesmo "a transformações sucessivas" (SANTOS, SILVEIRA, 2003, p. 23-24).

Contudo, para Santos e Silveira (2003), mais do que território, espaço território, territorialidade, o conceito "território usado" constitui a síntese de todas as expressões antes citadas, enquanto sinônimo de espaço geográfico.

Em tal ótica, os autores propõem a elevação desta base conceitual a um nível de categoria, evidenciando uma imbricada teia sistêmica existente entre as estruturas espaciais, seus elementos (tanto da existência material como imaterial) e suas variáveis em constante movimento, assim definido por ambos:

\begin{abstract}
"O uso do território pode ser definido pela implementação de infraestruturas, para as quais estamos igualmente utilizando a denominação sistema de engenharias, mas também pelo dinamismo da economia e da sociedade. São os movimentos da população, a distribuição, à agricultura, da indústria e dos serviços, o arcabouço normativo, incluídas a legislação civil, fiscal e financeira, que, juntamente com o alcance da extensão da cidadania, configuram as funções do novo espaço geográfico." (SANTOS, SILVEIRA 2003, p.21, grifo nosso).
\end{abstract}

A categoria "território usado", no que condiz a questão da judicialização do território, se encaixa perfeitamente enquanto ferramenta analítica do atual arranjo espacial, político, jurídico, social e econômico que se apresenta na Região Administrativa de Planaltina-DF.

Tal conceito abarca todos os agentes e técnicas (materiais e imateriais) que respondem e corresponde à relação dialética existente entre sociedade e espaço. O território usado é o espaço de todos, é o espaço banal, assim como expõe Andrade Grimm (2011) ao interpretar a categoria proposta pelo intelectual Milton Santos: 
(...) o território usado compreendido por Milton Santos como sinônimo de espaço geográfico, deve ser considerado como o espaço de todos e não apenas de determinados atores ou instâncias da sociedade. O autor não entende, portanto, o espaço como um espaço econômico, um espaço do turismo, um espaço das atividades agrícolas etc. $O$ entendimento do espaço geográfico como espaço banal foi inspirado em François Perroux, para quem o espaço banal, que é o espaço de todos, (...) se opunha ao "espaço econômico" propostos pelos economistas nas décadas de 1950 e 1960 (...)" (ANDRADE GRIMM 2011, p. 242).

Tomando como referência o raciocínio exposto acima e o caso da presente proposta de estudo, as normas advindas do ato de planejar, assim como a produção de jurisprudências decorrentes das decisões do Poder Judiciário sobre as questões político-jurídico e litígios existentes, que serão expostos mais adiante, constituem um recorte analítico, que tem por finalidade o entendimento da produção do espaço e de seu uso.

Todavia, seguindo a linha de interpretação exposta por Grimm (2011), não é permitido desprezar a totalidade da atuação dos demais elementos e estruturas que influenciam a formação do mesmo território em uso (Planaltina-DF), assim como, não o é, os eventos que marcam esse contínuo movimento que resulta no momento atual.

O território usado é o território da complexidade proveniente das atuações de seus diversos agentes e sucessivos eventos que responde pela produção dos fixos e dos fluxos sobre o espaço em questão, das formas, funções e estruturas espaciais (inclusive o arcabouço normativo) presentes ou escassas.

O território usado é o espaço produzido, tendo por acúmulos a soma/sobreposição das técnicas nele sedimentado, cristalizado em sua inércia dinâmica ${ }^{4}$, resultantes da produção social como é abordado por Santos e Silveira (2003), ao afirmarem:

\footnotetext{
${ }^{4} \mathrm{O}$ termo inércia dinâmica corresponde à herança apropriada pela totalidade que compõe o presente do que já fora produzido outrora através das formas-conteúdo, incorporando-se inconscientemente a "natureza" sócio espacial atual em processo de totalização - movimento do espaço. É o choque entre o velho e o novo exposto por Santos (2002, p. 140), pois em "cada lugar, o tempo atual se defronta com o tempo passado, cristalizado em formas. Para o tempo atual, os restos do passado constituem aquela espécie de "escravidão das circunstâncias anteriores" de que fala John Stuart Mill. É nesse sentido que falamos da inércia dinâmica".
} 
"Como já temos mencionado repetidamente, o território, em si mesmo, não constitui uma categoria de análise ao consideráramos o espaço geográfico como tema das ciências sociais, isto é, como questão histórica. A categoria de análise é o território usado. (...) A partir desse ponto de vista, quando quisermos definir qualquer pedaço do território, devemos levar em conta a interdependência e a inseparabilidade entre a materialidade, que inclui a natureza, e o seu uso, que inclui a ação humana, isto é o trabalho e a política." (SANTOS, SILVEIRA, p. 247).

O território usado é compreendido enquanto produto e condição de produção (devir) da dinâmica social, cuja análise se dá em uma perspectiva do presente.

Portanto, Planaltina-DF, enquanto fração de uma totalidade e ao mesmo tempo, uma totalidade, dispõe de características peculiares à lógica evolutiva do território nacional. Todavia, não se separa desta dinâmica e tampouco dos processos que regeram, que regem e que regerão o movimento do conjunto e de suas frações, que resultará numa reconstrução espacial. (SANTOS, 1985, 2002).

Enquanto fruto da convergência de ações múltiplas no movimento espacial em processo (totalização) e em períodos técnicos diversos que corroboraram na materialização dos objetos espaciais em suas distintas formas e funções, oriundos de seus atributos técnicos, somados à conjunção de seus elementos (pessoas, saberes, infraestruturas...) da complexidade de suas interrelações (composição de estruturas) e do trabalho empregado pela sociedade, temse no presente momento a existência de uma nova totalidade - Planaltina-DF.

A Região Administrativa de Planaltina (RA VI), conforme o mapa 01 e a figura 01, situa-se na porção Nordeste do Distrito Federal. Segundo a Coletânea de Informações Socioeconômicas produzidas pela CODEPLAN (2007, p. 11), a RA VI possui uma área total de $1.534,70 \mathrm{Km}^{2}$, sendo a maior em extensão dentre as regiões administrativas do Distrito Federal.

De acordo com a CODEPLAN (2007, p.11), os limites da RA VI se encontram definidos da seguinte maneira: ao Norte - Paralelo 1530’S Sul - Ribeirão Extrema; DF - 100; DF - 250. Leste - Meridiano 47ํ2ㄴ'WGr; Ribeirão Santa Rita; Rio Preto. Oeste - DF - 130; DF - 250; Rio São Bartolomeu; Córrego do Meio; linha que une as nascentes dos Córregos do Meio, Corguinho Chapadinha; Chapadinha e 
Terra Branca; Córrego Terra Branca; Córrego João Pires; Rio Palmeiras; Rio Maranhão.

Ainda tendo como referência os dados da CODEPLAN (2007, p. 0809), após a inauguração de Brasília em 1960, parte do antigo município, antes pertencente ao Estado de Goiás, é incorporado ao território do Distrito Federal. Contudo, a relação jurídico-institucional é apenas estruturada e legalmente promulgada no dia 10 de dezembro de 1964 , pela Lei $n^{\circ} 4.545$, que promove a reestruturação das competências de atuação do Poder Executivo do Distrito Federal, bem como da nova composição político-administrativa do DF.

Tal Lei dispõe, no título IV que trata das Administrações Regionais, sobre a questão da seguinte forma:

Art. 9ㅇ O Distrito Federal será dividido em Regiões Administrativas para fins de descentralização e coordenação dos serviços de natureza local.

$\S 11^{\circ}$ A cada Região Administrativa corresponderá uma Administração Regional à qual caberá representar a Prefeitura do Distrito Federal e promover a coordenação dos serviços em harmonia com o interesse público local.

§ 2o A Administração Regional será chefiado por um Administrador Regional, de livre nomeação do Prefeito, dentre servidores de comprovada idoneidade e experiência administrativa, integrantes ou à disposição do sistema de administração do Distrito Federal. 
Mapa 01 - Localização de Planaltina-DF

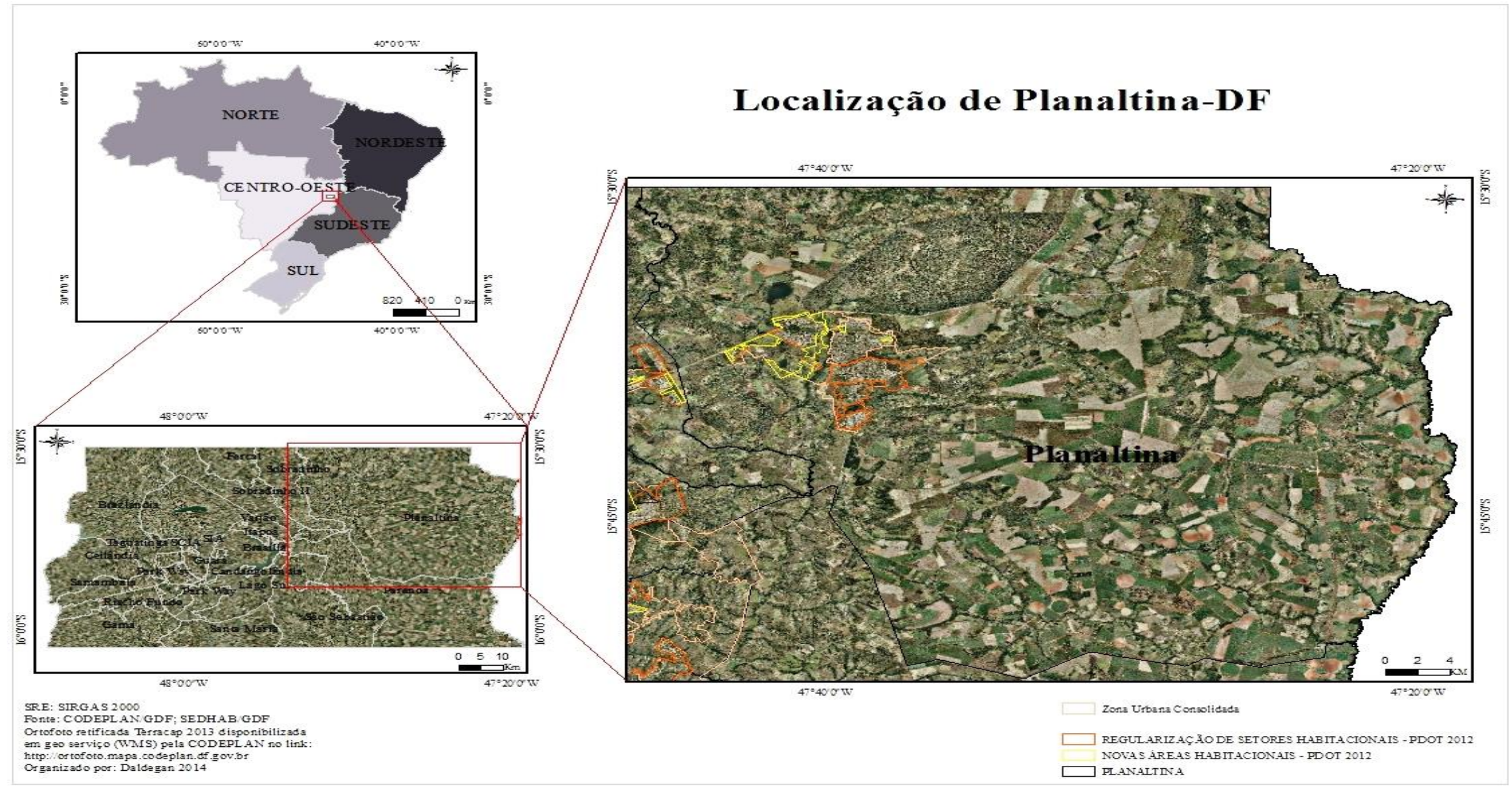

Fonte: Lima, 2014. 
Figura 01 - Planaltina e demais RA's do Distrito Federal.

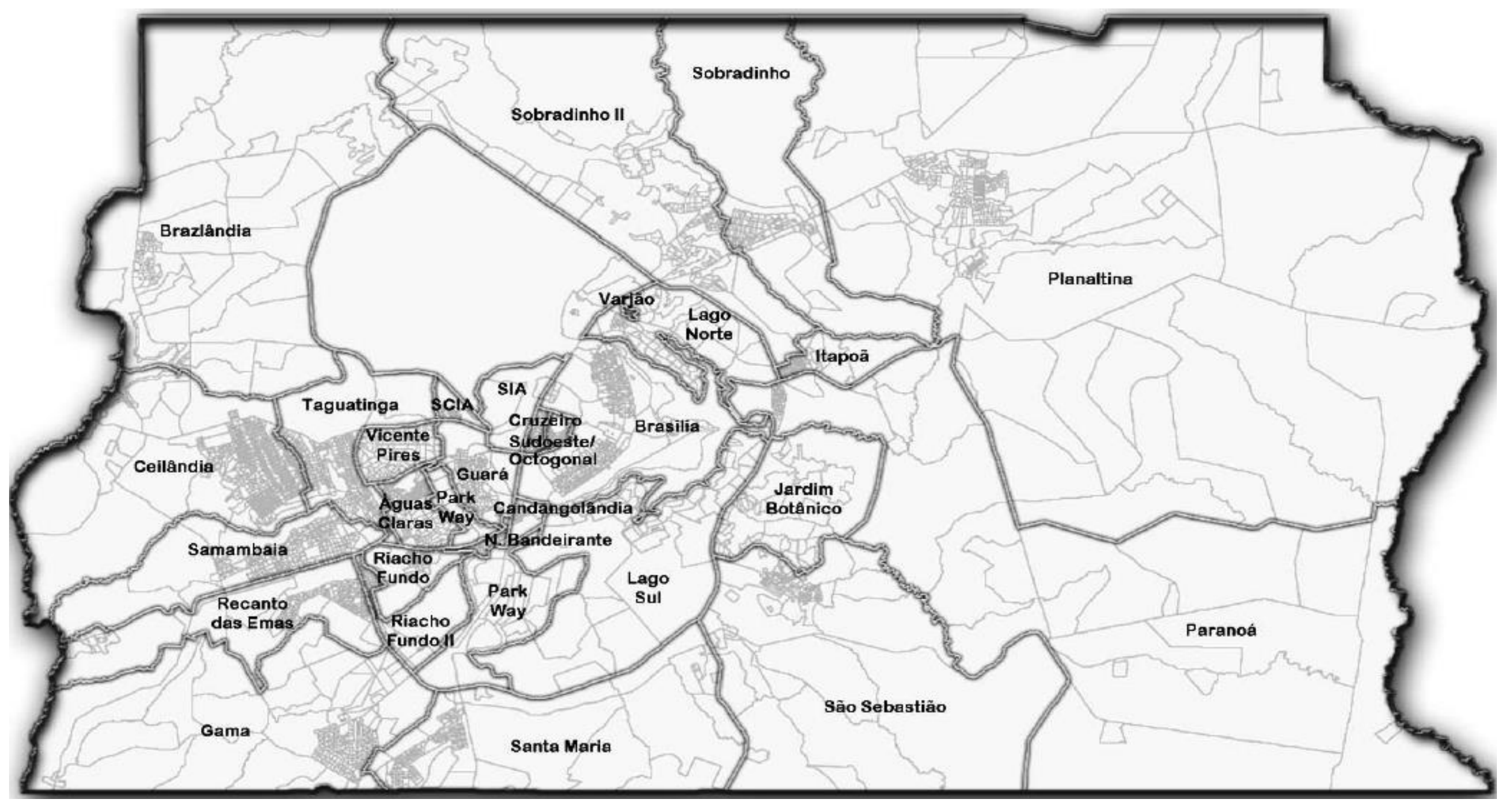

Fonte: CODEPLAN, 2012. 
§ 3을 Administrador Regional deverá residir obrigatoriamente, na sede de sua Região, desde que lhe sejam proporcionadas condições para este fim.

Art. 10. Os órgãos e serviços enquadrados no regime de Administração Regional ficam subordinados à autoridade do Administrador Regional, sem prejuízo da orientação normativa, do controle técnico dos órgãos centrais competentes de cada Secretaria.

$\S 1^{\circ}$ A supervisão global do sistema de Administração Regional competirá à Secretaria do Governo.

$\S$ 2ํ Cada Região Administrativa terá anexo próprio no Orçamento Geral do Distrito Federal. (Presidência da República. Lei no 4.545/64. In: http://www.planalto.gov.br/ccivil_03/leis/L4545.htm, acessado em 29 de novembro de 2013).

Posteriormente, a mesma Lei é "regulamentada pelo Decreto $n^{\circ} 456$, de 21 de outubro de 1965, que dividiu o Distrito Federal em oito Regiões Administrativas" ao qual se inclui Planaltina. "Em 1989, por força da Lei n 49/89 e o Decreto no 11.921/89, a RA VIII Jardim foi extinta", tendo parte do seu território integrado à RA VI (CODEPLAN, 2007, p. 08-09).

A Pesquisa Distrital por Amostra de Domicílio (PDAD, 2013, p. 12), também produzida pela CODEPLAN, demonstrou que a área urbana de PlanaltinaDF dispunha de cerca de 49.103 residências, com uma população urbana mensurada em 180.848 mil habitantes.

Ao setorizar a área urbana de Planaltina, a PDAD (2013) considera enquanto bairros que integram o centro urbano da RA VI o Setor Tradicional, núcleo consolidado anterior a construção de Brasília, e demais que surgiram pós-Brasília e que acompanharam o movimento crescente da demanda habitacional de então, como a Vila Vicentina, Setor Residencial Leste (Vila Buritis I, II e III), Setor Residencial Norte A (Jardim Roriz).

Tais espaços, que podem ser visualizados no mapa 02, são oriundos de políticas de assentamentos populacionais que ocorreram ao longo do fim da década de 1960 até o início dos anos de 1990, tendo como Modus operandi de lógica e intencionalidade, ao transcorrer do tempo, mutações que refletem a atuação 
do estado gestor e dos múltiplos agentes (políticos, corporativos, sociais) contidos no território em movimento. 
Mapa 02 - Área Urbana de Planaltina - PDOT 2012.

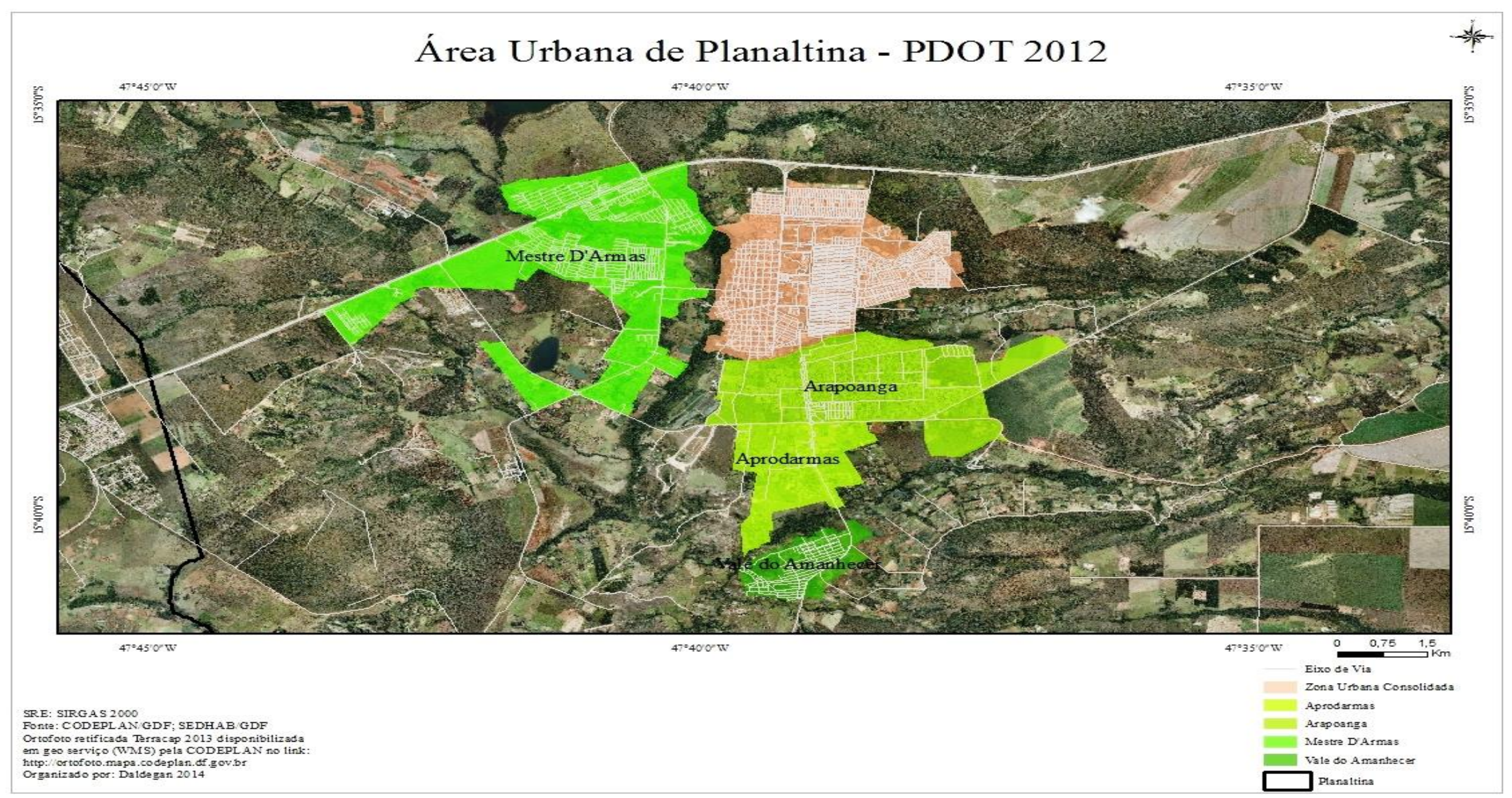

Fonte: Lima, 2014. 
Vale acrescentar, que além dos bairros citados, a cidade recebera também, nos últimos 10 anos, mais dois assentamentos populacionais: Buritis IV, cuja finalidade fora a realocação de parcela dos antigos moradores da Vila Estrutural e o Setor Residencial Oeste, o qual foi destinado aos servidores do Governo do Distrito Federal, em especial, de carreira militar (Bombeiros e Policiais Militares).

Somados aos setores já mencionados que integram o tecido urbano de Planaltina-DF, a cidade também detém em sua configuração territorial ${ }^{5}$ uma grande extensão de parcelamentos clandestinos, fato peculiar à dinâmica urbano-regional que reflete as demandas habitacionais desde a gênese de Brasília, ampliando-se cada vez mais com a chegada de fluxos populacionais atraídos por possíveis oportunidades de emprego ao longo das últimas décadas.

Corroborando com a afirmação acima, a PDAD (2013) explicita que dos 180.000 mil moradores que fixaram residência na cidade, 47,47\% são compostos por imigrantes e 52,53\% constituído por pessoas nascidas no Distrito Federal.

Observa-se que o número de pessoas naturais é ligeiramente maior do que os imigrantes no presente. Essa realidade também e verificada em períodos anteriores, tal como pode ser visto na tabela 01, a seguir, a qual trata da relação do quantitativo de migrantes em relação à população local desde a década de 1960 . Observa-se que o pico referente à chegada de migrantes se dá no transcorrer das décadas de 1970, 1980 e 1990, momento este que reflete o grande processo de espraiamento da cidade.

\footnotetext{
${ }^{5}$ Santos (2012, p.90) define configuração territorial enquanto a cristalização no espaço dos sistemas de objetos espaciais que refletem os momentos históricos, oriundo das relações de trabalho humano (técnicas) específicos de cada período da história "que torna-se cada vez mais complexo, exigindo mudanças correspondentes às inovações (...) técnicas" oriundas da "substituição de uma forma de trabalho por outra, de uma configuração territorial por outra". Ainda sobre o conceito relativo a configuração territorial, Santos (2012) ainda assevera:

O homem vai construindo novas maneiras de fazer coisas, novo modos de produção que reúnem sistemas de objetos e sistemas sociais. Cada período se caracteriza por um dado conjunto de técnicas. Em cada período histórico, temos um conjunto próprio de técnicas e de objetos correspondentes. Num momento B, muitos elementos do momento A permanecem; e surgem novos. É a inovação triunfante que permite sair de um período e entrar em outro.
} 
TABELA 01 - Planaltina-DF: População conforme o ano de chegada ao Distrito Federal, 2013.

\begin{tabular}{cccc}
\hline Anos & $\mathbf{N}$ ㅇ & \% & \% de Imigrantes \\
\hline Total & $\mathbf{1 8 0 . 8 4 8}$ & & \\
& & & \\
Nascidos no DF & $\mathbf{9 4 . 9 9 7}$ & $\mathbf{5 2 , 5 3}$ & \\
& & & $\mathbf{1 0 0 , 0 0}$ \\
Imigrantes & $\mathbf{8 5 . 8 5 1}$ & $\mathbf{4 7 , 4 7}$ & 3,28 \\
Até 1960 & 2.812 & 1,56 & 10,31 \\
De 1961 a 1970 & 8.849 & 4,89 & 19,37 \\
De 1971 a 1980 & 16.633 & 9,20 & 17,32 \\
De 1981 a 1990 & 14.869 & 8,22 & 27,66 \\
De 1991 a 2000 & 23.749 & 13,13 & 19,85 \\
Acima de 2000 & 17.043 & 9,42 & 2,21 \\
Não sabe & 1.896 & 1,05 & \\
\hline Fonte: CODEPLAN & - Pesquisa Distrital & por Amostra de Domicílios - Planaltina - \\
PDAD 2013 & & &
\end{tabular}

A tabela 02, apresentada na PDAD (2013), que se segue, explicita a composição da população migrante que se instala em Planaltina em correlação com os respectivos estados de origem, integrantes da Federação Brasileira. 
TABELA 02 - Planaltina-DF: População segundo a naturalidade, 2013.

\begin{tabular}{llll}
\hline Unidade de & $\mathbf{N}^{\circ}$ & $\%$ & $\%$ de Imigrantes \\
Federação & &
\end{tabular}

\begin{tabular}{|c|c|c|c|}
\hline Total & 180.848 & 100,00 & \\
\hline Distrito Federal & 94.997 & 52,53 & \\
\hline Outras UF & 85.851 & 47,47 & 100,00 \\
\hline Acre & 61 & 0,03 & 0,07 \\
\hline Alagoas & 496 & 0,27 & 0,58 \\
\hline Amapá & - & - & - \\
\hline Amazonas & 253 & 0,14 & 0,29 \\
\hline Bahia & 13.363 & 7,39 & 15,57 \\
\hline Ceará & 8.195 & 4,53 & 9,55 \\
\hline Espírito Santo & 279 & 0,15 & 0,32 \\
\hline Goiás & 16.358 & 9,05 & 19,05 \\
\hline Maranhão & 6.856 & 3,79 & 7,99 \\
\hline Mato Grosso & 126 & 0,07 & 0,15 \\
\hline Mato Grosso do Sul & 113 & 0,06 & 0,13 \\
\hline Minas Gerais & 13.698 & 7,57 & 15,96 \\
\hline Pará & 774 & 0,43 & 0,90 \\
\hline Paraíba & 4.878 & 2,70 & 5,68 \\
\hline Paraná & 582 & 0,32 & 0,68 \\
\hline Pernambuco & 2.596 & 1,44 & 3,02 \\
\hline Piauí & 10.948 & 6,05 & 12,75 \\
\hline Rio de Janeiro & 849 & 0,47 & 0,99 \\
\hline Rio Grande do Norte & 1.659 & 0,92 & 1,93 \\
\hline Rio Grande do Sul & 200 & 0,11 & 0,23 \\
\hline Rondônia & 137 & 0,08 & 0,16 \\
\hline Roraima & 11 & 0,01 & 0,01 \\
\hline Santa Catarina & - & - & - \\
\hline São Paulo & 1.617 & 0,89 & 1,88 \\
\hline Sergipe & 50 & 0,03 & 0,06 \\
\hline Tocantins & 1.637 & 0,91 & 1,91 \\
\hline Exterior & 32 & 0,02 & 0,04 \\
\hline Não sabe & 85 & 0,05 & 0,10 \\
\hline
\end{tabular}

PDAD 2013.

Além dessas informações, que atesta a importância dos movimentos migratórios na composição total da população contida na cidade, refletindo em sua configuração territorial e repercutindo na estrutura socioeconômica local, encontra-se o fato da existência de um grande contingente de acompanhantes que vieram juntamente com parentes no empreendimento do ato migratório.

Pode-se inferir que, dos 180.848 mil residentes, 85.852 mil são compostos por imigrantes. Deste total advindos de outros estados, 35.780 mil imigrantes vieram em busca de inserção no mercado de trabalho local. Os demais, 
47.036 mil, são compostos de parentes - predominantemente filhos - que acompanharam a vinda de seus pais (PDAD, 2013, p. 33).

Cabe destacar que dos mais de 80 parcelamentos $^{6}$ clandestinos constituídos ao longo dos últimos 30 anos, conectados a lógica exposta, tais frações da cidade caracterizam-se por serem verdadeiras cidades juridicamente inexistentes, contendo contingentes populacionais de grandes proporções.

Segundo as informações produzidas pela Secretaria de Estado de Desenvolvimento Urbano e Habitação (SEDUH) no ano de 2006 e que estão presentes no Diagnóstico Preliminar dos Parcelamentos Urbanos Informais no Distrito Federal, respectivamente, bairros como Setor Habitacional Arapoangas, Setor Habitacional Mestre D'Armas, Setor Habitacional Vale do Amanhecer e Setor Habitacional Aprodarmas, contavam com uma população total de 103.302 pessoas.

Confrontando tais informações com os estudos produzidos pela CODEPLAN (2007), estimava-se que a área urbana em questão, no ano de 2004, dispunha de um total de 141.097 habitantes. Neste contexto, ao confrontar tais dados estatísticos, constata-se que mais de dois terços da população urbana de Planaltina-DF viviam em parcelamentos clandestinos.

${ }^{6}$ Condomínios originados nos últimos 30 anos em Planaltina-DF: Ass. Residencial Sul Americana; Cachoeira; Parcelamento Rural na Fazenda Mestre D'Armas; Chácara Mestre D'armas $3^{\circ}$ Etapa; Chácara São Joaquim; Chácaras Lagoa Bonita; Confiança; COOHAPLAN - Itiquira; COOHAPLAN Vila Dimas; DVO; Eldorado; Esperança; Estância Mestre D'Armas I; Estância Mestre D'Armas II; Estância Mestre D'Armas III; Estância Mestre D'Armas IV; Estância Mestre D'Armas V; Estância Planaltina; Estância Planaltina I; Expansão da Vila Nova Espanca; Fazenda Mato Grosso/Bonsucesso; Flamboyant; Girassol; Jardim Oriente; Jardins Morumbi; João Correia SilvaEspólio; Loteamento Fazenda Mestre D'armas 1; Loteamento Pacheco; Mansões Arapoanga; Mansões Bonanza - Faz. Pipiripau; Mansões Bonsucesso; Mansões do Amanhecer; Mestre D'Amas Etapa III; Mestre D'Armas VI; Mod. Rurais Mestre D'Armas; Morada Nobre; Nosso Lar; Nova Esperança; Núcleo Rural Taquara; Parcelamento Rural na Fazenda Mestre D'Armas; Park Mônaco; Parque Sol Nascente; Planaltina Oeste; Portal do Amanhecer I; Portal do Amanhecer III; Portal do Amanhecer S/N; Portal do Amanhecer V; Portal V; Privê Morada Norte; Projeto Sete; Quintas do Amanhecer; Quintas do Amanhecer II; Quintas do Amanhecer III; Quintas do Vale Verde I e II; Rancho do Biriba; Recanto Feliz; Reparc. Mestre D'Armas Ch. 16; Res. São Francisco; Residencial Marisol; Residencial Nova Planaltina; Residencial Prado; Residencial Samauma; Residencial Sandray; Residencial Sarandy; Residencial Sersan; Residencial Veneza I; Residencial Veneza II; Rural Mestre D'Armas; Rural Mestre D'Armas (Recanto do Sossego); San Sebastian; Setor de Mansões Itiquira; Setor de Mansões Mestre D'Armas I; Setor Residencial Nova Esperança; Sítio Prycilla; Sítios Agrovalle; Sítio Prycilla; Vale do Sol; Vila Feliz; Vila Nova Esperança; Vila Nova Esperança ch. 33; Vivendas Nova Petrópolis.

(Fonte:http://www.regularizar.df.gov.br/pages/condominios/planaltina/index.php; acessado em 07 de novembro de 2013) 
Somente o Setor Habitacional Arapoangas, no ano de 2006, segundo o relatório da Secretaria de Estado de Desenvolvimento Urbano e Habitação (SEDUH), totaliza 51.548 habitantes, respondendo por $10 \%$ das pessoas que viviam em situação de clandestinidade quanto ao uso e ocupação do solo no Distrito Federal.

No mesmo ano, respectivamente, os setores habitacionais Mestre D'Armas, Vale do Amanhecer e Aprodarmas, dispunham, na devida ordem, 27.064, 22.360 e 2.330 habitantes, cujas residências encontravam-se (e ainda permanecem) em situação de ilegalidade jurídica.

Em tal perspectiva, verifica-se o acréscimo do número de moradores e, proporcionalmente, o aumento das demandas sociais que perpassam pelo processo de regularização da questão fundiária de tais setores, que ao serem constituídos, situam-se tanto em áreas particulares como em terras pertencentes ao Distrito Federal, de posse da Companhia Imobiliária de Brasília (Terracap).

Diante das situações sucintamente apresentadas, tendo em vista a conjuntura jurídica das terras de Planaltina-DF e a condição do uso de seus moradores, cabe brevemente tecer uma reflexão sobre os pares dialéticos legal e ilegal, assim como os conceitos atinente aos termos irregular e clandestino.

Juridicamente, Bonavides (2000, p. 140), ao discorrer sobre o princípio da legalidade, assevera que o termo em questão correlaciona-se à "aquilo que exprime inteira conformidade com a ordem jurídica vigente".

Já Kist (2002, p. 243), ao definir legalidade em um âmbito generalizado, afirma que trata-se de "um atributo e um requisito do poder, que será legal quando exercido em conformidade com leis estabelecidas e aceitas". Este posicionamento expresso na definição de Kist será claramente observado nas decisões judiciais a serem exposta nos próximos capítulos, pesando, em algumas interpretações e definições, o direito à propriedade e de propriedade em PlanaltinaDF, face a judicialização do território.

O termo ilegal é esclarecido por Cunha (2009) como sendo aquilo que é contrário a Lei. Já o vocábulo legal, é exposto pelo mesmo autor enquanto tudo aquilo que está em conformidade com a Lei, como algo legítimo. 
Seguindo essas linhas de definição, o glossário jurídico do STF define Lei enquanto "regra geral e permanente a que todos estão submetidos" (Superior Tribunal Federal. Glossário Jurídico). ${ }^{7}$

Já o verbete regra, remete-se ao termo regular, que segundo Nascente (1988, p. 542) vincula-se ao "estabelecimento de regras", uniformidade normativa que norteia as práxis em seus diversos campos, incluindo o social.

O mesmo autor define regularização como "ato ou efeito de regularizar", podendo ser interpretado como o transitar de uma inconformidade normativa para uma situação de legitimidade, legalidade perante o conjunto de normas estabelecidas. No entanto, qual o elemento que possibilita que todas as estruturas que contem e estão contidos no território em uso se submetam aos ditames da Lei? De que maneira esta submissão, ou não, repercute no exercício pleno ao direito de propriedade no qual se inserem os moradores da cidade de Planaltina-DF?

Em se tratando do direito de propriedade, o reconhecimento da dominialidade e uso do solo urbano perpassa pelo crivo normativo relativo às práticas sociais, somado à situação em que o bem em uso (solo urbano) deve constar juridicamente, qualificado, regulado por um ente - o Estado - em suas distintas instâncias de Poder.

Tal estrutura, legitimada pela sociedade, exerce o controle organizacional das diversas situações inerentes ao convívio social, através de contrato (sistema de normas em seus diversos segmentos) que é definido para regular os vínculos entre os membros da sociedade, bem como, em relação com o próprio Estado em suas diversas perspectivas de atuação/regulação, refletindo sobre as frações do todo social, os indivíduos.

Ao uma comparação conceitual entre Estado e sociedade e os laços políticos, jurídicos, sociais e econômicos entre estes, Bonavides (2000) tece uma trama de definições para chegar ao entendimento de tal conexão (Estado e

7 In http://www.stf.jus.br/portal/glossario/verVerbete.asp?letra=L\&id=184, acessado em 29 de novembro de 2013). 
sociedade), pautando-se pelo viés dos laços jurídicos que promovem esta coesão. Enquanto fração deste todo, Planaltina-DF também se submete a esta lógica.

Nessa perspectiva de coexistências entre sociedade/Estado, Bonavides (2000, p. 69-70) esclarece que, anterior à existência do Estado e da sociedade, tem-se a comunidade, cujas relações se dão mediante uma perspectiva orgânico-familiar solidária entre os elementos constitutivos de um grupo.

Já ao fazer alusão a Agesta (1967), Bonavides (2000, p. 70) sinaliza que a sociedade é o estágio evoluído da comunidade, contudo, esta última não está extinta de seu bojo, sendo sinônimo de contrato, havendo uma solidariedade mecanicamente "governada pela razão".

Para Bonavides (2000, p. 71 ), a sociedade é concebida enquanto um ente "interposto entre o indivíduo e o Estado, é a realidade intermediária, mais larga e externa, superior ao Estado, porém inferior ainda ao indivíduo, enquanto medida de valor".

Termos como "sociedade", "contrato" e "razão", são elementos que expressam a coexistência de conflitos entre os indivíduos, havendo a premência da regulação/ação mediante a existência de um ente que estabeleça uma harmonia entre os elementos constitutivos da coletividade, mesmo não havendo laços de solidariedade orgânica entre todos os indivíduos.

Nesta dimensão, Bonavides (2000, p. 79), explicita o conceito de Estado como sendo "a corporação de um povo, assentada num determinado território e dotada de um poder originário de mando".

Tais afirmativas repousam-se na perspectiva da existência de um ente regulador que não se sobrepõe à integridade dos direitos coletivos (comunidades e sociedade) e, tampouco, dos indivíduos; muito embora seja conferido o poder para que este Estado estabeleça normas, assim como o exercício de intervenções/ações sobre os indivíduos em suas relações sociais.

O termo povo passa a dar coesão às distintas escalas dos segmentos sociais presentes em um território, cuja razão de ser do Estado perpassa pela 
concordância contratual dos indivíduos que compõem o todo, e pelo todo composto pelos distintos segmentos e indivíduos.

Cabe aqui ressaltar ainda que, conforme avaliza Bonavides (2000, p. 90), após a Revolução Francesa (séc. XVIII), o povo transitou da condição de serobjeto, quanto à realidade dos Estados Absolutistas, à condição de ser-sujeito nos Estados Democráticos; gerando uma consequência jurídica: o exercício do direito à cidadania. No caso do presente estudo, o exercício do direito à cidadania vincula-se ao direito de propriedade face a judicialização do território de Planaltina-DF.

Dando prosseguimento ao raciocínio, mediante a perspectiva citada, o termo "povo" para Bonavides (2000, p. 90) simplifica a condição do exercício da cidadania em um prisma subjetivo, cujos indivíduos disporiam de direitos e deveres perante a esse ente e com todas as demais estruturas que formava o todo.

Vale destacar que o termo cidadania advindo da conceituação jurídica de povo, assim como o seu exercício, são enfatizados pelo autor enquanto elementos vinculados a sua relação jurídica com o ente regulador, o Estado, e entre os demais indivíduos mediante vigência de normas. Bonavides (2000) assim expressa tal relação:

Com efeito, o povo exprime o conjunto de pessoas vinculadas de forma institucional e estável a um determinado ordenamento jurídico, ou (...) o conjunto de indivíduos que pertencem ao Estado, isto é, o conjunto de cidadãos.

(...) povo é o conjunto de pessoas que pertencem ao Estado pela relação de cidadania, ou (...) o conjunto de indivíduos vinculados pela cidadania a um determinado ordenamento jurídico. (BONAVIDES et al., 2000, p. 92).

Ainda fazendo referência a essa explanação conceitual, povo, cidadania e Estado, são inter-relacionados por Bonavides (2000) segundo os seguintes elementos associativos:

Urge por conseguinte dar ênfase ao laço de cidadania, ao vínculo particular ou específico que une o indivíduo a um certo sistema de leis, a um determinado ordenamento estatal.

A cidadania é a prova de identidade que mostra a relação ou vínculo do indivíduo com o Estado. É mediante essa relação que uma 
pessoa constitui fração ou parte de um povo. (BONAVIDES, 2000, p. 93).

Pode-se compreender que, legalmente, a condição de cidadania passa pelo fato do indivíduo, elemento contido em uma estrutura maior, está em conformidade jurídica em relação ao Estado e demais indivíduos, cujos laços são efetivados mediante as práticas sociais consonantes as Leis estabelecidas.

O vínculo social advém da prática universalizada desse sistema jurídico pelo povo na base territorial, tendo enquanto ente regulador o Estado.

O indivíduo, pelo fato de estar em situação de conformidade aos ditames da Lei é reconhecido pelo Estado, sendo resguardados os seus direitos e garantias perante ao contrato estabelecido, como o exercício de propriedade sobre um bem adquirido ou herdado, assim como do acesso aos serviços a serem prestados por esse Estado para com o indivíduo, inserido em um contexto social, jurídico-institucional.

Quanto ao direito de propriedade, esse pode ser visto sobre vários aspectos. O primeiro destes é a ação de resguardar o referido direito promovido pelo Estado em detrimento ao reconhecimento dos direitos adquiridos pelo indivíduo (direito subjetivo), fruto de sua situação de legalidade jurídica, condição ao pleno exercício da cidadania, estando amparado pelo Estado pela comprovação da dominialidade exercida sobre o bem imóvel pelo detentor.

O outro aspecto condiz com o exercício do direito de propriedade segundo os ditames e limites determinados pela Lei em seu caráter coletivo, cujo direito está vinculado à sua função social, tendo que cumprir os ditames atinentes aos preceitos urbanísticos, ambientais, financeiros, dentre outros. Sobre a multiplicidade jurídica do direito de propriedade, Pagani (2009) assim expõe:

No ordenamento jurídico constitucional Brasileiro, o direito de propriedade está elencado como um dos direitos fundamentais do homem, e é intermediário entre os direitos que tratam da liberdade e da segurança. Com estes, o direito de propriedade interage, pois, de fato, a propriedade constitui em instrumento realizador da liberdade e garantia de segurança para o homem, na medida em que realiza os seus desejos e resguarda das necessidades. Ao direito de propriedade, além das restrições naturais e voluntárias são impostas as restrições de caráter legal, originárias da própria natureza do direito de propriedade. As restrições legais visam impedir que 0 exercício do direito de propriedade venha acarretar abusos e 
prejuízos ao bem-estar coletivo. Destarte, entende-se que a propriedade compreende um complexo de normas de direito privado e de direito público. Não pode mais ser considerada como instituição com interesse estritamente privado, e sim obtém, além desse, o interesse público, uma vez que o Estado encontra-se legitimado para controlar o correto exercício do direito de propriedade tendo em vista o cumprimento da função social.

Para a doutrina moderna não há mais divergência em relação à natureza jurídica do direito de propriedade, que é um direito subjetivo. Entretanto, ainda que seja um direito subjetivo, não é um direito absoluto e não se confunde com a função social, devendo ser exercido pelo seu titular em consonância com a função social a que corresponde. (PAGANI, 2009, p. 47-48).

Segundo os ditames da Lei, o estado de legalidade jurídica, condição vinculada ao exercício da cidadania ao se tratar do direito à propriedade em seu caráter subjetivo, garante ao indivíduo "usar, gozar e dispor da coisa, e o direito de reavê-la do poder de quem injustamente a possua ou detenha" (Código Civil Brasileiro, 2008, art. 1.228).

Nesta perspectiva, quanto ao uso e ocupação do solo, o ilegal permeia o fato do bem, oriundo de pessoa física ou pessoa jurídica, encontrar-se em desconformidade com a lei ou não dispor de documento comprobatório, face aos pré-requisitos determinados pelo Estado, cujo entrelaçamento dá-se pelo contrato estabelecido entre esse (sistema de normas) e suas práticas.

Nestes termos, a não dominialidade - registro do imóvel em cartório expressa uma das dimensões do exercício do direito de propriedade, expondo uma situação de precariedade jurídica de não plenitude quanto ao exercício da cidadania, e que em várias situações, a serem expostas nos capítulos subsequentes, enquadrariam não apenas alguns indivíduos, mas grande parcela da coletividade em uma situação de ilegalidade.

Essa situação de ilegalidade identificada, relativa ao território usado de Planaltina-DF, revela as contradições das relações de produção do espaço urbano, ao longo do seu processo de formação socioespacial, indissociáveis da lógica existente em múltiplas escalas espaciais e resultante, em geral, da mesma lógica histórica que se cristalizou sobre o território e suas frações. Todavia, será enfatizado 
que o caso de Planaltina-DF dispôs de grande singularidade, uma vez que o seu processo de produção sofre um choque com o novo que se impõe: Brasília.

Ainda traçando a relação legal e ilegal, direito de propriedade e precariedade jurídica, 0 art. $5^{\circ}$ da Constituição da República Federativa do Brasil, em seus incisos XXII e XXIII, expressa a dimensão coletiva atinente ao direito de propriedade, uma vez que explicita que "é garantido o direito de propriedade", sendo condicionada a esta que atenda, que cumpra a "sua função social".

Para que a função social da propriedade seja legitimada, o ato dominial deve enquadrar-se não apenas nas referências jurídicas que dão publicidade e veracidade a detenção do bem por procedimentos administrativos e judiciais contidos no sistema jurídico emanado pelo Estado, possibilitando desta maneira o acesso ao registro imobiliário pelo indivíduo e o uso e a detenção do bem não deve ferir os princípios estabelecidos no contrato social entre Estado, o cidadão e coletividade.

Neste sentido, a condição de legalidade jurídica da propriedade que a vincula ao cumprimento de sua função social pode ser expressamente identificada na Lei no 10.257/2001, também conhecida como Estatuto da Cidade.

A Lei citada dispõe sobre uma série de obrigações, pré-requisitos jurídicos que normatizam e condicionam o acesso e/ou uso da propriedade urbana, que mediante o seu cumprimento ou nos encaminhamentos em tal direção, legitimam a detenção e o uso do bem imóvel quanto à política de uso e ocupação do solo.

Relativo ao conceito de uso e ocupação do solo, o mesmo Estatuto da Cidade (2002, p. 41) o explicita de maneira associada à prática de macrozoneamento, sendo este a "base fundamental para definir o uso e a ocupação do solo na cidade", ou seja, constituindo uma das ferramentas para a elaboração de políticas que visam tal finalidade. O conceito de uso e ocupação é exposto nesses termos:

$\mathrm{Na}$ abordagem tradicional, a Lei de Uso e Ocupação é vista como um mecanismo de regulação dos usos urbanos baseado principalmente 
em modelos idealistas de distribuição de densidades e compatibilidade de usos. Aqui, complementa-se essa visão com uma nova maneira de tratar o uso e a ocupação do solo, incorporando a dimensão de seus efeitos sobre o processo de formação de preços no mercado imobiliário e na adequação entre as reais condições das diferentes partes da cidade e a ocupação que essas áreas podem receber. A Lei de Uso e Ocupação do Solo, portanto, pode passar a induzir usos e ocupações específicos, quando identifica distorções entre a capacidade e a real utilização de cada parcela da cidade. Da mesma maneira, a lei pode mediar conflitos entre usos e ocupações incompatíveis na cidade. (BRASIL, 2002, p. 34).

Enquanto instrumentos que viabilizam a proposição de leis condizentes ao uso e ocupação do solo, podem ser citados o macrozoneamento que auxilia na definição de um perímetro urbano, zoneamento de áreas centrais que se associam a preservação de áreas tombadas enquanto patrimônio histórico, e o zoneamento ambiental.

No caso do Distrito Federal, a Lei de Uso e Ocupação do Solo encontra-se em processo de construção (LUOS), sendo a mesma prevista na revisão do Plano Diretor de Ordenamento Territorial, Lei Complementar $n^{\circ} 803$. A LUOS conceitua a prática de uso e ocupação nos seguintes termos:

Por uso entende-se: conjunto das atividades que podem ser desenvolvidas no interior do lote.

Por parâmetros de ocupação entende-se: o limite da área que pode ser construída; a quantidade de área do terreno que pode ser ocupado; a quantidade de áreas livres permeáveis que deve ser conservadas no terreno; a altura máxima da edificação; os afastamentos obrigatórios e outros. (GOVERNO DO DISTRITO FEDERAL. Lei Complementar de Uso e Ocupação do Solo, 2013).

Nestes termos, a condição de legalidade jurídica da propriedade urbana deve resguardar, dentre outros elementos, os direitos individuais, coletivos, econômicos e ambientais que se sobrepõem ao território em uso, cujo fazer cumprir, por parte dos indivíduos, lhes inserem na situação de legalidade. Esta sobreposição normativa referente à Planaltina-DF expõe as contradições entre os indivíduos, até mesmo grande entre parcela da coletividade e o exercício do direito de propriedade na citada região administrativa.

Por consequência ao estado de legalidade da propriedade em uso, segundo os ditames da Lei, é garantido ao indivíduo ou à coletividade o direito de 
propriedade, assim como, a função social da propriedade. Os dispositivos abaixo expressam a relação entre direito a propriedade e sua função social:

Parágrafo único. Para todos os efeitos, esta Lei, denominada Estatuto da Cidade, estabelece normas de ordem pública e interesse social que regulam o uso da propriedade urbana em prol do bem coletivo, da segurança e do bem-estar dos cidadãos, bem como do equilíbrio ambiental.

Art. 2-A política urbana tem por objetivo ordenar 0 pleno desenvolvimento das funções sociais da cidade e da propriedade urbana, mediante as seguintes diretrizes gerais:

I - garantia do direito a cidades sustentáveis, entendido como o direito à terra urbana, à moradia, ao saneamento ambiental, à infraestrutura urbana, ao transporte e aos serviços públicos, ao trabalho e ao lazer, para as presentes e futuras gerações;

IV - planejamento do desenvolvimento das cidades, da distribuição espacial da população e das atividades econômicas do Município e do território sob sua área de influência, de modo a evitar e corrigir as distorções do crescimento urbano e seus efeitos negativos sobre 0 meio ambiente;

$\mathrm{V}$ - oferta de equipamentos urbanos e comunitários, transporte e serviços públicos adequados aos interesses e necessidades da população e às características locais;

$\mathrm{VI}$ - ordenação e controle do uso do solo, de forma a evitar:

a) a utilização inadequada dos imóveis urbanos;

b) a proximidade de usos incompatíveis ou inconvenientes;

c) o parcelamento do solo, a edificação ou o uso excessivos ou inadequados em relação à infraestrutura urbana;

d) a instalação de empreendimentos ou atividades que possam funcionar como polos geradores de tráfego, sem a previsão da infraestrutura correspondente;

e) a retenção especulativa de imóvel urbano, que resulte na sua subutilização ou não utilização;

f) a deterioração das áreas urbanizadas;

g) a poluição e a degradação ambiental;

h) a exposição da população a riscos de desastres;

VIII - adoção de padrões de produção e consumo de bens e serviços e de expansão urbana compatíveis com os limites da sustentabilidade ambiental, social e econômica do Município e do território sob sua área de influência; 
IX - justa distribuição dos benefícios e ônus decorrentes do processo de urbanização;

XII - proteção, preservação e recuperação do meio ambiente natural e construído, do patrimônio cultural, histórico, artístico, paisagístico e arqueológico;

XIII - audiência do Poder Público municipal e da população interessada nos processos de implantação de empreendimentos ou atividades com efeitos potencialmente negativos sobre o meio ambiente natural ou construído, o conforto ou a segurança da população;

XIV - regularização fundiária e urbanização de áreas ocupadas por população de baixa renda mediante o estabelecimento de normas especiais de urbanização, uso e ocupação do solo e edificação, consideradas a situação socioeconômica da população e as normas ambientais;

XV - simplificação da legislação de parcelamento, uso e ocupação do solo e das normas edilícias, com vistas a permitir a redução dos custos e o aumento da oferta dos lotes e unidades habitacionais;

$\mathrm{XVI}$ - isonomia de condições para os agentes públicos e privados na promoção de empreendimentos e atividades relativos ao processo de urbanização, atendido o interesse social.

XVII - estímulo à utilização, nos parcelamentos do solo e nas edificações urbanas, de sistemas operacionais, padrões construtivos e aportes tecnológicos que objetivem a redução de impactos ambientais e a economia de recursos naturais. (BRASIL, 2002).

Muito embora a norma exposta elenque uma série de incumbências em relação ao Estado, cujo intuito é possibilitar o acesso à moradia, gerando assim uma expectativa de exercício do direito de propriedade, verifica-se que a condição de posse/uso individual da propriedade, legalmente reconhecida pelo Estado, perpassa pelo atendimento de uma série de requisitos contidos no ciado texto legal.

Esses requisitos vinculam-se à permanência do indivíduo em área destinada apenas ao uso habitacional compatível com a legislação vigente que não se encontre em áreas de riscos - geralmente famílias de baixa renda - ou de proteção ambiental, que corresponde ao uso ambientalmente equilibrado do solo, assim como os possíveis impactos de vizinhança que o uso inadequado das áreas urbanas pode gerar ao não obedecerem às determinações legais. Outro elemento pode ser a subutilização dos imóveis que podem desdobrar-se na degradação urbana ou vincular-se à prática especulativa do uso da terra. 
Tais requisitos podem ser identificados em comandos como o bemestar dos cidadãos, o equilíbrio ambiental, a sujeição ao controle e uso do solo perante o Estado, que vincula-se à questão do planejamento do desenvolvimento das cidades, da distribuição espacial da população e das atividades econômicas, dentre outros elementos presentes na norma.

Cabe destacar os incisos XIV e XV contidos na Lei ㄲo. 10.257 que corroboram com o exercício de cognição face ao termo ilegal. Vê-se então que tais dispositivos absorvem as pessoas que não encontram-se no pleno exercício da cidadania, quanto à sua condição de precariedade jurídica mediante o uso e ocupação do solo dispostos nos demais tópicos da norma, não desfrutando desta maneira, ao pleno direito a propriedade e muito menos ao direito de propriedade. Este situação é amplamente observada em Planaltina-DF.

O código civil expressa, em alguns de seus mecanismos, o processo de formalização do direito de propriedade, o qual retira o indivíduo de uma situação de precariedade dominial. Algumas das normas relativas à importância do registro da titularidade do imóvel referem-se a esses termos no código citado dessa forma:

Art. 1.245. Transfere-se entre vivos a propriedade mediante o registro do título translativo no Registro de Imóveis

§ 10 Enquanto não se registrar o título translativo, o alienante continua a ser havido como dono do imóvel.

Art. 1.246. O registro é eficaz desde o momento em que se apresentar o título ao oficial do registro, e este o prenotar no protocolo.

Art. 1.247. Se o teor do registro não exprimir a verdade, poderá o interessado reclamar que se retifique ou anule. Ver tópico (685 documentos)

Parágrafo único. Cancelado o registro, poderá o proprietário reivindicar o imóvel, independentemente da boa-fé ou do título do terceiro adquirente. (CÓDIGO CIVIL BRASILEIRO, 2008, art. 12451246-1247).

No trecho acima, vale destacar o parágrafo primeiro do art. 1245 do Código Civil, pois este se aplica em várias situações de precariedade jurídica, contidas na questão da titularidade dos imóveis urbanos situadas na cidade de Planaltina-DF. 
A importância da titularidade que comprova a propriedade do imóvel por meio de registro cartorial ${ }^{8}$ é assim evidenciada em um dos textos legais recentes que abordam tal tema, a Lei ํo. 11.997/2009. Tal norma, além de dispor sobre o Programa Minha Casa, Minha Vida, trata também dos parâmetros para efetivação da regularização fundiária de loteamentos irregulares ou clandestinos localizados em áreas urbanas.

O art. 21, que compõe o segmento normativo que trata das regras de financiamento e atuação do setor financeiro para com o programa, expõe a busca pela garantia à posse quanto ao adquirente do imóvel e seus beneficiários diretos, mesmo que estes passem por uma série de privações econômicas que os impossibilitem de quitar o pagamento do patrimônio adquirido junto ao Estado.

Assim, o comando normativo impede as instituições financiadoras do programa, a retomada da propriedade adquirida. O Estado, em algumas situações abaixo descritas, tal como é exposto na Lei no. 11.997/2009, se compromete em ser o avalista do débito com as instituições privadas, com o intuito de legitimar a posse do bem, mediante a escrituração e registro imobiliário do imóvel, efetivando o exercício do direito de propriedade, ficando a cargo do adquirente a execução de tal procedimento administrativo. Este raciocínio é expresso da seguinte maneira na Lei:

Art. 20. Fica a União autorizada a participar, até o limite de $\mathrm{R} \$ 2.000 .000 .000,00$ (dois bilhões de reais), de Fundo Garantidor da Habitação Popular - FGHab, que terá por finalidades:

I - garantir o pagamento aos agentes financeiros de prestação mensal de financiamento habitacional, no âmbito do Sistema Financeiro da Habitação, devida por mutuário final, em caso de desemprego e redução temporária da capacidade de pagamento, para famílias com renda mensal de até $\mathrm{R} \$ 4.650,00$ (quatro mil, seiscentos e cinquenta reais);

II - assumir o saldo devedor do financiamento imobiliário, em caso de morte e invalidez permanente, e as despesas de recuperação relativas a danos físicos ao imóvel para mutuários com renda familiar mensal de até $R \$ 4.650,00$ (quatro mil, seiscentos e cinquenta reais).

\footnotetext{
${ }^{8}$ Santana de Melo (2006, p.07) define a função dos órgãos registrários nos seguintes termos:

Destarte, podemos definir o Registro de Imóveis como órgão auxiliar do Direito Civil destinado ao assentamento de títulos públicos e privados, outorgando-lhes oponibilidade a terceiros, com ampla publicidade e destinado ao controle, eficácia, segurança e autenticidade das relações jurídicas envolvendo imóveis, garantindo-Ihes presunção relativa da prova da propriedade.
} 
Art. 21. É facultada a constituição de patrimônio de afetação para a cobertura de que trata o inciso II do caput do art. 20, que não se comunicará com o restante do patrimônio do FGHab, ficando vinculado exclusivamente à garantia da respectiva cobertura, não podendo ser objeto de penhora, arresto, sequestro, busca e apreensão ou qualquer ato de constrição judicial decorrente de outras obrigações do Fundo.

Parágrafo único. A constituição do patrimônio de afetação será feita por registro em cartório de registro de títulos e documentos. (PRESIDÊNCIA DA REPÚBLICA. Lei $\mathrm{n}^{\circ}$ 11.997/2009. In http://www.planalto.gov.br/ccivil_03/_ato2007-

2010/2009/lei/l11977.htm; acessado em 29 de novembro de 2013).

O que se buscou brevemente, ao trabalhar os pares dialéticos legal e ilegal foi demonstrar a contradição imposta pelo contrato social estabelecido entre Estado, sociedade e os indivíduos pertencentes a essa estrutura, tendo em vista a disparidade de acesso à propriedade que cumpra todos os pré-requisitos que a caracterize enquanto legalizada por todos os cidadãos.

Essa impossibilidade, no caso de Planaltina-DF, está associada à fragilidade de acesso à habitação como resposta a lógica da rarefação das políticas públicas de aquisição de moradia por parte das famílias de baixa renda, assim como da classe média, estrato social cuja demanda aquece o inflacionado mercado imobiliário.

Estes fatos repercutem no uso especulativo do solo pelos agentes do Estado ou por particulares no caso de Planaltina-DF, sendo que estes últimos, muitas vezes, valem-se da precariedade jurídica das terras, cuja dominialidade é requerida pela União, Terracap e por seus supostos proprietários.

Nesta dinâmica, observa-se a presença de diversos agentes corporativos (políticos, financeiros, imobiliários) que contradizem a lógica da teoria política. Os seus interesses sobrepõem aos da coletividade, sobretudo o direito do individual a/de propriedade, ditando a desenvoltura do mercado imobiliário, assim como a normatização que possibilita, ou não, a inserção do indivíduo em uma condição de legalidade referente ao domínio do bem imóvel. 
Seguindo tal linha de pensamento, Carlos (2011) define o espaço urbano em movimento não apenas enquanto resultado das relações de produção, mas das determinações sociais, políticas, ideológicas e jurídicas presentes na composição da formação econômica e social de uma dada sociedade. Assim a autora assevera:

No espaço urbano, por exemplo, fundam-se os interesses do capital, a ação do Estado e a luta dos moradores como forma de resistência contra a segregação no espaço residencial e pelo direito à cidade. A ideia de urbano transcende aquela de mera concentração do processo produtivo stricto sensu; ele é um produto do processo de produção num determinado momento histórico, não só no que se refere à determinação econômica do processo (produção, distribuição, circulação e troca), mas também às determinações sociais, políticas, ideológicas, jurídicas que se articulam na totalidade da formação econômica e social. Desta forma, o urbano é mais do que um modo de produzir, é também um modo de consumir, pensar, sentir, enfim, é um modo de vida. É, todavia, na materialização da divisão espacial do trabalho que aparecem as relações contraditórias do processo de reprodução do capital. (CARLOS, 2011, p. 26-27).

A titularidade do imóvel em Planaltina-DF, cujo fim jurídico conduz ao registro cartorial do bem, caracteriza-se enquanto expressão da lógica do movimento da cidade que não é dissonante ao conflito estabelecido entre os múltiplos agentes ao longo do seu processo de formação. Lógica esta que contem em outras escalas espaciais e que está contida em Planaltina enquanto subespaço, lugar, mas que responde de forma singular a esse processo múltiplo.

Nesse sentido, Planaltina caracteriza-se por ser um mosaico complexo de sobreposições decisórias dos distintos Poderes, de normas e de agentes que ao longo do tempo exerceram/exercem o próprio poder sobre tal subespaço.

A atual condição de precariedade jurídica dos imóveis existentes na cidade é oriunda do acumulo de ações/intenções e omissões dos Poderes Públicos (Executivo, Legislativo e Judiciário) em suas distintas esferas que, em períodos distintos, somados aos demais agentes, revelam a lógica evolutiva do modo de produção que também passa por mutações.

Tem-se, enquanto resultados, a composição das formas espaciais e as características de sua coletividade social, que no caso de Planaltina-DF, mais 
recentemente, assinalam o misto de segregação socioespacial e especulação do solo urbano/rural.

No direito de propriedade e demais campos normativos, o ato de estar em situação de legalidade jurídica perante o Estado constitui-se fator complexo e oneroso para alguns segmentos sociais, principalmente os de baixa renda.

Além disso, é nítido que o tempo da burocracia destoa das necessidades sociais na vivência da espacialidade e temporalidade real, não contemplando os anseios imediatos do uso do território pelas camadas desprovidas economicamente, bem como os das mais abastadas.

Muitas vezes, a ação subversiva do ato de transgredir as normas vigentes que lhe retira a condição de vivência plena da cidadania (ilegalidade) expressa a luta pela busca de inserção social, cujo acesso à moradia e à titularidade do bem está presente no direito à propriedade (mesmo que os indivíduos, em muitos casos, desconheçam as suas garantias e deveres contratuais, constitucionais), segundo Pagani (2009).

Bobbio (1997) ao expor uma visão esclarecedora sobre o neocontratualismo numa perspectiva global, discorre que, atualmente, os indivíduos não cobram do Estado apenas a proteção jurídica da propriedade privada, cobram também a inalterabilidade desse direito.

É objeto das novas demandas também que esse ente, mediante ações junto à sociedade e aos indivíduos que a compõem, promova um novo ordenamento social que se preocupe com a diminuição das disparidades sociais e que, no estudo em questão correlacionado ao caso de Planaltina-DF, associa-se ao cumprimento da função social do direito a/de propriedade. Nestes termos, o autor se expressa:

O neocontratualismo, isto é, a proposta de um novo pacto social, global e não parcial, de pacificação geral e de fundação de um novo ordenamento social, uma verdadeira "nova aliança", nasce exatamente da constatação da debilidade crônica de que dá provas o poder público nas sociedades econômica e politicamente mais desenvolvidas, ou então - para usar uma palavra corrente - da crescente ingovernabilidade das sociedades complexas. A maior dificuldade que o neocontratualismo deve hoje enfrentar depende do fato de que os indivíduos detentores, cada um independentemente do outro, de uma pequena cota do poder soberano, protagonistas do contínuo processo de legitimação e re-legitimação dos órgãos encarregados de tomar as decisões coletivas - indivíduos portanto que são, em definitivo, titulares últimos do direito de determinar as 
cláusulas do novo pacto -, não se contentam mais em pedir, em troca da sua obediência, apenas a proteção das liberdades fundamentais e da propriedade adquirida através das trocas (é a teoria do estado mínimo de Nozick), mas passam a pedir que venha inserida no pacto alguma cláusula que assegure uma equânime distribuição da riqueza, para com isso atenuar, se não mesmo eliminar, as desigualdades dos pontos de partida. (BOBBIO, 1997, p. 148).

O fato da existência da condição de ilegalidade devem ser imputados não apenas aos indivíduos, mas também as ações, omissões do Poder Público ao longo do tempo, somados à dinâmica dos agentes corporativos, que no caso da área urbana de Planaltina-DF, em especial, podem ser exemplificadas na atual conjuntura jurídica do Setor Tradicional.

Ao tratar das dinâmicas de composição do espaço urbano do Distrito Federal, mas não fugindo do processo corrente em Planaltina-DF e mediante a perspectiva do arranjo das atuais áreas urbanas ilegais, Malagutti (1997), sob uma perspectiva jurídica, apresenta a distinção conceitual do que venha a ser loteamentos irregulares e parcelamentos clandestinos.

Para Malagutti (1997, p. 148), ao fazer uso do termo parcelamento clandestino e ao confrontá-lo e distinguí-lo com a terminologia parcelamento irregular, contrasta ambos demonstrando ser fruto de "aprovação efetuada pelo Poder Público".

Nestes termos, sobre a questão, Malagutti (1997) assim expressa à diferença de nomenclatura que conduz a situação jurídica do parcelamento do solo:

Os loteamentos e desmembramentos tornam-se legais quando aprovados pelo Poder Público, executados segundo a respectiva aprovação e registrados no cartório imobiliário competente, nos termos das normas jurídicas vigentes a época da aprovação, da execução e do registro do projeto. Entende-se, portanto, que o projeto urbanístico de parcelamento só é legítimo se realizado em conformidade com as leis municipais, e das leis federais que lhes sejam pertinentes, em tudo que lhe disser respeito a sua aprovação, a sua execução e ao seu registro. Quando aprovados, mas executados em discordância com a legislação, devem ser considerados irregulares; quando implantados sem a devida aprovação, devem ser considerados clandestinos. (MALAGUTTI,1997, p. 148).

Conforme o exposto, não restam dúvidas que os setores habitacionais Arapoangas, Estância Mestre D'Ármas, Aprodarmas, Vale do Amanhecer, e tantos outros encontram-se em completa situação de clandestinidade. 
A PDAD (2013, p. 19), ao tratar da questão relacionada à situação jurídica de posse e propriedade dos imóveis expresso na tabela 03, assevera que das mais de 49.000 residências contidas em Planaltina, "32,96\% declararam ter contrato de compra e venda, $26,23 \%$, escritura definitiva e $15,49 \%$, concessão de uso, enquanto $25,04 \% "$, declararam não disporem de imóveis.

Tabela 03 - Planaltina-DF: Domicílios ocupados conforme a posse de documento do imóvel, 2013.

\begin{tabular}{ccc}
\hline Tipo de Documento & № & $\%$ \\
\hline Não tem imóvel & 12.293 & 25,04 \\
Escritura definitiva & 12.883 & 26,23 \\
Concessão de uso & 7.607 & 15,49 \\
$\quad$ Contrato de & 74 & 0,15 \\
financiamento particular & & - \\
$\quad \begin{array}{c}\text { Contrato de } \\
\text { financiamento } \\
\text { governamental }\end{array}$ & - & \\
Contrato de compra e \\
venda \\
$\quad$ Outros & 16.183 & 32,96 \\
Total & 63 & 0,13 \\
\hline Fon & 49.103 & 100,00 \\
\hline
\end{tabular}

Fonte: CODEPLAN - Pesquisa Distrital por Amostra de Domicílios - Planaltina PDAD 2013.

$\mathrm{Na}$ tabela fica evidente o quantitativo de pessoas que não possuem imóveis na cidade, demonstrando uma das características do perfil socioeconômico dos habitantes de Planaltina-DF. Condição esta que em muitos casos os impulsionam a ocuparem parcelamentos clandestinos.

Todavia, além dessa situação, outro elemento que atesta a complexidade da situação jurídica da terra é expressa pela documentação dos imóveis, cujo baixo índice de moradias declaradas no censo possuem escritura definitiva - apenas $15 \%$ - tendo em outros $32 \%$ apenas o contrato de compra e venda. É notório que o termo registro sequer é mencionado.

Tais alegações reafirmam a condição de precariedade jurídica aos quais os moradores de Planaltina-DF se encontram. E o que é pior, essas informações são baseadas apenas na palavra dos entrevistados, não se tendo a plena certeza de fato que a totalidade daqueles que afirmaram ter apenas a escritura dos imóveis, assim efetivamente gozem de tal situação que ainda não lhes garantem a dominialidade do imóvel. 
Corroborando esta preocupação, tem-se o relatório produzido pela SEDHAB no ano de 2012, intitulado "Plano Distrital de Habitação de Interesse Social: diagnóstico da situação habitacional de interesse social". Este relatório traz informações sobre a conjuntura jurídica das propriedades contidas nas Regiões Administrativas do Distrito Federal.

Muito embora seja traçado um perfil geral das condições de precariedade jurídica dos imóveis em uma escala regional, tal análise reflete 0 cenário característico de Planaltina-DF. Conquanto, em alguns setores da cidade, como o Setor Tradicional, tal conjuntura de ilegalidade de seus imóveis revela-se sui generis tendo em vista o quadro do Distrito Federal, quiçá do Brasil. O diagnóstico expõe a situação nos seguintes termos:

Ao contrário do que o senso comum passou a considerar no Distrito Federal, não somente condomínios irregulares ou as chamadas soluções criadas pela própria sociedade para a falta de oferta pública de solução de moradia, encontram-se entre os Núcleos Habitacionais de Interesse Social que necessitam de Regularização Fundiária.

Todas as novas cidades criadas pela política de assentamento habitacional que consistia na distribuição de lotes como solução de moradia, encontram-se em situação de irregularidade já que a imensa maioria de seus moradores não receberam documentos definitivos ou que oficializem a propriedade ou mesmo a posse da Unidade Habitacional que atualmente ocupam.

Estarão incluídos como Necessidade Habitacional por Regularização Fundiária, portanto, tanto os chamados aglomerados subnormais e condomínios de interesse social, quanto às novas cidades, oriundas do Programa de Assentamento. (GOVERNO DO DISTRITO FEDERAL, 2012, p. 44-45).

Conforme fora exposto anteriormente, o caso de Planaltina, território usado no presente, traz em seu cerne um processo de formação socioespacial de no mínimo 200 anos, cuja sua complexidade jurídica não remonta apenas - segundo a terminologia de Malagutti (1997) - aos assentamentos irregulares ou parcelamentos clandestinos oriundos de uma produção social recente.

Planaltina-DF é uma totalidade, tendo em suas frações facetas juridicamente tão complexas quanto ao todo, cuja síntese em sua completude e de forma detalhada ainda não fora revelado em termos jurídicos. 
Para corroborar com tal afirmação tem-se nas figura 02 e tabela 04 , que estão a seguir, presentes no documento Plano Distrital de Habitação de Interesse Social (2012), a sinalização de que praticamente a totalidade da cidade de Planaltina está em situação de precariedade jurídica, concernente à questão da circunstância legal dos imóveis - registro cartorial - uma vez que suas extremidades não gozam de uma situação juridicamente regularizada.

Já na tabela 04 vê-se que a condição de ilegalidade não permeia apenas os parcelamentos clandestinos que se materializaram nos últimos 30 anos, mas também o setor central ao qual também está contido o Setor Tradicional, defrontando-se também com tal conjuntura face a precariedade jurídica de seus imóveis. 
Figura 02 - Cidades consolidadas sem regularização fundiária, por quantidade de unidades habitacionais.

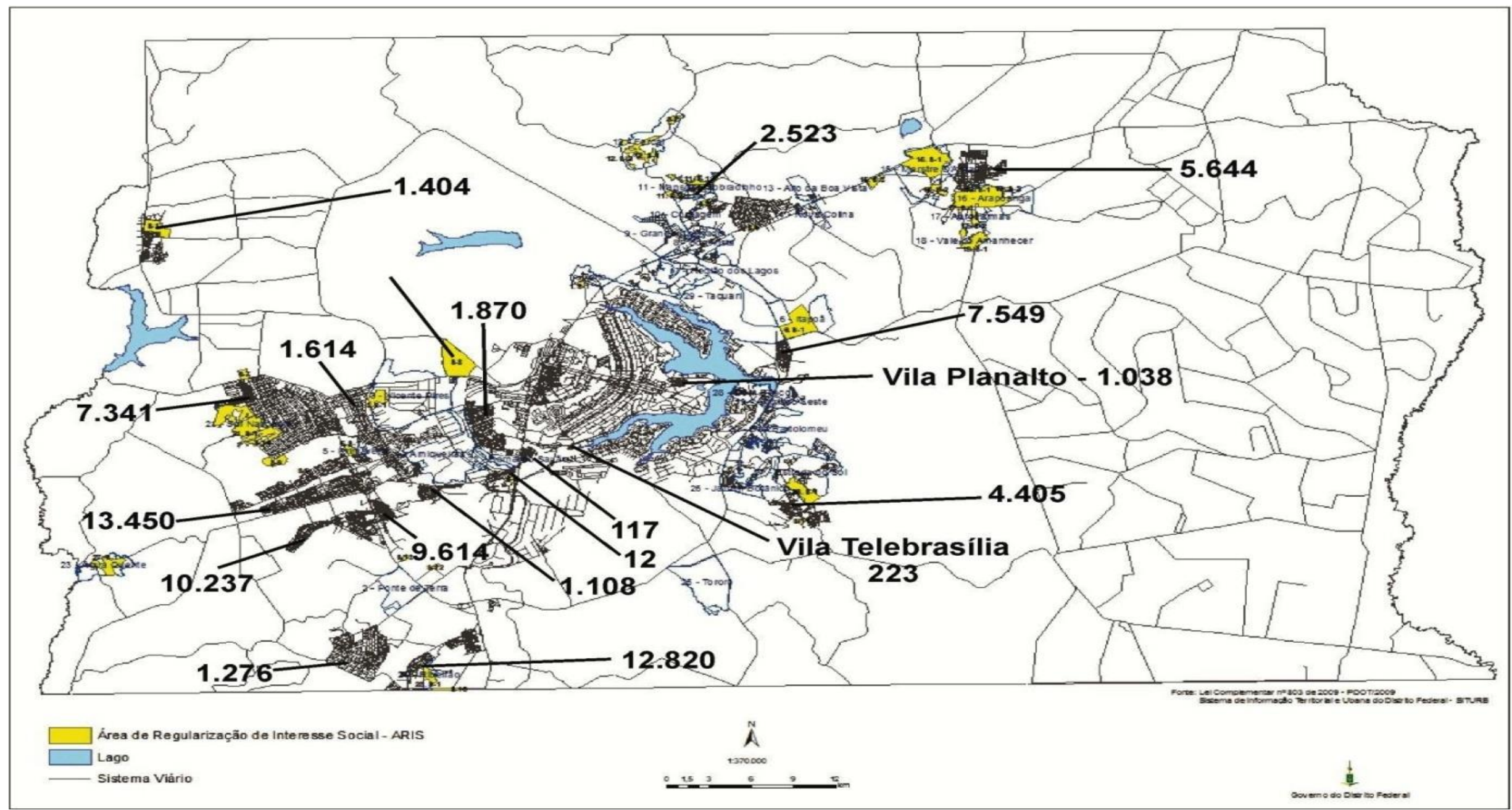

Fonte: Governo do Distrito Federal. Plano Distrital de Habitação de Interesse Social: diagnóstico da situação habitacional de interesse social (2012). 
Tabela 04 - Distrito Federal: Núcleos Habitacionais de Interesse Social com processo de regularização em andamento, 2012.

\begin{tabular}{|c|c|c|c|}
\hline Programa de Regularização & Cidades & $\begin{array}{c}\text { Unidades } \\
\text { Habitacionais }\end{array}$ & Situação \\
\hline 1 - QE 44 & Guará & 140 & \\
\hline 2 - QNP 22 e QNP 24 & Ceilândia & 939 & \\
\hline 3 - Pôr do Sol & Ceilândia & 2.084 & Em desenvolvimento \\
\hline 4 - Becos de Ceilândia & Ceilândia & 2.620 & \\
\hline 5 - Becos de Taquatinga & Taquatinga & 59 & \\
\hline 6 - Becos de Brazlândia & Brazlândia & 154 & \\
\hline 7 - Becos Gama & Gama & 538 & \\
\hline 8 - Pontas de quadra Taguatinga & Taguatinga & 178 & \\
\hline $\begin{array}{l}9 \text { - Pontas de quadra Riacho } \\
\text { Fundo II }\end{array}$ & Riacho Fundo II & ---- & \\
\hline $\begin{array}{l}10 \text { - Pontas de quadra } \\
\text { Sobradinho II }\end{array}$ & Sobradinho II & 590 & A iniciar \\
\hline 11 - Setor Habitacional Primavera & Samambaia & 1.200 & Contrato \\
\hline 12 - Setor Central de Planaltina & Planaltina & ---- & A Iniciar \\
\hline 13 - Condomínio Itapoã & Sobradinho & 12.000 & A Iniciar \\
\hline $\begin{array}{l}14 \text { - Núcleo Urbano de São } \\
\text { Sebastião }\end{array}$ & São Sebastião & 20.000 & $\begin{array}{c}\text { Em } \\
\text { Desenvolvimento }\end{array}$ \\
\hline $\begin{array}{l}15 \text { - Setor Habitacional Água } \\
\text { Quente }\end{array}$ & $\begin{array}{l}\text { Recanto das } \\
\text { Emas }\end{array}$ & 2.356 & Contrato \\
\hline 16 - Engenho das Lajes & Gama & 950 & A Iniciar \\
\hline 17 - Vila São José & Vicente Pires & 604 & Contrato \\
\hline $\begin{array}{l}18 \text { - Expansão da Vila São } \\
\text { José }\end{array}$ & Brazlândia & 585 & A Iniciar \\
\hline $\begin{array}{l}19 \text { - Condomínio Privê } \\
\text { Ceilândia }\end{array}$ & Ceilândia & 1.859 & A Iniciar \\
\hline 20 - Vila Planalto & Brasília & 2.450 & $\begin{array}{c}\text { Em } \\
\text { Desenvolvimento }\end{array}$ \\
\hline $\begin{array}{l}21 \text { - Área consolidada do } \\
\text { Paranoá }\end{array}$ & Paranoá & 18.500 & A Iniciar \\
\hline 22 - Vila Basevi & Sobradinho & 624 & Contrato \\
\hline 23 - Vila Telebrasília & Brasília & 350 & $\begin{array}{c}\text { Em } \\
\text { Desenvolvimento }\end{array}$ \\
\hline 24 - Porto Rico & Santa Maria & 1.926 & Contrato \\
\hline 25 - Vila Cauhy & $\begin{array}{c}\text { Núcleo } \\
\text { Bandeirante }\end{array}$ & 438 & Contrato \\
\hline 26 - Mansões Sobradinho I & Sobradinho II & 1.800 & Contrato \\
\hline 27 - Fercal & Sobradinho II & 336 & A Iniciar \\
\hline 28 - Buritis & Sobradinho II & 1.380 & Contrato \\
\hline 29 - Estrutural & SCIA & ----- & A Iniciar \\
\hline
\end{tabular}


Verifica-se, na tabela 04 , que sequer o quantitativo de unidades habitacionais irregulares, da área central de Planaltina-DF, chegam a ser expressas no documento, podendo-se especular quanto à magnitude do problema existente na cidade.

Neste sentido, tendo em vista a situação de precariedade jurídica de sua área central e a cognição dos processos que resultam no âmbito da materialidade, Santos (2002) explicita que para se compreender o todo é necessário o entendimento de suas frações, para que, posteriormente, se possa chegar a um todo novo. Nessa perspectiva é válido trazer o pensamento do autor:

(...) o movimento da totalidade permite entende-la, num primeiro momento, como uma integral e, num segundo momento, como uma diferencial. Enquanto integral, a totalidade é vista como algo uno e, frequentemente, em abstrato. Enquanto diferencial, ela é apreciada em suas manifestações particulares de forma, de função, de valor, de relação, isto é, em concreto." (SANTOS 2002, p. 122).

A priori, vê-se um todo que se encontra em uma situação de desconformidade com as normas vigentes, entretanto, só é possível compreender mais a fundo a multiplicidade de impasses legais que compõem o território em uso no presente (totalidade diferencial), via periodização, sendo utilizado para tal a categoria de formação socioespacial.

Neste exercício de periodização, faz-se necessário compreender o processo de produção deste mosaico urbano, bem como, as ações oriundas dos múltiplos agentes, carregados de diversas intencionalidades, que se acumulam ao longo do espaço-tempo.

Após o exercício de caracterização do objeto, é pertinente os seguintes questionamentos: quais são as lógicas que permeiam o processo de formação socioespacial da cidade de Planaltina, marcado pela condição de ilegalidade jurídica e posse precária das propriedades?

Mediante a multiplicidade de agentes envolvidos ao longo da formação socioespacial da cidade, de que maneira o Poder Judiciário contribui na produção dos sistemas de objetos espaciais e na relação de produção sociedade, espaço?

Para elucidar tais questionamentos em busca da compreensão do território usado no presente, da composição dos seus objetos espaciais, dos agentes que fazem uso deste território, bem como das lógicas atreladas à condição de 
ilegalidade jurídica dos imóveis urbanos, tem-se o início do entendimento dos processos de produção do espaço urbano de Planaltina através da operacionalização da categoria formação socioespacial cunhada por Santos.

1.2 - Planaltina pré-Brasília: a vigência de um meio pré-máquina.

Ao buscar a compreensão da constituição do espaço e do seu movimento, sua (re)produção, tem-se, enquanto anseio, a cognição dos processos, dos eventos, agentes, da multiplicidade e complexidade das inter-relações dos elementos, da composição de novas estruturas contidos no interior de um sistema explicativo e lógico, tendo por finalidade o entendimento da realidade concreta.

Para que seja, minimamente, possível captar os fenômenos urbanos em seu aspecto real ou próximo a este, se faz necessário, assim como no exercício de entendimento da produção do espaço geográfico, a realização do esforço de abstração para que o objeto seja apreendido em sua essência.

A essência do objeto concreto encontra-se no plano das ideias, cujo exercício teórico proporciona uma forma sistematizada de ver o mundo, na procura pela assimilação do real complexo.

Antônio Carlos Robert Morais (s.n.t.), ao expor a teorização de Luckac's face ao corte ontológico do objeto científico, por meio da utilização do recurso/instrumento interpretativo de pesquisa, totalidade/totalização (essência do todo em movimento), aborda tal exercício de abstração e concretude ao tratar do método dialético, mediante a multiplicidade de possibilidades de explicação dos fenômenos espaciais por intermédio da, antes mencionada, visão científica. Assim o autor expressa seu pensamento:

Os procedimentos analíticos que acompanham esta orientação são a abstração e a concretude. No movimento preliminar de abstração formaliza-se o mundo sensível estabelecendo recortes e isolando processos e fenômenos. Isso permite que se fale de cidade, metrópole, território, cultura ou capitalismo, sem especificação histórica ou geográfica. Ou seja, possibilita a construção de universais abstratos que servem para denominar qualquer manifestação empírica do fenômeno ou processo assim isolado (...) 
A concreção é um procedimento posterior de re-inserção das relações, de estabelecimento de nexos, de retomada de condicionantes históricos geográficos, de articulação das mediações ignoradas no procedimento anterior. É o transito do universal abstrato para o singular concreto, e esta passagem se dá pela particularidade (...)Neste sentido, concretar é particularizar os universos abstratos, adicionando-lhes singularidades espaciais e temporais, localizando-os - por meio de relações e mediações - em termos históricos e geográficos. Particularizar é, portanto, historicizar e também espacializar. (MORAIS, s. n. t.).

Em uma perspectiva de captura da essência do que venha a ser a cidade em sua complexidade, tem-se a necessidade de se apropriar dessas ferramentas, que no caso em questão, perpassa pela cognição do acumulo dos inúmeros processos, aos qual o espaço urbano de Planaltina-DF - fração do todo e ao mesmo tempo uma totalidade - veio a perpassar ao longo de sua constituição.

Com tal perspectiva propiciada pelo método dialético e de sua multiplicidade de possibilidades, é importante vislumbrar as proposições teóricas que, de fato, atendam os anseios de a assimilação do objeto de estudo.

Carlos (2011) define urbanização enquanto processo de produção espacial em constante transformações, caracterizada pela contínua dinâmica produtiva do capital em suas metamorfoses ao longo do tempo, mas, também, pela sociedade e suas relações espaciais que se modificam e se adaptam à luz das mutações produtivas, tendo em suas respectivas configurações territoriais, a materialização dos distintos momentos históricos derivados das relações sociais de produção que se sucedem. Nestes termos a autora se expressa:

Em suma, é o processo de reprodução do capital que vai indicar os modos de ocupação do espaço pela sociedade, baseados nos mecanismos de apropriação privada, em que o uso do solo é produto da condição geral do processo de produção da humanidade, que impõe uma determinada configuração ao espaço urbano. Tal configuração decorre dois modos de uso do solo: a) vinculado ao processo de produção e reprodução do capital e; b) e vinculado à reprodução da sociedade, tanto da força de trabalho (enquanto exército industrial ativo, ou exército industrial de reserva), enquanto população em geral (consumidores). Tal diferenciação emergiu da construção da noção de espaço-produto. (CARLOS, 2011, p.49).

Todavia, para Carlos (2011), o espaço urbano, produto das relações de produção, na qual o Estado constitui em um dos agentes norteadores de tal 
processo, também materializa-se enquanto espaço de resistência, tendo em sua população, principalmente os desprovidos, a vivência de uma constante luta contra a segregação residencial.

Nesta perspectiva, segundo Carlos (2009), os segregados buscam constantemente o direito à cidade, tendo na materialização da divisão espacial do trabalho a exposição do movimento de produção contraditória do capitalismo, enquanto resultado de sua dinâmica de produção desigual.

Para Soja (1993), em sua geografia histórica, o processo de urbanização dá-se de forma acumulativa em consonância à evolução do sistema capitalista ao longo do tempo, desdobrando-se na produção de consecutivas configurações territoriais e sua espacialização, tendo na composição da paisagem urbana o acavalamento de estratificações de formas que evidenciam o avanço do modo de produção capitalista.

Nesse pensamento e de maneira genérica, Soja (1993) propõe uma periodização de tais rearranjos urbanos em consonância às mutações sofridas pelo capital, tendo por base analítica as cidades norte-americanas, europeias e, em especial, o caso de Los Angeles. Em tal análise, a produção industrial, em suas novas lógicas que impactam a dinâmica espacial, constitue a locomotiva que impulsiona tal produção/reprodução do processo de urbanização.

Nessa proposta, o autor ressalta que a modificação dos arranjos urbanos em meio à evolução do processo de urbanização é condição para a reprodução do capitalismo em suas distintas facetas ao longo do tempo, se especializando segundo a lógica que visa a obtenção de superlucros e do disciplinamento de sua mão de obra.

Essa dinâmica ocorre em resposta às crises consecutivas que 0 sistema, em questão, veio a vivenciar ao longo do século $X X$, sendo que tais convulsões, também, caracterizam-se, segundo o autor, enquanto uma condição essencial de reengenharia e sobrevivência do próprio capital, impactando, por conseguinte, as estruturas sociais, estatais e na dinâmica financeira (capital financeiro especulativo). 
Nesse prisma, Soja (1993) define que o atual processo de urbanização perpassa por uma desarticulação do tecido urbano, condição essa para o desequilíbrio social.

Já Damiani (2004), ao propor uma análise do fato urbano segundo uma perspectiva crítica, descreve tal processo, em sua forma atual, enquanto produção do espaço totalizado pelos negócios da urbanização. Assim, nesta leitura em uma visão dos processos mais recentes, vê-se o impacto oriundo da materialização de Brasília sobre o movimento do espaço urbano de Planaltina.

Logo, em tal contexto, esse mecanismo reflete, em relação ao desenvolvimento capitalista, o aprofundamento das crises sociais, onde a atual produção/reprodução do espaço urbano caracteriza-se enquanto substrato da reprodução econômica do capital especulativo não produtivo, tendo em sua condição de acumulação o retorno à faceta primitiva, ou seja, o monopólio da terra. Contudo, a terra é tida enquanto mercadoria a ser comercializada. Este processo será melhor visualizado ao longo dos capítulos referente ao entendimento da formação socioespacial da cidade objeto.

Em tal visão, o Estado por meio do planejamento urbano, viabiliza a atuação das grandes construtoras e imobiliárias na produção da paisagem urbana, estando, tais setores, vinculados ao capital financeiro especulativo por meio do mercado de ações.

Esse conjunto de interações corresponde à nova maneira de reprodução do capital, que em meio à apropriação do solo, resulta na negação do espaço - enquanto mercadoria - para o homem, sendo o mesmo caracterizado por Damiani (2004, p. 311) como "espaço de desumanização", tendo na urbanização o "fundamento a proletarização absoluta", que é expresso materialmente em Planaltina com a ampliação dos bairros clandestinos.

Em sua análise, Damiani (2004) descreve, por um viés dialetizador, o atual processo de urbanização, utilizando-se de uma visão metodológica que prima pela discussão abrangente da atual composição do espaço urbano, pautado no conceito de redução estrutural. 
Damiani (2004, p. 331) aponta como fatores de aprofundamento das crises sócio espaciais os seguintes elementos: a crise do trabalho contida na crise do capital; a produção mercantil do espaço que internaliza a "metamorfose do capital produtivo em capital financeiro"; e o discurso ambiental enquanto exaltação da natureza e do natural contidas nas novas políticas de gestão territorial, ao passo em que se verifica uma rarefação e ineficácia dos projetos políticos mitigadores das crises sociais.

Já Milton Santos em sua leitura filosófica e epistemológica que interpreta a ciência Geografia enquanto filosofia das técnicas descreve o processo de urbanização, como sendo o acúmulo de diversos conteúdos técnicos e socioeconômicos resultantes do aprofundamento e complexificação da divisão do trabalho no interior de suas respectivas formações socioespaciais.

No interior destas formações socioeconômicas se materializam, no espaço, os sistemas de objetos carregados de intencionalidades, fruto de ações, intenções anteriores e atuais em um movimento contínuo, e que respondem as lógicas de uma totalidade maior: mundo.

As ações/intenções repercutem na elaboração das formas-conteúdo necessárias à produção/reprodução do sistema econômico, de maneira a levar em conta as particularidades naturais e sociais que corresponde às respectivas formações econômico-sociais e que resultam, em meio a tal dinâmica, na estruturação da unicidade espacial que acompanha a evolução das técnicas.

Nesse sentido, o mosaico urbano, traz consigo a complexidade evolutiva das técnicas a serviço do modo de produção em mutação constante, que rebatem no movimento do espaço urbano. Tal rebatimento se desdobra no plano atual, carregado de todo o acumulo histórico das relações de produção impressas sobre o mesmo espaço.

Daí a importância do exercício de periodização, cuja categoria formação socioespacial permite captar a multiplicidade, somada à complexidade das ações, das técnicas, associadas ao trabalho em seus distintos momentos, que resultam na composição de uma totalidade - a cidade - podendo ser identificado em 
suas partes, conjuntos que remontam a lógicas pretéritas de uso do território, formando no presente um novo todo multiforme.

Nesta perspectiva, o entendimento da produção do espaço urbano de Planaltina-DF, associado ao acúmulo de situações que conduzem a uma intrincada ilegalidade/precariedade jurídica das propriedades, perpassa pela leitura espaçotemporal e que levam ao modo de produção colonial e suas dinâmicas espaciais.

Assim, a categoria de formação socioespacial proposta por Santos (1977) consiste, justamente, na busca pelo entendimento que vai além da análise das formas já cristalizadas e contidas no espaço. Ele propõe a compreensão dos processos, das ações e eventos via recorte espacial - não desconsiderando a totalidade que o objeto está contido e que também o contem - por meio do exercício da periodização, decifrar a evolução do movimento territorial enquanto produto das relações de produção/reprodução.

Tais relações que criam e transformam as formas, podem lhes dar novas funcionalidades - ou até mesmo quando não se adaptam ao novo e passam a constituir-se em rugosidades - resultantes da dialética sociedade e espaço e de suas contradições.

Neste sentido, enquanto rugosidades ${ }^{9}$, além dos poucos casarões presente na área urbana de Planaltina-DF, há a permanência de inconformidades jurídicas quanto à precariedade escritural e registral das propriedades urbanas, que também se acumularam ao longo do tempo e que remontam às lógicas de produção do espaço urbano em seu contexto colonial.

Santos (1977, p. 82), ao desenvolver o seu pensamento quanto à categoria de formação socioespacial, se apoia no resgate teórico trabalhado por

\footnotetext{
${ }^{9}$ Santos (2002, p.140-141) define rugosidade da seguinte maneira:

(...) Chamamos rugosidade ao que fica do passado como forma, espaço construído, paisagem, o que resta do processo de supressão, acumulação, superposição, com que as coisas se substituem e acumulam em todos os lugares. As rugosidades se apresentam como formas isoladas ou como arranjos. É dessa forma que elas são uma parte desse espaço-fator. Ainda que sem tradução imediata, as rugosidades nos trazem os restos de divisões do trabalho já passados (todas as escalas de divisão do trabalho), os restos dos tipos de capital utilizados e suas combinações técnicas e sociais com o trabalho.

Em cada lugar, pois, o tempo atual se defronta como tempo passado, cristalizado em formas (...).

(...) As rugosidades, vistas individualmente ou nos seus padrões, revelam combinações que eram as únicas possíveis em um tempo e lugar dados.
} 
Sereni, quando este discute o conceito de formação econômico-social forjado por Marx e Engels, desenvolvido de forma mais aprofundada por Lênin. O objetivo do delineamento teórico da formação econômico social, segundo Santos:

\begin{abstract}
"O interesse dos estudos sobre as formações econômicas e sociais está na possibilidade que eles oferecem de permitir o conhecimento de uma sociedade na sua totalidade e nas suas frações, mas sempre um conhecimento específico, apreendido num dado momento de sua evolução. O estudo genético permite conhecer, a partir de sua filiação, as similaridades entre F.E.S.; mas isso não é suficiente. É preciso definir a especificidade de cada formação, o que a distingue das outras, e, no interior da F.E.S., a apreensão do particular como uma cisão do todo, um momento do todo, assim como o todo numa de suas frações (...) as formações econômicas e sociais não podem ser compreendidas senão no quadro de um movimento totalizador, no qual todos os seus elementos são variáveis que interagem e evoluem juntas, submetidas à lei do todo (...)" (SANTOS, 1977, p. 84, grifo nosso)
\end{abstract}

Como fora exposto por Santos (1977), a Formação Econômica e Social possibilita o exercício quanto à produção analítica concernente ao processo de constituição de uma sociedade em suas bases territoriais, mediante ao desvendamento e análise dos eventos históricos.

Somando-se aos eventos, tem-se as relações de trabalho e a inserção dessa mesma sociedade em meio a um contexto maior, que corresponde à totalidade a qual se inserem por intermédio das relações de produção.

Esta proposição, também permite compreender os desdobramentos advindos da atuação desta totalidade maior na composição das frações do todo contido na escala do território nacional.

Entretanto, para Santos (1977, p. 82), mais do que à formação econômica e social, uma análise limitada à história das relações de produção das sociedades em um determinado período, é a formação socioespacial, uma vez que o espaço é a "base da explicação, isto é, o trabalho do homem para transformar, segundo as leis historicamente determinadas, o espaço ao qual o grupo se confronta". Santos (1977) segue em sua linha de argumentação dizendo:

(...) Deveríamos até perguntar se é possível falar de Formação Econômica Social sem incluir a categoria do espaço. Trata-se de fato de uma categoria de Formação Econômica Social e Espacial, mais do que uma simples Formação Econômica e Social (F.E.S.), tal qual 
foi interpretada até hoje. Aceitá-la deveria permitir o erro da interpretação dualista das relações Homem-Natureza. Natureza e Espaço são sinônimos, desde que se considere a Natureza como uma natureza transformada, uma Segunda Natureza, como Marx o chamou. (SANTOS, 1977, p. 82).

Neste sentido, na busca de compreender essa fração do todo que é Planaltina-DF em seu contínuo processo de totalização, inicia-se o exercício de periodização que remonta à constituição da formação socioespacial da cidade de objeto em meio ao todo em seu movimento.

Santos e Silveira (2003, p. 20) salientam que para a realização de um estudo teórico pautado na leitura do território usado, "(...) uma periodização é necessária, pois os usos são diferentes nos diversos momentos da história (...)", tendo como respostas, a produção de formas e objetos geográficos que refletem a intencionalidade do uso territorial em determinados momentos de sua evolução.

Essa evolução é fruto da implementação das técnicas que são sobrepostas no território, do trabalho nele realizado e acumulado em detrimento à recíproca relação com a sociedade, por intermédio das relações de produção e das experiências vividas sobre mesma base territorial.

Dessa maneira, somados aos interesses hegemônicos cujas lógicas incidem ou replicam-se na escala local, o uso do território está imbricado no conjunto do todo em movimento e no modo de produção advindo de uma totalidade em atividade no qual se insere, cujo reflexo é a dinâmica do movimento urbano, bem como nos demais elementos produtores da atual configuração territorial em questão e no próprio território enquanto sistema, assim exposto por Santos (1985):

"A verdade é que, seja qual for à forma de ação, entre as variáveis
ou dentro delas, não se pode perder de vista o conjunto, o contexto.
As ações entre as diversas variáveis estão subordinadas ao todo e
aos seus movimentos (...) quando uma variável muda o seu
movimento, isso remete imediatamente ao todo, modificando-o,
fazendo-o outro, ainda que sempre e sempre, ele constitui uma
totalidade. Saia-se de uma totalidade para chegar à outra, que,
também, se modificará." (SANTOS, 1985, p.15).

O uso do conceito território usado, elevado por Santos a um patamar de categoria, vincula-se ao exercício de periodização e da compreensão dos elementos que compõem a fração em estudo por meio da formação socioespacial. 
Como é ostentado por Silveira (2006, p. 89), a categoria território usado constitui-se como "processo de empirização do tempo", aonde o tempo se "empiriciza na extensão, mas também em ações, em novos sistemas organizacionais, em normas jurídicas, em formas culturais", sendo o espaço caracterizado mediante a complexidade nele contido entre as existências materiais e imateriais.

A compreensão dos processos que se desdobram no cenário atual inclusive a judicialização do território - exige um olhar embasado no desvelar dos eventos pautados na consecução das técnicas, que aplicadas ao espaço, desencadeiam na sua produção material, na composição organizacional e na produção de regulamentações, assim como na acumulação das produções precedentes que também definirá a composição das formas do presente.

Essa periodização que culmina no território em uso do presente é possível através do uso da categoria de formação socioespacial, descrito por Santos e Silveira (2003):

Esses sistemas técnicos incluem, de um lado, a materialidade e, do outro, seus modos de organização e regulação. Eles autorizam, a cada momento histórico, uma formação e uma distribuição do trabalho. (...) Por essa razão a redistribuição do processo social não é indiferente às formas herdadas, e o processo de reconstrução paralela da sociedade e do território pode ser entendido a partir da categoria de formação socioespacial. (SANTOS, SILVEIRA, 2003, p. 20-21, grifo nosso).

A categoria de formação socioespacial, proposta por Santos (1977), consiste na busca pelo entendimento que vai além da análise das formas já cristalizadas contidas no espaço.

Propõe, na compreensão dos processos, nas ações e eventos via recorte espacial - não desconsiderando a totalidade que tal recorte está contido e que também o contem - por meio do exercício da periodização, decifrar a evolução do movimento territorial enquanto produto das relações de produção, reprodução.

Tais relações que criam e transformam as formas, podendo lhes dar novas funcionalidades, resultantes da dialética sociedade e espaço e de suas 
contradições, ou até mesmo ao não se adaptam ao novo constituir-se em rugosidades.

Santos (1977, p. 82), ao desenvolver o seu pensamento quanto à categoria de formação socioespacial, se apoia no resgate teórico trabalhado por Sereni quando discute o conceito de formação econômico social forjado por Marx e Engels, e desenvolvida de forma mais aprofundada por Lênin.

O objetivo, tendo em vista o delineamento teórico da formação econômico social para Santos (1977), possibilita o exercício analítica concernente ao processo de constituição de uma sociedade em suas bases territoriais, mediante ao desvendamento e análise dos eventos históricos, as relações de trabalho e a inserção dessa mesma sociedade em meio a um contexto maior que corresponde à totalidade ao qual se inserem, por intermédio das relações de produção.

Ao mesmo tempo, a formação econômica e social permite compreender os desdobramentos advindos da atuação dessa totalidade maior na composição das totalidades enquanto frações de um todo, correspondentes à escala do território nacional e de seus fragmentos.

Entretanto, para Santos (1977, p. 82), mais do que à formação econômica e social, uma análise limitada à história das relações de produção das sociedades em um determinado período, tem-se a formação socioespacial, uma vez que o espaço é a "base da explicação, isto é, o trabalho do homem para transformar, segundo as leis historicamente determinadas, o espaço ao qual o grupo se confronta". Santos (1977) segue em sua linha de argumentação dizendo:

“(...) Deveríamos até perguntar se é possível falar de Formação Econômica Social sem incluir a categoria do espaço. Trata-se de fato de uma categoria de Formação Econômica Social e Espacial, mais do que uma simples Formação Econômica e Social (F.E.S.), tal qual foi interpretada até hoje. Aceitá-la deveria permitir o erro da interpretação dualista das relações Homem-Natureza. Natureza e Espaço são sinônimos, desde que se considere a Natureza como uma natureza transformada, uma Segunda Natureza, como Marx o chamou." (SANTOS, 1977, p. 82).

A inclusão do espaço, enquanto elemento fundamental que justifica a proposição dessa nova categoria, dá-se pelo fato que todas as relações de 
produção, do trabalho, das relações sociais e experiências vividas, repousam, se desdobram sobre uma base material.

O espaço e o tempo são sinônimos, algo uno, sendo o espaço em sua concretude a própria materialidade. O tempo também o é. $\mathrm{O}$ elo entre ambos que propicia o movimento, a vida, o significado e consciência aos mesmos é a sociedade por intermédio do uso de suas técnicas.

1.2.1 - Entradas e Bandeiras: a lógica de produção do espaço em meio ao modo de produção colonial.

Planaltina-DF, enquanto substrato, base da produção social, tem em seu traço histórico, ocupações humanas anteriores a lógica imposta pelo sistema capitalista dos últimos cinco séculos.

Magalhães e Eleutério (2008), bem como Castro (1986), em tal perspectiva, trazem a profundidade espaço-temporal da presença de povos autóctones na região ao qual atualmente situa-se a região ao qual contém o sítio urbano de Planaltina.

Segundo Magalhães e Eleutério (2008, p. 107), na região condizente ao Planalto Central Brasileiro, anterior ao processo de colonização europeia, predominava a existência de povos nômades, os quais, linguisticamente, podem ser pertencentes ao tronco Jê.

Especificamente, Castro (1986, p. 15-92), aponta a presença dos índios Quirixás e Aruaques, enquanto primeiros habitantes da região de Planaltina, quando da chegada das bandeiras portuguesas. Quanto aos Quirixás, Castro (1986), por intermédio dos relatos do bandeirante Silva Braga, assim os descrevem:

Os índios Quirixás, da região de Mestre D’Ármas, eram trabalhadores valentes. Arriscando a perda de tudo, de todo o armazém e plantio, lutavam obstinadamente em defesa de seus direitos contra o domínio e a caça da mão de obra escrava. Contra o martírio de passar como cargueiros de tropa de animais de serviço pesado. 
No trecho rico em detalhes, Silva Braga registra as feições bem feitas do índio Quirixá e descreve suas habitações e rancharias. Pessoas ciaras, de estrutura regular, de boa aparência física, experientes, trabalhadores, e muito vivos. Viviam em comunidades pequenas, separados por famílias, mantendo alimentação para a subsistência do grupo. As habitações eram como aquelas desenhadas por Jean Baptiste Debret, de "forma de abóbodas circular" e "recoberta de enormes galhos de palmeiras, entrelaçados com arte". E, finalmente, a maneira de ser do índio, no roteiro de José Peixoto, leva a crê-lo sedentário. (CASTRO, 1986, p. 92-93).

Entretanto, a expansão europeia, que remonta em seu contexto inicial, entre o final do século $\mathrm{XV}$ e transcorrer do século $\mathrm{XVI}$, resulta em um primeiro embate entre sistemas sociais, cujas lógicas e uso do território davam-se de maneiras distintas.

Nesta perspectiva, tinha-se a gênese do sistema capitalista em sua dimensão comercial, tal qual é exposto por Santos (1985), cujas lógicas de expansão territorial executadas, associam-se às praticadas pelo império árabe, ao qual os países ibéricos foram subjugados anteriormente. Caberiam a Portugal e Espanha o início da mundialização do sistema capitalista, que ao longo dos séculos passaria por transformações.

Santos (1985, p. 24) descreve que a produção das cidades coloniais latino-americanas seguiram a mesma função quanto a dinâmica expansiva do império árabe, "atuando como instrumento de relações entre os espaços conquistados e a nação conquistada". O autor aponta também importantes elementos que fazem semelhantes tais processos (império árabe e países ibéricos), como a produção agrícola e o comércio, onde este último tinha por finalidade constituir-se enquanto "instrumento de relação de dependência entre os países do polo e da periferia".

Todavia, o diferencial entre a abrangência de tais processos de expansão, dá-se pelo fato do aperfeiçoamento das técnicas de navegação que ampliam a capacidade de atuação dos países ibéricos sobre os demais territórios, fazendo com que se tornassem grandes potências neste período, o qual remonta a gênese do sistema capitalista e ao início da formação socioespacial do território brasileiro. Este processo é assim descrito por Santos: 
É assim que chegamos ao nosso primeiro período; e não é por casualidade que, nele, os polos se encontram no Atlântico, isto é, Espanha e Portugal. A esse período corresponde o aumento da capacidade de transporte e de comércio, que substituem a agricultura como fator essencial do sistema. O mercado ampliado induz uma manufatura mais intensiva e é o responsável pela criação, nas Américas, de "espaços derivados", por intermédio das culturas de cana-de-açúcar, do fumo e, posteriormente, do algodão, cuja produção começa a ter efeitos sobre os lucros obtidos pelos diferentes países europeus. (SANTOS, 1985, p. 24-25).

Em um primeiro instante, o território brasileiro, segundo a perspectiva dos meios geográficos propostos por Santos e Silveira (2003, p. 27), é caracterizado enquanto meio natural, tendo por elementos a vivência dos "tempos lentos da natureza comandando as ações humanas de diversos grupos indígenas e pela instalação dos europeus, empenhados todos, cada qual ao seu modo, em amansar esses ritmos".

Efetivamente, tal contexto ocorre entre os anos de 1500 a 1532, quando as ações colonizadoras advindas de Portugal não ocorriam de maneira vigorosa. Entretanto, para Théry e Mello (2005), tendo em vista as empreitadas de países como Holanda e França na tentativa de se fixarem em terras apropriadas pelos portugueses, resultam em uma série de medidas tomadas pela corte lusitana, cuja finalidade repousava na efetiva ocupação e exploração do território.

Segundo Théry e Mello (2005), para incentivar tais ações, Dom João III promove a divisão da colônia em 13 capitanias hereditárias conforme a figura 03 , cujos donatários deveriam promover, dentro outras ações, o incentivo a ocupação territorial (concessão de sesmarias) e exploração dos recursos.

Nesta perspectiva, a ação/norma além-mar, resulta na alteração das dinâmicas sociais, no esfacelamento do modo de vida milenar, institui novas correntes migratórias via modal marítimo, desdobrando-se na composição de sucessivas sobreposições de materialidades, objetos espaciais, modos de vidas, frutos da evolução das técnicas, sendo estas impulsionadas pelos sistemas de produção que acompanham as tendências e demandas colôniais (Portugal) ou dos novos centros de gravidade do sistema capitalista que se sucedem. 
Figura 03 - Capitanias Hereditárias: economia e território no século XVI.

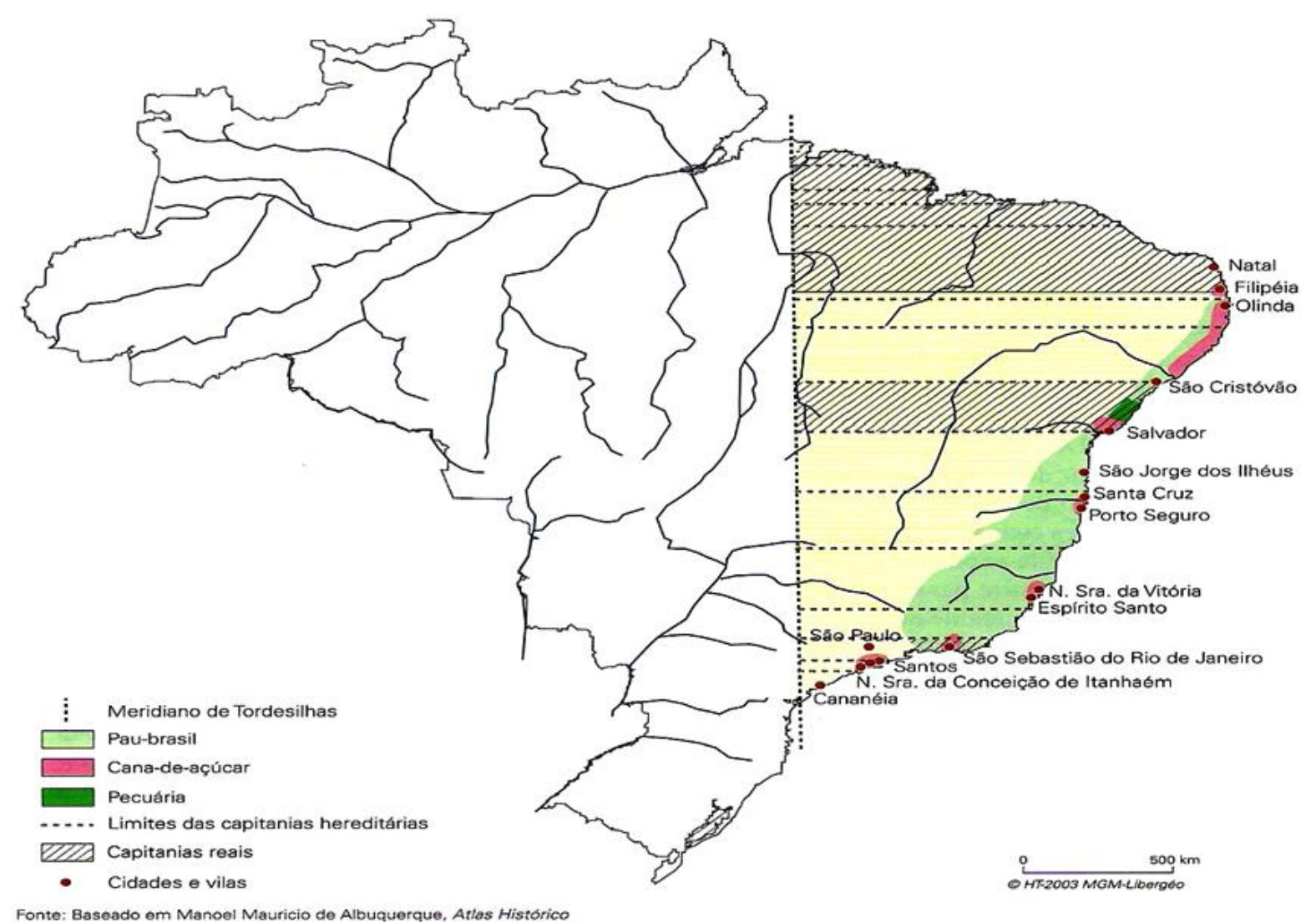

Fonte: Théry e Mello, 2005.

Esse mecanismo de funcionamento da colônia, considerado espaço derivado e suas respostas ao centro do sistema que passa a viger é assim exposto por Santos e Silveira (2003):

Relacionadas com a demanda do exterior, formam-se as zonas econômicas e criam-se verdadeiras famílias e gerações de cidades, testemunhando uma sucessão de divisões territoriais do trabalho fundadas em graus diversos de tecnificação. (SANTOS E SILVEIRA, 2003, p.31)

A ação citada tinha em vista a geração de riquezas para essa mesma Coroa, advindas da captação de impostos oriundos de atividades de exploração dos recursos minerais e atividades produtivas, cujo solo caracterizava-se enquanto principal meio de produção. 
Neste processo, Théry e Mello (2005) descrevem que no ano de1532, inicia-se o Pacto Colonial, baseando-se, para Szmrecsányl (1998, p.12) na "grande propriedade fundiária (sesmarias), na mão de obra escrava e na monocultura de exportação" enquanto elementos que irão perdurar durante séculos na dinâmica de produção do território brasileiro - inclusive em Planaltina.

Fazendo alusão à Planaltina, vê-se que o lugar, subespaço descrito por Santos $(1985,2002)$, constitui-se enquanto uma totalidade singular, mas não apartada das relações para com o todo em suas múltiplas escalas, que também estão em movimento (totalização).

Ao mesmo tempo, esse processo de totalização, cuja conjunto e suas partes coexistem em assincronia, processo este que responde pela produção das singularidades espaciais. Tal relação inter e intra-escalar associado a esse movimento é assim exposto por Santos (2002):

Em cada lugar, os sistemas sucessivos do acontecer social distinguem períodos diferentes, permitindo falar de hoje e de ontem. Este é o eixo de sucessão. Em cada lugar, o tempo das diversas ações e dos diversos atores e a maneira como utilizam o tempo social não são os mesmos. No viver comum de cada instante, os eventos não são sucessivos, mas concomitantes. Temos aqui o eixo das coexistências.

Os fluxos não tem a mesma rapidez. A velocidade de uma carta não é a de um telegrama, um telex, um fax. Os homens não percorrem as esmas distâncias no mesmo tempo, dependendo dos meios com que contam. Mas, no espaço geográfico, se as temporalidades não são as mesmas, para os diversos agentes sociais, elas todavia se dão de modo simultâneo. Constatamos, de um lado, uma assincronia na sequencia temporal dos diversos vetores e, de outro lado, a sincronia de sua existência comum, num dado momento. $O$ entendimento dos lugares, em sua situação atual e em sua evolução, depende da consideração do eixo das sucessões e do eixo das coexistências.

Cada ação se dá segundo seu tempo; as diversas ações se dão conjuntamente. Objetos particulares, que são individuais, funcionalmente perceptíveis, fundem-se num objeto comum, mas dificilmente discernível [...] Esse viver comum se realiza no espaço, seja qual for à escala - do lugarejo, da grande cidade, da região, do país inteiro, do mundo. A ordem espacial é a ordem geral, que coordena e regula as ordens exclusivas de cada tempo particular. (SANTOS, 2002, p. 159).

Neste sentido, Planaltina, enquanto fração do todo e um todo, é visualizada como estrutura que compõe um sistema de estruturas que perpassa por 
um contínuo processo de reprodução junto ao todo, mas que responde de forma específica. A fração do território usado, de maneira singular, é interpretada desta maneira, enquanto no plano do lugar/subespaço, cujo movimento de totalização também pode ser explicitado através de uma leitura da formação socioespacial desta fração indissociada do todo.

Um quarto elemento, o qual poderia ser acrescido ao pensamento de Szmrecsányl (1998), seria a importância da atividade aurífera que respondeu no processo de interiorização do território e na composição das primeiras redes de circulação de mercadorias e pessoas, tendo como atividades econômicas de suporte a produção de alimentos e, principalmente, a atividade pecuarista.

A esta última atividade econômica, Théry e Mello (2005), assim como Szmrecsányl (1998), Magalhães (2011), Castro (1986), entre tantos outros autores, imputam a principal função produtiva dos sertões ao qual Planaltina, em um contexto pós-entradas e bandeiras, se insere, mas precedido e impulsionado, sobretudo, pela efetiva descoberta do ouro no Brasil Central.

Após entrar em vigor o Pacto Colônial (1532), inicia-se em território brasileiro o período técnico (pré-máquina) e, ao mesmo tempo, para Santos e Silveira (2003, p.27) pode ser caracterizado pela "escassez" dos "instrumentos artificiais necessários ao domínio desse mundo natural".

Santos e Silveira (2003) também pontuam os elementos que impulsionaram o movimento no território nacional, associado à composição dos sistemas de produção que se desdobram na origem dos primeiros povoados, das cidades que compunham a "malha urbana" embrionária do país. Fatores como a presença da máquina estatal portuguesa e as funções/vocações produtivas iniciais desempenhadas nos segmentos do território são enumerados enquanto elementos constitutivos da estruturação das cidades da seguinte forma:

A interiorização do povoamento foi devida, de uma lado, à mineração e, de outro, à criação de gado nas fazendas. A exploração dos diamantes e do ouro foi responsável pela existência de inúmeros núcleos de vida urbana no interior dos estados de Minas Gerais, Bahia, Goiás, e Mato Grosso.

Em um primeiro momento, as aglomerações resultaram das instalações dos serviços do governo, começando pela fiscalização das atividades rentáveis tanto na agricultura como na mineração. 
Cidades do ouro como cidades do diamante, cidades de estrada de ferro, cidades de passagem, bocas do sertão e cidades planejadas pelas companhias de colonização são os tipos principais a partir dos quais Pierre Deffontaines (1944) assinala o dinamismo da urbanização brasileira. $O$ desenvolvimento urbano era uma consequência imediata da combinação de dois fatores principais: a localização do poder político-administrativo e a centralização correspondente dos agentes e das atividades econômicas. (SANTOS E SILVEIRA, 2003, p. 31-33).

Para Théry e Mello (2005), além da defesa da porção litorânea, em um primeiro momento, a Coroa Portuguesa promove o financiamento de uma série de expedições, tendo por finalidade a busca por ouro, pedras preciosas e especiarias (drogas do sertão) no interior do território: as entradas e bandeiras. Periodicizando tais entradas e bandeiras, estas iniciaram-se nos primórdios do período técnico/prémáquina (Santos, Silveira, 2003).

Ainda sobre o empreendimento de conquista e defesa do território colonial por parte dos portugueses, Castro (1986) descreve as ações empreendidas advindas de Portugal assim:

Após o descobrimento e subdivisão das terras de Santa Cruz em Capitanias Hereditárias, os colonizadores portugueses sentiram a necessidade de embrenharem-se sertão a dentro. Defesa e domínio. A defesa se faria pelo litoral, com o crescimento das cidades e vilas, formando verdadeiras fortalezas. O domínio das terras, pelo controle sistemático e cultivo das riquezas naturais e assenhoramento dos sertões com a formação de povoamentos (CASTRO, 1986, p. 73).

Santos e Silveira (2003, p. 30), também denominam tal período (século XVI ao início do século XIX) enquanto arquipélago de mecanização incompleta. Esta definição é oriunda da análise do "movimento da sociedade e a transformação dos conteúdos e funções dos lugares" em detrimento "às sucessivas divisões territoriais do trabalho", no qual, neste contexto, o espaço nacional reflete a somatória das funções desempenhadas por suas frações, cuja malha urbana, em sua gênese, é tida enquanto arquipélago, cujas poucas cidades ligam-se diretamente ao centro do sistema colonial.

É neste cenário pré-máquina, ou arquipélago de mecanização incompleta, que iniciam-se as entradas e bandeiras em direção ao Planalto Central. Somado a este fato, tem-se o genocídio das nações indígenas existentes e dos 
senhores do território de então, que no caso da atual região de Planaltina, tal embate também ocorrera.

Quanto a estes primeiros confrontos que remetem-se às origens do uso do território de Planaltina, mediante à inserção no sistema de produção colonial, Castro (1986) tece as seguintes considerações referente a tais embates entre as bandeiras e os índios Quirixás:

Os bandeirantes de um lado faziam a expansão territorial, de outro, levavam o ouro da Colônia e massacravam, dizimavam os silvícolas. O tratamento dispensado aos nossos indígenas era arbitrário, incomum, sem alguma consideração humana, que traziam os padres para a catequese.

A luta sempre era desigual: o civilizado armava-se com espingardas contra os porretes e flechas dos índios. Sem contar a crueldade a que eram submetidos se reagissem à caça ou preferissem a fuga. (CASTRO, 1986, p. 92).

Além dos conflitos territoriais representados pelo modo de vida dos Quirixás e o modo de produção colonial, Castro (1986) aponta, segundo registros históricos, a cronologia das bandeiras que exploraram o que corresponde ao atual território do estado de Goiás. Neste exercício, Castro (1986) discorre sobre as controvérsias quanto aos relatos produzidos que atestam a chegada das primeiras bandeiras a adentrarem em solo goiano:

Sebastião Marinho foi o primeiro palmilhador dos sertões de Goiás, em 1592. Segundo Affonso D'Escragnolle Taunay “de 1592 parece datar-se a entrada de Sebastião Marinho que um mapa anônimo castelhano localiza em território hoje goiano. Mas nada se sabe de certo sobre tal jornada e seu comandante [...]

O historiador Luiz Palacin afirma a possibilidade de outra bandeira ter sido a primeira a abrir picadas nos sertões goianos: "a primeira bandeira, que partia de São Paulo, possivelmente, chegou até os sertões goianos no Leste de Tocantins foi a de Antônio Macedo e Domingos Luiz Grau (1590-1593)". Embora, Modesto Gomes coloca como primeira bandeira, com a comprovação de documentos a bandeira de Domingos Rodrigues: "acompanhado de vários companheira de vários companheiros, com os quais se desgarrara da bandeira de João Pereira de Sousa Botafogo, que fora preso e remetido sob a escolta para São Paulo, Domingos Rodrigues perambulou cerca de quatro anos (1600), por terras do Brasil Central".

De quase todas as bandeiras que vieram aos Guayases, o historiador Pedro Taques noticia e as fundamenta com grande 
quantidade de cartas régias, inventários, confirmando-as, localizando-as nas nascentes do Rio Parapuava ou Paraopeba. Esta era a denominação do Rio Maranhão entre os índios Quirixás, habitantes de Planaltina, cabeceiras do Rio Tocantins. (CASTRO, 1986, p. 73-74).

A partir de ambas as datas - 1590 e 1592 - uma série de outras bandeiras são promovidas em direção ao Brasil Central, perpassando pelo Rio Maranhão - Parapuava de então - tendo por atividade fim a busca por ouro, pedras preciosas e captura de índios (Castro, 1986).

O interessante, é que alguns dos relatos de tais passagens estão associados a inventários que declaram a morte de bandeirantes ${ }^{10}$ e tropeiros as margens do Rio Parapuava, morada dos Quirixás.

Todavia, segundo Castro (1986), os primeiros indícios de ocupação colonial da região que hoje remonta o Distrito Federal, e por conseguinte, Planaltina, associam-se a entrada da expedição da bandeira paulista de Bartolomeu Bueno da Silva, o Anhanguera II, no ano de 1722.

Neste meio termo, passaram-se mais de um século de conflitos entre os índios Quirixás e as bandeiras (paulistas de maior expressão, baianos e do GrãoPará) que perambulavam pela região.

Em tal contexto, segundo Santos (1985, p. 23), o período manufatureiro (1620-1750) que sucede ao período comercial de grande escala (fim do século XV até meados de 1620), logo dará espaço para o período de Revolução Industrial (1750-1870) ocasionando na mudança de centro de gravidade do sistema capitalista.

Já na escala do território nacional, vigora ainda a lógica colonial, entretanto, ocorrera a expansão, entre os séculos XVII e XVIII, da atividade aurífera e da ampliação da ocupação territorial dos sertões por tal atividade e pelas demais que compunham um sistema de complementaridade produtiva, cuja finalidade repousava no abastecimento alimentar dos centros produtores de minério.

${ }^{10}$ Ver mais detalhes em CASTRO (1986). 
Santos e Silveira (2003, p.25), ao explorarem a periodização de Caio Prado Jr (1945), caracterizam o período que vai de 1640 a 1770 como sendo o da "expansão da colonização, marcada pela mineração e ocupação do Centro-Sul, a pecuária e o povoamento do Nordeste, a colonização do vale amazônico e a colheita florestal".

Neste contexto, segundo Castro (1986), é que Bartolomeu Bueno da Silva (Anhanguera II), após 50 anos da entrada de seu pai, adentra o território goiano, tendo por referência a expedição primeira de Anhanguera, cujos relatos apontavam a presença de ouro em Guayases.

Tal referência, somada à presença de Anhanguera II na expedição primeira capitaneada por seu genitor, constituía forte chamariz para a realização de nova empreitada.

O fruto decorrente da expedição comandada por Anhanguera II foram os relatos produzidos pelos integrantes da bandeira - José Peixoto da Silva Braga e Urbano Couto - que permitiram o retorno e a efetiva ocupação do território por estes e pelos demais colonizadores que se valeram de tais registros. Castro (1986) aborda sobre tal fato:

Em 1722, Bartolomeu Bueno da Silva, filho, atravessou Goiás, em duras e penosas lidas, passagem que um de seus auxiliares deixou detalhado roteiro. Este, José Peixoto da Silva Braga, através de observações e análises, deixou sinais visíveis e claros, que demonstram o reconhecimento do planalto central, com notas de identificação do Rio São Bartolomeu, Lagoa Bonita, Lagoa Feia, Riacho Pipiripau, nascentes dos grandes rios e divisor de Águas Emendadas.

Urbano Couto, um dos acompanhantes da tropa, deixou dois roteiros, um deles, enigmático, que contribui na demonstração da localização de Anhanguera nas terras de Mestre D'Ármas. Por isso mesmo, voltara tempos depois instalando-se na região, o que deixaria o seu nome emprestado a uma sesmaria do Sítio de Mestre D'Ármas. (CASTRO, 1986, p.77-89).

Conforme fora exposto por Castro (1986), a expedição de Anhanguera II resulta no surgimento de vilarejos, que no contexto, compunham a gênese do sistema de povoamentos de Goiás, cuja vocação pautava-se na extração mineral ou na produção de culturas de subsistência para abastecer tais localidades. Castro 
(1986) demonstra esse processo, podendo-se observar que tais aglomerados populacionais ocorreram entre o fim da primeira metade do século XVIII em diante. Sobre esta perspectiva, o autor expõe:

Os primeiros povoados dos Guayases nasceram do ouro. Desde o descobrimento, aqui e ali, foram sendo encontradas minas auríferas. Com o Anhanguera II, quase que permanentemente foram brotando minas em todos os quadrantes de Mato Grosso e Goiás. Ele próprio, Bueno, ao lado de suas descobertas incentivou grandemente a formação dos povoados do Estado. Descobriu as fontes termais (Caldas Novas) e que por julgar de origem vulcânica, água e lama medicinais, fez erigir nas localidades um Arraial, fundou "Borda do Mato" (Catalão), "Crixás" (que confundem-se com a fundação de Pilar de Goiás), "Arraial da Barra" (Buenolândia), "Ouro Fino", "Ferreiro e Santana" (sua sede, mais tarde, Vila Boa, hoje, Cidade de Goiás).

Em 1727, o bandeirante Manoel Rodrigues Tomás, companheiro de Anhanguera II, instalou-se no Vale do Rio de Meia Ponte, pondo em descoberta algumas minas. Aí, aflorou-se um número fabuloso de minas, de mineiros, comerciante e aventureiros. A culminância dos movimentos, em torno das minas, ocorreu no surgimento do Sítio das "Minas de Nossa Senhora do Rosário de Meia Ponto" (Meia Ponte, hoje, Pirenópolis).

As minas de ouro dos sertões dos Guayases nasciam nos lugares mais diversos. As minas do Maranhão, por exemplo, em 1730, as do Cocal -1732, as Trahiras - 1735, as de Cachoeira e São Félix 1736, outras em outras tantas datas. (CASTRO, 1986, p. 108).

Em consonância ao movimento de entradas e bandeiras no Estado de Goiás oriundas principalmente da capitania de São Paulo, que resultaram na produção das minas de exploração e nos núcleos de povoamento que davam suporte a esta atividade, outro fator importantíssimo impulsionou a ocupação da região.

Segundo Castro (1986), o surgimento e expansão dos Currais do São Francisco, entre os séculos XVII e XVIII, contribuiu bastante para a composição de uma rede - embora insipiente segundo Santos e Silveira (2003) - de circulação e distribuição de mercadorias. A finalidade repousava, dentro da divisão territorial do trabalho no sistema colonial, em abastecer as Minas Gerais de produtos oriundos da pecuária, além de vislumbrar a possibilidade de obtenção de riquezas através da extração mineral em território goiano, contribuindo fortemente com o processo de produção territorial de Planaltina. Nestes termos Castro expõe: 
No início do século XVIII, foram instalados os currais da Bahia no vale do São Francisco. Esse empreendimento tornou-se motivo essencial para a formação dos liames Nordeste e Sul, passando necessariamente por Goiás e particularmente por Planaltina. (CASTRO, 1986, p.77)

Castro (1986, p. 82) assevera que a função desempenhada pelas atividades produtivas oriundas dos Currais do São Francisco foram de vital importância para a vocação produtiva da região em estudo, tendo em vista que a herança pecuarista presente no Vão do Paranã e que chega, a posteriori, em Planaltina, se estende espaço-temporalmente por todo século XIX até o evento que corresponde à construção de Brasília. O autor descreve que os "baianos, com comércio do gado e procura do ouro, tiveram um papel de destaque na criação dos centros de pastagem e formação de povoamentos, que serviriam os mineradores no tempo do esgotamento das minas".

Ainda sobre a relevância dos Currais de São Francisco dentro do processo de formação socioespacial de Planaltina, bem como da importância da atividade pecuarista que resulta na composição da rede colônia da Estrada Real da Bahia, derivando em pousos (fazendas) e povoados e alguns centros comerciais, Magalhães e Eleutério (2008) asseveram que:

Em consequência da expansão dos currais, que inicialmente encontravam-se apenas no baixo São Francisco, próximos à sua foz, o povoamento estendeu rio acima em direção às nascentes. Nas novas regiões de povoamento, desenvolveram-se outras atividades agrícolas, entre as quais se destacaram o cultivo de mamona, o algodão, o milho, e a cana-de-açúcar. É muito importante observar que essa economia secundária ou subsidiária à atividade pecuarista serviu de apoio ao interesse minerador hegemônico, contribuindo de forma significativa para a consolidação de toda a região como uma das mais movimentadas do Brasil. (MAGALHÃES E ELEUTÉRIO, 2008, p. 95).

Mediante tais eventos - exploração das bandeiras paulistas e expansão dos Currais do São Francisco - depreende-se que a gênese de Planaltina, em seu processo de formação socioespacial, tem por motor a ampliação territorial oriunda do sistema de complementaridades produtivas impulsionadas, principalmente, pela produção aurífera. Muito embora, dentro de uma divisão do 
trabalho, a sua vocação embrionária esteja relacionada à atividade pecuarista, tal como é exposto por Magalhães:

O que estamos denominando de Sertão Planaltina, desde o século
XIX, veio sendo definido e estabelecido, principalmente pela
literatura, como lugar deserto e carente de civilidade, a Brasília
Barbarorum. De acordo com esse tipo de construção, sua origem
coincide com as ações dos primeiros colonizadores europeus.
Movimento que assenta alicerces no projeto lusitano de conquista da
hinterland brasileira. Segundo tal interpretação, há o entendimento
de que a primeira onda integração desse sertão ao universo europeu
se deu a partir da segunda metade do século XVII e sob a orientação
de diferentes vetores de colonização. Entre eles, o mais conhecido é
bandeirismo paulista. O outro percurso, menos vezes lembrado, mas
tão memorável quanto o primeiro, deveu-se às penetrações
patrocinadas pela expansão dos famosos "Currais do São
Francisco". (MAGALHÃES, 2011, p. 12).

Segundo Théry e Mello (2005), em termos de relevância em uma escala macro, o ofício ligado à extração mineral vem suprir a lacuna deixada pelo declínio econômico advindo da produção canavieira registrada já na primeira metade do século XVII, como efeito da forte concorrência produtiva empreendida por franceses e holandeses nas Antilhas.

Sendo assim, a produção aurífera desdobra-se, em um contexto prémáquina, nas relações de troca entre centros de extração de minerais - fruto das descobertas oriundas das bandeiras - e sua periferia produtora de alimentos, tanto nas grandes lavouras de subsistência como da atividade pecuarista.

Vê-se na formação socioespacial de Planaltina, de maneira especial, a conjunção das bandeiras paulista somado à expansão da atividade pecuarista advindas dos Currais do São Francisco. Tem-se na posse da terra o elemento ao qual se vinculam o status hierárquico dentro da divisão social do trabalho, refletindose nas relações de poder, bem como no contexto cultural local.

O fator indutor de tais ações procede do Estado português na busca por efetivar a ocupação territorial e maximizar a implementação de atividades produtivas que lhes garantisse a geração de riquezas para a Coroa.

Tanto é que, após a bandeira de Anhanguera II, verifica-se 0 estabelecimento de uma porção de sesmarias na região conhecida como Mestre D'Ármas, ocupadas por tropeiros portugueses como Urbano Couto - membro da 
tropa de Anhanguera II - assim como os beneficiados pelos donatários que receberam, por concessão, grandes extensões de terras na localidade em questão.

Sobre a lógica de atuação do Estado português na produção da dinâmica do território brasileiro, que resulta na configuração territorial colonial e materialidade primordial que dá a efetiva condição de posterior complexificação da expansão da divisão territorial do trabalho, Santos e Silveira (2003) explicitam:

A máquina de Estado servia para preservar e ampliar as fronteiras, manter o regime e a ordem, assegurar a coleta de impostos e, com a ajuda da lgreja, unificar a linguagem. A unidade política e linguística se dava ao mesmo tempo em que as diversas regiões, produzindo para o mercado externo, a este se ligavam praticamente sem intermediário, de modo que sua evolução espacial e econômica era ditada por relações quase diretas. (SANTOS E SILVEIRA, 2003, p. 32).

Muito embora o sistema produtivo implementado pela Coroa Portuguesa resultou no estabelecimento de uma relação direta entre as ilhas de produção - canavieira, aurífera, algodoeira, extrativista, dentre outros - e a metrópole, internamente, com o passar dos três primeiros séculos, um arranjo espacial de complementaridades produtivas se instalava sobre o território, ao sabor da disponibilidade dos recursos naturais existentes e da demanda do mercado externo que se consolidava.

Neste sentido, embora vigorava-se um sistema de produção pautado na mão de obra servil, os grandes centros extratores de minério, cujo auge ocorrera entre a segunda metade do século XVII e primeira metade do século XVIII, começaram a demandar de outras localidades - seja em uma perspectiva provinciana ou de regiões longínquas - provisões alimentares que suprisse as necessidades logísticas de tais polos.

Tendo como resultado, da "ampliação" de tais demandas, o surgimento e expansão de uma rede de circulação sobre o território - estradas reais, trilhas, caminhos - cuja finalidade repousava na circulação de informações, como as normas jurídicas produzidas pela metrópole, mercadorias como: alimentos, gado, ouro, diamantes e pessoas (comerciantes, viajantes, tropas). 
Todavia, como característica do período pré-máquina (séculos XVI ao início do século XX) abordado por Santos e Silveira (2003), tem-se, enquanto conquista a ser alcançada, a sobreposição das lógicas dos tempos impostos pela natureza, a artificialização do território enquanto condição de aceleração dos processos produtivos e de ampliação das relações comerciais, que no contexto brasileiro, ganharão contornos na segunda metade século XIX.

1.2 - Planaltina 1811: marco inicial da formação urbana da cidade goiana.

Muito embora a região, na qual se encontra o antigo município de Planaltina-GO não tivesse desenvolvido significativamente a atividade de extração do ouro, prata e diamantes, desempenhava a função de rota de passagem e estalagem, pouso para viajantes, comerciantes e grandes comitivas de boiadeiros originárias do Nordeste que iam em direção aos demais polos produtores de minério dos estados de Minas Gerais, Goiás e Mato Grosso.

As primeiras sesmarias locais, como fora exposto, advém dos avanços das últimas bandeiras promovidas sobre a localidade, na primeira metade do século XVIII, somado à expansão da atividade pecuarista oriunda do Nordeste, especificamente, em detrimento da dilatação das redes que compunham os Currais do São Francisco e que embrenharam-se no Vale do Paranã até a sua efetiva materialização na região em apreciação.

Quanto ao acesso e fixação na terra, Magalhães e Eleutério (2008, p. 108) descrevem que relacionados às empreitadas promovidas pelas bandeiras, inicialmente, as "grandes extensões territoriais eram doadas aos bandeirantes e bugreiros que obtivessem maior sucesso" em suas expedições. "Daí em diante, deveria limpar a terra com a expulsão dos elementos autóctones".

Somado a tal perspectiva pioneira decorrente do bandeirismo sangrento, identifica-se, enquanto fatores que contribuíram na produção do espaço que atualmente tem por materialidade a cidade de Planaltina-Df, a formação da rede urbana da porção centro-sul do Estado de Goiás, no século XVIII, via consolidação de centros como Vila Boa (Cidade de Goiás), Borda do Mato (Catalão), Meia Ponte 
(Pirenópoles em 1727), Santa Luzia (Luziânia me 1746), descritas por Castro (1986) e Bertran (2000).

Em associação a materialização das cidades acima citadas, em conjunto com a consolidação dos povoados resultantes das atividades produtivas atreladas a Estrada Real da Bahia como Couros, irão possibilitar fixação dos primeiros colonizadores na região de Mestre D'Ármas.

Ainda sobre a conjunção de ações promovidas pelo Estado Lusitano e a sua presença na região que acaba por impulsionar a sua ocupação, Castro (1986) expõe a importância dos postos de registro que consolidaram Mestre D'Ármas enquanto ponto de passagem obrigatória dos viajantes e comerciante das regiões Norte, Nordeste e Sudeste no transcorrer do século XVIII. Nestes termos, o autor expõe:

O registro de Lagoa Feia foi instalado na Picada da Bahia, que ligava Vila Boa e os Currais do São Francisco, passando por Mestre D’Ármas e cabeceiras da Lagoa Feia. O morro, local de construção do "olheiro", foi chamado de Serra do General, hoje Serra de São Pedro.

Noutro espaço, ligando as mesmas localidades, havia outra picada (hoje conhecida como estrada do Urbano), nela foi instalada um registro, distante 90 quilômetros do primeiro, numa região denominada de "Arrependidos".

O registro de Arrependidos, ideia do Conde de Sarzedas, só foi instalado por D. Marcos de Noronha (Conde do Arcos), $1^{\circ}$ Governo Geral de Goiás, em 1750, com os mesmos objetivos formulados para o primeiro. (CASTRO, 1986, p.111).

Mediante o uso do território por diversos agentes de então (mineradores, pecuaristas, agricultores, comerciantes, escravos, trabalhadores livres), agregado à conjunção de ações empreendidas pelo Estado Português - que desdobra-se no movimento do território nacional e em seus subespaços - dar-se início, entre as décadas de 1740/1750 o processo de povoamento e origem das primeiras fazendas na região, os quais contarão, no final da segunda metade do século XVIII, com a Fazenda Mestre D’Ármas.

Referindo-se primeiros colonizadores efetivos da terra, Bertran (2000, p.154-155) por meio de registros documentais, aponta a sesmaria de Manoel de Barros Lima, ao Norte do atual Distrito Federal, como sendo a, possivelmente, 
primeira implementada. Segundo o autor, possivelmente, houvera uma série de desmembramentos desta ao longo do tempo, dando-se "ou por herança e vendas, em parcelas menores".

Ainda sobre a sesmaria de Manoel de Barros, Bertran (2000, p.155) descreve, enquanto exceção na relação de posse da terra em termos de registro histórico, o caso de Manoel Joaquim Pereira e Castro Souto Mayor "de 1768, possivelmente proprietário absenteísta, ocupando a quina de nordeste - atual fazenda Bom Sucesso - de uma das duas sesmarias de Barros de Lima. Exceção esta presente na cadeia dominial de registro de uso da terra exposto pelo autor.

Bertran (2000) assevera que em termos de indícios históricos, com a ressalva de Barros de Lima, os demais sesmeiros que se instalaram na região irão fazeram a partir da década de 1770.

Magalhães e Eleutério (2008, p. 109) relatam que "sob o ponto de vista da evolução fundiária", Mestre D'Ármas e o complexo de sesmarias os quais remontam à configuração territorial da região, surgiram em decorrência do apogeu e, principalmente, do declínio das lavras auríferas desenvolvidas nas proximidades, como por exemplo, o caso de Santa Luzia.

O rápido crescimento das populações atraídas pela atividade aurífera, conforme entendimento dos citados autores, "levou a Administração Colonial a tomar medidas facilitadoras para o estabelecimento de pequenos núcleos de apoio à atividade mineradora". O resultado, quanto a isso foi a concessão de "imensos lotes de terras" (sesmarias) "como forma de incentivo à fixação de agricultores e pecuaristas em locais próximos à região mineira".

Todavia, o processo anteriormente exposto, no caso de Mestre D'Ármas, intensifica-se em resposta à decadência do ciclo do ouro em Goiás, principalmente nos arredores da atual cidade de Planaltina, tal como é exposto por Castro (1986):

Em 1736, afirma Luiz Palacin, os rendimentos obtidos como recolhimento da captação em Goiás corresponderam a 60712 oitavas, com a correspondente equivalência a $217,17 \mathrm{~kg}$. de ouro. No ano seguinte, os mineradores contribuíram apenas com 37.393 oitavas. Em 1738 e 1739, $281 \mathrm{~kg}$. de ouro, respectivamente. 
Com a volta da cobrança dos QUINTOS, a partir de 1750 , com a aplicação da lei somente em 1752, em Goiás, a produção de ouro ampliou-se atingindo índices máximos. Este vulto propagou-se, anos a fora, com pequenos decréscimos, até 1778, quando aconteceu a queda definitiva e notável das minas dos Guayases. Chegavam ao esgotamento as minas, com a consequente migração de seus mineradores.

Em Goiás, tudo correu bem até o ano de 1776, segundo Palacin: "Antes desta data, argumenta, a receita sempre superou a despesa, depois dela, a despesa, inversamente, sempre foi superior à receita". Esses fatos deram oportunidade ao aparecimento dos primeiros núcleos urbanos, cuja base econômica era a agricultura e a pecuária. Entre eles o núcleo do Sítio Mestre D’Ármas. (CASTRO, 1986, p.113).

Neste contexto que remonta a década de 1770, Bertran $(2000)^{11}$ demonstra a genealogia das famílias que ocuparam a região a partir de então, assim como a localização de suas propriedades que deram origem à dinâmica das relações de produção espacial e que conduziram à antiga sede goiana de Planaltina e sua extensão municipal. O autor expõe nestes termos:

A oeste de Planaltina, assentou-se Bernadino Joaquim de Souza Canabarro (1777) na chapada do ribeirão Mestre D'Ármas. A leste da mesma, deitou Antônio Gomes de Almeida (1772), residente em Vila Boa de Goiás, as suas terras do "pasto do Moquém". Pelo Sul, situava o próprio Gomes de Almeida como vizinho ao capitão Bento Nicolau de Oliveira, no ribeirão Estanislau, cujo requerimento data de 1769. O capitão Bento Nicolau de Oliveira, também reside em Vila Boa, onde segundo apontamentos existentes no Museu das Bandeiras, arrematou em 1774, o ofício de tesoureiro da fazenda de defuntos e ausentes da capitania. (BERTRAN, 2000, p.155).

Bertran (2000) relata ainda quem, nesta dinâmica de ocupação da terra, nomes como De Canabarro, de Souto Maior, Oliveira e Gomes de Almeida dão lugar aos Gomes Rabello e Alarcão, estes já figurando entre famílias colonizadoras no final do século XVIII e início do século XIX.

Estas duas últimas famílias, em somatória aos Guimarães advindos de Couros (Formosa), se revezaram ao longo do século XIX e transcorrer da primeira metade do século $X X$ no exercício do poder político e econômico em Mestre D’Ármas, posterior Planaltina, cuja primazia estava condicionada com a concentração e posse das terras.

\footnotetext{
${ }^{11}$ Ver mais detalhes em BERTRAN (2000).
} 
Conforme será exposto brevemente mais adiante, os fatores relacionados ao exercício das relações de poder, bem como as práticas sociais ligadas às tradicionais festividades religiosas, cuja territorialidade vinculava-se às antigas sesmaria setecentistas, oitocentistas, sofrerão profundas transformações mediante ao embate dialético entre o velho - Mestre D’Ármas, Planaltina - e o novo - Brasília.

Entretanto, cabe expor a importante ressalva explicitada por Bertran (2000), quanto às relações de uso e ocupação do solo já no período citado, tendo em vista que as dificuldades de estabelecer a cadeia dominial quanto aos registros que comprovam a propriedade da terra atualmente, originam-se em tal contexto. Nesses termos, o autor assevera:

Se pudemos distinguir anteriormente - nos anos de 1740 - as sesmarias fundadoras da região, teríamos passado uns vinte anos, a instalação de suas sesmarias povoadoras em muito maior quantidade de requerimentos.

Com as anteriores, nunca foram autenticadas conforme a legislação reinol, mas tiveram seus assentamentos reais: casas, senzalas, e fábricas de engenhos solidamente instalados, e que constituíam patrimônios reais, sujeitos a compras e vendas e vendas entre particulares. (BERTRAN, 2000, p. 154, grifo nosso).

Conforme será desenvolvido durante o transcorrer do estudo, verificase que a proposta face ao exercício de periodização através das relações de produção do espaço, tendo, enquanto uma das categorias analíticas a formação socioespacial, em suas múltiplas escalas, repercutirá na materialização do território usado no plano do presente.

Nesse sentido é pertinente afirmar que muito embora haja uma variação espacial (espaços singulares), o modo de produção que vige irá desdobrarse na produção da dinâmica social face a construção das frações do todo, desvelando-se também na sucessão dos períodos ao longo do espaço-tempo.

Logo, as ações dos diversos agentes, em consonância com demais elementos que compõem o todo e suas partes - como as normas que regulam as relações de produção através das inter-relações sociais - respondem na produção de materialidade enquanto fruto da interpretação social das normas em vigência, 
assim como da maior ou menor presença do Estado que resultaria no cumprimento ou não das mesmas.

Ou seja, a norma (técnica) reflete uma lógica oriunda da superestrutura que norteia as relações de produção em um território e suas frações, mas que em alguns casos, a flexibilização de sua aplicação dispõe de uma intencionalidade advinda dessa mesma superestrutura, tendo por finalidade a aceleração e o alargamento das próprias relações de produção social que irão repercutir no movimento do espaço e na retroalimentação da superestrutura de onde emanam as normas de produção do mesmo.

Como já exposto, Castro (1986) esclarece, remontando-se ao raciocínio de Nozoe (2006), a flexibilização da demarcação e registro das sesmarias, que tinha, como lógica a ampliação do espaço rural e a interiorização das relações de produção colonial sobre o território.

A falta do devido registro da terra relatado por Bertran (2000) no caso verificado em Planaltina e arredores, como Arraial de Couros (1746) e Santa Luzia (1736), irão repercutir em uma grande dificuldade no processo de desapropriação de terras para a efetiva implementação da Capital Federal na década de 1950.

Verifica-se também na cidade de Planaltina, então Goiás, o mesmo problema encontrado quanto aos registros notariais das fazendas. Entretanto, essa questão assenta-se na documentação dos imóveis urbanos, assim como das diversas plantas da cidade aprovadas pelo Poder Executivo local, anterior à construção da nova capital.

Tais fatos constituem como rugosidades (Santos, 2002), haja vista serem heranças das práticas de produção pretérita do espaço, que neste caso, influenciam as dinâmicas sociais do presente.

As situações de precariedade jurídica quanto ao registro dos imóveis rurais e urbanos - persistirá no decorrer do século XX, até os dias atuais, levando o Poder Judiciário a se envolver em tal questão, participando da dinâmica de produção do espaço urbano da cidade de Planaltina, mediante o proferir de decisões/ações. 
Tais entraves repercutirão na difícil tarefa de regularização jurídica das propriedades rurais e urbanas em Planaltina pós-Brasília, impactando diretamente nas relações de compra e venda das habitações, assim como na precariedade possessória dos imóveis urbanos. Estes pontos também serão aprofundadas mais adiante.

Todavia, vale ressaltar que as disputas judiciais relativas a questão do registro imobiliário dos imóveis e da sobreposição irregular de domínios de terras rurais no Brasil, não são nada recentes, sendo provenientes da frouxidão normativa e na atuação fiscalizadora do Estado Lusitano, já no processo de implementação jurídica das Capitanias Hereditárias contemplado pela Lei de Sesmarias de 1375.

Sobre essa questão, Nozoe (2006, p. 589) afirma que, além da situação de precariedade jurídica das terras brasileiras, que compreende o período de 1532 a 1850 (Lei de Terras); além dos elementos acima citados (fiscalização deficitária e inconsistências normativas sobre a posse da terra), acrescenta-se também, por parte dos beneficiários (sesmeiros), as dificuldades encontradas por esses em cumprir as demandas contidas na norma - demarcação da extensão da sesmaria e registro junto à Coroa - assim como o desinteresse, por parte dos mesmos, em cumprir a legislação. Sobre o tema, Nozoe (2006) assevera:

Justamente à inexistência de um regimento específico sobre as sesmarias, no arrazoado que encabeçava o alvará de 5 de outubro de 1795 atribuíram-se os abusos, irregulares e desordens, que têm grassado, estão e vão grassando em todo o Estado do Brasil, sobre o melindroso objeto das suas sesmarias.

Dentre os problemas fundiários prejudiciais aos interesses da Real Coroa, a medida baixada pelo príncipe-regente D. João mencionava, com ênfase, a distribuição de terras sem a devida observância do princípio da igualdade entre os súditos, as posses, a falta de demarcação judicial, que acabavam por avultar a quantidade de litígios e demandas judiciais que se arrastavam por longo tempo, que deterioram os cabedais de uns e fazem infalível a ruína de outros ... (NOZOE, 2006, p. 593-594).

Observa-se, já neste contexto, a presença da instância judicial através de suas decisões/ações, interferindo na lógica da produção espacial. Muito embora, as demandas que resultavam na tomada de posicionamento de tal instância de poder, tivessem enquanto elemento gerador dos conflitos a produção das normas e 
a executoriedade das mesmas que eram originários do poder centralizado na figura do monarca.

Vale explicitar também, segundo a exposição de Nozeo (2006), que tais debilidades se sobrepunham às gestões dos sucessivos reinantes e que, no caso de Planaltina, segundo relatos e documentos levantados em pesquisa documental a serem apresentados adiante, revelam a persistência de tais práticas que sobreviram com o tempo, ou que ganharam novos contornos.

Conforme asseverado por Nozeo (2006), a revisão da Lei de Sesmarias aplicada no Brasil, no ano de 1795, tinha por finalidade corrigir as distorções e omissões das normas anteriormente aplicadas, contudo, acabavam por dificultar ainda mais a possibilidade de execução do registro das propriedades pelos sesmeiros ou posseiros. Nestes termos o autor afirma que:

De pronto, chama a atenção o número e a minudência das determinações, muitas das quais já haviam constado de dispositivos baixados anteriormente, sobre a utilíssima condição de medir e demarcar as sesmarias, obrigação cuja dispensa os governadores e capitães-generais do Brasil ficaram proibidos de conceder; igualmente, o Conselho Ultramarino ficava impedido de confirmar cartas de concessão que não se fizessem acompanhar da respectiva certidão legal e autêntica de que a demarcação havia sido feita e a sentença passado em julgado. Ainda sobre o mesmo assunto, 0 alvará estipulava em dois anos o prazo para que antigos sesmeiros dessem cumprimento à determinação, ao fim do qual, contra os refratários, seria executada irremissivelmente a pena do comisso, que até agora se lhes tem tolerado. Na prática, a falta passava a ser severamente punida com a reversão das terras e subsequente incorporação ao patrimônio da Coroa, podendo ser distribuídas novamente. (NOZEO, 2006, p. 594).

Ainda segundo Nozeo (2006), já neste contexto colonial relativo à revisão da Lei de Sesmarias em 1795, o Poder Judiciário era tido como possibilidade mais rápida - mediante ao seu parecer decisório - para a obtenção de legitimidade jurídica referente à questão da dominialidade da terra, frente à sobreposição de limites de sesmarias em lides ocorridas. Contudo, cabia a este poder dar prerrogativa em suas decisões aos casos em que os querelantes não tivessem os títulos reconhecidos legalmente, resguardando assim, o posseiro. Nesta perspectiva, cabe ressaltar a exposição do autor: 
O exame dos dispositivos destinados a emprestar maior agilidade ao processo judicial de demarcação permite evidenciar com maior força a exclusividade comprobatória atribuído, no alvará em tela, aos documentos oficiais de doação, com primazia para aqueles confirmados pela Coroa. Assim, nos casos em que a mesma área era disputada por diferentes sesmeiros, o magistrado responsável pela medição obrigava-se a iniciar a demarcação pela carta confirmada mais antiga, sucedendo outras conforme a antiguidade. Em tais circunstâncias, as posses eram consideradas inadmissíveis e condenadas. As questões atinentes às posses só seriam judicialmente apreciadas - mesmo assim apenas no âmbito das leis e do direito comuns, portanto sem o benefício da legislação sumaríssima, menos onerosa e mais rápida - quando a disputa ocorresse entre pessoas sem título reconhecido. A prerrogativa não se aplicava quando a ação se dava no sentido inverso, isto é, quando o sesmeiro adentrava em terras de confinantes não titulados, mesmo daqueles que demonstrassem a diuturnidade de suas posses, ainda que respaldados em cartas de partilha, escritura de compra ou de doação, ou qualquer outro gênero de contrato. (NOZEO, 2006, p. 594-595).

O autor citado destaca que a normatização de 1795 em pouco tempo cai em desuso, tendo em vista a lógica de flexibilização advinda do Estado Português, cuja finalidade assentava-se no incentivo das ocupações periféricas do território, que tinha por objetivo a desconcentração de pessoas dos principais núcleos urbanos da época, assim como do fomento à produção agropastoril para abastecer os centros de produção aurífera.

Nessa lógica, o autor destaca que a flexibilização da Lei resulta em distorções como o beneficiamento de setores sociais que já dispunham de grandes extensões de terras e que acaba por desdobrar-se nas práticas culturais, gerando a atual dinâmica fundiária do país fortemente pautado na lógica da posse.

Todavia, essas distorções beneficiaram também o próprio Estado Lusitano, haja visto que a dilatação do sistema colonial de produção constituía em condição sine qua non para o sucesso do empreendimento colonial em terras brasileiras.

Para Nozoe (2006), a Lei de Terras de 1850 acabou por sacramentar e ampliar tais práticas de poder pautadas na concentração de terras devolutas de maneira irregular. A diferença foi que a propriedade da terra passa ser concebida como bem econômico, dificultando a aquisição dos despossuídos e ampliando as disparidades socioeconômicas em todo o território nacional, aumentando a questão da precariedade jurídica e dominial da propriedade da terra. 
1.3.1 - O surgimento do Largo de São Sebastião de Mestre D’Ármas.

No estudo em questão, conforme já fora explicitado, a década de 1770 constituiu-se enquanto um marco, tendo em vista o esgotamento das jazidas de ouro em território goiano. A consequência deste evento foi a crescente demanda pela terra que desdobrou-se na ampliação do número de sesmeiros e posseiros na região que hoje contempla Planaltina-DF.

Tal fato não ocorreu apenas em Goiás, mas em todo país, dando início, entre o fim do século XVIII e início do século XIX, a um novo momento de crescimento da econômico colonial, cujo motor retorna à atividade agroexportadora.

Esse contexto espaço-temporal, segundo Santos (1985), engloba o período da revolução industrial (1750-1870), cuja função dos espaços periféricos, como as colônias portuguesas, consistiam na produção de matéria-prima para o abastecimento da indústria maquinofatureira europeia. O Brasil dispunha de características típicas de um meio técnico pré-máquina ou arquipélago de mecanização incompleta (Santos, Silveira, 2003).

Se o auge da produção aurífera promove o deslocamento populacional (garimpeiros, pecuaristas, agricultores, escravos, trabalhadores livres), em conjunto com a máquina burocrática do Estado Português, para as porções interioranas do território nacional, com 0 advento do novo crescimento da economia agroexportadora, impulsionada pelas demandas externas, acaba por provocar o movimento inverso em direção às cadeias produtivas próximas do litoral. 
Figura 04 - Reestruturação do Sistema produtivo (séculos XVIII/XIX)

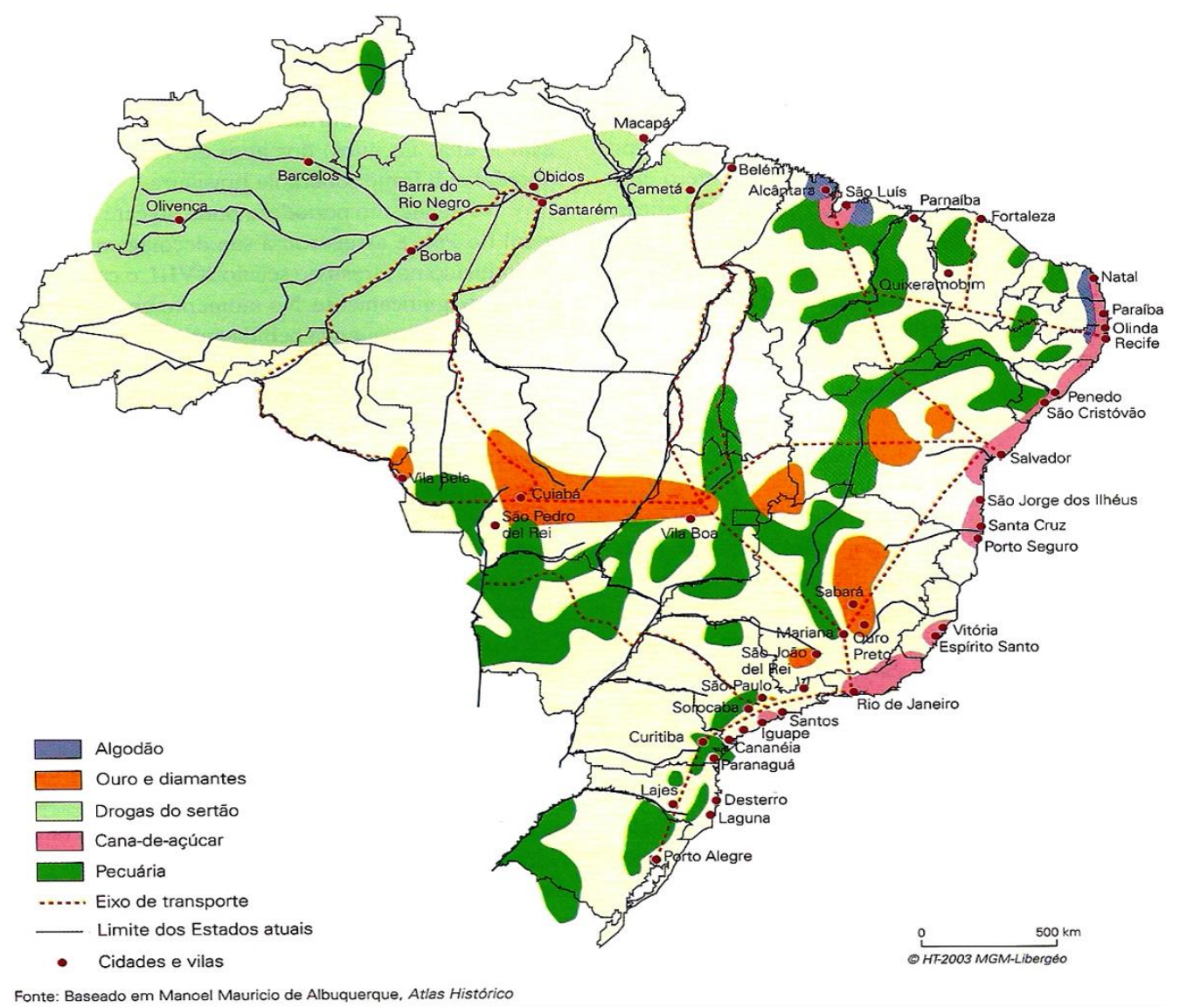

Fonte: Théry e Mello (2005).

Segundo Santos (2005), Théry e Mello (2005) e Szmrecsányl (1998), percebe-se a efetiva mudança do eixo político e econômico do país em direção à região Sudeste, que além de receber a Família Real Portuguesa em 1808, testemunhar, no transcorrer do século XIX, o desenvolvimento do complexo agroindustrial cafeeiro, assim como a mecanização do território.

Tais acontecimentos, segundo Santos (2005) repercutiram na concentração dos capitais produtivos em tal porção do território, que se desdobraram na implementação do conjunto de sistemas de objetos artificiais ferrovias, portos, pequenas cidades - e institucionais - como a burocracia estatal em 1822 com a vinda de bancos, instituições de pesquisa, embora rarefeitas necessários à produção, fluidez e distribuição das matérias-primas para o mercado externo. 
Nesse contexto de transição da atividade mineradora para um retorno à lógica agroexportadora, ocorreu, em uma perspectiva local, a ampliação do número de sesmarias na região que hoje é pertencente ao Distrito Federal, e, por conseguinte, a uma fração desta: Planaltina.

Segundo Castro (1986, p. 18), a toponímia Mestre D'Ármas é oriunda da provável instalação de um ferreiro na localidade, na qual, poucas décadas depois, daria origem às primeiras aglomerações populacionais ligadas a gênese da atual cidade.

Quanto à notoriedade do sítio, Castro (1986, p. 126) explicita que o mesmo não dispunha de relevância econômica no período, sendo, inclusive, o seu nome pouco conhecido pelos viajantes.

O autor assevera que a importância dessa localidade para a região, no final do século XVIII, residia no fato de ser usado enquanto ponto de referência, tendo em vista a sua proximidade com Águas Emendadas, assim como da associação enquanto local fundacional do Arraial de São Sebastião de Mestre D’Ármas.

Sobre a vida e a pessoa do Mestre D'Ármas, Castro (1986) descreve brevemente da seguinte maneira:

Ajuntando-se alguns elementos, cedidos nas pesquisas de campo e bibliográficas, pode-se traçar um perfil psicológico e um esboço de retrato do nobre artífice. Todo mestre, entre os mineradores, bandeirantes e autoridades do sertão, era português, em traje autêntico, da época: botina com pederneiras de couro; camisas e calças de tecido pardos, para enfiar nas matas. À moda, barba do queixo para atrás e cabelos um pouco compridos. Como ferreiro, 0 mestre deveria usar um avental de couro cru, comum na época, como proteção do corpo contra as altas temperaturas.

Os antigos contam: o Mestre D’Armas viveu aí com a sua mulher, sem filhos, criaturas calmas, ponderadas, comedidas, numa ponta de oficina, numa ponta de pensão, até às últimas décadas do século XVIII, início do século XIX, como os mais antigos contavam. Isto, à Rua $1^{\circ}$ de junho, atrás do posto de Gasolina Luza's (onde ainda há vestígios), em Planaltina. Aí viveu, por estimativa, 50 anos ou mais, do conserto de armas, de funilagem, da fundição de pequenos dotes de ouro, do fabrico de instrumentos agrícolas e soldagens, no rodar da roda de fole, nas ferragens dos carros de bois, no acender as brasas, na moldagem dos metais à forja e bigorna, no resfriar chiado na tina e nos acabamentos em uma mesa de ofício. (CASTRO, 1986, p. 120-121). 
Segundo Castro (1986), a fundação do Arraial de São Sebastião de Mestre D'Ármas tem como datação informada o dia 20 de janeiro de $1811^{12}$. Magalhães e Eleutério (2008, p. 2008) descrevem que o núcleo original dispunha de 200 famílias, segundo os dados documentais contidos nos "registros do Livro de Impostos Rurais", recolhidos pela diocese de Santa Luzia enquanto dízimo.

Nesta perspectiva, o sítio urbano de Planaltina-DF, em sua gênese, constituía o que é conhecido juridicamente enquanto Terra de Santo, haja vista que uma fração de tal propriedade foi doada ao santo milagreiro, como forma de agradecimento a alguma graça alcançada mediante promessas firmadas junto ao mesmo, em agradecimento à intercessão junto a Deus quanto às supostas graças a serem alcançadas.

Castro (1986) relata que o motivo para tal doação de terras para o Santo está associado a um grande surto de malária que acometera o povoado entre o final do século XVIII e início do século XIX. Sendo a promessa cumprida pelo Santo, a cura das epidemias, os moradores locais promoveram a doação de terras em favor do mesmo, São Sebastião. Este fato é descrito pelo autor da seguinte forma:

Daí, quando se conta, que os moradores do Sítio de Mestre D’Ármas foram acometidos de intensas epidemias, e que a partir disso, José Gomes Rabelo, como líder, e outros proprietários do Sítio, fizeram uma promessa a São Sebastião [...]

Depois de um longo tempo, o povo tendo conseguido se libertar da miséria da doença encaminhou ao Santo, através dos padres de Santa Luzia, a doação de um trecho de terras. Terras equivalentes à meia légua por uma, com a incumbência dos moradores construírem um orago a São Sebastião.

Após isto, José Gomes Rabelo e filhos construíram mais algumas casas em volta da igrejinha (dando origem ao Largo da Matriz de São Sebastião), que serviam-lhe em épocas de festas, pois as suas residências ficavam próximas da Lagoa Mestre D'Ármas. (CASTRO, 1986, p. 127-128).

\footnotetext{
${ }^{12}$ Embora Castro (1986) descreva de maneira precisa a gênese de São Sebastião de Mestre D'Ármas, cuja datação aferida corresponde ao dia 20 de janeiro de 1811, oficialmente a cidade passa a ser reconhecida apenas no dia 19 de agosto de 1859, quando o Arraial São Sebastião de Mestre D'Ármas passa a ser Distrito de Paz pertencente a Vila Formosa da Imperatriz.
} 


\section{Fotografia 01 - Praça de São Sebastião}

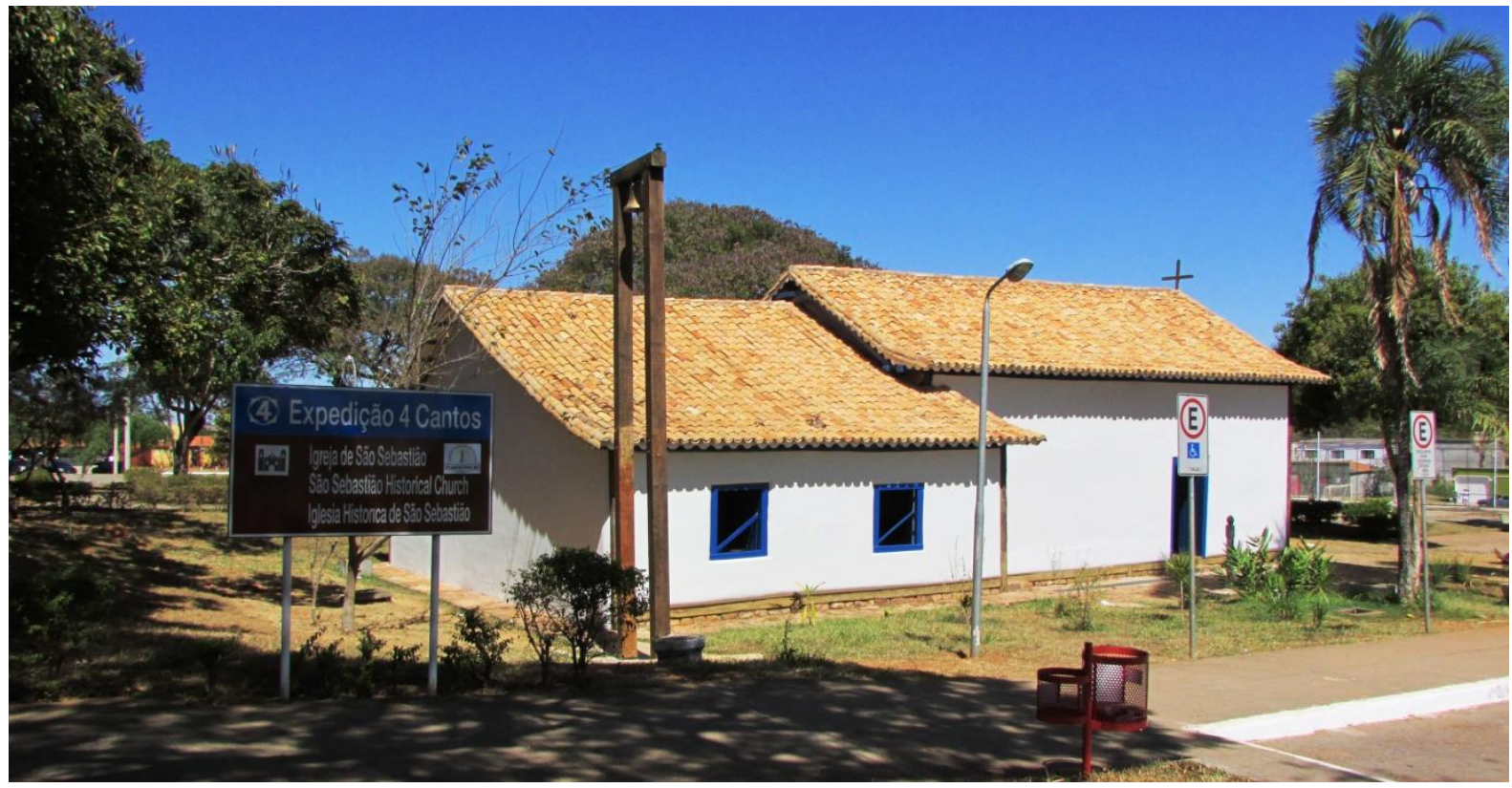

Fonte: Lima (2014).

O marco que pontua o começo do povoado está interligado documentalmente aos registros do livro de impostos rurais, bem como da solenidade de criação da Igreja de São Sebastião. Neste sentido, Castro (1986) faz inferências, referente a datação de origem do largo de São Sebastião de Mestre D'Ármas, dando início a consolidação populacional em torna das festividades cristãs:

Três razões nos levaram a crer que a data de fundação do Arraial foi 20 de janeiro de 1811. A primeira, que o Arraial não estava criado no final do ano de 1810 e que bem antes havia ocorrida a promessa, e de outro lado, que em 1812, o Arraial já havia sido criado há algum tempo antes; a segunda, a existência do cemitério dá-nos a existência da igreja, onde foi realizada a solenidade de criação do Arraial; a terceira e última é que, ajuntando os fatos de doação das terras ao Santo, o período que continha à data santificada em homenagem ao Santo, tudo, concorreram para a dedução de que o dia da criação do arraial foi 20 de janeiro de 1811. (CASTRO, 1986, p. 130).

Quanto à extensão de terras doadas ao santo, Magalhães e Eleutério (2008), trazem o dado de 200 alqueires de terras, o que corresponderia em um total, em alqueire paulista, de 242 hectares. 
Indo nesta direção, o relatório contido na Ação Declaratória de Nulidade de Ato Administrativo (processo 1.874/93), interposto pelo MPDFT junto ao TJDFT, aponta enquanto área pertencente ao santo, aproximadamente 200 hectares de terra.

Inclusive, tal documento traz uma descrição do processo de loteamento das terras entre os habitantes e a instância religiosa que efetivamente resulta no sítio urbano de Planaltina e substrato de implementação do poder público local. Para melhor entendimento é válido expor o relato contido no processo n 1874/93:

A trama urbana originou-se de terras pertencentes ao patrimônio da Igreja de São Sebastião. Em 1927 a Igreja permutou, com a Independência Municipal de Planaltina, uma área de 200 hectares de terras do dito patrimônio por igual quantia na fazenda denominada Monjolos. Embora tivesse a Igreja feito as transações acima descritas, tendo por base o Registro Paroquial de seu patrimônio, teve ela suas dúvidas quanto ao domínio de suas terras, pois, ingressou em juízo com uma ação levando a Registro Imobiliário, que teve o número de ordem 6.620; pela Cúria Arquidiocesana de Goiás.

Os habitantes do nucleamento adquiriram o direito de propriedade da pura e simples ocupação de uma determinada gleba. Por um processo natural em terras pertencentes ao patrimônio da Igreja, os ocupantes delimitaram seus lotes, abriram ruas, criaram praças e a paróquia fez as anotações iniciais gerando os registros das propriedades, que posteriormente, transferiram para a competência de cartórios quando a gleba passou para a propriedade da Administração Municipal. (MINISTÉRIO PÚBLICO DO DISTRITO FEDERAL E TERRITÓRIOS. Ação Declaratória de Nulidade de Ato Administrativo; processo $n^{\circ} 1874 / 93$ ).

Conforme a citação anterior, observa-se que nessa relação direta entre a produção do espaço urbano e a dominialidade da terra por parte da Igreja Católica, o elemento jurídico comprobatório da titularidade dos imóveis, contidos no antigo núcleo urbano, inicialmente, passam a ser os registros documentais produzidos pela entidade eclesiástica e que, durante muito tempo, serviram para atestar o uso e ocupação do solo pelas famílias que se fixaram no núcleo urbano.

portanto, assim como nas grandes propriedades fundiárias, o processo de uso e ocupação das terras de santo que correspondiam ao Largo de São Sebastião, se dava através do sistema de posse dos lotes, subdivididos segundo o 
consenso dos moradores já instalados na localidade, não dispondo, tais terras neste contexto, de valor monetário.

Castro (2014), em entrevista, descreve que essa subdivisão ocorria de forma amigável, e que, geralmente, os primeiros moradores tinham em comum, 0 fato de serem devotos do Santo, compondo possivelmente uma congregação religiosa vinculada à ocupação da terra. Todavia, a priori, não tendo uma relação direita de controle por parte da Igreja Católica. O domínio da terra pela Igreja ocorrerá após décadas depois do surgimento do arraial, propiciando à mesma a propriedade dos 200 hectares correspondente a antiga Fazenda Mestre D'Ármas.

Neste sentido, as terras ocupadas não dispunham da descrição de suas dimensões e nem de documentações que atestavam a propriedade do lote, já que as terras eram pertencentes ao santo, e segundo Castro (2013), o mesmo não se irritaria com o processo de ocupação e uso do solo. Castro (2013) com base na tradição oral e em exaustivas pesquisas históricas descreve tal dinâmica:

(...) Então veja bem, a doação de meia légua de terras por uma (...) construíram a igrejinha no meio pra poder fazer uma festa de homenagem ao santo. Olha, o que eles fizeram: começaram a convidar os moradores, crentes no São Sebastião milagroso, a adquirir terra nessa meia légua de terra e fizeram um oratoriozinho lá onde é a igrejinha (...)

- Então, estou lhe falando que o São Sebastião recebeu meia légua de terra e que eles fizeram uma igrejinha nu meio de uma praça, que depois foi descaracterizada. Pegaram um pedaço da praça e transformaram em lote. Era um quadradão a praça.

- A minha vó não soube me explicar, porque é que tomaram um pedaço da praça (...) e foram distribuindo lotes em volta, aí de repente foi surgindo uma ruelazinha... e o povoado aconteceu a partir desse, desse movimento.

- Bom, nós temos meia légua de terra por uma... agora eu pergunto pra você, vamos agora partir para os lotes desse primeiro arraial: não tinha! Não tinha a subdivisão que também era a olho!

- Oh, eu quero um lugar lá para construir uma casa... sim, constrói a casa perto da de Romão, do Félix... eu vou construir perto do Carlos, do Zé...

- Então, ia, ia tantos metro de frente, se a casa dele tivesse tantos metro de frente, falava: não, vou deixar uma entradinha aqui...

- Olha, não existia ninguém! Os primeiros foram tomando conta da terra! E povoando! E criando os lotes! Né... 
- Depois é que foram olhar o que foi fechado, e depois das primeiras ruas começarem a aparecer, não existia nenhuma determinação! Todo mundo que pagava imposto, não pagava imposto irrisório se não fosse dono de uma propriedade, e não um dono de um lote, né... e o estabelecimento de vendas e de armazénzinhos, aqui e acolá... um local que se fizesse pão, a venda de leite que vinha das fazendas...

(...) foi assim que o arraial foi começando, e não teve, esse começo, você... você viu que o começo lá das Sesmarias também dos sítios ninguém... aqui também, quem é que ia chegar... ai você me diz: de quem é a terra? A terra foi doada pra quem? Pro São Sebastião! Pro mártir São Sebastião!

- São Sebastião não ia achar ruim se o camarada botasse o lote dele! Não tinha ninguém pra fiscalizar! A terra era do Santo! Quem quisesse, quem fosse devoto do Santo, até podia ter um pedaço de terra maior! Ou quem tivesse um filho: não, aí é do meu filho: eu construo uma casa pra mim e o meu filho também constrói outra... não existia ninguém!

- Quem determinava? No começo a família Gomes Rabelo. Depois que veio surgir a família Alarcão (...) Os primeiros povoadores da região, que pagavam o dízimo lá em Luziânia, compreende? Então aqueles nomes, foram os nomes principais que reuniram e decidiram fazer a promessa. Eles também definiam a questão dos lotes... e não havia tamanho de lote, que hoje a gente bota o olho e diz: passou aí 20 centímetros! Tá errado!

- Daí, com uma certa visão de povoado, aí sim, quando se cria uma rua fala-se: não, tem uma outra rua, vamos criar uma outra rua aqui pra encher de casas. Aí sim fica casa de fundo, casa de frente... aí sim passa ter: vamos colocar mais uma rua por que... aí dá um espaço pro camarada tirar um lote... tirar! Tomar! Adquirir! Ser autorizado! Por quem? Pelos primeiros moradores! Quem doou as terras!? Representando quem? São Sebastião!

Porque os padres, não vieram assumir a terra. Que só vinham aqui em desobrigas. De três, de quatro em quatro meses... vinha um padre pra batizar... vinha um padre pra fazer algum casamento(...) mas não tinha um padre fiscalizando nada. Nem a Igreja nem nada! Não tinha ninguém e não há nenhum dado na história de Planaltina dizendo que a Igreja, tomando conhecimento da meia légua de terra - onde é que tá, vamos somar pra ver se tem meia légua mesmo! Não... que isso?

- Só depois mais tarde quando se registra em cartório, é que começa a aparecer dados mais retos, mais corretos... (CASTRO, 2014, grifo nosso).

Verifica-se na fala de Castro (2014) as dinâmicas de uso e ocupação do espaço urbano embrionário de Planaltina que remonta às primeiras décadas de sua existência. Castro (2014) ainda ressalta que, efetivamente, a Igreja passa a 
exercer fiscalização e registro das terras, a partir da década de 1880, tanto no perímetro urbano, como na área rural, principalmente sendo tal função, em seguida, desempenhada pela Intendência instituída no ano de 1892, o que corresponderia à elevação para a categoria de município atualmente, já contando com a instalação do Primeiro Cartório de Ofício e Registros Notariais.

Entretanto, quanto à questão fundiária, tem-se a partir da Lei de Terras n 601 de 1850 e na expedição dos registros paroquiais o elemento comprobatório da dominialidade da terra em substituição às normas contidas na Lei de Sesmarias que já não mais vigorava desde 1822 (NOZOE, 2006).

Depreende-se em Castro $(1986,2014)$ e nos demais documentos citados que, mesmo com o pequeno período de controle das terras exercidos pela Igreja Católica que durou uma década, foram expedidos Registros Paroquiais das propriedades rurais, assim como outros documentos que atestavam o uso e ocupação do solo dos moradores da Vila de Mestre D’Ármas, como o pagamento do dízimo pelos fiéis.

Além da precariedade documental, vários relatos, contidos nas pesquisas produzidas por Castro (1986) e Magalhães (2011), afirmam que predominava uma intensa relação de compra e venda de imóveis (rurais e urbanos) entre particulares, tendo, em vários casos, o simples acordo de palavra, através contrato de gaveta ${ }^{13}$, sem a expedição de um único documento sequer.

Segundo Processo Interno n. 135.000.703/1995 produzido pela Gerência da Unidade de Planejamento Territorial Norte (GENOR, 2012, s/p), vinculada a Secretaria de Estado de Habitação Regularização e Desenvolvimento Urbano (SEDHAB), a partir do ano de 1881, mesmo Mestre D’Ármas ao receber o Cartório de Ofício e Registros Notariais, o Poder Executivo local apenas promoveu inicialmente a "expedição de alvarás de concessão de propriedades relativas às

\footnotetext{
${ }^{13}$ A Associação dos Mutuários de São Paulo e Adjacências (AMSPA) define contrato de gaveta da seguinte maneira: (...) é um contrato não oficial, que somente tem existência perante as partes, comprador e vendedor. Por isso mesmo, é um contrato de elevado risco. Regra geral, o dono de um imóvel financiado resolve vender sua propriedade para outra pessoa, mas não faz isso de modo formal porque o novo proprietário não quer ou não pode fazer o financiamento nas condições de mercado. Então, o novo proprietário começa a pagar o contrato de financiamento como se fosse o antigo. A ideia é que, quando terminar de pagar, o novo proprietário possa então tomar posse do imóvel oficialmente. O contrato de gaveta, portanto, esconde uma situação irregular perante a lei. (http://www.amspa.com.br/novo/contrato-bancos/contrato-de-gaveta/; acessado em 01 de julho de 2014)
} 
Quadras em Branco que serviriam até 1961 para a comprovação de propriedades junto aos cartórios". Quadras em Branco por aparecerem em todas as plantas do loteamento sem a subdivisão dos lotes.

Dessa afirmação evidenciada, depreende-se que os registros das propriedades contidas na área urbana, em todo este período, foram diminutamente efetivados e quando assim o foram, não dispunham de validade jurídica, uma vez que constata-se que as plantas urbanas da cidade em seu contexto pré-Brasília, nunca foram registradas em cartório, tendo em vista a vigência da Lei n 54 de 1937.

Já no caso das propriedades rurais, registravam-se simples contratos de compra e venda entre particulares, cuja ocupação via posse das terras devolutas não era legalizada, não possuindo em alguns casos registro cartorial ou paroquial, contendo somente o memorial descritivo com a respectiva cadeia dominial das mesmas.

Sobre a precariedade jurídica das terras rurais que resulta na difícil tarefa de estabelecimento da cadeia dominial das mesmas, assim como de seus respectivos limites, Castro (2014) descreve a dinâmica de formação e ocupação das terras anterior à composição do Arraial de Mestre D'Ármas, que também se desdobra no transcorrer do século XIX e provavelmente, no século XX:

- Então, havia muita gente morando, aqui e acolá. Com autorização dos donatários, dos proprietários de Sesmarias.

- Então eles tinham essa autorização, vinham, localizavam mais ou menos as divisas (...) As divisas eram cantadas. O camarada chegava e dizia: daqui até aquele morro acolá... tudo isso é meu (...)

- (...) a situação era mais ou menos assim. O camarada tinha a autorização e aí ele passava a cerca e no que ele desse conta de passar a cerca era dele.

- Não tinha o certificado de propriedade... nessas fazendas. Aí depois, bem adiante é que isso começou a ser registrado. Pelas divisas e tal. Não houve assim, também, uma averiguação, uma fiscalização, se a pessoa estava encima das terras de quem autorizou, ou não! Por que deu um trabalho assim de muitas vezes, em cima do mapa, o Bertran e ... e olha que nós temos já um conhecimento né, uma localização, fazendo, traçando as divisas de tal ponto a tal ponto, o que tava no documento da Sesmaria, pra gente localizar no mapa. Olha que deu trabalho...

- Aí imagina antigamente, antes, na época do Sítio de Mestre D'Ármas. Não existia, não havia isso... 
- Eles recebiam a autorização ou do Presidente da Província, ou de algum elemento ligado a Corte Portuguesa, ou do próprio dono da Sesmaria: o sesmeiro. Ele tinha o documento que recebeu também de um Presidente da Província, ou de alguém ligado a Corte.

- Então ele tinha o documento e que tinha o descritivo porque eles buscavam no mapa e buscavam com o conhecimento já na prática por causa das minas.

- Então, não havia (...) definido nenhum... os primeiros sítios, vamos dizer assim (...) fazendolas, nem eram grandes latifúndios né... eram determinadas a olho! E nem se sabe ao certo, se aquela fazenda, era mesmo em cima do documento que o proprietário tinha do sesmeiro. É isso que eu quero dizer!

- Mais ou menos onde é isso? É perto de um riacho... ah, é tal... deve ser aqui... deve ser aqui! É quanto mais ou menos de terra? É tanto por não sei quantos hectares... eles falavam as medidas em braças, essa coisa toda... e pronto, é aqui! E a partir dali, com toda a certeza, todos os primeiros moradores antigos, quando a terra era boa, eles cercavam um pouco mais... porque sabiam que iam ter vantagem posteriormente, no futuro... (CASTRO, 2014, grifo nosso).

Fica notório, em todo este contexto pré-Brasília um grande vácuo jurídico quanto à situação de legalidade relativa ao uso e ocupação do solo, tanto em um contexto de Brasil Colônia, quanto no Império e na República. Dinâmica esta empreendida ao longo do tempo e continuada pela própria Prefeitura Municipal de Planaltina de Goiás, já em meados da primeira metade do século XX, referente ao contexto de produção do espaço urbano e rural, tendo em vista a ineficaz atuação do antigo Poder Executivo local no que tange à regularização da situação documental das propriedades, somando a isso o fator cultural.

Outro elemento a ser retomado mais adiante e que já foi citado anteriormente, remete-se às "Quadras em Branco" contidas no Setor Tradicional, objeto de lide judicial recente.

Referindo-se aos principais eventos, tendo como perspectiva a organização político-administrativa da região no contexto de século XIX, Castro (1986) pontua, dentre vários fatos, a criação, no ano de 1834, do $3^{\circ}$ Distrito de Santa Luzia, no qual estavam contidos Angicos e Mestre D'Ármas. Por conseguinte, Mestre D'Ármas é elevado da categoria de povoado à condição de distrito. Em 1836, em sequência ao evento anterior, tem-se a eleição dos primeiros juízes de paz. 
Castro (1986) ainda descreve a implementação dos cartórios imobiliários e de órfãos em 1871 e de registro civil em 1873; a delimitação municipal do Distrito de Paz de Mestre D’Ármas em 1880, recebendo o seu cartório de registro de imóveis; e, por fim, o advento da autonomia político-administrativa ao ser elevado da categoria de Distrito para Vila, pelo Decreto $n^{\circ} 52$ de 1891.

Relata também as constantes disputas políticas quanto à incorporação de Mestre D’Ármas à jurisdição do Distrito de Formosa da Imperatriz e as constantes pressões dos políticos e latifundiários locais para fazerem parte de Santa Luzia. Esses acontecimentos ocorrem de 1836 até 1892, quando o Decreto n 52/1891 passa a gerar o seu efeito.

Tais disputas estavam associadas às altas taxas tributárias pagas pelos grandes proprietários de terras do Distrito de Mestre D’Ármas para Formosa da Imperatriz, resultando em constantes disjunções e reintegrações entre Mestre D’Ármas e Formosa da Imperatriz e Mestre D’Ármas e Santa Luzia.

Mediante tais processos, os eventos que impactaram profundamente na dinâmica de formação socioespacial da então Vila de Mestre D’Ármas, posterior Planaltina $^{14}$, estiveram diretamente associados às especulações para com a interiorização da capital da recém-criada República Federativa do Brasil, instituída no ano de 1889.

A partir da Constituição de 1891, cria-se a expectativa de inserção do Sertão Planaltino (MAGALHÃES, 2011) à efetiva modernização e integração para com os eixos dinâmicos do país, quebrando o isolamento em relação ao restante do território desde meados do final do século XVIII (esgotamento das jazidas auríferas).

Neste sentido, a Missão Cruls, oriunda do comando constitucional contido na Constituição Nacional citada, efetivamente, inflama o espírito mudancista que já vigorava há tempos no sertão goiano, mobilizando toda a aristocracia política de Goiás, inclusive em Vila de Mestre D’Ármas.

\footnotetext{
${ }^{14}$ Acerca da toponímia da cidade objeto Castro (1986) descreve que além das denominações Arraial de São Sebastião de Mestre D'Ármas, Distrito de Mestre D'Ármas, Vila de Mestre D'Ármas, em 02 de Julho de 1910 esta passa a ser intitulada por força de Lei Estadual $n^{\circ} 363$ de Vila de Altamir. É apenas em 1917, por força de Lei Estadual n 541 que a cidade é cognominada Vila de Planaltina.
} 
1.4 - Comissão Cruls e o discurso mudancista: primeiros estudos quanto a transferência da capital para o Planalto Central.

Magalhães (2011) em "Sertão Planaltina: uma outra história de Brasília", descreve o processo de produção social regional mediante o olhar que permeia a História Cultural, tendo, enquanto espacialidade e temporalidade, as cidades de Planaltina, Luziânia e Formosa, que remonta desde o princípio do século XIX até a década de 1950. Década esta que retrata a construção de Brasília e a consumação do sonho mudancista da aristocracia política regional e local.

Em sua obra, Magalhães (2011) mediante os registros documentais obtidos sobre a cultura local (obras literárias, comunicações oficiais, jornais e memórias) apresenta a figura do planaltino, do sertanejo, em oposição aos estereótipos criados em tal contexto histórico - formulados, por exemplo, por Euclides da Cunha.

Diferentemente da imagem de pessoa matuta, iletrada e sofredora, Magalhães, ao tratar da sociedade Planaltina, imputa ao sertão e aos seus habitantes a imagem empreendedora e em constante movimento, tendo na composição dos complexos caminhos oriundos do seu modo de vida, a prova da existência de um corpo social nada inerte na região do Brasil Central.

Trazendo o sertanejo, o planaltino, enquanto categoria de análise, como fração de uma totalidade social e espacial, Magalhães (2011) assim caracteriza o sujeito total (abstrato) e multifacetado (concreto) em sua espacialidade:

O caráter dinâmico dos caminhos é o dado original e característico que impregna a cultura sertaneja. A identificação do homem sertanejo com os caminhos faz dele um apaixonado pelas viagens e por tudo o que transita por eles. Desse modo, ocorre o desenvolvimento de uma percepção aguda que lhe dá a possibilidade de conhecer cada detalhe da jornada, forçando por essa relação entre cultura e movimento. $E$ aquilo que a literatura normalmente define como sendo realidade imobilizada no tempo e no espaço, como naquele feudo extemporâneo da literatura de Alencar, o sertão, adquire então um inesperado dinamismo que produz generosas fissuras discursivas. (...) Por seu intermédio, é possível conceber o sertão, no sentido da cultura, mais pelo movimento do que pela fixidez. Tal dinamismo, porém, se rende ao conceito e não a um lugar específico. (MAGALHÃES, 2011, p. 30-31). 
Sobre a relação cultura, estratificação social e relações de poder, Magalhães (2011), ao explicitar a contradição entre a sociedade litorânea e o discurso de um interior atrasado espacialmente, propõe, enquanto síntese, a existência de uma elite erudita e articulada, tendo no uso dos veículos de comunicação (jornais) e no discurso progressista - pautado na razão e no saber científico - os elementos que comprovam a fissura discursiva de um sertão arcaico.

Entretanto, mesmo com a constante luta pela substituição da perspectiva metafísica pela razão, do isolamento regional frente ao dinamismo crescente da economia litorânea, do protagonismo político periférico a uma projeção nacional, Magalhães (2011) pontua a existência de uma sociedade feudal/colonial no contexto do século XIX, no qual, as diferenças socioeconômicas eram evidentes, todavia, em alguns casos, superadas pela unidade cultural ao qual permeava o desenvolvimento das práticas religiosas. Tal aglutinação passa a ser rompida com o novo modo de produção do espaço, resultante da construção de Brasília.

Referente às práticas sociais, às questões de cunho econômicoculturais, Magalhães assim expõe as singularidades sócio-espaciais do Sertão Planaltino:

(...) na sociedade Planaltina (rural, de base agropastoril e cultura tradicional), os contatos entre os grupos foram intensos. De certa forma, a cultura da classe dominante local é elaborada em posição dialógica com a das classes menos favorecidas. $O$ que não invalida, contudo, nem a existência, nem o acirramento das diferenças econômicas, sociais e políticas. (...) Obviamente, na sociedade Planaltina, as maiores diferenças eram as de ordem econômica. Os ritos populares das festas religiosas que desde a época colonial, amalgamavam os grupos sociais, apesar dos foros oficiais e canônicos, não deixavam de oferecer espaços compartilhados de intensa manifestação popular. Como pode ser constatado agudamente na maior festa popular de todo o Planalto Central, a Folia do Divino Espírito Santo. Tal situação só seria alterada com a ascensão da sociedade burocrática, aspecto intensificado pela construção de Brasília, e que aparece como permissão ligada aos valores da nova ordem. (MAGALHÃES, 2011, p. 32-33).

Ao demonstrar a perspicácia da figura do planaltino, Magalhães (2011), mediante o uso da dialética do esclarecimento promove uma leitura que os mesmos já realizavam no século XIX, tendo em vista 0 isolamento do Planalto Central 
Brasileiro face as relações sociais, econômicas e políticas para com a região litorânea, sendo enfatizado, inclusive, o desejo de modernidade e integração de tal porção do território para com o centro dinâmico do país.

Esses anseios advinham, principalmente, da classe aristocrática, que era composta pela elite política detentora da terra, cuja agricultura e, principalmente, a pecuária, constituíam as práticas econômicas que se desvelavam nos processos de produção espacial do sertão planaltino.

Neste contexto, muito embora existissem as diferenças locais, ao se tratar do projeto de desenvolvimento regional, havia uma solidariedade entre as elites políticas e econômicas de Goiás, tendo, enquanto desejo, a materialização dessa integração, bem como a ruptura do paradigma do espaço arcaico para o moderno, viabilizado, pela então utopia mudancista, ou seja, a transferência da capital para o sertão. Sobre esta utopia, Magalhães argumenta:

Apesar das diferenças, a nova capital, na perspectiva dos próprios planaltinos, representava também a realização de pelo menos duas utopias: a possibilidade de alcançar o desenvolvimento das forças produtivas em escala industrial e a sintonia regional com o esforço da criação de um país novo e moderno. Por isso, é lícito afirmar que os acontecimentos vinham ao encontro de antigos desejos locais. (MAGALHÃES, 2011, p. 08).

Dentro desta perspectiva exposta na obra de Magalhães, Castro (1986) também afirma:

A oposição feita principalmente pelos fazendeiros de Formosa atingia Mestre d'Armas, mas não encontrava respaldo entre os moradores, pois, essa oposição raramente vinha ao Povoado, pois os seus abastecimentos e fornecimentos eram feitos em Formosa.

A consequência disso é que, até a bem pouco tempo, havia uma diferença entre os habitantes de Formosa e Planaltina. E o que corrigiu esse dado foram às ligações e casamentos entre os planaltinenses e formosenses. Hoje, pode-se afirmar que a família formosense é uma extensão daqueles 'tradicionais' de Planaltina e vice-versa. Com Luziânia, ao lado de ter permanecido a preferência mútua, os laços familiares ficaram reduzidos a alguns casos, devido à distância. E no tempo da construção de Brasília, o interesse das três Cidades tornou-se único. "Uns poucos a favor e muitos contra", mas os posicionamentos equivaliam-se nos três lugarejos. $E$ o Estado não fez objeção em deixar Planaltina dentro do perímetro. Formosa e Luziânia não ficaram no Distrito Federal, pois o Estado 
tinha interesse sobre as suas arrecadações de impostos, principalmente, Formosa. (CASTRO, 1986, p. 142).

Conforme exposição de Magalhães (2011) e Castro (1986), o planaltino prefigura, no decorrer do século XIX e primeira metade do século XX, como um segmento dos inúmeros artífices do ideal mudancista. Muito embora, o seu distanciamento, relacionado a área polar (SANTOS, 2005) e a expressividade política local, dificultavam a difusão dos argumentos em prol de tal acontecimento. Todavia, Castro (1986) aponta alguns personagens que advogavam a favor de tal causa.

Anterior à constituição de 1891, várias manifestações, ações e articulações foram tomadas com o intuito de promover a transferência da capital do Império, até mesmo da Colônia, para o centro do Brasil. Dentre as várias manifestações, Castro (1986) enumera algumas que envolviam, diretamente, Planaltina enquanto região que viria a compor o território do novo Distrito Federal.

Segundo Castro (186, p.19) em 1813, Hipólito José da Costa Furtado de Mendonça, em um artigo publicado no Correio Braziliense na Inglaterra, critica severamente a escolha e implementação da nova Capital da Coroa Portuguesa na cidade do Rio de Janeiro. O mesmo posiciona-se favoravelmente a interiorização da capital.

No ano de 1823, segundo Castro (1986), a Assembleia Constituinte do Império apresentara proposta de interiorização da sede administrativa do país.

Entre 1840 e 1850, Castro (1986, p. 21) assevera que Francisco Adolfo de Varnhagen (Visconde de Porto Seguro), publica uma série de artigos, cuja insistência residia nos benefícios que a transferência da nova capital traria para o desenvolvimento do território nacional.

Além dos atributos físicos - como a grande disponibilidade hídrica em detrimento da existência de Águas Emendadas e das Lagoas circunvizinhas, somado ao relevo de altitude - Varnhagen enumera elementos de cunho geopolítico - como a defesa da sede administrativa que é dificultada por sua posição litorânea que justificavam a mudança da capital para o Planalto Central. 
Além de tais elementos apontados por Varnhagen, Magalhães e Eleutério (2008) descrevem que o Visconde de Porto Seguro concebia o território, mediante uma visão orgânica, associando ao centro do país como polo de irradiação do desenvolvimento, traçando uma analogia entre o território e o sistema circulatório de um corpo, tendo na localização centralizada da futura capital a possibilidade de desenvolvimento do restante do território.

Magalhães e Eleutério (2008, p.126) ainda expõem que, segundo Varnhagen, o local ideal para a construção da nova capital encontrava-se "na região compreendida pelo triangulo formado por três lagoas: Formosa, Mestre D'Ármas e Feia, de onde demandavam as nascentes dos três rios tributários das cabeceiras das três grandes bacias hidrográficas nacionais" do país.

Ainda nesta trajetória mudancista, Castro (1986, p. 21) expõe que, no ano de 1852, o Senador Holanda Cavalcanti, apresenta projeto de Lei trazendo justificativas para a interiorização da capital.

Em 1875 o Senador Jobim apresenta justificativas de cunho geopolítico, cuja finalidade, também reside na mudança da sede administrativa para o Planalto Central.

Como importante e última contribuição anterior a sua morte, Varnhagen descrito por Castro (1986), entusiasta mudancista, promove uma expedição, no ano de 1877, em direção à região que compreende o nascedouro das grandes bacias hidrográficas do Brasil, fazendo relatos positivos das condições físico-naturais por ele encontradas. Sobre essas descrições produzidas pelo Visconde de Porto Seguro, Castro expõe:

Adolpho Varnhagen, Visconde de Porto Seguro, escreveu da Vila de Formosa da Imperatriz, dia 28 de julho, ao Ministro Tomaz Coelho. No seu relato reúne os mais curiosos e interessantes elogios a região: "que reúne em si as três grandes conchas fluviais do Império...", "uma paragem da importância desta, única em relação ao Brasil todo, pela bondade de seu clima e pela fertilidade...". Continuando, escreveu: "Essa paragem bastante central, onde se deve colocar a Capital do Império, parece, quanto a nós, está indicada pela natureza na própria região elevada do seu território, donde baixariam as ordens, como baixam as águas que vão pelo Tocantins ao norte, pelo Prata, ao Sul, e São Francisco, a Leste." (VARNHAGEN, 1875 apud CASTRO, 1986, p. 23). 
Segundo Magalhães e Eleutério (2008), treze anos após a expedição de Varnhagen, a Missão Cruls, embasado nas informações colhidas pelo Visconde de Porto Seguro, vieram fazer cumprir as determinações oriundas do artigo terceiro da Constituição de 1891.

Com a promulgação da Constituição de 1891 e a disposição de seu artigo terceiro, "fica pertencendo à União, no planalto central da República, uma zona de 14.400 quilômetros quadrados, que será oportunamente demarcada para nela estabelecer-se a futura Capital federal" (Brasil, 1891), a utopia mudancista tornara-se mais próxima à realidade.

Magalhães e Eleutério (2008) ao se refereirem ao histórico evolutivo da cidade de Planaltina e ao fazerem menção à Comissão Cruls, expõem que a missão, muito embora vinculada à demarcação da área que receberia a futura capital do Brasil, geraram outras contribuições de grande importância. Assim os autores testificam:

Mais do que a demarcação de um quadrilátero de 14.400 quilômetros quadrados, previsto pela Lei Magna, a Missão chefiada pelo astrônomo Luís Cruls, fez um formidável estudo de toda a região do DF atual. O relatório resultante pode ser considerado como o primeiro, e um dos melhores Relatórios de Impacto no Meio Ambiente (RIMA) de que se tem notícia no país. (MAGALHÃES, ELEUTÉRIO, 2008, p. 127)

Segundo Magalhães (2011), a Missão Cruls contou com uma série de personagens planaltinos alinhados à causa mudancista, como o Dr. Americano do Brasil.

Castro (1986) relata também a participação de protagonistas de sua árvore familiar e de outros troncos genealógicos que remontam às antigas famílias tradicionais em tal evento, já como moradores da recém emancipada Vila. Todavia, Castro (1986) relata uma certa desconfiança de parte da população para com a realização desta missão em terras de Mestre D'Ármas:

(...) Depois de quase dois meses de viagem, num estudo que durou mais de um ano, a Comissão adentrava as terras da Vila Mestre D’Ármas. O contato, de parte da Comissão que ficou com a área que incluía Planaltina, foi feita em Formosa (...) 
Durante os meses que a Comissão permaneceu na região, todo o abastecimento de gêneros e mercadorias necessárias era feito em Santa Luzia, Formosa e Mestre D'Ármas. Mais próximos da Vila de Mestre D'Ármas, encontraram aí vários acompanhantes e informantes, entre eles João Gomes Rabelo, Tibúrcio Gomes Rabelo e Carolino de Souza Só. O povo admirava as suas histórias, e os questionava sobre todas as dúvidas da interiorização da Capital. E quanto mais se aprofundava, mais as perguntas ficavam soltas no ar sobre o futuro das famílias do povoado.

(...) Um e outro membro da Comissão, e mesmo o Cruls, afirmavam os antigos, que não demonstravam dúvida quanto ao quadrilátero que indicariam, e que seria escolhido, para a futura Capital. Era esse, diziam eles. O mais ameno, o mais rico em águas, o paraíso terral do sonho de Dom Bosco. (CASTRO, 1986, p. 149-150).

Neste evento, Magalhães (2011) relata um intenso exercício de divulgação e convencimento local, cujo alvo era a população. $O$ trabalho de articulação fora promovido pelas elites locais e de todo estado de Goiás. Estes buscavam demonstrar a importância da efetivação de tal determinação constitucional mediante o uso dos mecanismos de difusão informacional - jornal local denominado A Informação Goyana - cujo resultado esperado era a efetiva integração do sertão goiano a cadeia produtiva nacional.

Contudo, Castro (1986) ao tratar da chegada da Comissão Cruls em Planaltina, relata que o sonho mudancista era, acima de tudo, das elites. Já a temeridade quanto ao evento em relevo ficava para os proprietários de terras economicamente mais desfavorecidos, que temiam a desapropriação de suas posses para a construção da nova capital, já que o artigo terceiro da Constituição de 1891 definia que as terras que já vinham sendo ocupadas há tempos, e que estivessem contidas no quadrilátero determinado pelo texto legal, seriam de uso para a implementação da nova capital. Este contexto é ilustrado brevemente pelo autor a seguir:

Planaltina compreendeu melhor os estudos realizados pela Comissão Cruls, de 1892, muitos anos mais tarde. Todo o empreendimento do Governo no sertão, era respeitado com espreita e dúvida, pois tinha alguma semelhança com a cobrança do quinto, do dízimo e dos impostos. Construir uma cidade? Onde? Nas terras de quem? Críticas e avaliações corriam soltas nos comentários cotidianos da vida. Quem poderia entregar o torrão de sacrifício com uma indenização imposta? Desapropriação sem a consideração dos valores culturais e a acomodação harmônica, lenta e através dos 
anos, na formação do povoado, de seus habitantes? Esses questionamentos tiveram respostas, na época da Comissão Cruls em Planaltina. Porém, somente depois do lançamento da Pedra Fundamental, da Comissões do Djalma Poli Coelho e do Marechal José Pessoa, que o povoado acordou para o que esteve acontecendo. (CASTRO, 1986, p. 148).

Castro (1986) ainda expõe que os integrantes de tal Comissão produziram relatos positivos quanto da composição físico-ambiental da região, indo de encontro às afirmações do Visconde de Porto Seguro, não deixando dúvidas quanto ao potencial de possibilidade da materialização relativa à nova Capital na região de Mestre D’Ármas.

Após a divulgação dos estudos e relatos realizados na região pela Comissão Cruls, Castro (1986) faz uma importante ligação entre a possível construção da capital e a cidade de Planaltina e que repercutirá na dinâmica da produção do espaço urbano ao longo de todo o transcorrer do século XX, e início do $\mathrm{XXI}$.

Essa ligação remete-se ao processo de expansão da cidade, tendo em vista a valorização das terras, cuja provável construção da sede políticoadministrativa do país seria incorporada.

Todavia, o que Castro define como "prêmio", em outra perspectiva, pode ser sinalizado como crescente movimento especulativo, que resultaria ainda em um contexto pré-Brasília na composição de uma cidade repleta de irregularidades quanto ao registro de seus imóveis.

O primeiro legado de Brasília, anterior a sua concepção, associa-se ao movimento especulativo impulsionado pelos agentes locais - aristocracia política detentora das terras - que se valeram do possível privilégio da situação territorial, tendo, enquanto motor do processo, a mudança da capital. 
1.5 - 1922: A Pedra Fundamental e o prenúncio da especulação imobiliária.

Conforme exposto anteriormente, após a realização da demarcação do Quadrilátero Cruls e divulgação das informações sobre a região, muito se especulou sobre a implementação da nova capital administrativa do país no Planalto Central. A Vila de Mestre D’Ármas prefigurava como possível área a ser incorporado, ou provavelmente, ser o sítio a receber tal privilégio.

Contextualizando o período do início do século XX, Santos (1985, p. 23), em termos do movimento de produção do espaço global, o situa em uma dinâmica ainda inserida no período industrial (1870-1945).

Enquanto período histórico, o referido pensador descreve que, neste contexto, o planeta passava por sua segunda revolução industrial, "correspondendo pela aplicação de novas tecnologias e novas formas de organização, não só da produção material, mas quanto à energia e os transportes, permitindo uma maior dissociação de produção e consumo" (Santos, 1985, p. 23).

Em um cenário que abarca o território nacional, mesmo em uma geografização descontínua, Santos e Silveira (2003) identificam a existência de um meio técnico transicional, cujas lógicas das estruturas sociais, políticas, e da materialidade presente no território advindas do Período Colonial, em vias de entrada ao período de cientificização das bases produtivas do espaço nacional, estavam em pleno movimento: o meio técnico de circulação mecanizada e do início da industrialização.

Santos e Silveira (2003) tecem a seguinte caracterização deste meio geográfico:

(...) para o conjunto do país, pode-se situa-lo entre o começo do século XX e a década de 1940. É então que se estabelece uma rede brasileira de cidades, com uma hierarquia nacional e com os primórdios da precedência do urbanismo interior sobre o urbanismo de fachada. É, simultaneamente, um começo da integração nacional e um início da hegemonia de São Paulo, com o crescimento industrial do país e a formação de um esboço de mercado territorial localizado no Centro-Sul. Paralelamente, aumenta de forma acelerada a população global do país, mas de um modo geral permanecem as velhas estruturas sociais. (SANTOS e SILVEIRA, 2003, p.37). 
Percebe-se que os autores mencionados, ao explicitarem o contexto brasileiro (1900-1940), expõem elementos que sinalizam um processo de ruptura do sistema colonial pré-máquina para uma artificialização e intensa implementação da máquina (próteses), cuja abrangência começa a adentrar espacialidades, onde a dinâmica produtiva ainda se dava segundo a ótica dos tempos da natureza.

Santos e Silveira (2003) descrevem que neste momento, a posterior integração territorial é decorrente da entrada do país na fase industrial, cuja produção do movimento de sua rede urbana e da configuração de um sistema hierárquico entre as cidades é oriunda da divisão territorial do trabalho que se estabelece capitaneada pela indústria nacional em inserção.

Constata-se nesta leitura a necessidade de aceleração da integração do território através da implementação de sistemas de circulação, cuja finalidade repousava na extensão de um mercado interno que efetivamente iniciava a sua complexificação, tendo em vista a crescente demanda por matérias-primas advindas dos centros industriais nacionais como São Paulo.

Nesta perspectiva, Santos e Silveira (2003, p.37) apontam o surgimento de novos sistemas de objetos geográfico - aparelhamento dos portos, construção de estradas de ferro, implementação do sistema telegráfico - que cristalizaram-se sobre o território. Cabe ressaltar a interpretação dos autores quanto ao momento e o movimento do território em uso:

(...) Rompia-se, desse modo, a regência do tempo "natural" para ceder lugar a um novo mosaico: um tempo lento para dentro do território que se associava com um tempo rápido para fora. Este se encarnava nos portos, nas ferrovias, no telegrafo e na produção mecanizada.

(...) a máquina de produção e a máquina de circulação se espalham no território brasileiro, consolidando as áreas de mineração e contribuindo para criar áreas de monocultura de exportação, unidos aos portos litorâneos por estradas e ferrovias. A produção e a distribuição de energia até o início do século $X X$, circunscreviam-se aos centros urbanos, e a essas áreas de maior espessura da divisão do trabalho.

(...) As especializações regionais em matérias-primas de exportação garantiram sua vinculação aos portos e ao mundo. Mas a busca da integração nacional não era ainda um imperativo da construção dessas redes. (SANTOS e SILVEIRA, 2003, p. 37-38). 
A análise, conforme perspectiva do sertão planaltino proposta por Magalhães (2011) em associação com Santos e Silveira (2003), torna possível observar nitidamente a vivência desse tempo lento na produção do espaço local e sua desarticulação para com as áreas em pleno processo de inserção industrial.

A utopia mudancista buscava reverter tal atraso quanto à efetiva materialização de um surto de desenvolvimento regional. No início do século $\mathrm{XX}$, a velocidade da dinâmica de produção do espaço urbano de Planaltina, pode ser comparado a mesma intensidade do deslocamento espaço-temporal dos carros de boi que por ali transitavam, promovendo o abastecimento da cidade mediante as relações comerciais com Formosa e Luziânia.

Entretanto, a busca pela efetiva integração regional tendo em vista o artigo terceiro da Carta Constitucional de 1891, somado aos estudos produzidos pela Comissão Cruls, definitivamente colou o sertão goiano de Mestre D’Ármas como potencial sítio para receber a nova capital.

A sinalização para ista afirmação no parágrafo anterior ficou mais forte com a sanção do Decreto $n^{\circ} 4.494$ de 18 de janeiro de 1922, proposto pelo deputado mudancista Americano do Brasil, cujo objetivo residia na garantia do cumprimento da Constituição de 1891, tendo em vista a transferência da capital da República para o Planalto Central.

Para Farias (2006, p. 86), desde o ano de 1894 - divulgação do relatório produzido pela Comissão Cruls - a 1922 - lançamento da Pedra Fundamental presente na fotografia ํㅡㄴ 02 , a chama mudancista havia se arrefecido, transparecendo que "a causa da mudança da capital parecia não ter defensores". Contudo, a atuação do referido deputado Americano do Brasil reacende o projeto regional de inserção nacional.

Farias (2006), traz a importância simbólica de tal evento para as pretensões do que ele denominara de Grupo Goiano (mudancistas):

A ideia do monumento surgiu num momento no qual algo precisava ser feito para reavivar a chama da esperança de transferência da capital para o Planalto Central, naqueles tempos, quase apagados. (FARIAS, 2006, p. 86). 
Fotografia 02 - Pedra Fundamental (1922)

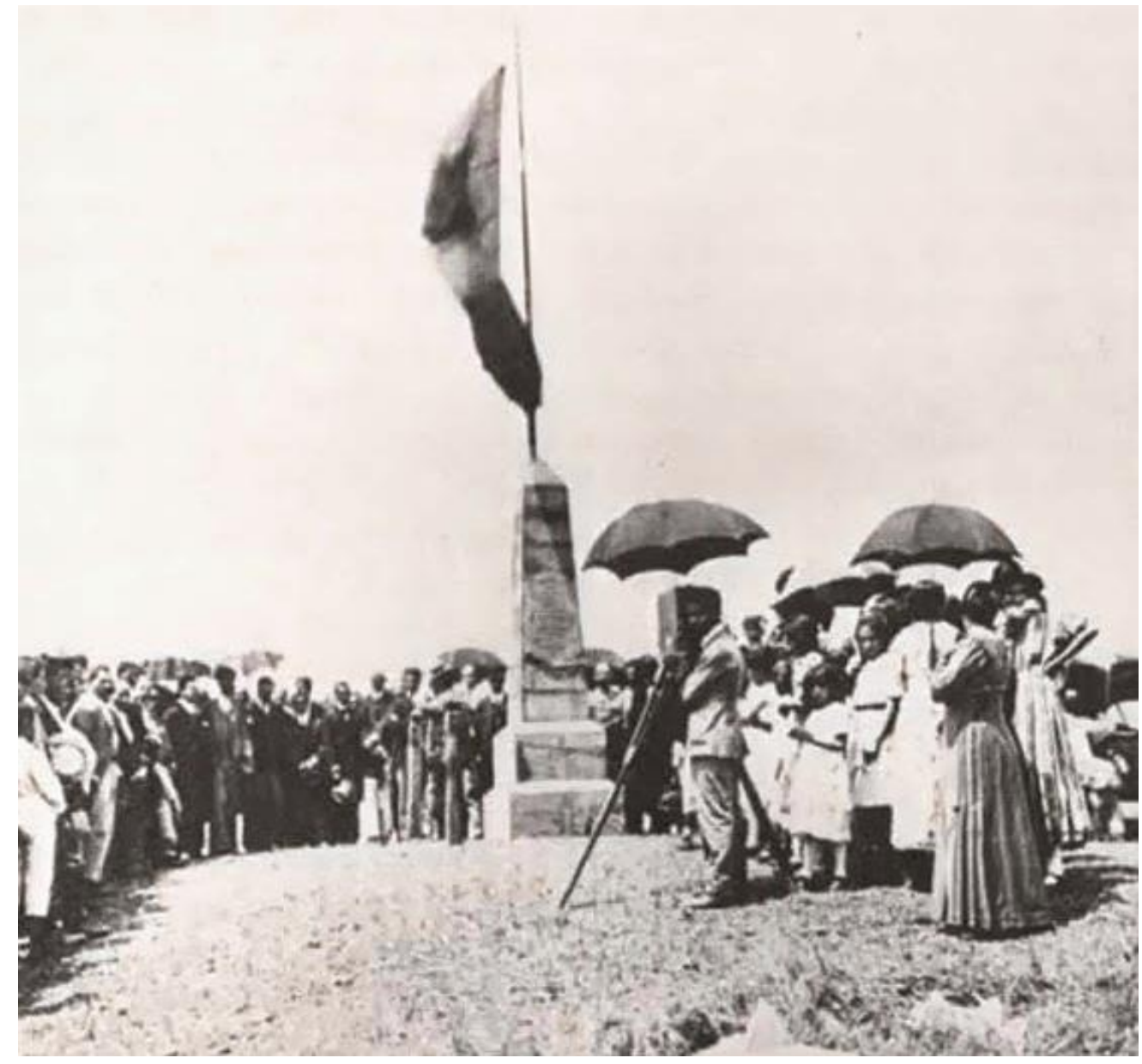

Fonte: Usina Literária. In: http://usinaarteliteraria.blogspot.com.br/2013/02/historia-deplanaltina-atraves-de-fotos.html; acessado em 11 de agosto de 2014.

Neste contexto, em resposta a proposição de Americano do Brasil, o presidente Epitácio Pessoa aprovou o texto legal em razão das celebrações do centenário de independência do país, tendo, enquanto comandos normativos, em tal documento, os seguintes dispositivos:

O Presidente da República dos Estados Unidos do Brasil: Faço saber que o Congresso Nacional decretou e eu sanciono a resolução seguinte:

Art. 1ㅇ A Capital Federal será oportunamente estabelecida no planalto central da Republica, na zona de 14.400 quilômetros quadrados que, por força do art. $3^{\circ}$ da Constituição Federal, pertencem à União, para esse fim especial já estando devidamente medidos e demarcados. 
Art. $2^{\circ} \mathrm{O}$ Poder Executivo tomará as necessárias providencias para que, no dia 7 de setembro de 1922, seja colocada no ponto mais apropriado da zona a que se refere o artigo anterior, a pedra fundamental da futura cidade, que será a Capital da União.

Art. $3^{\circ}$ O Poder Executivo mandará proceder a estudos do traçado mais conveniente para uma estrada de ferro que ligue a futura Capital Federal a lugar em comunicação ferroviária para os portos do Rio de Janeiro e de Santos, bem como das bases ou do plano geral para a construção da cidade, comunicando ao Congresso Nacional, dentro de um ano da data deste decreto, os resultados que obtiver.

Art. 4ํㅗa a execução deste decreto fica o Poder Executivo autorizado a abrir os créditos necessários.

Art. 5 Ficam revogadas as disposições em contrário. (Decreto $\mathrm{n}^{\circ}$ 4.494 de 18 de janeiro de 1922. In http://www2.camara.leg.br/legin/fed/decret/1920-1929/decreto 449418-janeiro-1922-545132-republicacao-91197-pl.html; acessado em 19 de dezembro de 2013).

Em depoimento ao livro "Planaltina...Relatos" (Governo do Distrito Federal, 1985), Hosannah Guimarães, Ex-Prefeito da cidade e também ExGovernador do Estado de Goiás, aborda sobre alguns eventos que trouxeram transformações à cidade planaltina e que buscavam vencer a lógica espaçotemporal oriunda do período colonial.

Embora, a priori, Hosannah (1985) não consiga pontuar elementos de transformação quanto à produção da dinâmica urbana da cidade correlacionado a implementação da Pedra Fundamental, posteriormente, o mesmo lista uma série de investimentos privados que a cidade recebera após tal acontecimento.

Tais investimentos ocorreram tendo em vista a possibilidade de efetiva integração de Planaltina a divisão territorial do trabalho, em um contexto mais amplo, enquanto resultado das ações mudancistas que repercutiriam na transferência da capital. A resposta para o questionamento que traçava uma correlação Pedra Fundamental e nova dinâmica urbana é elucidado da seguinte maneira por Hosannah (1985):

- Naquele tempo era uma cidadezinha de casas de adobe, de esteio de madeira. Casas toscas, como as que tinham as cidades do interior de Goiás. Na ocasião era até pequenina. Era a das menores, se fosse cidade. Funcionou, aí, então, como o cerne, o ponto central para os estudos da mudança, etc. 
- Planaltina era uma cidade simples com essa população, de casas simples, muito toscas, população muito variável, desde os muito pobres até aqueles que dispunham de algum recurso; cidade de vida comercial reduzida, o que havia de mais interessante era a criação e o comércio de bois. Passou a existir aqui indústria de curtume, indústria de charque, a casa com selaria, na Rua Salvador Coelho, perto do Gastão Salgado. Ali fazia selaria, calçados, tudo isso. Exportava, vendia. De modo que o primeiro polo industrial que se implantou no Planalto Central foi aí, porque Santa Luzia, Formosa, Cristalina e São João da Aliança, que seriam os quatro, inclusive Brazlândia, não tinha nada disso. A primeira cidade a ser iluminada com luz elétrica. Luz elétrica hidráulica. Quem teve a primeira charqueada, o primeiro curtume, a primeira indústria de artefatos de couro foi Planaltina. (GOVERNO DO DISTRITO FEDERAL, 1985, p.29).

Outro testemunho que descreve o progresso técnico que a cidade passara em associação ao discurso mudancista e como resposta à possível transferência da capital para o sertão planaltino, é exposto no diário de Gabriela Guimarães (1985), tendo como evento a implantação da Pedra Fundamental em 1822, fato este que alteraria a configuração territorial da cidade (mapa 03). Gabriela expõe, com nitidez, o impulso técnico que a cidade sofrera com o advento do obelisco que simbolizava a luta das elites locais mudancista pela conquista da modernidade.

De 1922 a 1930, Planaltina teve uma fase de grande progresso (...) Em 1923, Planaltina possuiu um telefone na residência do progressista fazendeiro Salviano Monteiro Guimarães, que ligava com a fazenda Salvia, vulgarmente cognominada RETIRO DO BAMBU, local onde funciona hoje o Colégio Agrícola de Brasília.

Neste ano entrou em Planaltina o primeiro carro a gasolina um FORD de propriedade deste fazendeiro, BALBINO CLARO DE ALARCÃO que era intendente municipal nesta época. Em 1926, foi substituído por Deodato do Amaral Louly (...) em cuja administração foi inaugurada a luz elétrica em Planaltina. Os sócios proprietários da usina elétrica eram os senhores: Vitoriano Bevinhatti, Salviano Monteiro Guimarães e Alexandre Salgado.

Planaltina foi à primeira cidade do Planalto Goiano a possuir luz elétrica. Em 1928, no dia 02 de setembro, foi criado na Vila, a AGÊNCIA TELEGRÁFICA (...)

A evolução de Planaltina teve seu período áureo de 1922 a 1930 com grande progresso no comércio e na indústria, charqueada, indústria de beneficiamento de couro, máquinas de beneficiar arroz, e cinema de propriedade de Manoel de Campos Salgado. O comércio de Planaltina nesta época, foi movimentado, "AS LOJAS GOIANAS", com filiais em Ipameri, Formosa, Cristalina, Luziânia e 
Planaltina, de propriedade da firma "BEVINHATTI, SALGADO, GUIMARÃES LTDA (...) (GOVERNO DO DISTRITO FEDERAL, 1985, p. 49-50). 
Mapa 03 - Planaltina (1910-1920).

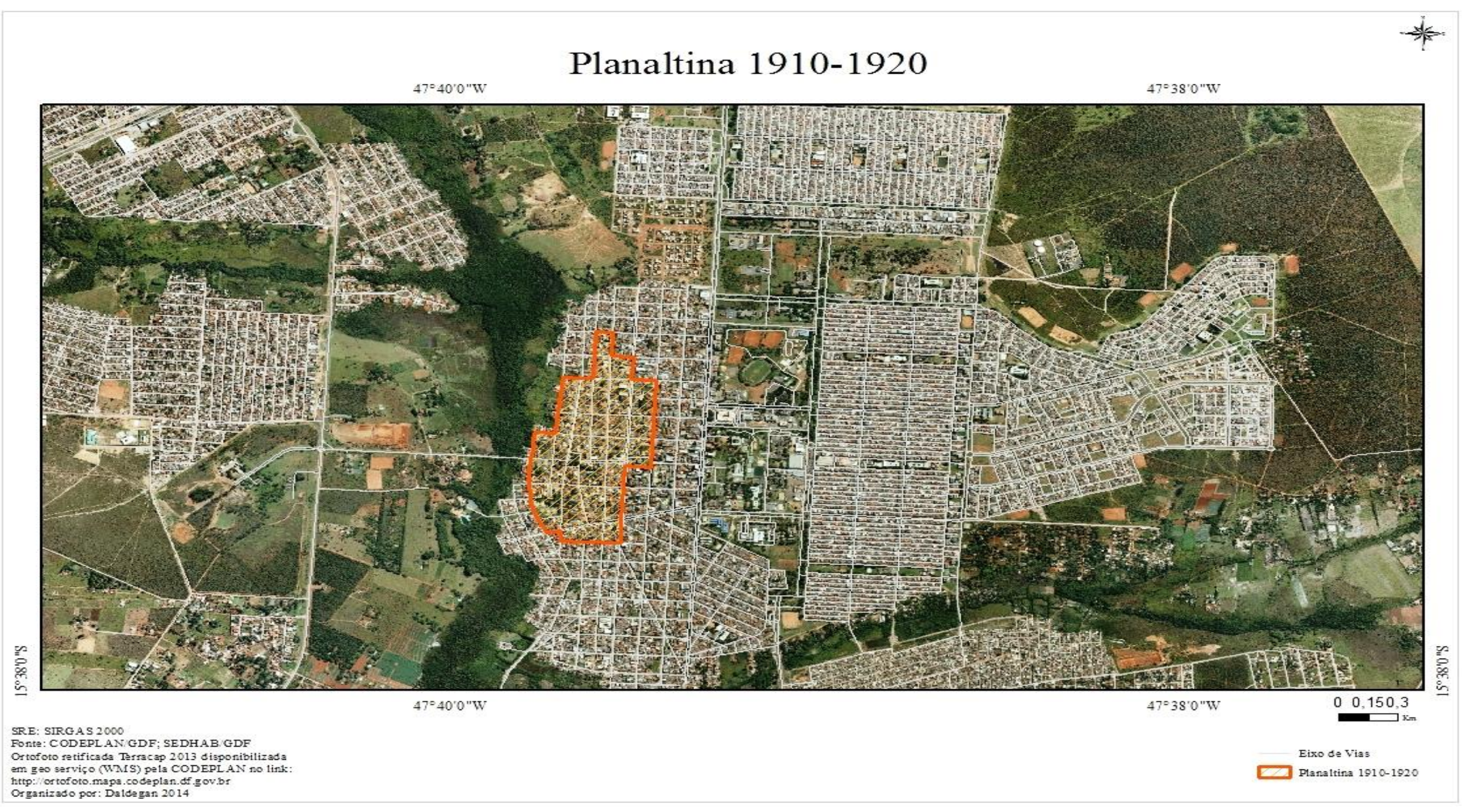

Fonte: Lima, 2014. 
Tais os objetos geográficos implementados, assim como as novas vocações produtivas da cidade goiana, se consolidaram após a sanção do Decreto n 4.494 de 18 de janeiro de 1922 e com a implementação da Pedra Fundamental, inaugurada no dia 07 de setembro de 1922. A fotografia 03 sinaliza essas mudanças.

Fotografia 03 - Planaltina: 1926.

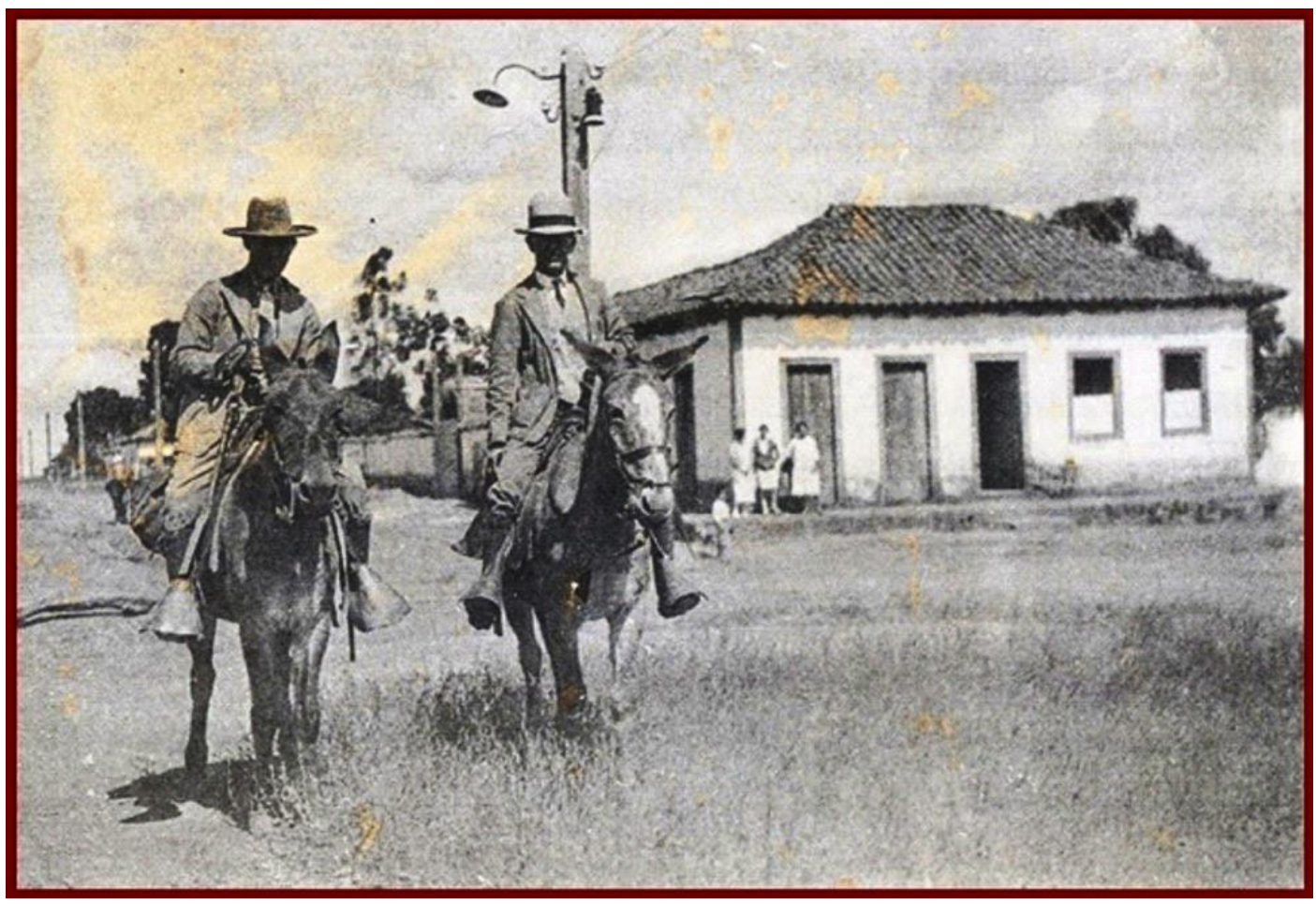

Fonte: Usina Literária. In: http://usinaarteliteraria.blogspot.com.br/2013/02/historia-deplanaltina-atraves-de-fotos.html; acessado em 11 de agosto de 2014.

Nesta perspectiva, a norma enquanto ação produz sua materialidade espacial através dos novos sistemas de objetos (SANTOS, 2002), que no caso em questão, não se resume apenas na edificação do obelisco, mas este, enquanto materialização do dispositivo normativo, prefigura como símbolo da efetiva mudança da dinâmica regional em virtude da posição local e até mesmo o Estado de Goiás face à hierarquia política e econômica vigente no contexto nacional.

Sobre a lógica desenvolvida por Santos (2002) quanto aos sistemas de ações e a repercussão deste nos sistemas de objetos espaciais, verifica-se que o 
decreto em apreciação, repercute também na produção do espaço urbano da cidade objeto e de seu entorno.

Nesse sentido, Castro (1986) brevemente faz a correlação entre os eventos agregados a Missão Cruls que repercutem na produção de uma visão positiva para com o município Planaltinense e que implicam na implementação da Pedra Fundamental, assim como a especulação imobiliária empreendida pelos agentes políticos do antigo município goiano. Contudo, tal análise se dá, de certa maneira, em uma perspectiva salutar, tendo em vista o movimento de dinamização da cidade entre as décadas de 1920-1930:

As consequências dessas referências, desses estudos para Planaltina foram um prêmio. Um privilégio que foi revelado à imagem, aos poucos. Com o lançamento da Pedra Fundamental, em 1922, foram criados os loteamentos Platinópolis, Planaltópolis, e Planaltinópolis, com postos de vendas em todas as Capitais brasileiras. (CASTRO, 1986, p. 151).

Esta mesma visão progressista é retratada por Gabriela Guimarães (Governo do Distrito Federal, 1985), cuja vertente analítica vislumbra a pretensa expansão urbana com uma possível melhoria do sertão de Planaltina, tendo em vista o discurso mudancista e a nova dinâmica espacial local associada à inauguração da Pedra Fundamental de 1922:

Nesta época surgiram os loteamentos: Planópolis, Platinópolis e Planaltópolis. Com esses loteamentos e a propaganda da mudança da Capital, Planaltina teve grande evolução. (GOVERNO DO DISTRITO FEDERAL, 1985, p. 49).

Posicionando-se criticamente sobre o movimento especulativo atrelado à fixação da Pedra Fundamental e ao Decreto-Lei que resguardava - mas não efetivava - a transferência da capital para o Brasil Central, Magalhães (2011), imputa às ações especulativas referentes à compra e venda de terras, no antigo município de Planaltina, à elite local esclarecida, que por sinal, também compunha a elite política, ou seja, a classe aristocrática de Planaltina, apoiadores do mudancismo.

Corroborando com as alegações de Castro (1986), Magalhães (2011) oferece relatos quanto às práticas especulativas daquele momento, sinalizando, 
inclusive, a divulgação da comercialização de plantas urbanas nos grandes jornais de circulação das principais capitais estaduais e regionais do país, sendo o prenúncio, a vanguarda do que iria ocorrer na região pós-inauguração de Brasília. Nessa ótica, Magalhães (2011), discorre que o citado movimento especulativo não se restringiu apenas ao então município de Planaltina:

A profusão de projetos de cidades inventadas na esteira do mudancismo é grande e complexa, contudo, em muitos casos, traziam embutidos o senso de oportunidade e realização de bons negócios, com a valorização das terras do Planalto Central. Esse tipo de interesse era perseguido por pessoas esclarecidas da região, que tinham como trunfo, a centralidade modernizadora, pois era portadora de privilegiado reconhecimento nacional, trazendo consigo o cunho da historicidade, ainda que não inteiramente compreendido.

Na edição de 15/05/1920, A Informação Goyana trouxe um pequeno anúncio indicador de que, de fato, desde os estudos de Cruls, as comunidades do Planalto Central repercutiam os movimentos do mudancismo através de interpretações muito particulares. Uma delas é essa perspectiva de alteração do valor das terras. Destoando do apego dos editores da revista às coisas de seu estado de origem, a Exma. Viúva D. Amélia Cavalcante, pessoa radicada no bairro do Meyer, colocava a venda "magníficas terras" da fazenda denominadas "Sítio do Rodeador". (...) totalizando os nada desprezíveis 60.000 hectares, localizava-se nas imediações do local escolhido para receber a futura sede administrativa do Estado. (MAGALHÂES, 2011, p.74-75).

Magalhães (2011), ao expor sobre este movimento especulativo que vigorou a partir de 1922, faz alusão aos relatos de Rosa (1972), nos quais ela empreende severas críticas à prática ilegal dos parcelamento de terras, promovida pelo então intendente de Planaltina-GO, Deodato Louly. Magalhães demonstra o relato de dela da seguinte maneira:

Lá para 1922, ano do primeiro Centenário da Independência, foi erigido num pico não muito distante de Planaltina, marco comemorativo, de iniciativa do deputado goiano Americano do Brasil, (...) O marco e o fordeco inspiraram, entretanto, o primeiro movimento no sentido de espicamento de terrenos, as grandes chantagens dos loteamentos. Deodato Louly, prefeito de Planaltina, também versado em coisas de medição de terras, bolou a primeira e mais honesta grilagem de vendas de lotes, da História do Brasil. $\mathrm{O}$ intendente, inventou a futura capital federal, a sombra do marco comemorativo do primeiro centenário do 07 de setembro. Comprou, com escritura passada, grandes pedaços de cerrado abrangendo pirambeiras e planuras (...) traçou na planta das glebas adquiridas, todos os ingredientes de uma grande capital. (...) Despejou propaganda, espalhou corretores. O comprador pagava preço 
barato pelo lote de sua escolha, (...) Sacramentada a transação, o adquirente recebia o documento legal, líquido e certo, que lhe transmitia a propriedade de "um lote na futura capital federal, no quadrilátero demarcado pela Comissão Cruls, de acordo com a Constituição". Ajudei meu Pai a ajeitar na jardineira que partia de Ipameri, pacotes e caixotes de escrituras - eram tantas, com destino a Planaltina, para os devidos registros no cartório. Depois os documentos eram devolvidos aos felizes proprietários do Rio, São Paulo, das principais cidades do Centro, do Sul, do Norte do Brasil, ... Buenos Aires, de ... Paris! (ROSA, 1972 apud MAGALHÃES, 2011, p. 75).

Observa-se que o movimento mudancista organizado pela aristocracia goiana, cuja articulação resulta nos eventos anteriormente citados (Constituição de 1891, Comissão Cruls de 1892 e o Decreto n 4.494 1922), propicia uma nova perspectiva de produção do espaço urbano de Planaltina, dentro de sua trajetória de formação socioespacial local, tendo na especulação fundiária e no uso e ocupação irregular do solo novas possibilidades de obtenção de lucros, assim como da divulgação da região para o cenário nacional atrelado a possível vinda da nova capital.

Vale explicitar a contiguidade da fundação da Pedra Fundamental de 1922 para como o Setor Tradicional da cidade de Planaltina, distando de um ponto a outro, apenas nove quilômetros.

Conforme fora exposto, tais ações se davam de maneira pouco ortodoxas. Segundo a descrição do autor, forjava-se escrituras e plantas de distintas supostas cidades, que corresponderiam à nova capital, situadas na mesma localidade (Morro do Centenário) ou em sítios próximos a Planaltina, tornando-se um grande escândalo de âmbito nacional. Magalhães (2011) descreve os acontecimentos, tendo Louly enquanto protagonista (Ou seria antagonista?), dessa forma:

Como se vê, não foram pequenas as consequências advindas da iniciativa do intendente Louly, pois, segundo os registros cartoriais, foram negociados mais de cem mil terrenos nos três loteamentos que compunham o empreendimento. Posteriormente, a própria capital da república veio de fato a ser erguida no mesmo lugar de um desses, Planópolis. Mas ele não foi o único, havia também Platinópolis e, como destacado em nossa pesquisa, Planaltópolis. (MAGALHÃES, 2011, p. 75). 
Tais eventos, segundo Magalhães (2011), ocorreram a partir de 1927, repercutindo embaraçosamente na posterior questão da difícil tarefa de promoção do processo de legalização dos imóveis urbanos e rurais do município e no processo de desapropriação de terras que iria ocorre a partir do ano de 1955.

Ainda com relação aos entraves advindos desta ação especulativa presente no processo de formação socioespacial da cidade de Planaltina, o relatório "Questões Fundiárias do Distrito Federal", produzido por Juvenal Antunes Pereira, lotado na, então, Secretaria de Desenvolvimento Urbano e Habitação (SEDUH), recapitulou o episódio Louly para exemplificar a gênese dos problemas fundiários presentes no Distrito Federal. Assim como o caso Louly, relatou também o parcelamento urbano efetivado no ano de 1956, também em Planaltina, evento este que será discutido no próximo capítulo.

Nessa perspectiva cabe demonstrar brevemente a análise de Juvenal Antunes Pereira sobre a questão da precariedade jurídica das terras e os impactos gerados ao processo de desapropriação no âmago sertão planaltino, em meio a sua formação socioespacial. Nestes termos tal análise é expressa:

(...) a problemática fundiária do Distrito Federal começa exatamente no ponto de indefinição dos limites das terras públicas, com os das terras particulares, que não puderam ser desapropriadas, face os documentos de propriedade não apresentarem filiação suficiente para enquadra-los nos direitos reconhecidos pelo decreto Lei $n^{\circ}$ 203/67, mesmo as terras baseadas no Registro Paroquial, direitos esses muito discutíveis já que decorrentes de registro feito por simples declaração dos próprios possuidores, como previu a Lei $n^{\circ}$ 601, de 1850

Essa desordem fundiária fez com que o problema dos loteamentos irregulares no território do Distrito Federal se recrudesça. Mas ele não é novo, pois ainda nos idos de 1956, a própria Comissão de Cooperação para a Mudança da Capital, quando os trabalhos de desapropriação se encontravam na sua fase mais intensa, encontrou situação semelhante, como o loteamento Nossa Senhora de Fátima, localizado na Fazenda Mestre D'Ármas, e a do loteamento Planaltópolis, na Fazenda Paranauá. (GOVERNO DO DISTRITO FEDERAL, 2001, p. 05-06).

De maneira irônica, Magalhães (2011, p. 24) discute ainda a repercussão econômica que o caso Louly teve na mídia nacional no ano de 1951, as vésperas da efetivação da transferência da nova capital para o Planalto Central. 
Em entrevista concedida à revista $\mathrm{O}$ Cruzeiro, Louly se defendeu de acusações quanto a prática ilícita de venda de terras em sua gestão como intendente de Planaltina de Goiás. Afirma o mesmo que dispôs de "terrenos urbanos gratuitos para a ocupação imediata na área da futura da capital do Brasil", tendo apenas como despesas para os contemplados, "a tramitação dos documentos, registros cartoriais e com a publicidade" (MAGALHÃES, 2011, p.24).

O detalhe de toda essa história apontado por Magalhães (2011, p. 24), é que "os lotes foram demarcados em terras de propriedade de Louly".

Magalhães (2011) evidencia ainda o depoimento de Louly dado no ano de 1951 ao Jornal do Planalto. Louly afirmou que as doações de lotes tiveram cunho patriótico e incentivador do processo de transferência da capital para o estado goiano. Nestes termos, Magalhães da voz ao personagem ao referendar-se no Jornal do Planalto (1951):

(...) a solução (da mudança da capital) demandava não somente a ação dos grandes poderes brasileiros, como o concurso e boa vontade de todas as pessoas, concebemos, em 1927, o plano de que um movimento de ideais em favor de tal interiorização teria eficaz importância na solução desse magno problema nacional./ Resolvemos, assim, distribuir a preço ínfimo, parte dos terrenos que então possuíamos no município de Planaltina, projetando para isso algumas plantas (...) (Jornal do Planalto, 1951 apud Magalhães, 2011, p. 24).

Quanto ao tema grilagem, Magalhães (2011) ainda assevera a organização das corporações locais em torno do ideal mudancista e de seus supostos benefícios, ao descrever o posicionamento da mídia local - A Informação Goyana - sobre os fatos expostos na revista O Cruzeiro e no Jornal do Planalto.

Magalhães (2011, p. 24) em suas apurações e interpretações sobre o acontecimento, testifica que o veículo de comunicação local se colocara em plena defesa de seu conterrâneo, utilizando-se do mesmo argumento patriótico proferido por Louly para com o fato, buscando resguardá-lo de "possíveis demandas judiciais de representantes dos milhares de investidores que haviam se tornado proprietários de terrenos nas cidades por ele investidas". 
Ao buscar entender esta dinâmica de produção do espaço urbano de Planaltina em uma perspectiva jurídica, conforme exposto no Processo Interno no 135.000.703/1995, desenvolvido pela Gerência da Unidade de Planejamento Territorial Norte (GENOR, 2012, s/p), tem-se justamente no mandato Louly a permuta das terras pertencentes a então Paróquia de São Sebastião, para o município goiano.

Esta ação fora possibilitada mediante a doação dos 200 hectares de terras da Fazenda Monjolo, pertencentes à Louly, para a prefeitura de Planaltina de Goiás. Ao tornar-se terra de domínio público, o então intendente efetua a troca da dominialidade da antiga Fazenda Mestre D’Ármas, de propriedade paroquial, para a fazenda Monjolo, e vice-versa, passando agora a área de 200 hectares, na qual situa-se o Setor Tradicional e demais bairros atuais, a ser efetivamente pertencente ao patrimônio municipal em tal contexto.

Essa transação, segundo a GENOR (2012), fora efetivada cartorialmente no dia 05 de dezembro de 1929, constando no livro 5, folha 73 do então cartório de Planaltina de Goiás. Daí origina-se a transcriçãa ${ }^{15}$ de número 303 , cuja dominialidade consta em favor do Município de Planaltina-GO, advindo de permuta efetuada entre Louly e a Paróquia de São Sebastião, cujos posteriores desmembramentos ou plantas deveriam ter sido registradas nas décadas posteriores e vinculadas a tal documento cartorial.

Muito embora a ação de Louly tenha sido louvável, o histórico produzido pela GENOR (2012) relata que, a partir de então, uma série de medidas foram tomadas pelo poder executivo local no sentido de legalização dos imóveis, mas, acima de tudo, promovendo novos parcelamentos.

Neste viés, vale frisar a afirmação expressa em páginas anteriores, qual seja, desde o surgimento do assentamento humano no início do século XIX, a cidade nunca teve uma planta urbana devidamente registrada em cartório, o que legalmente constitui em um grande entrave para o devido registro dos imóveis.

\footnotetext{
${ }^{15}$ Segundo o Decreto Lei $4.857 / 34$, anterior a Lei $6.015 / 73$, todo ato administrativo vinculado à transmissão do domínio de imóveis eram averbados no C - LIVRO 3 condizente ao livro de registros. Nesse livro eram feitos todos os atos translativos da propriedade imóvel, como compra e venda, doação, permuta, dentre outros. Assim, Santana de Melo (2006) define que as transcrições cartoriais são atos administrativos referentes a transmissão da propriedade.
} 
Seguindo esta lógica, tendo em vista o uso do território por seus agentes em pleno movimento - totalização - GENOR (2012) relata que a partir do ano de 1934, tem início a venda de glebas dentro dos 200 hectares que, neste momento, correspondia à antiga Fazenda Mestre D’Ármas a particulares. Todavia, ainda constata-se a ausência da planta do parcelamente do solo e o devido registro cartorial.

Efetivamente, a situação jurídica dos imóveis urbanos parcelados pela prefeitura de Planaltina de Goiás, que atualmente remontam ao atual Setor Tradicional (transcrição 303), entra em uma completa situação de irregularidade quando da vigência do Decreto-Lei $n^{\circ} 58 / 1937$, que dispõe sobre o loteamento e a venda de terrenos para pagamento em prestação. Assim, no artigo primeiro dessa Lei, encontram-se as seguintes determinações:

Art. $1^{\circ}$ Os proprietários ou coproprietários de terras rurais ou terrenos urbanos, que pretendam vendê-los, divididos em lotes e por oferta pública, mediante pagamento do preço a prazo em prestações sucessivas e periódicas, são obrigados, antes de anunciar a venda, a depositar no cartório do registro de imóveis da circunscrição respectiva:

I - um memorial por eles assinado ou por procuradores com poderes especiais, contendo:

a) denominação, área, limites, situação e outros característicos do imóvel;

b) relação cronológica dos títulos de domínio, desde 30 anos, com indicação da natureza e data de cada um, e do número e data das transcrições, ou cópia autêntica dos títulos e prova de que se acham devidamente transcritos;

c) plano de loteamento, de que conste o programa de desenvolvimento urbano, ou de aproveitamento industrial ou agrícola; nesta última hipótese, informações sobre a qualidade das terras, águas, servidões ativas e passivas, estradas e caminhos, distância de sede do município e das estações de transporte de acesso mais fácil;

II, planta do imóvel, assinada também pelo engenheiro que haja efetuado a mediação e o loteamento e com todos os requisitos técnicos e legais; indicadas a situação, as dimensões e a numeração dos lotes, as construções e bem feitorias, e as vias públicas de comunicação;

III, exemplar de caderneta ou do contrato-tipo de compromisso de venda dos lotes;

IV, certidão negativa de impostos e de ônus reais; 
$\mathrm{V}$, certidão dos documentos referidos na letra $b$ do $\mathrm{n}^{\circ} \mathrm{I}$. (Decreto-Lei $\mathrm{n}^{\circ}$ 58/1937. In http://www.planalto.gov.br/ccivil_03/decreto-lei/1937 1946/Del058.htm; acessado em 20 de dezembro de 2013).

No caso do núcleo urbano de Planaltina de Goiás, praticamente nenhum dos elementos que compõe o artigo primeiro da Lei citada, eram efetivamente cumpridos no processo de parcelamento urbano e por mais que tais informações existissem, essas não se encontravam registradas cartorialmente pela ausência da planta urbana acompanhado de memorial descritivo.

Ainda segundo a GENOR (2012, s/p) no ano de 1939, o prefeito municipal João Carlos de Alarcão decreta a Lei n ${ }^{\circ} 1$ de 12 de janeiro do mesmo ano, cujo teor dispunha sobre a possibilidade de convocação do "ocupante do lote visando a regularização da situação" dos respectivos imóveis.

Conforme relato da GENOR (2012, s/p), tal ação normativa objetivava "regularizar os alvarás antigos, cujos terrenos eram dados por concessão", ou até mesmo vendidos. Todavia, os "registros foram feitos em livros próprios, nos quais não constavam as dimensões e as áreas das propriedades, apenas os limites".

Nessa perspectiva, tem-se que mais uma vez, a planta da cidade e dos parcelamentos recém constituídos, não fora produzido e tampouco registrada cartorialmente, incorrendo repetidamente na ilegalidade tendo em vista o Decreto-Lei $n^{\circ} .58 / 1937$.

Sobre este fato, a sentença proferida pela Vara de Registros Públicos do Distrito Federal, em seu processo №. 2006.01.090919-9, na página 03, afirma claramente que a planta original - e proposições seguintes - não foram registradas em cartório.

De fato, o processo de formação do espaço urbano de Planaltina, no contexto pré-Brasília, foi constituído por uma série de acontecimentos que vinculamse a produção da dinâmica do ilegal quanto a questão do parcelamento, uso e ocupação do solo, sendo urbano ou rural.

Vê-se desde já a vivência de uma precariedade dominial do bem imóvel, cujos efeitos repercutiram ao longo do espaço-tempo, tendo em vista a lógica do movimento de totalização do território urbano em uso e em constante produção. 
Embora quase que inexpressivo dentro de uma "hierarquia regional" de nucleamentos urbanos oriundos do período colonial, o movimento do espaço urbano de Planaltina ganharia intensidade após a construção da nova capital.

Essa dinâmica espacial, segundo os relatos de Gabriela Guimarães (1985), fora quebrada com o arrefecimento do discurso mudancista pós-década de 1930, resultando em uma retração do processo territorial local. Assim Gabriela expõe tal acontecimento:

(...) Até 1930, Planaltina teve seu período de grande progresso, mas com o desvio da propaganda da mudança da Capital Federal para outras regiões, a cidade estacionou ou melhor regrediu. (GOVERNO DO DISTRITO FEDERAL, 1985, p. 50).

Relembrando mais uma vez a perspectiva do discurso mudancista e os impactos na dinâmica territorial regional, com a ascensão de Getúlio Vargas em 1930, Farias (2006) afirma que há uma arrefecimento quanto à efetivação da implementação da nova capital.

Segundo Farias (2006), embora constassem dispositivos que dispunham sobre a transferência da sede do Estado para o Quadrilátero Cruls, os mesmos, contidos nas Constituições de 1934 e 1937, não retratavam a mesma ênfase que dava a Carta Magna de 1891.

Muito embora, tenha-se na gestão de Vargas, a implementação da política de governo voltado à dinamização e povoamento da porção interiorana do Brasil, (A Marcha para o Oeste), a inauguração de Goiânia em 1933 sinaliza a busca pela ampliação e complexificação da divisão territorial do trabalho e a efetiva instauração de um mercado consumidor em escala nacional.

As expectativas mudancistas só ganharam novo fôlego com a nova Constituição de 1946 em seu artigo $4^{\circ}$ - das disposições transitórias - que define que a "Capital da União será transferida para o planalto central". A mesma carta ainda impunha as seguintes obrigações:

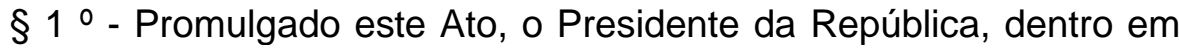
sessenta dias, nomeará uma Comissão de técnicos de reconhecido valor para proceder ao estudo da localização da nova Capital. 
$\S 2$ - $O$ estudo previsto no parágrafo antecedente será encaminhado ao Congresso Nacional, que deliberará a respeito, em lei especial, e estabelecerá o prazo para o início da delimitação da área a ser incorporada ao domínio da União.

$\S 3$ - Findos os trabalhos demarcatórios, o Congresso Nacional resolverá sobre a data da mudança da Capital.

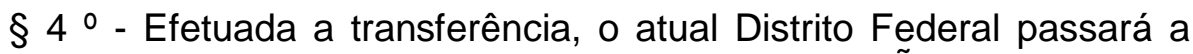
constituir o Estado da Guanabara. (CONSTITUIÇÃO BRASILEIRA DE 1946.

http://www.planalto.gov.br/ccivil_03/constituicao/constituicao46.htm; acessado em 19 de dezembro de 2013.

Como resposta ao comando presente no parágrafo primeiro do artigo quarto da Carta Constitucional de 1946, tem-se a efetivação da Comissão de Estudos para a Localização da Nova Capital do Brasil, capitaneada pelo General Polli Coelho em 1947, tendo os seus resultados favoravelmente divulgados no ano de 1948, em favor da interiorização da capital da República. A figura 05 expõe os possíveis sítios a serem escolhidos para a construção de Brasília pela referida comissão. 
Figura 05 - Comissão Polli Coelho: Propostas de sítio para a nova capital.

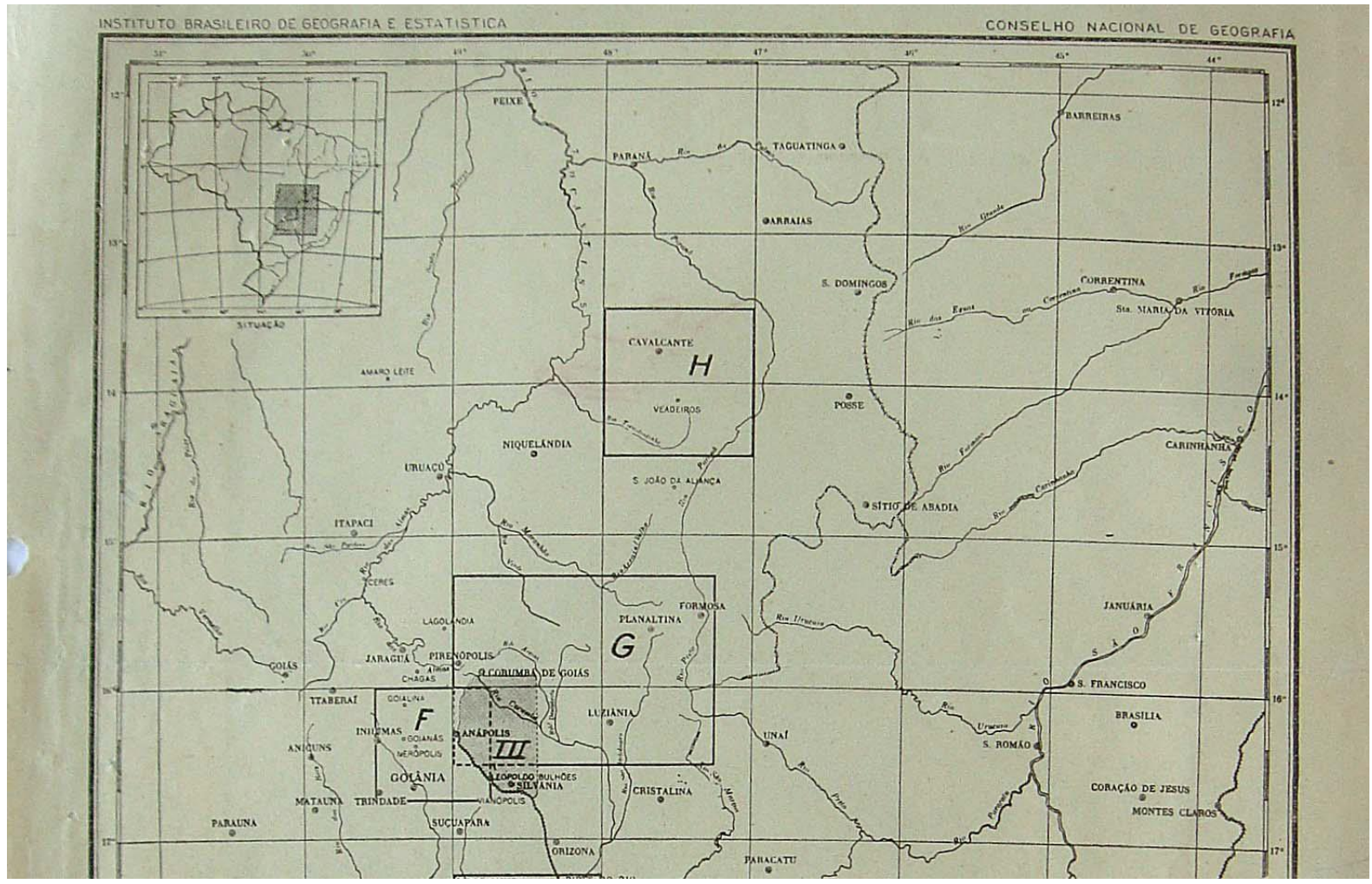

Fonte: Projeto de Lei $n^{\circ} 671$ de $1949^{16}$.

Dado a morosidade em termos de iniciativa do Poder Executivo Federal e atiçado pela ala mudancista em intensas discussões no congresso, em 1953 é promulgado no segundo mandato de Vargas a Lei $n^{\circ} 1.803 / 53$, que mais uma vez autorizava a execução de estudos objetivando a transferência da nova capital para o interior do país.

Essa nova Comissão de Localização da Nova Capital Federal, fora chefiada, inicialmente, pelo General Agnaldo Caiado de Castro (1953-1954), e, por fim, pelo Marechal José Pessoa Cavalcante de Albuquerque (1954-1955), tendo como resultado o Relatório Belcher que dispunha sobre o sítio que abrigaria a nova capital - sítio Castanho - assim exposto na figura 06 abaixo.

De forma pormenorizada, Magalhães (2011) e Farias (2006) descrevem uma intensa rivalidade entre o estado de Goiás - aristocracia mudancista goiana - e Minas - elite política e econômica do estado - para a instalação da nova capital em tais localidades.

${ }^{16}$ In http://bd.camara.gov.br/bd/handle/bdcamara/3285?show=full; acessado em 27 de dezembro de 2013. 
Ambos os autores detalham também as manobras e artimanhas de convencimento advindo dos mudancistas goianos em relação à alta hierarquia dos militares que promoveram os estudos, bem como para com a conquista dos congressistas, palco das discussões políticas sobre o tema. 
Figura 06 - Relatório Belcher: Sítio Castanho e a implementação de Brasília.

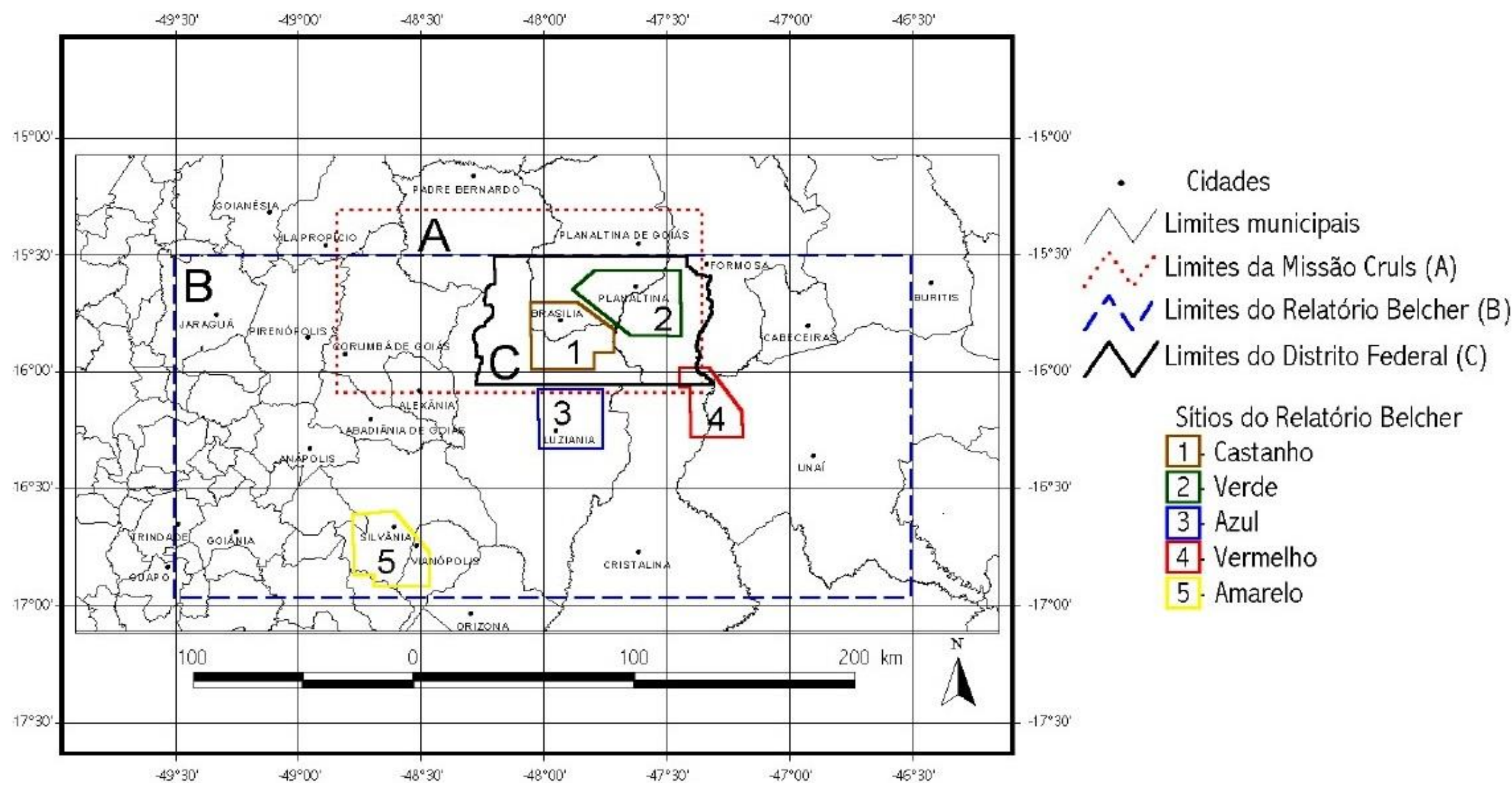

Fonte: Fortes, Barroso, Silva e Guedes, 2007. 
Todavia, tanto Magalhães (2011) como Farias (2006) relatam que a ação tomada pelo Grupo de Goiás, que dava o primeiro passo para a transferência da capital para o Planalto Central, dá-se com o Decreto Estadual de $n^{\circ} 480$ de abril de 1955, que assegurava para fins de utilidade pública as terras contidas no quadrilátero delimitado pelo relatório Belcher - figura 06 - para fins de desapropriação (tema a ser retomado no próximo capítulo).

Segundo Farias (2006), tal ato é articulado pelo então responsável pela Comissão de Estudos Marechal Pessoa e o Governador do Estado de Goiás, Juca Ludovico, tendo em vista que a solicitação de Pessoa ao então Presidente Café Filho não fora atendida - desapropriação das terras - evidenciando total desinteresse deste último para com a questão.

Em seguida, tem-se novo Decreto estadual de $n^{\circ} 1258$ de outubro de 1955, instituindo a Comissão de Cooperação para a Mudança da Capital, tendo como presidente Altamiro de Moura Pacheco, cujo objetivo era dar início ao processo de desapropriação dos imóveis contidos no quadrilátero do Distrito Federal, por iniciativa do próprio estado de Goiás. Farias (2006) aborda a importância de Altamiro Pacheco e das desapropriações de terras frente à disputa existente entre Goiás e Minas Gerais:

Nesta conjuntura, Pacheco engajava-se de vez e com força, no que denominei como Grupo de Goiás. A atmosfera de urgência naquele contexto (1955/56) foi o resultado da forma de agir deste grupo, pois este tinha a certeza de que forças contrárias, de Minas Gerais, espreitavam para entrar em ação. Naquele momento, é bom lembrar, pairava, ainda, a dúvida recorrente da vinda, ou não, da capital para o território goiano. Portanto, para fazer frente a isso, era preciso se adiantar, ficar sempre alerta, de prontidão. (FARIAS, 2006, p. 150)

Embora entre o período de 1927 até 1953, tivesse ocorrido um surto especulativo muito forte, promovido pela elite política municipal a reboque dos rumores mudancistas, em termos populacionais, a cidade de Planaltina-GO crescia ainda em um ritmo lento, bem como sua expressividade econômica.

Tal realidade pode ser constatada no testemunho dado por Hosannah Guimarães e Gabriela Guimarães (1985), sendo que o mesmo fato também era 
observado nos dados demográficos produzidos pelo IBGE entre os anos de 1951 a 1959, que demonstravam no início da década uma população urbana de 2.000 pessoas e já em 1959 o total de 2.103 habitantes na área urbana de Planaltina, dispondo então de apenas de 375 residências.

Ao interpretar os dados, verifica-se a plena vivência dos tempos lentos exposta por Santos e Silveira (2003), cuja dinâmica de produção socioespacial teve sua evolução intensamente impactada com a construção de Brasília. Tem-se em tal evento o choque dialético entre o velho e o novo que, enquanto tese e antítese, resultará em uma nova síntese, uma nova totalidade: a cidade de Planaltina nos dias atuais.

O exercício de operacionalização da categoria de formação socioespacial junto ao objeto de estudo, mostra-se de suma importância quanto ao entendimento das questões de litígio judicial do presente - território usado - assim como a compreensão do movimento espacial decorrente da produção do espaço urbano tendo em vista as dinâmicas sociais sobre este mesmo espaço, ao qual abarcam a política, a economia e os usos dados pelos agentes sociais contidos em tal base territorial.

Após uma breve análise do processo de formação socioespacial da cidade de Planaltina, que remonta desde o período colonial ao limiar da década de 1950 é importante trazer à tona alguns fatos correlacionados a desapropriação das terras locais que gerarão celeumas sociais e judiciais até a espacialidade e temporalidade moderna. 


\section{Capítulo 2 - A utopia da construção de Brasília: um embate dialético entre 0 velho e $o$ novo e suas repercussões na metamorfose da cidade de Planaltina (1950-1960).}

Conforme fora exposto anteriormente, a dinâmica de formação socioespacial da cidade de Planaltina, em um contexto pré-Brasília, teve a sua gênese em um cenário que remonta as primeiras Entradas e Bandeiras no final do século XVI. Todavia, a fixação das primeiras sesmarias ocorreu a partir do ano de 1740.

Entretanto, o auge deste processo inicial de estabelecimento do colonizador europeu, deu-se com a convergência de dois fatos: o primeiro relacionado ao declínio da atividade impulsionada, principalmente, pelas entradas e bandeiras paulistas, que fizeram emergir centros extratores de minério próximos à região de Planaltina - como Santa Luzia e Meia Ponte; e o segundo fator remete-se a implementação da atividade pecuarista, oriunda do avanço dos Currais do São Francisco e que se estabelecera na região de planaltina como vocação econômica.

Nesta confluência dos movimentos de produção do território, relata-se a ampliação das sesmarias em meados de 1770 em diante, imposta pelo esgotamento em Goiás das jazidas de ouro e pedras preciosas, tendo a terra uma nova função: pasto e produção de alimentos para a subsistência.

No contexto colonial, a norma que regula o uso e ocupação do solo que se dava por concessão de donatários, era a Lei de Sesmaria de 1375. Todavia, conforme fora exposto em Nozoe (2006), a debilidade das ações do Estado Português no campo normativo e fiscalizador, somados as práticas sociais perante a vigência da norma em seu efetivo descumprimento e tendo em vista o registro dos imóveis, acabaram por desdobrar-se em um amplo processo territorial de estado de precariedade jurídica face à situação dominial das terras.

Observou-se também, mediante raciocínio estabelecido por Bertran (2000, p. 154), que o mesmo processo ocorrera em escala local tendo em vista que, segundo o autor, grande parte das terras ocupadas pelo colonizador português em 
solo planaltino, nunca foram autenticadas conforme a legislação reinol, mas tiveram seus assentamentos reais: casas, senzalas, e fábricas de engenhos solidamente instalados e que constituíam patrimônios reais, sujeitos a compras e vendas entre particulares. Castro (2014) também descreveu esta dinâmica de formação e ocupação da área urbana em Terra de Santo e das fazendolas contidas nas cercanias e na Fazenda Mestre D’Ármas.

Assim, depreende-se que mediante a ação/omissão do Estado Português para com a dinâmica social de uso do território, que permeia a cultura do descumprimento da regulamentação quanto ao uso e ocupação do solo, somandose à vastidão do território a ser fiscalizado, impacta no processo de produção do espaço nacional, cuja práxis vinculada à mera ocupação e apossamento da terra perpetuasse no presente, tanto na produção do espaço agrário como nos arranjos urbanos.

Inclusive, conforme fora abordado, tal cultura é resultante da lógica de incentivo a ocupação de terras devolutas que teriam por objetivo a produção agropastoril, afim de abastecer os centros mineradores de forma complementar ao ciclo do ouro, e, posteriormente, ao sistema de produção agroexportador que se fortalecia na zona litorânea no transcorrer do século XIX, tal como é exposto por Nozoe (2006).

(...) a tolerância dos governantes e das camadas hegemônicas ao mecanismo informal de apropriação devia-se a sua compatibilidade com os imóveis de nossa colonização, dado que promovia a abertura de áreas pioneiras a custo reduzido, propiciava a drenagem da indesejável população mais turbulenta para a fronteira, onde poderiam dedicar-se à cultura de mantimentos ou à criação de algum gado, porcos ou aves, gêneros consumidos nas regiões mais densamente povoadas e com estrutura econômica organizada para o atendimento do mercado externo. (NOZOE, 2006, p. 597).

Conforme Bertran (2000), as brechas estatais, quanto às práticas de fiscalização da metrópole lusitana para com o uso e ocupação do território também deram-se em uma escala local, tendo na relação de compra e venda entre particulares o principal meio de aquisição das terras que compunham o sertão de planaltina (Magalhães, 2011). Contudo, inicialmente, o processo de assentamento 
dessas populações que posteriormente comercializaram suas terras ocorreu por meio de apossamento da terra.

Com a vigência da Lei de Terras n 601 do ano de1850, que substitui a Lei de Sesmarias de 1375 e as suas várias alterações realizadas ao longo dos séculos, averiguou-se, segundo Nozoe (2006), a ampliação dos conflitos fundiários no instituído Estado - latifundiário - Brasileiro.

Mesmo que o direito de posse tivesse sido vinculado à obrigatoriedade registral das antigas sesmarias por parte dos particulares neste contexto, no bojo de seu mecanismo os Registros Paroquiais não dispunham de instrumentos que atestassem a raiz dominial da propriedade, tampouco os seus limites (poligonais), tendo apenas na "simples declaração dos proprietários possuidores" (GOVERNO DO DISTRITO FEDERAL, 2001, p. 06) o elemento comprobatório para tal.

Dessa maneira, pode-se afirmar que a gênese da precariedade jurídica quanto à dominialidade dos imóveis - rural ou urbano - estava atrelada à produção do espaço enquanto traço característico da formação socioespacial do território brasileiro, também se aplicando as suas frações - subespaço/lugar - estando Planaltina associada a esta dinâmica.

A produção do espaço, juridicamente ilegal, conduz a essa situação de precariedade quanto à dominialidade da terra ocupada - urbana ou rural - ganhando novos contornos com a evolução das relações de produção sistêmicas advinda da metamorfose das técnicas e de sua aplicação sobre o espaço.

Nesse viés fica nítido, na produção do espaço urbano de Planaltina, o prenúncio quanto ao uso da terra por parte dos agentes especulativos, tendo no caso Louly em 1927 a convergência da possível materialização da capital no Planalto Central, que redundaria em um processo de alavancamento econômico do estado goiano e dos demais rincões do sertão brasileiro, segundo a perspectiva de suas elites.

Muito embora a dinâmica urbana de Planaltina não tenha se intensificado até o final da década de 1950, observa-se o crescente uso do território desde a Comissão Cruls até as vésperas da inauguração da nova capital, associado à atividade especulativa, estando tal ação atrelada ao discurso mudancista, que por 
sinal, ainda mantinha em seu traço característico a precariedade jurídica da terra ou dos imóveis urbanos parcelados e comercializados.

Tendo em vista a proposição da categoria de formação socioespacial em associação ao objeto de estudo, assim como os elementos que o integram, o espaço, o tempo e os eventos oriundos das múltiplas ações que incidem na construção da materialidade do território - fração de uma totalidade - e suas subdivisões - totalidade cindida -, tem-se na técnica o elo de empirização do tempo, uma vez que os objetos técnicos cristalizados sobre o espaço, oriundo das normas/ações, revelam as técnicas/produção específicas de um dado momento da história da sociedade, enquanto totalidade e fração, em seu processo contínuo de totalização.

Planaltina pré-Brasília transita dos tempos, cujas lógicas da natureza imperavam, para um período pré-máquina, tendo no movimento mudancista e em suas práticas espaciais a busca pela superação dos tempos lentos. Santos (2002) assim tece essa trama entre a produção do movimento do espaço que envolve a técnica, o tempo e os eventos que se dão em uma totalidade:

Tempo, espaço e mundo são realidades históricas, que devem ser mutuamente conversíveis, se a nossa preocupação epistemológica é totalizadora. Em qualquer momento, o ponto de partida é a sociedade humana em processo, isto é, realizando-se. Essa realização se dá sobre uma base material: o espaço e o seu uso; o tempo e o seu uso; a materialidade e suas diversas formas; as ações e suas diversas feições.

Assim empiricizamos o tempo, tornando-o material, e desse modo o assimilamos ao espaço, que não existe sem materialidade. A técnica entra aqui como um traço de união, historicamente e epistemologicamente. As técnicas, de um lado, dão-nos a possibilidade de empirização do tempo e, do outro lado, a possibilidade de uma qualificação precisa da materialidade sobre a qual as sociedades humanas trabalham. [...] Ao longo da história, as técnicas se dão como sistemas, diferentemente caracterizadas.

É por intermédio das técnicas que o homem, no trabalho, realiza essa união entre o espaço e o tempo. (SANTOS, 2002, p. 54).

Verifica-se, no contexto pré-Brasília ao qual Planaltina entra enquanto objeto de análise em seu movimento, pequenas transformações de sua base material, refletindo então em sua estrutura social, bem como em suas formas- 
conteúdo que compunham o sistema de objetos, uma posição irrelevante dentro de uma hierarquia nacional pautada na divisão territorial do trabalho.

Todavia, referente ao processo de produção, o qual remete-se ao final do século XIX, fica patente a possibilidade de novos rumos quanto a dinâmica de produção de sua espacialidade vinculada a implementação da nova capital.

Para Santos (1977), ao discutir a proposição da categoria formação socioespacial face a formação econômica e social de Marx, o surgimento, a existência dos distintos modos de produção - ao qual Planaltina está contida corresponde a períodos ou momentos específicos da história, onde as técnicas dão um salto evolutivo enquanto metamorfose, e se aplicam sobre o espaço, produzindo marcas que ecoam no tempo e que se desdobram em possibilidade de novas ações, tendo enquanto elo a técnica que se transmuta em uma totalidade em movimento.

Segundo Santos (1977), as formações sociais deixam marcas no espaço expressas em suas formas, na construção e no ordenamento de seus objetos geográficos, frutos da intencionalidade de suas ações frente ao uso da natureza que se impõe no ato do produzir, resultante da soma e sobreposição dos modos de produção e das "necessidades" prementes de consumo a cada momento.

Tal situação é derivada da evolução das técnicas implantadas de maneira específica no bojo da formação social específica, ao qual se busca, através de um recorte temporal-espacial, o exercício reflexivo da compreensão da constituição, não desprezando as ações do todo em movimento que incide sobre o lugar/subespaço, de Planaltina, enquanto fração do território nacional. Santos (1977) assim expõe:

"As relações entre espaço e formação social são de outra ordem, pois elas se fazem num espaço particular e não num espaço geral, tal como para os modos de produção. Os modos de produção escrevem a História no tempo, as formações sociais escrevem-na no espaço. (...) Tomada individualmente, cada forma geográfica é representativa de um modo de produção ou de um de seus momentos. A história dos modos de produção é também, e sobre este aspecto preciso, a história da sucessão das formas criadas a seu serviço. A história da formação social é aquela da superposição das formas criadas pela superposição de modos de produção, da sua complexificação sobre seu "território espacial", para empregar, ainda que Ihe dando um sentido novo, a expressão de Jean Brunhes 
(1913). O modo de produção é, segundo A. Cordova (1974:118) "uma forma particular de organização do processo de produção destinada a agir sobre a natureza e obter os elementos necessários à satisfação das necessidades da sociedade". Esta sociedade e "sua" natureza, isto é, a porção da "natureza" da qual ela extrai a sua produção, são indivisíveis e conjuntamente chamam-se formação "social'” (SANTOS 1977, p. 88).

Para Santos (1977), o processo de abstração proposto pela leitura pautada na categoria de formação econômica e social só adquire a sua concretude quando é sobreposta ao espaço, aonde os objetos geográficos com suas respectivas formas-conteúdo são evidências da evolução do modo de produção que se materializa com o trabalho e a sociedade, e que se relaciona sobre sua base territorial.

O próprio termo "modo de produção" constitui um exercício de abstração enquanto totalidade integral, onde a expressão cunhada por Marx abrange a amplitude da evolução das técnicas, que se materializa como fruto da ação humana por intermédio do trabalho sobre o plano espacial. Esse espaço é tido como totalidade diferencial, espaço particular - Planaltina enquanto abstração, fração de totalidades e uma totalidade.

O emprego do termo "totalidade" é utilizado por Santos (1977) como recurso de método, ponte entre a abstração e a concretude concernente à análise da formação social em seu plano cognitivo e na visualização de sua dinâmica em um espaço concreto, sendo o próprio espaço substrato e caracterizado enquanto formação econômica social. Tal relação é descrita dessa maneira pelo autor:

"Said Sha (1973) escreveu que a formação social é ao mesmo tempo uma totalidade concreta e uma totalidade abstrata. Seu ponto de vista deve aproximar-se o de Ph. Herzog (1971:88-89) para quem modo de produção e formação social devem ser pensados teoricamente ao mesmo tempo. Para este último, "o modo de produção é a unidade, a formação econômica e social, a especificidade", mas, acrescenta ele, "não há movimento de unificação que ao mesmo tempo não reproduza sobre bases novas as especificidades", regra que evitaria julgar o modo de produção como uma essência, e a F.E.S. como um simples fenômeno. (...) De fato, a formação social, totalidade abstrata, não se realiza na totalidade concreta se não por uma metamorfose onde o espaço representa o primeiro papel." (SANTOS 1977, p. 88-89, grifo nosso). 
Nesses termos, o emprego de uma visão de totalidade é o desfecho da proposição da análise pautada na formação socioespacial, onde os processos sociais locais, que envolvem a produção material e imaterial, daão-se como reações únicas que respondem na construção da particularidade dos lugares - produção de localizações, como o caso de Planaltina e de suas partes - de maneira simultânea a ao todo maior, muito embora a vivência de seus tempos seja de forma assincrônica.

A particularidade é consequência do movimento de produção e reprodução das singularidades do local em meio às demandas e ao movimento sistêmico do todo, que de forma direta ou indireta repercutem na exclusividade da materialização das formas-conteúdo dos lugares e de suas respectivas funções em sua própria dinâmica interna e em consonância com o todo.

O lugar/subespaço - Planaltina -, território em uso ao mesmo tempo, se constitui em um sistema complexo que pode responder de forma diferenciada aos estímulos e demandas de um sistema maior, contudo, sua reprodução em um plano interno dá-se de maneira singular em detrimento a existência de uma fração de sociedade que é única.

Tal singularidade social é carregada de valores únicos, formas de vivência, pensamento e percepções ímpares, dotadas de técnicas particulares, que embora se observe implementação destas globalmente - cuja finalidade seja a reprodução de uma mais-valia imposta por espaços centrais que compõem o centro do sistema - as respostas serão diferenciadas, resultando na produção de subespaços/lugares distintos, por sociedades específicas em espacialidades singulares, uma vez que a sua base natural também é singular. Nesses termos, SANTOS (1977) aborda a questão:

O dado global, que é o conjunto de relações que caracterizam uma dada sociedade, tem um significado particular para cada lugar, mas este significado não pode ser apreendidas senão ao nível da totalidade. De fato, a redistribuição dos papeis realizados, a cada novo momento do modo de produção e da formação social depende da distribuição quantitativa e qualitativa das infraestruturas e dos outros atributos do espaço. O espaço construído e a distribuição da população, por exemplo, não tem um papel neutro na vida e na evolução das formações econômicas e sociais. (...) $O$ espaço reproduz a totalidade social na medida em que as transformações são determinadas por necessidades sociais, econômicas e políticas. Assim, o espaço reproduz-se, ele mesmo, no interior da totalidade, quando evolui em função do modo de produção e dos seus 
momentos sucessivos. Mas o espaço influencia também a evolução de outras estruturas e, por isso, torna-se um componente fundamental da totalidade social e de seus movimentos." (SANTOS 1977, p. 91).

Neste entendimento da produção do espaço urbano de Planaltina enquanto singular, fração de uma totalidade em movimento, cujas estruturas presentes dialeticamente respondem ao uso particular de tal território, tem-se a justificativa de adoção da categoria de formação socioespacial enquanto elemento teórico de vital importância para a cognição do processo de construção de tal espaço particular. Logo, dar-se-á sequência a periodização que nos remete a produção da cidade de Planaltina.

2.1 - O marco da atual problemática fundiária: A Comissão de Cooperação para a mudança da Nova Capital (1955-1958).

Ao abordar o contexto da década de 1950 mediante a perspectiva da consecução das técnicas e os impactos destas na produção da complexificação das relações de produção na escala do território-nação, Santos e Silveira (2003) pontuam, enquanto elementos que respondiam no movimento do território, a vigência de um meio técnico-científico.

Este meio técnico-científico sucede o meio técnico de circulação mecanizada e do início da industrialização, sendo este último pontuado pelos autores, espaço-temporalmente, entre as décadas de 1900 a 1940.

Neste último período, verifica-se o fenômeno de composição da Região Concentrada e o princípio de uma vigorosa urbanização do interior do país, como resposta ao processo de consolidação da atividade de industrialização impulsionado pós-crise de 1929, desdobrando-se na consolidação da cidade de São Paulo enquanto posterior motor do território, ampliando-se as relações de produção e comercialização na região Centro-Sul do país.

Todavia, a partir do estabelecimento da hierarquia nacional de cidades, mediante ao processo de urbanização e industrialização tardia, ficara evidente as 
disparidades regionais e o diacronismo face a geografização das técnicas e as formas de uso dado sobre o território brasileiro.

Santos e Silveira (2003, p. 40) evidenciam tais disparidades ao apresentarem dados do crescimento populacional e da mobilidade espacial da população entre os anos de 1920 (30 milhões) a 1965 (83 milhões). Portanto, os autores asseveram que assim como ocorreu o crescimento demográfico em todas as regiões brasileiras, também verificou-se o fenômeno de redistribuição da população, cujos fatores vinculavam-se "a um novo equilíbrio demográfico regional e a um abandono do campo, com o aumento do número de cidades", fazendo grande "parte dos brasileiros do Norte e do Nordeste trocaram essas regiões pelas cidades do Sul".

Ainda sobre o fenômeno populacional que pontua bem o processo de urbanização e industrialização do país, a vigência de um meio técnico-científico e da consolidação de uma estrutura agrária concentradora e em vias de mecanização que resulta no fenômeno de êxodo rural, Santos e Silveira (2003) argumentam:

De modo geral, foram as cidades que mais ganharam com o crescimento da população brasileira. Entre 1940 e 1950, enquanto a população global aumentava de $24 \%$, a população urbana crescia $30 \%$. No período compreendido entre 1950 a 1960, o fenômeno é ainda mais nítido. O índice global foi de $39 \%$, mas o aumento urbano é de $54 \%$. O crescimento da população rural fica estacionária nesses dois decênios, com a mesma tabela de $16 \%$. Essa tabela é inferior à do crescimento vegetativo e resulta do êxodo rural, devido muito menos à existência de emprego nas cidades que à persistência de uma estrutura agrária defeituosa na maior parte do território brasileiro. (SANTOS, SILVEIRA, 2003, p. 40).

Segundo Santos e Silveira (2003, p. 42), com a contínua consolidação da indústria paulista em seu processo de diversificação produtiva, a extinção das barreiras alfandegárias e a ampliação dos modais de transporte, permitiram inicialmente a integração regional da porção Sul do país, condição e demanda para a ampliação da complexificação das atividades produtivas desenvolvidas pela indústria paulista.

$\mathrm{Na}$ vigência do meio técnico-científico, a região concentrada, capitaneada por São Paulo, passa a exigir uma efetiva integração territorial, cuja finalidade não apenas repousa no fornecimento de matéria-prima para o 
beneficiamento industrial e posterior exportação, mas também, para a consolidação e estabelecimento de um mercado consumidor interno.

Nesse sentido, Santos e Silveira (2003) destaca a importância da construção de Brasília enquanto elemento essencial para conexão da estrutura espacial e ampliação das relações de produção e consumo em um nível nacional, que viessem a favorecer a área concentrada capitaneada pela economia paulista, tendo no modo rodoviário o elo entre as redes de produção, circulação e distribuição em expansão, assim expressam eles:

(...) O traçado dessas estradas obedecia às novas exigências da indústria e do comércio, e assim acabou por reforçar a posição de São Paulo como centro produtor e, ao mesmo tempo, de distribuição primária. A criação de uma indústria automobilística e a construção de Brasília confluíram também para favorecer São Paulo e aumentar o desequilíbrio econômico. Constitui-se nesta cidade um parque de numerosas indústrias de base, cujo enorme mercado é dado pelo esforço de equipamento de todo o território e mesmo pelo abastecimento normal da população brasileira.

A construção de Brasília foi um passo importante, pois a rede de estradas, indispensável à afirmação do Estado sobre o conjunto do território, também era imprescindível para a expansão do consumo do que era produzido internamente. (SANTOS, SILVEIRA, 2003, p. 45-46).

Todavia, anterior à materialização de Brasília, teve-se, politicamente, um embate intenso entre os estados de Goiás e Minas Gerais para receberem a nova capital. No caso goiano e, principalmente, na região do sertão planaltino retratado por Magalhães (2011), havia o anseio pela quebra do isolamento e da rápida incorporação desta fração do território ao movimento que se acelerava com a vigência de tal meio técnico-científico (Santos e Silveira, 2003).

Utilizando-se da análise pautada na dialética do esclarecimento, Magalhães (2011) descreve alguns elementos almejados pela elite local tendo em vista a possível vinda da capital para o sertão planaltino, estado incluso neste processo o avanço do sistema educacional local.

Nesta perspectiva dialética, Magalhães (2011) testifica a consciência da elite planaltina quanto a possível transformação das relações sociais e culturais vinculadas ao choque entre a possibilidade do novo sobrepor-se as dinâmicas do 
velho, colocando em risco, inclusive, as relações de poder vigentes desde o contexto colonial.

Sobre esse simbolismo e a luta contra o arcaico frente ao desejo da imposição do moderno, Magalhães (2011) explicita os elementos idealizados neste projeto de modernidade externo quanto às práticas culturais até então existentes, assim como da inserção regional no eixo econômico e dinâmico do país da seguinte maneira:

Se pensarmos em termos de mentalidade, o interesse de participar desse autentico produto da modernidade, que é a educação formal, explica a preocupação em formar os filhos; contudo, não altera as práticas consideradas arcaicas presentes na sociedade sertaneja. No entanto, a utilização de termos da modernidade, como acontecia no entorno da própria palavra educação, era realizada como conceito submetido a uma forma exógena de apropriação. (...) O desejo de incluir-se no processo civilizador, expresso na apropriação de produtos até então estranhos para as elites locais, figurava como possível redenção das dificuldades existentes. É o que insinuava-seIhes por trás da possibilidade de contar em sua terra com as extraordinárias conquistas da civilização, seria traduzido em ideias como a de proporcionar a educação formal de qualidade para os seus, naquele caso; e, segundo uma noção macroeconômica, o deslocamento da corrente econômica nacional para o centro do País. (MAGALHÃES, 2011, p. 108-109).

A utopia mudancista, retratada por Magalhães (2011), ganhou em intensidade de acontecimentos após as Comissões de 1947 - Polli Coelho - e após a Comissão de escolha do sítio da nova capital em 1953, com o Relatório Belcher tem-se a escolha do sítio Castanha para a construção de Brasília.

Neste sentido, Magalhães (2011) demonstra as práticas de atuação geopolítica da aristocracia local - coronéis pecuaristas - tendo em vista em seu discurso de convencimento de ambas a comissões que frequentaram o sertão planaltino, uma justificativa patriótica de integração nacional, dinamização da economia e modernização das porções interioranas do território brasileiro.

No interior deste discurso havia a utopia mudancista, cuja busca incessante pelo fim do isolamento das dinâmicas socioeconômicas pujantes na região litorânea, impulsionavam a ala goiana na articulação da transferência da capital para Goiás. Essa ala, continha três importantes personagens citados por Magalhães (ano?), responsáveis pelo convencimento de Poli Coelho quanto às 
terras planaltinas: Hosannah Guimarães, Dr. Atenolino Borges, e Joaquim de Faria Pereira.

É válido brevemente trazer a exposição dos eventos tramados pelos mudancistas para convencimento da Comissão Poli Coelho de 1947, contidas em Magalhães (2011):

As artimanhas de três negociantes de terras, gado e política ajudaram na determinação dos elementos fundamentais na construção da modernidade brasileira: a definição do sítio adequado para a localização da nova capital. Tudo isso enlaçado no mais puro sentido das práticas do velho coronelismo ruralista goiano. Tudo descrito por esse "coronel diplomado" como sendo "fruto do relacionamento", o que na prosa simples do interior um valor inestimável. Para Guimarães, lembrando a amizade com Coelho, haveria um valor com foros de verdade: "as amizades é que trazem relações; as relações, um cochilar, um cochichar no ouvido do outro: ele é um homem bom". Hábito interiorano utilizado tanto na condução dos negócios, quanto nas tramas da política. Aspecto que resgata relações de honorabilidades pessoalíssimas, algo de muito valor na cultura daqueles sertões. Ali vigoravam práticas moldadas segundo costumes nos quais, esse cochilar ao pé do ouvido ai formando um universo delimitado por meio da influência pessoal (...) Naturalmente, Poli Coelho se viu mais e mais enredado nas teias das batalhas simbólicas da transferência da capital e, na decisão pela indicação ideal, atuou também um pouco daquilo que Ihe fora cochichado pelo amigo Hosannah.

Posteriormente, a solicitação dos pareceres técnicos dirigida ao Estado Maior do Exército, Coelho avaliou as divergências que esgarçavam a equipe técnica do Exército. Disputas que reeditavam as batalhas constituintes de 1946, nas quais a vitória do Planalto sobre o Triângulo aconteceu por margem de meros seis votos. (MAGALHÃES, 2011, p. 103-104).

Conforme fora citado anteriormente, a morosidade do Poder Executivo em dar os encaminhamentos para a construção da nova capital após a Comissão Polli Coelho, somado as intensas lutas entre os parlamentares goianos e mineiros travadas entre 1948 a 1955, ocasionaram em mais uma proposta de estudos para a transferência da possível sede dos Poderes do Estado.

Segundo Farias (2006), o início do processo de desapropriação das terras goianas para a construção de Brasília em 1955, foi combinado entre o então responsável pela Comissão de Estudos, Marechal Pessoa, e o Governador do Estado de Goiás, Juca Ludovico, tendo em vista que a solicitação de Pessoa ao então Presidente Café Filho não fora atendida. 
O resultado do acordo firmado entre o Marechal Pessoa e o Governador Ludovico, desdobra-se no Decreto estadual de n 480 de abril de 1955, que assegurava, para fins de utilidade pública, as terras contidas no quadrilátero delimitado pelo Relatório Belcher, para fins de desapropriação.

Dado a urgência quanto à iniciação de tal ação de desapropriação, tem-se novo Decreto estadual de $n^{\circ} 1258$ de outubro de 1955 que institui a Comissão de Cooperação para a Mudança da Capital, tendo como presidente Altamiro de Moura Pacheco, dar-se início ao processo de desapropriação dos imóveis contidos no quadrilátero do Distrito Federal por iniciativa do próprio estado de Goiás. Tal ação tinha por finalidade garantir a transferência da capital para o Planalto Central, haja vista as intensas disputas com o estado de Minas Gerais para receber a nova capital do país.

Diferentemente do previsto na Constituição de 1891 quanto à declaração de posse das terras contidas no Quadrilátero Cruls para a instituição da nova capital, tanto a Comissão de Estudos para a Localização da Nova Capital do Brasil (1947), como a Comissão de Localização da Nova Capital Federal (1953), explicitava a necessidade da desapropriação das terras locais, levando em conta as ocupações já estabelecidas.

Neste sentido, o Decreto-Lei o․ 3.365, de 21 de Junho de 1941, já tratava das questões condizente a desapropriação de terras por motivação de utilidade pública, estabelecendo os comandos que possibilitariam a atuação do governo do estado de Goiás na busca de garantirem a vinda da capital para o Planalto Central.

No caso da Comissão de Estudos para a Localização da Nova Capital do Brasil (1947), ou Comissão Polli Coelho, em relatório técnico apresentado a Câmara dos Deputados em 1949, apresentava em sua estrutura a proposição do Projeto de Lei ํo 671/49 (que aventa em sua página 67, entre os seu artigos primeiro ao terceiro) as coordenadas da localização do quadrilátero que corresponderia ao Distrito Federal.

Os artigos primeiro ao terceiro referem-se à diminuição da área total do Distrito Federal de $14.400 \mathrm{Km}^{2}$ para uma outra de aproximadamente $5.000 \mathrm{Km}^{2}$, já 
traçando também um contingente populacional para a nova cidade com apenas 500.000 habitantes, bem como tratavam da implementação de um plano rodoferroviário somado a um Plano Geral de Viação Nacional de integração, além de salientar a necessidade do Governo Federal efetivar um plano de desapropriação das áreas necessárias e o plano urbanístico da nova Capital.

Com o Relatório Belcher, produzido na vigência da Comissão de Localização da Nova Capital Federal (1953-1955), tem-se, além dos dispositivos que tratam de detalhar a construção da cidade - como plano de viação, a seleção do sítio, o esboços da nova cidade, esquemas de distribuição da água, coleta de esgoto, produção e abastecimento de energia eletro-hidráulica, projeto de colonização, financiamento das obras - elementos relacionados ao processo de desapropriação das terras capitaneado pelo estado de Goiás, acompanhado, inclusive em tal documento uma solicitação de cem milhões de cruzeiros para auxiliar o estado em relevo na tarefa em andamento.

Sobre a iniciativa de Goiás em declarar as suas terras para fins de desapropriação, tendo o aval do Marechal Pessoa, é assim expresso pelo Relatório Belcher:

O Governador de Goiás, numa perfeita compreensão de suas responsabilidades, baixou, então, o Decreto $n^{\circ} 480$, de 30 de abril de 1955, declarando de utilidade pública e de conveniência ao interesse social, a área escolhida pela C.L.N.C.F.

Dias após (11 de maio de 1955) a Assembleia Legislativa do Estado vota a lei $n^{\circ} 1.071$, lei essa que foi completada pelo Decreto $n^{\circ} 500$, de 11 de maio de 1955, do Governo de Goiás.

Esses atos patrióticos impediram que os gananciosos aproveitassem a ocasião para se locupletarem com desmedidos lucros, através de compra e venda de terreno.

Baixados os Decretos Governamentais e promulgada aquela lei, estava o campo aberto a novas realizações. Mas é evidente que o Estado de Goiás, em virtude de seus parcos recursos orçamentais, não poderiam enfrentar a vultosa despesa, embora o preço médio de cada alqueire, na área delimitada, seja relativamente barato. (CÂMARA DOS DEPUTADOS, 1955, p. 117-118).

Mesmo ao ser pontuado os esforços patrióticos pelo estado de Goiás na implementação do projeto de integração nacional e no caso em análise, na contenção de ações especulativas quanto ao uso e ocupação do solo nas terras da 
futura nova capital, será pontuado mais adiante que inevitavelmente essa faceta especulativa, como já ocorrera em décadas anteriores na região e em Planaltina, teria continuidade, inclusive, entre os anos em que a comissão goiana de cooperação esteve em atividade.

Segundo Fortes, Barroso, Silva e Guedes (2007, p. 5235) - somado a já instituída Comissão de Cooperação para a Mudança da Capital presidida por Pacheco - após a ratificação dos estudos que definiam os limites do Distrito Federal, assim como da escolha do nome da nova capital - Brasília - tem-se na aprovação da Lei no 2.874/1956 a instauração da Companhia Urbanizadora da Nova Capital do Brasil (NOVACAP), também responsável pela desapropriação de terras situadas no Quadrilátero do Distrito Federal, assim como da tomada de ações para a materialização da nova sede dos Poderes do Estado.

Art. $2^{\circ}$ Para cumprimento da disposição constitucional citada no artigo anterior, fica o Poder Executivo autorizado a praticar os seguintes atos:

a) constituir, na forma desta lei, uma sociedade que se denominará Companhia Urbanizadora da Nova Capital do Brasil, com os objetivos indicados no art. 3..;

e) firmar acordos e convênios com o Estado de Goiás, visando à desapropriação dos imóveis situados dentro da área do novo Distrito Federal e do seu posterior desmembramento do território do Estado e incorporação ao domínio da União;

Art. 3. A Companhia Urbanizadora da Nova Capital do Brasil terá por objeto:

1. Planejamento e execução do serviço de localização, urbanização e construção da futura Capital, diretamente ou através de órgão da administração federal, estadual e municipal, ou de empresas idôneas com as quais contratar;

2. Aquisição, permuta, alienação, locação e arrendamento de imóveis na área do novo Distrito Federal ou em qualquer parte do território nacional, pertinentes aos fins previstos nesta lei;

Parágrafo único. A companhia poderá aceitar doação pura e simples, de direitos e bens imóveis e móveis ou doação condicional, mediante autorização por decreto do Presidente da República. (Lei n 2.874 de 1956. In https://www.planalto.gov.br/ccivil_03/leis/19501969/I2874.htm; acessado em 27 de dezembro de 2013). 
Conforme o exposto na Lei ํo 2.874/1956, embora a Novacap oficialmente fosse a responsável por promover as desapropriações das terras que pertenceriam neste momento a União, fora a Comissão de Pacheco que conseguiu obter resultados mais expressivos, uma vez que das ações empreendidas, deu-se a elaboração da Planta Índice Cadastral (figura 07) que contém a descrição e a localização de todos os imóveis rurais do quadrilátero, bem como a desapropriação de mais de $60 \%$ das propriedades rurais do Distrito Federal (FARIAS, 2006).

Sobre o feito da comissão goiana, Oliveira (2008, p. 76) assevera que as desapropriações realizadas entre 1956 a 1958 ocorreram tendo em vista a regulamentação estabelecida pela Lei ํㅡㄴ 2.874/1956, e contrapondo Farias (2006), o autor citado afirma que um terço das terras foram incorporadas ao patrimônio da Companhia Urbanizadora da Nova Capital (Novacap), correspondendo exatamente a 30.843,637 alqueires geométricos, ou $1.928 \mathrm{Km}^{2}$.

Segundo Farias (2006, p. 98) a Planta Índice Cadastral (PIC - Figura 07), elaborada pelo engenheiro Joffre Mozart Parada, "até hoje, é utilizado como referência para os estudos de confusas questões fundiárias no DF".

Todavia, essa atuação da comissão goiana ocorreu de forma árdua, já que o processo de produção do espaço planaltino, conforme fora exposto, tem em seu movimento uma relação estreita com a precariedade jurídica em termos dominiais, que vincula-se também a formação socioespacial do território do Brasil desde meio geográfico período pré-máquina. Sobre esta questão, Fortes et all (2007) discorrem:

O estudo da cadeia dominial das fazendas anexadas, parcial ou integralmente ao DF, situadas nos municípios de Luziânia, Planaltina e Formosa, foi concluído em 1958. Revelou a presença de terras devolutas e as enormes dificuldades de levantamento de registros imobiliários, principalmente, devido à ausência de documentação por parte dos ocupantes. (FORTES et all, 2007, p. 5235). 
FIGURA 07 - Planta Índice Cadastral.

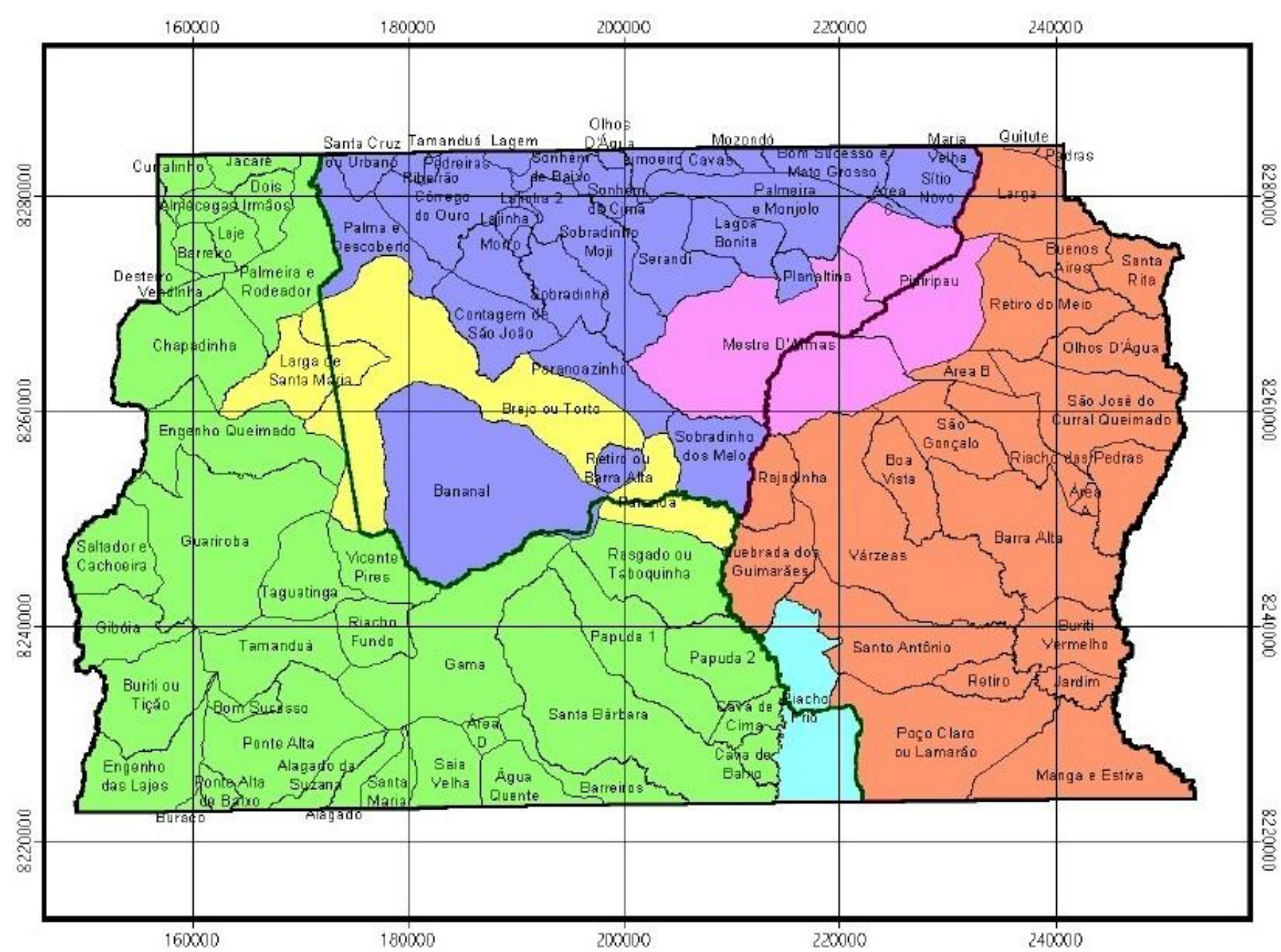

Antigos limites dos municípios goianos no Distrito Federal

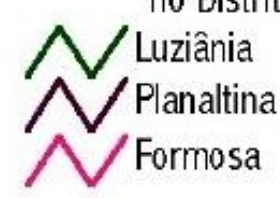

Localização dos imóveis (fazendas)

$\square$ Formosa

\section{Luziânia}

Luziânia/Formosa

Luziânia/Planaltina

Planaltina

Planaltina/Formosa

Gistema Cartográfico do Distrito Federal (SICAD

Datum horizontal Chuá

Proję̧āo UTM

Meridiano Central $45^{\circ}$ y

Fonte: Fortes et all, 2007. 
Ainda sobre o método de elaboração da Planta Índice Cadastral, Farias (2008) ao citar relatos de Pacheco (1975), explicita os detalhes da concepção da mesma da seguinte forma:

\begin{abstract}
Joffre Mozart Parada, em sua carta-relatório (apud PACHECO, 1975) afirma que finalizou este cadastro de imóveis do novo Distrito Federal, em complementação aos estudos jurídicos já realizados. Os imóveis foram classificados em três situações: "Imóveis divididos com planta, imóveis divididos sem plantas, e imóveis indivisos (PACHECO, 1975, p. 152 e 153). Parada só pôde chegar a esta elaboração da planta final, após utilizar trabalhos cartográficos já realizados pelo DERGO, e com subsídio das fotografias aéreas providenciadas pela extinta Comissão de Localização da Nova Capital. O relatório descreve, também, como utilizou registros antigos de imóveis que tinham planta para, a partir deles, traçar pontos e definir as outras divisões. (FARIAS, 2006, p. 102).
\end{abstract}

Essa difícil tarefa de se estabelecer a cadeia dominial dos imóveis rurais, assim como os seus limites poligonais, constitui-se em uma rugosidade (SANTOS, 2002), tendo sua gênese associada às origens do processo de formação socioespacial do território nacional, cujo Planaltina (subespaço) é pertencente a tal lógica.

É válido registrar que a precariedade jurídica das terras que compunham as antigas sesmarias passaram por ciclos de regularização fundiárias infrutíferos, segundo as práticas de uso e ocupação do território em sua base local, não fugindo a tendência evidenciada pelo todo. Sobre estes ciclos de regularização, Fortes et all (2007) expõem:

(...) Sesmarias (a partir de 1532), sobre as quais os sesmeiros detinham concessão de uso da terra, mas não sua propriedade legal, com autorização para abrigar arrendatários e meeiros, e também pelo regime da Posse (Lei da Boa Razão, 1769), permitindo a ocupação por qualquer pessoa livre de terras desocupadas, sendo comum, mas ilegal, a compra e venda de tais terras.

No período Imperial, foi extinto o regime de sesmarias e iniciou-se oficialmente a venda de terras, até então públicas (Lei das Terras: Lei 601/1850), garantiu-se a validação de sesmarias e legitimação de posses e concessões (Decreto 1.318/1858), resultando no Registro Paroquial de terras particulares, por meio do qual as terras públicas remanescentes, chamadas devolutas, seriam identificadas e demarcadas por exclusão.

No período Republicano, foram instituídos os Cartórios de Registro de Imóveis (Código Civil Brasileiro: 3.017/1916); garantiu-se a 
transferência de terras públicas para as unidades da federação e o domínio da União sobre terras devolutas situadas no distrito e territórios federais (Decreto-lei 9.760/1946) (...)

Entretanto, desde os registros paroquiais, a falta de controle no registro e cadastro de imóveis facilita a ocupação, parcelamento e venda irregulares de terras públicas por meio de fraudes e falsificação de títulos de propriedade (...) (FORTES et all, 2007, p. 5234).

Com base na descrição dos processos acima expostos, depreende-se a parca existência de registros cartoriais após a vigência do Código Civil de 1916, predominando, desta maneira, a frágil e numerosa presença de Registros Paroquiais, as relações particulares de compra e venda conhecidas como contrato de gaveta, ou simplesmente, a transação via acordos verbais, sendo atestado, em alguns casos, pela comissão goiana a inexistência de documentações que assegurassem a dominialidade da terra por seus ocupantes.

Estas situações de precariedade jurídica que é inerente ao pleno exercício do direito de propriedade, assim como os impactos oriundos da palavra desapropriação vinculados à formação socioespacial de Planaltina e às reações dos posseiros junto a atuação da comissão goiana de 1956, são descritos por Magalhães (2011) quanto a divulgação da Lei $n^{\circ} 1.071 / 55$ no Jornal do Planalto e que gerou desconfiança por parte dos planaltinos em perderem as suas posses, originando também um forte movimento político local quanto a questão das terras:

A entrevista do deputado Waldir de Castro atém-se ao problema da transferência da capital, mas o comentário refere-se ao projeto de lei parlamentar que previa proibição da venda de terras devolutas no raio de $500 \mathrm{Km}$ do sítio escolhido. O problema encontrava-se na interpretação da Lei $n^{\circ} 1.071$, de 11/05/1955, que autorizava ao executivo goiano desapropriar amigavelmente propriedades existentes naquela extensa região, o que resultou em decreto administrativo que suspendia as alienações de terrenos pertencentes ao estado. A reação dos proprietários foi de indignação, pois desconfiavam que a medida poderiam esconder artimanhas capazes de arrancar-Ihes as terras, cuja legalidade era dada pela posse antiga ou partilha de direito e herança. Tudo isso, acordado nos termos do reconhecimento das partes e no empenho da palavra. A mudança dos aportes legais das posses sinalizava com o perigo real de perder esse bem, pois as terras poderiam ser declaradas como devolutas. (MAGALHÃES, 2011, p.131). 
Trazendo para o caso das propriedades que perpassavam pelo processo de desapropriação e que viriam a constituir as terras do quadrilátero, Farias (2006) aponta mediante a constatação do advogado Domingos Juliano (Pacheco, 1975), integrante da comissão goiana, que em termos de organização documental e estabelecimento da cadeia dominial dos imóveis rurais, dar-se apenas em dois momentos do processo de formação socioespacial: o período setecentista até abolição dos escravos - década de 1880 - e, após este período, apenas com o trabalho empregado pela a então comissão de 1955. Tal situação é apresentada por Farias da seguinte maneira:

(...) concluo que, a despeito de algumas dúvidas, Registros Paroquiais eram referencias, ou uma base a que essa Comissão de Cooperação recorria para levantar a situação dos imóveis, que precisava ser regularizada antes da desapropriação.

O advogado Domingos Juliano, responsável pelo escritório fixo da Comissão de Cooperação em Luziânia, de 1957 até 1958, elaborou um relatório, o qual foi enviado a Pacheco e reproduzido no seu próprio relatório, contendo um balanço final de seu trabalho (...)

Este advogado escreve a respeito do povoamento da região, que teve dois ciclos de preocupação com o registro das propriedades. $O$ primeiro, foi aquele que denominou como "setecentista do ouro em Goiás até a abolição dos escravos". Embora com falhas, nessa época foram organizados os títulos de propriedade. O segundo ciclo iniciou-se em 1955, a partir do momento em que o Governo de Goiás declarou as terras, para a construção da nova capital, como de utilidade pública para efeito de desapropriação. Entre um e outro ciclo ele afirma que se assistiu a um período de desinteresse com relação ao controle dos registros de propriedade (...) (FARIAS, 2006, p. 146).

Ainda sobre a questão, vale lembrar a fala do próprio Domingos contida em (Pacheco,1975 apud FARIAS, 2006):

Centenas de inventários, dezenas de divisões tem que ser efetuadas, elos apagados ou ocultos ligando gerações devem ser reavivados e traduzidos à luz. Proprietários que não são proprietários ou que ignoram a existência de seus direitos, impostores, 'grileiros', ausentes, incapazes, toda um apequena legião de figuras tem que ser localizada na arena forense. Uma verdadeira rede de sucessões que está a exigir o trabalho dos interessados diretos na apuração e na descrição geodésica de cada imóvel, os quais, conforme já o afirmamos, estão de braços cruzados por motivos já expostos. (PACHECO, 1975, p. 138 apud FARIAS, 2006, p. 147) 
Quanto ao processo de desapropriação das fazendas e desmembramento destas, Oliveira (2008, p. 63) assevera que o objetivo da comissão de Pacheco girava entorno das desapropriações amigáveis e de preferência, mediante doação de terras a serem feitas pelos proprietários, cujas indenizações ocorreriam a custos simbólicos.

Todavia, vários expedientes foram utilizados para a promoção da desapropriação dos imóveis do Distrito Federal, dentre eles, além da transferência direta teve-se o estabelecimento do compromisso de compra e venda entre os particulares e os representantes de comissão, além dos mecanismos de desapropriação em comum $^{17}$ com posterior aquisição de grande parcela das terras por parte do Estado.

No total, Oliveira (2008) descreve 25 modalidades de desapropriação das terras que ocorrem a partir da comissão de 1956. Desta forma, vale a pena trazer tais modalidades como forma de apresentar a complexidade do processo de desapropriação das terras goianas que formariam o quadrilátero do Distrito Federal:

Terras de propriedade do Distrito Federal;

Terras de propriedade da União;

Terras devolutas;

Terras de propriedade do Distrito Federal e de terceiros, em regime de propriedade em comum;

Terras de propriedade da União e de terceiros, em regime de propriedade comum;

Terras de propriedade do Distrito Federal, parceladas e arrendadas pela Fundação Zoobotânica do Distrito Federal;

Terras de propriedade da União, parceladas e arrendadas pela Fundação Zoobotânica do Distrito Federal;

Terras não desapropriadas pelo poder público, tituladas pelo INCRA no Projeto Integrado de Colonização Alexandre Gusmão - PICAG;

Terras desapropriadas pela União, tituladas pelo INCRA no Projeto de Integrado de Colonização Alexandre Gusmão - PICAG;

Terras não desapropriadas pelo poder público, parceladas e arrendadas pela Fundação Zoobotânica do Distrito Federal;

Terras desapropriadas pelo Distrito Federal em poder de posseiros;

Terras desapropriadas pela União, em poder de posseiros;

Terras de propriedade do Distrito Federal e/ou da União transformadas em Áreas Isoladas, arrendadas pela Fundação Zoobotânica;

\footnotetext{
${ }^{17}$ A questão das terras desapropriadas em comum ocorre por que administrativamente se deram de maneira parcial, sem uma definição precisa de quais parcelas são públicas ou particulares haja vista a imprecisão demarcatória das terras o que abriu brechas para a reivindicação via judiciário para com a total indenização de parcelas reincorporadas ilegalmente pelos antigos proprietários, ou seus herdeiros ou novos adquirentes.
} 
Terras de propriedade do Distrito Federal, da União e/ou de particulares que integram parques, reservas biológicas, santuários ecológicos;

Terras de propriedade do Distrito Federal, da União, e/ou de particulares destinada à captação de água para abastecimento público;

Terras desapropriadas, ainda ocupadas pelos antigos proprietários e/ou seus herdeiros;

Terras consideradas de utilidade pública, para fins de desapropriação e ocupadas pelo poder expropriante;

Terras desapropriadas, ainda em demanda judicial por iniciativa dos desapropriados ou do poder expropriante;

Terras de propriedade particular ocupadas pelos seus proprietários;

Terras de propriedade de particular ocupadas por posseiros;

Terras de propriedade pública parcelada, loteada e vendida por particulares;

Terras de propriedade particular loteada clandestinamente;

Invasões rurais em cascalheiras, argileiras, cerâmicas, e áreas de mananciais;

Terras de propriedade de particular ocupadas pelo poder público;

Terras com ações movidas pela União. (OLIVEIRA, 2008, p. 72-73).

Oliveira (2008) explica que mesmo esses mecanismo, ao tentarem restringir a futura comercialização das terras entre particulares, reservando-as para a aquisição do Estado, em muitos casos, não foram efetivamente postos em prática, após os trabalhos da comissão goiana, pois a situação de precariedade documental dos Registros Paroquiais tornaram um grande entrave para a conclusão do processo em questão.

Oliveira (2008, p. 63) descreve enquanto elementos impeditivos para a concretização das transações de aquisição junto ao patrimônio da União, situações de duplicidade de existência de matrículas cartoriais e Registros Paroquiais da mesma propriedade em comarcas distintas, sendo também posto em dúvida a verdadeira dimensão dos imóveis, assim como a autenticidade dos documentos apresentados pelos seus supostos proprietários.

Outro fator que, no contexto, era interpretado de modo a retirar a credibilidade de tal documentação é mencionado por Farias (2006), já que no ato da apresentação dos Registros Paroquiais aos membros goianos da comissão de desapropriação, constataram que o pagamento do registro que deveria ser executado junto às paróquias na década de 1850 não fora efetivado, retirando, a princípio, a validade jurídica do mesmo. 
Farias (2006) ao traçar a lógica da vigência e predominância dos Registros Paroquiais no estado de Goiás e a relação de precariedade quanto a comprovação dominial da terra, busca a resposta em Luz (1982) para este fato identificado pela comissão goiana.

Farias (2006) verifica nas pesquisas desenvolvidas por Luz (1982) que o primeiro fator da precariedade documental assinalado pela comissão se devia à ineficácia da execução da política pública de efetivação dos registros paroquiais e da venda de terras devolutas no estado de Goiás, já que a região em exposto sequer dispunha de coletoria de tais emolumentos.

Outro elemento apresentado está associado à condição socioeconômica dos moradores da época, que dificilmente conseguiriam obter essas propriedades por meios legais, levando-os ao ato de apossamento das terras devolutas. Farias (2006) ainda relata outros fatores que associados à formação socioespacial da região, resultaram nas dificuldades de desapropriação das terras locais para o estabelecimento da nova capital:

(...) Dedicados à pecuária extensiva e a lavoura de subsistência, os proprietários em Goiás não tinham interesse em legalizar suas terras da forma prevista pela lei. Isto se deve ao fato de que, principalmente, entre outras questões, "melhor seria para eles manter a situação irregular, que possibilitava a incorporação de novas terras sempre que isso se fizesse necessário. Também, para estes proprietários, era possível 'legalizar' suas propriedades de maneira mais simples e pouco onerosa: através, por exemplo, de doações ao santo padroeiro do lugar, ou de compra e vendas que eram aceitas pelos cartórios locais, etc.".

Na República, com a Constituição de 1891, este quadro não se altera significativamente. A lei estadual de 1893 conferia o valor de título ao Registro Paroquial que a regulamentação da lei de 1850 não permitia.

(...) Debates sobre essas e outras questões judiciais acerca da propriedade da terra, ao que parece, somente foram iniciadas naquele período de atuação dessa Comissão de Cooperação. As conclusões de trabalhos realizados pelos membros desta comissão são consideradas referências ainda hoje na solução de pendências fundiárias no Distrito Federal. (LUZ, 1982, p. 50 apud FARIAS, 2006, p. 145).

A celeuma decorrente destas situações de precariedade dominial da terra, cujos Registros Paroquiais constituem o cerne da questão, na época, 
evidenciaram o choque dialético entre o novo que se impunha, através da aplicabilidade do arcabouço jurídico normativo já vigente, e o velho, que trazia em seu bojo as práticas sociais de produção espacial pretéritas, vinculados à fragilidade dominial das posses, que, segundo Oliveira (2008), não se distinguia face a extensão das terras rurais ou posição econômica de seus proprietários.

Sobre este embate dialético entre o velho e o novo, o moderno e o arcaico, Magalhães (2011) retrata estas novas relações espaciais impostas pela burocracia vinculada à construção de Brasília, que impunham outras condições de produção da espacialidade mediante a aceleração dos tempos, capitaneado pelo objeto espacial que viria a ser materializado - Brasília, o autor esclarece:

Quanto à semelhança de procedimentos, não há o que questionar. A nova ordem que pretendia ser moderna, juntamente com a nova capital, trazia o direito laico, racional e legal (...) Nesse sentido, as acomodações dominiais tradicionais, herdeiras de registros paroquiais, que há muito presidiam as legalidades da posse da terra estavam simplesmente sendo substituídas por um conceito diferente de propriedade, totalmente sustentada pela legalidade cartorial. (MAGALHÃES, 2011, p.155)

Este choque dialético de caráter espaço-temporal também é descrito por Farias (2006) ao contextualizar Magalhães (2004), referente à relação presente entre Registros Paroquiais, terras de santo e famílias tradicionais existentes em Planaltina, tendo em vista a pretérita dinâmica de uso do território associado às práticas religiosas e políticas de um contexto cultural dissociado da realidade capitalista vigente da modernidade. Assim Farias (2006) assinala:

(...) Magalhães (2004), analisa a sua ocorrência em Planaltina, através de um comentário feito por Arantes, no qual este magistrado jocosamente nos conta sobre a existência de um documento do século XIX, considerado válido, ainda em 1956, que explica a origem de terras pertencentes a Paróquia de Planaltina. Neste documento, segundo Arantes, o nome de Sebastião Carlos Alarcão constava como procurador de São Sebastião (...)

Os juristas chefiados por Pacheco, da mesma forma que optaram por conceder o direito de arrendamento, pelo qual os ex-proprietários podiam deixar seus rebanhos nas terras de que tinham sido desapropriados, também tiveram que reconhecer a procuração de Sebastião Carlos de Alarcão. E, se o fizeram, foi por necessidade de resolver, o mais rápido possível, a questão das desapropriações na área (...) (MAGALHÃES, 2004 apud FARIAS, 2006, p. 103). 
Segundo Farias (2006), mais do que o mero possuir de documentos que comprovassem a posse, vislumbrando o direito à propriedade inerentes à instrumentalidade jurídica, havia o laço afetivo entre os posseiros e a terra herdada de seus ancestrais.

Neste sentido, o autor identifica na Lei de Sesmarias oriunda do Direito Português, um vínculo anterior com Direito Justiniano, o qual assegurava a posse das terras ocupadas em territórios ermos, conquistados e anexados pelo Império Romano, que nesse caso, garantia o direito à propriedade dos cidadãos romanos que as ocupassem e as cultivassem, possibilitando a unidade sociopolítica do território.

Essa relação é reforçada, no caso brasileiro, quanto da revogação da Lei de Sesmarias em 1822 pela Resolução $n^{\circ}$ 76, mas que, ainda assim, havia previsto a continuidade da vigência do regime de posse, permitindo acontínua ocupação de terras, tendo em vista a lógica acima descrita.

Segundo Nozoe (2006), nesse meio tempo, entre 1822 e 1850, esta relação de posse pautada na permanência da Resolução $n^{\circ} 76$ resulta na expansão das propriedades rurais, assim como na precarização documental das mesmas, não podendo precisar a distinção entre terras de particulares e seus limites, assim como sobre terras devolutas griladas ou apossadas.

Em meio a este cenário juridicamente nada costumeiro para a nova burocracia que se instalava no sertão planaltino, em meados de 1956 em diante, tem-se nas constatações e apontamentos feitos pela comissão goiana, presidida por Altamiro Pacheco, toda a base de levantamento documental necessárias ao empreendimento das posteriores desapropriações, assim como, da materialidade a ser debatida nos tribunais acerca dos litígios que se empunham enquanto resultado das ações de desapropriações executados pela comissão goiana e das que ainda estavam por serem feitas.

Quanto à velocidade posterior dos processos de desapropriações efetivados já no contexto pós-Brasília, Oliveira $(2008)^{18}$ descreve que entre os anos

\footnotetext{
${ }^{18}$ Sobre o processo de desapropriação das terras contidas no Distrito Federal, Oliveira (2008, p. 66), com base nos dados da Terracap, afirma:

Dados da Companhia Imobiliária de Brasília (TERRACAP) divulgados pela Secretaria de Estado de Desenvolvimento Urbano e Meio Ambiente, dão conta de que $51,36 \%$ das terras do Distrito Federal
} 
de 1965 e 2005, foram desapropriados 10\% das terras pertencentes a particulares no Distrito Federal.

Dentre os fatores enumerados pelo autor que resultaram em tal desaceleração, tem-se a Comissão Parlamentar de Inquérito (CPI) instaurada no ano de 1961 que se estende até 1965, voltada à investigação das contas públicas e das instituições privadas que financiaram a construção de Brasília. Outro fator vinculou-se às intervenções judiciais descritas por Oliveira (2008), que a partir do ano de 1965 passam a obstar as desapropriações.

Além dessa dificuldade de traçar a cadeia dominial das propriedades, tendo em vista a precariedade documental atinente aos Registros Paroquiais, com a construção de Brasília - já em meados de 1958 - Farias (2006), Oliveira (2008) e Magalhães (2011), narram a dificuldade da realização de desapropriações amigáveis, uma vez que, com a celeridade do andamento da construção da capital e posterior materialização, as terras particulares tiveram os seus valores inflacionados.

Quanto a este inflacionamento, tanto Farias (2006) como Magalhães (2011), trazem relatos de Pacheco (1975) que expressavam a crescente dificuldade de promoção de desapropriações amigáveis, sendo indicado por Altamiro, inclusive, o uso do mecanismo de desapropriação judicial para efetivar a conclusão do processo iniciado no ano de 1956.

Todavia, após a saída da comissão goiana da tarefa de desapropriação das terras do Distrito Federal, deu-se continuidade ao processo em questão, que cada vez mais ganhava proporções complexas, pois, segundo Oliveira (2008), além da análise dos Registros Paroquiais e respectivos títulos, ainda havia a negociação de valores junto aos proprietários e ocupantes das fazendas. Estes elementos ainda se fazem presentes na produção do espaço urbano de Planaltina, tanto a negociata como os altos valores da terra especulada.

O Poder Judiciário local passou a figurar, nesse entendimento, em um sentido desfavorável a execução das desapropriações no ano de 1965, ano no qual, segundo Oliveira (2008), a Vara de Fazenda Pública passou a negar, perante a estão desapropriadas em comum, 6,83\% em processo de desapropriação, e um percentual representativo 33,28 das terras são de propriedade privada. 
Novacap, o direito de desapropriação do que já seriam terras públicas pertencentes à União, cuja base de argumentação jurídica sustentava-se no artigo terceiro do texto Constitucional do ano de 1891. Sobre esta questão, Oliveira (2008) faz a seguinte crítica:

$\mathrm{O}$ ato de desapropriação do Distrito Federal, parecia a época tão resolvido e ao mesmo tempo tão confuso, que leva a interpretações administrativas e jurídicas que asseguravam a aparente ação paradoxal do Estado. Requerer a desapropriação de terras para legitimar sua ocupação e negá-la não ter legitimidade o pedido. (OLIVEIRA, 2008, p. 67-68).

Em seguida, no ano de 1967, Oliveira (2008, p. 68) salienta que o Juiz de Registros Públicos solicitou ao Tribunal de Justiça do Distrito Federal "provimento proibindo os registros de imóveis do DF, de forma a não interferir nas desapropriações efetuadas pelo governo do DF, além do Decreto "N" n 636, de julho de 1967, que regulamentava a desapropriação das terras do Distrito Federal".

Ambas as ações tinham por finalidade interromper as transferências de propriedades até que se chegasse a um consenso quanto a legalidade do ato de desapropriação, os mecanismos jurídicos a seres usados, bem como a aceitação ou não dos Registros Paroquiais enquanto documentos que comprovariam a dominialidade das propriedades.

Sobre a questão, Oliveira (2008) relata o resultado da situação frente à execução das desapropriações das terras já ocupadas secularmente:

\footnotetext{
Essa proibição legal estabelecida em decreto perdura até 1975, quando é liberado registro para três casos específicos: para propriedades cujas posses possuíssem registro paroquial; para aqueles que já tivessem sentença julgada de usucapião até 01 de janeiro de 1917; ou, ainda, para as doações feitas pela União depois da promulgação da Constituição de 1891.

Nesse mesmo ano é identificado o primeiro condomínio "informal", o Country Club Quintas da Alvorada, hoje conhecido como Quintas da Alvorada. (OLIVEIRA, 2008, p. 68).
}

Até o presente momento, a discussão referente ao direito do exercício de propriedade sobre as terras contidas no quadrilátero do Distrito Federal, ainda é uma questão espinhosa, principalmente quando este direito está vinculado à 
comprovação da dominialidade da terra mediante a apresentação de Registros Paroquiais, tanto em propriedades rurais como na composição da malha urbana, através do parcelamento empreendido por particulares ou pela municipalidade, no qual a cidade de Planaltina também se inclui.

É importante destacar que a tentativa de blindagem das terras do Distrito Federal relacionado aos atos especulativos advindos das considerações formuladas pelo relatório Polli Coelho e nos esforços empreendidos pela comissão goiana de desapropriação, iriam resultar na produção de sucessivas políticas públicas a partir dos anos 60 em diante, que também tiveram por intuito preservarem o plano urbanístico de Brasília. Estas ações afetaram diretamente na dinâmica de formação socioespacial e no movimento da cidade de Planaltina.

Este evento assinalado por Oliveira (2008) - a constituição do Condomínio Quintas da Alvorada - também seria elemento de litígio judicial, cuja decisão refletiria na lógica da produção de políticas públicas, no novo uso do território por parte dos diversos agentes nele presentes, assim como no impacto perante a composição de novos sistemas de objetos espaciais, denominados por Malagutti (1997) como assentamentos clandestinos.

Conforme será exposto, a ação/decisão da instância Judicial, mediante o proferimento de acórdão, constituiu em um novo elemento normativo que incidiu nas relações sociais de produção espacial, repercutindo também na cidade de Planaltina. Estes eventos serão analisados com maior profundidade no quarto capítulo.

Todavia, ainda cabe refletir sobre os impactos sociais resultantes do processo de desapropriação das terras pertencente ao antigo município de Planaltina, assim como os ranços pessoais originados pelas desapropriações no processo de formação socioespacial da cidade objeto. 
2.2 - Os ranços do processo de desapropriação.

Magalhães (2011) sempre deixou claro em seus relatos quanto da atuação do movimento mudancista, que as articulações voltadas à transferência da capital para o Planalto Central era estabelecido por uma elite esclarecida, vendo na possibilidade de materialização da utopia da mudança um trampolim para o desenvolvimento econômico do sertão planaltino, tendo em vista a integração regional ao centro econômico e dinâmico do país - região concentrada.

Nesta perspectiva, havia também o anseio pela materialização de uma nova temporalidade sobre as bases espaciais que em muitos casos ainda se remetiam ao meio pré-máquina. Era a busca pela modernidade em seus mais diversos campos.

Percebia-se também, através do caso Louly (1927), a possibilidade da realização de negócios rentáveis atrelados à valorização das terras, tendo em vista a transferência da nova capital para Goiás, e não apenas isto, pois segundo Magalhães (2011), a aristocracia local também vislumbrava a oportunidade de figurar no alto escalão da política nacional, haja vista a proximidade com o novo centro do poder político.

Todavia, para Magalhães (2011), havia a consciência por parte desta elite esclarecida do risco quanto da mudança das relações culturais e das possíveis transformações nas relações de poder vigentes, haja vista a materialização desta modernidade simbolizada com a construção de Brasília e dos novos elementos sociopolíticos que esta traria.

O processo de produção do espaço planaltino girava ao entorno da posse da terra, independentemente da situação dos sujeitos em sua estratificação face a divisão social do trabalho.

Entretanto, como fora explicitado por Castro (1986), com a chegada da Comissão Cruls, desde o primeiro instante que efetivamente se cogitava a construção da nova capital no sertão goiano, criava-se assim uma animosidade por parte dos posseiros das antigas sesmarias quanto da perda de suas terras, 
principalmente aqueles que encontravam-se em uma realidade a parte da elite esclarecida.

O fato relatado por Castro (1986), relativo a comissão Cruls, ocorrera com a iniciação dos trabalhos desenvolvidos pela comissão goiana de cooperação em 1956, também explicitado por Magalhães (2011) e Farias (2006). Contudo, desta vez, não se tratava de uma mera especulação, mas de um fato consumado.

Com o início das desapropriações, até mesmo a aristocracia local passava a sofrer com o processo de desapropriação das terras, perdendo assim a sua identidade cultural, vinculo hereditário com os seus ancestrais e símbolo do status do poder político, gerando profundas transformações, podendo estas serem interpretadas como um grande choque dialético. Os fatos são descritos por Magalhães (2011) dessa forma:

Essa indiferença da tecnocracia desenvolvimentista em relação aos reclames do humanismo, ao contrário do que fora projetado, foi interpelado por reações políticas e culturais da alteridade negada (...)

A suspensão de costumes e festas tradicionais pode ser compreendida como representação crítica e simbólica da mutilação que também ocorria no campo econômico, da qual sobressai o processo de desapropriação territorial. O início das desapropriações possui um lastro antimoderno inegável, pois desaloja famílias e grupos sociais tradicionalmente assentados sobre a propriedade da terra sem oferecer-Ihes alternativa de escolha (...) (MAGALHÃES, 2008, p. 145).

Magalhães (2011) aborda em seus relatos, pautados nas notícias expostas sobre os veículos de comunicação, a atuação política de Gabriel Guimarães - que mais adiante será citado em uma lide vinculada ao espólio de supostas propriedades deixadas por particulares - em defesa do processo de desapropriação das terras planaltinas, as quais eram especuladas por ele e outros personagens locais como Deodato Louly. Conforme apresentado pelo autor, no ato das desapropriações, Gabriel Guimarães transitava da situação de fervoroso mudancista para opositor a tal evento, assim:

Na mesma edição, notificava-se também que o deputado Gabriel Guimarães havia protocolado na Presidência da Assembleia Legislativa do Estado de Goiás um pedido de esclarecimento ao Governo sobre o processo de desapropriação das terras da região da 
futura capital do país. Documento que indicava vigorar, entre os planaltinos, a desinformação, a dúvida e um pouco da consciência da exclusão.

Segundo as palavras desse, até então, fervoroso mudancista, a demora no início dos negócios estava trazendo um clima geral de mal-estar entre os proprietários das fazendas. Além disso, era possível verificar o início da ação de gente identificada como "gananciosos" especuladores, que se animavam diante da iminente elevação nos preços das terras. (MAGALHÃES, 2008, p. 131)

Segundo Magalhães (2011), os meios de comunicação locais, manobrados pela aristocracia vigente e que sempre fizeram apologia ao mudancismo, passaram a se posicionar contra a tal processo de desapropriação, sendo os tecnocratas liderados por Pacheco denominados de grileiros do asfalto, tal como é descrito pelo autor supradito:

Destoando dessa fala, cinco anos depois, diante do desencantamento produzido pelas desapropriações, o JP publicou artigo de autoria de seu editorialista e proprietário, Gabriel Guimarães. De forma pertinente com conhecidos conceitos planaltinos, o Jornal do Planalto alertava: Cuidado, vem aí a grilagem.

O texto deixa transparecer a denúncia de malefícios que a concretização do mudancismo poderia acarretar aos moradores da região. Nesse caso, o conceito que delimitava o perigo eminente, denominado grilagem, referia à prática amplamente utilizada no mundo sertanejo. A diferença era que, em vez de fazendeiros e jagunços exercendo a violência contra pequenos lavradores $\mathrm{e}$ posseiros, a ameaça transmuta-se em "grileiros do asfalto". (...) A denúncia na forma de um alerta dizia respeito aos problemas que começavam a fustigar antigos proprietários locais, ludibriando-os com leis desconhecidas e conceitos cartoriais, para eles, desimportantes, tomando-Ihes a terra. (MAGALHÃES, 2011, p. 152).

Para Farias (2006) e Magalhães (2011), tais acusações foram correlacionadas também aos métodos discursivos utilizados pelos membros da comissão goiana, afim de convencer os proprietários e posseiros, de que o melhor a ser feito era a doação - discursos patrióticos - ou que de qualquer maneira, a melhor escolha para os proprietários, seria a desapropriação e o recebimento da indenização destes por parte do Estado, pois não teriam mais a posse da terra. 
Magalhães (2011) tece as seguintes considerações sobre as marcas deixadas por tal evento - a desapropriação - para toda sociedade de Planaltina, independentemente de seu status social ou da extensão de suas propriedades:

\begin{abstract}
As evidências discursivas, no entanto, apontam para a ocorrência do movimento no qual o apoio incondicional ao mudancismo, face à contrariedade de seus interesses, transforma-se em crítica apensa à tomada de consciência, sobre os reais prejuízos. Principalmente em relação ao processo de desapropriação fundiária.

Em diversos depoimentos de antigos proprietários de terras da região do DF, encontramos evidências de que nem mesmo o tempo foi capaz de cicatrizar as feridas abertas em torno de questões tão fundamentais como esta. Em meados dos anos oitenta, alguns desses planaltinos ainda esperneavam a maldição em relação à condução do processo. (MAGALHÃES, 2011, p.150).
\end{abstract}

Tendo em vistas as considerações tecidas por Magalhães (2011) é de grande valia apresentar alguns depoimentos sobre os ranços gerados pelo processo de desapropriação das terras contidas no antigo município de Planaltina, ainda pertencente a Goiás, uma vez que é nítido entre tais famílias, nos dias modernos, ainda tratarem de tais questões com profundo pesar. Sobre a questão, Hosannah Guimarães (1985), um dos artífices mudancistas, assim se posicionara sobre o tema da desapropriação:

Dr. Hosannah - Era uma região de fácil desapropriação, porque as terras eram baratas, pois estavam no interior do Brasil. (...) Atrás disso tudo houve um grande trabalho de uma pessoa que estava mais ou menos metida nesse processo - o engenheiro Jerônimo Coimbra Bueno.

Então, há muito a dever ao Jerônimo e a todos nós que tivemos o máximo de boa vontade, entregando fazendas, terras enormes aqui, por preços insignificantes. Não chegou a haver propriamente nenhuma desapropriação.

Entrevistador - Como foi essa passagem de terras?

Dr. Hosannah - Foi feita por entendimento. A primeira escritura que se lavrou aqui em Planaltina foi a minha. Eu queria dar o exemplo. Então, dei toda área entre Sobradinho e o Torto.

Dei uma escritura por preço simbólico, porque para a União receber precisava a autorização do Congresso, para receber de doação. Para comprar não precisava. Veja como o problema jurídico é complexo.

Entreguei o alqueire a 80 centavos. Hoje não se dá 80 centavos nem para o menino que fica no ponto guardando o seu automóvel. Não se 
dá 80 centavos, pois fica com vergonha. Entreguei aquilo por 600 e tantos cruzeiros. (GOVERNO DO DISTRITO FEDERAL, 1985, p. 2627).

Depreende-se da fala de Hosannah Guimarães (1985), que mesmo ao promover a venda de suas terras como um gesto de contribuição a nobre causa da transferência da capital que traria inúmeros benefícios locais, ainda era possível identificar certo arrependimento, tanto pelo valor monetário das posses quanto pelo valor simbólico que as terras possuía. Terras estas herdadas do pai, Salviano Monteiro Guimarães.

Sobre o preço irrisório das desapropriações, Farias (2006) expõe o depoimento de seu Zuzu Guimarães dado em entrevista. Este deixa explicito os laços afetivos para com a terra de seus descendentes, assim como o valor ínfimo pago pelo estado de Goiás em sua aquisição.

Darcy: vocês tentaram aumentar o preço, mas não teve jeito?

Zuzu: não teve jeito, fomos maltratados pelo Governador (...)

Zuzu: todo mundo tem sentimento, perdeu tudo que tinha, ficou com a mágoa (riso).

Darcy: Ficou todo mundo da família?

Zuzu: Não só eu não. E o sitiante que tinha 20, 30 alqueires foi morar na vila em Formosa, nos bairros, em Brasilinha com a vizinhança. Foi sem sentimento perder tudo que tinha. Que o dinheiro não dava pra comprar nada.

Zuzu: Por isso que Juscelino morreu trucidado porque fez muita maldade. Não foi ele, mas foi ordem dele.

(...) Eu nasci aqui mesmo no Distrito Federal em 1912 e meu pai nasceu dentro do distrito, meu avô nasceu dentro do Distrito Federal meu bisavô também, agora eu, nasci na fazenda, só mudei pra Formosa depois que fui desapropriado (...) (FARIAS, 2006, p. 123142).

Quanto ao caso de Zuzu Guimarães, Farias (2006) afirma que sua antiga propriedade - Fazenda Barra Alta, anteriormente dentro dos antigos limites do Município de Formosa-GO, foi incorporada à posterior Região Administrativa de Planaltina-DF - em termos documentais, era uma das exceções encontradas pela comissão goiana, contendo na escritura a cadeia dominial dos antigos proprietários. 
Todavia, o registro do imóvel fora executado apenas no ano de 1919 no nome do pai, Antonino Guimarães, enquanto resposta à imposição normativa da Constituição de 1891 e do Código Civil de 1916.

Para o entrevistado de Farias (2006), a indenização advinda do estado de Goiás para com as terras desapropriadas se deu a "preço de banana"19, uma vez que não levava em conta a crescente especulação do preço das terras próximas ao quadrilátero, bem como os baixos valores pagos pelas benfeitorias existentes nas propriedades. Somados a tais elementos, existia o discurso proferido pelos membros da comissão de que as terras de posseiros e de particulares eram todas da União.

Nessa perspectiva, Farias (2006) dá voz a Zuzu Guimarães:

Zuzu: Ah, o dinheiro que eles me deram, pra 7 mil 500 (hectares), dava pra comprar nada (...) dava pra comprar uma chácara de 50 alqueires. (FARIAS, 2011, p. 107-108).

Assim como no relato de Zuzu Guimarães, Otaviano Guimarães (1985) expressa, abaixo, o valor recebido pela desapropriação, assim como a maneira como os diálogos de convencimento eram travados entre os membros das comissões de desapropriação das terras e os proprietários ou posseiros, uma vez que os discursos patrióticos não convenciam estes últimos da importância do ato de desapropriação amigável para implementação da nova capital:

Seu Otaviano: Proprietário aqui de chácaras, de terras foram obrigados a faze mau negócio porque o pessoal falava: "Ah! Você precisa vender isso por que a terra do Distrito Federal ninguém é dono". Aliás até eu acredito que ninguém é dono mesmos, mas nessa época agente tinha uma fé, agente tinha uma esperança de realizar alguma coisa, um sonho né, e foi completamente...

Entrevistador: O senhor chegou a vender terras?

Seu Otaviano: Vendi como se vendesse uma galinha, um cavalo ou um porco, diziam pra gente que agente não ia ser dono de nada mesmo, que ia ser desapropriado, então a gente foi forçado a fazer

${ }^{19}$ Farias (2006) ao tratar dos baixos custos do processo de desapropriação das terras contidas no quadrilátero do Distrito Federal, ao expor o caso de Zuzu Guimarães com base nos valores monetários do período, descreve que o montante recebido pelos 7.500 hectares de terras expropriadas de Zuzu correspondia a CR\$7.475.211,50. Esta importância convertido em dólares na cotação do período equivalia a apenas U\$ 52.949,41, valor este corrigido e convertido em Reais equipara-se a apenas $\mathrm{R} \$ 268.585,10$ nos dias hodiernos. Este montante expressa os baixos valores pagos no processo de indenização das terras locais executadas pela Comissão Goiana de 1956. 
mau negócio. (GOVERNO DO DISTRITO FEDERAL, 1985, p. 68$69)$.

Mesmo ao Otaviano reconhecendo a situação de precariedade da posse da terra, tendo em vista o longo processo de formação socioespacial, associado ao ato de posse advindo da ocupação das terras goianas, tem-se implícito em sua fala, mediante a tais ações de desapropriação, a total desconsideração por parte da burocracia que passa a viger em tais ações, perante os laços históricoculturais construídos ao longo de dois séculos pelos habitantes locais junto ao solo que tiravam sua subsistência.

Embora também seja reconhecido por parte destes expropriados as benesses advindas com a construção de Brasília, como o acesso a saúde, educação, novas oportunidades de empregos para os seus ascendentes, ainda é possível identificar as cicatrizes deixadas por tal evento, inclusive no ato de contestação judicial dos filhos e netos dos antigos proprietários das terras desapropriadas com o passar das décadas, até chegar aos tribunais nos dias atuais, como sendo um primeiro traço da judicialização do território de Planaltina.

Oliveira (2008) afirma com base em Malagutti (1997), que não se sabe ao certo, em meio à confusa interpretação jurídica - nas esferas do Poder Executivo e Judiciário - somado as ações de desapropriação inconclusas, o que de fato sejam terras do GDF (Terracap), o que são de propriedade da União e o que efetivamente ainda é de posse de particulares. O resultado disto são as constantes ações judiciais que perpassam as três esferas do Poder Judiciário. Nestes termos é explicitado pelo autor:

Sob uma ótica inversa da apresentada, um terço das terras são de propriedade privada, não contestadas pela Terracap. Contudo, isso não representa que todas as terras das quais a companhia declara de sua propriedade, são absolutamente entendidas assim, já que existem contestações judiciais movidas por particulares.

Por esse viés, nem tudo que é declarado de propriedade estatal assim o é, e a existência de documentos de propriedade, título de propriedade, e as contestações judiciais relativas a procedimentos não conclusos de desapropriações ajudam a corroborar essa ótica. (OLIVEIRA, 2008, p.66). 
Corroborando com tal afirmação de Malagutti (1997) e Oliveira (2008), Castro (2014) apresenta um caso de indenização de terras de particulares não desapropriadas pelo Governo do Distrito Federal - GDF e pela União. Terras essas que faziam parte do antigo município de Planaltina, referentes à antiga Fazenda Paranoá e que hoje perfazem as Regiões Administrativas pertencentes ao Paranoá e ao Itapoã.

Segundo Castro (2014), os sítios urbanos das cidades encontram-se sobre as terras do já falecido Sebastião de Sousa e Silva, e que mediante decisão judicial, via pedido de espólio, o GDF fora determinado a indenizar os filhos de Sebastião. Castro afirma:

Castro - Bom, o Paranoá foi construído em cima de terras de Planaltina. Tá havendo um problema aí, e eu faço parte do problema. Do problema não, eu faço parte da solução do problema.

- Então, tem que pagar uma indenização de dois bilhões e meio, o Governo do Distrito Federal, porque construíram duas cidades em cima as fazendas do Sebastião de Souza e Silva. Sem comprar, sem indenizar, sem nada.

- A família entrou, ganhou a questão... agora, por isso que eu digo que to sendo parte da solução. Eu to sendo utilizado pra provar quem que era filho do Sebastião de Sousa e Silva. Ele teve os filhos verdadeiros e da amante, e eu to ajudando na prova dos filhos da amante, que eram filhos dele. Provando. (CASTRO, 2014).

Castro (2014) ainda assevera categoricamente, indo de encontro a Oliveira (2008) e Malagutti (1997), que foram pouquíssimas as terras efetivamente desapropriadas em Planaltina. Entretanto, a Terracap sempre se posiciona enquanto proprietária das mesmas sem que haja efetivado o pagamento da indenização das terras. Castro (2014) enfatiza:

- Houve a desapropriação de terras, mais algumas só citaram que estavam sendo desapropriadas, sendo que os verdadeiros proprietários não foram procurados para eles fazerem indenização. Eles continuaram donos da terra e ainda tá na terra, né...

- Ah, a terra de fulano foi desapropriada! Muitas vezes dizem isso aí, e eu digo: não foram! Porque? Porque o dono tá lá ainda, até hoje ainda nunca recebeu nada...

- Nenhuma terra aqui do Monjolos foi desapropriada, que eram dos meus tios, nem dos meus parentes. A única que foi desapropriada foi 
uma terra dentro da Reserva de Águas Emendadas, que a minha tia vendeu pro Carlos Henrique, e o Carlos Henrique passou caríssima pro governo. Milhões! Um pedacinho de terra que era da minha tia. Esse foi indenizado.

- Pra criar o parque eles tiveram que comprar algumas propriedades... algumas construções que haviam sido feitas, né... (CASTRO, 2014)

Sobre a questão referente ao espólio de Sebastião de Sousa e Silva, ainda continua tramitando no TJDFT. Entretanto, a última decisão proferida quanto à dominialidade das terras que correspondem à antiga Fazenda Paranoá, tem-se decisão favorável à Terracap, determinando" a reintegração de posse sobre a área de terras da Fazenda Paranoá, objeto da Transcrição no 9.061 do Registro de Imóveis de Planaltina de Goiás" (TRIBUNAL DE JUSTIÇA DO DISTRITO FEDERAL E TERRITÓRIOS. APELAÇÃO CÍVEL 2009.01.1.149890-6, 01 de julho de 2013).

Neste caso, observa-se a duplicidade de matrículas de registro da propriedade, sendo que a matrícula utilizada para pedido de espólio dos descendestes de Sebastião de Sousa e Silva - matrícula ํo 12.980 - é datada do ano de 1979, presentes no segundo Cartório de Luziânia e no Primeiro Cartório de Registro de Imóveis de Brasília.

Segundo decisão proferida, este documento não dispõe de toda a cadeia dominial da terra, ferindo o princípio da continuidade, ou seja, o histórico relacionado às transações de compra e venda do imóvel e o reconhecimento do Estado relativo a essas ações por meio da efetivação de averbações sobre a matrícula do imóvel registrado, gerando assim dúvidas quanto à legitimidade do pedido de espólio.

Verifica-se também o trancamento da matrícula 12.980, sendo impedido as relações de compra e venda dos imóveis contidos nas terras em questão até que a lide seja solucionada, podendo o desbloqueio ser solicitado via Poder Judiciário em ação a ser interposta.

Contudo, tendo por base a Transcrição $\mathrm{n}^{\circ} 9.061$ do Cartório de Registro de Imóveis de Planaltina de Goiás, a Terracap alega que as terras correspondentes à Fazenda Paranoá haviam sido adquiridas junto a Victorino 
Bevenhati e Sebastiana de Souza Bevenhati, sendo esta última, filha de Sebastião de Sousa e Silva e que havia herdado tal porção de terras.

É também válido expor que este processo oㅜ 2009.01.1.149890-6, é apenas um dos quatorze vinculados a questão do espólio das terras de Sebastião de Sousa e Silva, sendo de fundamental importância a resolução da lide para a efetivação da regularização dos respectivos imóveis das cidades do Paranoá, Itapoã e condomínios presentes.

Tendo em vista as afirmações de Castro (2014), Oliveira (2008) e Malagutti (1997), somados às decisões preferidas pela Instância Judicial, vislumbrase a complexidade da situação fundiária em todo Distrito Federal, tendo em vista o processo de formação socioespacial da região, cujo Planaltina é partícipe e passa pela mesma situação. Situação esta a ser descrita no quarto capítulo.

Conforme fora exposto anteriormente, um dos grandes problemas quanto à comprovação documental e legitimidade da posse das terras do Distrito Federal, vincula-se à precariedade dos documentos que atestam a posse da terra. No caso do espólio em questão, os descendentes de Sebastião de Sousa e Silva alegam que as terras não foram indenizadas e essa disputa entre os particulares e o Distrito Federal, neste caso, vem se arrastando desde 1979.

Ao fazer uma breve pesquisa nos sites do TJDFT, STJ e STF, identificou-se alguns casos de contestações judiciais que remontam ao processo de desapropriações das propriedades que estavam situadas nos limites municipais de Planaltina de Goiás e que foram incorporadas ao quadrilátero de Distrito Federal ainda entre os anos de 1956 a 1960.

Assim, como no caso de Sebastião de Sousa e Silva, dentre os litígios a serem mencionados é válido mostrar o caso de requerimento de espólio terras de Gabriel de Campos Guimarães, representado por Francisca da Ressurreição Lobo Guimarães, junto ao STJ, no Recurso Especial № 839.131 - DF (2006/0048052-6). O não provimento do recurso impetrado se deu no dia 06 de agosto de 2009.

Esse recurso tinha por finalidade contestar decisões proferidas contrariamente a querelante, cujo teor associa-se, segundo esta, ao processo de desapropriação indireta da Fazenda Bananal que atualmente encontra-se o sítio 
urbano de Brasília, tendo em vista o não recebimento de indenização oriunda de tal desapropriação. Enfatizando, a Fazenda do Bananal esteve contida nos limites do antigo município de Planaltina-GO.

Segundo as análises documentais realizadas por Farias (2006), quanto ao processo de desapropriação da Fazenda Bananal, Gabriel de Campos Guimarães, então político, negociador de terras e detentor do Jornal do Planalto, anteriormente mudancista, mas amplamente contrário ao processo de desapropriação das terras planaltinas, conforme apontado em Magalhães (2011), não constava na cadeia dominial das terras registradas nos arquivos da Terracap, tendo enquanto últimos proprietários Jorge Pelles e Jerônimo José da Silva. Assim é exposto por Farias:

A Fazenda Bananal tinha 5.632,272 alqueires e pertencia a Hélio Rodrigues Queiroz, a Deodato Louly e a Salvador Ribeiro de Freitas. Posteriormente, Hélio Rodrigues vendeu a Jorge Pelles e a Jerônimo José da Silva, o seu quinhão, que equivalia a uma área de 4.752,066 alqueires. (FARIAS, 2006, p.102).

Já o referido processo recursal no 2006/0048052-6, tem como teor a vigência de uma sociedade existente entre Deodato Louly e Gabriel de Campos Guimarães e que as terras que anteriormente lhes pertenciam, haviam sido negociadas com Dionísio Meireles e Hélio Rodrigues Queiroz em momento anterior a efetiva atuação das comissões de desapropriação das terras do Distrito Federal. Nestes termos, constan o processo:

A dificuldade começa com a operação seguinte no registro do imóvel, em que "o falecido Gabriel de Campos Guimarães, depois de receber de volta as terras que não tinham sido doadas, vendeu juntamente com Deodato do Amaral Louly, tudo quanto possuíam na fazenda 'Bananal' a Dionísio Meireles e Hélio Rodrigues Queiroz, conforme escritura pública lavrada nas notas do 1ํ Tabelionato de Goiânia-GO, em 19.03.1946 e transcrita na Comarca da Planaltina-GO, sob o no 4.3352, reservando, para si, 100 e 175 há respectivamente". (Superior Tribunal de Justiça, RECURSO ESPECIAL № 839.131 DF 2006/0048052-6, p. 07).

O motivo gerador da ação indenizatória por parte da querelante está vinculado ao contrato estabelecido entre as partes no ato do negócio e uma vez concretizado, segundo o STJ, não cabe qualquer pedido de indenização, já que tanto a propriedade em questão como o suposto registro desta, que um dia fora de 
propriedade de Gabriel Guimarães, já havia sido registrado em nome do comprador sucessor, além da desapropriação com conseguinte indenização já ter sido executadas em 1956 pela comissão goiana e repassados ao domínio da Terracap.

Sobre a complexidade desta negociação pretérita e contestações judiciais nos dias presentes, tem-se transcrito no recurso especial:

\begin{abstract}
$\mathrm{Na}$ referida escritura pública as partes contratantes acertam o seguinte (f. 34):

Que, conforme o exposto, os dois casais outorgantes vendem, como efetivamente vendido têm, o primeiro a Dionísio Meireles e o segundo a Hélio Rodrigues de Queiroz, outorgados compradores, todos os direitos que lhe assistem sobre o saldo de terras que possuem na larga do Bananal inclusive direitos a reversão dos lotes não doados pela Prefeitura de Planaltina na forma acima declarada, reservando cada casal para si a área necessária para repor qualquer engano ou falta de acaso se verificar, tanto no levantamento da área do imóvel, como em algum lote cuja doação ficasse omitida por acaso como algum lote vendido na Planta Ruy Barbosa, ficando entendido que essa ressalva compreenderá apenas a área de cem (100) hectares da parte vendida pelo primeiro casal e cento e setenta e cinco hectares da parte vendida pelo segundo casal e as quais só poderão ser utilizadas para garantia dos negócios anteriores. (Superior Tribunal de Justiça, RECURSO ESPECIAL № 839.131 DF 2006/0048052-6, p. 07).
\end{abstract}

Os supostos lotes citados na negociação fazem parte do ciclo especulativo das terras, promovidas após o ano de 1922, com a fixação da Pedra Fundamental, tendo como símbolo, de tal evento, a venda de lotes da suposta nova capital, cujo nome era Planópolis e que havia sido promovido no sítio da posterior construção de Brasília por Deodato Louly.

Gabriel Guimarães, conforme será exposto, também se aproveita do evento relacionado à construção de Brasília para promover o parcelamento e venda de lotes nas imediações do quadrilátero do Distrito Federal, estando este envolvido no parcelamento das terras da Fazenda Bananal no ano de 1927.

Contudo, pressupõe-se, conforme o recurso especial citado, que grande parcela destes lotes não havia sido efetivamente vendida ou doada, e foi deixada, desta maneira, como reserva para posteriores negociações de Gabriel Guimarães e de Deodato Louly. 
Assim, quanto ao recurso interposto junto ao STJ pela querelante, temse o seguinte posicionamento dos magistrados:

Gabriel de Campos Guimarães, portanto, não se manteve como titular de área determinada, inscrita regularmente no registro de imóvel. Houve apenas uma ressalva de 100 ha com a exclusiva finalidade de garantir as alienações anteriores. Conforme consta da escritura (trecho transcrito na sentença - fl. 1.209): "ficando entendido que essa ressalva compreenderá apenas a área de cem (100) hectares da parte vendida pelo primeiro casal (...) as quais só poderão ser utilizadas para garantia dos negócios anteriores."

Foi por essa razão que a sentença, ratificada pelo TRF, aferiu que o autor da herança não era proprietário, na forma da legislação civil, dessa área de 100 ha.

Como dito, a existência do imóvel e a correspondente titularidade em favor do espólio não pode ser reexaminada em Recurso Especial (...) (Superior Tribunal de Justiça, RECURSO ESPECIAL № 839.131 DF 2006/0048052-6, p. 08-09).

Muito embora a lide citada, apreciada pelo STJ, cujo teor vincula-se ao espólio de Gabriel de Campos Guimarães, representado por Francisca da Ressurreição Lobo Guimarães, no Recurso Especial no 839.131 - DF (2006/0048052-6), tendo o seu não provimento no ano de 2009, ao analisar outros acórdãos, verificou-se que o teor deste mesmo Recurso Especial já havia sido impetrado anteriormente junto ao TJDFT e perpassado por decisão do STF, desde o ano de 1975.

A conclusão desta primeira tentativa de espólio das supostas propriedades de Gabriel Guimarães tem o seu desfecho no dia 30 de novembro de 1982, em Recurso extraordinário $n^{\circ}$ 96.969-1, tendo no teor decisório o não provimento da ação impetrada pela inventariante Francisca da Ressurreição Lobo Guimarães, no STF, haja visto que a ação iniciada no TJDFT fora requerido pela instância superior ao julgar que o TJDFT não tinha competência para julgar lide que envolvia diretamente os interesses atinentes à esfera federal.

Vale ressaltar que na lide, a União se manifesta enquanto codetentora das terras contestadas em conjunto com a Terracap, sendo desta maneira remetida a apelação junto ao STF, onde pela primeira vez, não fora deferido a apelação pela inventariante em questão. 
Assim como fora exposto no suposto direito de indenização, tendo em vista os espólios de Gabriel Guimarães, outros casos com o passar dos anos pósBrasília foram levados às cortes.

Uma das exceções que dá o ganho de causa ao expropriado e não à expropriante, pode ser observado no Recurso Extraordinário $n^{\circ} 71.385$, proferido no dia 16 de abril de 1971 pelo STF, tendo como recorrente o Distrito Federal e como recorrido Gerson Monteiro Guimarães, proprietário da Fazenda Várzeas, também situado na antiga comarca de Planaltina-GO.

Nesta lide, assim como fora explicitado em Oliveira (2008), e conforme citado no Recurso Extraordinário $n^{\circ} 71.385$, é dado o direito de indenização das terras com a devida correção monetária e pagamento de benfeitorias.

O processo de desapropriação da Fazenda Várzea ainda não havia sido concluído pós-inauguração de Brasília e tinha como base interpretativa por parte do Governo do Distrito Federal, assim como dos magistrados locais, que o processo de expropriação havia ocorrido de maneira indireta, somado ao não reconhecimento do exercício do direito de posse em detrimento a suposta precariedade jurídica dos documentos dos imóveis ainda em desapossamento.

Neste sentido, conforme é elucidado por Oliveira (2008, p. 70), cria-se o "mito do processo sumário de desapropriação, e a totalidade do domínio das terras como públicas", criando-se conforme o autor, uma "conotação ideológica" que visava promover a "preservação e contenção de um processo da dinâmica imobiliária privada". E o autor ainda conclui:

A reserva de boa parte do território do quadrilátero, durante esses mais de 50 anos, tem relação direta com esse discurso ideologicamente construído, que tem sua explicação à realidade, na proliferação das ocupações das terras privadas no Distrito Federal. (OLIVEIRA, 2008, p. 80).

Segundo o referido recurso extraordinário, o direito à indenização do expropriado fora reconhecido pelo STF, sendo associado aos três casos extraordinários apontados por Oliveira (2008). Estes elementos encontram-se explicitados no decreto "N" n० 636 de 1967 e ratificado em 1975, enquanto: propriedades detentoras de registros paroquiais, sentença de usucapião julgado até 
janeiro de 1917, e a última, ao qual se enquadra a lide, doações feitas pela união posterior à Constituição de 1891. Ratificando a informação, Juvenal Antunes Pereira assevera:

\begin{abstract}
Mas em razão dos termos da Constituição de 1891, quanto à localização da nova Capital, surgiram controvérsias sobre a possibilidade de existir, ou não, terras particulares na área por ela reservada e depois demarcada pela Missão Cruls, dúvida somente resolvida pelo Decreto-Lei $n^{\circ}$ 203, de 1967 que mandou que fossem respeitados os direitos dos proprietários, assim considerando aqueles cujas posses estivessem baseadas no chamado registro paroquial, em documento de venda ou doação que a União tenha feito depois da promulgação daquela Constituição, ou em sentença transitada em julgado em ação de usucapião até $1^{\circ}$ de janeiro de 1917. (DISTRITO FEDERAL, DECRETO №21.948, 2001, p. 04).
\end{abstract}

Embora os magistrados tenham chegado a uma conclusão quanto ao direito de indenização a ser recebido e corrigido monetariamente em favor do expropriado fica notório no parecer de um dos magistrados que o "mito do processo sumário de desapropriação" citado por Oliveira (2008), também conhecido juridicamente como desapropriação indireta, era insistentemente argumentado pela Novacap e posterior Terracap nos processos de desapropriação das terras. Assim é argumentado pelo Ministro Rafael de Barros Monteiro:

Irresignado, recorre extraordinariamente o Distrito Federal (...)
sustenta o recorrente haver o V. acórdão recorrido negado vigência
do art. $3^{\circ}$ do DI. $n^{\circ} 203$, de 27 de fevereiro de 1967 , desde que as
terras situadas na área do Distrito Federal já são do domínio da
União e, em consequência, não podia ser objeto de desapropriação.
(SUPERIOR TRIBUNAL DE JUSTIÇA, Recurso Extraordinário $n^{\circ}$
71.3851971, p. 05).

Sobre a contradição da moção de ação contra o expropriado movido pela Terracap, cuja finalidade assentava-se no não pagamento dos juros atinentes ao processo de desapropriação que se arrastava desde o ano de 1959, tem-se a fala do Ministro Amaral Santos que dá relevo ao discurso apregoado sobre a desapropriação indireta das terras do Distrito Federal, pós-inauguração de Brasília:

Entendo que o poder expropriante não tem interesse de recorrer, quando ele pode usar de um poder maior que é o de desistir da desapropriação. Se o expropriante entende que é proprietário de coisa e, portanto, não tem que desapropria-la, não irá propor ação de desapropriação. Então desiste dela. Mesmo depois de transitado em julgado, pode desistir da desapropriação. É um ato administrativo 
que a qualquer momento o poder expropriante poderá declarar: desisto da desapropriação. Não tem o interesse de agir, absolutamente. No caso dos autos, o poder público vem dizer: a coisa que estou expropriando é minha. E recorre? Se o poder expropriante reconhece que a coisa é dele, o que tem a fazer é desistir do recurso e propor ação reivindicatória ou qualquer outra ação, não ação de desapropriação. (SUPERIOR TRIBUNAL DE JUSTIÇA, Recurso Extraordinário nº 71.385 1971, p. 08).

Conforme pronunciado pelo Ministro Amaral Santos, não se desapropria propriedade cuja dominialidade é pertencente ao expropriante, a não ser que o expropriante não exerça o legítimo direito de propriedade sobre o bem. Este posicionamento converge com as considerações tecidas por Oliveira (2008) e Malagutti (1997) sobre o questionamento do discurso quanto da dominialidade das terras do Distrito Federal que sejam pertencentes à Terracap e que foram devidamente desapropriadas.

Conforme será apresentado no quarto capítulo, esta interpretação atinente às desapropriações indiretas pós-Brasília, causará consequências sobre as propriedades contidas na área urbana de Planaltina, alocadas no Setor Tradicional, antigo núcleo urbano do município de Planaltina, anterior a inauguração de Brasília e vigência legal do território do Distrito Federal.

Outra lide a ser exposta é o pedido de espólio de Sebastião Gomes Rabelo, falecido no ano de 1956, em recurso interposto por Gercina Maria Cardoso de Alarcão junto ao TJDFT, contidos no Agravo de Instrumento 2012.00.2.012328-5 AGI, junto à 5⿳亠丷厂 Turma Cível, gerador do acórdão 643.615.

Segundo o Agravo de Instrumento $\mathrm{n}^{-}$2012.00.2.012328-5, as propriedades requeridas correspondem às antigas fazendas Sobradinho, Morro da Canastra e Buraco, todas estas estavam inseridas no anterior do território pertencente ao município de Planaltina de Goiás, sendo o espólio impetrado junto a Segunda Vara Cível de Sobradinho, de Feito no2012.06.1.000274-6.

Em relatório contido no Agravo de Instrumento nº 2012. 00. 2. 0123285, oriundo do Feito no 2012.06.1.000274-6, é dado o não provimento a autora da ação, uma vez que o inventariante deveria comprovar o domínio dos bens, tendo em vista que os mesmos "atualmente pertencem à circunscrição do Distrito Federal e, certamente, possuem registro atualizados em um dos Cartórios de Registro de 
Imóveis do DF" (Tribunal de Justiça do Distrito Federal e Territórios, no 2012.00.2.012328-5 AGI, p. 03).

Fora exigido com base na Lei no 6.015/73 que trata do registro de bens imóveis, que fosse comprovado a dominialidade dos bens por meio de apresentação de cópias, contendo a atualização das matrículas dos imóveis junto aos cartórios de registros imobiliários presentes no Distrito Federal.

Já a autora do processo, alega que os imóveis requeridos em inventário dispõem de documentação contidas no Cartório do 1ํofício de Imóveis de Planaltina/GO, embora as terras tenham sido incorporadas ao Distrito Federal. A querelante ainda apresenta a seguintes argumentações geradoras do Agravo de Instrumento no 2012.00.2. 012328-5:

Refere que apenas parte das aludidas glebas, especificamente aquelas que constituem a Fazenda Morro Canastra foram objeto de desapropriação em comum, havendo sido incorporadas ao patrimônio da TERRACAP. No entanto, as demais glebas, por equívoco, foram tomadas pela Procuradoria do DF como dotadas da mesma condição, o que fez com que a Juíza da causa determinasse a comprovação da propriedade, mediante a juntada das matrículas atualizadas em um dos Cartórios de Registro de Imóveis do DF.

Afirma que após a transmissão automática do domínio, em decorrência do falecimento do autor da herança, nenhum ato importou a necessidade de registro, por isso, nos termos do art. 176, I, da lei $\mathrm{n}$-6.015/73, não fora aberta a matrícula dos imóveis, até mesmo porque, conforme orienta o art. 170 do mesmo diploma legal, o desmembramento territorial posterior ao registro não exige sua repetição no novo Cartório, constituindo, pois, uma faculdade do titular do domínio e não um imperativo normativo.

Assim, afirma que a decisão agravada implica, a um só tempo, violação ao princípio da facultatividade da repetição e à fé pública inerente aos registros cartorários. (Tribunal de Justiça do Distrito Federal e Territórios, nº 2012.00.2.012328-5 AGI, p. 04).

Conforme fora citado anteriormente, mediante 0 processo de desapropriação dos imóveis pelas comissões goiana e do Distrito Federal, uma das modalidades mais praticadas foi a desapropriação em comum, tendo em vista a resistência de seus antigos proprietários, em vida, de se desfazerem completamente de suas terras.

Inclusive, no site da Terracap, ao mostrar dos passos legais necessários para a promoção do processo de regularização dos condomínios, cita a 
questão da desapropriação em comum, enquanto um entrave histórico na formação socioespacial do Distrito Federal e da atual Região Administrativa de Planaltina. Tendo em vista a complexidade da questão, é válido expor tal descrição dos fatos:

A comprovação da propriedade da terra é outra questão de relevância no processo de regularização, uma vez que, na constituição do quadrilátero do Distrito Federal, muitos imóveis desapropriados não foram objeto de divisão e demarcação, permanecendo estas terras em comunhão de propriedade. Essa situação se reflete atualmente na impossibilidade de registro do parcelamento que teve seu projeto de regularização aprovado, mas se localiza em terras desapropriadas em comum. TERRACAP (http://www.terracap.df.gov.br/internet/index.php?sccid=281; 05/12).

Muito embora a argumentação da querelante seja respaldada juridicamente pela Lei 6.015/73, a decisão proferida no Agravo de Instrumento no 2012.00.2.012328-5, nega o provimento recursal, alegando a não comprovação do registro da terra, uma vez que estas seriam de domínio da Terracap, e, também, pelo fato da querelante não ter conseguido provar a existência de registros das propriedades em cartórios do Distrito Federal, conforme fora exigido com base na mesma Lei nำ6.015/73.

Todavia, o grande elemento de embate, que conduz à dúvida da efetiva desapropriação das terras com o consequente desmembramento das mesmas para o patrimônio da Terracap ou da União, é exposto em decisão proferida, levando a uma interpretação de um argumento corriqueiramente utilizado pela Terracap e respaldada pelo MPDFT, em ações cujo teor seja o mesmo da lide em questão, bem como das interpretações dos tribunais do TJDFT: a suposta desapropriação indireta $^{20}$. É válido a análise do trecho de tal decisão:

\footnotetext{
${ }^{20}$ Sobre a relação direito de propriedade e desapropriação indireta, Souza (2010, p. 17-28) faz as seguintes considerações:

Sendo um instrumento excepcional, a desapropriação somente pode ser aplicada se estiverem presentes os pressupostos legais que a autorizam. Ausente qualquer deles, defrontar-se-á com ilegitimidade. Os atos desapropriatórios devem ser justificados pela tutela de interesse de maior repercussão social.

(...) a justificativa para a desapropriação não se assenta em conduta ilegal do expropriado, mas na supremacia do interesse público sobre o privado.

(...) a expropriação justificada nas necessidades administrativas (art. 182, § $3^{\circ}$ ) impõe ao gestor público o pagamento de indenização prévia, justa e em dinheiro, nos mesmos moldes do art. 5ํ, XXIV (CF) (...)

Manifesta-se o entendimento de que a indenização plena trata-se de condição essencial para a identidade da desapropriação, sendo esta característica o traço basilar que a difere, justamente, do confisco (...), acerca do termo "desapropriação indireta", (Carvalho 2005-2006, p.120-121), no extrato doutrinário abaixo, traça comparativo entre desapropriação direta e indireta:
} 
As informações prestadas pelo Juízo a quo (fls. 104/105) dão conta de que a Terracap afirma que as glebas em questão situam-se no polígono formador das divisas do Distrito Federal, havendo sido objeto de desapropriação quando da criação da nova unidade federativa.

Tal questão, não suprida pela colação das matrículas atualizadas dos imóveis em Cartórios do Distrito Federal, impossibilita o prosseguimento da ação subjacente, haja vista a existência de dúvidas acerca do titular do domínio dos bens, as quais não podem ser suprimidas sem a devida averiguação, a se dar em ação própria e não no âmbito do Inventário.

Dessa forma, identifica-se acerto no posicionamento firmado pela Juíza a quo, ao exigir a comprovação da propriedade dos imóveis em tela, não sendo suficiente para demonstrá-la, em face da alegação de que se inserem no polígono definidor do território do DF, certidões expedidas pelo Cartório do $1^{\circ}$ Ofício de Imóveis de Planaltina/GO, reproduzindo realidade submetida ao antigo sistema das transcrições dos títulos. (Tribunal de Justiça do Distrito Federal e Territórios, no 2012.00.2.012328-5 AGI, p. 04).

Muito embora o pedido de abertura de inventário após mais de 50 anos seja algo no mínimo duvidoso, tendo em vista o alto valor das terras agora contidas no quadrilátero do Distrito Federal, somado à falta de atualização oriunda modificação do registro imobiliário também presente na Lei 6.015/73, que visa aperfeiçoar o registro dos imóveis, objetivando "estabelecer a matrícula como fator de individualização autônoma do imóvel, conferindo relevo ao cadastro do imóvel e não de seu proprietário", observa-se na decisão à cerca do Agravo de Instrumento nº

Por desapropriação direta se entende aquela realizada pela Administração Pública quando esta cumpre as normas jurídicas que legitimam a consumação do ato expropriatório, ou seja, é respeitado todo o prévio processo exigido. [...] Quando a Administração cumpre as normas atinentes, diz-se que exerceu uma desapropriação direta, mas devemos ter algumas reservas, pois alguns dispositivos do Lei no 3.365/41 não foram recepcionados pela Carta vigente, sendo notoriamente inconstitucionais. [...] Já a desapropriação indireta é conceituada como uma construção pretoriana (fomentada pelos juízes e tribunais), criada para dirimir conflitos concretos entre o direito de propriedade e o princípio da função social, nas hipóteses em que a administração pública ocupa propriedade privada sem observância de prévio processo de desapropriação (quando observa o prévio processo diz-se desapropriação direta), para implantar obra ou serviço público. Estas palavras são excessivamente simpáticas para definir desapropriação indireta; preferimos chamá-la de ato abusivo consubstanciado em esbulho praticado pela Administração Pública contra o cidadão em total desrespeito à Constituição Federal. Em suma, a Administração Pública toma para si bem alheio, sem qualquer atenção às regras que autorizam a desapropriação, agindo em odiosa ilegalidade.

A denominada "desapropriação indireta" sequer chega a ser desapropriação. Ora, com base no conceito elegido em item próprio deste estudo, tal instituto fora definido como perda indenizada da propriedade, com base em ponderação de predominância de interesses, em conformidade com critérios elegidos no ordenamento jurídico. Como na "desapropriação indireta" não há regular indenização, não se pode afirmar que ocorreu desapropriação. Se não há desapropriação, não pode existir, para o caso correlato, modalidade de desapropriação. 
2012.00.2.012328-5, que simplesmente a Terracap não apresenta os devidos documentos que comprovam a desapropriação e dominialidade da terra.

Conforme o exposto no Agravo de Instrumento, para que haja este embate entre a Terracap e o particular, para chegar-se a um posicionamento sobre a dominialidade da terra, faz-se necessário interpor ação diretamente contra a referida entidade. Neste aspecto, também gerando dúvidas advindas da parte da querelante, já que um dos artifícios discursais usualmente utilizados nas contestações de terras desapropriadas atualmente, estão ancoradas na questão da desapropriação em comum, também verificadas nesta lide.

Todavia, no acórdão proferido, não é apresentado qualquer indício de que as terras tenham efetivamente sido desapropriadas e devidamente indenizadas, levando a crer que estas perpassaram por desapropriação indireta, ou seja, mesmo com o processo de desapropriação iniciado no ano de 1956, com a inauguração de Brasília no dia 21 de abril de 1960, todas as terras contidas no quadrilátero, compulsoriamente seriam de domínio do Distrito Federal, mesmo não sendo indenizadas.

Os elementos expostos, conduzem mais uma vez a concordância com Oliveira (2008) e Malagutti (1997), ao afirmarem que a situação confusa dos atos de desapropriação das terras, assim como as diversas interpretações sobre a questão, constituem fatores sui generis face a realidade não menos complexa dos litígios em todo o território nacional, mas com peculiar complexidade no caso do Distrito Federal, e, em especial, no processo de formação socioespacial de Planaltina.

Para finalizar a análise do acórdão oriundo do Agravo de Instrumento no 2012.00.2.012328-5, tem-se a seguinte argumentação dos desembargadores sobre o pedido de recurso interposto pela querelante e o não provimento do mesmo:

Ocorre que a hipótese em estudo contempla situação atípica, decorrente da desapropriação de grande faixa de terra no propósito de criação da nova Capital do Brasil.

Diante dessa realidade, editada a lei 6.015/73 há tantos anos, bem assim em face do falecimento do autor da herança em 03/12/1956 (fl. 09), causa espécie que o Inventário haja sido distribuído somente tantos anos depois, ou seja, que nenhuma providência haja sido adotada pelos herdeiros para regularizar a situação registral das glebas que pleiteiam, mormente em face da coincidência de sua localização com aquela relativa às áreas que compõem o território do Distrito Federal. 
Assim, mormente em sede de Inventário, não há que se falar em propriedade das glebas sem a exposição da matrícula atualizada no Cartório que é competente para o registro há muitos anos.

$\mathrm{O}$ art. 984 do Código de Processo Civil orienta que a decisão sobre fato, que não se encontrar provado por documento, haverá de ser remetida aos meios ordinários, não havendo de ser deslindada no âmbito do próprio Inventário (...)

É óbvio que a afirmação prestada pela TERRACAP de que as terras pleiteadas integram o polígono formador das fronteiras do DF enseja dúvidas acerca da propriedade das aludidas glebas, o que confere razão á determinação judicial de juntada aos autos das matrículas dos imóveis. (Tribunal de Justiça do Distrito Federal e Territórios, no 2012.00.2.012328-5 AGI, p. 07-09)

Conforme fora exposto, vários elementos põe em dúvida o pedido de inventário em questão, tais como a temporalidade para a execução do mesmo, a origem documental de comprovação da dominialidade da terra, as argumentações sobre o processo de desapropriação em comum e os supostos equívocos em tal ação de desapropriação.

Também se coloca em xeque a efetiva dominialidade da Terracap para com boa parcela das terras contidas no quadrilátero do Distrito Federal, uma vez que ao inconcluso processo de desapropriação iniciado pelas comissões da década de 1950, somam-se aos argumentos e interpretações legais equivocadas frente ao legítimo direito de propriedade, exercido, mesmo que precariamente, pelos anteriores donos da terra, abrindo brechas para a atuação especulativa dos agentes presentes no território em uso.

Embora possa ser especulado se as terras em questão foram desapropriadas pela comissão goiana ou pela Terracap, ou se pertencem à particulares não indenizados, tem-se aí exemplos do ranço histórico gerado pela construção de Brasília referente aos antigos proprietários da terra, que geram contestações judiciais de seus descendentes e que circulam nas diversas instâncias que constituem o Poder Judiciário.

Assim como no caso dos imóveis rurais que perpassaram por processos de desapropriações conturbadas e que dificultam até os dias modernos a utopia da burocracia quanto a total dominialidade das terras da capital planejada, 
como é exposto por Holston (1993) ${ }^{21}$, vê-se o mesmo problema para com a cidade de Planaltina-DF e a efetivação de seu processo de regularização fundiária que afeta diretamente a sua malha urbana.

Mediante o exercício de compreensão do movimento da cidade através da adoção da categoria de formação socioespacial, fora exposto anteriormente à gênese dos ciclos de precariedade jurídica que refletem na condição presente do exercício do direito de propriedade.

Entretanto, com o passar do tempo, tal situação ganha em complexidade, já que verifica-se distintos ciclos de evolução desta situação, tendo em seu bojo, nas distintas frações da cidade, especificidades quanto a ilegalidade possessória e o pleno exercício do direito de propriedade. No próximo tópico, será exposto o final de um ciclo que nos remete à cidade de Planaltina enquanto sede do Município de Planaltina-GO, ou seja, em um contexto pré-Brasília.

2.3 - Planaltina-GO x Planaltina-DF: a perda da sede municipal, especulação imobiliária e a ampliação do espaço urbano irregular.

De acordo com os tópicos anteriormente expostos, tem-se no processo de formação socioespacial da cidade de Planaltina, em um contexto pré-Brasília, a gênese da precariedade jurídica que impacta no exercício do pleno direito a propriedade no contexto histórico em apreciação, e que repercute nos dias atuais.

Tomando como alicerce a proposta de periodização de Santos e Silveira (2003), este processo de precarização jurídica local tem a sua gênese em

\footnotetext{
${ }^{21}$ Para Holston (1993) todo o processo de materialização de Brasília segue os princípios apregoados pelo CIAM, cuja intencionalidade das desapropriações das terras privadas para a incorporação junto ao patrimônio público objetivava justamente a ampliação percentual desta em contraposição a primeira modalidade face ao controle da terra. Houston explicita que tais princípios expropriatórios apregoados pelos CIAM via Le Corbusier, tem sua gênese inspirada em Haussmann suas intervenções urbanísticas junto a cidade de Paris na segunda metade do século XIX. O total controle das terras via expropriações tem por intencionalidade a livre atuação dos arquitetos e urbanistas tendo em vista a aplicação dos princípios preconizados pelos CIAM. Além deste fato, será exposto a diante que tal controle das terras também gera efeitos deletérios para com a classe operária, resultando no processo de periferização e segregação socioespacial. Esses efeitos são observados na relação entre Brasília e Planaltina face ao processo de formação socioespacial.
} 
um contexto pré-máquina, avançando ao período da vigência de um meio técnicocientífico em meados da década de 1950.

Esse fenômeno geográfico - meio técnico-científico - inicia-se também em uma perspectiva regional com a efetivação do Plano de Metas de Juscelino Kubitschek, em acordos políticos firmados junto aos militares e à ala mudancista goiana que se desdobra na construção da nova capital do país: Brasília.

Para tal, fora explicitado, enquanto um dos elementos vinculados à construção da nova sede dos Poderes do Estado, a efetiva desapropriação das terras locais que receberiam a nova capital e que iriam compor o quadrilátero demarcado para tal evento.

É justamente neste ponto que se percebem as antigas dinâmicas locais de produção espacial indissociáveis à função desenvolvida pela região no meio prémáquina, cujo trabalho desempenhado pela sociedade local dá a gênese à estrutura fundiária e aos usos do território em movimento.

Conforme fora exposto, esta mesma situação de precariedade jurídica das propriedades contidas no núcleo urbano do antigo município goiano é reflexo das práticas sociais que correlacionam-se também ao processo de formação socioespacial em uma escala nacional, cujas lógica se reproduzem localmente (subespaço), produzindo tal espaço singular.

Neste sentido, a cidade vernacular que tem a sua gênese na Terra do Santo São Sebastião em 1811 - na Fazenda Mestre D'Ármas - passa a ser pertencente ao município mediante permuta realizada entre o intendente Louly e a Igreja Católica, cujos tramites se deram entre 1927 e 1929. Este fato associa-se ao primeiro movimento especulativo local vinculado à possível transferência da capital para a região de planaltina retratada por Magalhães (2011).

Conforme a GENOR (2012), a partir de 1934, a então prefeitura de Planaltina passa a alienar glebas contidas dentro da antiga Fazenda Mestre D'ármas, constando estas na transcrição $n^{\circ} 303$, fruto da permuta efetivada entre o intendente Louly e a entidade eclesiástica (Paróquia São Sebastião). 
Ainda segundo a GENOR (2012), tais alienações se davam através de Alvarás de Concessão, que já remete a uma situação de precariedade quanto à garantia do efetivo exercício do direito à propriedade, garantido apenas a posse e o uso do bem, isso sem mencionar que este parcelamento não dispunha de uma planta cadastral registrada em cartório.

Com a vigência da Lei $n^{\circ} 58$ de 1937, a situação do parcelamento urbano realizado até o referido momento, enquadra-se em situação de ilegalidade. Segundo a GENOR (2012), o prefeito João Carlos de Alarcão, busca promover a convocação dos habitantes da cidade para ação de regularização dos imóveis junto à prefeitura de Planaltina, usando de expedição do Decreto $n^{\circ} 3.039 / 38$, em consonância as determinações contidas nos dispositivos da Lei n 58/37.

Todavia, segundo GENOR (2012, s/p), a tentativa de regularização das propriedades que detinham apenas Alvarás de Concessão fora infrutífera, já que a cidade não possuía uma planta cadastral registrada em cartório, ou seja, "os registros foram feitos em livros próprios da Prefeitura Municipal, nos quais não constavam as dimensões das áreas de suas propriedades, apenas limites". Ainda, é expedido o Decreto-Lei $n^{\circ}$ 4/39 pelo Poder Executivo local que assegurava em favor do município:

Este Decreto-Lei $n^{\circ} 4$ considerava a vantagem decorrente para a Municipalidade, da venda ou de concessões de terrenos que se destinassem a pastos de animais, além dos destinados à construção. As Glebas vendidas ou concedidas para pastos de animais localizavam-se em torno da Cidade, principalmente próximas aos córregos Buritizinho, Atoleiro e Ribeirão Mestre D'Ármas. Estas, naturalmente, pela facilidade de água abundante para os animais e também por serem terras de melhor cultura. (GOVERNO DO DISTRITO FEDERAL, SECRETARIA DE ESTADO DE HABITAÇÃO, REGULARIZAÇÃO E DESENVOLVIMENTO URBANO, GERÊNCIA DA UNIDADE DE PLANEJAMENTO TERRITORIAL NORTE, PROCESSO no 135.000.703/1995, 2012, s/p).

Chega-se à conclusão de que a suposta regularização não fora efetivada, quanto menos o cumprimento das diretrizes contidas na Lei ํo 58/37, sendo os moradores ludibriados quanto à suposta legalização de suas propriedades alocadas no sítio urbano de Planaltina. 
Verifica-se também que essas "terras de pastos", a partir de então, passam a ser comercializadas, dando origem, posteriormente, aos loteamentos clandestinos existentes no presente. Cogita-se que muitas dessas terras comercializadas por particulares pós-Brasília eram devolutas, logo, griladas.

Já em sentença proferida pelo TJDFT, no processo no 2006.01.1.090919-9, ao ser feita dúvida arguida por Paulo Luiz Quintela de Almeida, titular do $8^{\circ}$ Ofício de Registro de Imóveis do Distrito Federal, localizado na Região Administrativa de Planaltina, dispõe da informação da produção do que seria a primeira planta urbana da cidade, cuja aprovação por parte da prefeitura data do ano de 1941, correspondente ao atual Setor Tradicional de Planaltina. Porém, não existe o registro desta em cartório, logo, não tendo validade jurídica segundo os dispositivos contidos no Decreto-Lei de ${ }^{\circ}$ 58/1937.

Esta situação de precariedade jurídica, que vincula-se a invalidade documental dos supostos registros naquele momento, assim como da modalidade possessória dos imóveis mediante a detenção de simples Alvará de Concessão, além de perdurarem entre os anos de 1941 a 1961 na cidade de Planaltina tendo esta como pertencente a Prefeitura de Goiás, perpassará aos ciclos espaçotemporais sucessivos e posteriores a construção e inauguração de Brasília, tal qual será descrito nos capítulos seguintes.

Com a vinda eminente da nova capital e a efetivação das ações de desapropriação das terras do município para a construção da nova capital, inicia-se um segundo ciclo de especulação imobiliária da área urbana em um contexto préBrasília, que afeta as municipalidades limítrofes, assim como a cidade de Planaltina.

Conforme exposição no tópico anterior, Magalhães (2011) identifica no discurso proferido pelos periódicos locais, como o Jornal do Planalto, uma mudança radical quanto ao sentimento mudancista capitaneado por grande parte das oligarquias locais constituídas por fazendeiros pecuaristas.

Esta mudança de posicionamento advinda de boa parte das oligarquias locais, somados às animosidades geradas também nos proprietários de terras menos esclarecidos, associado ao fato da possível perda das terras de todos estes 
pelo processo de desapropriação eminente, tais fatos são interpretados enquanto antítese dialética relacionada ao processo de formação socioespacial de Planaltina.

Este choque dialético espaço-temporal situa-se entres os anos de 1955 até a inauguração de Brasília, uma vez que, de forma vigorosa, o processo de desapropriação das terras locais englobou este contexto.

Neste sentido, Magalhães (2011) relata que uma das reações contraditórias desferidas pelos anteriores mudancistas, agora potenciais expropriados, dar-se com o parcelamento e venda de terras, que inclusive, dificultariam ainda mais as ações de desapropriações já em andamento.

É nítido também outro elemento contraditório apontado por Magalhães (2011) inerente às ações promovidas pelo o antigo movimento mudancista, já que cria-se, por uma parcela destes, um discurso anti-Brasília e a reboque e de maneira explícita, é acompanhado de anúncios nos jornais de propriedade desta aristocracia, dos novos empreendimentos imobiliários proposto como alternativa a então nova capital. Magalhães (2011) relata os fatos quanto ao surgimento de uma "verdadeira indústria de loteamentos oficiais e particulares" que se espraiam no antigo sertão planaltino:

Como parte dessas lutas, nas edições do Jornal do Planalto que circularam a partir de 1955, o ano do início das desapropriações, observamos o retorno de proposições, como as do intendente Louly, de que seria possível erguer uma alternativa regional ao projeto de Brasília, já em andamento. Ideia que frutificaria na forma de uma nova cidade denominada de São Gabriel. É claro que o empreendimento imobiliário que fora planejado por um dos proprietários do JP, Gabriel Guimarães, correspondia ao tipo de especulação projetado em muitos outros empreendimentos (...) Portanto, há no loteamento de São Gabriel a presença de um lastro sendo, também, mais do que uma mera opção sertaneja ao projeto de Brasília, um êmulo regional da nova capital. $E$, de acordo com o que foi divulgado por meio de cuidadosa estratégia de marketing, chegou a postar-se contra Brasília: "Preferimos São Gabriel". (MAGALHÃES, 2011, p.117).

Magalhães (2011, p. 118) cita uma série de loteamentos que surgiu a partir do ano de 1955, sendo esta anunciada "em insistentes editais de publicação por oficiais de cartório em publicidades". Conforme explicita o autor, a "fúria especulativa chegou a atingir áreas mais distantes, como o Sítio D’Abadiânia, 
Cabeceiras e São João D'Aliança". Ainda é relatado o surgimento de bairros de grandes extensões como no caso de Formosa-GO:

O Jardim Califórnia, o Loteamento Santa Cruz, o Jardim Paquetá, o Santo Inácio, o Bairro Imperatriz, o Jardim Oliveira, e as Mansões da Lagoa Feia, são exemplos desse tipo de iniciativa. Desses, alguns se encontravam em situações de proximidade com as cidades, outros nem tanto; contudo, nenhum, era reconhecido pela Novacap. (MAGUALHÃES, 2011, p. 119).

Já no caso de Planaltina, o empreendimento oriundo do movimento especulativo promovido por particulares, ocorreu o surgimento do loteamento denominado Bairro Nossa Senhora de Fátima (fotografia 04 - atual), na porção ao Sul do atual Setor Tradicional, além de outros parcelamentos que segundo relatos de Castro (2014), não gerou muito adquirentes. Todavia, ainda verifica-se a existência casas em tal localidade.

Fotografia 04 - Atual Bairro Nossa Senhora de Fátima.

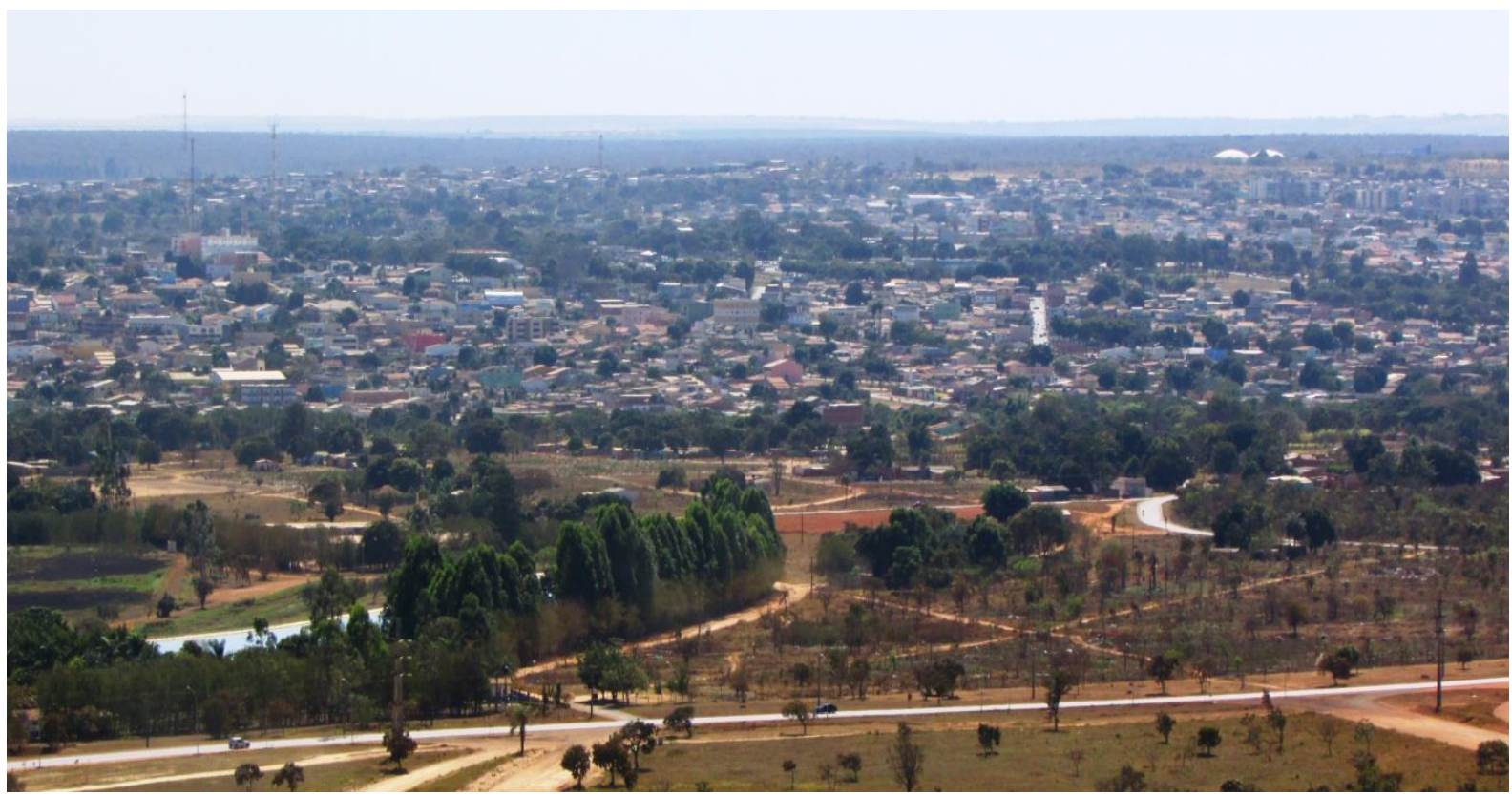

Fonte: Lima, 2014.

Castro (2014) expõe, sobre o Bairro Nossa Senhora de Fátima e demais parcelamentos particulares oriundos em tal contexto, que: 
- O Bairro de Fátima é de 54 (...) O bairro de Fátima era de uma empresa, Imobiliária Paula. Ela veio pra cá e pegou essa parte lá que não era habitada, adquiriu, registro, escritura, e tal... e lançou lá um loteamento. Perdão. Lançou um hotel, e em volta do hotel eles fizeram um loteamento. Na verdade era uma construção de um hotel, onde é hoje o CAGE.

(...) Teve uns loteamentos sim. Teve um loteamento de nome Santo Antônio, lá no Setor Sul, onde é hoje... no Setor Norte... no fim do Setor Norte onde é... antes... eu acho que no Parque Sucupira existia um loteamento de nome Santo Antônio. Vila Santo Antônio. Que depois sumiu. Do seu Dr. Antônio Ricardo Leite. Era o nome do dono desse loteamento.

- Então, houve sim os parcelamentos, mas alguns foram pra diante... nenhum foi pra diante... só o Bairro que ainda foi.

(...) o loteamento era particular mesmo, pra quem quiser comprar. Particular. Não tinha nenhum envolvimento com a... eles eram donos da terra. Tinham autorização, pagavam os impostos devidos, e começaram a vender lote pras pessoas que quisessem, independente de... e muitas pessoas que estão lá compraram da Imobiliária Paula. Seu Branditt... era o nome do homem. (CASTRO, 2014).

Já Magalhães (2011) descreve que a origem do bairro em questão está vinculado à prática especulativa, já que Planaltina encontrava-se dentro do quadrilátero demarcado para receber Brasília. Todavia, o autor não descarta também que este empreendimento fora uma retaliação ao processo de desapropriação das terras locais.

Sobre as motivações para a implementação de tal parcelamento, assim como da dimensão da gleba parcelada, vale dar voz a Magalhães (2011):

Os sinais denunciadores da consciência mudancista praticada localmente demonstram que a apreensão de valores ocorria de forma irreversível. Em janeiro de 1955, encontramos um edital de loteamento que aponta a atualização da questão fundiária na perspectiva de valorização das terras. Trata-se do lançamento de empreendimento que, até hoje, permanece em situação irregular, o Bairro de Nossa Senhora de Fátima, em Planaltina (JP, 01/01/1955). O anúncio e uma comunicação do Cartório de Registro de Imóveis da cidade que, por meio de seu oficial, Sr. Francisco Muniz Pignata, comunicava o parcelamento de uma área de 290 hectares, pertencente ao Sr. Iron Chaves e localizada ao sul da cidade de Planaltina. Da área total do loteamento, mais da metade fora destinado a lotes residenciais, sendo o restante preenchido por ruas, praças e logradouros de uso comum, conforme estabelecia a legislação dos parcelamentos urbanos. A escala fundiária permite pensar que, se a área urbana de Planaltina encontrava-se em um 
terreno de duzentos hectares, o novo loteamento poderia dobrar o tamanho da cidade e, nesse sentido, a sua população. A nota oficial foi apenas o primeiro de uma série empreendimentos imobiliários que vieram retalhando as terras próximas a futura capital. (...) Tanto em Planaltina quanto em Formosa, cultivava-se a consciência de que aquela seria uma oportunidade extraordinária para aumentar os rendimentos dos proprietários locais. Além disso, o loteamento representa também a mudança de postura local, que deixava de esperar pelas mudanças, passando a promovê-las. (MAGALHÃES, 2011, p. 117-118).

Contrapondo Magalhães e conforme fora exposto, Castro (2014) relata que as terras parceladas referentes ao Bairro Nossa Senhora de Fátima, ocorreram de forma legítima e seguiram todos os preceitos jurídicos perante a municipalidade, sendo estas escrituradas e registradas, portanto, não incorrendo de ilegalidade. Entretanto, também é válido lembrar que a planta urbana de 1941 que sofrera tais alterações, não tinha registro e memorial descritivo em cartório, já incorrendo de ilegalidade.

Todavia, ao confrontar os argumentos Castro (2014) e Magalhães (2011), tendo em vista a somatória dos eventos anteriores ao ano de 1955 e posteriores a este ano, fica notório que a problemática condizente a precariedade jurídica do solo urbano em Planaltina passa a ganhar robustez, tendo como fatores adicionais o inconcluso processo de desapropriação das terras que demarcando o primeiro ciclo de ilegalidade da produção do espaço urbano da referida cidade.

Numa perspectiva geral, tem-se o afloramento dos problemas jurídicos das terras ocultados em virtude da própria lógica da formação sócio-espacial do sertão planaltino, e que vem à tona com os trabalhos desenvolvidos pelas comissões de desapropriação das terras.

Conforme citado por Magalhães (2011), este estado de ilegalidade ainda persistia em quase a totalidade do núcleo urbano pré-Brasília, composto então pelo Setor Tradicional, Bairro Nossa Senhora de Fátima, Vila Vicentina em formação e terras adjacentes ao antigo núcleo urbano, que ao longo das décadas continuaram a ser comercializadas.

Ainda sobre a complexidade do problema jurídico advindo do parcelamento que origina o Bairro Nossa Senhora de Fátima e que impossibilita a 
sua desapropriação pela comissão goiana de 1955, bem como das intenções especulativas atreladas a este empreendimento, Juvenal Antunes Pereira delineia o seguinte relato:

(...) Aquela Comissão registrou, ainda, que o loteamento Nossa Senhora de Fátima, embora o mais recente aquela época, criava os maiores obstáculos à desapropriação face à irregularidade dos documentos, inclusive a imobiliária que efetuava as vendas dos lotes realizava obras apressadamente com o intuito de embaraçar a ação do Governo. A situação de hoje não é diferente. (DISTRITO FEDERAL, DECRETO № 21.948/2011, p. 06).

A prova de tal afirmação contida no relatório produzido por Juvenal Antunes Pereira, que pode ser observado na figura 08 , oferece um panorama a respeito da situação fundiária do Distrito Federal, elaborado pela Seduh, disponível em Oliveira (2008). 
Figura 08 - Mapa da situação fundiária do Distrito Federal

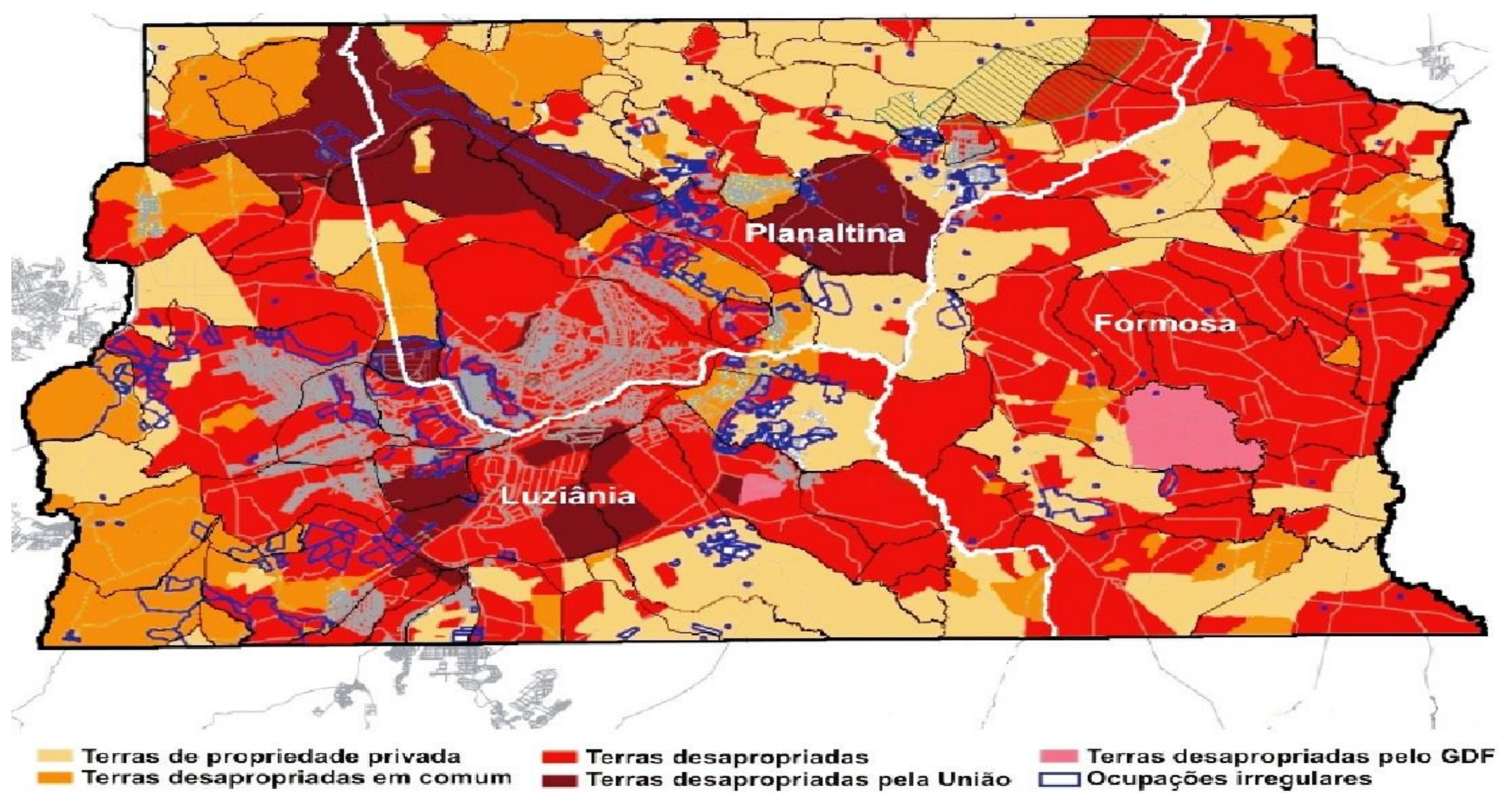

Fonte: SEDUH, 2007, apud Oliveira, 2008. 
Ao observar a localidade em que se situa o Bairro Nossa Senhora de Fátima, verifica-se que a referida gleba até o ano de 2007 ainda não havia sido desapropriada, abrindo brechas para o parcelamento das terras e negociações entre particulares, o que resulta na precariedade dominial do imóvel por parte do adquirente e na difícil tarefa de legalização da propriedade.

Segundo a GENOR (2012, s/p), as terras correspondentes ao Bairro Nossa Senhora de Fátima ainda não havia sido desapropriadas até o ano de 2012, podendo ser constatado, no respectivo documento, que no "Setor Tradicional, ainda existe uma parte da lagoa de oxidação de propriedade do Altisonante Assumpção, atualmente utilizada pela CAESB, que ainda não foi desapropriada".

Já em pesquisa realizada no site da $\operatorname{SEDHAB}^{22}$ em link que trata descrição das condições dos condomínios irregulares em Planaltina-DF, tem-se a afirmação de que, atualmente, tanto os 36 hectares que correspondem ao Bairro Nossa Senhora de Fátima, como os 106 hectares do Setor Habitacional Vale do Amanhecer, foram desapropriados, todavia, cabe aprofundamento quanto a tais afirmações, tendo em vista a possível distribuição das escrituras públicas dos lotes e a possibilidade da efetuação do registro em nome de seus habitantes.

A Ação Declaratória de Nulidade de Ato Administrativo que integra o processo n 1874/93 aduzido pelo Subprocurador-Geral do Distrito Federal, Ary Lopes Rodrigues, dispõe de mais elementos quanto à alienação de lotes que se remetem à questão do Setor Tradicional e áreas adjacentes parceladas pela prefeitura de Planaltina.

No referido documento é decalrado que entre os anos de 1956 a 1958, o então Prefeito de Planaltina de Goiás, Velusiano Antônio da Silva, preocupado com as recomendações feitas pela Novacap para que fosse escolhido outro sítio a receber a sede municipal e tendo em vista a necessidade de levantar recursos para a implementação de uma nova área urbana, "ultimou o loteamento e a venda de toda a área adjacente ao núcleo ocupado pela cidade" (TRIBUNAL DE JUSTIÇA DE DO DISTRITO FEDERAL E TERRITÓRIOS, Ação Declaratória de Nulidade de Ato Administrativo, 1994, p. 11).

\footnotetext{
${ }^{22}$ In: http://www.regularizar.df.gov.br/pages/condominios/planaltina/index.php; acessado em 07 de novembro de 2013.
} 
MAPA 04: Planaltina - 1958 - planta total.

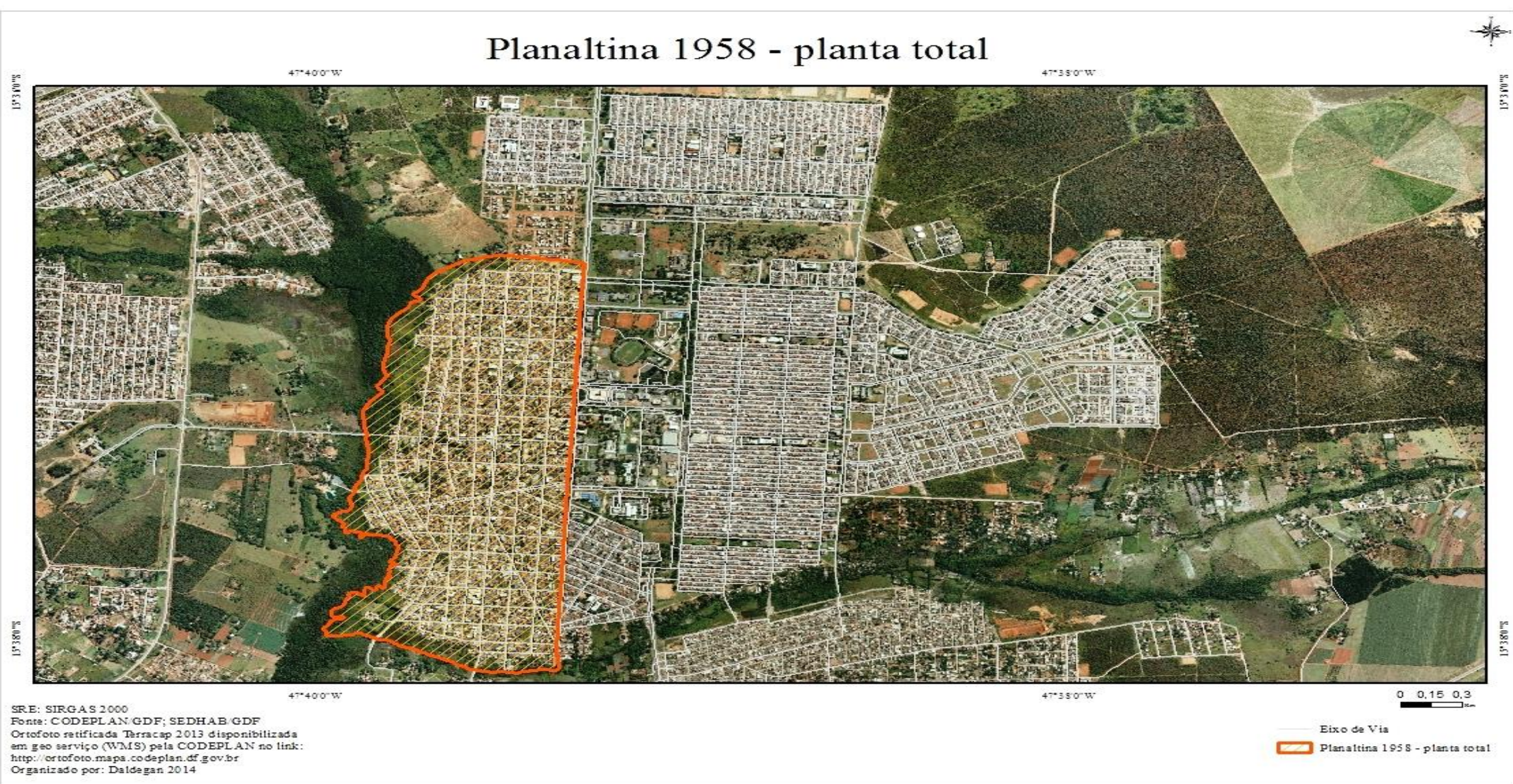

Fonte: Lima, 2014. 
Segundo a referida ação, "foram criados mais de 2400 lotes, que rodearam o núcleo tradicional e acompanharam o traçado viário já existente", conforme pode ser verificado na planta de 1958, exposta anteriormente no mapa 04. Todavia, vale salientar que segundo GENOR (2012, s/p), no ano de 1956, tendo em vista o processo de incorporação da cidade objeto ao quadrilátero do Distrito Federal, foi aprovado a Lei $n^{\circ} 83 / 56$ que regulamentava a "reversão de direitos sobre avenidas, ruas e logradouros entre a Novacap e a Municipalidade".

Observa-se nesta lógica especulativa que nem os particulares detentores de parcelas de terras nos 200 hectares contidas no interior da antiga Fazenda Mestre D’Ármas, nem a Prefeitura de Planaltina-GO, tampouco o cartório de registro local, não levaram em consideração a norma estabelecida, dando prosseguimento ao fracionamento da terra e o respectivo registro dos imóveis. Magalhães (2011) oferece a seguinte reflexão sobre o fato:

(...) Consideráveis poupanças particulares começaram a movimentar essa indústria de loteamentos. Na prática, o processo resultou no desmantelamento da situação fundiária existente. A legalidade que fora estabelecida através de convenções reconhecidas localmente e condicionadas pelo pequeno apelo populacional urbano estava com os dias contados, pois o radicalismo das mudanças apressava a pressão imobiliária sobre os terrenos, mudando toda a situação (...)

No meio das disputas de interesses, se fortalece a figura típica de muitos sertões, o grileiro, que vem inocular venenos corruptores nas novas gerações de políticos e administradores públicos. A consequência dessa situação é que, para o conjunto da população, restaria a acomodação de, mais uma vez, fugir para esse sertão modernos chamado ilegalidade. (MAGALHÃES, 2011, p. 119).

Analisa-se também que este decreto Lei $n^{\circ}$ 83/56, somado às interpretações posteriores sobre a concretização da desapropriação do núcleo urbano de forma indireta, tais quais os litígios anteriormente apresentados nas desapropriações rurais, resguardariam a dominialidade do sítio urbano da cidade de Planaltina (ver fotografia 05 a seguir) ao Distrito Federal.

Essa questão trará sérios problemas quanto ao pleno exercício do direito de propriedade no presente, por grande porção dos antigos e atuais moradores do Setor Tradicional, já que a situação de precariedade jurídica e de 
legalização das terras se arrastam desde o período pré-Brasília, até o território em uso nos dias modernos. O Poder Judiciário será partícipe desta questão.

Fotografia 05 - Planaltina (1958).

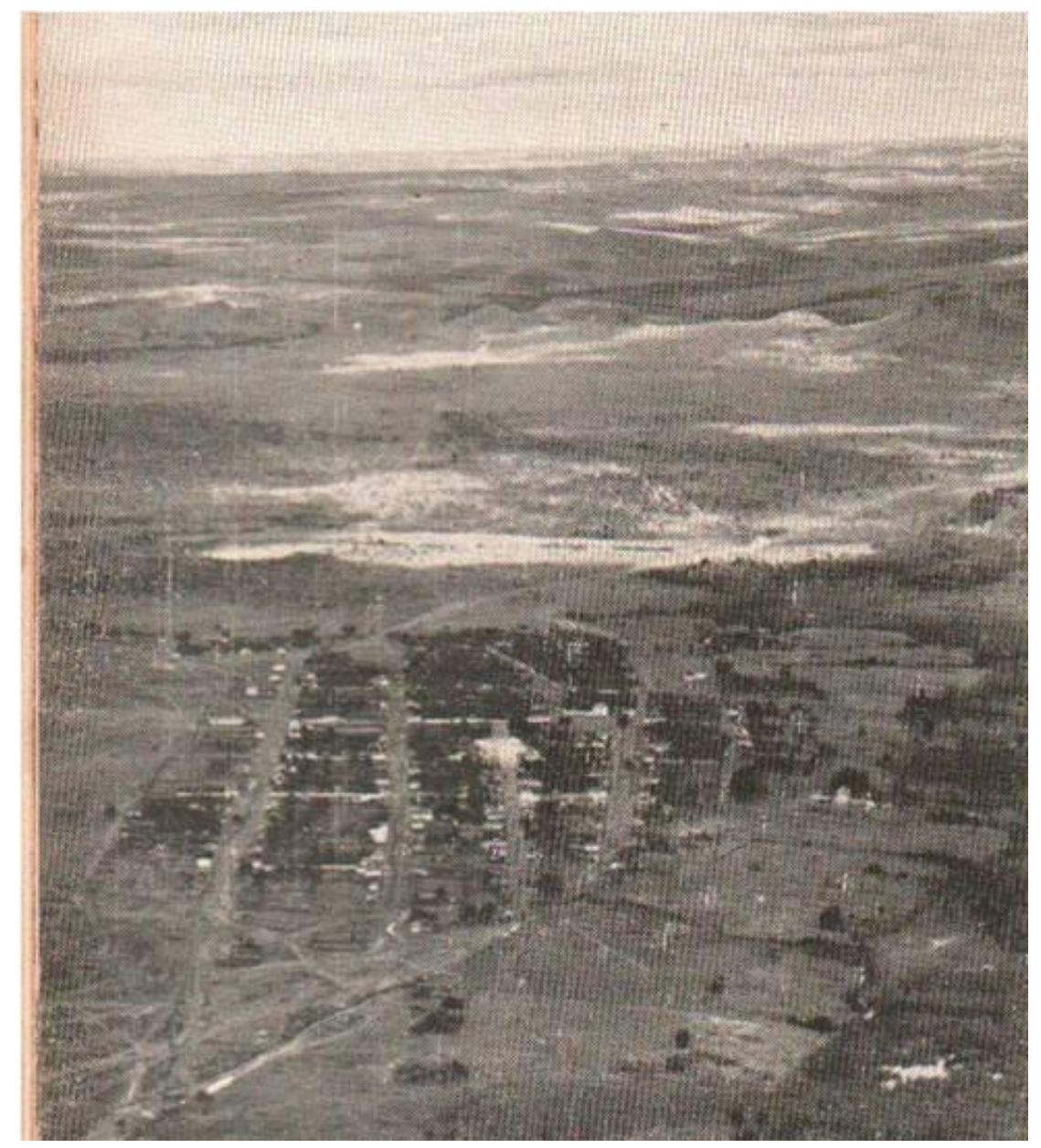

Fonte: Acervo público do IBGE (1958).

Ainda como fator agravante a essa precarização dominial da terra, segundo a GENOR (2012), as alienações executadas entre os anos de 1956 e 1958, por parte da prefeitura da cidade goiana, se dava mediante a expedição de Alvarás de Concessão, não sendo assegurando desta maneira a dominialidade dos lotes parcelados que ainda seriam pertencentes à prefeitura.

Outro agravante é apresentado no relatório da questão produzido pela GENOR (2012), que descreve que tais parcelamentos - empreendidos pela prefeitura e por particulares - entre 1956 e 1958, foram aprovados pela Portaria $n^{\circ}$ 17/58, pelo então Prefeito Veluziano Antônio da Silva. O resultado de tal 
normatização resguardou e incentivou o fracionamento da terra pelos habitantes locais, ampliando a precarização jurídica/documental dos imóveis e a efetiva dominialidade de seus supostos proprietários. Assim é explicitado em tal documento:

A criação de novos lotes propiciou aos proprietários das glebas adquiridas da Prefeitura, o aproveitamento destes em lotes. Estes passaram a usufruir como se fossem loteamentos seus.

A aprovação do loteamento (planta/58) teve o intuito de vender novos lotes como também, proporcionar o registro destes em Cartórios. A venda dos loteamentos continuou irregular, pois não obedeceu às normas do Decreto-Lei $n^{\circ} 58$, regulamentadas pelo Decreto 30/39. (GOVERNO DO DISTRITO FEDERAL, SECRETARIA DE ESTADO DE HABITAÇÃO, REGULARIZAÇÃO E DESENVOLVIMENTO URBANO, GERÉNCIA DA UNIDADE DE PLANEJAMENTO TERRITORIAL NORTE, PROCESSO № 135.000.703/1995, 2012, $\mathrm{s} / \mathrm{p})$.

Com base nos fatos descritos, vê-se que além da parte consolidada que hoje corresponde ao Setor Tradicional, até aquele momento, não disponha de uma planta devidamente registrada segundo a normatização estabelecida pela Lei no 58/37; a questão ainda ganha em amplitude com os novos parcelamentos promovidos pela Prefeitura e por particulares, já que não seguiam as normas estabelecidas que lhes garantiriam a legalidade face à situação registral de tais parcelamentos.

A GENOR (2012, s/p) assinala que da Portaria $n^{\circ} 17 / 58$ expedida pelo Executivo local e que aprovara os parcelamentos, dá origem a planta/58, interpretada, no presente estudo, enquanto sendo a segunda planta cadastral dos imóveis urbanos de Planaltina, cujo intuito associava-se ao incentivo a compra de novos lotes, assim como da efetivação do registro dos mesmos em cartório para gerar os recursos necessários à nova construção da sede municipal.

Entretanto, assim como na planta da cidade suscitada no ano de 1941, "a venda dos lotes continuou irregular, pois não obedeceu às normas do Decreto-Lei n 58/37" (GENOR, 2012, s/p), ou seja, a planta/58 não fora registrada em cartório, constando-se os mesmo equívocos cometidos na planta de 1941. Ratificando esta informação, faz-se salutar apresentar o trecho da sentença do processo 2006.01.1.090919-9, proferida pelo Juiz de Direito Substituto do TJDFT, João Batista Gonçalves da Silva: 
Principalmente a totalidade da área que hoje corresponde ao Setor Tradicional de Planaltina-DF foi de propriedade da INTENDÊNCIA MUNICIPAL DE PLANALTINA-GO, atual PREFEITURA DE PLANALTINA-GO, conforme Transcrição $n^{\circ} 303$ do Serviço Notarial e Registral de Planaltina-GO (registro anterior da matrícula do imóvel). Antes de 1960, época em que não existia do Distrito Federal, a mencionada Prefeitura, órgão então competente para tanto, aprovou o loteamento oficial da cidade, conforme Planta PR-4/1, que nunca foi levado a registro imobiliário, em desconformidade com o Decreto-Lei $n^{\circ}$ 58/37 (atualmente, o parcelamento para fins urbanos é regido pela Lei 6.766/79). Os imóveis constantes da Planta eram alienados por meio de Alvarás de Concessão que eram simplesmente registrados no $1^{\circ}$ Ofício de Planaltina-GO (antes de 1960) e alguns no $3^{\circ}$ Ofício de Registros de Imóveis do DF (entre 1967 e 2001). (TRIBUNAL DE JUSTIÇA DO DISTRITO FEDERAL E TERRITÓRIOS, PROCESSO № 2006.01.1.090919-9, 2007, p. 02).

Vale ressaltar que por mais que tais lotes concedidos por alvarás pudessem ser registrados em cartório, muitos contemplados pela política habitacional do município, em tal contexto, não chegaram a concretizar este ato administrativo, o que configura apenas em uma situação de posse não de domínio do imóvel, e acarretará, conforme será explicitado no quarto capítulo, em um elemento que colocará em risco o usufruto de tais imóveis por seus respectivos moradores.

Este fato que resulta no não usufruto pleno do direito de propriedade e precariedade jurídica dos imóveis contidos no Setor Tradicional no presente, correlacionado à dificuldade de obtenção dos registros dos imóveis atualmente, é exposto pela GENOR (2012) quanto da legalização dos lotes doados as famílias de baixa renda, contempladas pela política habitacional municipal desde o ano de 1939 até 1959.

Em decorrência dos Alvarás de Concessão não terem sido levados a registro cartorial, mesmo com a irregularidade inerente a planta da cidade, será interpretado mais a diante enquanto terrenos públicos pertencentes ao município de Planaltina de Goiás. Nestes termos é explicitado no documento a situação exposta:

A Câmara Municipal de Planaltina pela Lei $n^{\circ} 4$, autorizou o Poder Executivo a legalizar por doação, os lotes da atual planta da cidade, ocupados por pessoas pobres a mais de um ano, que tivessem construído sua moradia, seja de qualquer tipo ou preço. À doação constava a inalienabilidade pelo espaço de 10 anos a partir da data 
da escritura, e todas as despesas decorrentes à legalização dos lotes doados eram exclusivamente por conta do donatário.

Obs.: Foram poucas as doações que tiveram escrituras lavradas em cartório. Atribui-se a isso a pobreza dos donatários ou o interesse do próprio ocupante em vender seus lotes mediante pequeno montante. (GOVERNO DO DISTRITO FEDERAL, SECRETARIA DE ESTADO DE HABITAÇÃO, REGULARIZAÇÃO E DESENVOLVIMENTO URBANO, GERÉNCIA DA UNIDADE DE PLANEJAMENTO TERRITORIAL NORTE, PROCESSO № 135.000.703/1995, 2012, $\mathrm{s} / \mathrm{p})$.

A soma dos eventos descritos, que compreende entre os anos de 1934 a 1959, resultaram em posterior dificuldade de legalização dos referidos setores e de grande parte dos imóveis nele contidos.

No caso dos imóveis alienados por Alvarás de Concessão promovidos pela antiga prefeitura de Planaltina de Goiás e que não foram registrados em cartório, por diversos motivos - falta de recursos financeiros dos detentores, comercialização entre particulares apenas com uso do alvará ou mediante cessão de direitos, desconhecimento jurídico quanto da importância da efetiva legalização da propriedade, (conforme será aprofundado no último capítulo) levou os proprietários originários, ou posteriores adquirentes, a incorreram em sério risco quanto da perda dos imóveis para a atual Prefeitura de Planaltina de Goiás, já que uma vez não registradas, seriam consideradas como área pública pertencente à Planaltina-GO, segundo decisão judicial a ser exposta mais à frente.

Quantos as glebas parceladas por particulares entre 1939 e 1959 conforme a GENOR (2012, s/p), a exemplo do Bairro Nossa Senhora de Fátima, "dentro dos 200 hectares, localizadas entre a área consolidada do Setor e os Córregos Buritizinho, Atoleiro, e Ribeirão Mestre D'Ármas", conforme consta na planta/58, são considerados ilegais, já que o registro da referida planta não ocorreu, estando comprometido a legitimidade de tais parcelamentos, uma vez que as averbações a serem adicionadas na matrícula correspondente a Transcrição nํ 303, não poderiam ocorrer. É importante expor com detalhes a situação:

B) Situação fundiária das glebas que estão fora da área consolidado

- Estas glebas estão dentro dos 200 hectares e encontram-se localizadas entre a área consolidada do Setor e os Córregos Buritizinho, Atoleiro e Ribeirão Mestre D'Ármas. 
- Com o loteamento de 1958, estas glebas foram parceladas. Os lotes foram comercializados pelos proprietários das glebas e outros pela Prefeitura de Planaltina de Goiás, o que continua ocorrendo.

- A comercialização se deu, entretanto, antes da aprovação do registro da planta do loteamento, o qual, posteriormente não aconteceu, ficando assim o loteamento caracterizado como ilegal. (GOVERNO DO DISTRITO FEDERAL, SECRETARIA DE ESTADO DE HABITAÇÃO, REGULARIZAÇÃO E DESENVOLVIMENTO URBANO, GERÊNCIA DA UNIDADE DE PLANEJAMENTO TERRITORIAL NORTE, PROCESSO № 135.000.703/1995, 2012, $\mathrm{s} / \mathrm{p})$.

Verifica-se também conforme a GENOR (2012), que além da falta de registro da planta de tais parcelamentos antes expostos (1941 e 1958), estas também foram alienadas por Alvarás de Concessão, ampliando ainda mais o processo de precarização quanto ao exercício do direito de propriedade, desdobrando-se ainda no território em uso no presente, assim como na dinâmica de produção do espaço urbano pelos atuais agentes nele contido. Sobre a alienação das terras contiguas aos córregos do Atoleiro, Buritizinho e Ribeirão Mestre D’Ármas, tem-se a seguinte situação jurídica:

As referidas glebas foram vendidas e/ou cedidas pela Prefeitura Municipal, em 1939, com a destinação de pasto para animais. É necessário que seja verificada a propriedade destas, pois, a priori, a sessão de direitos não gera registros. Os adquirentes deverão ter um documento de doação da Prefeitura para efetuarem o registro. Nesta situação é possível que existam glebas que sejam de propriedade pública. (GOVERNO DO DISTRITO FEDERAL, SECRETARIA DE ESTADO DE HABITAÇÃO, REGULARIZAÇÃO E DESENVOLVIMENTO URBANO, GERÊNCIA DA UNIDADE DE PLANEJAMENTO TERRITORIAL NORTE, PROCESSO № 135.000.703/1995, 2012, s/p).

Essas glebas situadas fora da área consolidada e cedidas mediante alvarás de concessão, deram origem aos atuais loteamentos clandestinos, constituídos por bairros como Arapoangas, as Estâncias, assim como o Condomínio Mestre D'Ármas. Estes loteamentos clandestinos encontram-se em terras de particulares, ainda não desapropriadas pela União ou pela Terracap.

Várias destas terras pelo fato de supostamente enquadrarem-se como terras devolutas, tiveram através do expediente de grilagem a sua comercialização, 
sendo tal afirmação comprovada pela a ausência de registro das respectivas plantas urbanas em cartório.

Contudo, vale citar que o GDF não sabe ao certo a situação jurídica de várias glebas e lotes, resultando na pressão especulativa exercida sobre essas mesmas terras aos derredores do núcleo consolidado.

Quanto à legalidade da planta/58 e à situação de todos os adquirentes de boa-fé que ainda estão vivos ou herdeiros dos primeiros adquirentes dos imóveis ou que adquiriram posteriormente, é relatado pela GENOR (2012) a preocupação de que estes não sejam prejudicados na promoção de novos estudos que vislumbram efetivar a regularização do setor ainda em situação de ilegalidade jurídica, oriunda deste período.

Esta preocupação explicita ressalvas principalmente para com as propriedades que não foram registradas até a vigência da Lei nº 6.766 de 1979, o que impediria assim a efetiva regularização destes imóveis face a inexistência legal da planta citada. Assim, juridicamente, não existe planta registrada em cartório, não existe parcelamento, sendo então as terras pertencentes, a priori, à Prefeitura de Planaltina de Goiás.

O mecanismo de controle de novos parcelamento e alienações promovidas por particulares ou pelo poder público só se enquadra enquanto aspecto legal mediante registro cartorial, por mais que o ente promotor do parcelamento seja o Poder Executivo, como no caso de Planaltina.

Segundo a Lei № 6.015 de 1973, é o registro cartorial, mediante a unicidade da matrícula do bem imóvel, que possibilita o controle das sucessivas transações de compra e venda a serem averbadas, atestando e resguardando o domínio da propriedade por seu adquirente, além de dar fé pública pela publicidade do ato registral, assim como da possibilidade de verificar-se a condição de legalidade jurídica do lote ou residência mediante o princípio da continuidade. Para isso, o parcelamento promovido por particulares ou poder público deve efetuar o registro em cartório da planta urbana e do memorial descritivo do parcelamento ou desmembramento. 
A situação jurídica das terras do Setor Tradicional de Planaltina irá se agravar com o passar das décadas e, com isso, ampliando a precarização do exercício do direito de propriedade dos adquirentes dos lotes parcelados pela prefeitura da antiga cidade goiana e por particulares neste período.

Vale acentuar que mesmo com a falta de registro em cartório das plantas da cidade produzidas entre os anos de 1939 e 1941, entre os de 1956 e 1958 (planta/58), ferindo os princípios previstos na Lei oํ 58/37, terão os seus registros aceitos, inclusive no período pós-Brasília nos cartórios de $1^{\circ}$ e $3^{\circ}$ Ofício de Registro de Imóveis em Planaltina de Goiás, propiciando a possibilidade de desmembramentos dos imóveis contidos no Setor Tradicional pelos posteriores adquirentes dos lotes em determinadas quadras residenciais.

Observar-se-á que após o ano de 2006, a tentativa de desmembramento e registro de alguns imóveis contidos no referido setor serão obstados pelo Judiciário local. Ainda conforme será trabalhado no próximo capítulo, até o ano de 1979, anterior à vigência da lei № 6.766/79, a Administração Regional de Planaltina-DF facilitará o processo de desmembramento e registro dos imóveis. Após a vigência desta lei, tal fato será impedido legalmente, não podendo seguir os tramites legais (GENOR, 2012, s/p).

O Cartório já citado, até momento presente, também é constantemente procurado para que demonstre toda a cadeia dominial das glebas parceladas ao que corresponde a antiga fazenda Mestre D'Ármas, em seu contexto pré-Brasília, sendo que o estabelecimento desta cadeia dominial é condição imprescindível para a escrituração e registro dos imóveis ao ser verificado a raiz dominial dos lotes (princípio da continuidade), garantindo a efetivação do ato administrativo.

Entretanto, segundo entrevista realizada com o Tabelião Breno de Andrade Dohler, do $12^{\circ}$ Cartório de Ofício de Planaltina, no dia 28 de novembro de 2013, afirma que, com a vigência da Lei ํㅡ 6.015/73 que regulamentara os recentes procedimentos de efetivação dos registros imobiliários e com o surgimento de novos registros resultantes de novas relações de compra e venda entre particulares, somados aos atuais cartórios que passam a receber estes registros dentro do Distrito Federal, o levantamento da situação legal das propriedades contidas no Setor Tradicional e das terras contíguas torna-se praticamente um exercício 
hercúleo, tendo em vista que, para tal auditoria da cadeia dominial, existem imóveis que necessariamente tem uma parcela de seu histórico de compra e venda guardado em vários Cartórios de Registro de imóveis - $1^{\circ}$ Ofício de Registro de Planaltina de Goiás, $1^{\circ}$ Ofício de Registro de Imóveis de Brasília, do $3^{\circ}$ Ofício de Registros em Taguatinga e do $8^{\circ}$ Ofício de Registros de Imóveis em Planaltina-DF.

Seguindo este raciocínio, supostamente, para se estabelecer apenas a cadeia dominial de um único imóvel contido no núcleo do Setor Tradicional, todos esses cartórios teriam de ser consultados, sendo cobrado emolumentos para a divulgação de tais dados, além da necessidade de confrontação dos dados obtidos em cartório com a documentação dos residentes dos lotes. Essa complexidade se amplia quando se busca saber a situação jurídica de mais 10.000 lotes que correspondem a tal setor.

Voltando ao exercício de periodização também é importante frisar que as terras não desapropriadas, serão comercializadas já em um contexto pós-Brasília e mesmo em alguns casos não sendo reconhecido pela Administração Regional de Planaltina, conseguirão obter registro em cartório efetivados junto ao Cartório de Planaltina de Goiás, aonde fora gerada a Transcrição no 303 entre os anos de 1927 e 1929 e até mesmo nos cartórios contidos no Distrito Federal.

Assim, é esboçado o primeiro momento qual denominamos de contexto pré-Brasília. A cidade de Planaltina, em tese, foi gerada segundo as tradições oriundas do modo de produção colonial, que pautadas na religiosidade e nas explicações metafísicas dos fenômenos, que transcende as relações humanas, resulta no surgimento de seu sítio urbano em Terra de Santo São Sebastião.

A lógica de produção deste espaço urbano e os seus derredores antigas Sesmarias - não obedecia normas vigentes, tendo na relação estabelecida pela palavra e nos contratos de compra e venda entre particulares a base formal necessária ao pleno exercício do direito de propriedade, segundo os costumes locais incorporados em um contexto pré-máquina e eventos normativos que se seguem.

A materialização de Brasília é interpretada enquanto antítese ao movimento de formação sócio-espacial do sertão planaltino, cuja vigência dos novos tempos impostos pela burocracia Estatal expõe as dinâmicas pretéritas e os usos 
dados consonantes à produção do espaço local, sendo tais práticas anteriores atinentes ao uso do território entendidas por esta burocracia como um anacronismo face a vigência das normas determinadas por este mesmo Estado, e que no caso, regulavam a condição jurídica do pleno exercício do direito à propriedade e domínio do bem imóvel.

A síntese deste processo de formação socioespacial se dará no contexto pós-Brasília, ao qual o próximo capítulo explicitará este espaço em movimento, em totalização, tendo por finalidade a cognição da ampliação da condição da precariedade jurídica e dominial da propriedade urbana do núcleo tradicional.

Também será exposto o surgimento de novos setores da cidade em investigada, assim como da complexificação da produção do espaço urbano, sendo interpretado em um contexto pós-Brasília dois ciclos distintos de expansão da cidade: onde o primeiro momento abrange o período de 1960 e 1985, já o segundo abarcando o período de 1985 até o presente momento.

Será retratado no próximo capítulo este primeiro ciclo de produção do espaço urbano de Planaltina em um contexto pós-Brasília e os impactos gerados pelo embate dialético entre o novo e o velho em seus diversos segmentos estruturais ao qual constituem a complexidade do território usado.

Através da periodização dos eventos vinculados à cognição do processo de formação socioespacial da cidade de Planaltina, os segmentos estruturais acima mencionados associam-se a nova função delegada à cidade com a vigência de Brasília, gerando a perda da autonomia político-administrativa da cidade, assim como a imposição das novas normas que condizem ao planejamento urbano impactando na forma e no uso dado pela estrutura social para com o espaço urbano.

Será associado a essas transformações impostas pelo novo em detrimento ao velho a busca pelo controle da terra por parte do Estado, cuja finalidade vincula-se ao combate ao crescimento urbano espontâneo e na garantia da manutenção da monumentalidade urbanística e arquitetônica da nova capital do país. Neste sentido, Planaltina passa a abrigar os segregados provenientes das 
invasões de Brasília, segregados estes que possibilitaram a materialização da cidade modernista enfatizada por Holston (1993). 


\section{Capítulo 3 - Planaltina-DF: da autonomia à periferia precarizada em processo de expansão (1961- 1980).}

Dentro da proposta de entendimento do território usado do presente, que é caracterizado enquanto acúmulo das técnicas e das ações múltiplas ao longo do tempo e que repercutem na produção do espaço e de suas singularidades junto ao todo, busca-se na operacionalização propiciada pela categoria de formação socioespacial a cognição dos processos que desdobram na atual dinâmica de uso do território.

Em tal perspectiva, o objeto de estudo em questão que operacionaliza tais categorias é a cidade de Planaltina. Nesse viés, dentro do exercício de compreensão do seu processo de formação socioespacial, objetiva-se depreender os fatores que resultam na judicialização de seu território, assim como os impactos desta atuação do Poder Judiciário - em suas diversas instâncias - para com os agentes deste mesmo território usado, responsáveis pela cristalização das formas resultantes de tais ações/decisões judiciais.

É de suma importância salientar que a instância judicial não é o único Poder (estrutura) responsável por essa dinâmica de produção espacial e que resulta na judicialização do território, não sendo negligenciado a presença das demais estruturas que integram o Poder Público, em somatória com as outras variáveis e agentes presentes no território usado.

Logo, no presente segmento do exercício de compreensão da formação socioespacial de Planaltina-DF, será contemplado espaço-temporalmente as dinâmicas sociais de produção espacial que correspondem ao período do início da década de 1960 ao princípio da década 1980 (segundo ciclo de expansão de Planaltina).

Todavia, é válido a realização de uma breve releitura de tal exercício de cognição que entremeia a construção da materialidade e dos usos dados por sua respectiva formação social ao longo do tempo e que repercutem na lógica do movimento do espaço urbano em apreciação. 
Nesta lógica de produção que desdobra no movimento do espaço em questão em seu contexto pré-Brasília, pôde-se identificar, dentro deste movimento, as condições de materialização dos sistemas de objetos espaciais atualmente existentes, assim como os marcos, os eventos que auxiliam no entendimento da atual precariedade jurídica dos imóveis contidos na área urbana de Planaltina e que repercutem na condição atual do pleno exercício do direito de propriedade.

Num primeiro momento, tem-se a ocupação embrionária das terras que remontam ao contexto Colonial, que se iniciam na região a partir de 1740, mas que ganham impulso local com a baixa produtividade das minas de ouro oriundas do bandeirismo.

É nesse contexto colonial que, em 1811, surge o Largo de São Sebastião e o Arraial de São Sebastião de Mestre D’Ármas. Assim como no processo de composição da estrutura fundiária, Castro (2014) descreve que os lotes, na gênese, do atual Setor Tradicional eram tomados, tirados, apossados por aqueles que ali se fixaram, não havendo uma intervenção dos agentes do Estado quanto ao controle, uso e ocupação de tais terras.

Até o ano de 1892, o Distrito de São Sebastião de Mestre D'Ármas passou por disputas políticas que envolviam Luziânia e Formosa, conseguindo a emancipação político-administrativa no ano mencionado. Vale ressaltar que as dinâmicas de produção espacial, quanto ao uso e ocupação do solo, ainda seguiam as lógicas do período Colonial.

Já entre as décadas de 1920 e 1930, em resposta aos investimentos privados no agora município e com a implantação da Pedra Fundamental no ano de 1922, verificou-se um primeiro surto especulativo associado à possível transferência da capital. Já entre os anos de 1954 e 1958, registra-se um segundo momento de forte especulação das terras locais vinculado à efetiva construção de Brasília.

Ficou explicitada durante todo este contexto a gênese dos elementos que se desdobram na complexa situação fundiária da cidade em apenas um de seus bairros: o Setor Tradicional.

Também salientou-se que as terras ao redor do núcleo urbano, muito embora vigorassem mecanismos legais que determinassem o processo de 
regularização documental, como o regime de Sesmarias que perdurara até 1822, a Lei n ${ }^{\circ} 601$ de 1850, e as imposições normativas oriundas da Constituição de 1891 e do Código Civil de 1916, verificou-se uma predominância quanto a precariedade jurídica das terras associada ao mecanismo de posse.

Tais práticas vinculam-se ao fator cultural face às relações de compra e venda ou apossamento das terras; as dificuldades para com o cumprimento das legislações vigentes no âmbito do registro da terra por parte dos adquirentes ou posseiros, como no caso da vigência do regime de Sesmarias; assim como a atuação ineficaz do Poder Executivo local anterior à construção da nova capital no que tange a efetiva execução das medidas jurídicas que garantiriam a situação de legalidade de grande parcela dos lotes presentes no Setor Tradicional e das terras ao redor.

Ainda no caso referente às propriedades rurais, mostrou-se o choque dialético entre os mecanismos da nova burocracia que se instalava com a transferência da nova capital para o planalto central e as práticas sócioespaciais atinentes ao processo de produção do subespaço planaltino.

Nesse processo citado, interpretou-se juridicamente, sem levar em conta as práticas sociais locais, a questão da legitimidade da posse da terra através da apresentação dos registros paroquiais, sendo este documento usualmente apresentado nos atos de desapropriação de terras com a implantação de Brasília. Vale lembrar que existiam propriedades que nem mesmo deste documento dispunham, remontando as lógicas do Direito Justiniano adotados pelo Direito Português e sobrepostos ao território colonial com a vigência da Lei de Sesmarias de 1375.

Em relação ao Setor Tradicional, antiga sede do Município de Planaltina, fora explicitado o fato do registro cartorial das plantas da cidade (1941 e 1958), não terem sido efetivadas, sendo estas de importante valor jurídico, já que tal trâmite legal daria validade ao parcelamento do solo promovido pelo poder público ou por particulares, e que em tal contexto pré-Brasília correspondia às normas presentes na Lei n] 58/37. Cabe explicitar a atual divisão política existente entre Planaltina-GO e o Distrito Federal (figura 09), tendo em vista a situação de ambos na RIDE. 
Figura 09 - RIDE: Atual divisão política do Distrito Federal e Planaltina de Goiás.

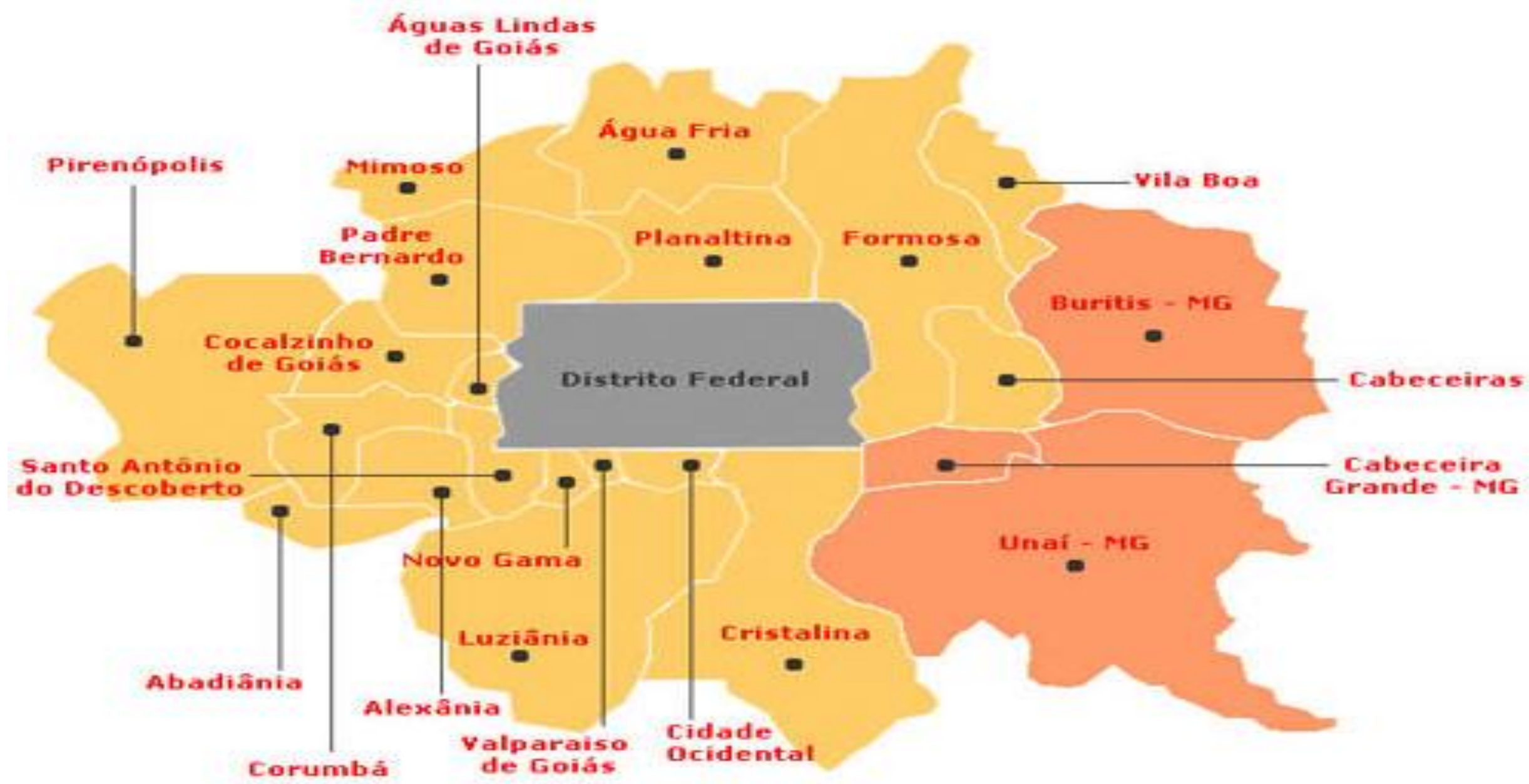

Fonte: http://www.valparaisoweb.com.br/estudo-viavel-criacao-municipios-entorno-df/. Acessado em 17 de novembro de 2014 
Neste sentido, a não efetivação do registro cartorial da planta urbana traz em seu bojo a precarização do uso e ocupação do solo, podendo impactar no pleno exercício do direito de propriedade, uma vez que, já em tal legislação - Lei no 58/37 - é explicitado que este documento dá publicidade ao ato de compra e venda dos imóveis a serem adquiridos ou doados, seja por entidade pública ou privada.

Neste ato de publicidade, tem-se a presunção da veracidade, da legitimidade de que a terra ou o imóvel, ou no caso em questão, a planta, contemple todos os requisitos jurídicos que caracterizam o estado de legalidade do bem comercializado ou doado.

É no registro da planta, acompanhado do memorial descrito da propriedade, segundo a Lei ํㅡ 58/37 em seu artigo primeiro, que se consta e dar-se a publicidade a situação jurídica das terras parceladas, como a denominação das mesmas, a área do parcelamento, os seus limites, sua situação geográfica, a comprobação da dominialidade da terra pelo ente promotor do parcelamento, sendo exigido para tal a cronologia dos títulos de domínio da terra, contendo o número e data das transcrições - compra, venda, permuta das negociações supostamente já realizadas - comprovando a posse legal do título da terra.

Para fins de registro, ainda era exigido à realização de avaliação técnica das condições propícias de ocupação da localidade, medição do loteamento com o uso de todos os requisitos técnicos e legais - na época um deles era o teodolito -, contendo suas dimensões e a numeração dos lotes, as dimensões e a nomenclatura das vias de comunicação e espaços livres, construções e equipamentos públicos a serem implementados em somatória as vias públicas de comunicação a serem realizadas no parcelamento.

Além da não efetivação do registro em cartório das plantas da cidade, observa-se também o fato de que os lotes eram negociados ou doados pela Prefeitura Municipal mediante expedição de Alvarás de Concessão, não produzindo efeito jurídico de propriedade por parte do comprador ou beneficiário, e neste sentido, as terras ou lotes ainda seriam de propriedade do município em questão.

Além destas situações descritas, tem-se os eventos que pontuam o processo de efetiva transferência da capital e que jurídico-judicialmente irão 
provocar profundos impactos na produção do espaço urbano da cidade de Planaltina.

Sabendo da incorporação da cidade ao território do Distrito Federal com a inauguração de Brasília, como já fora exposto, tem-se no ano de 1956 a promulgação da Lei $\mathrm{n}^{\circ}$ 83/56 que "regulamentou a reversão dos direitos sobre avenidas, ruas e logradouros públicos entre a Novacap e Municipalidade" (GENOR, $2012, \mathrm{~s} / \mathrm{n})$.

Pressupõe-se assim que os espaços públicos como as ruas, avenidas, praças, quadras esportivas, passariam a pertencer, a serem incorporadas ao patrimônio da instituída Novacap. Entretanto, verificar-se-á que, por decisão judicial, esta normativa cairá por terra, onde tal fato será discutido com maior profundidade no próximo capítulo.

Com a mudança da capital para o Planalto Central, usufruindo das terras já ocupadas secularmente, iniciou-se o processo de desapropriação das propriedades pertencentes aos seus respectivos possuidores. E no caso da cidade de Planaltina? Tendo em vista a Lei $n^{\circ}$ 83/56, a Prefeitura deveria também ser indenizada, uma vez que sua sede municipal estaria sendo incorporada ao território do Distrito Federal?

Estes fatos citados perfazem o exercício de entendimento das dinâmicas de produção local em questão e de suas singularidades perante o todo, muito embora identificou-se que o todo também repercute na construção do objeto em questão, via ações/normas externas ao lugar.

Essa ações/normas externas ao lugar/subespaço, oriundas de uma totalidade maior ao qual o subespaço pertence, podem ser interpretadas através da evolução do sistema jurídico, entendido enquanto técnica que regulam as relações possessórias ou dominiais da terra.

Seja no Período Colonial com a vigência da Lei de Sesmarias, seja no Brasil Império com a Lei de Terras de 1850, ou com as imposições normativas oriundas da Constituição de 1891 e do Código Civil de 1916, ou a promulgação da Lei 58/37 na Era Vargas que regia as questões condizentes ao parcelamento e uso 
do solo, ou também com a vigência da Lei no 2.874 que institui a Novacap e que delineia o processo de construção da nova capital.

Esta última Lei, determina que a compra e venda de terras contidas no quadrilátero, seria condicionada às suas ações/determinações advindas da Novacap, possuindo, deste modo, tal empresa pública o monopólio da terra. Neste sentido, interpretado tal normativa enquanto um dogma, que gerou grandes complicações referente à estrutura fundiária do recente Distrito Federal, tendo em vista que este preceito dogmático não fora concluído, criando-se um caleidoscópio juridicamente complexo face as terras contidas no quadrilátero.

Neste sentido, a proposição dos conceitos "território usado" e "formação socioespacial" à luz da judicialização do território, dá-se pela necessidade do resgate dos eventos que remetem ao entendimento da composição da dinâmica territorial regida pelo todo, e também, da produção do lugar - subespaço - trazendo ao plano do presente em sua complexidade.

Nessa lógica, o conceito de formação socioespacial é tido como leitura da assimilação da extensão histórica da sucessão dos eventos que respondem na produção do Estado-Nação, por uma respectiva sociedade em um movimento constante de totalização, que também se desdobra no plano do local/subespaço.

Tal possibilidade de desdobramento para o subespaço é ponto fundamental para a apreensão do todo, uma vez que Santos (2002, p. 118) considera que "o conhecimento da totalidade pressupõe" também "a sua divisão", a sua cisão:

\footnotetext{
A primeira noção a levar em conta é a de que o conhecimento pressupõe análise e a segunda noção essencial é a de que análise pressupõe a divisão. Daí o interesse de compreender o processo pelo qual a totalidade é cindida. Em seu tratado Elementorum Philosophia, quando se refere ao Estado (2. a e 3. a partes: "Teoria do Homem e do Cidadão), Thomas Hobbes diz que "tal como num relógio ou outro mecanismo algo complexo, é impossível saber com exatidão qual é a função de cada uma das peças e pequenas engrenagens, salvo desmontando o todo e estudando, um por um, a matéria, a forma, e o movimento dos elementos [...]". Karel Kosik (1967, p. 30) considera a decomposição do todo como 'o traço mais característico do conhecimento. (SANTOS 2002, p. 118).
} 
Já o movimento constante de totalização é tido como o contínuo processo do movimento da totalidade, sendo a mesma caracterizada como totalidade estruturada, que ao mesmo tempo é perfeita - acabada - e em movimento. A totalização é flecha do tempo, segundo exposto por Santos (2002) ao resgatar Sartre e Urs Jaeggi sobre a discussão concernente a totalidade e totalização:

\begin{abstract}
"Uma forma de afrontar o problema é retomar de Sartre a distinção entre totalidade e totalização, a primeira sendo o resultado e a segunda o processo, Na interpretação Urs Jaeggi (1969, p. 62) a totalização compreenderia o passado, o presente, o futuro. Ou, em outras palavras, a flecha do tempo somente se dá por intermédio de totalizações (...) A Totalidade está sempre em movimento, num incessante processo de totalização, nos diz Sartre. Assim toda totalidade é incompleta, porque está sempre buscando totalizar-se (...)". (SANTOS 2002, p. 118-119).
\end{abstract}

Essa flecha - movimento totalizante - culmina no atual momento, enquanto possibilidade do devir e condição dos processos do presente no que condiz ao uso do território por seus diversos atores e na estruturação de seus objetos - naturais e técnicos - em diversas possibilidades de coexistência e interconexão dos múltiplos elementos e variáveis que se dão no agora enquanto momento.

Esse agora enquanto momento é resultante do desdobramento do movimento do tempo histórico por intermédio dos eventos que se cristalizam no espaço evidenciando a sucessão dos períodos mediante a aplicação das ações sobre o espaço, carregadas de intencionalidade, cuja sua materialização na composição dos objetos espaciais revelam as relações de produção, assim como os diversos usos que as respectivas sociedades tiveram com tais objetos técnicos, bem como na implementação de novas técnicas refletindo a produção de novas totalidades.

Utilizando-se de tal raciocínio, é possível a efetivação de uma periodização dos eventos sobre o território em resposta a materialização dos objetos espaciais nele contidos, bem como uma análise da relação dialética existente entre as sociedades e os objetos fruto das técnicas, associado a uma leitura dos 
processos históricos que auxiliam na cognição da produção do lugar/subespaço. Santos (2002) assim declara sobre essa abordagem:

(...) O evento se inscreve na totalidade característica de um determinado momento, mas o faz como uma parte do todo. (...) Seu destino é realizar o todo na particularidade, viver plenamente e ativamente essa particularidade e assim contribuir à permanência do todo, deixando-o renascer com novas características.

(...) Mas a totalidade em movimento também inclui as ações tornadas possíveis em um lugar particular, a partir do qual acabam por influenciar outros lugares. $E$ as ações não são indiferentes à realidade do espaço, pois a própria localização dos eventos é condicionada pela estrutura do lugar. (...) Assim como as ações não tem existência independentemente dos objetos a que dão vida, também os eventos não ganham realidade fora dessa associação com os objetos. (SANTOS, 2002, p. 160-161).

Tal proposição é utilizada para situar a Região Administrativa de Planaltina-DF enquanto uma fração do todo complexo em movimento, como subsistema que compõe o sistema regional e nacional. Entretanto, a priori, a visão sistêmica relacionada ao conceito de formação socioespacial que conduz às dinâmicas do presente uso do território, vincula-se apenas ao estudo direcionado a escala do Estado-Nação, assim como é asseverado por Santos (2005):

"Um país, um espaço nacional, pode ser estudado como um sistema.
Não se trata, entretanto, de um sistema de elementos, como na
teoria clássica dos sistemas, mas de um sistema de estruturas ao
estilo de Gadelier (...) Um Estado-Nação é uma Formação
Socioeconômica. Um Estado-Nação é uma totalidade. Assim unidade
geográfica ou espacial de estudo é o Estado-Nação. A "região" não
é mais do que uma subunidade, um subsistema do sistema nacional.
A "região" não tem existência autônoma, ela não é mais do que uma
abstração se tomada separadamente do espaço nacional
considerado como um todo." (SANTOS, 2005, p. 43).

Conforme fora exposto, e em um primeiro olhar despretensioso, o conceito de formação socioespacial não se aplicaria ao estudo da escala do subespaço/lugar enquanto subsistema.

Todavia, a condição imperativa para o estudo do local - subespaço vincula-se ao atrelamento de uma visão simultânea dos processos históricos entre a grandeza exposta junto à totalidade em sua dimensão de Estado-Nação, pois o 
subsistema subespaço/lugar é regido por uma totalidade maior na qual está contida, por mais que tenha como resultado a materialização de espaços singulares.

Em tal perspectiva, o conceito de formação socioespacial utiliza-se da categoria totalidade enquanto fonte filosófica que tem por objetivo "o conhecimento e análise da realidade", do movimento do território enquanto "presente no Universo", contido no espaço geográfico, constituindo assim "uma unidade" (Santos, 2002, p. 115).

Mediante a esse ponto de vista, o Estado-Nação existe e coexiste de maneira simultânea com o todo em movimento - totalidade mundo - e nele está contido um caleidoscópio composto por totalidades, sendo essas partes, segundo Santos (2002), explicadas pela própria totalidade. Nesta perspectiva o autor afirma:

"Cada coisa nada mais é que parte da unidade, do todo, mas a totalidade não é uma simples soma das partes. As partes que forma a Totalidade não bastam para explica-la. Ao contrário, é a Totalidade que explica as partes. A Totalidade $B$, ou seja, o resultado do movimento de transformações da Totalidade $A$, divide-se novamente em partes. As partes correspondentes à Totalidade $B$ já não são as mesmas partes correspondentes à Totalidade A. São diferentes. As partes de $A\left(a^{1}, a^{2}, a^{3} \ldots\right.$ an) deixam de existir na Totalidade $B\left(b^{1}, b^{2}\right.$, $\left.b^{3} \ldots b^{\eta}\right)$. E não são as partes $a^{1}, a^{2}, a^{3} \ldots$ que se transformam em $b^{1}$, $b^{2}, b^{3}$..., mas a Totalidade A que se transforma em totalidade B." (SANTOS, 2002, p. 115-116).

Nesse viés, a categoria totalidade percebidaa por meio de suas cisões, somadas ao exercício de periodização do território nacional em sua formação econômico-social, proporciona chegar à escala do lugar que sofre as interferências do plano externo, sendo as suas bases lógicas estabelecidas pela escala da nação, onde esta última, também sofre com as ações externas.

O lugar, enquanto subespaço, é caracterizado por ser uma fração do todo produzido pela seletividade do modo de produção capitalista em conjunto com a natureza específica e ao trabalho específicos aí empregados, enquanto recursos que se combinam, mediante a sucessão dos períodos, que se desdobram na produção de localizações contidas no território. Santos (2005) assim expressa tal raciocínio:

"Os recursos totais de um Estado-Nação, são na verdade, indivisíveis, seja o capital, a população, seja à força de trabalho, a 
mais-valia etc. Em cada período histórico esses recursos combinamse e distribuem-se de maneira diferenciada. (....) As condições se fazem em lugares historicamente determinados, de forma que a combinação dos recursos (homens, capital, infraestruturas, instituições, ecologia) se transformam em sinônimo de localização. Pode-se falar, então, de uma diferenciação espacial e de uma distinção específica para cada lugar (...)". (SANTOS 2005, p. 43-44).

É por meio da totalidade, via necessidade de aprofundamento do conhecimento verdadeiro do todo - que se dá por intermédio do desvendar de suas frações - é que se chega ao entendimento do real: à escala do lugar.

O lugar/subespaço dentro do contexto do trabalho envolto por uma totalidade, constitui-se enquanto espaço singular, fruto da confluência de múltiplas ações - essas enquanto vetores - que se materializam em nova totalidade e em totalização.

Esse processo de totalização não é autônomo, pois o lugar subespaço/subsistema - está diretamente vinculado a uma totalidade maior território nacional - que por sua vez, vincula-se a totalidade mundo. Tal reflexão é corroborada pela seguinte afirmação:

O conhecimento da totalidade pressupõe, assim, sua divisão. O real é o processo de cissiparidade, subdivisão, esfacelamento. Essa é a história do mundo, do país, de uma cidade... Pensar a totalidade, sem pensar a sua cisão é como se esvaziássemos de movimento. (SANTOS, 2002, p.118).

O lugar/subespaço, nesse aspecto, ganha relevo, pois é no plano do lugar/subespaço que é possível enxergar a concretude do movimento contínuo dessa totalidade; é no plano do lugar que se tem a vida em sua permanente vivência.

É no lugar/subespaço aonde se estabelecem as relações afetivas com a paisagem, com as pessoas, com o mundo mediante a condição de vê-lo, percebêlo, e vivenciá-lo. O mundo converge no lugar, e simultaneamente, o lugar é o mundo em sua particularidade. Essa questão é abordada por Santos (2002) da seguinte maneira: 
Cada lugar é, a sua maneira, o mundo. (...) Mas, também, cada lugar irrecusavelmente imerso numa comunhão com o mundo, torna-se exponencialmente diferente dos demais. (...) Para apreender essa nova realidade do lugar, não basta adotar um tratamento localista, já que o mundo se encontra em toda parte. (SANTOS, 2002, p. 314).

A Região Administrativa de Planaltina, nesse contexto, vem a ser o lugar/subespaço em que se busca compreender sua dinâmica evolutiva por mediação da análise dos processos históricos, dos eventos, que repercutem na composição de seus objetos geográficos, somados ao trabalho ao longo do tempo, desdobram-se na materialização das respectivas formas-conteúdo contidas sobre esse espaço em particular.

Para tal, a ação constitui-se em um dos elementos característicos da sociedade e nesse aspecto, objetiva-se também compreender, de maneira específica, a repercussão e amplitude do agir de uma fração do sistema que compõe o todo, que é o Poder Judiciário. Muito embora, saiba-se que não apenas uma análise pautada na ação de tal Poder seja capaz de responder aos anseios quanto à compreensão do real, (território usado).

É nesse sentido que com a operacionalização da categoria de formação socioespacial no presente estudo, identifica-se os múltiplos agentes, fatores e eventos que caracterizam e dão o suporte necessário para a compreensão dos conflitos e da ação do Poder Judiciário no território em uso do presente, em uma fração especifica que compõe o todo: Planaltina.

É justamente nesse ponto que o lugar/subespaço é uma categoria de grande importância em sua junção com o território usado a que também se adiciona ao entendimento de sua formação socioespacial, através de uma perspectiva de movimento sincrônico com o todo, mesmo que a vivência de seu tempo em consonância com as outras totalidades seja assincrônico.

Neste sentido, fazendo um breve exercício de abstração, ao ser proferida a palavra território brasileiro, visualiza-se não apenas os limites deste território, mas a vastidão territorial que está contido dentro dos limites e ao qual as divisas a contem. Contudo, este todo também é composto por suas partes ao qual emerge um novo todo, o território usado. 
Se o território usado é sinônimo de espaço geográfico, o subespaço contem e está contido neste território usado, entretanto, respondendo de forma singular as relações de produção e atuação dos agentes presentes nesta fração que possui a complexidade advinda do uso do território.

O todo pode ser interpretado em um relacionamento solidário entre as partes integrantes do território nacional com o lugar/subespaço ou entre o lugar/subespaço em conjunto com outras partes que compõem uma totalidade maior e que regem o sistema. Já o lugar/subespaço é a confluência do todo em sua particularidade: é o espaço-tempo em sua concretude.

Tendo em vista o anseio pela captura do movimento espaço-tempo da cidade objeto de estudo, através do acúmulo da produção social que resulta construção da materialidade contida no espaço (sistema de objetos) e das ações que dão e/ou norteiam os usos dados por seus inúmeros agentes ao qual se inclui o Poder Judiciário e os demais poderes do Estado em esferas distintas em totalização, dar-se-á sequência ao esforço de cognição da produção do espaço urbano de Planaltina, tendo em vista a periodização dos processos.

3.1 - Da autonomia à periferia precarizada.

Tecendo uma leitura da configuração territorial da cidade no princípio da década de 1960, tem-se a continuidade da consolidação espacial do Setor Tradicional, sede do antigo município Goiano; o crescimento do bairro contiguo ao centro conhecido como Vila Vicentina, cuja ocupação ocorrera por doação de terras pertencentes à Igreja Católica aos seus respectivos moradores, e que se inicia na segunda metade da década de 1950; a presença de moradores compradores do parcelamento particular correspondente ao Bairro Nossa Senhora de Fátima; assim como da comunidade espírita que se instalara em terras particulares na porção mais ao sul da cidade no ano de 1959, conhecido como Vale do Amanhecer, todavia, em processo de produção. Parte desta configuração territorial pode ser observado no mapa 05. 
Após a inauguração de Brasília no dia 21 de abril de 1960, interpretouse juridicamente, por décadas, que o sítio urbano de Planaltina havia sido incorporado ao patrimônio da Novacap mediante desapropriação indireta, sendo o sítio urbano de tal contexto exposto no mapa 05.

Outro elemento que leva a esse entendimento é a aprovação da já citada Lei $n^{\circ}$ 83/56 que trata da reversão de direitos sobre avenidas, ruas e logradouros públicos entre a Novacap e a Prefeitura de Planaltina, então Goiás.

Conforme fora citado no princípio desta dissertação, em CODEPLAN (2007, p. 08-09), a relação jurídico-institucional que incorpora Planaltina ao Distrito Federal é estruturada e legalmente promulgada apenas no dia 10 de dezembro de 1964 , pela Lei n 4545 , que promove a reestruturação das competências de atuação do Poder Executivo do Distrito Federal, bem como da nova composição políticoadministrativa do DF.

Também conforme fora exposto, a divisão política que delineia os limites da Região Administrativa VI é explicitado com Decreto $n^{\circ} 456$ de 21 de outubro de 1965, que dividiu o Distrito Federal em oito Regiões Administrativas ao qual se inclui a RA VI da cidade de Planaltina (CODEPLAN, 2007).

Nesse processo de incorporação da cidade de Planaltina ao quadrilátero do Distrito Federal, Ihe é retirada a autonomia político-administrativa efetivamente conquistada entre os anos de 1891 e 1892 ao ser elevada a vila à condição de Distrito de Mestre D’Ármas.

Castro (2014) relata que após a inauguração de Brasília e até meados de 1961, ainda vigorava localmente a antiga estrutura político-administrativa do Município pré-existente a Brasília, uma vez que a localização da nova sede municipal estava em processo de escolha e implementação.

Segundo a Lei $n^{\circ} 4.545 / 64$ que dispõe sobre a reestruturação administrativa do Distrito Federal, deixa claro em seu artigo terceiro que, muito embora o sistema administrativo - a então Prefeitura do Distrito Federal - tivesse um caráter descentralizado, as Administrações Regionais não disporiam de personalidade jurídica, havendo assim uma grande relação de controle e 
dependência criada entre as Administrações Regionais e a então Prefeitura do Distrito Federal. 
MAPA 05 - Planaltina 1958.

Planaltina 1958

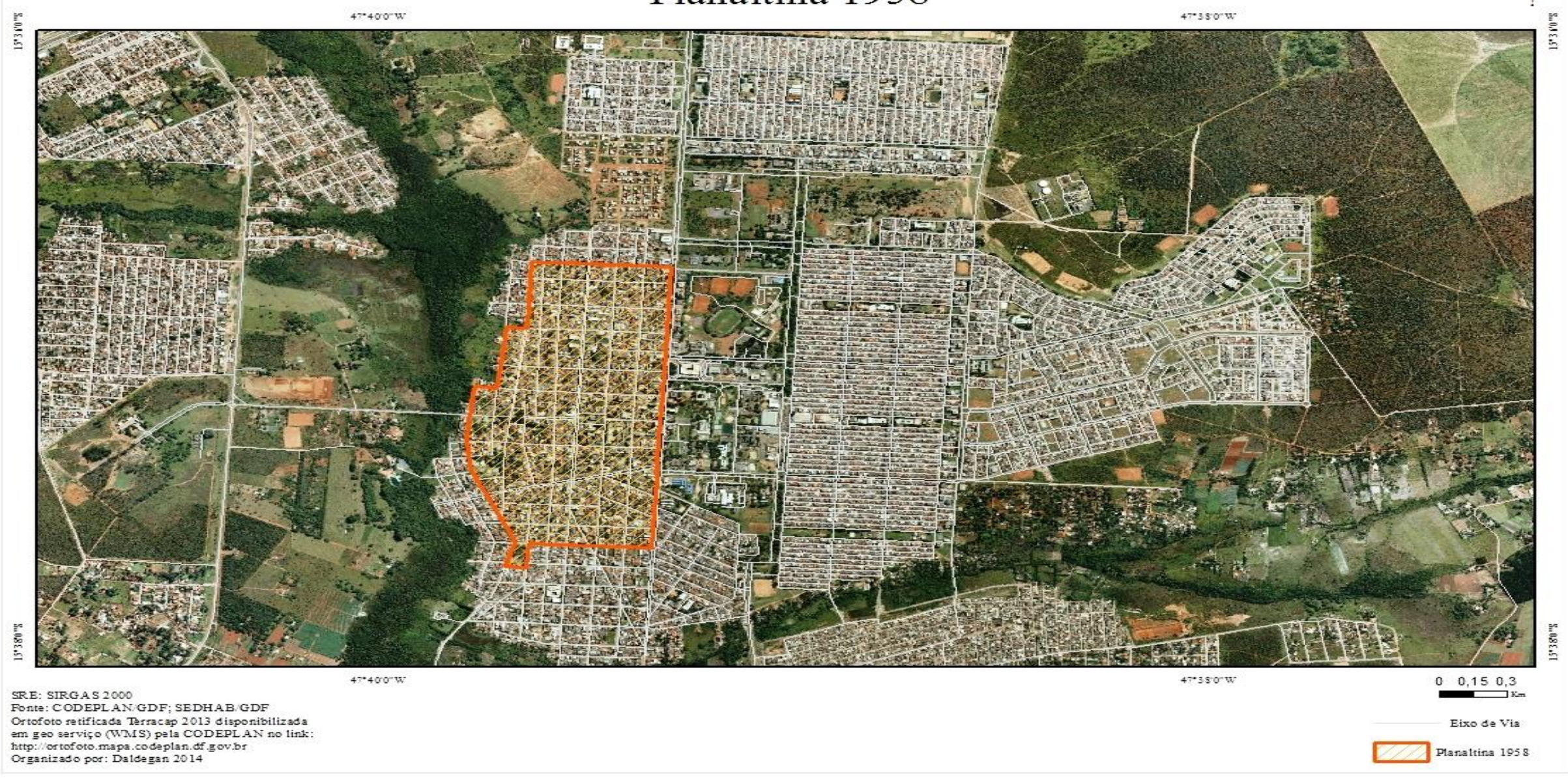

Fonte: Lima, 2014. 
$\mathrm{Na}$ afirmação anterior é, ao ser explicitado no $\S 1^{\circ}$ do art. 10 da referida Lei que determina que a supervisão global do sistema de Administração Regional era de competência da Secretaria do Governo da então Prefeitura do Distrito Federal, evidenciando a perca de autonomia e a inexistência dos Poderes Executivo e Legislativo de caráter municipal nas novas Regiões Administrativas.

Outro trecho da Lei № 4.545/64 expressa a nova relação políticoinstitucional estabelecida com a inauguração de Brasília e a incorporação da sede do antigo Município de Planaltina-GO a Administração Pública do Distrito Federal.

Em seu art. 9o determina que a "Administração Regional será Chefiada por um Administrador Regional, de livre nomeação do Prefeito"23, chefe do recém instituído Poder Executivo no Distrito Federal, retirando a possibilidade de pleito eletivo que culminaria na escolha dos membros dos Poderes Executivo e Legislativo locais, que há décadas era realizado.

Tais determinações explicitadas juridicamente correspondem ao ônus resultante do choque oriundo da instalação da nova burocracia, que modificam as estruturas político-administrativas e sociais locais, tornando-se um símbolo e, ao mesmo tempo, um fato quanto à nova dinâmica de produção territorial, assim como das novas lógicas de dependência que se estabeleceram com a implantação do Novo - Brasília - sobre o velho - a cidade de Planaltina.

$\mathrm{Na}$ entrevista cedida à compilação de depoimentos presentes no livro "Relatos... Planaltina" (1985), Paulo Magalhães, arquiteto, urbanista e administrador de Planaltina, responsável pela elaboração do primeiro plano urbanístico da cidade pós-Brasília que data do ano de 1965, traz um pouco desse embate entre a nova estrutura que se instala e que repercute nas dinâmicas sociais de produção espacial já consolidado há tempos.

Segundo percepção do mesmo, expressa que a adaptação da sociedade local à nova estrutura político-administrativa não demorou muito a acontecer. Paulo fala dessa mudança de status adquirido pela cidade que anteriormente desempenhava a função de sede municipal e que com a

${ }^{23}$ PRESIDÊNCIA DA REPÚBLICA. Lei $\mathrm{n}^{\circ} 4.545$ de 1964 . In http://www.planalto.gov.br/ccivil_03/leis/L4545.htm; acessado em 29 de novembro de 2013. 
implementação de Brasília passa a ser uma cidade satélite, periférica em relação à nova capital do Brasil:

(...) fui convidado para fazer o Plano de Urbanização da cidade. Havia uma preocupação muito grande, porque Planaltina era sede de município, era uma cidade independente no Planalto e com a delimitação do quadrilátero do Distrito Federal, Planaltina ficou dentro do quadrilátero. Então ela perdeu essa condição de sede de município e passou a funcionar como cidade satélite. Houve uma perda de status, digamos assim. Ao mesmo tempo, essa perda de status não foi assim brusca. Embora ela estando dentro do quadrilátero, ela ainda atendia, de certa maneira, à região toda do Município de Planaltina. (GOVERNO DO DISTRITO FEDERAL, 1985, p. 91).

Por mais que a cidade de Planaltina ainda exercesse influência sobre as comunidades anteriormente pertencentes aos seus limites territoriais, Paulo Magalhães destaca que a falta de autonomia política-administrativa constituía em uma grande dificuldade de assimilação da sociedade local, que já havia em seu histórico uma tradição de atuação política local, refletindo-se inclusive nas manifestações culturais. Paulo Magalhães assim expressa:

Entrevistador - queria que você falasse um pouquinho para gente sobre a sua experiência como Administrador de Planaltina, suas relações com as forças políticas do lugar.

Paulo - Foi muito interessante à experiência de Administrador, foi bastante válida, porque é um problema de relação humana. A relação inclusive com uma região, uma dinâmica política muito intensa da comunidade. Sempre foram muito políticos. Agora é claro que na condição de cidade satélite havia uma defasagem, o que de fato eles desejavam era ter o prefeito deles mesmo. Como acontecia sempre(...)

Entrevistador - E essas festas tradicionais da cidade. A população participava muito desde essa época?

Paulo - Na minha época houve um certo esfriamento, não digo uma decadência, um amortecimento, acredito que isso depois foi mais reativado, isso talvez pelo fato dessa confusão que ocorreu em relação a Brasília. Que os moradores de Planaltina, os antigos, participaram de forma muito positiva em relação à criação e construção da Nova Capital(...) Então eles eram muito orgulhosos disso e consideravam muito importante a mudança da Capital, mas o choque tinha que haver...

Entrevistador - Você acha que houve mesmo? Agente andou conversando com as pessoas de lá e eles não falam disso... não têm 
nenhuma análise mais aprofundada do fato de ter perdido a representação política direta, a Câmara...

Paulo - De fato isso foi de pouca duração, digamos assim, isso não foi uma coisa que perdurou. Foi um momento da História do Brasil, especificamente de Planaltina, em que houve uma espécie de reação muito natural face ao impacto muito forte (...) (GOVERNO DO DISTRITO FEDERAL, 1985, p. 95).

Paulo Magalhães, em seus argumentos, apresenta a visão segundo o seu relato do sujeito externo as dinâmicas e práticas sociais de produção espacial secular, interpretando o digerir dos novos processos, a nova lógica de reprodução espacial oriundo do choque dialético entre Planaltina e Brasília, enquanto tese e antítese que, nesse momento desdobra-se em uma síntese sócio espacial em movimento, em totalização.

Nesse olhar, em vias de construção desta síntese, muitos agentes que presenciaram e participaram dessas transformações reagiram de maneiras distintas a nova dinâmica que se impunha no território em uso - subespaço.

Em muitos depoimentos dos antigos moradores, há aqueles que viram a implementação de Brasília com bons olhos, uma vez que passaram a ter acesso a serviços e oportunidades que anteriormente, a antiga municipalidade não conseguia oferecer em função da inexpressividade econômica.

Todavia, até esses favoráveis a tal transformação reconhecem que tais mudanças geraram conflitos e mesmo resistências ao novo que se impunha, seja na antiga sede que perdera a sua autonomia política ou na nova sede, cujos agentes políticos anteriores se depararam com os novos agentes políticos oriundos da nova realidade em metamorfose, originados da construção da nova capital. Como exemplo disto, tem-se o depoimento de Hosannah Guimarães:

Entrevistador - Essa mudança de Planaltina para cidade-satélite, ao invés de um município independente, autônomo; isso causou algum transtorno na vida política local e para a população, ou isso foi uma coisa absorvida pelas pessoas? Como é que se deu essa passagem; foi tranquila?

Dr. Hosannah - A passagem não deixou de alterar, porque a antiga sede ficou dentro do Distrito Federal e a maior parte do município ficou pertencente ao Estado de Goiás. Isso trouxe uma profunda alteração política, que foi profundamente desvirtuada no que concerne às eleições em Goiás, porque o município, que naquela 
ocasião, tinha, no total, cerca de dois mil eleitores, dos quais partes iguais estariam na sede, partes iguais na zona rural, que ficou pertencente a Goiás, passou a ter um número de eleitores seis, oito vezes maior; seis, oito mil eleitores. Esse eleitorado foi alistado, foi qualificado como eleitor do resto do município, da nova Planaltina, sem que, todavia, eles aqui residissem e tivessem a grande parte, nenhum vínculo que justificasse essa sua qualificação como eleitor aqui de Goiás, já que eram pessoas de Brasília: operários, familiares, pessoas vindas de outros estados que queriam título de eleitor. (...) o número de eleitores realmente residentes no município era de $20 \%$, $30 \%$, no máximo (...) o mais, eram forasteiros (...) elegendo elementos que vinham para cá mais influenciados pelos interesses em assumir o poder político (...) (GOVERNO DO DISTRITO FEDERAL, 1985, p. 36-37).

Conforme o exposto no segundo capítulo, além do ranço do processo de desapropriação dos antigos proprietários locais; além da expansão do movimento especulativo e da ampliação da complexificação jurídica das terras; somando-se a sobreposição do sistema jurídico-normativo fruto da racionalidade burocrática do Estado, tendo em vista as práticas possessórias herdadas localmente desde o Período Colonial, fica evidente o embate dialético entre o velho e o novo.

Ao novo desejado outrora impõe-se nova lógica social de produção espacial, resultando, inclusive, em novos agentes que darão uso aos territórios oblíquos a então recente sede dos Poderes do país. Este fato também se desenvolve até mesmo em localidades mais distantes, com a ampliação das redes de circulação territorial que permitiram a complexificação e o espraiamento do movimento em direção aos espaços periféricos mais longínquos ao centro dinâmico do país.

Todavia, confrontando a fala de Paulo Magalhães quanto às marcas deixadas pela perda da autonomia político-administrativa usurpada por Brasília com sua inauguração, com as novas lógicas de atuação desta nova burocracia na dinâmica de produção do espaço urbano de Planaltina, percebe-se na fala de Otaviano Guimarães o impacto sentido por muitos dos antigos moradores da cidade ao se confrontarem com os novos rumos postos com a vigência de Brasília, em uma perspectiva atinente às mudanças políticos-institucionais que reverberam na estrutura social local e nas práticas de produção e uso do território. Nestes termos é exposto: 
Entrevistador - para nós que estamos fazendo este trabalho, tá muito difícil ainda saber como é que a população se viu diante da perda da autonomia política e, de forma geral, como é essa passagem do município autônomo para Cidade-Satélite?

Seu Otaviano - Foi uma mudança tão grande que eu não posso nem explicar. Porque eu vou fazer uma comparação pra você. Se eu tinha um cavalo, eu arriava ele e montava nele sem pedir licença, sem falar com ninguém. Agora hoje, você tem o cavalo, você não pode arriar, você não pode montar nele. Nós tínhamos um Fórum, você podia casar, registrar um filho. Certidão de óbito você podia tirar na cidade. Agora tudo você tem que fazer fora. Agora que nós temos esse cartório. (GOVERNO DO DISTRITO FEDERAL 1985, p. 69-70).

Tomando por referência a fala de Otaviano Guimarães, com a perda da autonomia política e da concentração da gestão do território centralizado na Prefeitura de Brasília ao qual a cidade de Planaltina passa a se subordinar, verificase um retrocesso político-institucional vivenciado pela cidade nas primeiras décadas após a inauguração da nova capital.

Observa-se também a rigidez normativa que passava a viger em detrimento das políticas de uso e ocupação do solo produzidas pós-inauguração de Brasília e que estão associadas ao esforço de blindagem da cidade planejada contra o espontaneismo predominante da dinâmica de produção do espaço urbano das grandes cidades do país em tal contexto.

É relevante ressaltar que em detrimento dessa tentativa de manter o plano urbanístico de Brasília inalterado, frente ao processo de crescimento populacional e demanda habitacional que a capital recém-inaugurada já sofria, dá-se início ao primeiro ciclo de expansão de Planaltina pós-Brasília.

3.2 - O processo de expansão da cidade relacionado à rigidez normativa.

Com o movimento do espaço urbano da cidade de Planaltina, resultante das relações de produção social em seu processo de totalização, esboçou-se todo um primeiro contexto que remete a um período pré-Brasília. 
Mediante o exercício de periodização associado à leitura dos meios geográficos proposto por Santos e Silveira (2003), fora exposto quanto ao objeto de estudo, o avanço de um meio pré-máquina - contexto colonial - até o princípio da geografização de um meio técnico-científico que se materializava sobre o território, tendo Brasília como símbolo e até mesmo condição necessária para o espraiamento das diversas redes dos objetos técnicos que permitiriam o efetivo uso do território pelos agentes internos e externos ao país.

A construção de Brasília corresponde a um evento importantíssimo, tanto nas transformações das dinâmicas territoriais em escala nacional e também local, pois responde às necessidades prementes de integração territorial enquanto possibilidade de difusão de um meio técnico-científico - ainda que de forma desigual - que se apresentava em âmbito mundial e perpassava, no panorama nacional, por sua geografização na região Sudeste do país. Santos (1996) aborda a importância de Brasília dentro do contexto já citado:

A construção de Brasília é a ocasião para que aconteça um novo pacto territorial. Não se dirá que a obra monumental animada pela vontade férrea de Juscelino Kubitschek tenha sido encomendada para, deliberadamente, obter esse fim. Ela se inscreve em um movimento bem mais amplo, o da modernização de um país, cujo território devia se equipar de um modo adequado a uma enorme mudança programada. Equipam-se alguns pontos privilegiados do território, mediante uma obra consciente de renovação urbana; o próprio território como um todo é chamado a ter mais fluidez. A passagem, no processo de evolução do capitalismo, de um nível para outro, exige esses dois esforços conjugados. A nova dimensão do capitalismo, reclamava, também, um Estado mais moderno, territorialmente mais forte porque mais capaz de ser onipresente, isto é, de fazer chegar ordens e mensagens, agentes e mensageiros, a todos os confins. Brasília justifica os grandes investimentos em infraestrutura, que encurtam o tempo das informações e das viagens, e avantajam as atividades mais famintas do espaço. Estas, que coincidem com os monopólios e oligopólios, nacionais e multinacionais, estendem a sua área de mercado que, em muitos casos, confundir-se-á com os próprios limites geográficos, facilitando a concentração econômica e a concentração espacial, beneficiando, assim, a indústria paulista e sua base territorial, que, então, era sobretudo a aglomeração. (SANTOS, 1996, p. 102).

Essa geografização se consolida com a implementação de políticas indutoras de urbanização e industrialização forjadas pelo Estado brasileiro pós-crise de 1929, como alternativa para a promoção do avanço do sistema produtivo e 
econômico mediante a diversificação dos gêneros industriais, uma vez que a lógica nacional assentava-se praticamente sob a sua vocação agrícola procedente do contexto colonial, cujas dinâmicas da natureza impactavam as regras da dinâmica social.

Para dar fluidez e permitir o avanço do meio técnico-científico possibilitando o amadurecimento das relações de produção e circulação sobre o território, assim como a apoderamento do sistema hegemônico possibilitando suas ações em escala nacional, tem-se a materialização de Brasília.

Contudo, uma condição chave para a implementação de tal nó articulador do sistema de redes em expansão, necessitava, além da realização dos diversos estudos de sua viabilidade, além da produção dos vários comandos normativos que previssem o orçamento e a efetivação da construção da capital; além de um projeto urbanístico explicitando a organização de seu sistema de objetos espaciais, cuja forma e função relaciona-se a ser o centro monumental e moderno de comando político-administrativo do país; necessitava de homens e mulheres para erguerem a nova capital.

Segundo Holston (1993) essa necessidade de mão de obra braçal, tendo enquanto traço o incentivo de sua vinda de distintas localidades impulsionado por um discurso patriótico a princípio - os bandeirantes ou pioneiros, ou os que vieram por regime de contratação em um segundo momento - vincula-se à alegoria do novo que surge em uma espacialidade desprovida de uma sociedade local, fazendo alusão aos primeiros bandeirantes que desbravaram o Brasil Central desde meados do final do século XVI.

Para o autor, tal alegoria, de forma subliminar, nega as dinâmicas de produção espacial originárias de um país arcaico, representado pela sociedade localmente pré-existente, assim como do todo. Este é o princípio contido na concepção da cidade modernista idealizada pelo Congrés Internationaux d'Arquitecture Moderne - CIAM, cujo mentor fora Le Corbusier.

Ao mesmo tempo, ficou notório o ato publicitário do Estado, que em seu discurso pregava a necessidade de desenvolvimento acelerado via execução do 
Plano de Metas, sendo Brasília a Meta Síntese, símbolo de um país que necessitava de rápida integração.

Entretanto, Holston (1993) descreve que o novo - Brasília - concebido em negação ao velho, estava sendo construído justamente pela velha estrutura existente, ou seja, as elites políticas e econômicas, detentoras dos meios de produção, em somatória à base da estratificação social, que no caso de construção de Brasília eram denominados de pioneiros e candangos - que depois serão agrupados a uma única categoria: segregados.

Todos esses eram fruto e reflexo do modo de produção vigente, da formação socioespacial que a utopia urbanística de Brasília buscava sobrepor por intermédio das proposições/ações de seus arquitetos e urbanistas, embasados nas propostas do CIAM. Todavia, contraditoriamente, trazia em seu bojo quanto da execução do projeto, as velhas lógicas e práticas de produção sócioespaciais vigentes, reproduzidas logo no princípio da materialização da cidade modernista.

Um dos elementos idealizados por seus arquitetos e urbanistas relacionados à concepção de Brasília, segundo Holston (1993), condiz com a produção de uma cidade para todos, desprovida de um arranjo que explicitasse qualquer evidencia de estratificação social.

Essa proposição associa-se ao modelo soviético de concepção do espaço urbano moderno que também transitava nas discussões promovidas pelo CIAM, sendo esta um condensador social das distintas classes, transformadora da realidade social local e irradiadora destas transformações para toda realidade territorial vigente.

Ainda conforme Holston (1993), a essa lógica arcaica, combatida pelo projeto utópico da capital modernista, relacionam-se as experiências anteriores de produção do espaço urbano segregador, explicitando, em sua forma e função, a existência de uma estrutura social estratificada, cuja base é oprimida pela práxis capitalista referente ao acesso e monopólio da propriedade privada, à insalubridade e ao caos do arranjo urbano, podendo também incluir na análise a presença de uma estrutura político-jurídico desigual quanto ao cumprimento dos deveres constitucionais. 
Neste sentido, Holston (1993) descreve que a proposta da cidade modernista tinha, enquanto símbolos a serem combatidos, o modelo urbano das cidades industriais da Europa dos séculos XVIII e XIX, tendo por princípios e inspiração a visão de uma cidade que rompesse com as lógicas de seu espaçotempo, cuja sua reprodução desvinculasse das relações de produção e trabalho impostos pelo sistema capitalista de então.

Holston (1993, p.45) enfatiza que embora o projeto de cidade elaborado pelo CIAM tivesse influência nas mais distintas demandas políticoideológicas - sindicalistas catalães, coletivistas de Moscou, fascistas italianos e técnicos burocratas - a priori, em seu discurso, Le Corbusier se propunha a transformar as estruturas sociais vigentes mediante a modificação do modo de vida urbano, através do reordenamento das cidades com a aplicação dos instrumentos de planejamento. Houston (1993) dá voz à percepção de Le Corbusier (1967) sobre a junção capital, mecanização do trabalho e arranjo urbano da seguinte forma:

Pegue um avião. Voe sobre nossas cidades do século XIX, sobre aqueles imensos sítios incrustados com fileiras e fileiras de casas sem coração, marcados por cânions de ruas sem alma. Olhe para baixo e julgue por si mesmo. Afirmo que tais coisas são o signo de uma trágica desnaturalização do trabalho humano. São prova de que os homens, subjugados pelo titânico crescimento da máquina, sucumbiram às maquinações de um mundo impulsionado pelo dinheiro. (LE CORBUSIER, 1967, p. 341 apud HOLSTON, 1993, p. 47).

Com base no exposto, o caos urbano também era atribuído à presença de um Estado Liberal, cujo contrato estabelecido junto às sociedades europeias privilegiavam e resguardavam apenas os direitos individuais dos detentores dos meios de produção, complexizando-se cada vez mais com a evolução do sistema capitalista, onde nessa crescente relação caótica entre Estado, capital, trabalho, resultava na forma urbana tinha como referencial a concentração da propriedade privada, cuja funcionalidade pautava-se na reprodução da mais-valia.

Em um contexto em que os direitos individuais serviam apenas para o aprisionamento, escravidão da classe trabalhadora em prol do patronato, resguardado pelo Estado Liberal o qual usa de maneira deturpada os direitos fundamentais individuais, incluindo o direito à propriedade, tal fato é explicitado por 
Marx e Engels (1999) na análise evolutiva do sistema capitalista e na ascensão política da burguesa:

Vemos, pois, que a própria burguesia moderna é o produto de um longo processo de desenvolvimento, de uma série de revoluções no modo de produção e de troca.

Cada etapa da evolução percorrida, pela burguesia era acompanhada de um progresso político correspondente. Classe oprimida pelo despotismo feudal, associação armada administrandose a si própria na comuna; aqui, república urbana independente, ali, terceiro estado, tributário da monarquia; depois, durante o período manufatureiro, contrapeso da nobreza na monarquia feudal ou absoluta, pedra angular das grandes monarquias, a burguesia, desde o estabelecimento da grande indústria e do mercado mundial, conquistou, finalmente, a soberania política exclusiva no Estado representativo moderno. O governo moderno não é senão comitê para gerir os negócios comuns de toda a classe burguesa.

Onde quer que conquistado o poder, a burguesia calcou aos pés as relações feudais, patriarcais e idílicas. Todos os complexos e variados laços que prendiam o homem feudal a seus "superiores naturais" ela os despedaçou sem piedade, para só deixar subsistir, de homem para homem, o laço do frio interesse, as duras exigências do "pagamento à vista". (...) Fez-se da dignidade pessoal um simples valor de troca; substituiu as numerosas liberdades, conquistadas com tanto esforço, pela única e implacável liberdade do comércio. Em uma palavra, em lugar da exploração velada por ilusões religiosas e políticas, a burguesia colocou uma exploração aberta, cínica, direta e brutal. (MARX e ENGELS, 1999, p. 10-11, grifo nosso).

Tendo em vista todos esses elementos de cunho degradante associado ao processo de formação socioespacial das nações europeias, e que culminam na crise social e urbana do século XIX, também podem ser observados nos primórdios da concepção da cidade modernista. Esta é resultado dos ideais de Le Corbusier, difundidas nos congressos internacionais promovidas pelo CIAM (1928 a 1960) e codificadas na Carta de Atenas em 1931.

Holston (1993) informa que a Carta de Atenas é resultante do consenso entre arquitetos e urbanistas dos países do Norte, frequentadores do CIAM, e que dispunha sobre os princípios atribuídos às funções a serem desenvolvidas por uma cidade (moradia, trabalho, lazer, circulação e centro 
público $\left.{ }^{24}\right)$, idealizadas pelo pensamento modernista. Estas funções são aplicadas no caso de Brasília por dois discípulos de Le Corbusier: Oscar Niemeyer e Lúcio Costa.

Entretanto, Holston (1993) enfatiza que o projeto da cidade modernista idealizado por Le Corbusier, em seu interior, pautava-se nas propostas de revitalização dos espaços centrais aplicados por Barão Hausmann no início dos anos de 1850, cuja finalidade era promover a salubrização da cidade de Paris, acometida por intensas epidemias de cólera associado à superpopulação presente na cidade.

Essa salubrização ocorreria mediante a desapropriação das propriedades contidas no espaço urbano industrial desprovido de vida, segundo Le Corbusier, resultando para Holston (1993, p. 54), na: "Haussmanização de Paris e das demais capitais europeias que acabaram por importar tal modelo de política urbana".

Dessa Haussmanização resulta a elaboração e aplicação de um novo código urbanístico - como o qual o Estado passa a desfrutar do direito de desapropriação de bens imóveis mediante interesse público - assim como a reconfiguração dos objetos espaciais que compunham a então malha urbana dessas grandes capitais europeias, cujo arranjo era proveniente da atividade industrial.

Conforme Holston (1993), as críticas feitas pelo CIAM - tendo como mentor Le Corbusier, que por sinal se inspirara em Hausmann - ao arranjo urbano das cidades do século XIX e início do XX, explicitam, e ao mesmo tempo condenam o fracasso do planejamento da cidade industrial em si, que se dava segundo as demandas produtivas e patronais - cidade da máquina; assim como o monopólio da propriedade privada da terra que deveria passar para as mãos do Estado, supostamente para evitar o uso especulativo do solo urbano.

Segundo Holston (1993), a crítica quanto à concentração dos imóveis urbanos nas mãos de particulares e o incentivo do Estado para promoção das desapropriações, tinha por intencionalidade facilitar o trabalho dos urbanistas e arquitetos em suas proposições e execuções de projetos, que buscava a

\footnotetext{
${ }^{24}$ Segundo Holston (1993) a quinta função atribuída à concepção do planejamento urbano fora criado por Lúcio Costa junto ao projeto de Brasília.
} 
materialização de uma cidade ideal. Mas o que seria essa cidade ideal? Quem efetivamente faria uso dela? $E$ no caso de Planaltina/Brasília: quais os desdobramentos desta utopia? Brasília enquanto um condensador social efetivamente existiu?

Conforme exposto por Holston (1993), os princípios aplicados por Hausmann e profundamente adotados por Le Corbusier, não tratavam da questão das demandas habitacionais da classe operária e empobrecida, acabando por se transformar em um instrumento promotor da segregação sócio espacial e de horizontalização das cidades mediante à constituição de uma nova periferia.

Inclusive, tais processos no caso brasileiro - revitalização de áreas centrais que responde na produção de singularidades espaciais; esgarçamento do tecido urbano e as dificuldades de deslocamento das populações das periferias para os centros equipados e detentores dos postos de trabalho; altos investimentos estatais em conjunto com corporações privadas quanto ao equipamento das áreas centrais, e parcos investimento em programas habitacionais para a periferia ou ausência destes, ampliando a demanda habitacional face a população crescente em situação de risco social; constituição de vazios urbanos que possibilitam a revalorização e especulação das terras próximas ao centro equipado - é interpretado por Santos $(2005,2009)$ enquanto fenômenos que correspondem a metrópole corporativa ou urbanização corporativa.

Retomando as ideias de Holston (1993), é importante evidenciar a questão da Haussmanização/ segregação sócio espacial das cidades europeias e as consequências desta para a classe operária:

(...) a haussmanização - ou seja, o evisceramento dos bairros centrais de diversas cidades europeias - não resolveu o problema da habitação de massa nem proporcionou o tipo de distribuição igualitária dos recursos humanos que os CIAM propunham. Com efeito, tinha propósitos e efeitos exatamente opostos: os da garantia à cidade para os ricos, marginalizando os pobres. Esses projetos urbanísticos de larga escala "resolveram" o problema habitacional das classes operárias empurrando-as para a periferia. As largas avenidas cortavam bairros de trabalhadores em cisões cirúrgicas destinadas a remover as "classes perigosas" do núcleo das cidades. (HOLSTON, 1993, p. 55). 
Tendo em vista esse raciocínio, embora com um discurso social, a lógica do planejamento urbano universal modernista adotado pelo CIAM, idealizado por Le Corbusier enquanto desdobramento das proposições/ações de Hausmann, atendia perfeitamente os interesses das elites corporativas e dos burocratas, independentemente da ideologia professada, tanto no final do século XIX, como na passagem da primeira para a segunda metade do século XX, em sua diversidade de anseios.

Elementos como: amplas praças salubres; centralização dos serviços e gestão burocrática do Estado; estruturação de uma periferia satélite em relação ao centro, são expressos por Holston (1993) como novas possibilidades de controle e uso a serem adotadas pelo patronato e pelo o Estado, em detrimento às constantes reivindicações promovidas pela classe operária, e que causavam transtornos às elites, corporações e gestores de tais capitais europeias.

Neste sentido, ao citar Engels (1872), Holston (1993) enfatiza que as amplas praças e avenidas possibilitariam a execução de manobras militares mais eficientes para conterem as rebeliões operárias; com o estabelecimento da relação centro-periferia o processo de estratificação social ficaria mais nítido, além de promover o afastamento dos problemas de ordem social da centralidade constituída; outro elemento condiz com a revitalização dos espaços centrais que passam a ser utilizados pelas elites econômicas, aquecendo o mercado imobiliário como resposta a concentração de equipamentos públicos que valorizariam tais terras.

Segundo Holston (1993), tendo em vista todos os elementos citados, Le Corbusier sofre várias críticas de arquitetos e militantes esquerdistas na França, ao propor o uso em larga escala das proposições de Haussmann entre os anos de 1920 e 1930 em Paris.

Le Corbusier reviu em sua proposta urbanística a retirada do conceito da presença das Cidades-Satélites, receptáculo da classe operária expurgada dos antigos centros, para a existência de um único espaço a ser usufruído por toda classe trabalhadora, sem distinções de classes, tal como fora idealizado na proposta de concepção de Brasília. 
Todavia, os princípios e a continuidade da Haussmanização estavam postos, sendo verificados tais processos na implementação da nova capital brasileira. Entretanto, algo paradoxal nessa haussmanização brasiliense se dá pelo fato de que as pessoas removidas para a nova periferia são resultantes das ações e demandas da burocracia que implementa Brasília e que faziam parte da alegoria bandeirista negadora da sociedade local já constituída e, também, da vigência de um pais cujo sistema produtivo e social ainda sofria com a herança deixada pelo sistema colonial.

Neste sentido, Holston (1993) descreve que a utopia da cidade modernista, condensadora social e transformadora da sociedade brasileira, nascia com fortes traços de estratificação social já nos acampamentos instalados pela Novacap e pelas construtoras privadas.

Isso se refletia nos cognomes, formas de tratamento dados entre as distintas categorias de trabalhadores, como os pioneiros, candangos, doutores e, posteriormente, os burocratas, para quem a cidade fora verdadeiramente construída. Outro elemento que revela este traço inicialmente segregador são as distintas condições de alimentação e regalias, quanto às habitações existentes próximos aos canteiros de obra de onde Brasília fora erguida.

Holston (1993) assevera que o fator gerador dos primeiros loteamentos clandestinos que surgem a partir do ano de 1958 nas cercanias da capital em construção, associam-se ao alto custo dos alugueis pagos pelos trabalhadores clandestinamente contratados pelas empreiteiras privadas, somados à vinda de seus familiares que acompanharam os respectivos chefes de família que vieram trabalhar nos canteiros de obra de Brasília.

Tais trabalhadores, afirma o autor, contratados irregularmente pelas empreiteiras eram oriundos principalmente da região Nordeste. Estes constituíam em refugiados da grande seca de 1958 e que buscando sobreviver aos fatores climáticos extremos em somatória à oportunidade de trabalho, vieram em grande número, resultando no aumento populacional da cidade ainda em construção e na geração de lucros para as empreiteiras privadas, uma vez que os salários pagos eram baixos para os trabalhadores clandestinos se comparados aos trabalhadores regulares. Assim, a tabela 05 descreve as respectivas origens desses migrantes. 
Tabela 05 - Distrito Federal: Migração para o Distrito Federal por local de nascimento, migração direta ou indireta e região da última residência, 1959.

\begin{tabular}{|c|c|c|c|c|c|c|}
\hline \multirow{2}{*}{$\begin{array}{l}\text { Região de } \\
\text { nascimento } \\
\text { ou última } \\
\text { residência }\end{array}$} & \multicolumn{2}{|c|}{$\begin{array}{c}\text { Local de } \\
\text { nascimento }\end{array}$} & \multicolumn{2}{|c|}{ Migração } & \multicolumn{2}{|c|}{$\begin{array}{l}\text { Região da última } \\
\text { residência }\end{array}$} \\
\hline & $\mathbf{N}^{\circ}$ & Total (\%) & Direta & Indireta & $\mathbf{N}^{\circ}$ & Total (\%) \\
\hline Norte & 358 & 0,6 & 49,4 & 50,6 & 297 & 0,5 \\
\hline Nordeste $^{25}$ & 24.511 & 43,0 & 59,2 & 40,8 & 15.489 & 27,2 \\
\hline $\begin{array}{l}\text { Nordeste } \\
\text { ocidental }\end{array}$ & 3.364 & 5,9 & 62,9 & 37,1 & 2.485 & 4,4 \\
\hline Nordeste orie & 13.175 & 23,1 & 65,8 & 34,2 & 8.874 & 15,6 \\
\hline $\begin{array}{l}\text { Nordeste } \\
\text { meridional }\end{array}$ & 7.972 & 14,0 & 46,8 & 52,3 & 4.130 & 7,3 \\
\hline Sudeste & 16.386 & 28,8 & 66,5 & 33,5 & 17.844 & 31,3 \\
\hline Sul & 883 & 1,6 & 51,9 & 48,1 & 987 & 1,7 \\
\hline Centro-Oeste & 13.459 & 23,6 & 95,5 & 4,5 & 21.979 & 38,6 \\
\hline $\begin{array}{l}\text { Países } \\
\text { estrangeiros }\end{array}$ & 1.216 & 2,1 & 6,4 & 93,6 & 78 & 0,1 \\
\hline TOTAL $^{26}$ & 56.953 & 100,0 & 70,7 & 29,3 & 56.953 & 100,0 \\
\hline Urbano & & & & & 44.753 & 78,6 \\
\hline Rural & & & & & 11.189 & 19,6 \\
\hline
\end{tabular}

Fonte: IBGE (1959) apud Holston (1993, p. 224).

Holston (1993) expõe que no transcorrer da construção e após a inauguração de Brasília, já existiam grupos, movimentos de contramobilidade espacial, tendo em vista a luta travada pelos candangos construtores da nova capital em permanecerem em Brasília. Este movimento de contramobilidade é exposto na tabela 06 a seguir.

${ }^{25}$ O Nordeste Ocidental compreende o estado do Maranhão e do Piauí; o ocidental os estados do Ceará, Rio Grande do Norte, Paraíba, Pernambuco e Alagoas; o meridional compreende Sergipe e Bahia (Holston, 1993, p. 224).

${ }^{26} \mathrm{O}$ total inclui 140 migrantes sem especificação de lugar de nascimento ou de ultima residência. Entretanto, as rubricas rural e urbano não incluem os 1101 migrantes que não especificaram nenhuma das duas como condições de sua última residência. 
Tabela 06 - Distrito Federal: População por tipo de povoamento, 1959.

\begin{tabular}{|c|c|c|}
\hline \multirow{2}{*}{$\begin{array}{l}\text { Localidades } \\
\text { I. Povoamento preexistente }\end{array}$} & População & Porcentagem \\
\hline & $(6.600)$ & $(10,3)$ \\
\hline Planaltina & 2.245 & 3,5 \\
\hline Brazlândia & 335 & 0,6 \\
\hline Zona Rural & 4.000 & 6,2 \\
\hline II. Povoamentos Planejados permanentes & $(2.270)$ & $(3,5)$ \\
\hline \multicolumn{3}{|l|}{ 1. Plano Piloto } \\
\hline Fileiras de casas da FCP ${ }^{27}$ & 2.270 & 3,5 \\
\hline III. Povoamentos Planejados provisórios & (37.315) & $(58,0)$ \\
\hline \multirow{2}{*}{$\begin{array}{l}\text { 1. Acampamentos de construção } \\
\text { a. Novacap }\end{array}$} & $(25.750)$ & $(40,0)$ \\
\hline & $(4.186)$ & $(6,5)$ \\
\hline Velhacap & 1.318 & 2,1 \\
\hline \multirow{2}{*}{\multicolumn{3}{|c|}{$\begin{array}{l}\text { Candangolândia } \\
\text { b. Institutos de Previdência social }{ }^{28}\end{array}$}} \\
\hline & & \\
\hline $\begin{array}{l}\text { b. Institutos de Previdência social }{ }^{88} \\
\text { Plano Piloto - Asa Sul }\end{array}$ & 8.737 & 13,6 \\
\hline c. Empreiteiras Particulares & $(12.827)$ & $(19,9)$ \\
\hline Acampamentos da Praça dos Três Poderes & 7.064 & 11,0 \\
\hline Outros acampamentos & 5.763 & 9,0 \\
\hline 2. Cidade Livre (Núcleo Bandeirante, 1961) & 11.565 & 18,0 \\
\hline VI. Povoamentos ilegais (invasões) & $(18.129)$ & $(28,2)$ \\
\hline 1. Zona urbana ${ }^{29}$ & $(9.873)$ & $(15,4)$ \\
\hline a. Vila Sara Kubitschek (Taguatinga, 1958) & 3.677 & 5,7 \\
\hline \multirow{2}{*}{$\begin{array}{l}\text { b. Vila Amaury (Sobradinho, 1960) } \\
\text { c. Vila Planalto }{ }^{30} \text { (Gama, 1960) }\end{array}$} & 6.196 & 9,6 \\
\hline & [6.500] & \\
\hline $\begin{array}{l}\text { c. Vila Planalto (Gama, 1960) } \\
\text { d. Vila do IAPI (Ceilândia, 1971) }\end{array}$ & [8.084] & \\
\hline 2. Zona rural & 8.256 & 12,8 \\
\hline TOTAL & 64.314 & 100,0 \\
\hline
\end{tabular}

Fonte: IBGE (1959); Silva (1971); Epstein (1973) apud Holston (1993, p. 218).

${ }^{27}$ Holston (1993, p. 218) explicita que as quinhentas casas geminadas construídas ao longo da W-3 pela Fundação da Casa Popular (FCP) foram imediatamente ocupadas por membros do alto escalão dos quadros técnicos e administrativos da Novacap e suas famílias. No censo do IBGE de 1959, essa população não foi desagregada da população dos acampamentos de construção do Plano Piloto. Para distingui-las, usou-se as diferenças em suas condições de moradia, tal como registradas pelo censo, fazendo-se uma estimativa proporcional (baseada em 500 casas) de todas as residências registradas como "duráveis", "individuais", "com água corrente" e "ligação com fossa céptica".

${ }^{28}$ Holston (1993, p. 218-219) trata da contribuição dos institutos de previdência na construção dos prédios de apartamentos das superquadras. Segundo o autor, embora os próprios institutos tenham empregado alguns operários na construção, a maioria dos empregados entre os 8.737 listados ali (é impossível dizer quantos exatamente) trabalhavam para empreiteiras particulares contratadas pelos institutos. Holston (1993) cita o exemplo do acampamento da IAPC na SQS 106, que era ocupada pela firma Kosmos Engenharia.

${ }^{29}$ Holston (1993, p. 219) assevera que a tentativa do governo em reassentar os habitantes dos assentamentos clandestinos deu origem às cidades satélites ilegais autorizadas, enumeradas entre parênteses com suas respectivas datas de fundação. A população atribuída à Vila Sara Kubitschek é a da cidade-satélite de Taguatinga, que havia recebido quase todos os seus moradores na época do senso.

${ }^{30}$ Holston (1993, p. 219) descreve que a população da Vila Planalto e da Vila do IAPI, ambas citadas entre colchetes, são do ano de 1964, sendo esta última uma amalgama de várias favelas menores, incluindo a Vila Tenório, Vila Esperança, Vila Bernardo Sayão, Morro do Querosene e Morro do Urubu. 
É nesse contexto que se dá a Haussmanização às avessas em Brasília, uma vez que antes mesmo da cidade ser inaugurada, dar-se início à remoção das primeiras ocupações clandestinas das terras próximas, até mesmo, dentro dos limites urbanos da nova capital planejada.

O candango e o pioneiro, símbolos da alegoria vinculada à construção de uma nova espacialidade e temporalidade através de esforços patrióticos, cravado nas termas hermas, inabitadas do Brasil Central, cujo simbolismo retrata o limiar do moderno que sobrepõe ao tradicional, o Brasil rústico, ultrapassado, também são negados.

Os idealizadores de Brasília ao negarem o candango enquanto negação do que já pré-existia localmente, também negam o princípio da cidade enquanto condensador social, cidade para todos e, ao mesmo tempo, afirmam para quem a cidade verdadeiramente estava sendo construída: para a elite política e para os burocratas.

Nesta perspectiva, Holston (1993) assevera que embora não houvesse uma proposta prévia de possível incorporação social e espacial da figura dos pioneiros e candangos nos limites urbanos da futura capital do país, já vigoravam dispositivos que previam esta Haussmanização dessa população para periferia que possivelmente poderia se instalar nas cercanias da nova capital. $O$ autor expõe tal raciocínio da seguinte maneira:

A rebelião dos pioneiros forçou o Estado a reconhecer seus direitos à cidade. Não, contudo, ao Plano Piloto propriamente dito, mas sim a cidades na periferia da capital. Esse desdobramento constituiu um duplo desvio em face das intenções originais. Nem o Plano Piloto de Lúcio Costa nem as diretrizes originais da Novacap previam a criação de Cidades-Satélites no Distrito Federal. Em vez disso, apontavam para a construção de uma capital que acomodasse meio milhão de pessoas por volta do ano 2000. Estas especificações constavam na Lei 1.830, de janeiro de 1953. Além disso, o Plano Piloto enfatizava que "deve-se impedir a enquistação de favelas tanto na periferia urbana quanto na rural" (art. 17). Assim, os planejadores de Brasília estabelecem desde o início uma das intenções radicais da nova cidade: não deveriam deixar que se desenvolvesse a periferia de miséria operária que, de forma legal ou não, tipicamente se tem produzido à volta das metrópoles brasileira. (HOLSTON, 1993, p. 257). 
Todavia, conforme é exposto na anterior tabela 06, resultante dos movimentos sociais de contramobilidade espacial, Holston (1993) demonstra que as primeiras populações que haviam se instalado clandestinamente próximo a Brasília, transitam da condição de clandestinidade para uma legalidade precarizada.

Essa legalidade precarizada se dá tanto na difícil situação de cumprimentos dos requisitos legais para efetivamente exercerem o direito de propriedade, tendo em vista as exigências imposta pela Novacap para a instalação dos candangos nas terras comercializadas pelo Estado, como na questão relacionada ao acesso às infraestruturas urbanas que lhes dessem, desde já, a dignidade supostamente concedida via remoção e periferização.

Inserida em tais processos no espaço e no tempo, Planaltina passa por transformações relativas à modificação de sua forma, readquirindo nova função e metamorfoseando-se quanto a sua estrutura social que impacta no uso do território. Por forma, função, estrutura e processo, Santos (1985) as concebem conceitualmente segundo os seguintes contornos:

Forma é um aspecto visível de uma coisa. Refere-se, ademais, ao arranjo ordenado de objetos, a um padrão. Tomado isoladamente, temos uma mera descrição de fenômenos ou de um de seus aspectos num dado instante do tempo. Função, de acordo com o Dicionário Webster, sugere uma tarefa ou uma atividade esperada de uma forma, pessoa, instituição ou coisa. Estrutura, implica a interrelação de todas as partes de um todo; o modo de organização ou construção. Processo pode ser definido como uma ação contínua, desenvolvendo-se em direção a um resultado qualquer, implicando conceitos de tempo (continuidade) e mudança. (SANTOS, 1985, p. $50)$.

Com base nestes conceitos acima expostos, a função da cidade de Planaltina é modificada com a vigência de Brasília, pois além de perder a sua autonomia político-administrativa, ao se tornar uma Cidade-Satélite - princípio de Haussmann - passa também a ser receptáculo dos operários segregados antes e pós-inauguração de Brasília, sendo que grande parcela destes proviam das invasões da Asa Norte.

No entanto, é válido ressaltar que o processo de remoção e instalação da população ocorre apenas no ano de 1969, tal como é exposto na fotografia 06. 
Sobre a localização e o processo de remoção das invasões e realocação no que viria a ser a Vila Buritis, novo bairro da cidade de Planaltina, cuja função vincula-se como receptáculo dos operários e migrantes segregados, Castro (2014) relata:

Lima - Aqui (Vila Buritis) já é a partir de 70, né?

Castro - Sessenta e nove. Vinte e seis de janeiro de sessenta e nove.

Lima - Que teve o projeto do Magalhães, se não me engano em 65, $66 \ldots$

Castro - Bom, é, teve um projeto de ocupação da área (Vila Buritis). Mas eles já estavam pensando em tirar as invasões de Brasília. Invasão do IAPI, Invasão da Vila do Querosene... tem uma série... tem a da Asa Norte, ali perto da UNB... ali era cheinho de barracos ali; onde era o CIEN, perto da UNB, e ai pra lá até o final da L2 ali, era cheinho de barracos de tabua (...)

- Ali da frente do CIEN; do CIEN pra baixo até topar com a Asa Norte, aonde você visse era cheio de barracos de um lado e de outro, atrás, e tal... de gente que tinha ajudado na construção de Brasília!

- Eu tenho as fotografias dos primeiros barracos colocados lá (Vila Buritis); dos caminhões trazendo os barracos! Do mutirão das casas que foram construídas na quadra 04 , lá no mutirão (...)

- Quando o Prefeito era Silvano Bonfim, e ele estava com o problema de abrir as ruas, ai ele soube que tinha um engenheiro da Novacap, chamado José Bonifácio de Oliveira, que era da minha família, primo meu, sobrinho da minha mãe... ele precisava das máquinas e esse Bonifácio tinha as máquinas que ele precisava pra abrir as ruas do Buritis. Ele foi à casa da minha mãe, e foi minha mãe que ligou pro Bonifácio, e ela até falou assim:

- ô Facin, eu to aqui te ligando porque o Silvano Bonfim ta aqui e ele é o Prefeito aqui da cidade, e tal... e ele tá precisando de máquina pra pudê fazer um assentamento aqui.

- E aí ele falou: é claro tia! Passa o telefone pra ele aí! É claro que vou arrumar...

- E aí ele arrumou as máquinas pra ele abrir as ruas pra pudê fazê a Vila Buritis. (CASTRO, 2014). 
Fotografia 06 - Vila Buritis: 1969.

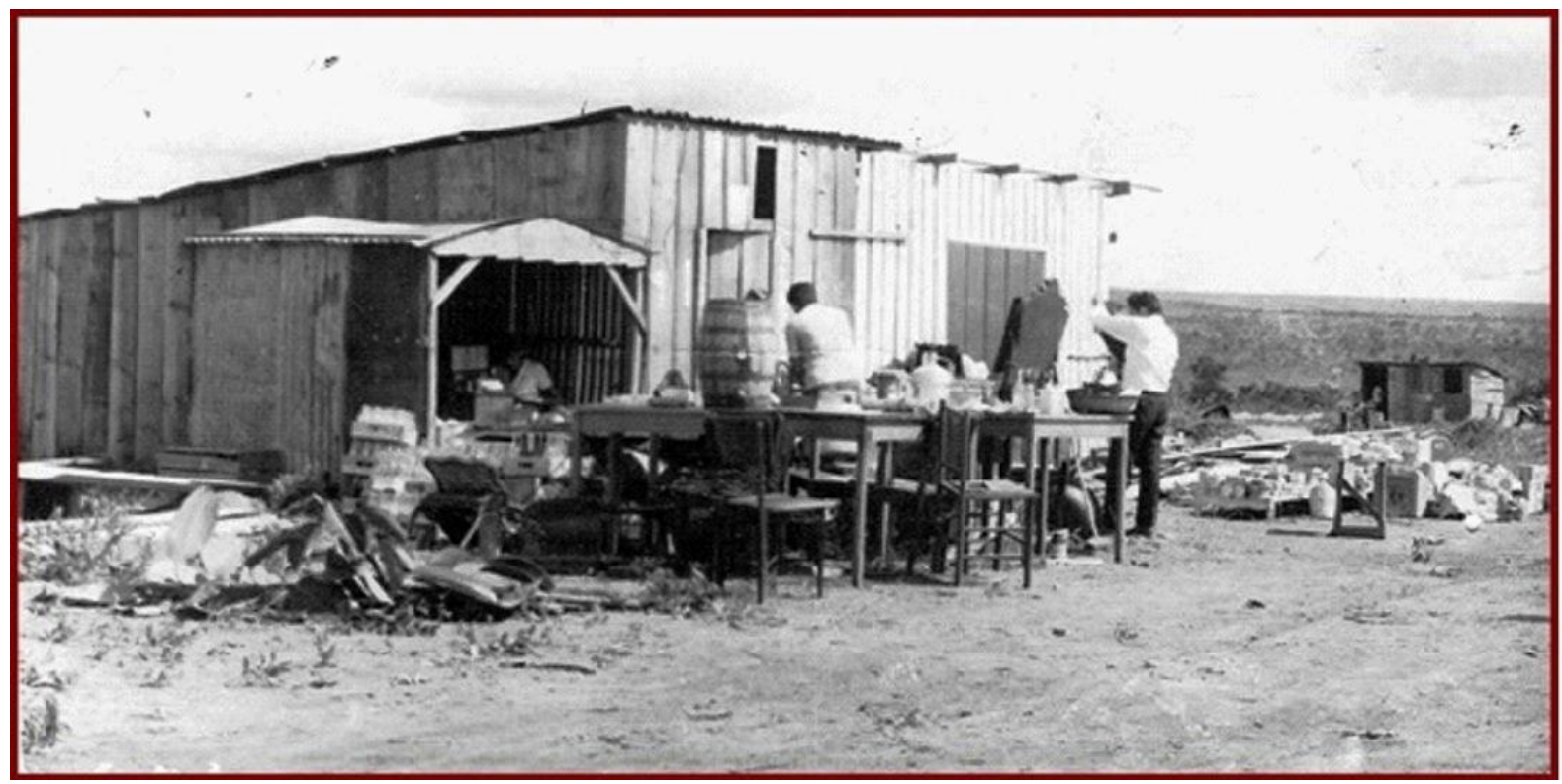

Fonte: Mário Castro ${ }^{31}$.

Tomando como referência os relatos de Castro (2014), tendo em vista as descrições de Holston (1993) e o sistema conceitual de Santos (1985), quanto à forma, a composição do sistema de objetos da cidade de Planaltina ganha novos contornos, cuja premissa, contraditoriamente, era manter as antigas características de sua formação socioespacial pré-existente a Brasília, mesclando-se com o novo projeto urbanístico que implantava-se segundo a concepção modernista da nova capital. Este fato pode ser observado na fotografia 06 que imageticamente expressa o processo de composição da então Vila Buritis.

Ou seja, o arcaico negado é mantido, e o que fora segregado operários migrantes - enquanto elemento presente na alegoria da cidade modernista, é afixado mediante um discurso inclusivo, proposto pelo urbanismo moderno, entretanto, sem impactar na área urbana e na sociedade já fixadas há tempos. Neste sentido é válido expor o que o idealizador do projeto - Paulo Magalhães - defende, assim como suas intenções face ao embate dialético entre o velho e novo:

Ocorre que Planaltina, quando começaram as construções de Brasília, existia com características de cidade do começo do século

${ }^{31}$ Usina Literaria. In: http://usinaarteliteraria.blogspot.com.br/2013/02/historia-de-planaltina-atravesde-fotos.html; acessado em 11 de agosto de 2014. 
XIX, digamos. Embora já tenha coisa contemporânea, a estrutura básica da cidadezinha guardava todas as características de final do séc. XVIII, em termos das construções, das áreas ocupadas, da urbanização, etc., do ponto de vista da estrutura familiar. A parte econômica também.

Então houve um choque. A preocupação na parte urbanística era de que se você tinha que criar novos espaços, tendo em vista o crescimento de Planaltina, que se procedesse de tal forma que isso não viesse a destruir a cidade antiga. Então seria como você trabalhasse organizando o espaço de forma que você pudesse ter um processo de aculturação entre os habitantes da Vila com suas características e esses novos habitantes que vinham com outra bagagem cultural, quer dizer, uma cultura diferenciada com suas características e que fatalmente teria que ocorre um choque como de fato ocorreu. Não só em Planaltina como em outras cidades do Planalto.

Foi aí que surgiu a Vila Buritis, porque você tinha duas maneiras de proceder: ou você fazia o crescimento de Planaltina por extensão, isto é, você ia ampliando Planaltina no sentido do crescimento horizontal; ou você faria o crescimento de uma forma diferente, quer dizer por replicação de modelo, doação de um novo modelo, que no caso foi a Vila Vicentina, e você tinha o espaço de permeio que nós chamávamos na época de "Centro de Vivência". Esse espaço de permeio teria exatamente essa função de encontro de população, quer dizer, dos antigos de Planaltina com os novos (...) cujo resultado final seria uma aculturação dos mesmos. Este espaço existe até hoje, onde estão as escolas, hospital, etc.

Entrevistador - Como você pensou a Vila Buritis?

Paulo - A Vila Buritis tinha quatro áreas de vizinhança onde eu procurava já introduzir certos conhecimentos mais novos de urbanismo como por exemplo procurar separar o máximo, o tráfego dos veículos do tráfego de pedestres. Criar centros de quadras, eram quase que como superquadras, onde você teria a escola primária, pequeno equipamento de atendimento, por exemplo, açougue, armazém, farmácia (...) Então as escolas primárias deveriam funcionar nesses centros. Seria uma espécie de coração dessas áreas de vizinhança de 5.000 habitantes. Já o curso secundário ele iria funcionar no Centro de Vivência (...) Você em Planaltina antiga, o Centro de Vivência, Planaltina nova, que é a Vila Buritis e depois então uma seria uma faixa que era uma nova faixa comercial, daí para diante então você tinha um espaço reservado para expansão futura de Planaltina. Então o Plano mostra a você por exemplo, o passado permanecendo, que era a cidade antiga, o espaço de permeio pra uma aculturação, presente, e uma perspectiva de futuro pra essa comunidade. (GOVERNO DO DISTRITO FEDERAL, 1985, p. 91-93).

Tendo em vista as explicações de Paulo Magalhães quanto à nova forma adquirida por Planaltina e da organização dos novos objetos espaciais, assim como da significação dada aos pretéritos sistemas de objetos, fica nítida a tentativa 
de harmonização ante o todo: a cidade. Esta nova configuração territorial pode ser obervada no mapa 06. 
Mapa 06 - Planaltina 1965 -1967.

Planaltina 1965-1967

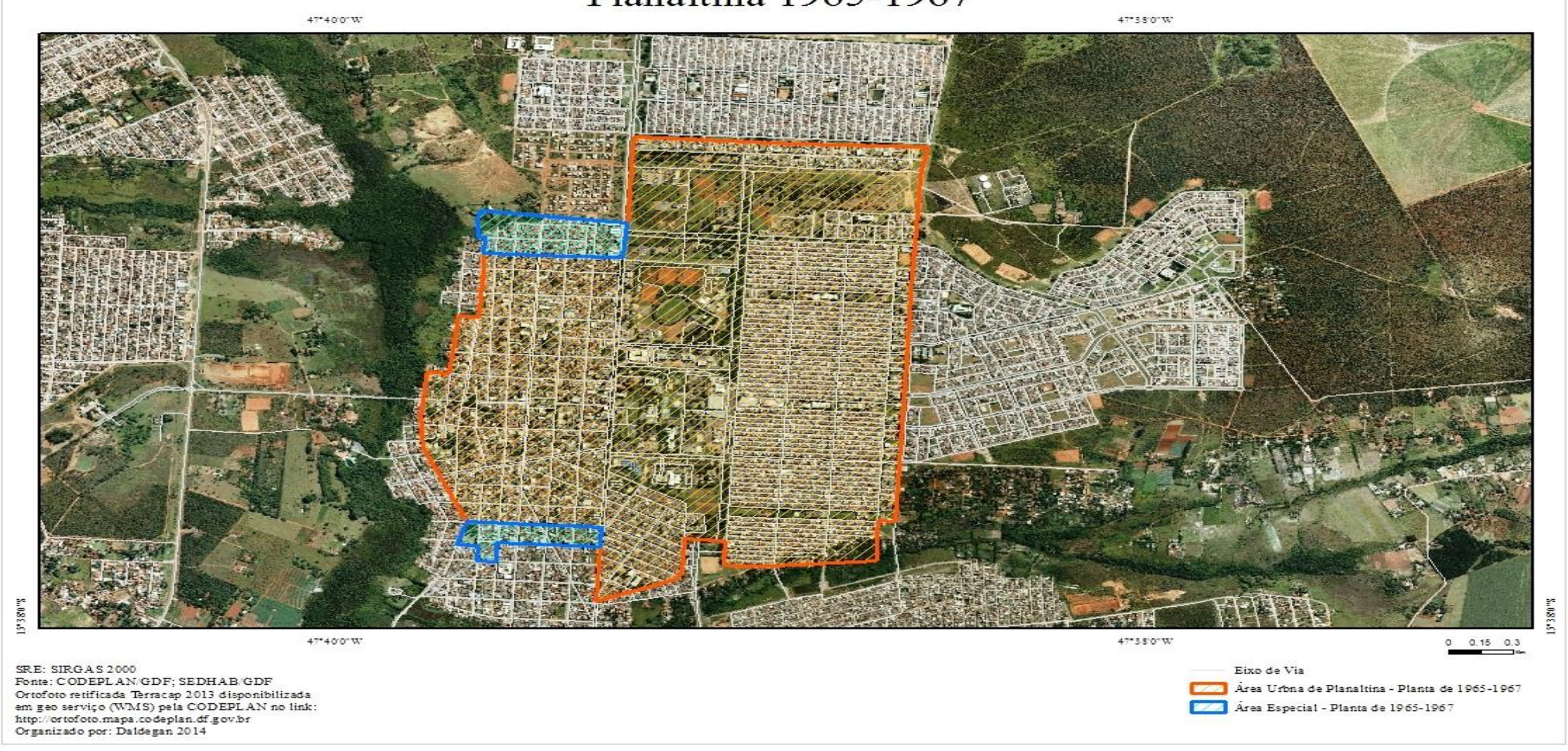

Fonte: Lima, 2014. 
Contudo, mediante o exercício de abstração, fica evidente que este novo total se dá pela soma de outra parte, uma nova fração, cujo significado dado ao território em uso e em movimento de totalização resultará em um novo todo complexo e conflituoso em detrimento a estrutura social pré-existente.

A estrutura social que nesse contexto passa a vigorar - goianos versus candangos - entra em conflito,tendo em vista as novas dinâmicas territoriais de uso do espaço urbano. O choque dialético que se estabelece, cujas transformações espaciais resultam do planejamento que inseria uma nova comunidade na já tradicional cidade pré-existente, causa um grande desconforto entre os antigos moradores e a nova disposição espacial dos equipamentos anteriormente presentes, com o remanejamento destes equipamentos em função da nova população que passa a compor o novo setor da cidade.

Com o processo de renovação populacional e chegada de novos moradores que passam a utilizar o sistema de objetos constituídos, essas inovações passam a serem incorporadas, naturalmente absorvidas pelos novos habitantes. $\mathrm{E}$ mesmo que, a priori com a chegada dos novos usuários, a relação de uso do território não possua um significado de cunho histórico e afetivo, notou-se que tal vínculo passava a se estabelecer com o passar do tempo.

Todavia, as alterações promovidas com base em princípios urbanísticos modernistas, redistribuindo a composição dos sistemas de objetos espaciais procedente da realocação dos candangos na cidade de Planaltina, a priori, são vistas, por muitos dos antigos moradores, como algo que descaracterizava a cidade, retirando a função do Setor Tradicional quanto aos papeis de centro detentor dos serviços públicos e do comércio, que migraram para o novo Centro de Vivência.

Neste sentido, é válido expor o sentimento de Otaviano Guimarães quanto à nova realidade da cidade pós-Brasília, percebendo, em seu ponto de vista, o aspecto positivo referente à vinda dos novos moradores, assim como a amargura das transformações espaciais, fruto do planejamento que responderia na constituição de uma nova totalidade: cidade, objetos espaciais, sociedade, novo uso do território em totalização:

Entrevistador - Como a cidade viu a vinda da Vila Buritis? 
Seu Otaviano - Pra mim foi uma coisa normal. Achei bom aumentar mais o barulho pra nós, mais alegria né?

Entrevistador - A cidade teve um Plano Diretor. O desenvolvimento da cidade ficou orientado nesse sentido: Setor Tradicional, Centro de Vivência, Vila Buritis. Como é que o senhor vê isso?

Seu Otaviano - uma coisa que eu não concordo. Tiraram tudo daqui, até a casa de loteria. Olha, o Banco está lá em cima. A Caixa Econômica vai lá pra cima, porque ali ela não vai ficar. Então a Administração devia deixar a casa de comércio aqui em baixo. Dar autonomia aos proprietários para construir loja de comércio aqui embaixo. Nós precisamos de ir pra lá pro Buritis e largar isso aqui, é uma verdadeira solidão que vai acabando tudo. Até nessa parte eu culpo Brasília, por que Brasília está fazendo isso. É uma galhardia tão grande, que eles só querem o que é deles. O que é novo, o que eles trouxeram pra cá eles valorizam. O que é velho eles não valorizam. (GOVERNO DO DISTRITO FEDERAL, 1985, p. 70-71).

Somado a essa percepção exposta por Otaviano Guimarães, outros moradores acentuam o sentimento de que este centro de vivência havia reafirmado o processo de segregação sócioespacial entre os novos moradores e os antigos, já que na Vila Buritis encontravam-se as populações originárias das invasões de Brasília e no Setor Tradicional havia a presença daqueles que habitavam há tempos e davam uso ao território em questão. Quanto ao Centro de Vivência e o cumprimento de sua função urbanística, Hosannah Guimarães relata a sua concepção assim:

Hosannah - Houve alguma mistura. Não foi uma mistura muito profunda, não, mas há sempre uma mescla. Então, a cidade sofreu. Conserva o seu aspecto tradicional naquela parte que era tradicional e na parte que foi planejada para a transferência das invasões conserva essa população adventícia que veio para Planaltina. E vamos crescendo aí nessa mistura, com as metamorfoses, as transformações que o impacto de duas civilizações - uma ultra conservadora, que era a local, outra advinda de todas as regiões do Brasil, principalmente do Nordeste, através das transferências de invasões - criou-se essa situação nova que nós estamos vivendo aí, que há quase uma divisão da área sede da administração, através daquela faixa que ficou reservada mesmo para separar a área dos que vieram, da área que já existia e onde está localizada o campo de futebol, a casa do Administrador regional, a Administração Regional, o Banco do Brasil, a Rodoviária, a Televisão, o Posto de Revenda, o Minibox, enfim, toda aquela faixa que está entre a Avenida Independência e os Buritis. (GOVERNO DO DISTRITO FEDERAL, 1985, p. 40). 
Tendo em vista a percepção de Hosannah Guimarães sobre o Plano urbanístico de 1965, Paulo Magalhães se expressa afirmando que grande parte dos problemas relacionados à concepção da Vila Buritis e o Centro de Vivência que passa a existir, é produto da maneira de como as remoções foram executadas, assim como do modo como efetivamente fora aplicado o seu projeto, dando a entender que a execução do novo plano urbanístico de Planaltina fora implantado às pressas.

Entretanto, fica nítido na fala de Hosannah Guimarães, que efetivamente o Centro de Vivência constituía uma barreira entre o velho e o novo. Depreende-se também que a organização dos objetos espaciais, em função da implementação de novos setores habitacionais, causara uma certa negação quanto ao seu uso por parte dos habitantes previamente existente.

Também há de se ressaltar que com a acomodação social oriunda do posterior incremento populacional e dos equipamentos públicos presentes no Centro de Convivência, obrigatoriamente esse espaço acaba por tornar-se um ponto de encontro obrigatório para os moradores da cidade. Isto se dá pela concentração do comércio e pela presença concentrada dos equipamentos públicos e administrativos contidos nesta localidade.

Muito embora existisse uma pressão crescente sobre as terras no que condiz ao seu uso e ocupação entre as décadas de 1960 e 1980, resultante das políticas rígidas de combate ao parcelamento do solo urbana e rural, sendo apenas permitidos aqueles implementados pelo Estado, cuja finalidade era evitar a ampliação da periferia já existente em Brasília, verifica-se que a configuração urbana de Planaltina proposta por Paulo Magalhães é mantida até meados da primeira metade da década de 1980 .

Também é notório que enquanto premissa do CIAM, ou seja, o total controle das terras públicas, a problemática do déficit habitacional só tende a aumentar no período em questão, gerando pressões, por parte da população, para ter acesso a parcelamentos urbanos, assim como pressão das corporações ligadas ao mercado imobiliário que também queriam atuar face ao domínio exercido pela Novacap, posterior Terracap. 
Tal fato é ratificado na fala de Otaviano Guimarães, tendo em vista que com a vigência de Brasília norteada pelos princípios do direito urbanístico propalado pelo CIAM, tem-se a imposição das normas de usos e ocupação do solo atrelados à burocracia estatal que se sobrepõe as antigas lógicas de posse da terra, vinculado à dinâmica de produção espacial do contexto colonial localmente. Assim Otaviano Guimarães se expressa:

Entrevistador - O Sr. Pode localizar pra gente que tipo de coisa o Sr. vê como deficiente com a vinda da Capital?

Seu Otaviano - Antes da mudança da Capital, nós que somos proprietários e outros que também são, aliás, mesmo que eu não fosse proprietário, mas falando de um modo geral, nós tínhamos uma liberdade ampla, de nós construirmos uma residência, por simples que fosse, ou melhor que fosse sem tanto protocolo, sem tanta dificuldade, como agente está tendo hoje. Quer dizer, a Capital trouxe um verdadeiro entrave, uma verdadeira dificuldade. Primeiro necessita de uma Planta que agente não tem possibilidade, depois vem mais outra coisa, depois mais uma outra coisa, uma série de coisas. Um puxado pra você fazer numa casa, você tem que fazer uma nova planta. Então trouxe tanta dificuldade pra nós que nós nos encontramos numa situação de uma barreira completamente intransponível. (GOVERNO DO DISTRITO FEDERAL, 1985, p. 68$69)$.

Esta situação relatada por Otaviano Guimarães (1985) também é identificada por Holston (1993), contudo, este salienta a dificuldade de permanência dos candangos nos lotes concedidos pela Novacap.

Neste sentido, além dos vínculos contratuais estabelecidos na relação de compra ou possíveis modificações na planta residencial, constituem em elementos onerosos para os candangos que buscam serem incorporados a uma situação de legalidade quanto ao uso e ocupação do solo, assim como para os antigos goianos, que além de dispendioso, foge aos princípios e costumes anteriormente construídos na trajetória da formação sócioespacial local.

Para Holston (1993), toda essa exigência imposto pela burocracia estatal representada pela Novacap - forma de pagamento das propriedades ofertadas pelo Estado, planta de edificação, cronograma de execução de obras, dentre outros elementos - constituíam mecanismos utilizados pela empresa pública 
para desencorajar a permanência dos candangos realocados nos respectivos bairros das então instituídas Cidades-Satélites.

Tais exigências constituíam, conforme é salientado por Otaviano Guimarães, grandes obstáculos face ao pleno exercício do direito a propriedade, mesmo nos espaços reservados a classe operária, tendo como saída a venda de seu lote e a ida para novos assentamentos clandestinos que então passaram a surgir continuamente no Distrito Federal.

Sobre os dispositivos contidos nos contratos de promessa de compra e venda estabelecidos entre a Novacap e os adquirentes, bem como as normas a serem cumpridas pelas populações economicamente desprovidas e que dão a noção da dificuldade de efetivação das cláusulas previstas em tais mecanismos reguladores, Holston (1993) tece um breve comentário:

(...) Em primeiro lugar, é um contrato de venda direta, não um acordo de arrendamento. Essa venda se dá em hasta pública, não dependendo mais de uma seleção dos interessados, sem restringirse a determinados grupos de status. Segundo, suas condições são bem diferentes: $30 \%$ à vista, e o restante em trinta pagamentos com $6 \%$ de juros ao ano mais correção. Terceiro, embora o contrato de compromisso da Novacap obrigue o arrendatário a construir uma casa, o pacto de retrovenda do novo contrato especifica que depois de quatro meses da data da compra, o proprietário terá de apresentado à Terracap: 1) planta definitiva da casa e 2) um cronograma físico-financeiro mostrando os prazos para as etapas da construção e uma prova dos meios de que dispõe para pagar cada etapa. Mais ainda, no prazo de 36 meses, o proprietário tem de demonstrar que terminou a construção, apresentando o "habite-se". O não atendimento destas três condições dá a Terracap o direito de, ao fim dos três anos, resgatar o terreno, ou seja, o proprietário é obrigado a vendê-lo de volta à Terracap, vindo daí o nome de contrato. Contudo, durante esses três anos, o proprietário pode vendê-lo a qualquer hora, a qualquer pessoal, e a qualquer preço, sem aprovação prévia (...)

Sem dúvida, o contrato de retrovenda é mais favorável ao comprador do que o contrato de compromisso. Em geral, contudo, estas vantagens só estão à disposição de compradores de alta renda. Os brasilienses das classes trabalhadoras consideram proibitivas as exigências (...) (HOLSTON, 1993, p. 305).

Em documento anexo (01), é possível ver um contrato particular de promessa de compra e venda e seus os dispositivos, os quais delineiam tal relação contratual evidenciadas na abordagem de Holston, cuja dificuldade de acesso aos 
lotes comercializados pela Novacap/Terracap, assim como do cumprimento de suas exigência, foi retratado por Otaviano Guimarães (1985).

Mesmo sendo explicitadas as condições de difícil acesso as terras comercializadas pela Novacap/Terracap, delimitado no contexto espaço-temporal entre as décadas de 1960 e 1980, cuja dificuldade de fixação e legalização imposta pela política habitacional replica no pleno exercício do direito de propriedade em um contexto atual; após breves pesquisas realizadas nos sites das distintas esferas do Poder Judiciário, a princípio, não se identifica a existência de lides entre a Terracap e supostos proprietários não indenizados da localidade que atualmente corresponde as quadras de 01 a 06 da Vila Buritis.

Isso demonstra que efetivamente essas terras foram devidamente desapropriadas e que as relações de compra e venda dos lotes ocorrem segundo os ditames legais. Sobre essa relação comercial lícita, o Tabelião Breno de Andrade Zoehler, do $12^{\circ}$ Cartório de Ofício de Planaltina testifica que o assentamento em questão segue todos os preceitos legais, uma vez que fora implementado pela Novacap.

Todavia, ainda enquanto traço cultural que remonta ao contexto colonial referente às práticas de regularização da situação jurídica dos imóveis, ou a ausência dela, o referido tabelião explicita que as escrituras de grande parte dos imóveis que correspondem a Vila Buritis ainda não foram efetivadas.

Tal fato também se dá quanto a não averbação dos registros em nome dos seus respectivos ocupantes, caracterizando uma situação de precariedade em detrimento da dominialidade e efetivo exercício do direito pleno a propriedade, cujas transações, até então, usualmente, se dão por sessão de direitos ${ }^{32}$. Tendo em vista esta situação, é válido expor a fala do referido Tabelião sobre a questão:

\footnotetext{
${ }^{32}$ A Lei $n^{\circ} 6.015$ em seu art. $129,9^{\circ}$, determina que "Estão sujeitos a registro, no Registro de Títulos e Documentos, para surtir efeitos em relação a terceiros (...) os instrumentos de cessão de direitos e de créditos, de sub-rogação e de dação em pagamento. A Cartilha dos Atos Notariais e de Protestos assevera que a cessão de direitos possessórios caracteriza-se quando "a pessoa tem a posse de um imóvel e não possui a propriedade, podendo ceder os direitos possessórios a terceiros", via notarial cessão de direitos. (CARTILHA DOS ATOS NOTARIAIS E DE PROTESTOS. In: http://www.colegionotarialrs.org.br/site/images/stories/Cartilhas/cartilha_\%20atos_e_\%20protestos_\%202012.pdf; acessado em 05 de maio de 2014).
} 
Um problema que agente tem, muito crasso, com relação à regularização do Distrito Federal, dentro dessas política habitacionais, eles enviam para os cartórios (...) e os cartórios tem que mandar correspondência, tem que entrar em contato com essas unidades, com as pessoas, para que essas pessoas venham receber o lote delas: é gratuito para eles! E as pessoas não vem, não vem! Você manda, você liga (...) e eles não regularizam.

E porque não regularizam? Por um milhão de motivos. Por que 0 brasileiro não é muito afim de regularizar as coisas. O que agente vê é isso.

Quando é que eles regularizam? Quando vai dar o "pepino". Quando já estão correndo atrás do prejuízo aí eles regularizam. Mais até ai, estão recebendo praticamente de graça para consolidar a propriedade dele, pra poder alienar com financiamento, ou algo assim, agente vê é que é baixo. Eu não tenho uma estatística aqui, mas é baixo o percentual de pessoas que, sendo convocadas, comparecem a serventia.

Geralmente o quê você vê são geralmente os adquirentes: os terceiros, quartos, quintos adquirentes depois (...) que vem fazer. Então é muito a conta gota (...) sendo que é algo que é benéfico a eles.

No Brasil não tem essa cultura, por que a posse é muito mais prestigiada do que a propriedade. (ZOEHLER, 2013).

Mesmo ao perceber que a questão do exercício pleno do direito de propriedade também passa pela desinformação quanto à importância da escrituração e registro dos imóveis em cartório, identifica-se que essa possibilidade de regularização da situação do bem imóvel, contidos nas quadras pertencentes à Vila Buritis em comparação ao Setor Tradicional, são de fácil resolução.

Conforme será exposto no próximo tópico, verifica-se que o pleno exercício do direito de propriedade quanto aos imóveis contidos no Setor Tradicional, com a vigência de Brasília, cada vez mais ganha em complexidade sem haver uma resolução quanto às questões que colocam a situação documental das habitações ainda em precariedade jurídica, dificultando a efetivação do registro em cartório das mesmas.

As situações a serem descritas a seguir, muito embora configurem inércia ou omissão quanto da atuação do novo Poder Executivo local ou até mesmo dos proprietários dos imóveis, acabarão por transitar nos tribunais no transcorrer da década de 1990 até os dias atuais, repercutindo na judicialização do território de Planaltina e, em especial, do Setor Tradicional. 
3.3 - A continuidade da precariedade jurídica do Setor Tradicional (19611980.

Conforme fora abordado nos capítulos anteriores que remontam o exercício de periodização pautado no uso da categoria formação socioespacial, cujo objeto é a cognição da produção do espaço urbano da cidade de Planaltina correspondente ao atual Setor Tradicional em seu contexto pré-Brasília, apresentouse uma série de eventos que resultam na questão da precarização jurídica de sua área urbana face ao não cumprimento de várias determinações de uma série de dispositivos legais, dentre eles, a Lei oㅡ 58/37 que dispunha sobre o parcelamento e a venda de lotes.

O desdobramento de tais eventos impactarão no pleno exercício do direito de propriedade, repercutindo na judicialização do território usado. Este último interpretado enquanto sinônimo de espaço geográfico, cuja complexidade das múltiplas ações dos diversos agentes e estruturas espaciais, se dão no âmbito do presente.

Fora relatado que a Prefeitura de Planaltina-GO, na tentativa de ordenar e regularizar da situação jurídica de sua área urbana, não obtivera sucesso, uma vez que o seu ato não resultara no efeito jurídico esperado, já que ambas as plantas da cidade (a de 1941 e de 1958), elaboradas no contexto pré-Brasília, não foram registradas em cartório.

Também foi explicitado que mesmo as plantas urbanas não tendo sido levadas a registro, foram utilizadas por distintas gestões do então Poder Executivo local com intuito de efetivar as políticas urbanas municipais, tendo enquanto resultado o registro em cartório de algumas propriedades.

Observou-se também que, além das plantas da cidade não passarem por registro, muitas propriedades alienadas pela então prefeitura se deram mediante a emissão de Alvarás de Concessão, não dispondo assim o contemplado, em um primeiro instante, do pleno exercício ao direito de propriedade, tendo em vista que a mesma modalidade não possuía efeito registral, associado ao fato de que o domínio do terreno ainda seria da referida prefeitura.

Contudo, tais propriedades alienadas apenas por Alvarás de Concessão, segundo a política urbana local, foram incentivadas a serem registradas 
em cartório para efeito de regularização tendo em vista a política municipal implementada. O que verificou-se foi que a maioria dessas propriedades não foram registradas e logo comercializadas, perpassando tal situação ao contexto pósBrasília.

Neste primeiro momento, observou-se também a implementação de loteamentos particulares que estariam dentro dos limites da antiga Fazenda Mestre D'Ármas e que corresponderia à Transcrição $n^{\circ} 303$, como o caso do Bairro Nossa Senhora de Fátima. Mas, pelo fato da planta/58 não ter sido registrada, tais parcelamentos também ficaram em situação ilegal juridicamente, tendo em vista os dispositivos do artigo $1^{\circ}$ da lei $n^{\circ} \mathrm{n} 58 / 37$.

Segundo Castro (2014), com a inauguração de Brasília, um terço do território pertencente à Prefeitura de Planaltina de Goiás é incorporada aos limites do Distrito Federal, incluindo a área urbana de Planaltina contida juridicamente na Transcrição $n^{\circ} 303$.

Vários proprietários que adquiriram lotes no Bairro Nossa Senhora de Fátima foram indenizados e suas residências desconstituídas, entretanto, ainda existem antigos adquirentes que residem em tal localidade. Todavia, a SEDHAB garante a total desapropriação deste bairro, bem como do Setor Habitacional Vale do Amanhecer em informações recentemente disponibilizadas em seu site.

Como fora exposto, com a inauguração de Brasília e a vigência de um novo sistema político-administrativo, a partir do ano de 1965, Paulo Magalhães é nomeado Administrador Regional acumulando também as funções de arquiteto e urbanista.

Em sua gestão, Paulo Magalhães produz o novo Plano Urbanístico da cidade, cujas finalidades repousavam na elaboração de uma nova planta urbana para a regularização dos imóveis urbanos contidos no Setor Tradicional, além da implementação da Vila Buritis - quadras de 01 a 06 -, assim como na contenção da expansão urbana da cidade, uma vez que anteriormente a vigência da nova capital, terras não desapropriadas pertencentes a particulares, ainda estavam sendo alienadas, comercializadas. 
Conforme relatório produzido pela GENOR (2012), os dois últimos objetivos foram efetivamente alcançados, já que no transcorrer da década de 1960 até o princípio da década de 980, ocorrera à implementação da Vila Buritis e a contenção da expansão das áreas adjacentes à cidade, próximas aos Córregos do Atoleiro, Buritizinho e Ribeirão Mestre D’Ármas, que viriam a espraiar-se a um momento posterior e de maneira clandestina.

Estes eventos espaço-temporalmente correspondem ao que é interpretado como segundo ciclo de expansão da cidade, que até a primeira metade da década de 1980 era restrito ao já consolidado Setor Tradicional, Vila Vicentina, Vila Buritis. Esta proposta de configuração territorial pode ser visualizada no mapa 07.

Todavia, ainda existiam moradores remanescentes do Bairro Nossa Senhora de Fátima e do Vale do Amanhecer, sendo que o primeiro setor fora parcelado pelo seu respectivo proprietário, já o segundo caracterizado enquanto invasão de terras particulares.

Segundo a GENOR (2012) o Plano de Urbanização de Planaltina, executado pelo Administrador Paulo Barbosa Magalhães, resultou nas plantas PR2/1 (Plano Diretor da Cidade), PR-3/1 (Setor Industrial e Residencial), PR-4/1 (Setor Tradicional) e PR-5/1 (Vila Vicentina). Visualmente, tal ordenamento encontra-se no mapa 07.

No esforço de conter o crescimento da cidade, somado à preservação de seu núcleo tradicional, a Ação Declaratória de Nulidade de Ato Administrativo no 1874 de 1993 relata que Paulo Magalhães eliminou da planta correspondente ao Setor Tradicional (PR-4/1) mais de 1200 lotes das extremidades Norte e Sul do Córrego Mestre D'Ármas, presentes na planta/58, elaborada pela Prefeitura de Planaltina de Goiás. 
Mapa 07 - Sobreposição das plantas de Planaltina em 1958 e 1965-1967.

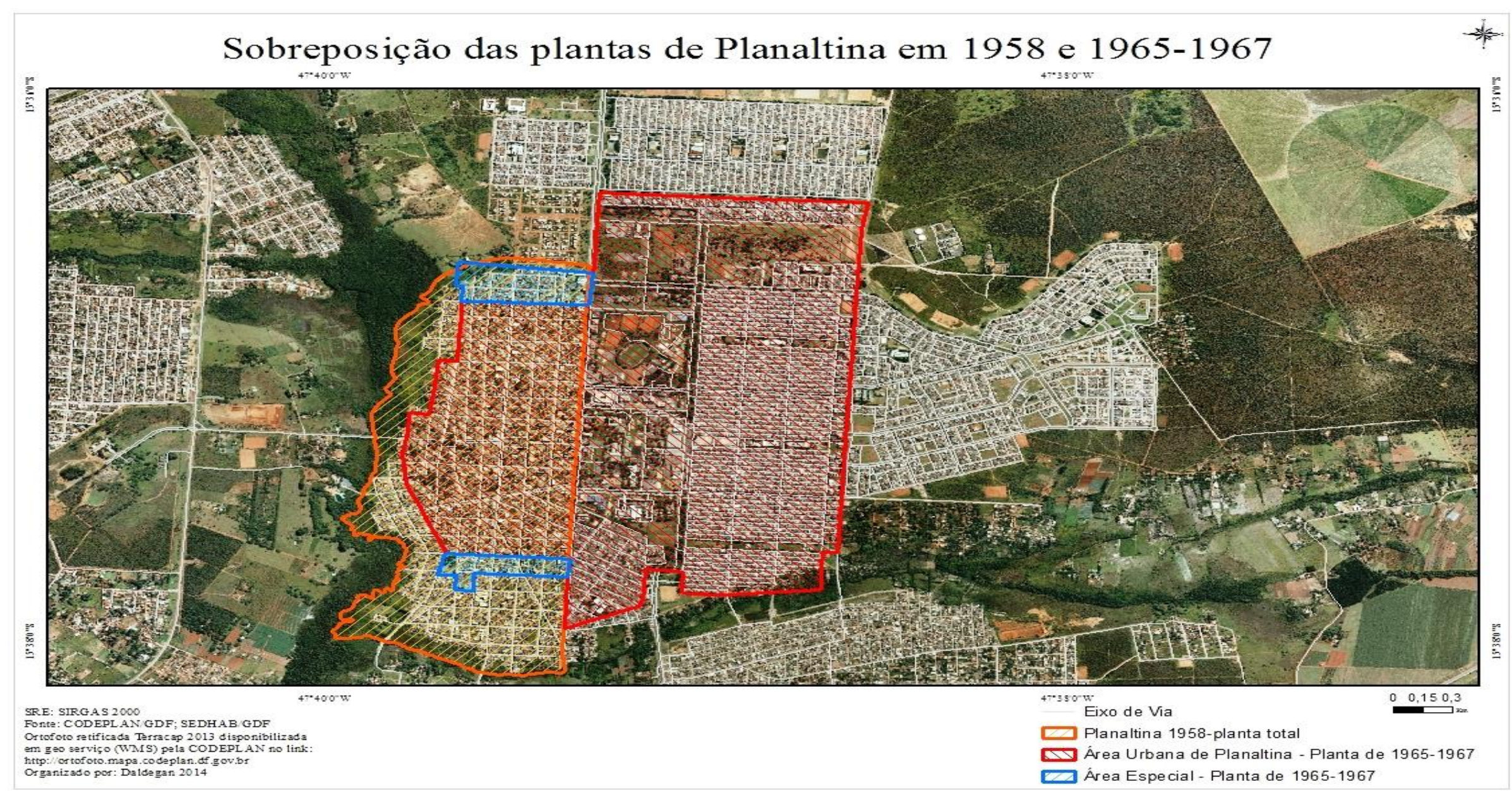

Fonte: Lima, 2014. 
Devido à dificuldade de acesso às informações contidas nas plantas de 1941 e de 1958, deduz-se que boa parte dos lotes excluídos corresponde ao atual Setor Sul da cidade, tendo enquanto prova documental o Alvará de Concessão (anexo 02), cuja data de aquisição corresponde ao dia de 09 de março 1960, já dispondo inclusive do atual endereço e referências aos demais lotes contidos no setor atualmente. As terras deste setor só seriam novamente comercializadas a partir década de 1980, pelas imobiliárias e, posteriormente, pela Prefeitura de Planaltina de Goiás.

Outro elemento que ajuda a comprovar tal inferência pode ser vista na figura 10, extraída da folha SD.23-Y-C-4 MI-2215 (IBGE, 1993). Embora sua data de impressão seja do ano de 1993, ao observar a legenda da referida folha, constata-se que a cobertura aérea fora realizada no ano de 1982 e o apoio em campo em 1983. Ou seja, embora tenha sido impressa no ano de 1993, a configuração territorial disposta remonta à primeira metade da década de 1980, contendo apenas um grande vazio urbano entre o Setor Tradicional e o Bairro Nossa Senhora de Fátima, situando-se, no referido vazio, o atual Setor Sul de Planaltina.

Segundo a GENOR (2012), além destas eliminações de loteamentos, foram criadas na PR-4/1 áreas especiais superpostas a 212 lotes contidas na planta/58 situadas no Setor Tradicional, além de deixar sem destinação diversas áreas que constavam na planta anterior, constituindo cartograficamente em áreas em branco.

Ou seja, amplia-se a dificuldade de se estabelecer efetivamente uma interpretação do que eram lotes particulares ou terras públicas para a destinação quanto ao uso público (praças, quadras esportivas, lotes destinados à alocação de escolas, hospitais, dentre outros).

Entretanto, conforme consta no anexo 02, vários lotes que haviam sido retirados ou fora dado novas destinações com planta PR-4/1 já haviam sido inclusive comercializados pela Prefeitura de Planaltina de Goiás entres os anos de 1958 e 1961, somando-se as alienações incorporadas à planta/58 oriundas da planta elaborada em 1941. 
FIGURA 10: Configuração urbana de Planaltina (1983).

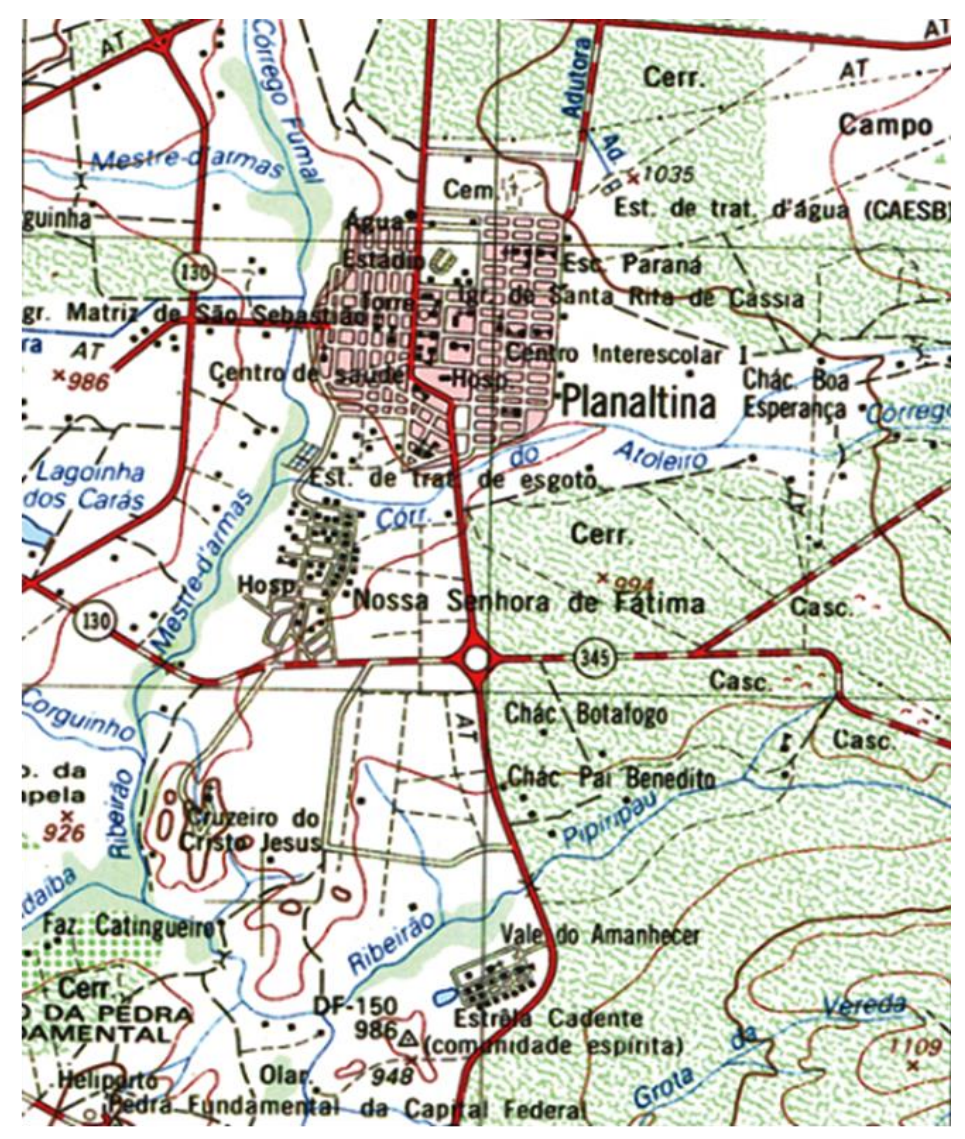

Fonte: Instituto Brasileiro de Geografia e Estatística (1993) carta SD-23-Y-C-IV, MI 2215.

O resultado dessa sobreposição de plantas urbanas e de seus respectivos memoriais descritivos não registrados em cartório é relatado na Ação Declaratória de Nulidade de Ato Administrativo ํo 1874 de 1993, da seguinte maneira:

Com essa situação surgem duas ordens de problemas segundo o Grupo de Regularização Fundiária da Terracap:

Da impossibilidade de registro dos terrenos que integram que tiveram apenas seus respectivos contornos definidos, sem que fossem criados os lotes correspondentes;

Dos lotes que constavam da planta anterior, aprovada pela Prefeitura Municipal de Planaltina-GO e não constam da atual, aprovada pelo Governo do DF.

(...) Os proprietários excluídos ficaram inibidos de exercerem os seus legítimos direitos de propriedade, isto é, os interessados não podiam a partir daí edificar, terem acesso a financiamentos e disporem 
livremente da propriedade. (MINISTÉRIO PÚBLICO DO DISTRITO FEDERAL E TERRITÓRIOS. Ação Declaratória de Nulidade de Ato Administrativo de número. A. S. 1874/1993, p. 12).

Mesmo com tais problemas - sobreposição de limites, desconsideração de lotes anteriormente alienados pela prefeitura de Planaltina de Goiás pelo novo Plano Diretor, dentre outros elementos anteriormente citados - a GENOR (2012) relata que a PR-4/1 é aprovada pelo Decreto "E" n 172 de 16 de janeiro de 1967, sendo homologado pelo Prefeito do Distrito Federal, Plínio Castanhede.

Segundo as informações contidas na Ação Declaratória de Nulidade de Ato Administrativo n 1874 de 1993 em sua página de número12, com a aprovação da nova planta urbana em 1967, a Terracap dá prosseguimento à tentativa de legalização dos lotes situados no Setor Tradicional, sendo estes registrados nos cartórios do Distrito Federal.

Os lotes registrados seriam aqueles cuja origem documental proviam de Registros Paroquiais, dos Alvarás de Concessão e, até mesmo, os lotes não contemplados no plano diretor por estarem sem destinação na planta PR-4/1: os lotes em branco ou vazios. Sobre o processo de regularização, o relatório mencionado ainda descreve:

Muitos destes registros foram conseguidos após os trabalhos
iniciados pela Terracap em 1973, que visavam à regularização dos
lotes do Setor Tradicional. Estes trabalhos não foram conclúdos,
porém algumas situações ficaram definidas, por exemplo, uma
padronização dos memoriais descritivos e da documentação da
certidão dos imóveis fornecidas pela Administração Regional que
atestavam os limites de cada propriedade. (MINISTÉRIO
PÚBLICO DO DISTRITO FEDERAL E TERRITÓRIOS. Ação
Declaratória de Nulidade de Ato Administrativo de número. A. S.
1874/1993, p. 12).

Contudo, segundo a GENOR (2012), além dos elementos que comprometeriam a validade da nova planta produzida para a cidade, o relatório cita que nenhuma providência foi tomada para a inscrição da PR-4/1 em cartório, constituindo em mais uma tentativa em vão de alcançar a almejada regularização do Setor Tradicional. 
Com a vigência da Lei ํㅜ 6.766/79 que passa viger em detrimento a vários dispositivos contidos Lei no 58/37, tanto a planta/58, como a PR-4/1 passam a não produzirem efeito legal pelo fato de não terem sido registradas em cartório, infringindo vários dispositivos explicitados nesse texto legal, tais como os artigos $6^{\circ}$, $7^{\circ}, 9^{\circ}$, e outras normas contidas na nova Lei de parcelamento do solo.

Vale ressaltar que mesmo Planaltina sendo incorporada ao território do Distrito Federal, tendo enquanto símbolo o progresso, a modernidade, a aceleração das dinâmicas espaço-temporais, tendo em vista o arcaísmo das porções interioranas ao qual o Sertão Planaltino de Magalhães (2011) se incluía, vê-se que a ineficácia e lentidão relacionada à condução das políticas públicas não acompanharam o traçado urbanístico da cidade futurista, padecendo dos mesmos erros de outrora.

Entretanto, o que mais impressiona no relatório produzido e emitido pela Genor (2012, s/p), é que após a aprovação da planta em 1967, percebe-se que a PR-4/1 não dispunha de efeito jurídico apenas no dia 05 de abril do ano de 1984, sendo identificado pelo DAU/SVO (Departamento de Arquitetura e Urbanismo/ SIVSOLO) "por tratar de proposta de loteamento de área não regularizada após verificação daquele departamento de não haver Decreto aprobatório nem registro em cartório". O referido relatório ainda pontua:

Obs.: Esta planta, não tendo efeito legal, pois não foi registrada em cartório no período de 6 meses de validade do Decreto " $E$ " $n^{\circ} 172$, teve efeito administrativo, quando pautou as atividades administrativas da RA-VI e dos órgãos de Distrito Federal. (GOVERNO DO DISTRITO FEDERAL; SECRETARIA DE ESTADO DE HABITAÇÃO, REGULARIZAÇÃO E DESENVOLVIMENTO URBANO. Processo 135.000.703/1995. Gerência da Unidade de Planejamento Territorial Norte, 2012).

Outro fator que atesta a ausência do efeito jurídico da planta PR-4/1por esta não conter registro cartorial, se dá pelo fato data a Administração Regional de Planaltina conceder até o período anterior à vigência da Lei 6.766/79 Certidões de Desmembramento e Certidões de Imóveis, contendo nestas os seus limites. Após referida Lei entrar em vigor, a Administração para de emitir as certidões que possibilitariam aos supostos proprietários o registro dos imóveis em cartório. 
Tomando como referência todos esses relatos, evidencia-se que o pleno gozo do direito de propriedade dos habitantes do Setor Tradicional, a cada década que passa em seu contexto pós-Brasília ganha em complexidade. Em uma sociedade em que a dominialidade e usufruto da terra ocorria através do acordo verbal, conflita-se com a nova ordem burocrática imposta pela transferência da nova capital para o Planalto Central.

Este evento faz emergir toda a situação de precariedade jurídica das propriedades rurais e urbanas, assim como da fragilidade face ao pleno exercício do direito de propriedade pelos moradores locais. Estas situações são herdadas pela nova administração que passa a agir sobre os antigos problemas locais e sobre as velhas dinâmicas de produção do espaço urbano herdados por sua formação socioespacial, negando-as, a princípio, conforme fora exposto por Holston (1993).

No caso de Planaltina, é perceptível no processo de totalização de seu espaço urbano a continuidade dos problemas de cunho administrativo que impactam nas dinâmicas sociais de uso do território. O resultado de tais eventos é acontinuidade da precariedade jurídica dos imóveis, dificultando o registros em cartório dos imóveis contidos na antigo Setor Tradicional.

No próximo e último capítulo será exposto a continuidade do processo de formação socioespacial da cidade objeto, cuja síntese - território usado no presente - passará por seu terceiro ciclo de expansão, segundo ciclo pós-Brasília, ampliando os seus limites e lides territoriais, assim como as demandas quanto da atuação do Poder Judiciário em suas distintas esferas perante os litígios que vem a surgir.

Será exposto também que os problemas referentes à efetiva regularização de várias propriedades contidas no Setor Tradicional se ampliam, uma vez que Prefeitura de Planaltina Goiás passa a requerer do Distrito Federal o pagamento de indenização dos espaços urbanos contidos em tal setor junto aos tribunais, argumentando que a dominialidade exercida anterior a Brasília ainda vigora, desdobrando-se no caso mais complexo junto ao todo em suas partes que constituem a cidade de Planaltina. 
Logo, será evidenciado a acumulação dos problemas de ordem jurídica face a legalidade ou a ilegalidade dos imóveis, assim como os desdobramentos das decisões de tal instância de poder no uso do território e na composição dos sistemas de objetos espaciais. 


\section{Capítulo 4 - IV - 0 território usado e seus múltiplos agentes: A judicialização territorial em Planaltina- DF (de 1985 aos dias atuais).}

No transcorrer do presente estudo, buscou-se compreender e explicitar a formação socioespacial da cidade de Planaltina, tendo em vista em seu processo de totalização o acúmulo do trabalho oriundo dos múltiplos agentes em distintos períodos, cujas ações repercutiram na composição dos seus objetos espaciais, nas formas-conteúdo, assim como nas transformações atinentes à estrutura social, que ao mesmo tempo, produziram e deram usos aos sistemas de objetos contidos no território.

No exercício de periodização propiciado pela categoria de formação socioespacial, almejou-se expor os processos que responderam na construção e de uso juridicamente precarizado do espaço urbano, desdobrando-se na fragilidade quanto ao exercício do direito de propriedade de seus habitantes em meio ao movimento de totalização.

Neste sentido, aspirou-se, através da periodização contida na categoria de formação socioespacial, trazer a simultaneidade e a complexidade dos processos em suas múltiplas escalas em consonância aos ciclos de expansão do espaço urbano de Planaltina, até chegar ao presente.

Nesta perspectiva, Planaltina-DF é interpretada enquanto território usado e tida como fração (subespaço/lugar) de uma totalidade maior e ao mesmo tempo uma totalidade, um todo também composto por partes, podendo tal inferência ser percebida ao analisar-se a expansão de sua malha urbana em conjunto aos distintos ciclos de crescimento da cidade, assim como da situação jurídica dos loteamentos que se sucedem. Essa leitura espaço-temporal é enfatizado por Bernardes et all (2000) da seguinte maneira:

(...) A riqueza da geografia como província do saber reside, justamente, no fato de que podemos pensar, a um só tempo, os objetos (a materialidade) e as ações (a sociedade) e os mútuos condicionantes entretecidos com o movimento da história. As demais ciências humanas não dominam esse rico veio epistemológico. 
O território usado constitui-se como um todo complexo onde se tece uma trama de relações complementares e conflitantes. Daí o vigor do conceito, convidando a pensar processualmente as relações estabelecidas entre o lugar, a formação socioespacial e o mundo. (BERNARDES et all, 2000, p. 03)

Essa trama, a qual propõe-se analisar o presente estudo, face à judicialização de Planaltina, território usado, é suscitada por Bernardes et all (2000) ao discutirem sobre a importância da produção de uma leitura complexa e totalizadora quanto da real simultaneidade de fatores que se desdobram sobre 0 espaço.

Essa complexidade e simultaneidade de ações, repercutem na produção dos objetos espaciais associados à multiplicidade de intencionalidades oriundo dos mais diversos agentes contidos no território usado, ou até mesmo externos a este território em uso, independente da intensidade, abrangência ou expressividade de suas ações.

Sobre o território usado, sinônimo de espaço geográfico e de espaço banal e da multiplicidade de agentes que produzem sua materialidade, Bernardes et all (2000) assim se expressam quanto à categoria em relevo:

A compreensão do espaço geográfico como sinônimo de espaço banal obriga-nos a levar em conta todos os elementos e a perceber a inter-relação entre os fenômenos. Uma perspectiva do território usado conduz a ideia de espaço banal, o espaço de todos, todo o espaço. Trata-se do espaço de todos os homens, não importa as suas diferenças; o espaço de todas as instituições, não importa a sua força; o espaço de todas as empresas, não importa o seu poder. Esse é o espaço de todas as dimensões do acontecer, de todas as determinações da totalidade social. (BERNARDES et all, 2000, p. 0203).

O território usado é o espaço receptáculo de diversas ações, cujo Poder Judiciário também está contido e que também o contém, uma vez que sua atuação e sua razão de existência coadunam com a própria sociedade, aonde tal instância em seu movimento dialético é fruto desta mesma sociedade, mas também interfere sobre esta em seu movimento em virtude de suas ações. 
Nessa ótica, pode-se apreender que o território usado é composto pelo acúmulo de sucessivas totalidades cuja leitura desta complexificação é propiciado mediante a cognição das respectivas formações socioespaciais em análise, tendo em suas respectivas sociedades historicamente delimitadas pelo seu refazer-se fruto de seu movimento, a diversidade de elementos que confluem no plano do lugar/subespaço.

Tem-se enquanto componentes estruturantes neste constante refazer, as técnicas e as ações em associação com as formas produzidas. Assim, as normas jurídicas são interpretadas como técnica, e as decisões emanadas pelo Poder Judiciário enquanto ações vinculadas a essa técnica, desdobrando-se no plano espacial e na composição dos sistemas de objetos. Essa interpretação não despreza as demais estruturas que compõem o todo e que interagem de maneira simultânea. Sobre as relações comentadas, Silveira (2011) expõe que:

(...) a cada momento histórico, o território de um país pode ser visto como um campo de forças que operam sobre formas "naturais" e artificiais. Mas estas formas têm um papel dinâmico, participando na produção de maiores densidades técnicas, informacionais e normativas. Todavia, se as formas são importantes, também o são as ações humanas, isto é, o comportamento no território das pessoas, das instituições, das empresas, determinando um dinamismo que varia segundo sua origem, sua força, sua intencionalidade, seus conflitos. O território usado é assim uma arena onde fatores de todas as ordens, independentemente da sua força, apesar de sua força desigual, contribuem à geração de situações. (SILVEIRA, 2011, p. 04-05).

O Poder Judiciário em suas diversas esferas, ao lidar com a sociedade - que se constitui em uma totalidade e que também pela existência dos distintos segmentos influenciam e convergem na produção material dos objetos geográficos em seu movimento contraditório, é impactado pelas ações desses segmentos sociais locais que, corporativamente, induzem na produção do movimento do território.

Vale ressaltar que a norma jurídica enquanto técnica, compõe-se efetivamente do acúmulo de costumes que são codificadas imaterialmente em diretrizes, que ao longo do tempo foram estabelecidas com o objetivo de regerem as relações sociais, ganhando robustez e complexidade com o tempo. 
Logo, a norma jurídica enquanto técnica é caracterizada no tempo presente como herança acumulada advinda da produção das sociedades anteriores, ganhando novos contornos, ao passo em que novas totalidades surgem - novas sociedades, com novas técnicas, novas relações de produção, novos modos de vida, novas demandas sociais e corporativas. A norma é o fundamento que se dá a ação, decisão do Poder Judiciário.

Santos (2002) trata da relação existente entre as normas e sua atuação em diferentes escalas, assim como da intencionalidade de sua produção e aplicabilidade da seguinte maneira:

(...)Como as ações, as normas também se classificam em função da escala de sua atuação e pertinência.

A ordem mundial é cada vez mais normativa e, também, é cada vez mais normada. Esse fato responde à preeminência da técnica em todos os aspectos da vida social, já que o próprio fenômeno técnico é ser, há um tempo, normativo e normado (...) (SANTOS, 2002, p. 228).

Percebe-se que o território usado - sinônimo de espaço - torna-se o receptáculo de todas as ações, tendo no plano do lugar, subespaço, enquanto fração desse território, a possibilidade de compreender a mecânica da convergência dessas múltiplas ações na produção de um espaço singular.

As categorias totalidade, técnica e lugar/subespaço, através do exercício de abstração nos propiciam tal análise, tendo na técnica a fusão das inúmeras maneiras de execução do trabalho associado à construção das normas que regem a produção. Esta produção é fruto das relações sociais e que dialeticamente com suas mutações repercutem na construção de novas normas e vice-versa, como nas novas dinâmicas espaciais de produção e vice-versa.

Tal raciocínio nos permite, também, transitar do abstrato ao concreto, uma vez que para Santos (2002) a busca efetiva pelo estabelecimento de um sistema de teorização tem por ambição o alcance da totalidade em sua integridade, em sua realidade, sua concretude e o lugar/subespaço mediante a confluência das técnicas - tendo a norma, sua interpretação e as decisões/ações um de seus 
componentes - a possibilidade efetiva de visualização da dinâmica da vida real. Nestes termos o autor expressa que:

A totalidade é a realidade em sua integridade. (...) A totalidade é o conjunto de todas as coisas e todos os homens, em sua realidade, isto é, em suas relações, e em seu movimento.

Assim, o espaço, é, antes do mais, especificação do todo social, um aspecto particular da sociedade global. A produção em geral, a sociedade em geral, não são mais do que um real abstrato, o real concreto sendo uma ação, relação ou produção específicas, cuja historicidade, isto é, cuja realização concreta somente pode dar-se no espaço. (SANTOS, 2002, p. 116-120).

Como fração de uma totalidade, a Região Administrativa de Planaltina responde de maneira impar ao modo de produção capitalista em seus distintos períodos e, atualmente, a sua configuração territorial retrata essa lógica que perpassa e é edificada ao longo do tempo, mediante aos processos resultantes das ações que se desdobram na composição de sua forma-conteúdo, dos objetos geográficos nela contidos, advindos de múltiplos agentes. Tais objetos são carregados de intencionalidades e moldados pelas técnicas em virtude da evolução da produção e do trabalho.

As normas em sua "forma jurídica" (Santos 2002, p. 82) assim como as decisões proferidas pelo Poder Judiciário em suas diferentes esferas, também são caracterizadas enquanto "ação", fruto da evolução das técnicas em prol da produção do espaço conforme a diversidade de demandas, em detrimento da multiplicidade de agentes contidos no território usado.

As normas, assim como as técnicas caracterizam-se como comandos que constituem os sistemas de ações que repercutem na materialização do sistema de objetos espaciais - forma-conteúdo. Tais normas, no caso em apreciação, são interpretadas e proferidas por um elemento que também é peça que constitui tal totalidade: O Poder Judiciário e suas decisões/ações.

Para obter-se o entendimento das ações - fruto da sociedade, sinônimo de espaço geográfico - do presente, faz-se necessária a cognição de suas produções e transformações ao longo do tempo. Nessa perspectiva, a formação socioespacial é fundamental para a percepção dos desdobramentos dos eventos 
que resultam no uso do território do presente, dos múltiplos agentes nele contidos, e nas suas possibilidades futuras, uma vez que a totalidade em seu movimento de totalização é passado, presente e futuro.

Compreende-se dessa maneira a formação socioespacial da cidade de Planaltina juridicamente, enquanto produção precarizada do território em uso no presente, cuja gênese advém das lógicas de produção do território nacional em seu contexto colonial que também se reproduzem na localidade, cujo processo se desdobra desde o contexto pré-Brasília até o momento presente - terceiro ciclo de expansão da cidade.

Neste sentido, o lugar, subespaço é tido como a possibilidade de análise concreta da totalidade em seu processo de totalização, sendo a Região Administrativa de Planaltina a escala em estudo para a apreensão de uma ação fracionada que advém do agir múltiplo das diversas estruturas e elementos ao qual se inclui o Poder Judiciário, ou seja, Planaltina é fração do território usado enquanto subespaço, sendo ao mesmo um todo: território usado.

O Poder Judiciário, mesmo sendo um único elemento mediante a uma complexidade maior, pode impactar na dinâmica sistêmica de um todo, e do todo maior em detrimento as suas decisões, ao mesmo tempo em que interage com os demais estruturas constituintes da sociedade e com a mesma. É essa relação complexa, descrita por Santos (1985), que ocorre no espaço que caracteriza o território usado, assim descrito:

O estudo das interações entre os diversos elementos do espaço é um dado fundamental da análise. Na medida em que função é ação, a interação supõe interdependência funcional entre os elementos. Através do estudo das interações, recuperamos a totalidade social, isto é, o espaço como um todo e, igualmente, a sociedade como um todo. Pois cada ação não constitui um dado independente, mas um resultado do próprio processo social. (SANTOS, 1985, p. 07).

Conforme fora exporto por Santos (1985), a judicialização do território em uso no presente é resultante dos múltiplos processos sociais que responderam na construção de suas respectivas totalidades, herdadas de forma integral ou parcial por outras totalidades socioespaciais em totalização, tal qual o caso da cidade de Planaltina. 
Será exporto adiante que mesmo com a composição de uma nova totalidade que corresponde à cidade de Planaltina no presente, dispondo de novas partes de um novo todo, verificasse a continuidade de questões relacionadas à precariedade jurídica do solo urbano que perfazem ao seu ciclo pré-Brasília, de um contexto pré-máquina, avançando ao atual meio geográfico que é o caso do Setor Tradicional.

Em somatória, em consonância ao movimento contínuo de totalização, em Planaltina, surgem novos bairros possuidores de novas situações que ampliam o leque de complexidade jurídica do território usado do presente, constituindo uma nova totalidade frente à própria trajetória de formação socioespacial.

Nesse prisma, fica evidente que as decisões/ações do Poder Judiciário nas diversas instâncias relativa à cidade objeto, e principalmente, quanto a questão do Setor Tradicional, resultam do acúmulo de omissões dos demais agentes que compõe o território usado - Poder Executivo, Legislativo da sociedade local, o próprio Judiciário, entre outros agentes - gerando as lides em que a postura decisória da instância é exigida.

É nessa nova totalidade que se ampliam os conflitos territoriais resultantes dos processos socioespaciais, repercutindo desta maneira na atuação/decisões do Poder Judiciário em suas diversas esferas. Dialeticamente, as ações do Poder Judiciário também contribuirão na dinâmica de produção do território em questão. Este agir oriundo do Poder Judiciário em suas diversas instâncias é interpretado mediante a categoria judicialização que será exposta a seguir.

4.1 - Judicialização: do que se trata?

Para Santos (2002) em sua teorização, o espaço geográfico é tido enquanto sinônimo de sistema de objetos e ações. Ambos relacionam-se simultaneamente, tendo na explicação do fenômeno espacial não apenas a predominância dos objetos ou das ações, mas a relação recíproca entre os mesmos. 
Para o autor, toda ação tem em seu bojo uma intenção, sendo que o resultado dessa energia aplicada redunda na materialização dos objetos espaciais.

Os objetos espaciais, por sua vez, conduzem a determinados tipos de ação em virtude da potencialidade que os mesmo oferecem mediante o seu uso. Sobre essa correlação objetos e ações, Hägerstrand (1992) apud Santos (2002, p. 93) para exemplificar tal reciprocidade relacional mediante a concepção de que a ação/intenção humana projeta-se temporalmente - em seu transcorrer - sobre a produção material da paisagem. Nestes termos, Santos expõe tal raciocínio:

(...) Segundo o geógrafo sueco, a ação é ação em uma paisagem e é a paisagem que dá a forma da ação. Mas onde Hägerstrand escreve paisagem, teríamos escrito espaço. Feita essa ressalva, o importante é realçar a inseparabilidade entre ação e objeto, para afirmar, como estamos fazendo, que o tema central da geografia não é separadamente os objetos, nem as ações, mas objetos e ações tomados em conjunto.

A ação é tanto mais eficaz quanto os objetos são mais adequados. Então, a intencionalidade da ação se conjuga a intencionalidade dos objetos e ambos são, hoje, dependentes da respectiva carga de ciência e de técnica presente no território. (SANTOS, 2002, p.93-94).

Para Santos $(2002,95)$, "a ação não se dá sem que haja um objeto", onde a materialização do mesmo é a concretude de sua potencialidade, enquanto pré-concepção, podendo ser enxergado a intenção da ação ao passo em que se concretiza o objeto. Assim, a identidade, a existência de uma sociedade pode ser aferida por intermédio da composição e usos dados aos seus sistemas de objetos, onde esta mesma sociedade os contém e está contida nestes. Sobre essa relação, o autor explicita:

(...) Na verdade, porém, o que chamamos de sociedade somente adquire concretude quando a enxergamos simultaneamente como continente e como conteúdo dos objetos. E estes se individualizam e ganham expressão e significado, quando ao serviço da sociedade. (SANTOS, 2002, p. 95).

Nessa inseparabilidade entre objetos e ações, Santos (2002) define como objeto toda a materialidade que compõe o espaço, estando o mesmo listado em duas categorias: os objetos naturais e artificiais. Já a ação é substancial ao ser humano, já que a essência do mesmo repousa sobre suas ações. 
A ação é imbuída de uma racionalidade intencional, mas, essas ações, mais do que nunca, são externas ao indivíduo, haja vista que o agir é advindo também de instituições, grupos, firmas, do Estado e suas estruturas.

Seguindo o raciocínio de I. Braun e B. Jeorges (1992) exposto por Santos (2002), existem três categorias do agir: agir técnico, formal e simbólico. Essas ações são submetidas às normas, estando as três interligadas a outras três ordens correspondentes, que seriam: a ordem da forma técnica, a ordem da forma jurídica e a ordem do simbólico; estes elementos se dão de maneira simultânea.

As ações se estendem na composição da materialidade e é nesse aspecto que se busca apreender os efeitos de uma dessas categorias de ação na dinâmica espacial: a ação formal, cujo campo jurídico-normativo está contido. Logo, ao propor-se uma leitura pautada na judicialização do território é importante expor do que se trata tal fenômeno político-jurídico.

Valle (2012, p.17) descreve tanto a judicialização quanto o ativismo judirídico como "um processo de expansão decisório do Poder Judiciário em direção às áreas de competência tradicionalmente exercidas pelos demais poderes" produção de normas e execução das mesmas - levando dessa maneira a uma possível transformação do sistema político brasileiro, tendo na instância judiciária o recaimento da primazia da interpretação das questões normativas mediante à sua atuação sobre as lides que the cabe julgar.

Nesse sentido, para Valle (2012), a postura ativa do judiciário estaria correlacionada às questões de resguardo dos preceitos constitucionais, objetivando o controle da elaboração normativa advinda do Poder Legislativo, assim como da proposição e execução das políticas públicas por parte do Poder Executivo, uma vez que a defesa da Constituição também vincula-se ao efetivo cumprimento perante a sociedade.

Quanto à relação entre direito de propriedade e políticas públicas a que venham resguardar tal garantia, juridicamente, o direito de propriedade pode ser interpretado como direito individual (subjetivo) e coletivo (sociais), já que a propriedade deve cumprir a sua função social, cuja titularidade que atesta a 
dominialidade exercida sobre o bem, resguarda não só o indivíduo, mas a coletividade que também tem o direito a tal amparo.

Ao serem discutidas as questões relacionadas à postura do Estado na tomada de decisões referente às questões sociais e territoriais, torna-se essencial a elucidação do conceito de política pública.

Souza (2006), ao abordar conceitualmente política pública, constrói sua argumentação definindo tal ramo tanto em seu campo teórico quanto prático. Em seu viés acadêmico, política pública constitui um sub-ramo da ciência política, tendo o seu atual corpus teórico desenvolvido pela academia norte-americana.

Segundo Souza (2006, p. 22) para a escola europeia, política pública constituía o ramo de estudo cuja finalidade repousa na formulação de "bases teóricas explicativas sobre o papel do Estado e de uma das mais importantes instituições do Estado - o governo - produtor, por excelência, de políticas públicas".

A escola norte-americana, ao desenvolver estudos sobre política pública, dispõe de sua gênese no meio acadêmico, "sem estabelecer relações com as bases teóricas sobre o papel do Estado, passando direto para a ênfase nos estudos sobre a ação dos governos" (Souza, 2006, p. 22).

Antes de promover a própria definição de política pública, Souza (2006) traz à tona uma série de reflexões conceituais desenvolvidos por grandes nomes de tal ramo teórico. Sobre as diversas interpretações finalísticas concernentes ao papel dos governos e suas ações mediante a implementação de política pública, esclarece que:

Não existe uma única, nem melhor definição sobre o que seja política pública. Mead (1995) a define como um campo dentro do estudo da política que analisa o governo à luz de grandes questões públicas e Lynn (1980), como um conjunto de ações do governo que irão produzir efeitos específicos. Peters (1986) segue o mesmo veio: política pública é a soma das atividades dos governos, que agem diretamente ou através de delegação, e que influenciam a vida dos cidadãos. Dye (1984) sintetiza a definição de política pública como "o que o governo escolhe fazer ou não fazer". A definição mais conhecida continua sendo a de Laswell, ou seja, decisões e análises sobre política pública implicam responder às seguintes questões: quem ganha o quê, por que e que diferença faz. (SOUZA, 2006, p.24). 
Após essa exposição conceitual a respeito do que seja política pública, Souza (2006) produz a sua própria definição e apresenta segundo a seguinte perspectiva:

\begin{abstract}
Pode-se, então, resumir política pública como o campo do conhecimento que busca, ao mesmo tempo, "colocar o governo em ação" e/ou analisar essa ação (variável independente) e, quando necessário, propor mudanças no rumo ou curso dessas ações (variável dependente). A formulação de políticas públicas constitui-se no estágio em que os governos democráticos traduzem seus propósitos e plataformas eleitorais em programas e ações que produzirão resultados ou mudanças no mundo real. (SOUZA, 2006, p. 26).
\end{abstract}

Para Silva e Melo (2000), a arte de produzir e implementar política pública constitui-se enquanto uma engenharia social e não simplesmente uma produção manufatureira segmentada de medidas, tendo na "policy circle" o instrumento avaliativo da elaboração e aplicação de tais políticas com o objetivo de alcançar a atividade fim de tal produção, que é benefício do seu público alvo. Silva e Melo assim expressam quanto à definição quanto política pública:

Essa visão da implementação como correção de rota está fundada em uma analogia pouco consistente entre a manufatura e as políticas públicas. Na manufatura há uma clara divisão de trabalho entre as tarefas de concepção (trabalho intelectual) e a execução (trabalho manual) de um produto. Uma política pública deve ser vista como engenharia social. $O$ policy circle deve ser visto como um campo estratégico no qual se observa uma relativa indistinção entre não só os implementadores e os formuladores, mas também a população meta de um programa. Na realidade, a forma de uso ou consumo dos produtos da política altera a política e à semelhança do que se afirmou em relação aos implementadores "cria políticas". (SILVA e MELO, 2000, p. 11-12).

No caso da cidade de Planaltina, observa-se, enquanto fatores preponderantes que repercutem na judicialização do território concernente aos embates para com os demais Poderes, elementos que vinculam-se principalmente a execução das políticas públicas atinentes ao direito à propriedade, fragilizado por omissões, falhas ou equívocos na aplicação destas ao longo de sua formação 
socioespacial, tendo em vista a impossibilidade do pleno exercício do direito de propriedade por grande parcela de seus habitantes.

Sobre a questão relacionada à distinção interpretativa entre direito a propriedade e o direito de propriedade, faz-se necessário o entendimento da acumulação de ações equivocadas que recaem sobre a possibilidade de exercer o domínio sobre o bem imóvel, Pagani (2009) assim os define:

A propriedade passa de uma concepção predominantemente estática da ordem das coisas para outra frequentemente dinâmica e evolutiva, nascendo daí uma nova e abrangente situação que clama por novas formas de análises.

Faz-se necessário que a propriedade seja analisada sob a ótica estática e dinâmica, sendo a primeira sob o prisma da proteção daquele que já proprietário, mantendo-se o status quo do titular do domínio (...); e a segunda sob o enfoque daquele que aspira ter propriedade ou mesmo à moradia e ainda, daquelas propriedades funcionalizadas. Ainda que para a efetivação do direito à moradia não seja necessário ter o domínio da coisa imóvel no sentido estático.

O direito de propriedade considerado no seu caráter estático traduzse na proteção do direito de propriedade daquele que já é proprietário de uma determinada coisa e, neste sentido, o ordenamento jurídico dispõe de diversos dispositivos legais que protegem o direito de propriedade daquele que é proprietário.

(...) A concepção individualista tradicional do direito de propriedade cede lugar para a propriedade socializante e funcional. Assim tratamse interesses diversos entre aqueles que têm e aqueles que aspiram ter a propriedade. O caráter estático da propriedade diz respeito à tutela daquele que já tem o direito de propriedade, ao passo que a propriedade no aspecto dinâmico diz respeito àquele que ainda não é sujeito titular do direito à propriedade. Quando se refere ao aspecto dinâmico da propriedade significa o direito de ter propriedade, no direito de acesso à propriedade ou ainda no direito de acesso à moradia. (PAGANI, 2009, p. 90-91).

Mesmo ao ser interpretado por Pagani (2009) que o exercício do direito de propriedade configura-se como uma vertente estática, individualista e tradicional perante a complexidade face às novas demandas sociais associadas ao termo propriedade, observa-se, quanto ao caso da cidade de Planaltina, e em especial, de vários moradores do Setor Tradicional, que, pelo fato de efetivamente não gozarem do efetivo domínio perante o usufruto de seus respectivos imóveis urbanos, resultante, entre outros fatores, da ineficácia das políticas públicas habitacionais, tiveram, inclusive por vias judiciais (judicialização do território), a contestação do 
direito à moradia, ou seja, o direito à propriedade, que por várias décadas já estavam ocupadas por seus habitantes, assim como da impossibilidade, em outros casos, das relações de compra e venda a serem efetuadas segundo os preceitos legais.

Neste sentido, tendo em vista o exercício do direito de propriedade assim como os demais direitos sociais prestacionais em disputa face ao território em uso, ao qual discutisse a questão habitacional da cidade de Planaltina, Valle (2012) afirma que o fenômeno concernente a judicialização, em um olhar abrangente, é interpretado enquanto expansão decisória do Poder Judiciário junto aos demais Poderes do Estado.

A autora explicita que tal fato tem a sua gênese decorrente da elaboração da Carta Magna de 1988, cujo texto ao discorrer sobre os direitos e garantias sociais associado aos direitos fundamentais (como 0 direito de propriedade, saúde, dentre outros), constituíram em elementos que abriram "espaço para a judicialização em sentido amplo e para o exercício da jurisdição constitucional" por parte do Poder Judiciário (Valle, 2012, p.36).

Como resultado dessa expansão relativa a atuação do Poder Judiciário, Valle (2012) relata que o princípio do equilíbrio entre os Poderes exercido através do uso do mecanismo de controle recíproco entre estes, que visa equanimemente limitar a competência de atuação atribuída aos Poderes (conhecido como a teoria dos pesos e contrapesos ${ }^{33}$ ), é colocado em xeque, já que a primazia

\footnotetext{
${ }^{33}$ Sobre a teoria dos Pesos e Contrapesos, Bonavides (2000) a conceitua nos seguintes termos:

"As técnicas de controle que medraram no constitucionalismo moderno constituem corretivos eficazes ao rigor de uma separação rígida de poderes, que se pretendeu implantar na doutrina do liberalismo, em nome do princípio de Montesquieu. Consideremos a seguir na prática constitucional do Estado moderno as mais conhecidas formas de equilíbrio e interferência, resultantes da teoria de pesos e contrapesos.

Dessa técnica resulta a presença do executivo na órbita legislativa por via do veto e da mensagem, e excepcionalmente, segundo alguns, da delegação de poderes, que o princípio a rigor interdita, por decorrência da própria lógica da separação.

Com o veto dispõe o executivo de uma possibilidade de impedir resoluções legislativas e com a mensagem recomenda, propõe e eventualmente inicia a lei, mormente naqueles sistemas constitucionais que conferem a esse poder - o executivo - toda a iniciativa em questões orçamentárias e de ordem financeira em geral.

Já a participação do executivo na esfera do poder judiciário se exprime mediante o indulto, faculdade com que ele modifica efeitos de ato proveniente de outro poder. Igual participação se dá através da atribuição reconhecida ao executivo de nomear membros do poder judiciário.

Do legislativo, por sua vez, partem laços vinculando o executivo e o judiciário à dependência das câmaras. São pontos de controle parlamentar sobre a ação executiva: a rejeição do veto, o processo
} 
decisória oriunda das sentenças proferidas acabam por restringir a atuação dos demais Poderes que compõem o Estado.

Valle (2012) ressalta que cada vez mais tem-se, enquanto tendência, uma crescente interferência do Poder Judiciário - em suas três instâncias do pacto federativo - a respeito da produção normativa e da execução das políticas públicas, muito embora essa prevalência seja mais intensamente exercida pelo STF.

Ao expor a sua inquietação quanto ao empoderamento do Poder Judiciário, Valle (2012) chega a levantar a hipótese de que essa acentuada judicialização da produção e execução das políticas públicas, no caso brasileiro, possa ter sido um movimento político premeditado para não desgastar a imagem dos Poderes Executivo e Legislativo em resposta às pressões sociais, tendo em vista as interpelações realizadas por essa mesma sociedade sobre temas polêmicos, tais como o direito de/a propriedade que se visualizam no território em uso, Planaltina.

A autora expressa o seu entendimento dessa forma:

Além disso, a judicialização promove 0 entrincheiramento constitucional de direitos: tanto o Executivo quanto o Legislativo podem, mediante apoio (deliberado) a essa estratégia de transferência de poderes, retirar temas controvertidos do debate público, os quais dificilmente seriam decididos em sentido favorável, seja porque não há consenso seja porque não foram suficientemente debatidos. A judicialização de questões sociais polêmicas pode reduzir custos (eleitorais ou de apoio político) de uma decisão controvertida ou, ainda, obstaculizar a abertura de um debate sobre políticas públicas ou reformas políticas à participação da sociedade, por exemplo. Essas premissas constituem-se em importantes instrumentos analíticos para se investigar a visibilidade conferida ao

de impeachment contra a autoridade executiva, aprovação de tratado e a apreciação de indicações oriundas do poder executivo para o desempenho de altos cargos da pública administração.

Com respeito ao judiciário, a competência legislativa de controle possui, em distintos sistemas constitucionais, entre outros poderes eventuais ou variáveis, os de determinar o número de membros do judiciário, limitar-Ihe a jurisdição, fixar a despesa dos tribunais, majorar vencimentos, organizar o poder judiciário e proceder a julgamento político (de ordinário pela chamada "câmara alta"), tomando assim o lugar dos tribunais no desempenho de funções de caráter estritamente judiciário.

Enfim, quando se trata do judiciário, verificamos que esse poder exerce também atribuições fora do centro usual de sua competência, quando por exclusão de outros poderes e à maneira legislativa estatui as regras do respectivo funcionamento ou à maneira executiva, organiza o quadro de servidores, deixando assim à distância os poderes que normalmente desempenham funções dessa natureza.

Sua faculdade de impedir porém só se manifesta concretamente quando esse poder - o judiciário frente às câmaras decide sobre inconstitucionalidade de atos do legislativo e frente ao ramo do poder executivo profere a ilegalidade de certas medidas administrativas". (BONAVIDES, 2000, p. 178-180) 
Poder Judiciário (...) assim como as consequências de tal participação na mobilização e participação da sociedade. (VALLE, 2012, p. 35).

Todavia, Valle (2012) reconhece que a judicialização das políticas, assim como a posição ativista do Poder Judiciário, além de ter a sua razão de ser prevista na Constituição Federal, ganha cada vez mais apoio popular, já que os seus integrantes não dispõem de cargos eletivos, possuindo maior autonomia para lidarem com temas controversos e de grande tabu social.

Nesse prisma, a ineficácia e a inércia do ato de legislar por parte do Poder Legislativo ou de promover política pública pelo Executivo, que vinculam-se ao tratamento de questões de complexa discussão, acabam por abrir brechas que demandam a ação/decisão do Poder Judiciário. Assim, o Poder Judiciário passa, através de suas decisões a interferir na produção normativa e no direcionamento da implementação das políticas públicas.

Já Botelho (2011) assevera que o fenômeno da Judicialização é oriundo da atual vigência do Estado Democrático de Direito no Brasil, uma vez que o texto constitucional assegura a acessibilidade universal aos direitos fundamentais individuais e sociais. Embora seja discutido por este as questões correlatas às ações prestacionais à saúde a serem propiciadas pelo Estado, o direito à propriedade e de propriedade também são contemplados nesta discussão.

Ele aponta problemas de cunho normativo que abrem brechas a um posicionamento politicamente ativo do Poder Judiciário quanto à eficácia para com as questões prestacionais, tendo em vista a não execução ou prestação ineficaz das políticas públicas que possibilitariam o efetivo cumprimento do preceito constitucional presente no art. $6^{\circ}$. Neste sentido, judicialização e politização do Judiciário seriam sinônimos.

Para Botelho (2011, p. 58), um dos fatores problemáticos ocorre no tocante à abrangência dos direitos sociais - e no caso em debate, os direitos sociais prestacionais que englobam o direito de/a propriedade, dentre outros - no que tange a elaboração do comando constitucional, tendo por discussão se efetivamente o Estado deve promover tais ações de maneira universal, abarcando a totalidade da população. 
Nesse aspecto, a discussão sobre a ação prestacional recai na indagação quanto a quais estratos sociais podem ser efetivamente incorporados em ações prestacionais integrais pelo Estado, haja visto que a concepção dos direitos fundamentais tem por finalidade possibilitar o acesso material dos cidadãos que, em virtude de sua incapacidade econômica, não consigam resguardar suas necessidades.

Portanto, a eficácia jurídica ${ }^{34}$ dos direitos fundamentais fica comprometida, uma vez que a positivação do texto constitucional, segundo Botelho (2011), é tida por muitos autores como confusa e metodologicamente inadequada, tendo em vista a sua elasticidade quanto ao grande quantitativo de direitos fundamentais (mistura entre direitos individuais e sociais) a serem prestados, assim como da imprecisão normativa para tais tipos de direitos e ações prestacionais a serem executadas.

Contudo, para Botelho (2011), o grande problema que resulta na judicialização referente aos direitos sociais prestacionais vincula-se principalmente, ao campo da proposição específica e execução das políticas públicas por parte do Poder Executivo, já que os comandos normativos oriundos do Poder Legislativo, que preveem as demandas sóciais a serem supridas, foram contemplados em quase sua totalidade. $\mathrm{O}$ autor descreve os pontos que evidenciam tal inércia por parte do Poder Executivo em suas três dimensões do pacto federativo:

Vê-se que o problema certamente está na formulação, implementação e manutenção das respectivas políticas públicas e na composição dos gastos nos orçamentos da União, dos estados e dos municípios. Ressalta-se que a situação se torna mais complicada onde o Poder Público mantém-se inerte, ou seja, onde ainda não foram instalados os serviços necessários ou onde funcionam precariamente.

Diante do mau funcionamento ou mesmo inexistência dos serviços essenciais para o bem-estar da população, impõe-se a formulação de políticas públicas protetivas de determinadas categorias sociais marginalizadas economicamente excluídas, políticas estas que demandam principalmente o gerenciamento pelo Estado (...). (BOTELHO, 2011, p. 102, grifo nosso).

\footnotetext{
${ }^{34}$ Para BOTELHO (2011, p. 100), eficácia jurídica é interpretada como a "capacidade (potencial) de uma norma constitucional para produzir efeitos jurídicos", ou seja, se materializarem face as demandas sociais.
} 
No caso de Planaltina, essa ineficácia ou inércia está atrelado a proposição e execução das políticas de uso e ocupação do solo que propiciem o efetivo exercício do direito de propriedade. Assim, a precariedade jurídica dos imóveis se dá, cumulativamente, em distintos ciclos de expansão da malha urbana de Planaltina, tanto em um contexto pré-Brasília, como nos ciclos de crescimento pós-Brasília, explicitados através do exercício de periodização em meio à análise da formação socioespacial da cidade.

Conforme será abordado nos tópicos a seguir, essa ineficácia ou inércia resultarão na judicialização de Planaltina, território usado, cuja morosidade na tomadas de ações, principalmente, por parte do Poder Executivo (não descartando os demais agentes), desdobram-se no precário exercício do direito de propriedade ao longo das décadas.

Botelho (2011) ainda expressa também à necessidade de certa cautela e reflexão para com a tomada de decisões do Poder Judiciário - em suas diversas instâncias - sobre as questões que envolvem os demais Poderes do Estado, já que o crescente empoderamento da instância judiciária também poderia recair na supressão de competências dos demais Poderes em suas distintas esferas do pacto federativo.

Nesse viés, seria ampliado o peso e a área de atuação do judiciário, comprometendo a existência e legitimidade do Estado Democrático de Direito, já que o princípio que determina a igualdade entre os Poderes para assegurar de fato o equilíbrio e a autonomia entre estes, venha a ser afetada, impossibilitando uma maior efetividade para com as ações prestacionais de incumbência estatal, colocando em cheque a composição da estrutura do Estado. Nestes termos, Botelho (2011) defende tão visão:

Em síntese, o que se está a propor aqui é a exigência de um Judiciário não intervencionista, mas que, contudo, ouse controlar a falta de qualidade das prestações dos serviços básicos e exigir a implementação de políticas sociais eficientes, não podendo as decisões da administração pública se distanciar da programaticidade principio lógica da constituição.

Doravante, constata-se que o princípio da separação dos poderes permanece absolutamente válido e importante em sua essência. $O$ poder concentrado ainda mostra-se como ameaça aos direitos individuais e, portanto, controlá-lo através da divisão de seu exercício 
permanece uma necessidade imperiosa. (BOTELHO, 2011, p. 134, grifo nosso).

Percebe-se que Botelho (2011) salienta a questão da ampliação da atuação do Poder Judiciário enquanto recurso constitucional de controle dos atos dos demais Poderes, mas explicita a importância do equilíbrio na produção das decisões dos Magistrados, já que o controle constitucional, vigente em seu caráter difuso, pode repercutir negativamente no andamento das políticas públicas prestacionais enquanto resultado de tomada de decisões arbitrárias sem o devido respaldo técnico, podendo comprometer de fato toda uma cadeia prestacional oriunda do Estado.

Tendo em vista essa possibilidade, Botelho (2011) se coloca favorável a uma postura receosa ligado à expansiva atuação do Poder Judiciário, cujo bom senso por parte das decisões dos Magistrados esteja em primeiro lugar. $\mathrm{O}$ autor assim expõe:

Por outro lado, vê-se que a separação dos poderes, em si mesma, não representa um obstáculo lógico ao controle pelo poder judiciário das ações ou omissões inconstitucionais praticadas pelo Poder Público, aí incluída a determinação de prestações positivas com fundamento constitucional, mas, sim, um limite a ser respeitado pelo juiz, que deve sempre se pautar pela autocontenção. (BOTELHO, 2011, p. 134, grifo nosso)

Essa postura conservadora de Botelho (2011) demonstra a preocupação recente advinda dos estudiosos do ramo jurídico sobre o entendimento dos impactos advindos do posicionamento do Poder Judiciário e seus efeitos no plano concreto, tendo em vista a produção de decisões.

Botelho (2011) explicita que essa busca nitidamente demonstra que o Poder Judiciário cada vez mais se preocupa em compreender os desdobramentos concretos de suas ações, decisões sobre a sociedade, assim como os impactos dessas ações nos cofres públicos e a viabilização das políticas públicas por intermédio da análise econômica do custo dos direitos.

Reconhece-se então que as decisões, ações advindas dos Magistrados, independentemente de seu nível hierárquico sobre as questões que 
condizem ao ordenamento territorial, extrapolam os limites das salas do júri ou da suprema corte, tendo por efeito a composição de uma materialidade. Sobre a necessidade de compreensão dos impactos oriundo das decisões/ações proferidas pelos juízes, Botelho (2011) atesta:

O tratamento individualizado dado pelo Poder Judiciário a questões de natureza eminentemente econômica e coletiva muitas vezes despreza os efeitos que gerariam para além do processo. Apresentase, em sua quase totalidade, incapaz de compreender e se ajustar a uma realidade que necessita de ações que busquem a satisfação do social de maneira global. O grande mérito da análise econômica do direito, então, é que suas preocupações fazem com que o juiz deva ter consciência do impacto econômico-social de suas decisões, para além do simples enquadramento normativo do caso sub judice.

Importante destacar que não se pretende que a atuação do magistrado afaste ou negue princípios jurídicos e fundamentos valorativos, não baseados na racionalidade econômica. Pretende-se apenas que sua conscientização econômico-social aumente as suas possibilidades de escolha e decisão no caso concreto, sempre de forma fundamentada, afastando assim a pura submissão à lei e a regras que impõem uma aplicação a priori. (BOTELHO, 2011, p. 120).

Todavia, pouco se sabe sobre a relação entre tais decisões/ações na dinâmica de evolução do espaço geográfico - sinônimo de território usado - tendo em vista a dinâmica de seu movimento, assim como na composição de seus objetos, que logicamente, incide sobre as dinâmicas sociais, que, cotidianamente, conforme fora teorizado por Santos (2002), responde na produção desse mesmo espaço e dos elementos nele contidos.

Ao se tratar da relação dos sistemas de objetos e ações somados à questão do exercício do direito de propriedade, de que maneira tais decisões/ações advindas do Poder Judiciário, em suas diversas instâncias, se materializam e repercutem sobre Planaltina, território usado? Quais os desdobramentos de tais decisões sobre a capacidade do Estado em efetivar, propiciar aos moradores o pleno exercício do direito de propriedade?

É válido lembrar que o direito de propriedade, no caso do Distrito Federal e de grande parcela da cidade de Planaltina-DF, passa pelo processo de desapropriação de terras de particulares, e, conforme fora explicitado no caso do 
espólio de Sebastião de Souza e Silva e demais, sempre envolvem valores astronômicos a serem pagos pelo Estado.

Neste sentido, em associação ao objeto de estudo, a categoria judicialização é interpretada enquanto a crescente atuação do Poder Judiciário proferindo decisões/ações em suas distintas instâncias, que no caso atinente ao direito de propriedade e ao direito a propriedade (moradia), o Judiciário é impelido a agir quando provocado/demandado.

O agir, conforme fora constatado mediante a realização de pesquisa junto aos sites do TJDFT, STJ e STF, se dá, consequentemente, através de ações propostas pelo Ministério Público: em ação civil pública, em ação direta de inconstitucionalidade, em ações propostas por particulares, em ação de usucapião e em ações criminais por meio de abertura de inquérito policial.

Todas essas ações refletem a complexidade e a multiplicidade de agentes presentes em Planaltina-DF, território usado no presente, assim como conflitos que materializam-se sobre o território face à tentativa de conquista do direito à propriedade, bem como do seu resguardo (direito de propriedade).

Uma outra maneira no qual o Poder Judiciário deve proferir decisão sobre a questão do legítimo exercício do direito de propriedade, está condicionado ao procedimento administrativo de dúvida prevista na Lei nํ 6.015 que dispõe sobre os registros públicos, na qual se inclui o bem imóvel.

Tal procedimento é requerido uma vez que o tabelião titular do cartório de registro de imóveis argui ao Juiz de Direito pertencente à Vara de Registros Públicos sobre a possibilidade de geração de matrícula seguida de registro do imóvel em cartório ou mediante a apresentação do título de compra e venda de bem imóvel realizada entre particulares, cuja averbação em caso de inexistência de registro gere matricula do imóvel e a dominialidade de seu respectivo adquirente.

Embora o procedimento administrativo de dúvida seja caracterizado enquanto ato administrativo, este gera uma sentença, uma decisão sobre a dúvida levantada quanto à legitimidade e a possibilidade legal de efetivação do registro de imóvel em cartório. Esta outra faceta de decisão, ação do Poder Judiciário está previstos nos artigos que vão do 198 ao 207 da referida Lei nº 6.015/73. 
Tendo em vista a multiplicidade de demandas junto ao Poder Judiciário atinente à questão da efetivação do exercício do direito de propriedade, assim como do disciplinamento promovido pelos Poderes do Estado relativo ao exercício de tal direito, identificam-se duas vertentes de ação do Judiciário, sendo a primeira caracterizada como judicialização das políticas públicas de ordenamento territorial e, a segunda, interpretada como judicialização do território (enfatizado no presente estudo).

Embora ambas numa relação de causa e efeito sempre estejam interligadas, propõe-se que uma leitura da judicialização das políticas públicas de ordenamento territorial vincula-se às ações/decisões condizentes a inconstitucionalidade da elaboração de normas inerentes à proposição de políticas públicas de uso e ocupação do solo advindo do Poder Executivo, que firam os princípios constitucionais e a Lei Orgânica no caso do Distrito Federal referentes ao tema.

Somente para efeito de exemplo quanto à judicialização das políticas públicas de ordenamento territorial, dentre várias ADl's (Ação Direta de Inconstitucionalidade) proferidas pelo MPDFT nas últimas duas décadas junto ao TJDFT, tendo em vista a inconstitucionalidade das normas provenientes da constante revisão do Plano Diretor de Ordenamento Territorial do Distrito Federal, tem-se no processo $\mathrm{n}^{\circ}$ 2009.00.2.017552-9 uma ilustração do teor da discussão a ser promovida em tal debate, cujo tema é sim expresso em sua ementa:

Ação Direta de Inconstitucionalidade. Lei complementar N 803/2009. Lei que dispõe sobre a revisão do Plano Diretor de Ordenamento Territorial - PDOT. Emendas parlamentares. Possibilidade, desde que haja pertinência à matéria da proposição e não acarrete aumento de despesa. Artigos impugnados que tratam do uso e ocupação do solo. Iniciativa reservada. Exorbitância do poder de emenda. Ofensa aos princípios da política de desenvolvimento urbano. Ocupação desordenada de território. Inconstitucionalidade formal e material. (TRIBUNAL DE JUSTIÇA DO DISTRITO FEDERAL E TERRITÓRIOS. Ação Direta de Inconstitucionalidade; processo $n^{\circ}$ 2009.00.2.017552-9. Brasília, 2010, p.01).

No caso exemplificado acima pela ADI no 2009.00.2.017552-9, interpretada como judicialização das políticas públicas de ordenamento territorial, vêse enunciado, em sua ementa, a correlação entre normatização e os efeitos a serem 
produzidos sobre o território, oriunda da proposição de leis que direcionam a implementação das políticas públicas de uso e ocupação do solo, havendo um embate entre o Poder Judiciário e o Executivo, além do envolvimento do Poder Legislativo no caso em questão. Ao ser provocado mediante ADI, o TJDFT profere sua decisão/ação sobre os questionamentos levantados pelo MPDFT quanto à constitucionalidade da norma elaborada.

Já a judicialização do território é interpretada como disputas territoriais que demandam decisões judiciais relacionadas ao exercício do direito de propriedade, de acesso à propriedade (posse e uso), em somatória às questões de legitimação inerentes à prestação de serviços públicos em locais de ocupação clandestina, estando em xeque o controle do território em uso e a acessibilidade à moradia.

Tais lides podem ser identificadas em ação civil pública, ações propostas por particulares, ação de usucapião, ações criminais via abertura de inquérito policial e por procedimento administrativo de dúvida advindas dos Cartórios de Registro de Imóveis aos Tribunais de Justiça.

Interpreta-se, quanto aos fatores que desdobram-se na judicialização do território, as múltiplas demandas de interesses inerentes ao uso do território pelos diversos agentes que o constitui, assim como da ineficaz aplicação das políticas públicas face ao uso e ocupação do solo pelo Poder Executivo que originam os embates judiciais.

Conforme fora exposto ao longo dos capítulos anteriores, o traço predominante da judicialização do território em Planaltina-DF vinculou-se a ineficácia ou omissões do Poder Executivo, frente à implementação das políticas públicas relacionadas à regularização da situação jurídica dos imóveis urbanos, desapropriação das terras de particulares e pertencentes à prefeitura de Planaltina de Goiás, que com a vigência de Brasília acabam por serem ampliadas.

Assim, verifica-se a dilatação da questão inerente à precariedade jurídica da terra que acaba por impactar no pleno gozo do direito de propriedade e na judicialização de Planaltina, território usado, espraiando-se em seu contexto pósBrasília com o acúmulo das fragilidades pré-Brasília e intensificadas com a vigência 
de novas leis e políticas de uso e ocupação do solo, cuja rigidez inerente a estas, viriam a limitar o acesso à propriedade e o efetivo direito de propriedade por seus postulantes. Essas questões serão retomadas no próximo tópico.

4.2 - O terceiro ciclo de expansão de Planaltina: da rigidez à privatização e ampliação das demandas sócio-judiciais.

Conforme exposto no terceiro capítulo, com a materialização de Brasília verifica-se um novo ciclo de expansão do espaço urbano de Planaltina, uma vez que sua forma, função, assim como a estrutura social se modificam.

Tais processos são oriundos da nova lógica de uso a ser dada ao território em uso enquanto desdobramento da construção da nova capital do país, que incorpora e impacta Planaltina-DF em seu processo de formação socioespacial, já que a cidade em questão passa a ser anexada aos limites do Distrito Federal.

O reflexo desses eventos é visualizado na perda da autonomia políticoadministrativa da cidade, bem como na ampliação do seu sistema de objetos espaciais (forma), cuja finalidade repousava no assentamento de parte dos candangos que participaram da construção de Brasília, além da leva de migrantes que se fixaram no Distrito Federal após a inauguração da capital, somando-se aos moradores pré-existentes da cidade de Planaltina.

As ações direcionadas à blindagem da capital modernista buscavam conter previamente a dinâmica de crescimento espontâneo que predominava nas demais áreas urbanas do território nacional e que já ganhavam contornos expressivos com o andamento da construção de Brasília entre os anos de 1958 e 1960. Paviani (2009) assim descreve essa dinâmica no âmbito do Distrito Federal ao qual Planaltina também será inserida neste processo:

(...) em 1958 o governo local deflagrou um processo de interminável criação de cidades-satélites - todas visando proteger o Plano Piloto de ocupações ilegais, irregulares e informais (favelas), as denominadas "invasões". Desfecha, ao mesmo tempo, o 
polinucleamento urbano e a periferização com segregação socioespacial. (PAVIANI, 2009, p. 80).

Sobre tal processo de segregação socioespacial somado à estruturação do polinucleamento descrito por Paviani (2009), resultante da Haussmanização explicitado no terceiro capítulo por um olhar de Houston (1993), Ferreira e Steinberger (2005) tecem críticas quanto às ações do novo poder público que se estabelece, cujas práticas protetivas ao Plano Piloto dão início às cidadessatélites enquanto receptáculo dos segregados e tendo como traço característico o fato de serem cidades desprovidas de vida econômica.

Tais elementos acima expostos são perceptíveis no segundo ciclo de expansão da cidade de Planaltina, relativos à nova dinâmica estabelecida entre centro-periferia, descrito pelas autoras da seguinte maneira:

(...) o primeiro impasse ocorreu logo no início da implantação da cidade, cujo modelo de gestão impedia, legalmente, a formação de favelas e a ocupação irregular no seu interior. Os trabalhadores, que vinham atraídos pelo canteiro de obras, formavam "vilas" junto aos acampamentos provisórios das construtoras. O Estado, dono da terra, criou núcleos urbanos fora do limite do Plano Piloto. Para esses locais distantes, sem infraestrutura, sem emprego e nem funções econômicas definidas, as "cidades satélites", foram transferidos os trabalhadores. Portanto, a solução do problema de moradia dos pobres se fez com a sua exclusão do perímetro planejado, forçando a segregação espacial. Essa seletividade opôs centro e periferia: o primeiro com suas funções de núcleo do poder, enquanto na segunda, apenas cidades-dormitório das classes de baixa renda. Com isso, gerou-se a valorização do centro em relação à periferia. Não obstante, a especulação imobiliária também se instalou na periferia à espera de valorização. (...) No conflituoso jogo de forças dos agentes da urbanização brasileira, a gestão do território em Brasília teve o Estado como principal promotor. Gerouse assim, uma ocupação calcada na desigual distribuição espacial de renda, estabelecendo-se as bases territoriais do futuro aglomerado urbano polinucleado. (FERREIRA e STEINBERGER, 2005, p. 72).

Nessa perspectiva, a nova função da cidade de Planaltina, em seu segundo ciclo de expansão, equivale a receptáculo da população segregada que habitavam as invasões da Asa Norte, assim como de outras ocupações de terras contiguas à cidade de Brasília. 
Conforme fora exposto no capítulo anterior, essas invasões em sua gênese, segundo Holston (1993), são resultantes da crescente contratação de trabalhadores advindos principalmente da região Nordeste pelas empreiteiras particulares, sendo um dos elementos que compunham a alegoria bandeirista a que se fazia alusão à necessidade de interiorização da capital do país.

Para concretizar-se tal interiorização sobre as terras ermas e inabitadas, que correspondem ao sertão planaltino interpretado por Magalhães (2011), necessitava-se de operários desbravadores para a operacionalização do discurso modernista que justificava a construção de Brasília.

Segundo os relatos de Castro (2014), a partir de 1969 a cidade de Planaltina perpassa por seu segundo ciclo de expansão (o primeiro pós-Brasília), ao receber grande parcela da população de trabalhadores e novos migrantes segregados. Neste segundo ciclo, diferentemente do contexto pré-Brasília, observase a vigência do sistema de normas rígidas que disciplinam o uso e ocupação do solo e que incidem sobre Planaltina.

Neste viés, ao fazer uma analogia à leitura frente à gestão do território do Distrito Federal proposto por Ferreira e Steinberger (2005), tem-se neste contexto (entre os anos de 1960 e 1980), o efetivo controle estatal da terra, ao qual é incorporado, no espaço urbano de Planaltina, as quadras residências correspondentes a Vila Buritis, assim como da exclusão de setores residenciais (como o Setor Tradicional Residencial Sul e Bairro Nossa Senhora de Fátima) anteriormente previstos na Planta de 1958, quando a cidade ainda pertencia ao Estado de Goiás.

Sobre as características dessa estatização das terras contidas no quadrilátero do Distrito Federal, do controle rigoroso atinente à manutenção urbanística de Brasília que reverberam na produção do espaço urbano de Planaltina entre as décadas de 1960 e primeira metade da década de 1980, Ferreira e Steinberger (2005) assim as descrevem:

(...) inaugurava-se um modelo de gestão do uso e ocupação do solo que se opunha à urbanização tradicional. Marcado pelo controle estatal rígido, tal modelo tinha como mecanismos de poder: o monopólio estatal da terra e um plano urbanístico a ser implantado. Este estabelecia os limites da cidade a ser criada, congelava 0 
perímetro urbano e dava o respaldo técnico às ações do Estado. Nessa perspectiva, os projetos e programas desenvolvidos posteriormente enfatizavam o zoneamento funcional da cidade, privilegiando a dominação da natureza com a construção de uma nova paisagem e a submissão do homem a essa racionalidade imposta como a melhor alternativa tecnicamente elaborada. (FERREIRA e STEINBERGER, 2005, p. 69-70).

Conforme demonstrado nos capítulos anteriores, o uso dado a Planaltina em meio ao seu processo de formação socioespacial em seu primeiro ciclo de expansão, era caracterizado pelas lógicas de ocupação e posse da terra, somados aos equívocos e negligencias originárias do poder público municipal quanto à execução das políticas públicas habitacionais e de regularização das propriedades rurais e urbanas, que resultaram no estado de precarização jurídica do solo urbano ao não seguirem os ditames legais para a promoção dos parcelamentos urbanos (como a Lei no 58/37).

Nesse prisma, utilizando-se de um viés dialético, o novo que se estabelece sobrepõe-se ao velho, sendo notório, inclusive, na dinâmica de produção normativa, tendo em vista os comandos e demandas que passam a disciplinar rigidamente o uso e ocupação do solo urbano com a vigência de Brasília.

Assim, vê-se que nessa nova dinâmica de movimento da cidade em seu segundo ciclo de expansão ocorre por intermédio dos ditames da Novacap, Terracap, somado às normas locais, que freiam, inclusive, as ações e interesses dos agentes privados pré-existente a vigência de Brasília. Todavia, essa contenção será debelada no terceiro ciclo de crescimento da cidade em processo de totalização.

Essa rigidez normativa, que é traço da estatização do uso do território explicitado por Ferreira e Steinberger (2005), é percebida fortemente através da utilização do discurso ambiental, cuja finalidade vincula-se supostamente à proteção dos recursos hídricos do Distrito Federal.

Neste sentido, as autoras afirmam o que realmente pode ser visualizado no contexto entre as décadas de 1960 e final dos anos de1970, é a construção da "falácia da preocupação ambiental no DF" (Ferreira e Steinberger, 2005, p.72), já que as normas restringiam ao máximo a ocupação populacional nas 
bordas da cidade de Brasília, recaindo tais normatizações, principalmente, sobre as famílias de baixa renda, sendo estes comandos interpretados como instrumentos de contenção e seleção dos estratos sociais a habitarem as terras da capital federal.

Quanto a essa seleção dos habitantes que teriam a primazia sobre a condição de morar na capital federal em relação aos demais, fator estruturador da relação dialética centro-periferia que se busca estabelecer, Holston (1993) aborda tal processo através da seguinte lógica:

A solução do governo foi, portanto, fazer com que o acesso à propriedade ao Distrito Federal dependesse de critérios de status que ele próprio estabeleceu. Esta regulamentação do mercado imobiliário foi o mecanismo essencial de que se valeu na tentativa de controlar a ocupação. Sua estratégia tinha dois componentes básicos. Primeiro, a administração manteve a dicotomia entre centro e satélites restringindo o acesso as residências funcionais no Plano Piloto aos membros do grupo de status correspondente. Segundo, continuando com suas projeções de uma imagem exemplar para a periferia, regulamentou a distribuição dos terrenos também nas cidades-satélites. (...) De um lado, os regulamentos aplicados à distribuição de terrenos nas cidade satélite muitas vezes impediram os migrantes de obtê-los por via legal e, assim, estabeleceram condições para o surgimento de novas favelas.

Três categorias tinham o direito de residir no Plano Piloto: funcionários eleitos pelo governo federal; os que tinham posições na hierarquia burocrática, de ministro a escriturários e contínuos; além daqueles recrutados pelo GTB para a transferência dos órgãos governamentais do Rio para Brasília; e um pequeno número de elites pioneiras (...)

Em contraste, aqueles que não eram admitidos no Plano Piloto e quisessem morar no Distrito Federal tinham de procurar residências nas cidades-satélites. Constituíam, desse modo, uma categoria residual de migrantes, incluindo: 1) os trabalhadores na construção e nos serviços públicos; 2) os que trabalhavam para os órgãos governamentais sem pertencer ao serviço público regular (em geral trabalhadores manuais e empregados de escritório);3) comerciantes com poucos recursos; e 4) os desempregados. Esses migrantes tinham vivido nos acampamentos de construção, na Cidade Livre e nos povoamentos da periferia ilegal.

Em resumo, as elites de poder, de status e de classe no conjunto dos migrantes de Brasília pré-inaugural foram para o Plano Piloto, enquanto as camadas mais baixas foram para as cidades satélites. Num cálculo bem prudente, essas camadas inferiores compreendiam cerca de $90 \%$ dos pioneiros. (HOLSTON, 1993, p. 279-280). 
A respeito das normas ambientais, Ferreira e Steinberger (2005) listam algumas, tendo como fator basilar resguardar a ocupação do solo como justificativa velada ao processo de segregação socioespacial, bem como do controle do parcelamento da terra, tendo em vista a grande demanda já existente conforme exposto acima por Holston (1993) explicitado.

É salutar, quanto ao desenvolvimento de tal raciocínio, enunciar alguns trechos da reflexão estabelecida por Ferreira e Steinberger (2005), referente à relação elaboração de textos legais de cunho ambiental e suas implicações sobre a rigidez das políticas de uso e ocupação do solo, que também repercutem na dinâmica de produção do movimento do espaço urbano de Planaltina em seu segundo ciclo de expansão:

A definição do Código Sanitário do Distrito Federal que propôs conter a ocupação da Bacia do Paranoá (lei 5.027, de 1966) e tinha por objetivo diminuir a pressão da demanda habitacional na bacia;

A elaboração do Plano Diretor de Água, Esgoto e Controle da Poluição do Distrito Federal (PLANIDRO) em 1970 que ressaltava a preocupação de preservar a Bacia do Paranoá, levando em conta o crescimento urbano. Recomendava a não ocupação dos espaços livres na Bacia; e

O surgimento do Programa Especial da Região Geoeconômica de Brasília (PERGEB), em 1977, fruto das diretrizes do II PND em 1974. Evidenciava a importância de Brasília como polo regional, mas seu objetivo, de fato, foi resguardar o "espaço vital" da capital. (FERREIRA e STEINBERGER, 2005, p. 71).

Além do discurso ambiental direcionado à suposta proteção da Bacia do Paranoá, que legitimava a contenção das ocupações irregulares próximas ao Plano Piloto e na remoção dos invasores para localidades mais distantes da capital, Ferreira e Steinberger (2005) dão ênfase ao PERGEB (Programa Especial da Região Geoeconômica de Brasília) enquanto política promotora do fortalecimento e integração regional, tendo a nova capital como locomotiva de tal processo.

Todavia, ao explicitarem a exposição de motivos que norteava essa política pública, ficou nítido a busca pela manutenção incólume da área urbana de Brasília, blindando-a da dinâmica de metropolização nacional vigente, uma vez que a cidade passa a constituir-se em um polo de atração populacional. 
As autoras citam o texto que norteiam à intencionalidade do PERGEB, que assim como as leis ambientais, davam respaldo a continuidade da política de erradicação de invasões ao qual Planaltina se insere, entretanto, como receptáculo dos segregados. Sobre a exposição de motivos relativos ao PERGEB, Ferreira e Steinberger (2005) explicitam que:

(...) a estratégia de contenção da escala local do Distrito Federal repousa na firme convicção de que a maturação precoce de Brasília ameaça reproduzir o modelo de urbanização das grandes metrópoles brasileiras, comprometendo as funções do Governo Federal e de indutora do desenvolvimento do Centro-Oeste, projetadas para a cidade. (Exposição de Motivos, 1977, apud FERREIRA e STEINBERGER, 2005, p. 71).

Depreende-se também que, além da blindagem segregadora da área urbana de Brasília, tendo em vista a manutenção de sua função geopolítica, outro elemento em jogo era a efetiva busca pelo controle estatal total das terras contidas no quadrilátero, via relações de compra e venda ou de concessão para distintas formas de uso totalmente viabilizado pelo Poder Público, constituindo-se em uma lógica diferenciada das dinâmicas de produção dos espaços urbanos de então no Brasil.

Nessa perspectiva, segundo Oliveira (2008), o discurso da total dominialidade das terras pelo novo Poder Executivo local era apregoado utilizandose da afirmativa quanto à contínua execução das supostas expropriações das terras, via mecanismos de desapropriação amigável (direta), promessas de compra e venda firmadas entre os proprietários da terra e o Poder Público e, sobretudo, de maneira indireta, embora tais processos, perceptivelmente, já se caracterizassem enquanto inconclusos e morosos.

Assim, pode ser interpretado que a apropriação ideológica das terras do Distrito Federal, que se dava mediante a retórica infundada da expropriação indireta, foi utilizada em conjunto aos instrumentos normativos de uso e ocupação que impediam a promoção de loteamentos particulares e relações de compra e venda a serem efetivadas sem a prévia aprovação do Poder Executivo local, ou da proibição do adensamento de áreas de proteção ambiental determinadas pelas normas expostas por Ferreira e Steinberger (2005). 
Neste sentido, mesmo com a inconclusa desapropriação das terras, os respectivos donos não gozariam da primazia de comercializá-las por meio dos ditames legais, ocasionando, segundo Oliveira (2008), em posturas proibitivas para tal possibilidade advindas do Poder Público, estando estas justificadas respaldadas no uso do texto normativo presente no art. 25 da Lei $n^{\circ} 2874 / 56$, que determina o seguinte:

\begin{abstract}
"Tornar-se-ão indivisíveis os lotes de terras urbanas do futuro Distrito Federal, desde que alienados pela Companhia Urbanizadora da Nova Capital do Brasil. Fica expressamente proibida a alienação das mais áreas de terras do mencionado Distrito, a pessoas físicas ou jurídicas de direito privado". (LEI N ${ }^{\circ} 2.874$ de 1956. In https://www.planalto.gov.br/ccivil_03/leis/1950-1969/l2874.htm; acessado em 27 de dezembro de 2013).
\end{abstract}

Segundo explicitado no segundo capítulo, durante mais de duas décadas o Poder Executivo utilizava-se dos discursos jurídicos para justificar as suas ações restritivas quanto à privatização do parcelamento da terra, através das supostas execuções de desapropriações de maneira indireta (inconclusas) ou ao argumentar a normatização explicitada pelo art. 25 da Lei no 2.874/56 para efetivar o controle dominial sobre o Distrito Federal.

Os resultados inerentes ao uso dessas justificativas à apropriação ideológica da terra mencionado por Oliveira (2008), repercutem no travamento das relações de compra e venda de terras rurais e dos possíveis novos loteamentos urbanos a serem realizadas por particulares. Fato este verificado em Planaltina.

Essa prática discursiva, ao resguardar o suposto total domínio do GDF sobre as terras do quadrilátero, constituía-se em um mecanismo para ocultar o fato referente às inconclusas e morosas desapropriações, fato este correlacionado ao inflacionamento das indenizações a serem pagas, além dos crescentes embates judiciais envolvendo a Novacap, Terracap e particulares, tendo em vista o reconhecimento dominialidade da terra e a possibilidade de se receber por ela ou gozar do direito de comercializa-las.

Quanto a total desapropriação dos imóveis rurais, a priori, interpretado através do mecanismo de desapropriação indireta, ocasionaram, a princípio, uma grande escassez da oferta de lotes a serem comercializados entre os agentes 
privados, podendo as terras apenas serem alienadas legitimamente pelo Novacap, Terracap.

Tal conduta restritiva também era legitimada não só pelo art. 25 da Lei no 2.874/56, uma vez que no art. $1^{\circ}$ da Lei $n^{\circ}$-58/37, em seu inciso $1^{\circ}$, também determina que qualquer loteamento urbano implementado por particulares deve, previamente, obter aprovação de sua respectiva prefeitura municipal.

Essa assertiva possibilitou a escrituração dos lotes e a transmissão do domínio em averbação a ser executada, já que a planta do loteamento, somado ao seu memorial descritivo, disporiam de matrícula em livro de registro do respectivo cartório contido na cidade enquanto resultado da aprovação do Poder Público. Contudo, até então, só o Poder Público constituía-se enquanto promotor de tais parcelamentos, logo, apenas estes dispunham de aprovação legal.

A Lei $n^{\circ} 6.766 / 79$, nos artigos $1^{\circ}$ ao $9^{\circ}$, expressava que além da prévia aprovação, tais parcelamentos teriam que enquadrar-se ao plano de ordenamento territorial a ser norteado pelo Poder Executivo municipal, fruto da implementação de sua política urbana a ser definida e efetivada.

Sobre a lógica do discurso proibitivo, tendo em vista a suposta total dominialidade das terras do Distrito Federal em poder do Poder Executivo, cuja finalidade, a princípio, era a contenção das ações especulativas, Oliveira (2008) assevera:

O mito do processo sumário da desapropriação e a totalidade do domínio das terras como públicas, tem sua conotação ideológica, uma vez que, o discurso que se cria visa à preservação de um processo da dinâmica imobiliária privada.

(...) Mesmo que partes do discurso fossem sendo desfeitas no decorrer dos anos pelas meras observações dos fatos como a não conclusão de contratos de compra direta entre Estado e particulares registrados por compromissos de compra e venda, processos judiciais de desapropriação não concluídos e desistências do interesse público em alguns casos, a imagem que se criou de um contínuo processo de desapropriação e a restrição ao loteamento privado, não destituíram o poder da proposta original que era a contenção da especulação imobiliária. É estabelecido um controle alternativo pela proibição, já que a eliminação da ação do mercado imobiliário é absolutamente impossível no sistema econômico ao qual o Brasil é integrante. (OLIVEIRA, 2008, p. 70). 
Esse controle da terra segundo Holston (1993) adveio das diretrizes provenientes da Carta de Atenas de 1931, possibilitando a livre atuação dos arquitetos e urbanistas objetivando o livre exercício do planejamento e gestão urbana da cidade, além de desconcentrar a dominialidade das terras historicamente detidas pelo segmento privado, que no caso da cidade de Planaltina correspondiam às propriedades pertencentes a particulares e imobiliárias que já atuavam localmente.

Entretanto, Holston (1993) também salienta que esse controle do solo exercido pelo Poder Executivo acabou por torna-se um mecanismo especulativo promovido pelo próprio Estado, através das ações engendradas pela Novacap/Terracap frente à dinâmica local condizente ao mercado de terras.

Daí a importância das restrições e proibições impostas pelo Poder Público local sobre as terras que integravam as demais cidades satélites, que além de evitar a atuação dos agentes privados, possibilitaria a efetivação de ações unilaterais do GDF sobre a dinâmica de produção das áreas urbanas, além da acumulação de capitais advindas das alienações.

Essa total dominialidade das terras apregoada pelo Poder Público é equivocadamente internalizado por Holston (1993) no contexto de sua pesquisa, já que de maneira relutante, é reconhecido pela Terracap e SEDHAB, atualmente, a inconclusa ação expropriatória das glebas contidas no quadrilátero. Todavia, o autor explicita acertadamente a importância da manutenção da dominialidade das terras pelo GDF, pelos seguintes motivos:

Tendo regulamentado o acesso à propriedade no Plano Piloto, os planejadores não poderiam admitir o surgimento de um mercado imobiliário desregulamentado nas cidades satélites; ou seja, não poderiam permitir que corretoras imobiliárias privadas desenvolvessem a periferia como em outras cidades brasileiras. Isto teria violado o seu modelo de urbanização exemplar. Assim, tendo desapropriado toda a terra do Distrito Federal, o governo tornou-se o único urbanizador. Sob a supervisão geral da Novacap, criou departamentos imobiliários em cada uma das subprefeituras para regulamentar a subdivisão da terra e da distribuição dos lotes (...). Embora a regulamentação imobiliária tenha de fato inibido a especulação, que com certeza teria elevado os preços para além do alcance de muitos dos migrantes favelados, seus efeitos foram paradoxalmente similares (...). Em essência, se não em todos os 
detalhes, também se aplicam, contudo, a outras cidades-satélites. (HOLSTON, 1993, p. 283-284).

Cabe, referente a esse raciocínio de Holston (1993), fazer um paralelo com a lógica de Oliveira (2008), já que o controle alternativo das terras pela proibição dispunha de um amparo legal (Lei oㅡ 58/37, Lei ํo 2.874/56, Lei no $6.766 / 79$ ), mas que ao não ser efetivado o processo de desapropriação por completo no quadrilátero do Distrito Federal, prejudicou tanto os antigos proprietários que não poderiam usufruir do pleno direito do exercício de propriedade, tendo em vista a impossibilidade de alienação de suas terras (mesmo dispondo de um caráter especulativo), já previsto no Código Civil de 1916, assim como nos efeitos negativos decorrentes da concentração da oferta de terras e do inflacionamento das habitações promovida pela Novacap, Terracap.

Neste sentido, Holston (1993) interpreta que, no contexto em questão (décadas de 1960 a 1980), a oferta controlada de lotes pela Novacap, Terracap, resulta na supervalorização das terras públicas, cujas licitações a conta-gotas, condizentes à comercialização para a população de classe média, assim como dos segmentos de baixa renda, não supriam a crescente demanda habitacional de ambos os estratos sociais.

Tal como em Ferreira e Steinberger (2005), em somatória a uma perspectiva especulativa, Holston (1993) demonstra também que essa política urbana de monopólio da terra teve por finalidade selecionar os habitantes situados em Brasília, promover a remoção da massa empobrecida instalada nas cercanias da capital para as recém instituídas cidades satélites, e ainda sim, com as demandas contratuais firmadas entre a Novacap, Terracap, junto aos contemplados, segregados, uma série de exigências que inviabilizariam a permanência dos mais desprovidos economicamente nos loteamentos destinados a estes, distantes da cidade modernista.

Nesse viés, trazendo o caso da cidade de Sobradinho situada a $13 \mathrm{Km}$ de distância a Oeste da área urbana de Planaltina e já se fazendo alusão a perspectiva espaço-temporal demonstrado por Ferreira e Steinberger (2005) que é caracterizado como estatização do território e que corresponde ao segundo ciclo de 
expansão de Planaltina, é pertinente retomar Holston (1993) ao retratar exatamente as ações que evidenciam a concentração especulativa das terras, bem como da criação de loteamentos efetivados pela Terracap, em somatória a inflacionada possibilidade de acesso a propriedade no Distrito Federal:

(...) Como a Terracap cria e regula o mercado de residências por meio de seus loteamentos, pode-se tomar por certo que essa exclusão é deliberada. Se o valor da terra mantivesse baixo, isso talvez não teria ocorrido. Contudo, o preço médio de 5,1 mil dólares que a Terracap fixou em 1976 para o leilão de terrenos no lado leste da rua Central estava além do alcance dos trabalhadores mesmo qualificados. Desde então, os preços de leilões para terrenos similares subiram ainda mais. Em junho de 1981, um terreno foi vendido a 12 mil dólares, um valor de $140 \%$ em quatro anos e meio. Como a Terracap tem o poder de fixar os preços, ela influencia diretamente no sobe-e-desce dos valores da propriedade e, portanto, na especulação imobiliária. (HOLSTON, 1993, p. 305-306).

Conforme constatações de Holston (1993), pode-se observar que boa parcela dos contemplados pelas políticas habitacionais promovidas neste contexto de estatização da terra, foram impelidos a venderem os seus lotes posteriormente.

Conforme o exposto no capítulo terceiro, isso se deu pelo fato dos contemplados/segregados não disporem de condições financeiras para cumprirem com as demandas contratuais impostas pela Novacap/Terracap condicionadas à aquisição da moradia (a quitação do débito rigorosamente no prazo estabelecido no contrato de promessa de compra e venda, a elaboração da planta do imóvel, descrição da execução das obras a serem efetivadas em três anos, habite-se, dentre outros elementos).

O resultado de tal ação "deliberada" (Holston, 1993, p.305) foi a dificuldade desses extratos empobrecidos (já neste contexto de estatização da terra descrita por Ferreira e Steinberger) em concretizarem a aquisição dos imóveis ou permanecerem por longo tempo nestes.

Esse processo pode ser evidenciado em Planaltina com a implementação da Vila Buritis (Setor Residencial Leste), cujos documentos que compõem o anexo 3 demonstram a dinâmica de comercialização dos lotes que ainda sequer possuíam suas respectivas escrituras, sendo as transmissões 
viabilizadas e reconhecidas pelo Poder Judiciário em cartórios notariais via notarial cessão de direito.

É pertinente frisar que essa possibilidade de negociação do título referente à promessa de compra e venda estabelecido entre a Novacap, Terracap e o contemplado, proibia sua transmissão a terceiros. Tal imposição pode ser observada na cláusula sétima contida no contrato (anexo 3), uma vez que não se teria por parte do novo adquirente as garantias de devolução do lote à Novacap,Terracap, tendo em vista a não quitação do débito concernente às terras ainda pertencentes à empresa pública.

Vale ressaltar também que este instrumento contratual (promessa de compra e venda) não se trata de escritura referente ao lote, não sendo reconhecida a efetivação da relação de posse do comprador/contemplado, ainda em processo de quitação junto a Terracap. Muito menos dispondo este documento de efeito registral do imóvel, o que resultaria na consolidação do domínio do bem pelo adquirente.

Neste sentido, a transmissão da promessa de compra e venda do respectivo imóvel entre particulares por meio de cessão de direitos, usualmente praticado ainda nos dias modernos, embora ateste a transmissão da cessão do direito de compra e possível posse do lote, não resguarda o pleno exercício do direito de propriedade, sendo prática recorrente no segundo e terceiro ciclos de expansão da cidade de Planaltina.

Assim, o resultado de tal ação deliberada pelas políticas públicas habitacionais no período que corresponde ao segundo ciclo de expansão de Planaltina, é a contínua dinâmica de venda, expulsão/segregação socioespacial e seleção dos estratos sociais de melhores condições econômicas a ocuparem o solo urbano.

Todavia, essa mesma ação também originou constantes demandas ao acesso a moradia economicamente viável pelas camadas empobrecidas, cujos moradores, impelidos a revenderem os seus lotes, retornam a uma condição de invasores das terras contidas no Distrito Federal, ou passam a adquirem ou ocuparem terras contíguas ao quadrilátero, em somatória aos novos migrantes que adentram o quadrilátero. 
Sobre a dinâmica de expulsão intencional das camadas mais pobres da população face às políticas públicas habitacionais, que também repercute no segundo ciclo de expansão de Planaltina, Holston (1993) a explicita o seguinte:

Do ponto de vista da Terracap, esses resultados são melhorias que afetam toda a vizinhança, elevando o seu prestígio e o valor da propriedade. Entretanto, tais melhorias também dão origem a um processo de afastamento dos pobres da zona urbana, um processo que poderíamos chamar de "gentrificação". Quero indicar com esse termo um desenvolvimento imobiliário conduzido pelo Estado, no qual pessoas com acesso privilegiado a iniciativas do governo acesso baseado em riqueza ou status - remover moradores que não tem tal acesso. O contrato de retrovenda e a compra em hasta pública podendo ser visto como mecanismo de tal remoção, pois não apenas atraem pessoas que podem construir casas bem mais caras do que as anteriormente encontradas na periferia de Brasília, mas também, o que é mais importante, porque tende a restringir o acesso a lotes de terrenos vendidos desta maneira exatamente a esse tipo de pessoas. (Holston, 1993, p. 306).

A somatória de todos os fatores brevemente recordados e outros elementos adicionados ao entendimento quanto o uso do território do Distrito Federal ao qual Planaltina está contida, sendo impactada em seu processo de formação socioespacial, desvelaram-se no princípio especulativo do solo no final da década de 1970 e no surgimento dos primeiros condomínios ilegais (parcelamento clandestinos) no quadrilátero, replicando-se nos espaços contíguos a Brasília e, também, na cidade de Planaltina.

Estes parcelamentos clandestinos eram fruto das demandas habitacionais da classe média e de baixa renda, tal como explicitado por Holston (1993), Paviani (2009), Ferreira e Steinberger (2005), sendo que aquele último extrato social era composto, predominantemente, por migrantes, cujo perfil socioeconômico resultou em grandes dificuldades para obterem o acesso à moradia.

Interpreta-se que: somando à crescente demanda habitacional gerada pelos distintos extratos sociais; adicionando-se as políticas habitacionais e ofertas de lotes a conta-gotas; a especulação e inflacionamento das terras promovidas pela Novacap/Terracap nas primeiras décadas após a vigência de Brasília; as desapropriações inconclusas e a expectativa de obtenção de lucros pelos antigos proprietários das terras e imobiliárias pré-existentes, constituíram em uma série de elementos que resultam na ampliação das invasões de terras públicas e 
implementação dos parcelamentos clandestinos (condomínios) no Distrito Federal, entre o fim da década de 1970 e início dos anos de 1980.

As invasões foram efetivadas pelos extratos sociais empobrecidos, ocorrendo tanto sobre terras públicas como de proprietários particulares, organizado através de associações de moradores, que desde o ano de 1958 caracterizam-se como prática de inclusão social face a questão habitacional do Distrito Federal.

Outro fato novo atrelado a este estrato é o estabelecimento de contrato de compra e venda ou promessa de compra e venda, promovido pela grilagem de terras públicas ou parcelamento efetivado por particulares e rotulados de condomínios, cujos baixos preços também acabaram por atraírem a referida estratificação social a sua aquisição. Neste processo, assim como nas invasões, tem-se também a existência e atuação das associações de moradores.

Todavia, a origem dos condomínios rurais, advindos dos parcelamentos de áreas próximas às cidades satélites, correlacionam-se as demandadas geradas pela classe média, e até mesmo os extratos mais abastados. Assim como nas invasões em tal contexto, os parcelamentos clandestinos se deram sobre terras públicas via grilagem ou através de contratos de compra e venda entre particulares ou pela atuação das imobiliárias que já detinham a propriedade de terras, ou agenciam a sua venda, e, até mesmo, articulam negociatas sobre terras griladas.

Além dos fatos e agentes enumerados nesta dinâmica que transita da situação de estatização do solo para a sua privatização segundo a leitura de Ferreira e Steinberger (2005), e que compõe a complexidade do processo de formação socioespacial bem como do uso do território de Planaltina, tem-se na decisão/ação oriunda do Poder Judiciário (TJDFT) explicitado por Malagutti (1997) a possibilidade de reconhecimento das transações efetuadas por particulares sobre as terras do Distrito Federal, fugindo ao controle do Poder Executivo e pondo em xeque a ideologia da dominialidade das terras exercidos por esta instância de Poder, tal como exposto por Oliveira (2008). 
Este fato constitui-se um marco que impacta na dinâmica de produção e uso do território, transitando de uma lógica predominantemente estatal para a possibilidade crescente quanto à ação dos agentes privados.

Estes agentes tinham como meta a flexibilização normativa, cujo escopo vincula-se a produção de novos espaços residenciais privados até então obstados pela postura restritiva emanada do Poder Executivo de então, que já em um contexto de privatização do solo verificar-se-á uma conduta de relativização normativa e fiscalizadora para com a ocupação das terras no quadrilátero.

Constata-se que estes eventos desdobraram-se também no movimento da cidade de Planaltina (totalidade cindida/subespaço e ao mesmo tempo contida em uma totalidade integral) em seu processo de formação socioespacial, uma vez que o resultado é a nova expansão do sistema de objetos espaciais no terceiro ciclo desse movimento, tendo enquanto lógica mais abrangente em termos de periodização a gênese de um meio técnico-científico-informacional no contexto nacional (Santos e Silveira, 2003).

Sobre a participação do Poder Judiciário nesta dinâmica, pode ser observado no acórdão n 13.615, resultante da Apelação Civil $n^{\circ} 4.890$, proferida no dia 22 de agosto de 1977, como resposta a dúvida $n^{\circ} 39.160$ condizente à possibilidade de registro das terras adquiridas e que derivam no primeiro condomínio rural privado (Country Club Quintas da Alvorada) contido no quadrilátero do Distrito Federal, sem a prévia aprovação do Poder Executivo.

Acerca dos fatos que remontam à crise que se estabeleceu, tendo em vista a ideologia da dominialidade das terras do Distrito Federal pelo Poder Executivo (Oliveira, 2008) em conflito com os demais interesses dos múltiplos agentes contido no quadrilátero no final da década de 1970, Malagutti (1997) assim descreve o surgimento do Quintas da Alvorada, que embora não seja pertencente à Região Administrativa de Planaltina, a decisão judicial, sobre tal lide, acabará por repercutir na dinâmica de produção dos sistemas de objetos cidade, território usado no presente:

A primeira notícia que se tem sobre loteamento "clandestino", com as características peculiares como os conhecemos hoje no DF, data de 1975, quando nascia o primeiro empreendimento imobiliário na área 
rural, com ofensa à legislação que regia a atividade. Tratava-se do loteamento denominado inicialmente de "Country Club Quintas da Alvorada", posteriormente alterado para "Quintas da Alvorada", localizado na Fazenda Taboquinha, entre as cabeceiras do Ribeirão Taboca e o Córrego Mata Grande, na região do futuro Lago São Bartolomeu. Nessa mesma ocasião, tiveram início diversos loteamentos nos municípios vizinhos, localizados no Estado de Goiás.

(...) Em 1977, com a divulgação do assunto pelos jornais, a população do DF começou a tomar conhecimento de que a problemática estava tomando vulto. $\mathrm{O}$ noticiário divulgou a dúvida levantada à Procuradoria Geral do DF - PGR, pelo Cartório do $2^{\circ}$ Registro de Imóveis do DF, proceder ou não o registro de uma escritura de compra e venda do imóvel Quintas da Alvorada, que se apresentava com todos os requisitos de um "loteamento mascarado", sob a forma de condomínio.

Em resposta, a PGR defendia a tese da impossibilidade da transcrição no Registro de Imóveis por entender que o condomínio, realmente, não passava de um loteamento disfarçado. Após um impasse dentro da própria Curadoria de Registros, ficou definida (...) - Tribunal de Justiça do DF - a possibilidade de registro dessas primeiras glebas particulares, oriundas de um parcelamento particular, no DF. (MALAGUTTI, 1997, p. 152).

O deferimento da possibilidade de registro em cartório dos lotes contidos no condomínio denominado Quintas da Alvorada, é considerado um grande marco para Malagutti (1997) e Oliveira (2008), impulsionador do espraiamento dos loteamentos clandestinos e ampliação das invasões de terras públicas (objetos espaciais) no Distrito Federal, gerando uma nova faceta de produção do território em uso, tendo em vista a possibilidade de reconhecimento dos atos administrativos (escrituração e registro), que caracterizariam estes parcelamentos por intermédio do Poder Judiciário.

Neste sentido, interpreta-se que a decisão/ação proferida pelo Poder Judiciário, incidiram-se sobre o plano espacial através da interpretação dos distintos agentes que dão uso ao território, como uma nova possibilidade de contornar as normas urbanísticas vigentes, desvelando-se em novas ações que irão repercutir na (re)produção dos sistemas de objetos espaciais caracterizados enquanto parcelamentos clandestinos/ condomínios.

A respeito dos efeitos concretos oriundos de tal decisão/ação quanto à resposta aos questionamentos produzidos por Botelho (2011), é pertinente ressaltar 
a descrição do panorama dos debates sobre a lide, e os seus impactos sobre o plano espacial, resultante da decisão contida no acórdão $n^{\circ} 13.615$ relatada por Malagutti (1997):

Conforme já previsto à época, esta decisão jurídica abriu precedentes na região, estimulando novos parcelamentos, disfarçados em chácaras e sítios de recreio.

A proliferação dos loteamentos clandestinos continuou nos anos seguintes, a todo vapor. $\mathrm{Na}$ realidade, o ponto principal de toda a questão residia em se definir, jurídica e semanticamente, se esse tipo de empreendimento, pelas suas características e à luz da legislação, constituía-se em "loteamento" ou "condomínio". Se ele se configurasse como loteamento, estaria na faixa de jurisdição da prefeitura local, e teria que se subordinar à Lei $n^{0}$ 6.766/79; se o entendimento fosse de que se constituiria em condomínio rural, o regime seria o Código Civil e a regulamentação do Incra. No pronunciamento do Desembargador Clenon de Barros Loyola, transcrito a seguir, confirma-se a ideia de burla à legislação: "nos contratos desse tipo, o encobrimento do loteamento clandestino é facilmente identificável, pois os proprietários instituidores do condomínio evitam na redação dos contratos, expressões como "loteamento", "parcelamento do solo", "lote", mas não conseguem disfarçar a verdadeira finalidade do empreendimento. Violentam a Lei no 6.766/79, deixando de observar diretrizes para o uso do solo, de requerer a aprovação pela prefeitura e de solicitar, quando é o caso, a alteração do solo rural para fins urbanos". (MALAGUTTI, 1997, p. 153).

A decisão/ação do TJDFT, ao tratar dos fatos segundo a mera perspectiva semântica, acabou por desconsiderar as normas vigentes que respaldavam a postura restritiva do Poder Executivo local, condizentes à necessidade de prévia aprovação de loteamentos urbanos previstos nas Leis no 58/37, nำ 2.574/56 e nำ 6.766/79.

Em tal decisão, abriu-se o precedente para a possibilidade de registro dos parcelamentos ditos clandestinos, implementados por particulares mediante a efetivação da averbação em cartório de registro de imóveis, garantindo aos novos adquirentes a dominialidade do bem imóvel reclamado pelo GDF.

O fato gerador do impasse teve sua gênese no reconhecimento da legitimidade do ato da transação que foge ao controle do Executivo local, uma vez que lavra-se a escritura do imóvel em cartórios notariais, garantido assim, de início, 
o direito de posse dos novos adquirentes, dando-se publicidade ao ato de compra e venda.

Contudo, o direito de propriedade ainda não havia se consubstanciado, já que fora posto em questão tal possibilidade, tendo em vista que essas terras (a exemplo da Fazenda Taboquinha) haviam sido declaradas para fins de utilidade pública pelo GDF e passaria por desapropriação.

Assim, no procedimento de dúvida fora questionado a legalidade da possível efetivação de averbação no livro de registros do $2^{\circ}$ Cartório de Registro de Imóvel, que consumaria na transmissão do domínio da propriedade aos novos adquirentes de fato, garantindo-lhes o pleno exercício do direito de propriedade sobre o bem alienado em terras declaradas de utilidade pública para fins de desapropriação.

Todavia, além do impasse semântico, hermenêutico que determinaria a possibilidade ou não do registro do referido parcelamento, sendo este um condomínio ou loteamento, resultando na respectiva aplicação da legislação urbanística ou agrária para fins de registro ou não, teve-se enquanto argumento recorrentemente sustentada pelos condôminos na Apelação Cível nํㅜ 4.890, a impossibilidade restritiva advinda do Poder Executivo face às relações de compra e venda de terras empreendidas por particulares, tendo em vista que, efetivamente, por mais que as terras em questão fossem declaradas para fins de desapropriação, enquadradas enquanto de utilidade pública, ao não se consumar o pagamento indenizatório, o então proprietário teria todos direitos de aliená-la, tal como previsto no Código Civil de 1916 (direito de propriedade) e em várias jurisprudências emanadas sobre o tema.

Além desta alegação exposta, prontamente aceita pelos desembargadores na produção do acórdão $n^{\circ} 13.615$, fora refutado qualquer vício formal ou defeito quanto ao título (escritura) a ser registrado, assim como do mecanismo de compra e partilha da terra efetivada pelos 128 adquirentes e o direito de negociá-las pelo então proprietário, sendo observado o princípio da continuidade, ou seja, não se tratava de terras griladas, já que a efetivação do desmembramento da propriedade em questão provinha de uma antiga sesmaria, cujo seu primeiro 
registro datado do ano de 1805, do $1^{\circ}$ Cartório de Registros de Luziânia, em documento anexo ao processo.

Algo que Malagutti (1997) também não cita foi a postura tendenciosa e crítica dos magistrados, tendo em vista a decisão monocrática relativa à sentença de dúvida proferida pelo Juiz Carlos Gomes Sanromã, a respeito da possibilidade de registro do referido condomínio, já que todos os requisitos legais como a escritura, a forma de aquisição e partilha das terras, caracterizariam o ato jurídico de alienação enquanto legítimo ou perfeito, assim como da existência de um condomínio e não de loteamento, sendo esta última modalidade sob o julgo jurídico das Leis 58/37 e $2.874 / 56$.

Nesta perspectiva, cabe citar os pontos em questionamento sobre a referida lide, assim como do posicionamento unânime dos desembargadores que reconhecem a legitimidade do registro em cartório do Condomínio Quinta da Alvorada. Nestes termos o Desembargador Leal Fagundes se pronuncia sobre a questão:

As razões de apelo arguem que: a) o Decreto 3008/75, declaratório da utilidade pública de parte da gleba adquirida, não obsta o registro, porque a propriedade particular expropriada só ingressa no domínio público, depois de paga o preço como garante a Constituição Federal (Art. 153, § 22) e consoante a repertório doutrinário e jurisprudencial colacionado; b) a irrelevância do número de compradores da referida gleba e da indicação, no título, em avos, da parte ideal de cada consorte, por que a lei civil não dá esses fatos como descaracterizadores do condomínio; c) a planta divisória da gleba em quinhões não significa o alegado loteamento dissimulado; d) a escritura registrada não representa um loteamento com a capa de condomínio; e) não ser o caso de loteamento sujeito à aprovação do Governo local; f) o invocado art. $3^{\circ}$ do Decreto-Lei $n^{\circ} 271 / 67$ não impeditivo do condomínio adotado; g) o também invocado art. 28 da Lei $\mathrm{n}^{\circ}$ 2874/56, arrimo da sentença apelada, diz respeito a loteamentos externos, circunvizinhos à área do Distrito Federal.

Quanto ao Decreto $n^{\circ} 3008 / 75$, não passa de mero ato declaratório, sem força para impedir alienação a terceiros do bem particular objeto da declaração, eis que tal bem só se torna inalienável, quando, efetivamente, ingressa no domínio público, fato que só se consuma com o pagamento do preço justo (...)

O título registrado está, formalmente, perfeito, como reconhece a Dra. Oficiala, suscitante da dúvida comandada, na inusitada consulta (...)

Assim, se o título registrado está, formalmente, perfeito, se a lei civil e a doutrina não impede que, qualquer que seja o número de 
pessoas, adquiram área, rural ou urbana, para o desfrute condominial, se, afinal, os pressupostos do condomínio estão atendidos, não vejo como, por mera excogitação subjetiva da intenção dos compradores, negar o registro.

(...) Que haverá, por trás do renhido empenho do Governo local? Política, idiossincrasia, obliteração do vislumbre jurídico, por conveniência administrativa? (TRIBUNAL DE JUSTIÇA DO DISTRITO FEDERAL E TERRITÓRIOS, apelação cível $n^{\circ} 4890$, 1977).

Sobre a questão da legitimidade do ato registral e da decisão monocrática apensa à ideologia da dominialidade das terras pelo Poder Executivo, o Desembargador Leal Fagundes ao proferir o seu parecer contido no acórdão 13.615, se expressa criticamente quanto à questão em discussão:

Então, e a bem da verdade, toda a controvérsia dos autos surgiu de maneira espúria, ou seja, a Dra. Oficiala de Registro consultou o Dr. Juiz dos Registros Públicos sobre título registrando, porque a área dele constante estaria abrangida por ato declaratório de utilidade pública, não impeditivo da alienação e nem, consequentemente, do registro do título, como reconheceu o próprio consultante, que esclareceu, na consulta imprevista, não ser o caso da dúvida, regulada no art. 198 da "Lei dos Registros Públicos"; o Dr. Juiz consultado, louvado em pareceres do Governo local, deu pelo loteamento mascarado e mandou que o Cartório do Registro levantasse a dúvida, que seria julgada por ele mesmo e que já estava, portanto, prejulgada, até porque consta do instrumento da mesma dúvida, ser ele obediente às determinações do Dr. Juiz, na decisão na consulta referida.

Assim, a oposição ao registro de que se trata é do interesse exclusivo do Governo local, eis que os órgãos do Ministério Público, que oficiaram nestes autos, opinaram em prol do apelante, o que explica o empenho e a insistência da Procuradoria do mesmo Governo, no ingresso aos autos, de modo, também, espúrio, essa é que a verdade, quase sempre dura e desagradável. (TRIBUNAL DE JUSTIÇA DO DISTRITO FEDERAL E TERRITÓRIOS, apelação cível $\left.\mathrm{n}^{\circ} 4890,1977\right)$.

Tendo exposto as críticas contundentes pelos desembargadores quanto da prévia decisão atinente à impossibilidade de registro em cartório do Condomínio Quintas da Alvorada, que segundo a interpretação destes, negaram o direito de propriedade e as prerrogativas vinculadas a este contidas na Constituição, assim como no Código Civil de 1916 em detrimento a primazia da Lei nํㅜ 2.874/56, transcreve-se abaixo o posicionamento do Juiz Carlos Gomes Sanromã, cujo 
argumento explicitamente toma partido do discurso restritivo do Poder Executivo e de sua total legitimidade para o uso e ocupação das terras do Distrito Federal, por mais que estas não tenham sido desapropriadas em sua totalidade.

Assim o referido Juiz expressa sua interpretação sem mesmo o GDF ter previamente se posicionado sobre a questão:

\begin{abstract}
Em Brasília, temos as disposições excepcionais estabelecidas por motivos políticos e sociais, que até mesmo podem investir contra outras disposições ou contra o direito comum, por isso não se estendo além do âmbito expressamente designado, como o fazem as leis ditas para viger na nova capital e a já mencionada $2874 / 56$. Sua legitimidade, como direito excepcional, é indiscutível, pairando acima de qualquer outra norma (...) pois a regra estriba-se numa razão geral, a exceção, numa particular; aquela baseia-se mais na justiça, esta na utilidade social, local ou particular (...)

Legítima, portanto, a incidência do Decreto-Lei n ${ }^{\circ} 58 / 37$ e o art. 28 da Lei $n^{\circ} 2874 / 56$. Este, segundo notícia dos que a ajudaram em sua elaboração, teria surgido para evitar a proliferação de favelas. E situam essa área da linha perimétrica para fora. Seria o mesmo que admitir a constituição de favelas DENTRO de Brasília e para proteger a cidade das favelas, proibi-las FORA. O que efetivamente pretendeu o legislador foi preservar a Nova Capital de qualquer lei geral que abandonasse o sistema até então seguido, como de fato ocorreu. A Lei $n^{\circ 2874 / 56}$ é especial, não tendo sido atingida. (TRIBUNAL DE JUSTIÇA DO DISTRITO FEDERAL E TERRITÓRIOS, apelação cível $\left.\mathrm{n}^{\circ} 4890,1977\right)$.
\end{abstract}

Fato curioso contido na sentença de dúvida proferida pelo Juiz Carlos Gomes Sanromã e que suplanta o discurso da cidade de Brasília enquanto socialista, ou condensador social, é a negação a lógica da produção dos espaços urbanos Brasileiros mediante a constituição de suas áreas periféricas e que no caso da nova capital, previamente já se vislumbrava da sua reprodução sobre as terras do Distrito Federal e em seu entorno. A assim, conforme anteriormente explicitado, temse nos textos jurídicos a garantia da preservação da função geopolítica da cidade vinculada ao modelo segregador.

Algo que também fica claro é a divergência interpretativa entre os membros do Poder Judiciário sobre a legitimidade da atuação restritiva condizente à possibilidade de alienação de terras por particulares dentro do quadrilátero do Distrito Federal, assim como das contradições existentes entre o Poder Executivo, produtor das políticas públicas de uso e ocupação do território, e o Judiciário, que 
efetivamente detém os mecanismos administrativos consumadores quanto ao reconhecimento da legitimidade dos atos de compra, venda, posse e domínio.

Uma vez que o posicionamento do Poder Judiciário é contrário ao rígido controle das terras, coloca em xeque a ineficaz atuação do Poder Executivo sobre as inconclusas ações de desapropriação das terras do Distrito Federal e, no caso em questão, da importância dada pela referida esfera de Poder referente à necessidade da efetiva execução das desapropriações e incorporação das propriedades privadas em seu patrimônio, ao qual o Quintas da Alvorada é integrante, assim como outras terras não desapropriadas (Região Administrativa de Planaltina).

Esse questionamento é realizado pelo Desembargador Juscelino Ribeiro ao arguir os motivos que impediam a efetivação do registro da alienação em relevo e da posição restritiva do Poder Executivo que se manifestara também no Ministério Público e no posicionamento decisório de segmentos da magistratura.

Nestes termos, o Desembargador Juscelino Ribeiro indaga sobre a eficácia da postura restritiva do Poder Executivo quanto ao combate do princípio do processo de privatização do solo no quadrilátero, cujo discurso respalda-se na perspectiva ambiental vinculada ao Decreto $n^{0} 3.008 / 75$ :

Senhor Presidente, tive a oportunidade de ler este processo com todo o cuidado, toda a cautela e realmente fiquei embevecido com a leitura das razões oferecidas por ambas às partes.

(...) Não como se poderia impedir o registro dessa escritura, dada a condição de documento formalmente perfeito, sem qualquer defeito, sem qualquer vício aparente. Se o Distrito Federal pretende impedir que se formem condomínios desta natureza, é evidente que o caminho não é este escolhido pelo digno Governo do Distrito Federal. O Governo dispõe de instrumentos necessários a impedir que tal ocorra, desde que o seu interesse é defender a população da poluição, que foi mencionada como um dos motivos capazes de impedir que se estabelecesse este condomínio. Disse o representante do Distrito Federal que a instalação de condomínio desta natureza, na área em que foi feita, importaria em poluição no futuro, mas o Governo do Distrito Federal poderá defender-se, através de ação expropriatória, como aliás, foi mencionada por um de seus Procuradores em processo acessório.

Não vejo, Senhor Presidente, como poderia o Judiciário encampar esta pretensão, que tem mais possibilidade de ser solucionada no âmbito do Poder Executivo. Aqui, nós temos que encarar unicamente o processo, o que está no processo. Já se disse que o que não está 
nos autos não está no mundo. Se há interesses outros por trás desta pretensão, não nos cabe examina-la se não no momento em que eles vierem devidamente processados, na forma legal. (TRIBUNAL DE JUSTIÇA DO DISTRITO FEDERAL E TERRITÓRIOS, apelação cível $\left.n^{\circ} 4890,1977\right)$.

Embora não seja verdadeiramente possível mensurar a intenção dos adquirentes da terra e empreendedores do Condomínio Quintas da Alvorada quanto ao objetivo de burlar ou contornar a legislação do registro de imóveis (Lei no 6.015/73) face ao ato de parcelamento urbano e aquisição parcelada (Lei ํo 58/37), o reconhecimento da negociação legitimada pelo acórdão proferido pelo TJDFT, gera a expansão dos sistemas de objetos espaciais, como a sobreposição de tal ação do Poder Judiciário em detrimento ao Poder Executivo local.

A possibilidade de reconhecimento das negociações empreendidas por particulares junto ao Poder Judiciário, cujo embasamento se dá nos atos praticados pelos adquirentes (provavelmente de maneira juridicamente premeditada ao valessem das brechas legais) do Quintas da Alvorada, serão replicadas esdruxulamente nos demais casos de parcelamentos da terra rural no Distrito Federal.

Essa prática reproduz-se em Planaltina, seguindo a mesma lógica exposta por Holston (1993), se feita à correlação quanto à produção dos condomínios rurais adquiridos pelos extratos mais pobres da cidade, que para serem reconhecidas como legítimos, buscavam efetivar a mesma padronização condizente ao ordenamento dos lotes e os seus endereçamentos atinentes ao caso Quintas da Alvorada.

Sobre essa relação de invasões, condomínios rurais e busca do reconhecimento do direito a, de propriedade no Distrito Federal, tendo em vista uma perspectiva do embate dialético entre legal e ilegal, Holston (1993) produz a seguinte análise expondo o exemplo das ocupações de terras na Região Administrativa de Taguatinga:

(...) A despeito de suas aparentes anomalias, segue um dos padrões residenciais oficiais de Brasília: aquele projetado para as casas rurais às margens dos povoamentos urbanos, o que é precisamente a sua situação. O fato de que seus moradores viviam lá como em um povoamento rural e de que o padrão oficial é seguido pode ser visto 
no seu sistema de endereços. Os moradores identificam suas casas por eles mesmo, seguindo o código de endereços oficiais de Brasília, exatamente como se estivessem legalmente registradas pelas autoridades locais. (...) Para o endereço das chácaras, usa-se a designação dessas quadras adjacentes. Por exemplo, a chácara número 3 em uma área vizinha à Q-15 tem o código QI-15-Ch-3, ou seja, Quadra Interna 15-Chacara 3. Numa concordância estrita, as casas de Vila Chaparral seguem esse sistema: cada uma leva o endereço QSC-25-Ch (x), já que o acesso à Vila Chaparral está no fim da vila de serviço do conjunto 25 da Quadra Sul C. Assim, o código de endereços na Vila Chaparral indica um agrupamento de casas rurais adjacentes a uma quadra - exatamente a sua situação em relação as quadras de Taguatinga. Desse mesmo modo, os favelados tomaram de empréstimo a lógica da tipologia residencial oficial de Brasília e a estenderam a uma área de assentamento ilegal. (Holston, 1993, p. 297-298).

O termo esdrúxulo referente à dinâmica de produção dos novos condomínios, no caso de Planaltina, condiz aos procedimentos de parcelamento das terras, bem como da modalidade de compra e venda (compromisso de compra e venda) pago a prestações entre as partes, assim como dos endereçamentos dos lotes ou casas, que ao contrário do caso do Quintas da Alvorada e analisado através da mera perspectiva semântica, grande parte destes dispõe de todas as características que os enquadram juridicamente enquanto loteamentos, tal qual estabelecido na Lei $\mathrm{n}^{\circ}$ 6.766/79, que regem e determinam os elementos de legalidade de tais parcelamentos repassando para o GDF a prévia aprovação ou não.

Em outros parcelamentos, na tentativa de lhes serem atribuídos essa legitimidade e que reincide ao caso do Quintas da Alvorada, cuja legislação estaria associado ao direito agrário, vê-se a repartição do que seriam as quadras residências em módulos, fazendo alusão ao termo "módulo rural" correlacionado a Lei $n^{\circ}$ 4.504/64 (Estatuto da Terra), tal como exposto no anexo 4.

Esse anexo, promessa de compra e venda em parcelamento de gleba que resulta no Condomínio Mestre D’Ármas, prevê inclusive a segurança jurídica do ato em questão ao atestar que o referido parcelamento não recaia sobre o Decreto nº 6.004/81, que já declaravam para fins de utilidade pública a desapropriação das terras que dariam origem ao Parque Ecológico das Águas Emendadas, lembrando a questão descrita no Decreto 3.008/75 que também determinava a Fazenda 
Taboquinha (Quintas da Alvorada) para fins de desapropriação pelo fato de dispor de mananciais para o abastecimento da cidade de Brasília.

Este elemento de burla a legislação também se expressa na toponímia dos parcelamentos clandestinos, como Parcelamento Rural na Fazenda Mestre D'Armas, Chácara Mestre D'armas, Loteamento Fazenda Mestre D'armas, Módulos Rurais Mestre D'Armas, dentre outros. Fato este pode ser visualizado na fotografia 07 que trata dos Padrão dos endereços dos parcelamentos de terras rurais após decisão judicial favorável aos adquirentes do Quintas da Alvorada, em Planaltina.

Fotografia 07 - Padrão dos endereços dos parcelamentos de terras rurais, após decisão judicial favorável aos adquirentes do Quintas da Alvorada em Planaltina.

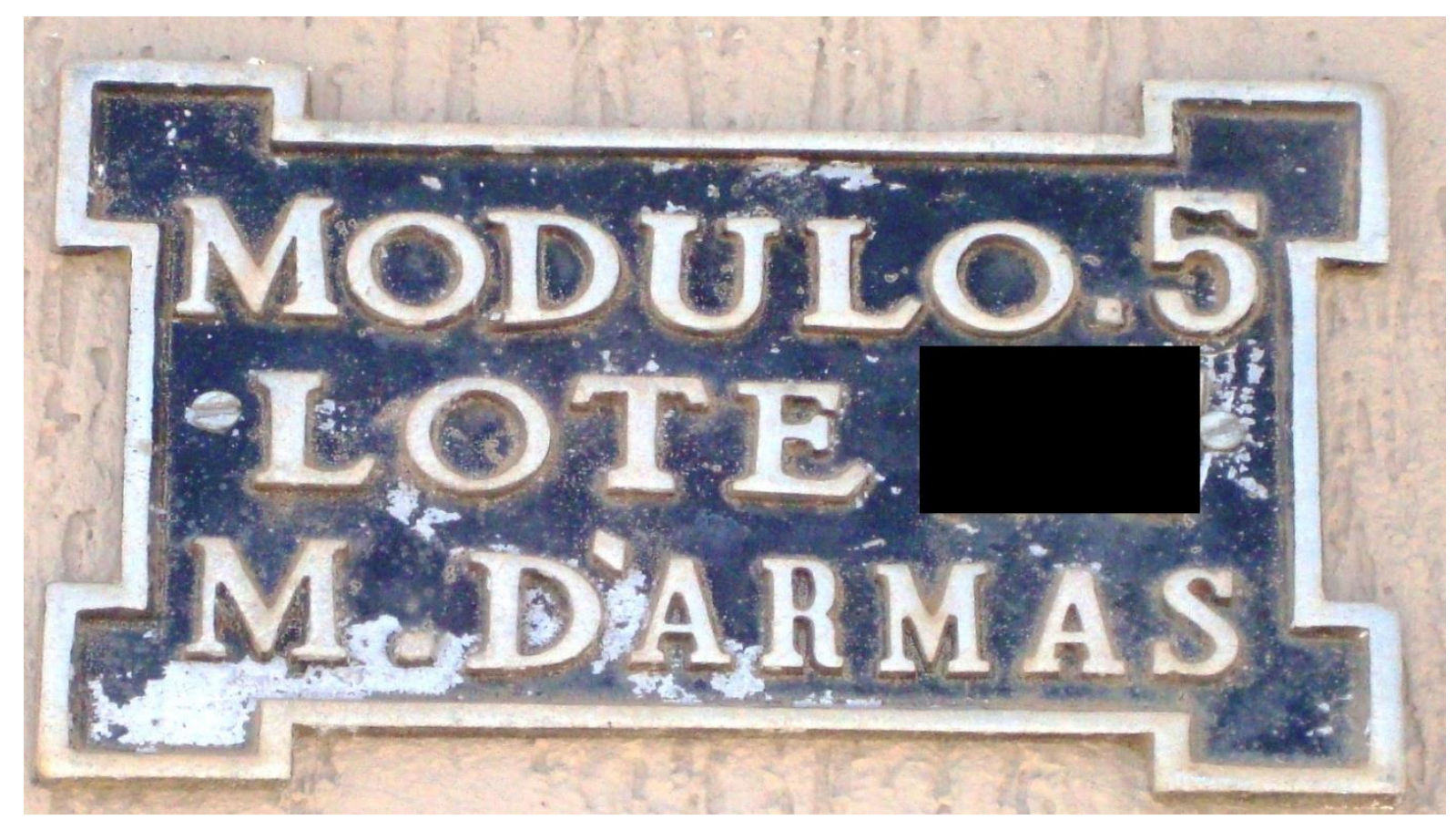

Fonte: Lima, 2014.

Depreende-se que estes resultados (decisão judicial e materialidade constituída), efetivaram-se em decorrência da inércia do Poder Executivo em não promover a total desapropriação das terras do Distrito Federal, tal como estava previsto na Lei oㅜ 2.874/56. 
Neste prisma, interpreta-se que as ações restritivas respaldadas em diversas legislações, acabavam por suplantar art. 524 do Código Civil de 1916: "A lei assegura ao proprietário o direito de usar, gozar e dispor de seus bens, e de reavêlos do poder de quem quer que injustamente os possua".

Tendo a consumação de tais fatos, percebe-se que a decisão resultante da apelação cível n4890, proferida no ano de 1977, provoca também mudanças na produção normativa atinente às políticas públicas de ordenamento territorial a partir de então, ao qual Ferreira e Steinberger (2005) e Malagutti (1997) evidenciam uma nova lógica de flexibilização das legislações face ao uso e ocupação do solo, assim como a flexibilização quanto ao intervencionismo do Poder Executivo na efetivação da fiscalização da ocupação de terras, caracterizando o contexto de privatização do solo que também se incide sobre Planaltina.

Quanto a esse processo de flexibilização normativa sobre o uso e ocupação do solo, este fato é visualizado já na elaboração do PEOT (Plano Estrutural de Organização Territorial) no ano 1978, tal como é exposto a seguir por Ferreira e Steinberger (2005), logo após a decisão do TJDFT sobre a questão do Quintas da Alvorada. Assim as autoras descrevem o evento:

A segunda dimensão geopolítica do modelo de gestão territorial representou uma flexibilização das normas de controle do uso e ocupação do solo. Seu marco foi o Plano Estrutural de Organização Territorial do Distrito Federal (PEOT) aprovado em 1978. De fato, esse foi o primeiro plano que envolveu o território do DF como um todo. Tinha por objetivo definir áreas de expansão urbana, à luz dos contextos regional e nacional. Contrariamente ao PLANIDRO, admitiu a ocupação urbana mais intensa dentro dos limites da Bacia do Paranoá, mas, paralelamente, priorizou áreas de ocupação fora da mesma. (FERREIRA e STEINBERGER, 2005, p. 73).

Nesse sentido, denota-se que a decisão proferida pelo TJDFT dispôs de um peso normatizador, abrindo caminho para a concretização dos interesses corporativos frente ao uso especulativo do solo que se traduziu na produção das novas normas que se materializam no território em uso.

Fica perceptível que cada vez mais essa flexibilização normativa, quanto à produção das políticas públicas territoriais elaboradas pelo Poder Executivo 
local e chancelada pelo Poder Legislativo já em um contexto de redemocratização, ganha em volume.

Exemplo a ser dado para com esse fato é a produção da lei ํㅜ 54/89, que determinou a regularização ou desconstituição dos parcelamentos clandestinos e invasões no Distrito Federal, cujos seus efeitos se darão tardiamente, como será exposto por Malagutti (1997), já que poucos foram os loteamentos efetivamente regularizados ou desconstituídos.

Embora o território usado seja a confluência de ações simultâneas dos múltiplos agentes nele contidos, assim como da diversidade de objetos espaciais nele presentes, fruto do trabalho vinculado às ações/intenções sobre ele incididos, vê-se no caso em questão que, as decisões proferidas pelo Poder Judiciário em suas diversas instâncias, poderiam repercutir na relação dialética entre este mesmo território usado e a sociedade ao qual Ihe dava o uso, ecoando na sua dinâmica de reprodução, ou seja, em sua materialidade em totalização, influenciando, ou até mesmo resultando na gênese de objetos espaciais.

A confirmação de tal afirmação pode ser constatado na interpretação de Malagutti (1997), tendo em vista os desdobramentos de tal ação/decisão oriunda do TJDFT na produção do sistema de objetos espaciais, seguindo o raciocínio de Santos (2002) ao descrever a dinâmica condizentes aos sistemas de ações e sua implicação nos sistemas de objetos.

Malagutti (1997) explicita o desenrolar desta dinâmica, fruto do acórdão $n^{\circ} 13.615$, tendo enquanto perspectiva a ampliação dos parcelamentos clandestinos no Distrito Federal e da nova dinâmica de elaboração normativa face às políticas públicas de uso e ocupação do solo, assim como da própria postura inerte (intencional?) do Poder Executivo, tida por Ferreira e Steinberger (2005) como fatores que viabilizaram o processo de privatização do solo. Assim Malagutti (1997) expressa sobre isso:

Os últimos dados levantados pelo Governo do Distrito Federal - GDF - apontam números alarmantes relacionados ao parcelamento irregular do solo rural, sob a forma de loteamentos clandestinos. Iniciados por volta de 1977, somavam cerca de 150 loteamentos em 1985, quando foi criado o primeiro Grupo de Estudos para solucionar o problema. Em 1989, quando da promulgação da Lei n 54/89 que "dispõe sobre a regularização ou desconstituição de parcelamentos 
urbanos implantados no território do DF, sob a forma de loteamentos ou condomínios de fato", e quando a premissa maior era que a regularização devesse ser uma medida de exceção, constatavam-se cerca de 170 empreendimento. Em 1992, quando da promulgação do Plano Diretor de Ordenamento Territorial - PDOT/92, onde se deu uma abertura para novos cadastramentos para loteamentos implantados de fato, somavam-se cerca de 200 empreendimentos. Em 1995, chegaram ao número quase inacreditável de 529 empreendimentos cadastrados (GDF - set/95). Verifica-se, portanto que, em 1989 a regularização devesse ser uma exceção, hoje em dia, torna-se praticamente irreversível o quadro de ocupação urbana clandestina no DF. (MALAGUTTI, 1997, p.153).

Ainda sobre os desdobramentos dos processos que repercutiram na privatização do solo do Distrito Federal, tendo em vista a expansão dos parcelamentos clandestinos que correspondiam aos condomínios, assim como do crescente número de invasões de terras públicas e privadas, é válido trazer algumas informações contidas na reportagem publicada no site da Central Brasileira de Notícias (CBN) no dia 22 de março de 2014, cujo título é: "Número de invasões de terras públicas no DF salta de 19 para $25 \%$ em um ano". A referida reportagem trata da questão em foco trazendo os seguintes fatos:

Construções irregulares vão desde barracos a mansões em condomínios de luxo e decks particulares à beira do Lago Paranoá.

Com uma população que cresce a uma taxa duas vezes maior que a média do país, o Distrito Federal enfrenta o desafio de controlar as ocupações irregulares do solo. As invasões ocupam um quarto do território - marca alcançada em 2013 após aumento de 31\% da área ocupada ilegalmente. São 600 mil moradores à margem da lei. Segundo a Secretaria de Habitação local, atualmente existem 670 condomínios irregulares, muitos deles de luxo, além de outras 500 áreas invadidas. Essas ocupações estão em regiões pobres, como Estrutural, Ceilândia e Planaltina, mas também em áreas nobres, como a orla do Lago Paranoá, onde os moradores constroem puxadinhos e ostentam decks, churrasqueiras, piscinas e espaços de lazer em áreas consideradas públicas e de proteção ambiental.

Com um trabalho de prevenção falho, as invasões acabam se consolidando, o que inviabiliza a remoção das famílias e obriga a regularização das áreas. No período de um ano, 3 mil pessoas receberam escrituras dos lotes. Mas quando nem isso é possível, resta a demolição. Em 2013 foram quase 4 mil edificações irregulares removidas e 38 pessoas, suspeitas de grilagem de terras, foram presas. 
Além dos entraves judiciais, a demora na concessão de licenças ambientais pelo Instituto Brasília Ambiental freia ainda mais 0 processo de regularização, inclusive nos condomínios. Para mudar o cenário, a promessa do governo e das instituições de defesa ambiental é de aumentar o número de operações de combate às ocupações.

A previsão é de que pelo menos 800 ocorram até o fim do ano do ano.

(In:

http://cbn.globoradio.globo.com/editorias/pais/2014/03/22/NUMERODE-INVASOES-DE-TERRAS-PUBLICAS-NO-DF-SALTA-DE-19PARA-25-EM-UM-ANO.htm\#ixzz2yiA0d2Su; acessado em 12 de abril de

Conforme explicitado na reportagem, essa dinâmica de privatização do solo também se materializa em Planaltina, caracterizando-se enquanto sendo inerente ao terceiro ciclo de expansão.

O que se constata nesta nova dinâmica de uso e produção de Planaltina em processo de totalização, é a composição de um verdadeiro mosaico complexo quanto à situação jurídica das terras em detrimento do misto de bairros constituídos por sucessivas políticas urbanas, em distintos períodos, marcado em alguns momentos pela rigidez e em outros pela flexibilização normativa e fiscalizadora, que permissivamente resultam no uso e ocupação do solo de forma ilegal, segundo os ditames normativos.

Este mosaico complexo que é inerente à formação socioespacial de Planaltina e que está associado à discussão em voga sobre a precariedade jurídica das habitações contidas em área urbana, refletindo no pleno gozo ao direito de propriedade, tivera o seu início anteriormente à construção de Brasília com a constituição do Setor Tradicional, Vila Vicentina, Vale do Amanhecer e lotes alienados que não foram inclusos na planta urbana da cidade em 1965, tais como o Bairro Nossa Senhora de Fátima e Setor Tradicional Residencial Sul.

Planaltina amplia-se com os novos setores efetivados pelas políticas de remoção de invasões executadas pela Novacap, Terracap, somado às licitações de lotes que originam as quadras residenciais alocadas na Vila Buritis, equivalendo ao seu segundo ciclo de expansão. 
O terceiro ciclo de crescimento (o segundo pós-Brasília) pode ser caracterizado enquanto um misto de invasões, parcelamentos empreendidos pelo Poder Executivo, assim como do espraiamento dos condomínios rurais em terras particulares (tal como o caso do Quintas da Alvorada) ou da atuação de grileiros sobre as terras públicas desapropriadas pela Comissão Goiana a partir de 1956.

Neste sentido, Paviani (2009) explicita os fatos inerentes a tal processo de privatização da terra que se converte no esgarçamento do tecido urbano (objetos espaciais) no Distrito Federal, e que também é característico do momento em análise, face a expansão do espaço urbano de Planaltina. É válido salientar as circunstâncias intrínsecas à precariedade jurídica das terras que se consubstanciam na condição do morar, no uso do solo:

A falta de políticas públicas de médio e longo prazo para atender à
demanda reprimida provocou a ocupação de terras no DF, por vezes
ao arrepio de leis ambientais. Esses assentamentos privados são
mais conhecidos como "condomínios irregulares ou ilegais". Nesse
caso, ferem a legislação porque ocupam áreas de proteção ambien-
tal (APAs) - margem de córregos e matas ciliares. Contam-se às
centenas e, presentemente, o GDF tenta identificar quais desses
condomínios podem ser "regularizados". Todavia, lucram grileiros e
especuladores que, ocupando terras de outrem (do governo federal,
distrital ou de outros proprietários), serão beneficiados, apesar do
malfeito contra a natureza ou contra a propriedade privada. Por isso,
o século XXI já se inaugurou há quase uma década e a estrutura do
território se mostra incompleta sob o ponto de vista legal,
administrativa e fiscal, pois há moradores que pagam IPTU e demais
taxas de urbanização e outros não pagam por se constituírem em
condomínios ainda não regularizados. Mesmo assim, alguns desses
já contam com serviços da Companhia de Eletricidade de Brasília
(CEB) e da Companhia de Águas e Esgoto (CAESB). (PAVIANI,
2009, p. 82).

O terceiro ciclo de expansão de Planaltina tem o seu início no ano de 1985, repercutindo na ampliação dos objetos espaciais seguindo ainda a lógica pautada na remoção de invasões, bem como da oferta de lotes promovido pela Terracap, característico ainda do contexto de estatização do solo.

Assim, desde a implementação do Plano Urbanístico proposto por Paula Magalhães em 1965, toda a orientação quanto ao uso e ocupação do solo se dava com base na planta urbana PR-1/2 e PR-4/1 (Setor Tradicional), e que por 
duas décadas fora seguida, evitando-se o espraiamento da cidade, garantindo a primazia da alienação de terras apenas pela Novacap, Terracap.

Contudo, neste caso, as remoções de 1985 ocorreram em decorrência do surgimento de uma invasão nas proximidades da cidade, denominada "Invasão do DVO", sendo estes moradores de baixa renda alocados pela Terracap em terrenos próximos a Vila Buritis, dando origem a Vila Buritis II.

Fica claro que embora a função de Planaltina ainda permanecesse a mesma após a construção de Brasília, ou seja, alocar a população segregada de baixa renda, observa-se que a sua área urbana também começava a sofrer as pressões referentes à demanda a moradia.

A crescente escassez de habitação legalizada, decorre da somatória de fatores anteriormente expostos, que acrescido à nova postura do Poder Executivo e ao posicionamento do Poder Judiciário local na decisão contida no acórdão $n^{\circ} 13.615$, repercutirá também na lógica de privatização das terras descrita por Ferreira e Steinberger (2005), ou seja, em novas práticas de uso do território em seu processo de produção/movimento ilegal.

Quanto à nova postura do Poder Executivo, é descrito por Paviani (2009) sobre uma perspectiva clientelista, já que um novo cenário político se estabelece após o processo de redemocratização, e que repercute na flexibilização normativa e no afrouxamento da fiscalização atinente ao uso e ocupação do solo, reverberando na reprodução do espaço urbano de Planaltina. Assim, Paviani estabelece a correlação entre crescimento dos assentamentos implementados pela Terracap, e o surgimento de novas cidades clandestinas da seguinte forma:

A partir de 1988, com a nomeação do governador e eleição de deputados para Câmara Distrital, as instituições públicas passaram a barganhar apoio político e troca de favores tendo como moeda terrenos nos diversos "assentamentos semiurbanizados" que se multiplicaram no DF.

Milhares de "sem teto" e inquilinos de fundo de quintal foram aquinhoados com terrenos em Santa Maria, Samambaia, Recanto das Emas, Riacho Fundo, Paranoá, Itapuã e extensões de glebas para moradia em outras cidades-satélites. (PAVIANI, 2009, p. 83). 
Essa prática clientelista explicitado por Paviani (2009) não repousa apenas nas políticas habitacionais simbolizadas pela implementação de assentamentos urbanos horizontais semiurbanizados, ela também se traduz no atendimento de interesses de outros segmentos corporativos que há tempos buscavam romper a rigidez condizente ao uso e ocupação do solo, que por décadas vigorou no Distrito Federal.

Um desses segmentos é o setor imobiliário, que no caso de Planaltina, já possuíam um amplo estoque de terras a serem comercializadas, sendo estas de particulares ou griladas. Este fato também se reproduz no Distrito Federal com a ampliação das invasões e vendas de terras que se consubstanciarão em verdadeiras cidades juridicamente ilegais, clandestinas.

Assim como foi exposto por Malagutti (1997) e na reportagem veiculada pela $\mathrm{CBN}$, tem-se em Planaltina, em seu terceiro ciclo de expansão, a proliferação dos loteamentos clandestinos (condomínios) anteriormente impedidos com a Planta de 1965.

Este processo corresponde às alienações de terras sobre as antigas propriedades rurais próximas aos córregos Buritizinho, Atoleiro e Ribeirão Mestre D'Ármas (GENOR, 2012); somado à venda de lotes localizados em setores anteriormente excluídos na Planta urbana de 1965, como o Setor Tradicional Residencial Sul, alienado anteriormente por particulares e pela Prefeitura de Planaltina de Goiás; adicionando-se a esse terceiro ciclo os parcelamentos passíveis de regularização efetivados pela Terracap, como a Vila Buritis II, Vila Buritis III, Vila Buritis IV (Setor Residencial Leste), Jardim Roriz (Setor Residencial Norte A), Vila Nossa Senhora de Fátima (Setor Residencial Oeste).

Quanto aos loteamentos clandestinos, a SEDHAB, em seu site, enumera a existência de 84 parcelamentos clandestinos na Região Administrativa de Planaltina, sendo que destes, para efeito de estudos de regularização urbana, 56 fazem parte da malha da cidade, enquadrados enquanto ARIS (Área de regularização de interesse social), dispondo predominantemente de população de baixa renda com até cinco salários mínimos. 
Para ilustrar a dinâmica de produção do espaço urbano de Planaltina, em seu terceiro ciclo de expansão que ocorre a partir de 1985, é pertinente expor os mapas temáticos 08 e 09 que tratam da evolução multitemporal que culmina na atual configuração territorial da cidade, bem como o quadro complexo da condição jurídica dos setores que compõem a área urbana em exposto. 
Mapa 08 - Os três ciclos de ocupação urbana em Planaltina: 1958; 1965-1967; 1980-2012.

Os três ciclos de ocupação urbana em Planaltina: 1958; 1965-1967; 1980-2012

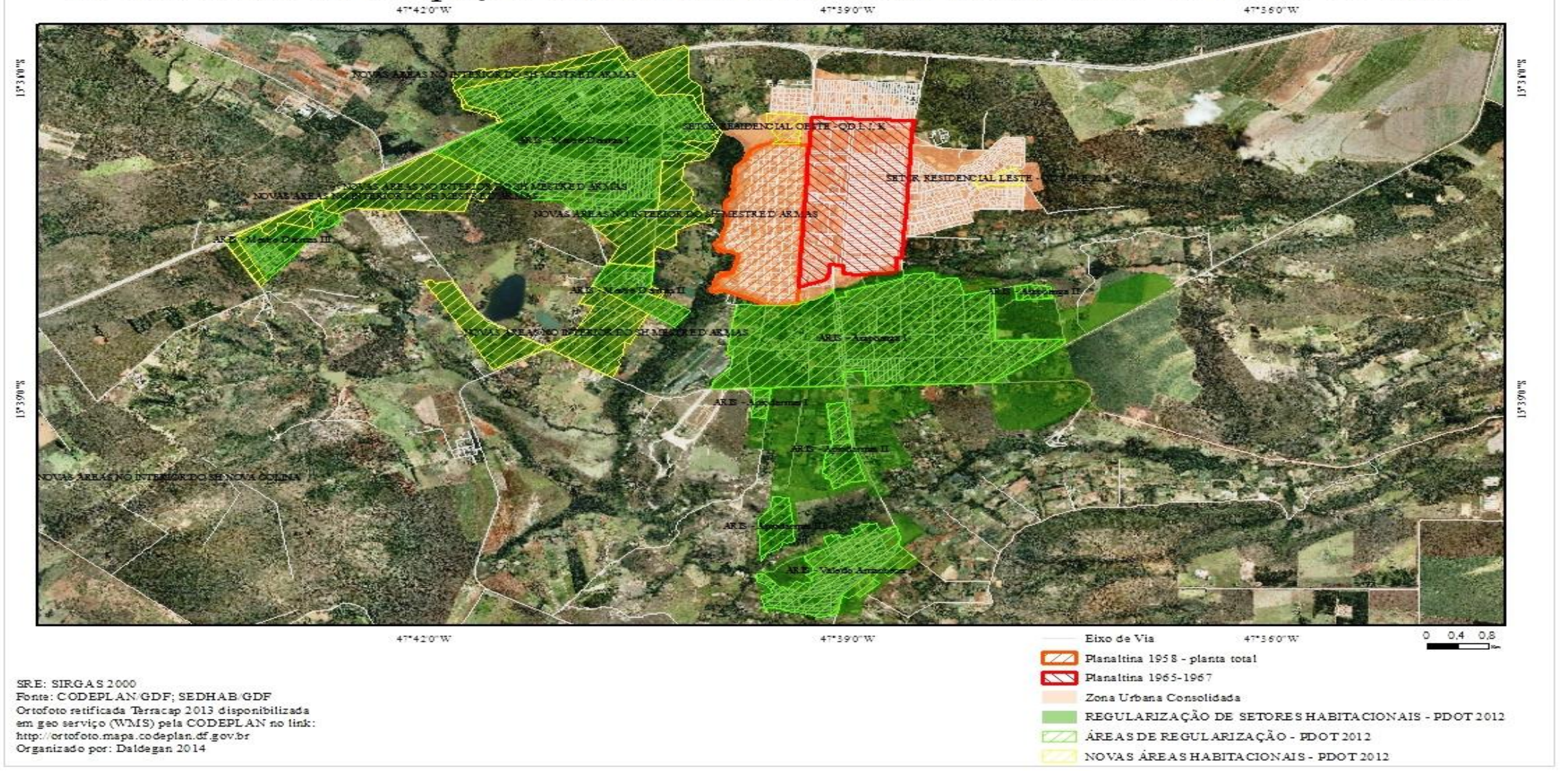

Fonte: Lima, 2014 
Mapa 09 - Quadras com matrículas trancadas - Estratégia de Regularização Fundiária - PDOT 2012.

Quadras com matrículas trancadas - Estratégia de Regularização Fundiária / PDOT 2012

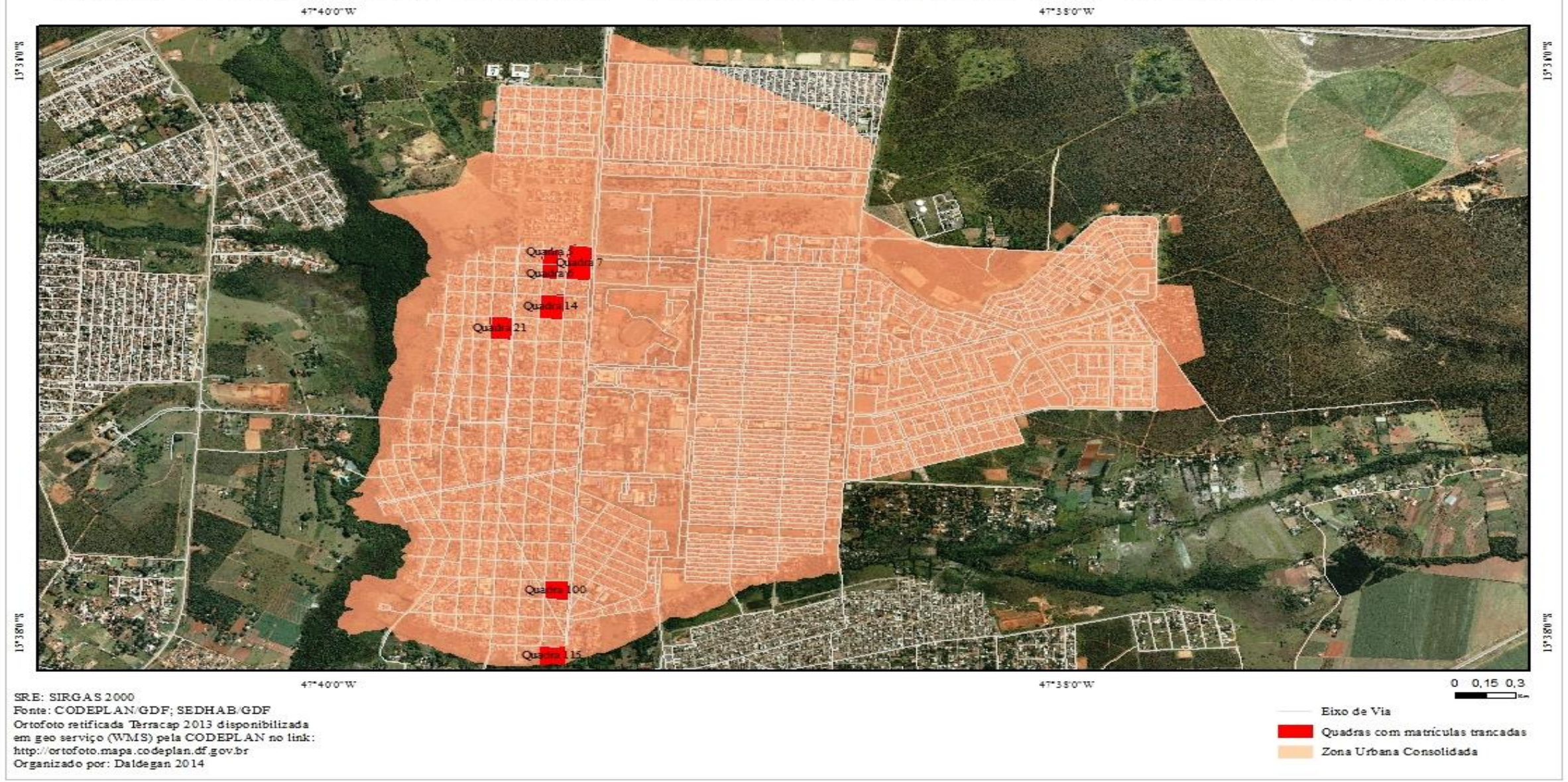

Fonte: Lima, 2014. 
O parágrafo segundo do art. 1.245 do Código Civil relativo à "aquisição pelo registro do título", define que "enquanto não se registrar o título translativo, 0 alienante continua a ser havido como dono do imóvel'. Apenas esse trecho da norma resume a condição de precariedade jurídica aos quais os moradores dos condomínios clandestinos se encontram, não exercendo plenamente o direito de propriedade ao adquirirem e construírem suas habitações em tais loteamentos.

A impossibilidade do registro dos imóveis em nome dos seus respectivos adquirentes, garantindo-Ihes o domínio dos mesmos, é resultante das alienações de terras particulares (os condomínios) e públicas (grilagem) no terceiro ciclo de expansão da cidade de Planaltina, cuja dinâmica correlaciona-se ao não cumprimento dos requisitos legais contidos na Lei no 6.766/79 (vigente no contexto), atrelados também à Lei no 6.015/73.

Conforme análise de alguns títulos, estes parcelamentos, diferentemente do caso Quintas da Alvorada, em termos dos atos jurídicoadministrativos, de longe não os enquadram enquanto condomínios rurais e sim enquanto loteamentos urbanos em chácaras e fazendas contigua à cidade de Planaltina, tanto em termos semânticos expressos nos contratos (anexo 5), assim como do próprio ato de compra e venda, recaindo sobre os princípios descritos na Lei $n^{\circ} 58 / 37$ e de no 6.766/79 (loteamento e a venda de terrenos para pagamento em prestações).

A ausência de alguns elementos previstos em ambas as leis em tais empreendimentos, como o memorial descritivo e planta do loteamento registrada em cartório, que possibilita a averbação do registro individual de cada lote; a prévia aprovação do loteamento pelo Poder Público segundo as normas municipais que disciplinam o uso e ocupação do solo; a implementação de infraestruturas básica, são fatores desconformes àlegitimidade dos loteamentos comercializados, não atendendo os pré-requisitos da Lei no 6.766/79, que também delineia as condições para a emissão do registro em paralelo à Lei $\mathrm{n}^{\circ}$ 6.015/73.

O que se verifica quanto às relações de compra e venda, ao analisar os títulos das aquisições dos lotes em tais parcelamentos, é o estabelecimento de contratos de compromisso de promessa de compra e venda ou de transmissões de 
seção de direito de compra e venda, gerando sequer escritura pública, uma vez que tão poucos tiveram a prévia aprovação do Poder Público, quanto menos disporiam de memorial descritivo e planta registrada em cartório.

Todavia, em vários títulos, destaca-se lavrar-se tanto a escritura quanto o registro do imóvel em cartório após a quitação da compra. Entretanto, tais ações não foram efetivadas, sendo inviável, inclusive, identificar se pelo menos a alienação se deu sobre terras particulares ou públicas (grilagem), já que é impossível verificar o princípio da continuidade nos contratos, um dos elementos que garantiria que pelo menos a negociação não estaria ocorrendo sobre terras griladas.

Neste sentido, com base nos fatos supra expostos, vale explicitar alguns dos elementos demandados pela Lei $\mathrm{n} \cong 6.766 / 79$ para a constituição de loteamentos urbanos legais, passiveis de efetivação de registro cartorial e que regiam a produção do espaço urbano legalizado ao qual não se enquadram os condomínios de Planaltina:

Art. $2^{\circ}$. O parcelamento do solo urbano poderá ser feito mediante loteamento ou desmembramento, observadas as disposições desta Lei e as das legislações estaduais e municipais pertinentes.

$\S 1^{0}$ - Considera-se loteamento a subdivisão de gleba em lotes destinados a edificação, com abertura de novas vias de circulação, de logradouros públicos ou prolongamento, modificação ou ampliação das vias existentes.

$\S 5^{\circ} \mathrm{A}$ infraestrutura básica dos parcelamentos é constituída pelos equipamentos urbanos de escoamento das águas pluviais, iluminação pública, esgotamento sanitário, abastecimento de água potável, energia elétrica pública e domiciliar e vias de circulação.

Art. $3^{\circ}$ Somente será admitido o parcelamento do solo para fins urbanos em zonas urbanas, de expansão urbana ou de urbanização específicas, assim definidas pelo plano diretor ou aprovadas por lei municipal.

Parágrafo único - Não será permitido o parcelamento do solo:

$\mathrm{V}$ - em áreas de preservação ecológica ou naquelas onde a poluição impeça condições sanitárias suportáveis, até a sua correção.

Art. 6․ Antes da elaboração do projeto de loteamento, o interessado verá solicitar à Prefeitura Municipal, ou ao Distrito Federal quando for o caso, que defina as diretrizes para o uso do solo, traçado dos lotes, do sistema viário, dos espaços livres e das áreas reservadas para equipamento urbano e comunitário, apresentando, para este fim, requerimento e planta do imóvel contendo, pelo menos: 
I - as divisas da gleba a ser loteada;

$\mathrm{V}$ - o tipo de uso predominante a que o loteamento se destina;

Art. $9^{\circ}$ Orientado pelo traçado e diretrizes oficiais, quando houver, o projeto, contendo desenhos, memorial descritivo e cronograma de execução das obras com duração máxima de quatro anos, será apresentado à Prefeitura Municipal, ou ao Distrito Federal, quando for o caso, acompanhado de certidão atualizada da matrícula da gleba, expedida pelo Cartório de Registro de Imóveis competente, de certidão negativa de tributos municipais e do competente instrumento de garantia, ressalvada o disposto no $\S 4^{\circ}$ do art. 18 .

$\S 1$ - Os desenhos conterão pelo menos:

I - a subdivisão das quadras em lotes, com as respectivas dimensões e numeração;

II - o sistema de vias com a respectiva hierarquia;

$\S 2^{\circ}$ - O memorial descritivo deverá conter, obrigatoriamente, pelo menos:

I - a descrição sucinta do loteamento, com as suas características e a fixação da zona ou zonas de uso predominante;

Art. 12. O projeto de loteamento e desmembramento deverá ser aprovado pela Prefeitura Municipal, ou pelo Distrito Federal quando for o caso (...)

Art. 19. Examinada a documentação e encontrada em ordem, o Oficial do Registro de Imóveis encaminhará comunicação à Prefeitura e fará publicar, em resumo e com pequeno desenho de localização da área, edital do pedido de registro em 3 (três) dias consecutivos, podendo este ser impugnado no prazo de 15 (quinze) dias contados da data da última publicação.

Art. 20. O registro do loteamento será feito, por extrato, no livro próprio.

Parágrafo único - No Registro de Imóveis far-se-á o registro do loteamento, com uma indicação para cada lote, a averbação das alterações, a abertura de ruas e praças e as áreas destinadas a espaços livres ou a equipamentos urbanos. (LEI № 6.766 de 1979. In http://www.planalto.gov.br/ccivil_03/_Ato20072010/2009/Lei/L11997. htm; acessado em 20 de abril de 2014).

Tendo em vista que muitos parcelamentos clandestinos foram executados à revelia de tais preceitos em Planaltina, neste terceiro ciclo de expansão, os seus respectivos adquirentes, por mais que detenham em mãos, de boa fé, os títulos de compra e venda firmados entre particulares, verifica-se que o direito à propriedade é precário, sendo este, em algumas vezes (dependendo da 
circunstância processual e da orientação hermenêutica do magistrado a julgar a lide) reconhecido judicialmente. Todavia, muito distante de caracterizar-se em pleno direito de propriedade.

Neste sentido, a condição de reconhecimento do direito à propriedade, em vários casos, incide-se na queda de braço entres os adquirentes de boa fé em busca do reconhecimento legal de tais parcelamentos junto ao Poder Público, já que os alienantes e imobiliárias, que intermediaram essas negociações, se eximem das responsabilidades quanto da efetivação das ações de urbanização, da aprovação dos loteamentos, assim como do registro em cartório do memorial descritivo e de sua planta, condições para a efetiva postulação quanto à obtenção ao exercício de domínio do imóvel.

Assim, o artigo 236 da Lei n 6.015 determina que "nenhum registro poderá ser feito sem que o imóvel a que se referir esteja matriculado", ou seja, ao se tratar de loteamento a ser aprovado pelo Poder Público, muitos alienantes se quer buscaram promover tal ação previamente, valendo-se da falta de conhecimento jurídico de muitos adquirentes, recaindo ainda no artigo 237 da mesma lei: "ainda que o imóvel esteja matriculado, não se fará registro que dependa da apresentação de título anterior, a fim de que se preserve a continuidade do registro".

Expõem-se assim algumas das situações que respondem pela precariedade jurídica dos parcelamentos clandestinos originados no terceiro ciclo de expansão da cidade de Planaltina, que conforme explicitado, tais adquirentes passam a demandar do Poder Judiciário, através de ações judiciais, pelo reconhecimento ao direito à propriedade em face de sua permanência em localidades, por exemplo, em desconformidade a legislação ambiental, ou por acesso a serviços públicos, como energia elétrica e água potável, caracterizando um dos traços da judicialização do uso do território que se amplia em tal contexto espaço-temporal.

Um exemplo que expressa a complexidade do território usado do presente enquanto acúmulo de ações e omissões do Poder Executivo e Legislativo, somando-se as ações/decisões do Poder Judiciário, em conjunto aos diversos agentes espaciais com suas intenções e demandas e que dão uso a Planaltina, 
caracterizando-a muito bem em seu terceiro ciclo de expansão (privatização do solo e sua judicialização), pode ser observado no acórdão gerado pela Segunda Turma Cível do TJDFT, oriunda da Ação Cível no 2011.01.1.223930-2.

Este acórdão é bastante recente, proferido no dia 26 de junho de 2013. O fato julgado condiz à ação anulatória de ato administrativo demolitório (Auto de Intimação Demolitória no D026555-OEU), que seria executado pela AGEFIZ (Agência de Fiscalização do Distrito Federal) em desfavor de Maria Neta de Lima Brandão, possuidora da residência edificada no Bairro Estância Mestre D’Ármas 5, que, conforme consta em relatório, encontra-se em área de proteção ambiental, estando em desacordo com o Código de Edificação do Distrito Federal de 1998 e com a legislação ambiental vigente.

Segundo a apelante, teria adquirido posse da área por meio da Cooperativa Habitacional dos Trabalhadores e Servidores de Baixa Renda do Planalto (COOHAPLAN), com quem teria firmado Contrato Particular de Cessão de Direito de Compra e Venda da fração de terra, dando início à construção de sua moradia.

Embora tenha sido dado provimento em favor da apelante quanto à anulação da intimação demolitória, o resultado não fora unânime, tendo enquanto posicionamentos interpretativos, de um lado, a manutenção do direito à propriedade, já que para esta área está previsto a execução do processo de legalização expressa na revisão do PDOT (Plano Diretor de Ordenamento Territorial) de 2009 (Lei Complementar $\left.n^{\circ} 808\right)$.

O posicionamento contrário, contido no referido acórdão, expressa que o poder de polícia exercido pela AGEFIZ é pertinente, tendo em vista que, se a referida moradia estivesse edificada em locais previamente orientados pela política pública de uso e ocupação do solo, a habitação disporia da licença ambiental e da titulação do imóvel que atestaria a condição de legalidade de tal empreendimento.

Neste sentido, cabe demonstrar o relato do voto contrário ao deferimento da apelação, proferido pelo Desembargador J. J. Costa Carvalho, que expressa a fragilidade do direito à moradia, à propriedade, dos adquirentes dos imóveis contidos nestes parcelamentos clandestinos em Planaltina: 
Ora, se a autora não possui a documentação apta a desconstituir a presunção de validade do ato administrativo que pretende impugnar já seria suficiente para julgar improcedente o pedido. Sim, pois a intimação demolitória que tem por substrato a ausência de alvará de construção, devidamente expedida no âmbito do poder de polícia da autoridade competente, observadas as demais formalidades, só poderia ser anulada se o intimado provasse que tem o alvará.

Tal situação é agravada pelo fato de tratar-se de obra erigida irregularmente em área de preservação permanente, fato este admitido pela autora à fl. 09, quando, ao citar julgado desta e. Corte em fundamento ao seu pedido de antecipação dos efeitos da tutela, esclareceu que "na ocasião [do julgamento citado] apesar de reconhecer tratar-se de área de preservação permanente, exatamente como no caso dos autos, o e. TJDFT assim decidiu".

Assim, considerando que a autora não trouxe aos autos qualquer documento capaz de elidir a presunção de legitimidade do ato administrativo, não merece prosperar o pedido de anulação. (TRIBUNAL DE JUSTIÇA DO DISTRITO FEDERAL E TERRITÓRIOS. Ação Cível nº 2011.01.1.223930-2; 26 de junho de 2013).

Quanto à relação entre parcelamentos clandestinos e acesso aos serviços essenciais, vê-se que estes também são pleiteados via judicial, constituindo outro traço do complexo processo de judicialização do território em uso no presente.

Esta demanda expressa nitidamente a busca por alternativas economicamente viáveis para com o acesso a moradia que, assim como no caso anteriormente exposto, retratam espacialmente a relação dialética existente entre poder aquisitivo e situação espacial comandada pela lógica do mercado imobiliário que se soma a condição de legalidade jurídica dos imóveis.

A busca ao acesso referente aos serviços essências como água potável, saneamento básico, energia elétrica, são simbólicos no que tange ao reconhecimento do direito à moradia e a uma vida digna. Entretanto, em decorrência da condição clandestina dos parcelamentos urbanos, tais serviços, em muitas situações, são negados às populações mais carentes, materializando a lógica expressa por Santos (2009) quanto da vigência da metrópole corporativa, que também se replica no Distrito Federal e em Planaltina, fração de uma totalidade e, ao mesmo tempo, uma totalidade. 
Vale expor o entendimento de Santos (2009) quanto à lógica da metrópole corporativa que também se reproduz em Planaltina, fruto da dialética centro-periferia, poder aquisitivo e situação espacial que movem as engrenagens da especulação imobiliária materializando-se na produção dos sistemas de objetos espaciais:

(...) O modelo radial, que leva as cidades a se expandir seguindo os eixos da circulação regional e inter-regional, conduz, espontaneamente, a formação de espaços vazios nos países de economia liberal. Isso se dá com ainda maior força quando o poder público é incapaz de atribuir serviços essenciais à totalidade da população. Lugares aonde não chegam água encanada, esgotos, a eletricidade, o calçamento, são por definição, desvalorizados. Sua desvalorização é relativa, em comparação com aquelas outras áreas providas desses serviços básicos. Esse é um dos fundamentos da especulação. (SANTOS, 2009, p.103).

No caso de Planaltina, um exemplo quanto à existência destas demandas por serviços públicos, advindas da população de baixa renda alocada em parcelamentos clandestinos, pode ser visualizado nos acórdãos proferidos nas apelações cíveis ํo 20120111018093ACJ de 18 de dezembro de 2012, e de no 20120110917719ACJ de 11 de dezembro de 2012, ambas oriundas do TJDFT.

Nas duas apelações têm-se, enquanto demanda judicial, o pedido de fornecimento de energia elétrica por parte da Companhia Elétrica de Brasília (CEB) aos moradores do parcelamento clandestino cognominado Condomínio Mestre D'Ármas. Em ambas observa-se como resultado o não provimento unânime de tal demanda, contendo rigorosamente as seguintes alegações:

1. Sentença irreparável, tendo em vista que a negativa de fornecimento de serviço de abastecimento de energia elétrica decorre da não exibição de documentação hábil a comprovar a ocupação regular de imóvel em área onde há parcelamento irregular do solo.

2. Legítima a recusa da CEB Distribuidora S.A. em obediência ao princípio da legalidade. Direito à dignidade não ampara pretensão de ocupantes de lote irregular. Usufruto de serviço público de fornecimento de energia elétrica exige estrita obediência aos ditames legais fixados no Decreto 32.898/2011, que visa ao controle e à erradicação de ocupações irregulares do solo e de áreas de proteção ambiental. Além disso, estabelece a Constituição Federal que a prestação de serviços públicos deve sujeitar-se à política de desenvolvimento urbano (art. 182). (TRIBUNAL DE JUSTIÇA DO 
DISTRITO FEDERAL E TERRITÓRIOS. Ação Cível no 20120111018093ACJ; 18 de dezembro de 2012)

Fato que chama a atenção em ambas às decisões, se comparadas ao acórdão proferido na questão referente ao ato demolitório, é a discordância interpretativa quanto à situação condizente à precariedade jurídica dos imóveis alocados em parcelamentos clandestinos, tendo em vista os direitos básicos, mesmo que esses parcelamentos encontrem-se em áreas de reserva ambiental, que no caso de Planaltina é constituído em quase sua totalidade por famílias de baixa renda.

Contudo, neste último acórdão explicitado na Ação Cível no 20120111018093ACJ, chama a atenção a seguinte afirmativa: "Direito à dignidade não ampara pretensão de ocupantes de lote irregular" e "energia elétrica exige estrita obediência aos ditames legais fixados no Decreto no $32.898 / 2011$, que visa ao controle e à erradicação de ocupações irregulares do solo e de áreas de proteção ambiental" (TRIBUNAL DE JUSTIÇA DO DISTRITO FEDERAL E TERRITÓRIOS. Ação Cível no 20120111018093ACJ; 18 de dezembro de 2012)

$\mathrm{O}$ direito à dignidade se constitui um dos fundamentos contido no artigo $1^{\circ}$ na Carta Magna de 1988, estando também vinculado aos direitos sociais previsto no artigo $6^{\circ}$ (direito à moradia) dessa Constituição da República Federativa do Brasil.

Ou seja, o fato jurídico que remete à precariedade jurídica quanto ao direito "de" propriedade, que se correlaciona à condição socioeconômica dos habitantes de parcelamentos clandestinos, Ihes negam uma vida digna, estando tal estado de dignidade associado ao direito a, de propriedade e aos serviços públicos a serem efetivados pelo Poder Público, mesmo que este não seja diretamente o promotor dos parcelamentos do solo.

Já a respeito do Decreto Distrital no 32.898/2011, que determina em seu artigo $6^{\circ}$ a proibição de "instalações de redes de energia elétrica e água, iluminação pública, ligações de energia elétrica e água" em novos parcelamentos de 
terras no Distrito Federal, não se aplica ao caso do Condomínio Mestre D’Ármas, já que se trata de ocupação consolidada.

Observa-se também que a não prestação de tais serviços fere inclusive os princípios contidos no art. 55 da Lei Federal o 11.997/2009, que prevê em seu parágrafo único a "realização de obras de implantação de infraestrutura básica e de equipamentos comunitários pelo poder público, bem como sua manutenção, pode ser realizada mesmo antes de concluída a regularização jurídica das situações dominiais dos imóveis", prevalecendo o direito à moradia e à dignidade da pessoa humana.

Para dar desfecho a análise da judicialização em uma perspectiva mais abrangente e recente do território em uso, ou seja, a área urbana de Planaltina em seu terceiro ciclo de expansão, tem-se os múltiplos casos de parcelamentos clandestinos de terras que acabam por gerarem processos criminais.

Essa análise propicia visualizar a dinâmica de produção do espaço urbano que resulta das demandas sociais relativas ao acesso à propriedade economicamente viável, mas que juridicamente não cumprem os pré-requisitos legais, tais como exposto anteriormente na Lei no 6.766/79.

É pertinente afirmar que todos os parcelamentos clandestinos consolidados em Planaltina e que se originaram na década de 1980, enquadram-se no art. 50 da Lei oㅜ 6.766/79, ou seja, cabe ação criminal. Entretanto, observa-se temporalmente que apenas parte daqueles parcelamentos constituídos, a partir da segunda metade da década de 1990 até os dias atuais, passam a sofrer denúncias e investigações. A título de ilustração é válido trazer o teor da norma citada:

Art. 50. Constitui crime contra a Administração Pública.

I - dar início, de qualquer modo, ou efetuar loteamento ou desmembramento do solo para fins urbanos, sem autorização do órgão público competente, ou em desacordo com as disposições desta Lei ou das normas pertinentes do Distrito Federal, Estados e Municípios;

II - dar início, de qualquer modo, ou efetuar loteamento ou desmembramento do solo para fins urbanos sem observância das determinações constantes do ato administrativo de licença; 
III - fazer ou veicular em proposta, contrato, prospecto ou comunicação ao público ou a interessados, afirmação falsa sobre a legalidade de loteamento ou desmembramento do solo para fins urbanos, ou ocultar fraudulentamente fato a ele relativo.

Pena: Reclusão, de 1(um) a 4 (quatro) anos, e multa de 5 (cinco) a 50 (cinquenta) vezes o maior salário mínimo vigente no País.

Parágrafo único - O crime definido neste artigo é qualificado, se cometido.

I - por meio de venda, promessa de venda, reserva de lote ou quaisquer outros instrumentos que manifestem a intenção de vender lote em loteamento ou desmembramento não registrado no Registro de Imóveis competente.

II - com inexistência de título legítimo de propriedade do imóvel loteado ou desmembrado, ressalvado o disposto no art. 18, $\S \S 4^{\circ} \mathrm{e}$ $5^{\circ}$, desta Lei, ou com omissão fraudulenta de fato a ele relativo, se 0 fato não constituir crime mais grave. Pena: Reclusão, de 1 (um) a 5 (cinco) anos, e multa de 10 (dez) a 100 (cem) vezes o maior salário mínimo vigente no País. (LEI № 6.766 de 1979 . In http://www.planalto.gov.br/ccivil_03/_Ato20072010/2009/Lei/L11997. htm; acessado em 20 de abril de 2014).

Considerando Planaltina enquanto território usado na perspectiva do presente, resultante da conjunção de eventos e ações que se deram no transcorrer de sua formação socioespacial, serão citados apenas alguns processos criminais que expressam nos últimos vinte anos a dinâmica atinente ao uso e ocupação do solo de forma clandestina, fator este que colocam os seus adquirentes em situação de precariedade jurídica.

O primeiro exemplo está no processo ํo 1998.05.1.004297-2 que trata do conflito de competência suscitado pelo Juiz de Direito da $1^{\text {a }}$ Vara do Juizado Especial Criminal de Planaltina, contrapondo o Juiz de Direito da Vara Cível de Planaltina, tem em seu teor, além da questão de quem detém a atribuição de proferir decisão sobre a lide, o fato condizente ao parcelamento clandestinos implementado no ano de 1996 em área de 4,28 hectares na Fazenda Mestre D’Armas em Planaltina/DF.

Embora este loteamento não conste nos cadastros da SEDHAB ou Terracap, figurando como parcelamento clandestino em área de regularização de 
interesse social, o mesmo também está consolidado, localizado nas imediações do antigo Bairro Nossa Senhora de Fátima.

Como segundo tem-se o conflito de competência no 43.376 - DF 2004/0068164-4, mas que desta vez tramitou no STJ, apresenta em seu teor o parcelamento de 40 lotes em área pertencente à União, denominada de Chácara dos Buritis, estando esta localizada na Estrada Vicinal 10, Km 1, T 10c, lote 138, em Planaltina. Sobre a dinâmica de constituição deste parcelamento clandestino, assim consta nos altos do processo:

(...) os ora denunciados, no período de Setembro de 1997 a, pelo menos, Abril/2001, livre e conscientemente, uniram esforços para o fim de promover loteamento/desmembramento do solo, para fins urbanos, sem autorização dos órgãos públicos competentes, mediante instrumentos de promessa de venda que manifestavam a intenção de vendas de lotes em loteamento não registrado no Cartório de Imóveis competente, e, ainda, sem possuírem título legítimo de propriedade do imóvel.

(...) laudo mostra, ainda, que em 04/04/2001, data em que os Peritos compareceram ao local, ainda estava exposta uma faixa anunciando a eventuais compradores a venda das "chácaras", inclusive com pagamento parcelado.

Acresça-se que o Serviço de Patrimônio da União e o Instituto Nacional de Colonização e Reforma Agrária - INCRA (fls. 129) informaram que tamanho mínimo do módulo rural no Distrito Federal (inclusive na área onde localizado o empreendimento irregular) é de 2,0 ha, de sorte que o possuidor não poderia transferir área inferior àquela, e, mesmo assim, mediante prévia comunicação ao SPU, para fins de cobrança do devido laudêmio. (SUPERIOR TRIBUNAL DE JUSTIÇA. Conflito de Competência no- 43.376 - DF 2004/0068164-4; 25 de maio de 2005).

Os relatos mencionados descrevem a dinâmica de constituição dos parcelamentos clandestinos em Planaltina, constituídos em áreas rurais próximas a cidade, dispondo de todas as características de parcelamentos urbanos previstos na Lei no 6.766/79.

Porém, como no caso em exposto, mediante a prática de grilagem em terras públicas e privadas, verifica-se que a alienação destas se dera via promessa de compra e venda, não contendo assim o registro dos referidos parcelamentos em 
cartório, fato este que associa-se a não de autorização do Poder Público para a implementação dos loteamentos, ferindo inclusive a legislação agrária.

A apelação criminal $n=20110510058855$ APR que tramitou no TJDFT trata de outro parcelamento clandestino, o do Residencial Park 2 na Fazenda Lagoa Bonita, contiguo a Estação Ecológica das Águas Emendadas. Tal loteamento iniciado no ano de 2001 fora desconstituído, tendo os agentes sido indiciados e condenados, a princípio, conforme as penalidades previstas no art. 50 da Lei no $6.766 / 79$.

O que chama atenção neste processo é a descrição da dinâmica de constituição do loteamento em questão, que por diversas vezes se replicou no caso da expansão da cidade de Planaltina em seu terceiro ciclo em face de implementação dos parcelamentos clandestinos, que, conforme fora descrito anteriormente, dar-se através da atuação de associações de moradores junto com o proprietário da gleba a ser parcelada.

O grande detalhe reside justamente no fato de que várias destas associações foram criadas pelos próprios proprietários da terra a serem fracionadas com o intuito de maximizar as transações, tal como exposto na apelação criminal no 20110510058855APR que exemplifica essa dinâmica que se desdobra sobre o território em uso:

Infere-se dos autos que o apelante, na condição de advogado, deu início ao parcelamento em 2001, quando elaborou o Estatuto da Associação dos Moradores do Residencial Park 2 e o Termo Particular de Adesão à referida entidade, o qual previa a subdivisão de gleba na Fazenda Lagoa Bonita em 78 lotes de $200 \mathrm{~m}^{2}$, com características de frações urbanas e transferia as unidades parceladas aos respectivos aderentes (...)

Assim, ao promover a venda, promessa de venda ou até mesmo anúncio de lotes no local, o apelante praticou atos de implantação de loteamento, sem autorização do Poder Público, ou seja, sem observância dos trâmites legais. (TRIBUNAL DE JUSTIÇA DO DISTRITO FEDERAL E TERRITÓRIOS. Apelação Criminal $\mathrm{n}^{\circ}$ 20110510058855APR; 08 de outubro de 2012). 
Tais processos criminais que também retratam a judicialização do território, refletem a contínua demanda ao acesso a propriedade exposta por Holston (1993) que se desdobra em Planaltina, território usado.

Esta demanda incessante é explicitada nos dados da CODEPLAN (2013) apresentados no primeiro capítulo no que se refere ao número de domicílios ocupados, expressando o quantitativo de habitações em terrenos não legalizados, resultante da lógica da escassez de domicílios legais e economicamente acessíveis e da privatização do solo tratado por Ferreira e Steinberger (2005).

Esta conjuntura, acrescida às omissões do Poder Público, e em especial, do Poder Executivo nas últimas três décadas, abre brechas para a atuação dos agentes especuladores, promotores de tais parcelamentos, recaindo no movimento dialético entre o par legal e o ilegal que concretamente pode ser visualizado na composição dos objetos espaciais (loteamentos promovidos pelo Estado e parcelamentos clandestinos) materializados sobre o território.

A expansão dos parcelamentos clandestinos influenciam na própria dinâmica dos valores da terra na cidade, tendo em vista o centro composto por loteamentos implementados pela Terracap e passíveis de obtenção de escritura pública e registro em cartório (procedimento administrativo que resguarda o direito de propriedade), inclusive, algumas habitações pré-existentes no Setor Tradicional. Estes dispõem de elevados valores em relação a sua periferia imediata e ilegal.

Todavia, mesmo nestes parcelamentos clandestinos, cujo direito de propriedade não pode ser plenamente exercido no presente momento por não cumprirem os preceitos legais, observa-se o inflacionamento dos preços dos imóveis ou até mesmo dos lotes vazios alocados em vários bairros irregulares em Planaltina.

Esta nova dinâmica vincula-se a vários fatores, como a já citada demanda habitacional, a localização e metragem dos lotes, mas, sobretudo, a especulação gerada pela possibilidade de regularização destes parcelamentos, já sendo reconhecidos enquanto Áreas de Regularização de Interesse Social (ARIS) pela SEDHAB e Terracap, ou seja, parcelamentos clandestinos consolidados e de baixa renda a serem legalizados. 
Este fato especulativo associa-se ao TAC $n^{\circ}$ 002/2007 (Termo de Ajuste de Conduta) firmado entre o Ministério Público junto ao Poder Executivo, cuja meta a ser obrigatoriamente cumprida repousa na regularização fundiária destes parcelamentos, gerando as primeiras audiências públicas para tal, e também previstas na revisão do PDOT de 2009 (Lei Complementar 803 que também fora judicializada).

Assim, seguindo o movimento especulativo inerente ao par dialético legal e ilegal quanto da possibilidade de regularização das terras, verificasse 0 surgimento de grandes comércios atacadistas e varejistas em algumas localidades, como no Setor Habitacional Mestre D'Ármas e no Setor Habitacional Arapoangas, elevando ainda mais o preço dos lotes nestes setores de Planaltina.

Fotografia 08 - Expansão da rede de comércio sobre parcelamentos clandestinos e o encarecimento da terra - Instância Mestre D’Ármas.

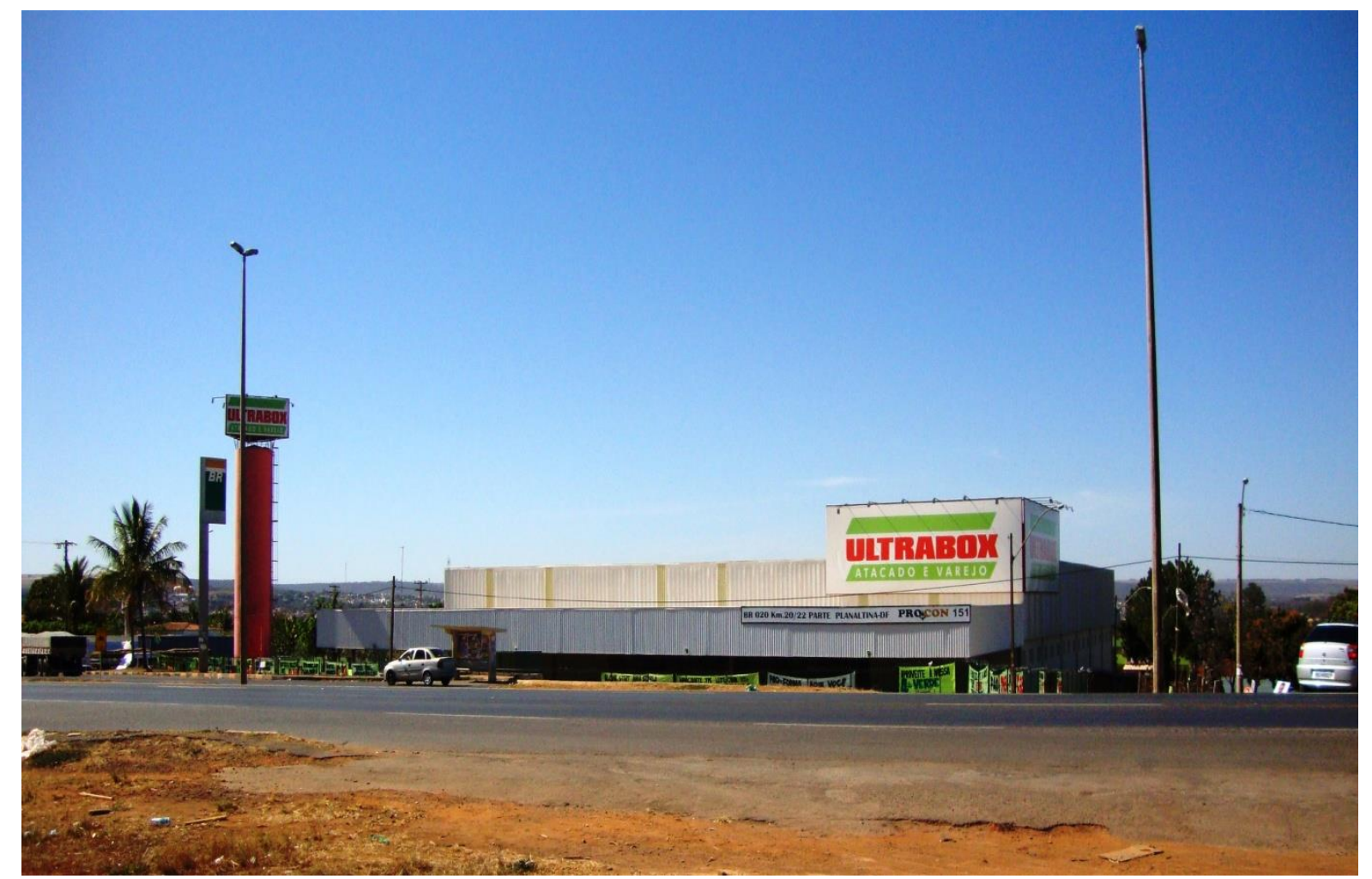

Fonte: Lima (2014). 
Fotografia 09 - Expansão da rede de comércio nos parcelamentos clandestinos e o encarecimento da terra - Arapoanga.

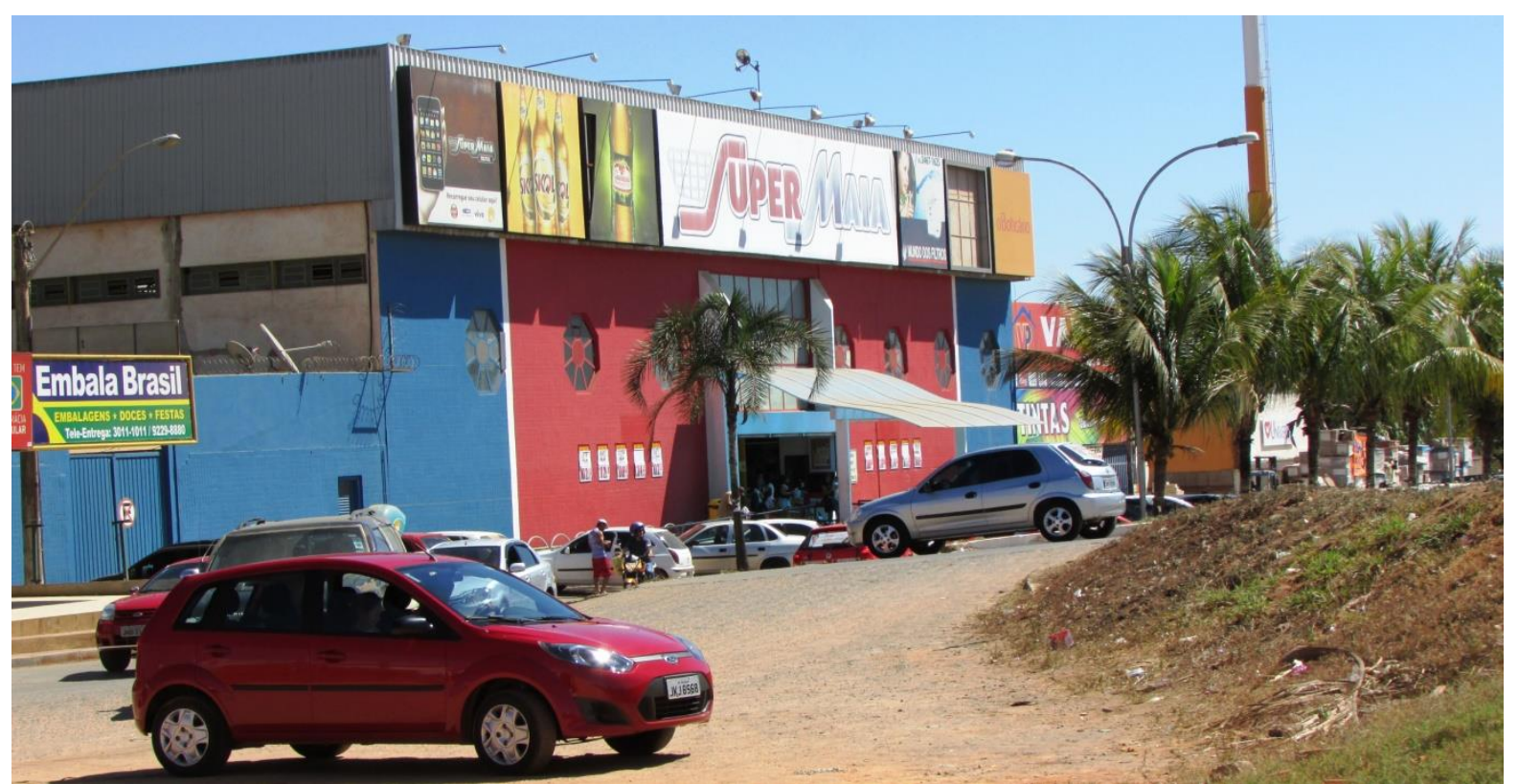

Fonte: Lima (2014).

Fotografia 10 - Expansão da rede de comércio nos parcelamentos clandestinos e o encarecimento da terra, em virtude da construção de um shopping entre o Setor Tradicional e Instância Mestre D’Ármas.

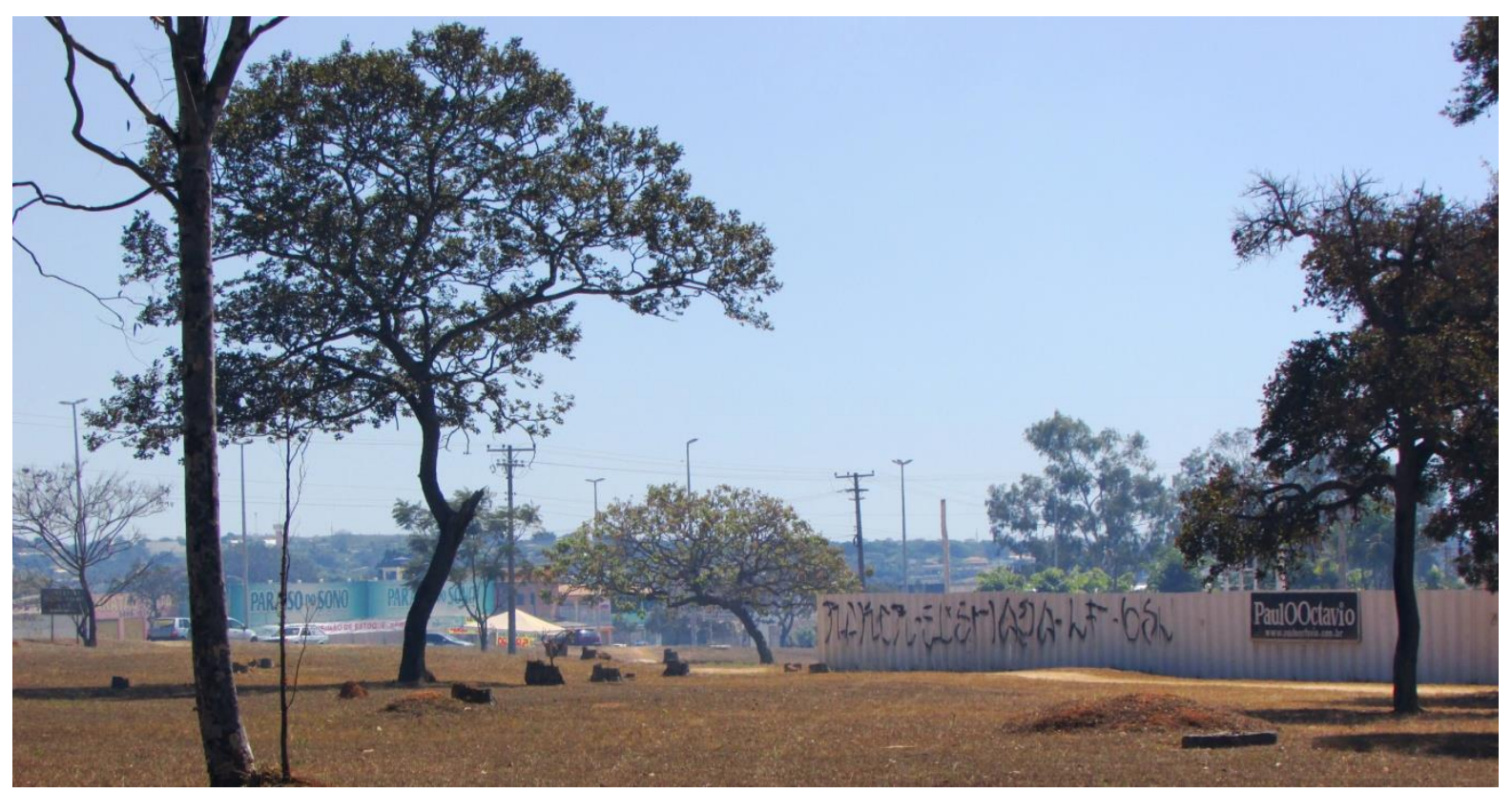

Fonte: Lima (2014). 
O mecanismo dessa dinâmica associado à escassez de acesso à moradia, desvela-se no esgarçamento do tecido urbano por meio dos parcelamentos clandestinos, fruto das demandas sociais judicializadas.

Enquanto resultado de tal processo em termos socioespaciais, em face da possível regularização desses loteamentos empreendidos em Planaltina em seu terceiro ciclo de expansão, verifica-se como produto a modificação do padrão de algumas construções, evidenciando a tendência de novos usos destas frações do território por outros segmentos sociais mais endinheirados. Esta dinâmica é sintetizado perfeitamente por Santos (2009) ao descrever o movimento urbano vinculado a lógica da metrópole corporativa. Assim Santos (2009) expõe esta trama:

(...) o provimento de recursos sociais a áreas urbanas até então deles desprovidas acarreta uma valorização e uma consequente redistribuição da população, segundo os seus níveis de renda. A cidade é um teatro de um sistema de pressões em que as classes altas e médias buscam ocupar os lugares já consolidados ou em via de consolidação em matéria de serviços e previamente ocupados pelos mais pobres, enquanto estes, sob pressão do consumo, deixam-se seduzir pela perspectiva de uma melhoria financeira apenas momentânea e abandonam os lugares que ajudaram a valorizar, indo se localizar mais adiante, em frações da cidade onde há menos amenidades. A chegada incessante de novos urbanos tem, também, um papel de pressão, graças à sua demanda de terras suplementar para residência. (...) É irônico que os melhoramentos obtidos pelos pobres, com os seus próprios meios, com sua imaginação e suas mãos, terminem por criar as condições para que se exerçam novas formas de especulação. A trampa da especulação os persegue, convidando-os a vender suas casas melhoradas e a se deslocar para ainda mais longe.

Especulação, consumo, metrópole corporativa mantêm viva a tendência para a ampliação do tamanho urbano e a cidade continua a crescer. (SANTOS, 2009, p. 103-104-105).

Essa tendência de novo uso das frações do território, por outros segmentos sociais mais endinheirados, tendo em vista os extratos socioeconômicos mais endinheirados, pode ser visualizada nas fotografias 11 e 12.

Quanto à possibilidade de regularização de tais parcelamentos clandestinos e que já causa impactos quanto ao preço do solo nestas localidades, é evidenciado pelo Tabelião Breno de Andrade Zoehler. 
Fotografia 11 - Habitações de padrão socioeconômico elevado em loteamentos clandestinos - Arapoanga.

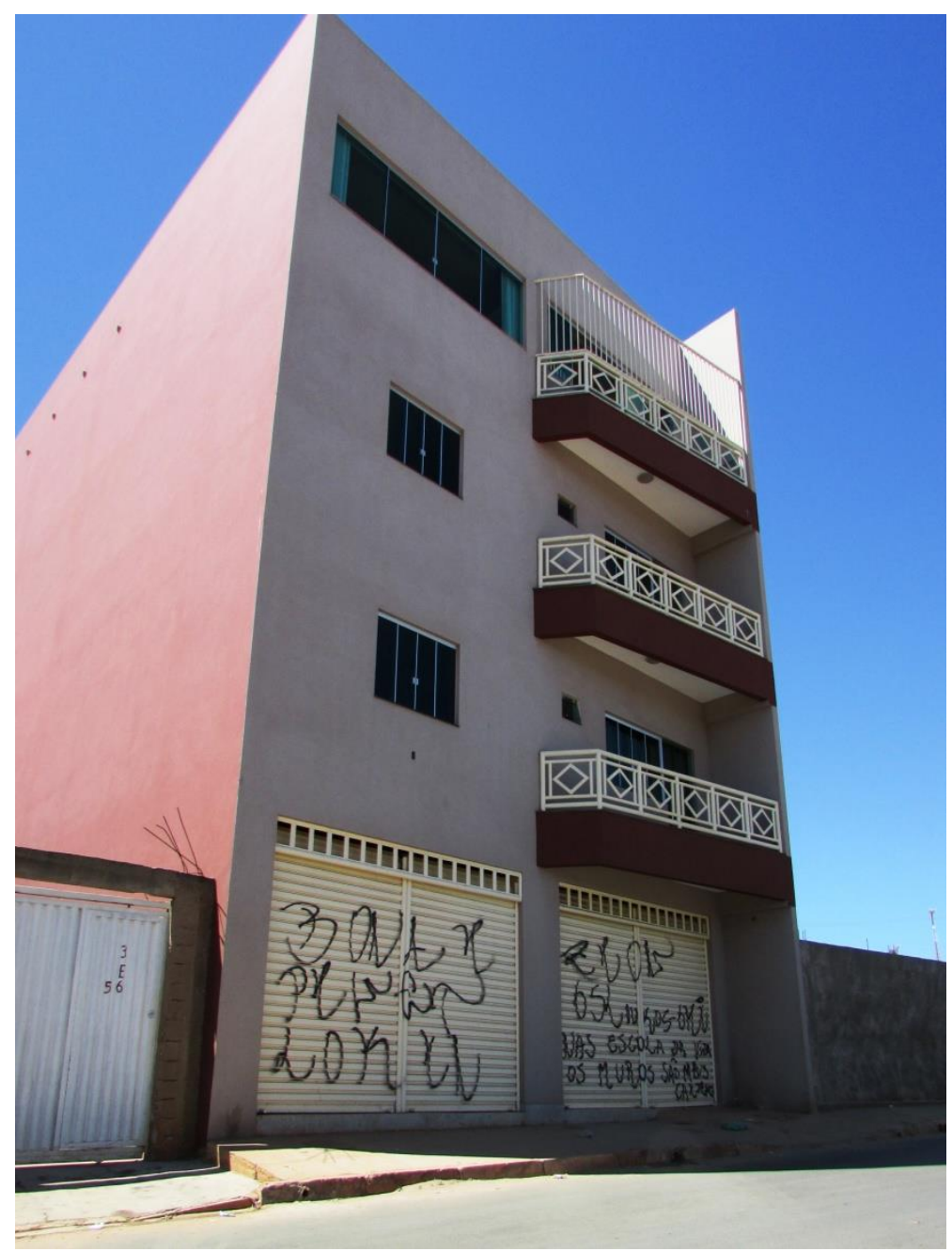

Fonte: Lima (2014).

Apesar destes loteamentos (como, por exemplo, o Setor Habitacional Arapoanga) encontrarem-se em desconformidade com a legislação, impossibilitando o pleno exercício do direito de propriedade de seus adquirentes, juridicamente a resolução de tal situação é menos complexa se comparado ao caso do Setor Tradicional de Planaltina, segundo relatado por Zoehler (2013).

Um dos elementos expostos por Zoehler (2013) que colocam esses parcelamentos em uma condição de "fácil resolução jurídica" está associado à recente constituição dos mesmos. Este fato facilitaria a identificação dos alienantes e (supostos) proprietários das glebas para dar-se início aos trâmites de efetivação das transmissões documentais dos desmembramentos para os compradores ou 
possível indenização das terras aos quais os títulos ainda estejam vinculados aos proprietários promotores dos parcelamentos.

Fotografia 12 - Habitações de padrão socioeconômico elevado em loteamentos clandestinos - Mestre D’Ármas.

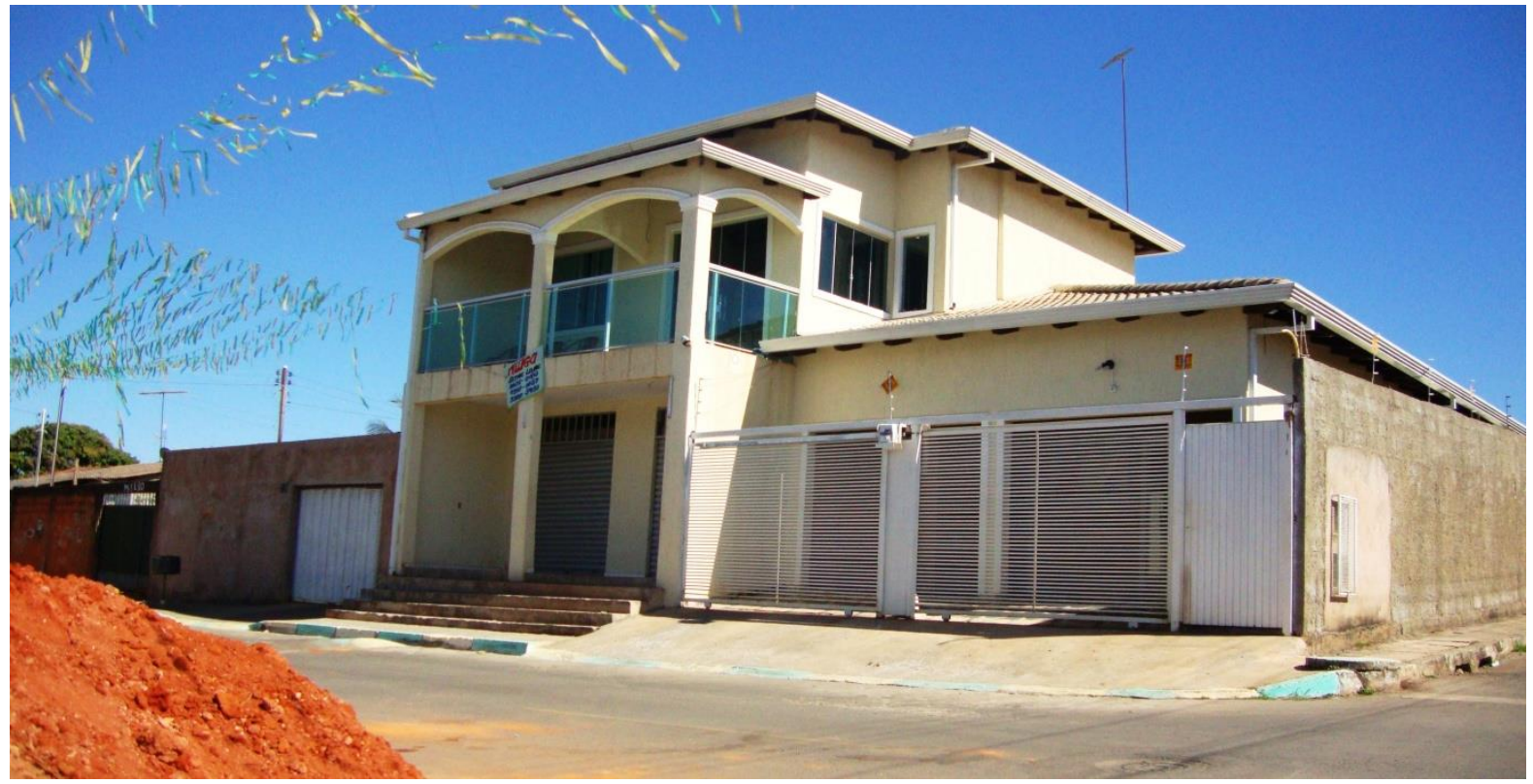

Fonte: Lima (2014).

Sobre o estabelecimento da cadeia dominial dos sucessivos desmembramentos que possibilitariam a desapropriação e regularização dos parcelamentos clandestinos, fazendo alusão ao caso do Setor Habitacional Arapoanga e a respeito da complexidade da situação jurídica do Setor Tradicional, Zoehler (2013) assevera que:

(...) Existem setores que são mais tranquilos, como por exemplo, o Araponga é mais tranquilo, juridicamente. Por que lá é oriundo de uma matrícula muito bem definida; você tem uma matrícula só que gerou...Teve um agente específico que gerou esse desmembramento, e esse agente específico depois desmembrou em algumas poucas glebas, que são mesuráveis... Dá para você fazer uma cadeia tranquila. Isso dai geraram tais, e você tem também as suas matrículas que são esses 22 ha, que seriam os menores parcelamentos, onde alguns outros agentes participaram fazendo determinadas alienações. 
Ele é um objeto muito mais simples, juridicamente. O Arapoanga é muito mais simples. Agora o Setor Tradicional, até pela sua história, é tão velho, é tão complexo (...) o Setor Tradicional você entra em problemas federativos, você entra em problema de morosidade não só judiciais, mas também administrativas. (ZOEHLER, 2013).

Tais ações de regularização dos parcelamentos clandestinos são previstas e efetivamente postas em prática, atualmente, por meio da Lei no 11.997/2009. Embora altere ou sobreponha alguns mecanismos normativos previstos anteriormente na Lei $n^{\circ} 6.015 / 73$ ou na Lei $n^{\circ} 6.766 / 79$, o texto legal reconhece a necessidade de promoção das ações administrativas e jurídicas, tendo em vista o preceito contido no artigo 1.245 do Código Civil de 2002 que plenamente vigora, estando o domínio vinculado ao alienante, já que o registro em cartório de tais loteamentos não foram gerados, ou seja, o domínio destes loteamentos ainda vinculam-se aos seus alienantes.

Contudo, o Poder Público busca estabelecer acordos para que as referidas transmissões do domínio da terra sejam efetivados mediante acordos com o seus proprietários/ loteadores. Estes mecanismos são assim expostos de maneira nítida nos artigos 47 e 57 da Lei n 11.997/09 da seguinte maneira:

Art. 47. Para efeitos da regularização fundiária de assentamentos urbanos, consideram-se:

$\S 1^{\circ} \S 1^{\circ} \mathrm{A}$ demarcação urbanística e a legitimação de posse de que tratam os incisos III e IV deste artigo não implicam a alteração de domínio dos bens imóveis sobre os quais incidirem, o que somente se processará com a conversão da legitimação de posse em propriedade, nos termos do art. 60 desta Lei.

Art. 57. Encaminhado o auto de demarcação urbanística ao registro de imóveis, o oficial deverá proceder às buscas para identificação do proprietário da área a ser regularizada e de matrículas ou transcrições que a tenham por objeto.

$\S 1^{\circ}$ Realizadas as buscas, o oficial do registro de imóveis deverá notificar o proprietário e os confrontantes da área demarcada, pessoalmente ou pelo correio, com aviso de recebimento, ou, ainda, por solicitação ao oficial de registro de títulos e documentos da comarca da situação do imóvel ou do domicílio de quem deva recebê-la, para, querendo, apresentarem impugnação à averbação da demarcação urbanística, no prazo de 15 (quinze) dias.

$\S 7^{\circ} \mathrm{O}$ poder público poderá propor a alteração do auto de demarcação urbanística ou adotar qualquer outra medida que possa 
afastar a oposição do proprietário ou dos confrontantes à regularização da área ocupada.

$\S 8^{\circ}$ Havendo impugnação apenas em relação à parcela da área objeto do auto de demarcação urbanística, o procedimento seguirá em relação à parcela não impugnada.

$\S 9^{\circ} \mathrm{O}$ oficial de registro de imóveis deverá promover tentativa de acordo entre o impugnante e o poder público.

§ 10. Não havendo acordo, a demarcação urbanística será encerrada em relação à área impugnada.

(PRESIDÊNCIA DA REPÚBLICA. Lei $\mathrm{n}^{\circ}$ 11.997/2009. In http://www.planalto.gov.br/ccivil_03/_ato20072010/2009/lei/l11977.ht $\mathrm{ml}$; acessado em 29 de novembro de 2013).

Embora não descreva claramente os possíveis procedimentos administrativos para a consolidação das desapropriações, a Lei ํo 11.997/09 ressalta o caráter de urgência referente à efetivação do registro da planta dos parcelamentos clandestinos a serem desmembrados, o que possibilitaria expedir as escrituras públicas dos imóveis, garantindo, a priori, a posse deste por seus adquirentes. Neste termos, vê-se nos artigos 65 e 66 este procedimento:

ART 65-Parágrafo único. O registro do parcelamento decorrente de projeto de regularização fundiária de interesse social independe do atendimento aos requisitos constantes da Lei $n^{\circ} 6.766$, de 19 de dezembro de 1979.

Art. 66. O registro do parcelamento resultante do projeto de regularização fundiária deverá importar:

I - na abertura de matrícula para toda a área objeto de regularização, se não houver; e

II - na abertura de matrícula para cada uma das parcelas resultantes do projeto de regularização fundiária.

(PRESIDÊNCIA DA REPÚBLICA. Lei $\mathrm{n}^{\circ}$ 11.997/2009. In http://www.planalto.gov.br/ccivil_03/_ato20072010/2009/lei/l11977.ht $\mathrm{ml}$; acessado em 29 de novembro de 2013).

Dentre os inúmeros propósitos almejados pela Lei nº 11.997/09, além de buscar proporcionar o direito à moradia de maneira mais célere, ou seja, através do "estímulo à resolução extrajudicial de conflitos" (art. 48 - IV), desjudicializando estas ações face ao resguardo da posse, em um primeiro momento, vislumbra, em 
um segundo, com a consolidação das ações de desapropriação e regularização fundiária, a concretização do direito de propriedade através da transmissão do domínio segundo o previsto neste texto legal:

Art. 58. A partir da averbação do auto de demarcação urbanística, o poder público deverá elaborar o projeto previsto no art. 51 e submeter o parcelamento dele decorrente a registro.

$\S 1^{\circ}$ Após o registro do parcelamento de que trata o caput, o poder público concederá título de legitimação de posse aos ocupantes cadastrados.

Art. 59. A legitimação de posse devidamente registrada constitui direito em favor do detentor da posse direta para fins de moradia.

Art. 60. Sem prejuízo dos direitos decorrentes da posse exercida anteriormente, o detentor do título de legitimação de posse, após 5 (cinco) anos de seu registro, poderá requerer ao oficial de registro de imóveis a conversão desse título em registro de propriedade, tendo em vista sua aquisição por usucapião, nos termos do art. 183 da Constituição Federal.

(PRESIDÊNCIA DA REPÚBLICA. Lei $n^{\circ}$ 11.997/2009. Innhttp://www.planalto.gov.br/ccivil_03/_ato20072010/2009/lei/l11977 .html; acessado em 29 de novembro de 2013).

Ao tratar da questão da judicialização do território usado na perspectiva do presente, teve-se, enquanto exercício, a busca pelo entendimento dos fatores e eventos vinculados à formação socioespacial que responde no movimento da cidade de Planaltina-DF.

Neste sentido, a cidade é interpretada enquanto totalidade integral, e ao mesmo tempo, uma totalidade cindida, subespaço, cujos agentes produtores de tal materialidade em totalização, responderam mediante suas ações à lógica vigente em seus distintos ciclos de expansão e que resultaram na constituição da singularidade perante o todo.

Nesta trajetória, muito se enfatizou quanto à constituição do núcleo urbano vernacular (Setor Tradicional) e das metamorfoses dos sistemas de objetos espaciais, tendo nas transformações o reverberar das intenções/ações que não se apartam das ações externas incididas sobre tal subespaço, sendo estas de cunho 
político, jurídico e econômico, interpretadas de maneira a possibilitarem movimentos de retração ou de expansão do todo em seus distintos ciclos.

O desdobramento de tais processos repercutem no presente e na intensa judicialização de uma fração do todo que é o Setor Tradicional, enquanto acúmulo de outras ações/intenções e omissões originárias dos diversos agentes que Ihe deram uso ao longo de sua formação socioespacial e que acabam por demandarem decisões/ações da instância judicial.

Sendo assim, para dar fechamento ao entendimento quanto à correlação entre precariedade jurídica, direito de propriedade e judicialização do território, cabe expor o caso do Setor Tradicional neste último e terceiro ciclo de produção do território em uso, tendo em vista os fatores geradores dos problemas jurídicos e os impactos das decisões (ações) judiciais sobre a questão dominial das propriedades (sistema de objetos espaciais).

4.3 - A judicialização do Setor Tradicional.

Quanto à judicialização do Setor Tradicional, constata-se que este fato é resultante, preponderantemente da somatória de omissões relacionadas às sucessivas políticas públicas habitacionais e de regularização fundiária que remontam à fase final do primeiro ciclo de expansão de Planaltina (pré-Brasília), ainda pertencente ao estado de Goiás, e perpassam ao segundo e terceiro ciclos de produção do espaço urbano da cidade, cuja síntese do movimento dialético resumese na ampliação da complexificação das questões jurídicas do setor em relevo.

Associado a este fato também observa-se a inércia dos moradores quanto à tomada de ações para com a regularização das propriedades face às respectivas iniciativas promovidas pela municipalidade goiana ou pela gestão do GDF, o que garantiria o pleno exercício do direito de propriedade.

Agrega-se também ao conflito, já em um contexto pós-Brasília, a promoção de desmembramentos e averbação de vários lotes reconhecidos em 
Cartórios de Registro (braço do Poder Judiciário) no Distrito Federal, sem a devida permissão do Poder Executivo, fato este que demonstra um movimento assincrônico frente à questão entre ambos os Poderes, assim como das fragilidades para com a questão do controle referente ao uso e ocupação da terra.

Acerca das omissões sucessivas do Poder Executivo, nos distintos ciclos de expansão da cidade, conforme exposto em capítulos anteriores, dos fatos relacionados à ausência de registro em cartório das diversas plantas urbanas e memoriais descritivos do setor, tanto em sua fase pré-Brasília, assim como após a construção da nova capital, já se constituem em elementos que colocariam em situação de precariedade jurídica os imóveis do setor em uma perspectiva atual, território usado no plano do presente.

Essa carência de cumprimento do citado preceito legal impacta no exercício do direito de propriedade dos respectivos adquirentes, uma vez que tal situação dificulta a tomada de ações por parte dos novos proprietários ou por parte daqueles que dão uso aos respectivos terrenos há décadas, para com o registro em cartório e a efetivação da dominialidade sobre o bem, segundo prevista na Lei no $6.766 / 79$.

Com a incorporação de Planaltina ao Distrito Federal, explicitou-se ao longo dos capítulos mediante ao exercício de cognição da formação socioespacial da cidade que, vários lotes alienados, ainda em um contexto pré-Brasília, foram excluídos da nova planta urbana elaborada em 1965, gerando cartograficamente as áreas em branco ou a eliminação por completo da planta PR-4/1, como o caso de vários lotes presentes no núcleo do Setor Tradicional, além do Setor Tradicional Residencial Sul e quadras presente no extremo norte do núcleo vernacular (Setor Tradicional Residencial Norte).

Em detrimento à complexidade da questão, em inúmeros documentos levantados sobre o assunto não há uma descrição precisa de quais as quadras ou lotes se enquadrariam em uma série de situações que as colocariam em condição de precariedade jurídica, fato este que, no território usado do presente, constitui em elemento comprobatório da dificuldade quanto à tomada de ações para a regularização jurídica de grande parcela dos imóveis existentes no Setor Tradicional, 
assim como em suas extremidades ao Sul e ao Norte. Isso denota a acumulativa precarização jurídica do setor em debate e de suas extremidades ao Norte e ao Sul.

Fato que corrobora a afirmação acima decorre da sobreposição das plantas urbanas e de seus respectivos memoriais descritivos não registrados em cartório em um longo tempo, que acabam por gerarem a impossibilidade de registro de vários terrenos que integram o Setor Tradicional e os Setores Tradicionais Residenciais Norte e Sul.

Outro elemento, já mencionado, condiz com a árdua identificação destes problemas em virtude das matrículas de diversos imóveis encontrarem-se diluídas em distintos cartórios no Distrito Federal e em Planaltina de Goiás e, até mesmo, da efetiva execução de registros cartoriais mediante desmembramentos não autorizados pelo Executivo no transcorrer do segundo e terceiro ciclos de expansão da cidade, em desconformidade com as normas vigentes.

Isto transcorre do fato da geração imprecisa de informações nestes eventos, como por exemplo, a inexistência do delineamento dos contornos urbanos definidos sem a produção de informações exatas quanto aos seus polígonos no primeiro ciclo de expansão Setor Tradicional e que avançam, ao longo das décadas pós-Brasília, além da existência de lotes que constavam nas plantas aprovadas pela Prefeitura Municipal de Planaltina-GO e passam simplesmente a inexistirem na PR4/1, aprovada pelo Governo do Distrito Federal em meados de 1967 pelo Decreto "E" n०172.

Assim, segundo a Ação Declaratória de Nulidade de Ato Administrativo (processo no 1.874/1993), tem-se como resultado, quanto aos lotes excluídos da planta urbana já produzida pelo GDF em 1965, a proibição dos respectivos moradores de exercerem o seu direito de propriedade, não podendo os interessados, a partir daí edificarem, terem acesso a financiamentos e disporem livremente dos imóveis e, quando assim o fizeram, os posteriores adquirentes, muitas vezes sem terem a noção da condição jurídica da habitação, acabaram por não exercerem também o pleno direito de propriedade sobre o bem adquirido.

Conforme foi explicitado no capítulo terceiro, as informações contidas na Ação Declaratória de Nulidade de Ato Administrativo em processo $\mathrm{n}^{\circ} 1874$ de 
1993, com a aprovação da nova planta urbana em 1967, a Terracap dá prosseguimento à tentativa de legalização dos lotes situados no Setor Tradicional, sendo vários destes registrados nos cartórios do Distrito Federal.

Os lotes registrados seriam aqueles, cuja origem documental proviam de Registros Paroquiais, dos Alvarás de Concessão e, até mesmo, os lotes não contemplados no plano diretor por estarem sem destinação na planta PR-4/1: os lotes em branco ou vazios.

Segundo a GENOR (2012), vários destes lotes foram efetivamente legalizados após a atuação da Terracap, todavia, sem descrever precisamente no relatório quais seriam as quadras ou imóveis regularizados. Somado a isto, boa parte das propriedades ainda careceram de registro cartorial, não apontando claramente quais seriam.

Mesmo com a inconclusa atuação do Poder Público sobre a questão da regularização dos lotes, algumas situações ficaram definidas, como a padronização dos memoriais descritivos e da documentação da certidão dos imóveis fornecidas pela Administração Regional que atestavam os limites de cada propriedade.

Conforme a GENOR (2012), embora as plantas e memoriais descritivos das plantas de 1941 e de 1958 não possuíssem registro cartorial, ambas norteavam as ações do Poder Executivo municipal, tendo na expedição dos Alvarás de Concessão o elemento que juridicamente transferiria a posse dos lotes contidos no Setor Tradicional e em suas extremas (Setor Tradicional Residencial Norte e Sul).

Entretanto, como fora evidenciado no terceiro capítulo, com a vigência da Lei nำ6.766/79, tanto as plantas de 1941 e 1958 (ilegal segundo a Lei ํㅜ 58/37), como a PR-4/1, passam a não produzirem efeito legal por não terem sido registradas em cartório, infringindo vários dispositivos explicitados no referido texto legal, tais como os artigos $6^{\circ}, 7^{\circ}, 9^{\circ}$ e outras normas contidas na nova Lei de parcelamento do solo.

As omissões quanto a política urbana são tão latentes, assim como os desencontros entre os Poderes Executivo e Judiciário face ao controle da questão jurídica dos lotes que, apenas no ano de 1984 se constatou que a Planta PR-4/1 não 
produzia o efeito jurídico para fins registrais, pois não fora registrada em cartório no período de 6 meses de validade do Decreto "E" $n^{\circ} 172$, sendo utilizada apenas para fins administrativos quando pautou as atividades da RA-VI e dos órgãos de Distrito Federal.

A partir de então, segundo a GENOR (2012), Inicia-se o convênio no 037/84 firmado entre a CODEPLAN e a Administração Regional de Planaltina com o objetivo de efetuarem estudos para mais uma tentativa de efetivar a regularização do Setor Tradicional.

Para a GENOR (2012), estes novos estudos geraram novas plantas referentes ao Setores Tradicionais, assim como os Setores Residenciais Sul e Norte, dispondo de poligonais compostas pela URB 74/85 (área histórica e faixa de proteção ambiental), MDE 74/85 (memorial descritivo) e NGB 74/85 (normas de edificação e gabarito), o que resultou na aprovação por parte da Administração Regional de Planaltina e na permissão desta para a efetivação de desmembramentos dentro das respectivas poligonais pelos proprietários dos lotes, com o intuito de registra-los em cartório.

Entretanto, as poligonais citadas, ao seguirem as diretrizes gerais de georreferenciamento dispostos na produção da planta geral URB 09/89, não seguiram o padrão SICAD (Sistema Cartográfico do Distrito Federal) regulamentado pelo Decreto no 4.008, de 26 de dezembro de 1977, resultando na sua não aprovação pelo GDF e, muito menos, no seu registro em cartório.

Sendo assim, estas plantas urbanas (URB 74/85 e URB 09/89), ainda que sejam utilizadas para finalidade de tomada de ações administrativas, em termos de execução de registro de imóveis e desmembrados, denota-se que se encontram desatualizadas e inaptas, por mais que se saiba que tal prática ainda ocorra quanto a alguns lotes destes setores da cidade.

Segundo GENOR (2012), os motivos para a não aprovação e desatualização das plantas urbanas, estão correlacionados a vários fatores, como a falta de consulta às demais empresas públicas e prestadoras de serviços, a exemplo da CAESB (Companhia de Saneamento Ambiental do Distrito Federal), cujos polígonos delimitados afetam diretamente a disposição das redes de abastecimento, 
impossibilitando legalmente o desmembramento e registro dos imóveis em várias porções do Setor Tradicional, Norte e Sul.

Outro fator citado no relatório produzido pela GENOR (2012) a respeito da aprovação da URB 09/89, condiz ao fato de que os prazos dos decretos que homologariam a execução das etapas do referido georreferenciamento, simplesmente extrapolaram o tempo legal previsto para a realização e validação dos trabalhos segundo os parâmetros contidos na Lei no 6.766/79.

Além destes pontos enumerados, GENOR (2012) ainda expõe que na URB 09/89 fora verificado divergências nas dimensões dos lotes levantados em campo pela CODEPLAN em comparação aos limites das dimensões das propriedades descritas nas escrituras registradas em diversos cartórios de registros de imóveis, tanto da parte de Goiás como do Distrito Federal, o que resulta na impossibilidade de registro cartorial da referida planta, uma vez que poderia ser motivo de moção de várias ações judiciais contra o GDF oriundas dos supostos proprietários dos imóveis.

Este fato correlaciona-se as demandas jurídicas dispostas na Lei ํㅡㄴ 6.766/79, uma vez que o desencontro ou imprecisão destas informações acabam por ferir vários artigos do referido texto legal (como os artigos $9^{\circ}, 10^{\circ}, 11^{\circ}, 12^{\circ}, 18^{\circ}$, entre outros) que tratam dos requisitos legais para a legítima efetuação de parcelamentos, desmembramentos e a averbação destes em cartórios de registros de imóveis.

A GENOR (2012) informa ainda que a sobreposição de plantas associada à desregulamentação quanto ao disciplinamento face ao uso e ocupação do solo que se soma à tomada de ações em desconformidade com as sucessivas regulamentações que tratam do tema, além da atuação desconexa entre os Poder Executivo e Judiciário (Cartórios Notariais, de Registro de Imóveis, Promotoria de Registros Públicos), repercutem espacialmente e juridicamente na situação dominial dos imóveis.

Espacialmente, tendo em vista o ordenamento do sistema de objetos, verifica-se, enquanto um dos efeitos deste processo de desregulamentação das várias políticas urbanas da cidade, e de maneira notória, a despadronização dos 
endereços residenciais, tanto no Setor Tradicional como nos Setores Tradicional Residencial Norte e Sul, reflexo das diversas ações tomadas pela sucessão dos Poderes Públicos nos distintos ciclos de expansão de Planaltina, observando-se que todas as plantas, inclusive a última, URB 09/89, não dispuseram de registro cartorial.

Além das omissões correntemente cometidas pelo Poder Executivo, e até mesmo pelo Poder Judiciários acima descritos e que perfazem os três ciclos de expansão de Planaltina/Setor Tradicional, tem-se outras situações pontuadas pela GENOR (2012) que implicam na complexificação registral das propriedades contidas no referido bairro.

Com a produção das poligonais da URB 74/85, somando-se o MDE 74/85 e NGB 74/85 e que resultaram na planta URB 09/89, identificou-se áreas desapropriadas e ocupadas irregularmente ainda no ano 1965, sendo estas entregues a funcionários públicos, como é o caso das Quadras 71 e 11-A, que hoje estão totalmente construídas e cuja ocupação está consolidada.

Conforme a GENOR (2012) os primeiros ocupantes venderam os lotes pela cessão de direitos sem ter havido prestação de contas com a Novacap, o que implica na impossibilidade de obtenção da escritura pública e na efetivação do registro cartorial.

Outro fato vincula-se ao desmembramento de vários lotes sem a autorização da Administração Regional de Planaltina anterior a vigência da Lei $6.766 / 79$, os quais foram registradas diretamente em cartório. O problema se acentuou uma vez que fugiu do domínio da Administração Regional de Planaltina. Por esta razão, no cadastramento realizado pela CODEPLAN na URB 09/89, existem várias nomenclaturas para o mesmo lote.

Somando-se ainda a estes problemas levantados, a GENOR (2012) traz uma série outros casos que foram constatados pela CODEPLAN quanto à precariedade jurídica dos lotes ou de quadras inteiras que constituem o Setor Tradicional, Setor Tradicional Residencial Norte e Sul, principalmente no levantamento cadastral e na documentação recolhida para a elaboração da Planta Geral do Setor, sendo estes problemas da seguinte ordem: 
Lotes que possuem registro e não estão de acordo com 0 levantamento cadastral;

Lotes que foram graficados na Planta Geral e que não possuem nenhuma documentação, além de não estarem ocupados;

E por fim, mais recentemente, lotes que não possuem nenhuma documentação estando ocupados há aproximadamente 17 anos, sendo estes graficados conforme levantamento cadastral;

Este último caso vincula-se a um dos elementos que repercutirá na judicialização do Setor Tradicional em somatória ao Setor Tradicional Residencial Norte e Sul, já que o fato impulsionador de tais ocupações dá-se em virtude do embate judicial que passa a existem entre GDF e a Prefeitura de Planaltina de Goiás quanto à legítima dominialidade das referidas terras que perfazem a Transcrição $\mathrm{n}^{\circ}$ 303, sendo estas áreas públicas e residenciais contidas em tais setores.

Segundo a Ação Declaratória de Nulidade de Ato Administrativo (processo $\mathrm{n}^{0}$ 1.874/1993) movida pelo Ministério Público do Distrito Federal e Territórios sobre a referida lide, a partir do ano de 1988, o que corresponde ao terceiro ciclo de expansão da cidade de Planaltina, o Município de Planaltina de Goiás passa a requerer ao Poder Executivo do Distrito Federal, através do processo administrativo $n^{\circ} 135.000 .757 / 88$, a dominialidade das áreas públicas contidas no Setor Tradicional, ou seja, o seu efetivo desmembramento, tendo como argumento que tais setores, descritos na Transcrição $n^{\circ} 303$, não haviam sido desapropriadas pelo GDF.

A Ação Declaratória de Nulidade de Ato Administrativo (processo no 1.874/1993) descreve que, a priori, as áreas pleiteadas por Planaltina de Goiás corresponderiam as setores excluídos da Planta Urbana PR-4/1 e que estavam contidas na Planta 58 aprovada pela anterior Prefeitura goiana, como a totalidade do Setor Tradicional Residencial Sul, assim como os lotes em branco ou vazios resultante da reelaboração da planta no ano de 1965. Além destes, foram requeridos os espaços livres de uso comum, vias, praças, áreas destinadas a edifícios públicos e outros equipamentos urbanos.

O que torna tal situação em um fato muito peculiar e ao mesmo tempo paradoxal é justamente a reivindicação da dominialidade de terras entre unidades distintas da federação, ou seja, entre o Município goiano, que tivera suas terras 
anexadas após a construção de Brasília e versus o Governo Distrito Federal, cuja ocupação já está consolidada por décadas.

O fato contraditório nesta questão que nos remete a uma visão dialética, conforme será explicitado, é que a síntese entre o choque, anteriormente descrito entre o velho que é característico das lógicas de produção da formação socioespacial de Planaltina em seu primeiro ciclo de expansão, e o novo, Brasília, antítese a tal dinâmica de produção da ilegalidade frente ao uso do território, e que nos atos de desapropriação expôs toda a situação de precariedade jurídica dos imóveis (rurais e urbanos) do Município, tem em sua síntese, território usado do presente, o acúmulo de ilegalidades, além de terem justamente por parte da Prefeitura goiana a reivindicação de habitações concedidas aos moradores que foram possibilitadas graças a execução de política habitacionais em um contexto pré-Brasília.

Neste processo paradoxal, o ato do reconhecimento quanto ao efetivo domínio requerido pela Prefeitura de Planaltina de Goiás permitiria, segundo o Código Civil, que este ente, conforme o art. 1.228, pudesse livremente "usar, gozar e dispor da coisa", além desfrutar do "direito de reavê-la do poder de quem injustamente a possua ou detenha".

Assim, tem-se como relato da Ação Declaratória de Nulidade de Ato Administrativo (processo1.874/1993) que por diversas vezes foram solicitados pedidos de desmembramento das áreas acima citadas dentro do Setor Tradicional, e em suas extremidade. Tais pedidos (processos administrativos) foram examinados pela Procuradoria Geral do Distrito Federal e todas as solicitações de desmembramento foram prontamente negadas.

Entretanto, segundo a Ação Declaratória de Nulidade de Ato Administrativo movida pelo MPDFT (Ministério Público do Distrito Federal e Territórios) contra a municipalidade goiana, além da contínua insistência face à emissão de solicitações de desmembramento para a Procuradoria Geral do Distrito Federal que persiste até o ano de 1993, a Prefeitura Municipal de Planaltina de Goiás toma outro caminho em busca de seu pleito.

Este novo caminho deu-se através do Ofício $n^{\circ} 117 / 93$, encaminhado diretamente ao Governador do Distrito Federal no respectivo ano, cujo intuito era 
"pedir a agilização dos atos necessários ao reconhecimento do (...) domínio sobre as áreas citadas" (processo nำ1.874/1993, folha 15).

Em resposta ao ofício, o chefe do Poder Executivo do Distrito Federal solicita a abertura de processo administrativo junto a Terracap, tendo como resultado produzido por sua Divisão Jurídica o seguinte parecer:

A circunstância de o Setor Tradicional de Planaltina, antiga sede urbana do respectivo município, perder sua autonomia, integrar ao território do Distrito Federal, e assim se submeter à outra jurisdição político-administrativa, em nada afetou, nem poderia afetar o direito de propriedade dos munícipes que o habitam, nem dos que remanesceram no município goiano preservado com área menor, ou dos que se tornaram distritais, nem ainda das próprias pessoas jurídicas de direito público interno que prevaleceram em territórios precisamente definidos.

O Município de Planaltina de Goiás manteve, assim, em sua plenitude, o direito de propriedade, de que era titular, e que lhe adveio com a mencionada transcrição $n^{\circ} 303$, representativa do bem que lhe coube por força de permuta celebrada com a Igreja Matriz de São Sebastião.

Esse direito de propriedade, ou de domínio, de que é titular o Município de Planaltina de Goiás sobre os terrenos, lotes ou áreas especiais que não foram por ele próprio alienados, a qualquer título (venda, doação, permuta, etc.), independe de reconhecimento por parte do Distrito Federal, da Terracap, da União, ou de quem quer que seja, já que the é assegurado pelo próprio sistema jurídico, isto é, pela Constituição e pelas normas que disciplinam o direito de propriedade no país.

Em face de todo o exposto, sugiro que, se aprovado o entendimento supra, seja encaminhado expediente ao ilustre e dinâmico Prefeito de Planaltina de Goiás, instruindo com cópia da presente manifestação, comunicando-lhe independer de qualquer iniciativa do Distrito Federal, ou de seus órgãos descentralizados, ou da União o exercício do direito de propriedade daquele município sobre os terrenos que integram o Setor Tradicional de Planaltina-DF, originários do loteamento que teve como base a transcrição $n^{\circ} 303 e$ ainda não alienados pelo próprio Município de Planaltina de Goiás. (MINISTÉRIO PÚBLICO DO DISTRITO FEDERAL E TERRITÓRIOS. Ação Declaratória de Nulidade de Ato Administrativo, processo no 1.874/1993, folha 16).

Embora haja diversas especulações quanto a uma possível articulação entre os membros do Poder Executivo de ambas as esferas federativas neste evento, o que resultou na pronta resposta ao Ofício n 117/93 por parte da Terracap, 
observa-se algo que vem sendo enfatizado em toda a trajetória do processo de formação socioespacial da cidade de Planaltina-DF, tendo em vista a inoperância do Poder Executivo em seus três ciclos de expansão quanto ao processo de regularização do referido setor.

Mesmo sendo controverso as circunstâncias que resultam na emissão do parecer presente no processo 1.874/93, que assegura claramente que as áreas públicas, vias, terrenos, lotes, inclusive aqueles que foram alienados pela Prefeitura goiana via Alvarás de Concessão ou com o aval do GDF após a inauguração de Brasília, constituem em patrimônio pertencente à Prefeitura de Planaltina de Goiás.

Neste sentido, denotando-se que no processo de transferência da capital e após tal evento, quanto ao Setor Tradicional, assim como as suas extremas ao Norte e ao Sul, não foram transmitidas para o patrimônio do Distrito Federal, ou seja, não foram desapropriados e muito menos averbado este ato administrativo em cartório de registro, isto não garantiria a dominialidade das terras ao GDF. O resultado de tudo isto impactará no direito a, de propriedade dos moradores locais, enquanto desdobramento de tal inércia.

Conforme testifica a respectiva Ação Declaratória de Nulidade de Ato Administrativo (processo no 1.874/1993), após a produção do parecer antes citado, o presidente da Terracap envia o relatório realizado pelos técnicos da referida empresa pública a Prefeitura de Planaltina de Goiás.

O desdobramento deste evento resulta na abertura do Edital de Concorrência Pública n 003/93 pela Prefeitura goiana, com o intuito de alienar "76 (setenta e seis) lotes, situados no Setor Tradicional e na Av. São Paulo x Mestre D'Ármas (...) todos ocupados por terceiros, mais 28 (vinte e oito) outros lotes, situados na Rua Mestre D’Ármas e na Av. Independência" (processo nํ⒈874/1993, folha 18).

Neste sentido, vale expor a abrangência de tal ato licitatório sobre os imóveis, terrenos e áreas públicas que a referida licitação passa a contemplar:

Áreas que se quer chegaram a ser loteadas: as nominadas quadras 06, 06/A e 07, que sequer existem registros;

Áreas situadas nos espaços vazios, vias e praças;

Áreas já alienadas aos atuais moradores pelo próprio Município de Planaltina do Estado de Goiás: De 1956 a 1958 (...) criou-se desta 
forma mais de 2.400 lotes que rodearam o núcleo tradicional e acompanharam o traçado viário já existente;

Áreas que na sua quase totalidade não estão regularizadas, perante o registro imobiliário;

Áreas que foram excluídas do Plano Diretor da cidade de Planaltina. (MINISTÉRIO PÚBLICO DO DISTRITO FEDERAL E TERRITÓRIOS. Ação Declaratória de Nulidade de Ato Administrativo; processo $\mathrm{n}^{\circ}$ 1.874/1993, folhas 20-21).

Sendo assim, os imóveis alienados por Alvarás de Concessão promovidos pela antiga Prefeitura de Planaltina de Goiás, ainda no primeiro ciclo de expansão da cidade, os quais não foram registrados em cartório por diversos motivos ao longo do tempo, a partir de então, os seus moradores passam a correrem sérios riscos quanto a perda de seus imóveis para a atual Prefeitura goiana, já que uma vez não registrados, seriam considerados como pertencentes ao patrimônio da citada municipalidade.

É válido destacar que o edital lançado pela Prefeitura de Planaltina de Goiás desconsiderou veementemente a posse exercida pelos moradores do referido setor - ocupados por terceiros -, assim como o direito à propriedade, evidenciando a situação de precariedade jurídica dos citadinos que apenas dispunha de Alvarás de Concessão e que Ihes garantiam apenas o uso do terreno, o que não lhes asseguravam o domínio dos referidos lotes (direito de propriedade).

Entretanto, conforme exposto, a totalidade do Setor Tradicional em somatória aos dos Setores Norte e Sul contidos na Transcrição $n^{\circ} 303$, independentemente de estarem ocupados ou não, passaram a sofrer o assédio da Prefeitura de Planaltina de Goiás, estando livres apenas aqueles imóveis que no transcorrer dos ciclos de expansão da cidade obtiveram o registro em cartório via desmembramento, o que lhes possibilitaram usufruir do pleno direito de propriedade, ou seja, o domínio do bem.

Fica evidente que o desconhecimento jurídico por parte dos moradores locais referente a importância de se promover a consolidação do domínio dos referidos bens imóveis, atrelado à inércia quanto à efetivação da desapropriação do setor pelo Poder Executivo pós-Brasília, além da ausência face à efetivação de políticas públicas a serem promovidas pelo Poder Público para instruírem ou garantirem o domínio dos imóveis por seus ocupantes, resultam no embate dialético legal versus ilegal que passa a tramitar nos tribunais a partir do ano de 1993, assim 
como no acúmulo de mais uma situação de precariedade jurídica que abrange não apenas os moradores do Setor Tradicional, mas também os habitantes de suas extremadades.

É neste contexto que a Ação Declaratória de Nulidade de Ato Administrativo (processo $n^{\circ}$ 1.874/1993) em análise, fora proposta pelo MPDFT junto ao TJDFT, com o intuito de invalidar o ato relacionado ao parecer emitido pelo presidente da Terracap, uma vez que segundo o então Subprocurador-Geral do Distrito Federal, Ary Lopes Rodrigues, em seu entendimento, o fato de tal laudo técnico ter sido encaminhado diretamente ao Prefeito de Planaltina de Goiás sem que houvesse um posicionamento final do Chefe do Poder Executivo do Distrito Federal, o caracterizaria como ato administrativo sem validade jurídica, o que resultaria na anulação do Edital n 003/93.

Esta alegação pode ser visualizada da seguinte maneira na referida Ação Declaratória de Nulidade de Ato Administrativo:

O que foi exposto deixa patente que praticou a Presidência da Terracap ato NULO - porque contaminado pelo vício da incompetência (art. $2^{\circ}$, 8, e parágrafo único, a, da Lei $n^{\circ} 4.717$ de 1965) -, quando dirigiu ao Prefeito do Município goiano de Planaltina o Ofício n 196/93-PRESI, datado de 08 de julho de 1993, ato com o qual decidia, definitivamente, postulação que não Ihe fora feita, mas sim, tinha sido endereçado ao Governador do Distrito Federal, esta a autoridade competente para decidi-la.

Bem por isso, a mesma autoridade - o titular da Presidência da Terracap -, reconhecendo que houvera exorbitado de sua competência, já houve por bem oficiar ao Prefeito do Município goiano de Planaltina, comunicando que ANULOU o mesmo Ofício $\mathrm{n}^{\circ}$ 196/93PRESI, datado de 08 de julho de 1993, pelo que ficava 0 mesmo sem qualquer validade, para quaisquer efeitos legais. (MINISTÉRIO PÚBLICO DO DISTRITO FEDERAL E TERRITÓRIOS. Ação Declaratória de Nulidade de Ato Administrativo; processo $\mathrm{n}^{\circ}$ 874/1993, folha 19).

Ainda a respeito da validade do edital, tendo em vista a alienação de imóveis, terrenos, áreas públicas, promovido por Planaltina de Goiás em PlanaltinaDF, o referido Subprocurador, acima mencionado, assevera também que a dominialidade das terras em questão já se estabelecera em favor do Distrito Federal por força de Lei Constitucional prevista no art. $3^{\circ}$ da Carta Magna de 1891. 
Este argumento, conforme explicitado nos capítulos primeiro e segundo da presente dissertação e embasado nas exposições de Farias (2006), Oliveira (2008) e Malagutti (1997), era constantemente usado desde a Comissão Goiana de 1956, passando antes, já no contexto pós-Brasília, pela retórica do MPDFT, TJDFT e pelo Poder Executivo para justificar as inconclusas desapropriações de terras no Distrito Federal e a sua efetiva dominialidade, cujo resultado em grande parte das disputas judiciais, eram favoráveis a este posicionamento até a vigência do Decreto "N" n 636, de julho de 1967, que passa a regulamentar as expropriações das terras contidas no quadrilátero.

O argumento explicitado, mesmo após o Decreto "N" nำ 636/67 ter vigorado, em várias outras lides pesquisadas observou-se o seu uso pelo Ministério Público e Poder Executivo, entendimento este que atualmente está superado.

Também, como fora evidenciado nos dois primeiro capítulos desta dissertação, outra alegação muito recorrente e constantemente empregada pelo Poder Público do Distrito Federal, e em especial o Poder Executivo até os dias modernos para justificar o seu efetivo domínio junto às terras incorporadas ao seu quadrilátero, cujas ações expropriatórias não haviam sido, ou ainda não estão consumadas, está na interpretação jurídica pautada pela desapropriação indireta enquanto mecanismo garantidor do exercício do direito de propriedade por este ente federativo. Esta argumentação também se faz presente na Ação Declaratória de Nulidade de Ato Administrativo (processo no 1.874/1993) de seguinte maneira:

Assim, à luz do art. $2^{\circ}, \S 2^{\circ}$, da Lei de Desapropriações (Decreto-Lei $n^{\circ} 3.365$, de 21 de julho de 1941), ao Distrito Federal - no exercício das atribuições que cabem ao Estado - era dado desapropriar bens pertencentes ao Município de Planaltina, do Estado de Goiás.

E foi assim que o fez.

Por isso, se a norma contida no art. $3^{\circ}$ da Constituição de 1891 não transferiu, para o Distrito Federal, o domínio das terras situadas em seu território, ocorreu que, com a implantação da nova Capital do Brasil, na área definida pelo art. $1^{\circ}$ da Lei Federal $n^{\circ} 2.874$, de 19 de novembro de 1956 - que inclui porção de terras antes inseridas nos limites do Município de Planaltina, do Estado de Goiás -, consumouse de qualquer forma, a DESAPROPRIAÇÃO INDIRETA das áreas que, antes, estivessem no território de Municípios situados na mesma área e que, ocupadas administrativamente pelo Distrito Federal, não foram objeto de desapropriação amigável ou judicial. 
Eis por que é desnecessária, no caso destes autos, qualquer decisão sobre o alcance do art. $3^{\circ}$ da Constituição de 1891: as áreas situadas no território do atual Distrito Federal, ocupadas administrativamente, e que, antes da mudança da Capital Federal efetuada em 21 de abril de 1960, permanecessem ao território de Municípios nelas situadas, se não foram objeto de desapropriação amigável ou judicial, ainda assim hoje PERTENCEM AO DISTRITO FEDERAL, EM RAZÃO DE DESAPROPRIAÇÃO INDIRETA CONSUMADA. (MINISTÉRIO PÚBLICO DO DISTRITO FEDERAL E TERRITÓRIOS. Ação Declaratória de Nulidade de Ato Administrativo; processo $\mathrm{n}^{\circ}$ 1.874/1993, folhas 09-10).

Além das alegações do Poder Público quanto à efetiva dominialidade das terras do Distrito Federal por sua nova instância administrativa, que por muito tempo pautaram-se no art. $3^{\circ}$ da Constituição de 1891 , assim como na questão interpretativa embasada na consumação das desapropriações indiretas, observa-se também no relatório da GENOR (2012, s/n/) quanto ao Decreto $n^{\circ} 83 / 56$, que regulamentava a "reversão de direitos sobre avenidas, ruas e logradouros entre a Novacap e a Municipalidade", caracterizara-se, em termos argumentativos, como elemento comprobatório da efetiva dominialidade da nova estrutura administrativa sobre as terras do quadrilátero, incluindo-se nisto o Setor Tradicional e extremidades.

Todavia, tendo em vista a plêiade argumentativa por parte do Poder Público do Distrito Federal quanto à efetiva dominialidade das terras e, em especial, as alegações contidas na Ação Declaratória de Nulidade de Ato Administrativo em relevo, na tentativa de desqualificar e invalidar o Edital de Concorrência Pública ${ }^{\circ}$ 003/93 efetuada pela Prefeitura goiana que colocara em risco a posse e o uso dos lotes anteriormente alienados pela mesma Prefeitura de Planaltina-GO em seu contexto pré-Brasília, via Alvarás de Concessões, embora tal procedimento administrativo seja considerado imoral, juridicamente fora interpretado (decisão/ação) pelo Poder Judiciário enquanto legal.

Em sentença proferida pelo Juiz do TJDFT, Álvaro Luís de A. Clarini, no dia 03 de março de 2000, referente à tramitação da Ação Declaratória de Nulidade de Ato Administrativo (processo $n^{\circ}$ 1874/93) e outros, como a Medida Cautelar no 10.048/93, que também tentava obstar a execução do Edital de Concorrência Pública n 003/93 (revenda de lotes já ocupados no Setor Tradicional e demais áreas públicas), encontra-se decisão contrária ao Governo do Distrito Federal. 
Esta decisão/ação é resultante das análises periciais desenvolvidas ao longo da tramitação da lide, tendo em vista que assim como fora detectado no estudo técnico desenvolvido pela Divisão Jurídica da Terracap no ano de 1993, ao qual tentou-se a impugnação, o resumo dos autos relata que em deferimento do TJDFT a solicitação pericial requerida por Planaltina-GO realizada pela Promotoria de Registros Público do mesmo MPDFT no ano de 1993, tem enquanto resultado que a transmissão das áreas públicas, lotes, dentre outros já citados, nunca fora realizado entre as partes, uma vez que não existem registros cartoriais que comprovariam tal ato administrativo. Fato este também alegado pela Prefeitura goiana.

Esta decisão/ação assemelha-se às circunstâncias relatadas quanto à lide atinente ao Quintas da Alvorada em termos jurisprudenciais, tendo em vista que ambas as arbitragens levam em consideração o inconcluso processo de desapropriação das terras a serem executadas por parte do GDF.

No caso do Quintas da Alvorada alegava-se que as terras haviam sido declaradas para fins de utilidade pública e a serem desapropriadas pelo GDF, todavia, o simples fato de haver o interesse não garante de imediato a dominialidade sobre o bem pleiteado, ou seja, não há consumação do processo expropriatório, sendo assegurado ao então proprietário dispor livremente de seus bens.

Esta lógica jurisprudencial também fora aplicada ao Setor Tradicional, uma vez que a desapropriação indireta só se efetivaria com a plena indenização do bem e transmissão do domínio entre as partes, e que no caso em questão, as terras ocupadas administrativamente pelo GDF e que não possuem registro que comprovem a transmissão das áreas por ato expropriatório, em somatória aos lotes alienados apenas por Alvarás de Concessão, cujas transmissões não foram efetivadas junto aos cartórios de registros de imóveis, possibilitariam ao proprietário, Planaltina de Goiás, Ihes dar a destinação que assim achasse prudente, conforme consta no Código Civil acerca do direito de propriedade.

Para clarificar as interpretações expostas, é válido demonstrar a exposição formulada pelo Juiz do TJDFT, Álvaro Luís de A. Clarini, sobre a nulidade do ato licitatório promovido por Planaltina de Goiás que colocará à venda imóveis e áreas públicas no Setor Tradicional e extremidades, assim como da suposta dominialidade exercida pelo Distrito Federal sobre estas localidades: 
Por outro lado, vale registrar que a desapropriação é modo de aquisição de domínio originário, que utiliza forma complexa, posto demandar procedimento administrativo que compreenda duas etapas distintas, sendo uma declaratória, circundada por formalidades próprias à publicidade e legitimidade do ato, e outra executória, com a estimativa da justa indenização e transmissão do bem para o patrimônio do expropriante. Sem a implementação de uma dessas etapas, não se pode ter por concretizado o ato de expropriação, valendo ressalvar que, no caso estritamente em análise, além de não ter restado configurada a existência do requisito alusivo à formalização da propriedade da res para o patrimônio do expropriante, não pode igualmente perseverar a alegação de desapropriação indireta, mesmo porque o imóvel em tela é bem dominial e o autor não fez a necessária prova do apossamento do mesmo.

Nesse sentir, mostra-se irretocável o elucidativo posicionamento ostentado pela doutrina já consagrada entre nós, no sentido de que a desapropriação... "é um processo administrativo (e não um ato) porque se efetiva através de uma sucessão ordenada de atos intermediários (declaração de utilidade, avaliação, indenização), visando à obtenção de um ato final, que é a adjudicação do bem ao Poder Público, ou ao seu delegado beneficiário da expropriação".

Seguindo a linha exposta precedentemente, andou bem o ilustre representante do Ministério Público, que, analisando a questão, corretamente conclui, in verbis:

"Ora, ainda que amigavelmente se fizesse a expropriação, o registro imobiliário não é dispensado e figura como prova da propriedade, como preveem o Código Civil e a Lei de Registros Públicos já citados e ratifica a doutrina: a via administrativa consubstancia-se no acordo entre as partes quanto ao preço, reduzido a termo para a transferência do bem expropriado, o qual, se imóvel, exige escritura pública para a subsequente transcrição no registro imobiliário".

Por outro lado, a prova pericial produzida nos autos foi conclusiva no sentido de que o domínio dos bens imóveis localizados no Setor Tradicional de Planaltina-DF, constantes no Edital $n^{\circ} 003$ em comento, pertence ao acervo imobiliário do Município de PlanaltinaGo. Assim, conclui-se que o ato administrativo vergastado não merece a pecha de ilegal, razão pela qual o suporte fático em análise mostra-se eficiente. Via de consequência, o provimento de mérito, no particular, deve ser negativo. (TRIBUNAL de JUSTIÇA DO DISTRITO FEDERAL E TERRITÓRIOS. Ação Declaratória de Nulidade de Ato Administrativo; processo $n^{\circ} 1.874 / 93$, folhas 364367).

Em termos de dinâmica produtiva dos objetos espaciais face a esta lide, entende-se que até o momento da decisão proferida no ano 2000 e que sacramenta, por via judicial, o reconhecimento da dominialidade de grande parcela do Setor Tradicional em favor de Planaltina de Goiás, o surgimento de algumas das 
novas quadras residenciais, assim como de prédios comerciais em localidades que anteriormente não eram previstos na planta PR-4/1, materializam-se segundo uma perspectiva especulativa por parte da Prefeitura goiana e dos adquirentes, tendo em vista a expectativa de ganho do embate em relevo.

Ou seja, a gênese de quadras como a 01, 06 e 07 no Setor Tradicional Residencial Norte (sendo que nesta última a sua destinação prevista na Planta 58 era de praça esportiva, o que de fato o era), não caracterizam-se enquanto objetos espaciais diretamente associados a decisão, ação do Poder Judiciário. A quadra 07 do Setor Tradicional pode ser visualizada na fotografia 13.

Contudo, após o proferimento da sentença (ao qual não se discute a sua legitimidade interpretativa), essa dinâmica é potencializada, observando-se novas alienações de áreas públicas vazias destinadas a implementação de equipamentos públicos, como escolas, praças, postos de saúde, ou até mesmo, como no caso de parcela da quadra 07 do Setor Tradicional Residencial Norte, a mudança de sua destinação anterior, ou seja, alienações de praças esportivas que passam a dar lugar a residências. A quadra 07 pode ser visualizada na fotografia 13.

É possível ainda verificar, nos anexos do processo no 2000.01.5.006181/8, referente à Apelação Cível movida no ano de 2002, que as quadras 04, 05, 06, $06 \mathrm{~A}, 09,11 \mathrm{~A}, 12,13,14,18,21,24$, dentre várias outras, situadas no Setor Tradicional Residencial Norte e Sul, também são oriundas de tal dinâmica, frutos do Edital no 003/93, que muito embora estivessem previstas na Planta de 1958, tiveram os seus limites alterados.

Tendo em vista o exposto, o fato da não consumação da dominialidade das terras a ser exercido pelo GDF impacta diretamente no uso fragilizado (posse) pelos antigos moradores e novos adquirentes, que também se enquadram numa situação de precariedade jurídica face ao exercício dominial. 


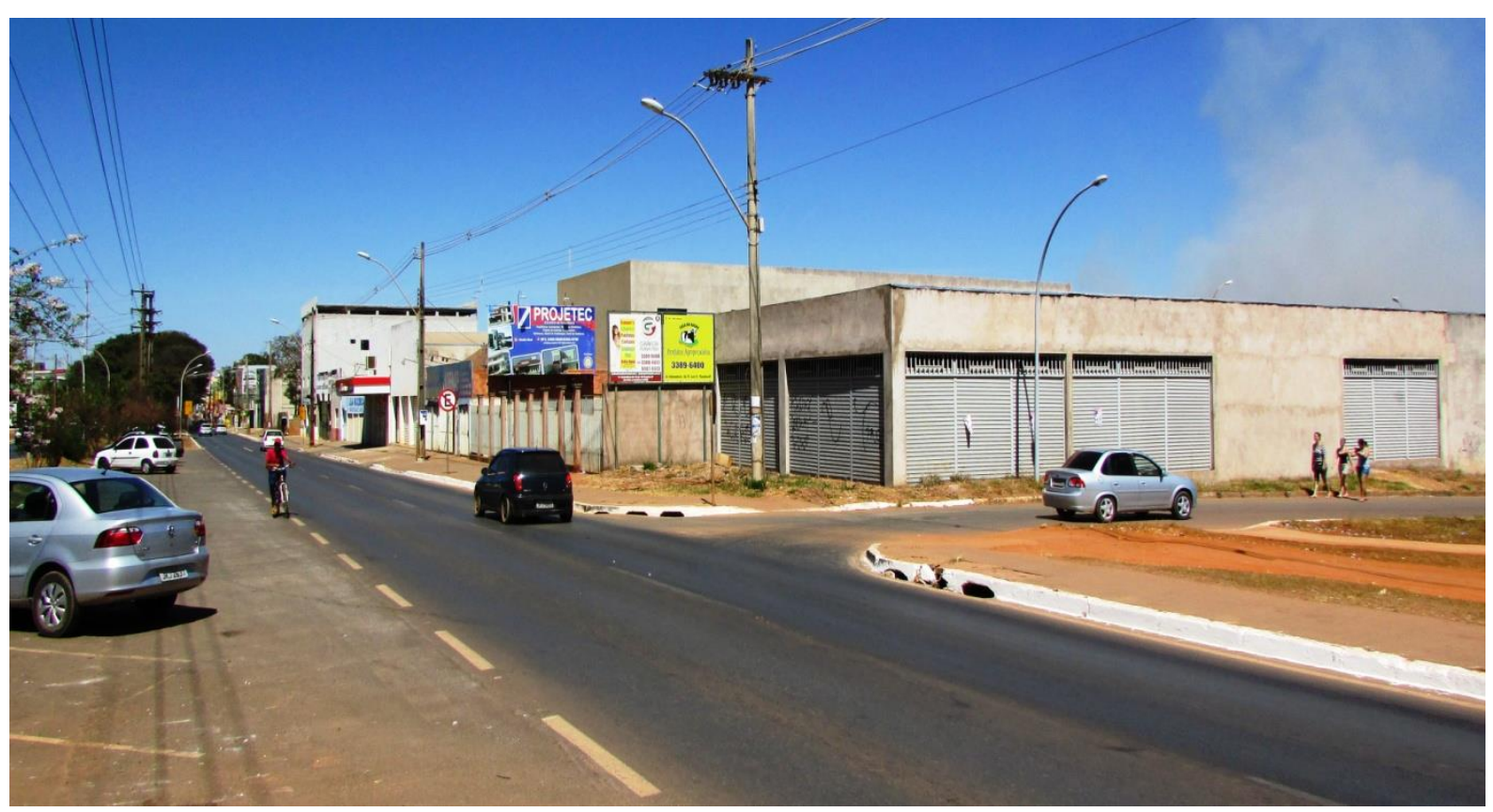

Fonte: Lima (2014).

Constata-se também o surgimento ou reconfiguração dos sistemas de objetos espaciais presentes nestas localidades, resultantes da não consumação do ato expropriatório por parte do GDF pós-inauguração da capital federal, potencializado pelo posicionamento decisório advindo do Poder Judiciário, uma vez que a forma e a função se alteram em virtude da intenção atinente a alienação das terras por parte da então Prefeitura de Planaltina de Goiás, já que espaços destinados a presença de equipamentos públicos dão lugar as novas habitações.

A partir do reconhecimento dominial das terras do Setor Tradicional como pertencentes à Planaltina-GO, além da alienação das áreas públicas ainda vazias e sem matrícula aberta em cartório, segundo exposto na Ação Declaratória de Nulidade de Ato Administrativo, processo no 1.874/1993, outra prática passa a ganhar força, sendo esta, conforme exposto anteriormente, vinculada à emissão de novos títulos, pela recente Prefeitura de Planaltina de Goiás, de lotes já ocupados por pessoas que dispunham apenas de Alvarás de Concessão emitidos pela mesma municipalidade em seu contexto pré-Brasília, e que também acabam por transitar nos tribunais.

No caso do Setor Tradicional, tendo em vista a sua judicialização, o direito de propriedade sobrepõe-se ao direito à propriedade (posse), podendo ambos 
serem vistos dialeticamente de forma antagônica, corroborando o discurso da necessária consumação do domínio do bem para com o efetivo reconhecimento do Estado frente à condição cidadã no que tange ao resguardo de sua habitação previsto na Constituição.

Tal fato é constatado na Apelação Cível (processo $\mathrm{n}^{\circ}$ 2000.01.5.006181-8) enquanto desdobramento da Ação de Nulidade de ato Administrativo (processo $\mathrm{n}^{\circ} 1.874 / 93$ ), cuja finalidade era novamente invalidar 0 Edital $n^{\circ}$ 003/93. A referida Apelação Cível é movida pelo Distrito Federal em favor dos moradores do Setor Tradicional com o intuito de evitar que estes não perdessem o direito de posse de seus imóveis para Planaltina de Goiás e posteriores adquirentes, haja vista sua prévia ocupação através de Alvará de Concessão.

Contudo, na respectiva Apelação Cível, além do debate atinente à nulidade do ato administrativo oriundo do edital, efetivamente é discutido a legitimidade dominial dos compradores dos títulos recém emitidos por Planaltina de Goiás (novos Alvarás de Concessão) para com os imóveis já constituídos e ocupados há décadas pelos moradores de Planaltina-DF, tal como explicitado no referido processo:

Foi proposta ação anulatória por Rosa dos Santos Rabelo em desfavor de Adalberto Neco da Rocha e outros buscando seja invalidado 0 ato de aquisição do imóvel dos réus. Nos mesmos autos, o Distrito Federal ingressou com oposição. Ambos os pedidos foram julgados improcedentes.

Adalberto Neco da Rocha e outros propuseram ação reivindicatória em desfavor de Mauro D'Abadia dos Santos Rabelo e Rosa dos Santos Rabelo, dizendo serem os proprietários do lote de terreno n. 1 da quadra 22 na Rua Hugo Lobo, em Planaltina-GO, sendo que o imóvel foi ocupado indevidamente pelos réus. O primeiro Réu foi excluído do processo e a demanda foi julgada procedente para julgar a Ré a devolver aos autores o imóvel descrito (...). A Ré, Rosa dos Santos Rabelo, interpôs Recurso de Apelação. Alega a Recorrente que a forma de aquisição do domínio do imóvel em comento foi manobrada pelos apelados, conforme a documentação acarreada pela apelante. Diz que a aquisição foi feita em conluio com o chefe do executivo da Comarca de Planaltina-Goiás, em verdadeiro desrespeito ao direito preferencial que milita em favor da Apelante, que detém de boa fé a propriedade em litígio, remanescente de seus pais há mais de meio século, mansa e pacificamente. (TRIBUNAL DE JUSTIÇA DO DISTRITO FEDERAL E TERRITÓRIOS. Apelação Cível. Processo no 2000.01.5.006181/8. Brasília, 18 de novembro de 2002). 
É válido destacar, quanto ao relato dos autos do processo que objetiva o proferimento de acórdão, que o endereço do imóvel em disputa, embora situado em Planaltina-DF, é citado enquanto pertencente ao domínio de Planaltina de Goiás, fato este que acompanha a decisão monocrática oriunda da sentença condizente ao processo oํ 1.874/93 (Ação declaratória de Nulidade de Ato Administrativo).

Assim, fica nítida a primazia do domínio sobre a posse, ou seja, o direito de propriedade em detrimento ao direito à propriedade, sendo a dominialidade do Setor Tradicional exercida pela municipalidade goiana, tendo em vista que a transmissão das referidas terras não foram administrativamente executadas sobre a transcrição n 303 em favor do Distrito Federal.

Ao seguir este raciocínio, a prefeitura goiana tinha a livre prerrogativa de "usar, gozar e dispor da coisa, e o direito de reavê-la do poder de quem injustamente a possua ou detenha" (Código Civil Brasileiro, 2008, art. 1.228), o que supostamente não tornaria nulo o ato administrativo relacionado ao Edital oㅡ 003/93.

Em entendimento unânime, os desembargadores do TJDFT proferem acórdão contrário ao Distrito Federal, assim como aos então usuários dos imóveis. Esta decisão é fundamentada no fato do GDF não dispor de documentos comprobatórios que the dariam o direito de exercer essa dominialidade sobre os setores em litígio, tal qual atesta a Lei oㅜ 6.015/73 que assevera:

Art. 195 - Se o imóvel não estiver matriculado ou registrado em nome do outorgante, o oficial exigirá a prévia matrícula e o registro do título anterior, qualquer que seja a sua natureza, para manter a continuidade do registro.

Art. 197 - Quando o título anterior estiver registrado em outro cartório, o novo título será apresentado juntamente com certidão atualizada, comprobatória do registro anterior, e da existência ou inexistência de ônus". (PRESIDÊNCIA DA REPÚBLICA. Lei n 6.015 de 1973. http://www.planalto.gov.br/ccivil_03/leis/L6015original.htm; acessado em 03 de janeiro de 2014).

Esta mesma situação também se aplica aos então moradores do terreno n. 1 da quadra 22 da Rua Hugo Lobo, conforme relatado nos altos, uma vez que não conseguiram também comprovar a dominialidade do respectivo imóvel em litígio, não dispondo de escritura e registro cartorial, apenas Alvará de Concessão. 
Já a parte que adquiriu o título resultante do Edital ํo 003/93, a priori, consubstanciou a possibilidade jurídica de exercer a posse do imóvel em disputa, haja visto que, pelo fato das terras não terem sido desapropriadas (Transcrição $n$ ๑303), pertencem à Comarca de Planaltina de Goiás, podendo esta dar nova destinação ao bem, sendo o título emitido oriundo da nova alienação reconhecido enquanto legítimo.

Embora nenhuma das plantas urbanas e memoriais descritivos préBrasília tenham sido registradas, tais setores ainda constavam enquanto pertencentes à Prefeitura de Planaltina-GO averbada na transcrição $n^{\circ} 303$, fruto de permuta junto a Paróquia São Sebastião, podendo, a priori, promover nova alienação de seu bem. E é neste sentido que se constrói a argumentação do relator do processo em apreciação:

Cumpre verificar se 0 ato administrativo consubstanciado no Edital de Concorrência Pública de $n^{\circ}$ 003/93, executado pelo réu, com o objetivo de alienar vários lotes situados no Setor Tradicional de Planaltina apresenta algum vício. Neste contexto, convém ressaltar que não visa esta ação a delimitação das áreas de Planaltina-DF e Planaltina de Goiás, até porque se trata de ação anulatória de ato administrativo, não tendo qualquer cunho de direito real. Portanto, $o$ cerne da questão cinge-se unicamente em saber a quem pertencem os lotes objeto da Concorrência Pública n003/93.

Inicialmente, ponderou o Distrito Federal que, com a implementação da nova Capital do Brasil, algumas porções de terras inseridas nos limites do município de Planaltina do Estado de Goiás foram desapropriadas indiretamente para o Distrito Federal. Neste ponto, os lotes objeto da Concorrência Pública, segundo o Autor, estariam inseridos na porção de terra a Planaltina-DF.

Entretanto, impõem-se a observância do laudo pericial que fez a análise do local segundo os documentos juntados pelas partes. Concluiu o nobre perito que os imóveis elencados no edital estão localizados dentro da porção territorial do Município de Planaltina de Goiás, in verbis:

"Todos os imóveis constantes do referido edital situam-se dentro do Setor Tradicional de Planaltina, cuja área corresponde aquela indicada tanto na certidão do Cartório de Registro de Imóveis de Planaltina quanto na planta da Fazenda Mestre D'Ármas (...) e identificada como Patrimônio de Planaltina. Portanto, e considerando-se a documentação apresentada, os imóveis listados estão localizados dentro da porção territorial do Município de Planaltina de Goiás." 
Neste contexto, a Terracap também reconheceu a titularidade das terras como sendo do Réu.

Como se não bastasse não consta no Cartório de Registro Imobiliário qualquer ato translativo de domínio das terras de Planaltina de Goiás para o Distrito Federal. E ainda que se trate de desapropriação indireta, necessário se faz o devido registro como formalidade a dar existência à relação jurídica.

Na hipótese dos autos, vê-se que os imóveis objeto da Concorrência Pública, segundo laudo pericial e o registro no Cartório competente, pertencem a Planaltina de Goiás, de forma que o referido ato administrativo não se encontra eivado de nulidade, tão pouco em dissonância com a Lei no 8.666/93 e a Lei Municipal 346/93.

Com relação ao recurso de Rosa dos Santos Rabelo, buscando caracterizar como ilegal a forma de aquisição por Adalberto Neco da Rocha e s/m, (...) julgo não existir razão recorrente.

(...) em 1993, a Administração Pública concede ao Apelado o lote descrito, depois lhe vendendo e Ihe transmitindo a propriedade com a inscrição do título no Cartório competente.

Pondera, então, a Recorrente que tinha a posse do imóvel anteriormente ao ato translativo de domínio. A posse quando tolerada pelo poder público não induz à propriedade, de forma que a terra ainda pertencia à prefeitura Municipal de Planaltina, podendo esta dispor do bem, inclusive para transferir a propriedade (...)

Neste diapasão, considerando que a Recorrente não trouxe provas capazes de fragilizar aquelas produzidas pelos apelados, é de se negar provimento ao seu apelo. (TRIBUNAL DE JUSTIÇA DO DISTRITO FEDERAL E TERRITÓRIOS. Apelação Cível. Processo no 2000.01.5.006181/8. Brasília, 18 de novembro de 2002).

Ao tratar-se do bem dominial, no caso em relevo, verifica-se que a vertente analisada segundo a perspectiva jurídica (abstrata) sobrepõe à lógica fática sobre o uso do território em sua concretude espacial, uma vez que mesmo o Setor Tradicional estando contido no Distrito Federal não consuma o pleiteado direito de propriedade para com as terras em questão, já que os procedimentos administrativos expropriatórios sobre os setores (declaração de utilidade pública, avaliação, indenização e transmissão do bem) não foram consumados.

Nessa perspectiva, os ritos administrativos produzem enquanto provas materiais da alienação, tanto o título de aquisição através da emissão da escritura pública, elemento este que dá publicidade a negociata, como a averbação em cartório de registro, ou seja, o processo translativo do domínio enquanto procedimento que efetiva juridicamente a transmissão do bem imóvel. 
Estes elementos, conforme 0 exposto, também não foram apresentados pelos anteriores moradores da quadra 22 do Setor Tradicional, ou seja, obtenção de escritura pública e o efetivo registro em cartório, logo, acabaram por exercer apenas posse precária sobre o bem, e, consequentemente, não dispondo do pleno direito de propriedade.

Todavia, a judicialização do Setor Tradicional, território usado no plano do presente, ganha contornos ainda mais complexos quando os compradores relacionados ao Edital ㄲo 003/93, ou terceiros adquirentes destes imóveis alienados por Planaltina de Goiás junto aos seus primeiros compradores (terceiro ciclo de expansão da cidade), pelo fato de não terem ciência do imbróglio jurídico das terras. Ao tentarem atualmente efetivar a transmissão dominial dos mesmos junto ao $8^{\circ}$ Cartório de Registro de Imóveis situado na cidade de Planaltina-DF, não obtiveram êxito para exercerem plenamente o direito de propriedade.

Isto porque um novo entendimento sobre a questão é erigido enquanto desdobramento das decisões atinentes aos processos $\mathrm{n}^{\circ} 1.874 / 93$ e de $\mathrm{n}^{\circ}$ 2000.01.5.006181/8, tendo em vista a legalidade das alienações executadas com base no Edital no 003/93, promovidos pela Prefeitura de Planaltina de Goiás junto às terras do Setor Tradicional.

Esta nova interpretação é fruto do procedimento de dúvida, processo $\mathrm{n}^{\circ}$ 2006.01.1.090919-9, previsto na Lei $n^{\circ} 6.015$ em seu art. 198, cuja temática trata-se da legitimidade da execução do processo administrativo de registro cartorial dos imóveis, sendo tal ato administrativo solicitado pelo Tabelião Paulo Luís Quintela de Almeida a Vara de Registros Públicos, objetivando a emissão de parecer para que se dê continuidade a averbação de boa fé.

O que se vê no processo $n^{\circ}$ 2006.01.1.090919-9, diferentemente do caso do Quintas do Alvorada e até mesmo quanto aos processos anteriores sobre o Setor Tradicional em termos de decisão/ação do Judiciário, é o travamento de várias matrículas oriundas do Edital $n^{\circ}$ 003/93, o que implica na impossibilidade de da transmissão dominial dos lotes alienados por Planaltina de Goiás, muito embora haja a prenotação dos mesmos.

Além deste fato, atinente ao bloqueio das matrículas (ver anexo 6) oriundas do Edital $n^{\circ}$ 003/93, outra situação citada no procedimento de dúvida remete ao acúmulo de situações de ilegalidade do Setor Tradicional como um todo, 
assim como de suas extremidades, ao longo das décadas, situações estas já expostas ao longo da dissertação e que impossibilitam a efetivação do registro dos imóveis destas localidades no momento presente.

Neste sentido, a produção e uso do território correspondente à área urbana de Planaltina-DF tem, enquanto síntese de seu movimento dialético e fruto de sua formação socioespacial, a ampliação da precariedade jurídico-dominial das habitações, cujo seu núcleo vernacular expressa a situação mais complexa face a regularização fundiária ao qual o Poder Judiciário é partícipe de tal dinâmica em associação ao Poder Executivo e sociedade civil.

Assim, o procedimento de dúvida (processo n²006.01.1.090919-9) arguiu sobre a licitude da transmissão do domínio atinente ao lote 16 da quadra 07 , situado na Rua Sergipe (Setor Tradicional Residencial Norte). O que se verifica é que o referido terreno é oriundo do Edital $n^{\circ} 003 / 93$, estando este situado sobre área pública de uso comum, cuja função destinava-se ao lazer, ou seja, praça de esportes.

Outro elemento que é exposto em tal procedimento de dúvida é que este lote, fruto do Edital $n^{\circ} 003 / 93$, conseguiu obter o registro cartorial no $3^{\circ}$ Registro de Imóveis do Distrito Federal, alocado em Taguatinga, uma vez que consta em tal processo administrativo que mesmo sendo reconhecido o domínio das terras do Setor Tradicional por parte da Prefeitura de Planaltina de Goiás (inclusive em pelo STJ), a efetivação do registro cartorial já vinha sendo obstado por sentença judicial para evitar maiores imbróglios jurídicos desde o ano de 1993.

Todavia, conforme expõe o procedimento de dúvida, as alienações continuaram a ocorrer e em várias destes lotes (como a quadra 01) conseguiu-se obter o registro cartorial no período de 1993 a 2003 junto ao $3^{\circ}$ Cartório de Registro de Imóveis, uma vez que no tramite processual, em alguns momentos, as matrículas destes lotes foram descerradas, possibilitando a averbação em livro de registro.

Nesta perspectiva, o procedimento de dúvida questiona a possibilidade de efetivação de tal transmissão do lote 16 situado na quadra 07, já que este lote (dentre vários outros) não constam na planta original da cidade, valendo destacar que nenhum memorial descritivo ou planta foi registrado ao longo dos três ciclos de expansão da cidade de Planaltina, fato este que coloca em dúvida a legalidade quanto a obtenção dos respectivos registros cartoriais ao longo das décadas. 
Questionou-se também a legitimidade da efetivação dos registros dos novos Alvarás de Concessão emitidos em 1993, já que estes, segundo consta no procedimento de dúvida, além de não produzirem o efeito jurídico de escritura pública não dispunham de assinaturas entre as partes, fato este que não estabeleceria um consenso contratual entre as mesmas (Planaltina de Goiás e adquirente), ferindo inclusive princípios previstos na Lei $n^{\circ}$ 8.666/93 (licitações e contratos) condizente aos procedimentos licitatórios, além de não seguir as normas pré-estabelecidas na Lei ํㅜ 6.015/73 para o reconhecimento da legitimidade do contrato de compra e venda.

Esta tentativa de efetivação da transmissão do domínio por meio de registro cartorial das terras oriundas do Edital $n^{\circ} 003 / 93$, busca justamente valer-se dos Decretos $n^{\circ}$ 9.105/85 (referente à planta URB/85 E MDE/85) e $n^{\circ}$ 24.246/03 (revisão do decreto anterior) que abriam precedentes possibilitando 0 desmembramento de vários lotes contidos no Setor Tradicional, fruto das alienações realizadas pela Prefeitura de Planaltina de Goiás e seu primeiro ciclo de expansão, e que por várias circunstâncias até então não foram efetuados.

Neste sentido, os mecanismos previstos em ambos os decretos não se enquadrariam ao quadro atinente ao Edital $n^{\circ}$ 003/93, uma vez que estavam previstos quanto à obtenção dos registros apenas os lotes delineados na URB/85, fruto da junção dos memoriais descritivos e plantas não registradas de 1965, $1958 \mathrm{e}$ 1941, e que não explicitavam a presença de quadras residenciais em áreas públicas ou o surgimento de novas quadras habitacionais.

Assim, verifica-se que a não desapropriação das terras desde a Comissão Goiana de 1956, somado à não efetivação do registro das plantas e memoriais descritivos, impulsionaram Planaltina de Goiás a iniciar o processo licitatório de suas terras, prática esta ampliada com a decisão do Poder Judiciário (de forma indiscutível) ao emitir sentenças e acórdãos pelo TJDFT e STJ, declarando a dominialidade das terras de Setor Tradicional em favor do município goiano, fato este indiscutível.

Todavia, segundo consta no procedimento de dúvida, nestes desmembramentos deveriam constar a aprovação do Governo do Distrito Federal e da Administração Regional de Planaltina, fato este que não acontece de forma vultosa nas alienações provenientes do Edital $n^{\circ}$ 003/93, uma vez que mesmo o 
domínio do Setor Tradicional ao ser reconhecido em favor de Planaltina de Goiás, cabe ao Distrito Federal geri-las. Assim, é importante frisar trechos do processo $\mathrm{n}^{\circ}$ 2006.01.1.090919-9 que trata do tema:

Ocorre que a partir de 1960, falece a competência para a Prefeitura de Planaltina-GO para alterar a planta PR-4/1, passando a organização territorial da cidade satélite de Planaltina a ser encargo do Distrito Federal. Assim, ainda que se considere que as vias e equipamentos públicos continuem no domínio da Prefeitura (...) deveria a Prefeitura promover desafetação ${ }^{35}$ da área e alteração do projeto de loteamento original, com aprovação do órgão competente do GDF, a fim de transformar áreas públicas em bens dominiais e, então, tomar as providências necessárias para alienação (avaliação prévia, autorização legislativa, licitação na modalidade concorrência e lavratura de escritura pública).

Conclui-se, portanto, que a Prefeitura não poderia ter transformado a Praça de Esportes na Quadra 07, dividindo-as em lotes, sem antes observar os procedimentos legais, com aprovação do Distrito Federal.

Como, contudo, sequer a Planta original foi registrada, a situação torna-se sui generis. Não parece razoável declarar a nulidade da esmagadora maioria dos registros dos imóveis do Setor Tradicional de Planaltina, por falha do prévio registro do Memorial do Loteamento, porque isso causaria evidente transtorno social na cidade. Por isso, aceitar-se-ia dar continuidade aos registros anteriores, desde que houvesse reconhecimento formal pelo Distrito Federal, por sua Administração Regional de Planaltina, da alteração do projeto levado a termo pela Prefeitura de Planaltina-GO. Por isso foi exigida a emissão de Certidão do órgão do DF nesse sentido.

Solicitada a Certidão, o pedido respectivo recebeu despacho do seguinte teor, conforme cópia apresentada pelo interessado: "Analisando os autos deste processo, existe (sic) três despachos exarados com 0 indeferimento dos requerentes, com base nos processos do TJDFT $n^{\circ}$ 00035029/93, e APC no 2000.01.5.006181/8 (...) sem o ciente dos requerentes. Dando busca na relação dos desmembramentos realizados no período de 06.12.1985 a 24.11.2003, amparados pelos Decretos $n^{\circ} 9105 / 85$ e no 24.246/2003, não há nenhum documento que originou o Lote $n^{\circ} 16$ da Quadra 07, da Rua Sergipe do Setor Tradicional de Planaltina - DF. Diante destas situações jurídicas e técnicas, resta aguardar a conclusão dos processos, que até a presente data está sub judice".

${ }^{35}$ Junior (2003, p. 435) define desafetação da seguinte maneira:

(...) é o instituto de direito administrativo mediante o qual o Estado, de maneira solene, declara que o bem é parte integrante do domínio público. É a destinação da coisa ao uso público. A operação inversa recebe o nome de desafetação, fato ou manifestação do poder público mediante o qual o bem público é subtraído à dominialidade estatal para incorporar-se ao domínio privado do Estado ou do particular. 
Não havendo reconhecimento do Distrito Federal com relação ao parcelamento ocorrido, não há como dar seguimento aos registros efetuados á mencionada Quadra 07 do Setor Tradicional. (TRIBUNAL DE JUSTIÇA DO DISTRITO FEDERAL E TERRITÓRIOS. Dúvida; processo no 2006.01.1.090919-9. Brasília, 25 de agosto de 2006).

Observa-se no relatório atinente ao procedimento de dúvida (processo no 2006.01.1.090919-9) que, além do acúmulo de ilegalidades das situações já registradas ao longo da exposição da formação socioespacial da cidade, como a não efetivação do registro cartorial das sucessivas plantas e memoriais descritivos ao qual o Setor Tradicional está inserido como núcleo histórico, bem como da abrangência da precariedade jurídica dos imóveis que evoluiu nos três ciclos de expansão da área urbana, no caso do Edital $n^{\circ}$ 003/93, os adquirentes de tais lotes encontram-se em um fogo cruzado quanto às disputas jurídicas e judiciais entre ambos os entes federativos. Os moradores não conseguem consolidar o domínio dos imóveis tendo em vista que a questão registral só poderá ser efetivada mediante a emissão de Certidão pela Administração Regional de Planaltina (o que não ocorre) ou, efetivamente, com a aquisição do domínio de tal setor pelo GDF via desapropriação (fato que se arrasta ao longo das décadas).

Além das possibilidades expostas que não estabelece um consenso ou ato concreto, cabe destacar o parecer procedente da dúvida emitido pelo Ministério Público, advindo da Vara de Registros Públicos do Distrito Federal, que ressalta a ilicitude da alienação das terras e da impossibilidade de registrá-las, uma vez que juridicamente tal setor (Setor Tradicional e suas extremidades), consolidado há décadas, inexiste juridicamente, tendo em vista a ausência de planta e memorial descritivo registrados em cartório. Assim, segundo tal parecer, o edital $n^{\circ}$ 003/93 careceria de legalidade, uma vez que os lotes alienados não possuem plantas nem memorial descritivo depositado em cartório, tal como é exposto pelo MP:

Conforme informou o Sr. Oficial, nem a planta original e nem a planta PR-4/1, aprovada pela Prefeitura de Planaltina/GO, órgão competente à época pela região, foram registradas.

Logo, antes à existência do registro do loteamento, o setor tradicional da região administrativa de Planaltina/DF não existe legalmente. Cristalina, portanto, a impossibilidade do Sr. Oficial, que deve 
examinar, cuidadosamente, $\mathrm{o}$ atendimento às exigências legais, registrar o título apresentado.

Muito embora no presente procedimento não se discuta questões extrínsecas aos registros em si mesmo, salienta-se que o artigo 37 da Lei $n^{\circ}$ 6.766/79 estabelece que "é vedado vender ou prometer vender parcela de loteamento ou desmembramento não registrado". E os artigos 82 e 145 do Código Civil (1916) dispõem:

Art. 82 - A validade do ato jurídico requer agente capaz, objeto lícito e forma prescrita ou não defesa em lei.

Art. 145 - É nulo o ato jurídico:

$(\ldots)$

II - quando for ilícito ou impossível o seu objeto;

III - quando não revestir de forma prescrita em lei.

Assim, como a lei proíbe a venda ou promessa de venda sem o registro do loteamento, previamente aprovado, o negócio jurídico entabulado pelas partes tem objeto ilícito e não atendeu à forma prescrita na lei, estando eivado de nulidade.

Por fim, o fato do loteamento ter sido aprovado pela Prefeitura de Planaltina/GO, não significa, por si só, que será regularizado pelo órgão competente. Para que a área seja regularizada necessária a avaliação das questões impostas pela legislação ambiental, agrária e urbanísticas, dentre outros requisitos exigidos, bem como a submissão ao registro imobiliário. (MINISTÉRIO PÚBLICO DO DISTRITO FEDERAL E TERRITÓRIOS. Processo $\mathrm{n}^{\circ}$ 2006.01.1.090919-9. Brasília, 18 de dezembro de 2006)

Tendo em vista os pontos levantados pelo Oficial do $8^{\circ}$ Ofício de Registro de Imóveis do Distrito Federal, somado ao parecer técnico emitido pela Promotoria de Registros Públicos do Ministério Público do Distrito Federal e Territórios, tem-se proferimento de sentença à dúvida referente ao processo no 2006.01.1.090919-9 pela Vara de Registros Públicos do Distrito Federal, vinculado ao TJDFT.

Seguindo a linha argumentativa tecida, a decisão monocrática proferida ao processo administrativo assevera que as alienações incorrem de ilegalidade, já que os preceitos legais previstos nas Leis nำ 58/37, no 6.766/79 e n 6.015/73 não foram seguidas, julgando procedente a dúvida levantada.

Assim, juridicamente o Setor Tradicional inexiste, segundo tal parecer, uma vez que não dispõe de plantas e memoriais descritivos registrados em cartório, 
tendo como consequência a precariedade jurídica dos imóveis contidos em tal setor, incluindo aqueles oriundos do Edital $n^{\circ} 003 / 93$.

A sentença proferida é favorável ao bloqueio das matrículas, cuja finalidade é o travamento das ações de compra e venda dos imóveis ou terrenos em tal setor, constituindo-se assim em uma nova dinâmica face a ação/decisão ao qual fora exposto no caso Quintas da Alvorada e até mesmo no Setor Tradicional após a legitimação do domínio de Planaltina de Goiás para com as terras do sítio urbano vernacular.

Nesta perspectiva, embora não seja diretamente o Poder Judiciário, em suas diversas instâncias decisórias, um agente que se aproprie e altere o território em uso, observa-se que através de interpretações dadas por este Poder quanto aos conflitos resultantes da multiplicidade e simultaneidade de uso dado pelos inúmeros elementos espaciais (incluindo os múltiplos segmentos corporativos) através de sentenças e acórdãos (decisões) emanados em virtude destas disputas, revertem-se em comandos (ações) que são decodificadas pelos demais agentes contidos no território usado e que dão materialidade as determinações judiciais (ou as brechas deixadas por estas), repercutindo na produção de novos sistemas de objetos espaciais, ou, no estancamento desta produção.

Para salientar esta nova postura decisória e de cognição quanto à situação jurídica das terras contidas no Setor Tradicional, tendo em vista o intuito de travamento das relações de compra e venda em virtude da impossibilidade da transmissão dominial do bem imóvel vinculado aos lotes oriundos do Edital $\mathrm{n}^{\circ}$ 003/93, é válido transcrever a sentença proferida ao procedimento administrativo de dúvida, processo nำ2006.01.1.090919-9:

O parcelamento em foco ocorreu em Planaltina/GO antes da vigência da Lei $n^{\circ} 6.766$, de dezembro de 1979. Porém, como à época já era exigível sua inscrição (Decreto-lei $n^{\circ} 58$, de 10 de dezembro de 1.937), não é possível cogitar sequer a denominada "averbação de controle" (artigo 167, II, n 4, Lei ํㅜ 6.015/73), só permitida para os casos de desmembramento anterior à vigência da Lei $n^{\circ} 6.766 / 79$ e não para os de loteamento.

Válido ressaltar que não ampara ao apresente do título à existência de registros indevidos de várias unidades do loteamento, uma vez que erros pretéritos, ainda que não evidentes, não justificam sua reiteração ou prática de outros atos análogos, porquanto nesses casos inexiste direito adquirido. 
É dizer, então, que lote oriundo de parcelamento irregular é juridicamente inexistente, sendo indispensável à prévia regularização para ingresso no fólio real, pouco importando haja registros anteriores ultimados com ofensa à lei, já que erros passados não justificam novos.

Apesar de o título não ser válido do ponto de vista tabular, o contexto no qual ele foi concebido está a exigir do Governo do Distrito Federal a pronta implementação de atos necessários à regularização fundiária do loteamento, sobretudo porque ele está consolidado há anos em zona urbana de Planaltina/DF. E mais, todos os adquirentes são de boa-fé, porquanto adquiriram os imóveis do próprio ente público então senhor da faixa de terra (Intendência Municipal de Planaltina/GO), ou com base em dados constantes de matrículas descerradas na Serventia competente.

Diante do quadro de nulidade que está a grassar a tábua predial, é certo que os terceiros de boa-fé - que se serviram dos registros que estão em situações assemelhadas - poderão ser prejudicados, sobretudo diante da impossibilidade da transferência da titularidade, pelo menos até a regularização tabular. É dizer, há imperiosa necessidade de bloqueio administrativo das matrículas, a fim de preservar a segurança inerente aos assentos públicos.

Aplicável ao caso vertente, portanto, o disposto nos $\S \S 3^{\circ}$ e $4^{\circ}$ do art. 214 da Lei no 6.015/73, rezam:

$\S 3^{\circ}$ - Se o juiz entender que a superveniência de novos registros poderá causar danos de difícil reparação poderá determinar de ofício, a qualquer momento, ainda que sem oitiva das partes, o bloqueio da matrícula do imóvel.

$\S 4^{\circ}$ - Bloqueada a matrícula, o Oficial não poderá mais nela praticar qualquer ato, salvo com autorização judicial, permitindo-se, todavia, aos interessados a prenotação de seus títulos, que ficarão com prazo prorrogado até a solução do bloqueio.

Portanto, como medida correcional administrativa acautelatória, e com o intuito de prevenir eventual ocorrência de vícios registrários e salvaguardar direitos de terceiros adquirentes de boa-fé, impõe-se o bloqueio de todas as matrículas dos imóveis, cujos descerramentos se deram em situações semelhantes à matrícula sob apreciação.

Posto isso, julgo PROCEDENTE a Dúvida e determino, após o trânsito em julgado, que se proceda na forma preconizada pelo art. 203, I, da Lei de Registros Públicos.

Determino a imediata extração de cópias destes autos para fins de, até ulterior deliberação judicial, bloquear as matrículas descerradas em situações análogas.

À vista das peculiaridades do caso e do interesse social que encarta, oficia-se ao Governo do Distrito Federal (...) para que envide os esforços necessários à regularização da área, caso seja do seu 
interesse. (TRIBUNAL DE JUSTICCA DO DISTRITO FEDERAL E TERRITÓRIOS. Processo no 2006.01.1.090919-9. Brasília, 14 de maio de 2007)

Se num primeiro momento a decisão, ação oriunda do Poder Judiciário é favorável a dominialidade do Setor Tradicional para Planaltina de Goiás, o que acaba por reconhecer a legitimidade e impulsionar a ampliação das alienações de terras fruto do Edital $n^{\circ}$ 003/93, tendo em vista o desbloqueio de várias matrículas que geraram a averbação no $3^{\circ}$ Cartório de Registros Públicos do Distrito Federal, noutro momento, o decisum objeto do processo no 2006.01.1.090919-9 tem por finalidade conter a dinâmica espacial face às relações de uso do território juridicamente precarizado, tendo em vista o novo bloqueio das matrículas dos imóveis alienados pela municipalidade goiana no terceiro ciclo de expansão da cidade, refreando assim a dinâmica de produção de novos objetos espaciais ou as relações de compra e venda que envolvam estes.

Algo que também fica evidente quanto ao bloqueio das matrículas enquanto ação/decisão, mesmo ao ser proveniente de ato administrativo, é a determinação emitida ao Governo do Distrito Federal em tomar um posicionamento urgente frente à questão da regularização do Setor Tradicional e de suas extremidades, o que necessariamente conduziria ao processo de desapropriação do setor em somatória à realização de estudos técnicos (ambientais, georreferenciamento, dentre outros), com o intuito de propiciar aos respectivos moradores a plena cidadania via exercício do direito de propriedade, que se consubstancia com a emissão das escrituras públicas e averbação em cartório de registro da transmissão do domínio do imóvel.

Conforme o exposto referente às distintas sentenças emitidas frente à questão da Judicialização do Setor Tradicional e à legitimidade das alienações oriundas do Edital $n^{\circ}$ 003/93, vê-se que o Poder Judiciário ao transcorrer do processo se contradiz. Não quanto à dominialidade das terras em favor de Planaltina de Goiás, mas a respeito da legitimidade das alienações e registros efetivados relativos a alguns lotes oriundos do Edital $n^{\circ}$ 003/93 e, até mesmo, os demais imóveis registrados ao longo das décadas e que perfazem a Transcrição nº 303. 
Constata-se a impossibilidade de averbação das alienações realizadas após 2007, oriundos do Edital $n^{\circ} 003 / 93$ e que acarretam na condição de precariedade jurídica de seus novos adquirentes.

Nesta perspectiva, o ato administrativo do devido registro da planta é ilegal, necessitando de parecer favorável ao desmembramento e emitido pela Região Administrativa de Planaltina, cuja concordância não se estabelece ao argumentar que a destinação das áreas alienadas foram alteradas, conforme consta no art. 17 da Lei no 6.766/79: "os espaços livres de uso comum não poderão ter a sua destinação alterada pelo loteador, desde a aprovação do loteamento, salvo as hipóteses de caducidade da licença ou desistência do loteador".

Todavia, o acúmulo de omissões frente à efetiva regularização do parcelamento do Setor Tradicional coloca em questão inclusive a aplicação do dispositivo legal citado, já que nem mesmo plantas urbanas registradas o referido setor dispõe.

O que fica evidente, no caso da materialização espacial dos sistemas de objetos espaciais e da complexidade e simultaneidade das ações dos distintos agentes espaciais que se originam com a não desapropriação das terras do Setor Tradicional e que se desdobram no Edital $n^{\circ}$ 003/93 e nas batalhas judiciais de então, é o jogo de forças entre o Distrito Federal e Planaltina de Goiás para saber de quem é o dever de arcar com os custos atinentes ao processo de legalização, bem como quanto aos valores a serem pagos para a transmissão do domínio das áreas públicas e terrenos ainda não desapropriados, tal como se observa na ementa e no transcorrer do processo $n^{\circ}$ 135.000.380/2011 encaminhado pela Administração Regional de Planaltina ao MPDFT:

EMENTA. DIREITO CONSTITUCIONAL E URBANÍSTICO. CASA CIVIL DA GOVERNADORIA DO DISTRITO FEDERAL. ADMINISTRAÇÃO REGIONAL DE PLANALTINA. REGULARIZAÇÃO FUNDIÁRIA E URBANÍSTICA DO SETOR TRADICIONAL DE PLANALTINA-DF. INÉRCIA DA MUNICIPALIDADE DE PLANALTINA DE GOIÁS, TITULAR DA ÁREA. COMPETÊNCIA DO DISTRITO FEDERAL NA CONDUÇÃO DA REGULARIZAÇÃO. ART. 40 DA LEI № 6.766/79. NECESSIDADE DE PRÉVIA NOTIFICAÇÃO JUDICIAL DO TITULAR DA ÁREA E EMPREENDEDOR. PODER-DEVER DO DISTRITO FEDERAL EM PROCEDER A REGULARIZAÇÃO DO SETOR. PRECEDENTES DO STJ. 
(...) Com a finalidade de lotear o setor, o Município aprovou a planta PR-4/1, que nunca foi levada a registro. Ainda que sem os registros autônomos (matrículas), os imóveis foram comercializados mediante Alvarás de Concessão emitidos a época pela Prefeitura de Planaltina de Goiás. E nem mesmo após a venda dos imóveis por meio de Alvarás, foram realizados os estudos adequados à sua implementação pela municipalidade.

Assim, em decorrência da inexistência de registro do loteamento e da carência de documentos relativos a determinação da propriedade, impossibilitados estão os moradores deste setor de adquirirem o registro de seus imóveis.

$\mathrm{Na}$ hipótese vergastadas nos autos, é patente a competência e o poder-dever do Distrito Federal em conduzir o processo de regularização fundiária/urbanística do Setor Tradicional de PlanaltinaDF, independente da titularidade da área ser do Município de Planaltina-GO. A única providência prévia que o Distrito Federal teria de adotar, segundo o art. 40 da Lei no 6.766/79, é a NOTIFICAÇÃO JUDICIAL DO EMPREENDEDOR (...) para que ele dê seguimento ao processo de regularização junto à SEDHAB. Caso a notificação judicial não surta efeito, e a Municipalidade quede inerte, o Distrito Federal, assume, desde o início, a condução do processo, imputando o ônus financeiro aquela municipalidade. (PROCURADORIA GERAL DO DISTRITO FEDERAL. Procuradoria do Meio Ambiente, Patrimônio Urbanístico e Imobiliário; processo № 135.000.380/2011. Brasília, 26 de março de 2013).

O resultado desta correlação de forças, entre Planaltina de Goiás e GDF, propicia aos moradores do Setor Tradicional e, em especial dos adquirentes dos lotes do Edital n 003/93, ou àqueles expropriados por não disporem do domínio destes, uma expectativa angustiante tendo em vista a inconclusa resolução da questão que se fosse diferente, Ihes tirariam da condição de posse precária sobre os bens para o pleno exercício do direito de propriedade via registro dos imóveis.

Somado a alta complexidade do Setor Tradicional e suas extremidades face à precariedade jurídica e dominial dos respectivos imóveis, observa-se em Planaltina, em seu terceiro ciclo de expansão, a horizontalização desta condição jurídica para com o uso do território, uma vez que a dominialmente "exercida" sobre o mesmo se dá de maneira precária.

Este fato também necessita ser observado urgentemente pelo Poder Público, uma vez que a dimensão dos problemas socioespaciais vinculados a esta condição clandestina de aquisição da terra, que revela justamente a dinâmica de produção corporativa do espaço urbano exposto através da ótica teórica de Santos 
em suas obras, repercutem na ineficácia do gozo do direito de propriedade, logo, do reconhecimento da plena cidadania em uma perspectiva individual e coletiva, haja visto a amplitude da questão.

Tendo em vista todos os elementos expostos condizentes ao processo de formação socioespacial de Planaltina que culmina em complexidade jurídica que Ihe é peculiar enquanto território usado no plano do presente, serão tecidas a seguir as considerações finais. 


\section{Considerações finais - A judicialização territorial de Planaltina-DF: os entraves político-jurídicos frente à necessidade do viver e da regularização do solo urbano}

Ao se tratar da dinâmica de produção e movimento da cidade de Planaltina-DF, constatou-se em meio a sua formação socioespacial evidências da construção de uma lógica permeada intencionalmente, no incentivo ao espraiamento da população brasileira em seu contexto colonial para as terras ermas, para os sertões.

Todavia, o apossamento das terras constituiu-se enquanto prática recorrente de tais sertanejos, retratado por Magalhães, tendo em vista a produção do Sertão Planaltino. Essa mesma lógica de posse da terra e dos primeiros ocupantes também é assinalada por Bertran e Castro, sendo exposto que na maioria das situações de uso da terra fugiam às normas estabelecidas pela Coroa Portuguesa explicitadas na Lei de Sesmarias de 1375, readaptada para a dinâmica colonizadora.

Verificou-se, neste prisma utilizando-se da visão de Nozoe, que mesmo a margem das normas, a burla de tal mecanismo jurídico face à precária fiscalização constituía-se enquanto omissão intencionalmente praticada pela Coroa Portuguesa, cujo intuito era garantir a ocupação do território desbravado pelo bandeirismo, em especial por paulistas, baianos e bandeiras oriundas do Grã-Pará, permitindo posteriormente o espraiamento da atividade aurífera no Brasil Central e na constituição de sistemas de produção complementares pautados nas lavouras de subsistência e na atividade pecuarista.

Assim, constata-se no caso do Sertão Planaltino, enquanto fração de uma totalidade maior e ao mesmo tempo uma totalidade, que efetivamente as primeiras sesmarias são resultantes das perambulações de Bartolomeu Bueno da Silvam e Anhanguera filho. Todavia, o que passa a predominar, a partir da segunda metade do séc. XVIII, é a lógica pautada na ocupação e posse da terra atrelada à 
precariedade jurídica com relação à concessão de tal direito dado pela Coroa Portuguesa.

Este processo de ocupação de uso do território atrelado à precariedade jurídica da posse da terra que se vincula à dinâmica de formação socioespacial do Sertão Planaltino, ganha em intensidade após o esgotamento das minas de Santa Luzia. Logo se estabelece, enquanto vocações produtivas, a agricultura dos gêneros voltados à subsistência e, especialmente, a pecuária bovina, atividade herdada da expansão dos Currais do São Francisco. Essas práticas econômicas se deram culturalmente pautada pela lógica da posse juridicamente precária da terra.

Essa lógica da posse fragilizada da terra numa perspectiva agrária, também se replica na produção do espaço urbano de Planaltina-DF, em seu processo de formação socioespacial na primeira metade do século $\mathrm{XX}$ segundo os relatos de Castro, ou seja, ainda num contexto espaço temporal pré-Brasília em seu primeiro ciclo de expansão. Vale ressaltar que as origens do espaço urbano embrionário de Planaltina-DF remontam ao ano de 1811, sobre as terras do Santo São Sebastião, tal qual fora descrito pelo intelectual citado.

Conforme fora exposto, Planaltina-DF, enquanto subespaço, é interpretada como produto singular da convergência de múltiplas ações de uma totalidade integral, enquanto fração do todo em movimento, vinculada, interconectada a esse todo em movimento, tendo em vista a evolução linear do espaço-tempo em distintos contexto (contextos pré-máquina, meio técnico da mecanização incompleta, meio técnico da circulação mecanizada e dos inícios da industrialização, limiar para a introdução do meio técnico-científico).

Neste sentido, as singularidades de Planaltina-DF atreladas à precariedade jurídica que permeia a dinâmica de uso do território por meio da posse em todo o primeiro ciclo de produção da cidade, como das propriedades rurais ao seu redor, reproduzem de forma singular as práticas de produção do todo (território nacional). Todavia, passam a ganhar ares juridicamente ilegais ou de posse precária com o decorrer do estabelecimento dos sistemas de normas que viriam a regular as questões atinentes ao direito de propriedade em uma escala do Estado-Nação entre meados da segunda metade do século XIX em diante. 
Assim, fora demonstrado esta dinâmica com o advento da Lei $n^{\circ} 601$ de 1850 que dispunha sobre as terras devolutas do Brasil Império enquanto norma substituta da Lei de Sesmarias de 1375 e suas alterações, onde esta primeira estabelece o mecanismo de aquisição de terras pertencentes à União através de título de compra, bem como de elementos jurídicos que determinam o domínio das terras, da prévia posse pacífica, sendo ratificado os respectivos limites via Registros Paroquiais.

A terra passa neste contexto a ser mercadoria, desdobrando na ampliação dos conflitos judiciais, segundo Nozoe numa perspectiva abrangente, tendo em vista os elementos jurídicos correlacionados ao exercício do direito à propriedade e o direito de propriedade a serem reconhecidos pelo Estado, mas que até a concretização das ações mudancista não se aplicava efetivamente no Sertão Planaltino.

O fato de não vigorarem remete-se às distintas lógicas espaçotemporais existentes no Brasil em seu processo formação socioespacial, sendo vista inclusive pelas oligarquias tradicionais locais enquanto espaço periférico, atrasado em relação aos centros da economia nacional no alvorecer do século XIX e princípio do século $X X$. Neste prisma, quanto à questão jurídica das terras ermas, pouco se observava quanto ao rigor fiscalizador, resultando assim no estabelecimento e consolidação das convenções locais frente à ocupação e negociação do uso da terra.

Este conflito de distintas lógicas produtivas, temporais e normativas será vivenciado no Sertão Planaltino com a concretização do sonho mudancista com a implementação de Brasília. O choque que se estabelece entre precariedade jurídica das terras, direito de/a propriedade, é evidenciado com o início das desapropriações para a instalação da nova capital no ano de 1956, que frequentemente passará aos tribunais após a inauguração da capital nos anos de 1960, uma vez que as expropriações das terras contidas no quadrilátero não são concluídas.

Segundo um olhar dialético, Brasília, enquanto antítese, imprime transformações no processo de formação socioespacial da cidade de Planaltina-DF, 
impactando a lógica e a dinâmico espaço-temporal do Sertão Planaltino, repercutindo desta maneira nas estruturas sociais até então vigentes, como as questões atinentes a posse da terra e seus proprietários aos arredores da cidade objeto.

Verifica-se neste embate entre o velho e o novo não só a imposição de tempos céleres, da arquitetura e da burocracia que se instalam, mas, sobretudo, das imposições normativas que podam a lógica de uso e ocupação da terra, pautadas, de maneira predominante, na palavra firmada entre as parte. A lógica jurídica pautada na formalidade dos contratos escritos, transmissão de títulos via cartório e nas normas de uso e ocupação do solo passam a sobrepor a lógica da posse herdada do Período Colonial.

Esta afirmativa pode ser constatada uma vez que várias propriedades rurais não dispunham de titulação, ou Registros Paroquiais. As que detinham o documento mencionado, por muito tempo fora interpretado nos procedimentos administrativos de expropriação enquanto títulos podres, já que não fora efetivado o pagamento do emolumento, uma vez que em Goiás não existia coletoria. Além disso, constata-se com a Comissão Goiana de 1956 a existência de terras cujos limites não condiziam com as documentações ou sequer dispunha de titulação da terra, dentre outras situações.

Ao se tratar da cidade de Planaltina-DF em seu contexto pré-Brasília, percebeu-se, em meio à lógica de produção por meio da formação socioespacial, a sua produção espontânea fundada na crença religiosa, e que posteriormente, na primeira metade do século $X X$, vê-se, enquanto lógica, a negação de instrumentos jurídicos pelo Poder Executivo da municipalidade goiana na produção do espaço urbano, como a Lei $n^{\circ}$ 58/37 que normatizava as políticas de loteamentos e venda de terrenos a prestações, estando este correlacionado a outros instrumentos jurídicos condizentes ao direito de propriedade previsto nas Constituições e ao Código Civil de 1916.

Assim, motivado por uma expectativa mudancista, desde a década de 1920 até o ano de 1961, ano esta em que se dá a transferência da sede administrativa de Planaltina de Goiás para terras contiguas ao novo Distrito Federal, 
tem-se um grande movimento especulativo, materializando-se na expansão dos sistemas de objetos espaciais da cidade em associação à precariedade jurídica quanto à posse de vários lotes alienados via Alvarás de Concessão.

Além da não efetivação do domínio de vários lotes obtidos por meio dos mencionados alvarás, constata-se também a carência de registros cartoriais das plantas urbanas de Planaltina, então pertencente ao estado de Goiás, produzidas em 1941 e 1958, o que torna ilegal a efetivação da matrícula dos parcelamentos em cartório.

Assim, verificou-se, neste contexto, a alienação de terras privadas e executadas pela Prefeitura goiana, aonde alguns dos imóveis foram registrados irregularmente (inclusive, após o primeiro ciclo de expansão de Planaltina-DF) e outras sendo alienadas apenas por Alvarás de Concessão, correspondendo aos lotes do Setor Tradicional e de suas extremas, ao Norte e ao Sul.

Em somatória a estes fatos, averiguou-se anos depois a não efetivação da desapropriação das áreas públicas vias, terrenos, lotes contidas na Transcrição n 303 (Setor Tradicional) pelo novo Poder Executivo que se instala, o que veio a causar o processo de Judicialização do Setor Tradicional em um contexto atual, ou seja, território usado no plano do presente.

O resultado é a contestação da dominialidade do setor não apenas entre os Poderes Executivos de ambos os entes federativos (GDF versus Prefeitura de Planaltina de Goiás), mas entre a municipalidade goiana e os antigos moradores do bairro em questão e com os novos proprietários adquirentes dos lotes alienados através do Edital n003/93 via Alvarás de Concessão, expropriando os primeiros adquirentes que também exerciam a posse dos lotes mediante expedição de Alvará de Concessão, que não consubstanciaram o seu direito de propriedade através do desmembramento e registro em cartório, o que resultaria na transmissão do domínio do bem imóvel.

Assim, numa perspectiva dialética, Planaltina-DF enquanto tese, antítese e síntese, reflete, no espraiamento de sua malha urbana, um caleidoscópio complexo de setores irregulares, passíveis de regularização, parcelamentos 
clandestinos e casos de extrema complexidade jurídica, sendo citado em especial o Setor Tradicional e suas extremas que espaço-temporalmente antecede a Brasília.

Resumidamente, estima-se que mais de dois terços da cidade podem ser descritos juridicamente enquanto inexistente, incluindo-se ai o seu núcleo vernacular, muito embora os seus sistemas de objetos espaciais, desde então, estejam cristalizados sobre o território em uso, sendo passíveis de obtenção de escritura e registro em cartório, atualmente, apenas os loteamentos implementados pela Nova, Terracap, a partir do final da década de 1960 até os dias modernos. Tais setores seriam: Vila Buritis I, II, III, IV; Setor Residencial Norte "A" (Jardim Roriz), Setor Residencial Oeste (Vila Nossa Senhora de Fátima).

Já a produção do loteamento irregular (Setor Tradicional e extremidades) e demais bairros clandestinos (Arapoangas, Estâncias, dentre vários outros), espaço-temporalmente, respectivamente, corresponde ao primeiro ciclo de expansão (em diante) e terceiro ciclo de produção do espaço urbano.

Assim denota-se que a precariedade jurídica atrelada ao não exercício do direito de propriedade é um traço vinculado ao processo de formação socioespacial de Planaltina, que é atrelado às sucessivas políticas urbanas, desde o contexto pré-Brasília, assim como em seus dois ciclos de expansão pós-Brasília.

Traço característico dos distintos ciclos de produção da cidade é vinculado à ineficácia ou inércia por parte do Poder Executivo quanto da efetivação do processo de desapropriação/regularização do Setor Tradicional e, posteriormente, dos demais bairros clandestinos, incluindo-se no caso destes últimos à permissividade (intencional) para com a materialização dos mesmos.

No caso dos bairros clandestinos, a gênese destes associam-se a vários elementos, como a lógica de oferta a conta-gotas de habitações propiciadas pelo GDF ao longo das décadas, somando-se a não execução das desapropriações das terras contidas no quadrilátero.

Nesta dinâmica viu-se que a decisão judicial favorável à alienação das terras entre particulares que dera origem ao Condomínio Quintas da Alvorada, 
enquanto resposta a não efetivação das expropriações a serem executadas pelo GDF, repercute na sistemática reprodução de outros condomínios em Planaltina-DF.

Mesmo estes condomínios terem sido configurados enquanto clandestinos, demonstrando que embora juridicamente a decisão proferida pelo Poder Judiciário fora fundamentada, esta se constituiu enquanto comando interpretado pelos agentes que dão uso ao território, que se desdobrando em ações que se cristalizam sobre o espaço na produção dos sistemas de objetos, embora também se reconheça as omissões do Poder Executivo.

Assim, verifica-se que, mesmo com a prevalência do novo (Brasília e sua burocracia estatal), as velhas lógicas e práticas para com a gestão e o controle do uso e ocupação do solo acabam por persistir, sendo explicitado no território usado do presente a ausência de plantas e memoriais descritivos da cidade, na ampliação dos objetos espaciais clandestinos e na persistência da irregularidade daqueles já cristalizados. Estes fatos geram a acumulação de elementos que complexificam a cada década a efetivação da regularização de toda a cidade, mas em especial do Setor Tradicional.

No caso do Setor Tradicional, a frustração do exercício do direito de propriedade se potencializa também em virtude da não efetivação da transmissão do domínio da Transcrição $n^{\circ} 303$ entre a Prefeitura de Planaltina de Goiás e GDF ao longo das décadas, constituindo em elemento que impacta principalmente os moradores de tal setor, já que aqueles que ao longo das décadas não desmembraram e registraram seus imóveis, somados aos adquirentes das áreas alienadas contidas no Edital $n^{\circ}$ 003/93, atualmente por decisão judicial, não conseguem juridicamente exercerem o domínio sobre os respectivos imóveis.

Observa-se então que o processo de judicialização do território usado do presente reflete e impacta sobre a precariedade jurídica que é inerente à implementação dos setores da cidade em desconformidade com as sucessivas legislações que regulam o tema ao longo das décadas (Setor Tradicional loteamentos ilegal, e demais loteamentos clandestinos).

A produção deste território usado judicializado tendo como partícipes, ao transcorrer da formação socioespacial da cidade, o Poder Executivo mediante 
omissões ou ações inconclusas, a sociedade civil em sua diversidade de estratificações sociais e interesses que atuam ao sabor das possibilidades (legais e ilegais) de conquista de sua habitação ou interesses especulativos e o Poder Judiciário, através de ações, decisões que se cristalizam no território usado por meio dos distintos segmentos sociais.

Contudo, as decisões, ações oriundas do Poder Judiciário que constitui em elemento que é interpretado enquanto judicialização do território usado, tem enquanto dinâmica a demanda de posicionamento decisório face aos conflitos que se estabelecem entre os múltiplos agentes espaciais, ao qual se inclui o próprio Poder Público em suas distintas esferas.

Também vale ressaltar que as decisões, ações do Poder Judiciário não apenas repercute no movimento do território, mas também na tentativa de travamento do mesmo, tal qual fora demonstrado no caso do Edital $n^{\circ}$ 003/93, via decisão proferida ao procedimento administrativo de dúvida oriunda do processo $\mathrm{n}^{\circ}$ 2006.01.1.090919-9, que trata da efetivação do registro cartorial das alienações promovidas por Planaltina de Goiás sobre o Setor Tradicional de Planaltina-DF, cujo resultado é o trancamento das matrículas dos imóveis.

Este fato reflete na fragilizada posse do bem e na atual impossibilidade do exercício do direito de propriedade, uma vez que os lotes contidos nas quadras 06, 07, 14, 21, 22, 100, 115 do Setor Tradicional, também necessitam passarem por todos os trâmites de regularização, assim como os loteamentos clandestinos estabelecidos no terceiro ciclo de expansão da cidade.

Todavia, o caso do Setor Tradicional só não expressa situação jurídica calamitosa, em decorrência baixa procura de seus moradores para com a efetivação do registro de seus imóveis, o que resultaria na ampliação de tal quadro face ao trancamento das matrículas. Isso decorre das mudanças de destinações e dimensões das quadras ao longo das décadas, enquanto intercruzamento da multiplicidade de plantas não registradas, acrescentando-se a inércia para com a desapropriação do setor em voga pelo GDF, desdobrando-se nas alienações promovidas pela Prefeitura de Planaltina de Goiás nesses últimos anos. 
Levando em consideração o todo, o processo de desapropriação dos lotes do Setor Tradicional assim como dos bairros clandestinos, possibilitariam o desbloqueio das matrículas ou inscrição dos imóveis em cartório, caso acompanhados de suas respectivas plantas urbanas, memoriais descritivos, em somatória aos laudos positivos face às questões ambientais e fundiárias, possibilitando a emissão das escrituras públicas e a transmissão do domínio para os respectivos moradores.

Assim, ao tratar especificamente do caso do Setor Tradicional e a precariedade jurídica dos imóveis, assim como da dificuldade face à regularização das terras, ressaltou-se que a decisão emitida, oriunda do processo $\mathrm{n}^{\circ}$ 2006.01.1.090919-9 que busca inibir as relações de compra e venda por meio do travamento dos registros dos imóveis, tem por intuito forçar o GDF a promover a regularização do setor, independente do ônus, tendo em vista a protelação de tal ato jurídico que por muitas décadas fora justificado pela ideologia do legítimo direito de propriedade sobre a suposta consumação das desapropriações indiretas, dentre outras justificativas infundadas que Ihes resguardariam o domínio das terras do quadrilátero, assim como as terras situadas na atual Região Administrativa de Planaltina.

Por conseguinte, a imposição oriunda da decisão do Poder Judiciário ao Poder Executivo se dá pelo fato da acumulação de múltiplas ilegalidades resultantes da inércia/omissões do Poder Executivo, muito embora várias das situações tenham sido herdadas com a incorporação de Planaltina-DF ao quadrilátero.

Entretanto, mesmo havendo esta herança, o resultado da não desapropriação das terras de Planaltina de Goiás repercute na fragilizada relação de posse dos antigos moradores do setor para com o bem (particulares e até mesmo o GDF), uma vez que o domínio não fora consubstanciado, sendo passível até mesmo de perda ou na impossibilidade de efetivação do exercício do direito de propriedade nas relações de compra e venda e transmissões, a serem realizadas no referido setor. Ambas as possibilidades advém do processo de judicialização do território usado. 
Quanto às alienações oriundas do Edital $n^{\circ} 003 / 93$, conclui-se que para que as relações de compra e venda serem vista como de boa fé, é necessário a existência de planta e memorial descritivo registrados em cartório, algo que Planaltina de Goiás não possui mais competência para fazê-lo. Nesta perspectiva, se o loteamento não dispõe da aprovação do Governo do Distrito Federal, este é interpretado enquanto ilegal, carecendo de regularização.

Embora seja decidido pelo TJDFT e STJ a dominialidade do Setor Tradicional em favor de Planaltina-GO, o entendimento antes citado, fruto do processo $n^{\circ}$ 2006.01.1.090919-9, é favorável ao ato de nulidade administrativo 1874/93, uma vez que, mesmo Planaltina de Goiás tendo o direito de dispor livremente de seus bens, este não poderia licitar as terras contidas no Distrito Federal, tendo em vista que as plantas de 1941 e 1958 nunca foram aprovadas, contrariando os dispositivos da Lei № 6.766/79 que determinam o registro de memorial descritivo e planta em cartório.

Com este entendimento questiona-se também a licitude de várias transmissões, aberturas de novas matrículas e efetivação dos registros cartoriais por meio do desmembramentos que foram efetivados em todos esses anos no referido setor com a permissão do Poder Público, tanto no primeiro, como no segundo e terceiro ciclos de expansão de Planaltina-DF, ao qual o Setor Tradicional perpassou, haja visto que até o presente momento a cidade não disponha de ambas legalmente averbadas.

Assim, imputa-se também ao Poder Judiciário parte do ônus quanto às questões atreladas à precariedade jurídica das terras, somando-se, a isso, a inércia do Poder Executivo em todos os ciclos para com a efetiva legalização do setor.

A questão do Setor Tradicional (e suas extremidades), se levado a fundo quanto à interpretação da norma, tendo em vista os procedimentos administrativos exigidos e presentes nas Leis de parcelamento do solo (58/37 e 6766/75), embora mesmo implantado pelo Poder Público, pela falta da documentação atinente ao loteamento, todo o setor é tido enquanto ilegal.

Quanto à decisão proferida no Processo oํ 2000.01.5.006181/8, pergunta-se: como é possível alienar terras se estas não dispõem de memorial descritivo e planta registrada em cartório? Além disso, verifica-se a impossibilidade da efetivação da dominialidade dos imóveis pelos adquirentes dos lotes via Edital 
003/93, já que a Lei ํㅜ 6.015/73, em seu art. 195-B $\S 2^{0}$ também determina que à abertura de matrícula de imóveis urbanos e o seu registro em cartório circunscrevese os limites territoriais dos respectivos municípios, impossibilitando a execução de tal ato administrativo pela Prefeitura Goiana em associação com o seu Cartório de Registro.

Este mesmo é previsto na Lei 6.766/79 ao determinar no art. 21 que quando a área loteada estiver situada em mais de uma circunscrição imobiliária, o registro será requerido primeiramente perante aquela em que estiver localizada a maior parte da área loteada.

Sendo assim, cabe ressaltar que, embora o domínio do Setor Tradicional seja exercido por Planaltina-GO, esta Comarca não poderá efetivar a consumação da transmissão do domínio junto aos novos adquirentes em seu respectivo Cartório de Registro de Imóveis, estando estes enquadrados em uma situação de precário posse dos lotes, tal como os demais.

Além deste fato exposto e ainda segundo os dispositivos contidos na Lei ํㅡ $6.015 / 73$ no art. 195-B, a possibilidade do Distrito Federal de solicitar ao registro de imóveis competente a abertura de matrícula de parte ou da totalidade de imóveis urbanos sem registro anterior, está vinculado ao exercício de seu domínio assegurado pela legislação por meio de requerimento acompanhado dos documentos previstos, ou seja, é imperativo o processo de efetiva desapropriação das terras contidas na Transcrição $n^{\circ} 303$ (Setor Tradicional e extremidades) para que se efetive um dos passos do processo de regularização do setor.

Outro elemento que cabe citar relaciona-se aos dispositivos legais contidos na Lei oㅡ 6.766/79 e que constituem como fatores de disputa em relação à regularização dos setores, já que no art. 12 da norma citada, destaca que o projeto de loteamento e desmembramento deverá ser aprovado pela Prefeitura Municipal, ou pelo Distrito Federal quando for o caso.

Embora o domínio das terras seja exercido sobre Planaltina-GO, as políticas públicas face à gestão e planejamento ficam a cargo do Distrito Federal. Frente a isso impõe-se o dever moral ao GDF em efetivar as desapropriações e a regularização do setor em questão, no intuito de promover a resolução de uma situação que perdura há décadas, que se complexifica e se estende temporalmente 
cada vez mais ao percorre os tribunais, desdobrando-se na amplificação da problemática que se horizontaliza no território em uso do presente.

Enquanto alternativa jurídica para a célere resolução da questão, garantindo, a princípio, pelo menos a posse dos imóveis pelos respectivos adquirentes tanto do primeiro quanto do terceiro ciclo de expansão do Setor Tradicional de Planaltina-DF e demais parcelamentos clandestinos, recomenda-se a aplicação dos dispositivos legais contidos na Lei no 11.997/2009 para fins de desapropriação e o rápido reconhecimento do exercício de posse sobre o bem.

Os dispositivos que vão do art. 46 ao 71 buscam simplificar o processo de expropriação e regularização fundiária de áreas urbanas de interesse social, utilizando-se dos instrumentos de demarcação urbanística que possibilitam conferir aos ocupantes, de forma mais ágil, o título de legitimação de posse, que embora não se reverta de imediato em direito de propriedade, constitui-se como o primeiro passo para tal, resguardando juridicamente os seus ocupantes quanto à situação de precariedade jurídica dos imóveis.

Tendo em vista a busca pela desjudicialização da regularização dos parcelamentos clandestinos prevista no inciso $\mathrm{VI}$ do art. 48, constitui-se em uma busca por uma resposta positivada para com a condução do processo de regularização dos parcelamentos ilegais e clandestinos, muitas vezes travados nos tribunais face a discordância entre as partes (expropriantes e expropriados), vinculado às questões referentes ao montante a ser pago com a efetivação das desapropriações ou a quem cabe o ônus quanto ao pagamento dos custos de empreender tal ação.

Outros elementos como o descerramento das matrículas de imóveis bloqueadas por questões judiciais ou até mesmo a abertura de matrículas antes inexistente também são ações possíveis e vinculadas ao instrumento demarcação urbanística referente à Lei no 11.997/2009, contudo, devendo seguir os tramites jurídicos necessários para que o ato administrativo não incorra em ilegalidade.

Logo, elementos como planta urbana, memorial descritivo, títulos e transcrições cartoriais relativos ao setor em demarcação; laudos e pareceres 
favoráveis e oriundos dos órgãos ambientais e municipais (licenciamentos urbanísticos e ambientais) também são exigidos e tal processo.

A celeridade do processo quanto à garantia de posse do bem ocorrerá uma vez que averbado o auto de demarcação urbanística sobre a transcrição do título da terra em regularização, o poder público deverá elaborar o projeto de legalização da área e submeter o parcelamento dele a registro, propiciando ao Poder Público conceder, logo em sequência, o título de legitimação de posse aos ocupantes cadastrados para fins de moradia.

Após a obtenção do título de legitimação de posse, a Lei $\mathrm{n}^{0}$ 11.997/2009 prevê a consumação da dominialidade sobre o bem após cinco anos, sendo possibilitado ao contemplado solicitar ao oficial de registro de imóveis a conversão desse título em registro de propriedade.

Todavia, o requerente deve comprovar a posse legítima do bem através da apresentação de certidão atualizada da matrícula do imóvel, do projeto de regularização fundiária aprovado, e se for o caso, dos instrumentos de instituição e convenção do condomínio.

Por fim, vale salientar que embora seja enfaticamente discursado a importância do direito à propriedade enquanto elemento que resguarda ao cidadão o direito à cidade, em virtude da posse do bem, verifica-se que é apenas na consumação do domínio, ou seja, do exercício do direito de propriedade que efetivamente esta cidadania é efetivada juridicamente, havendo a necessidade do despertar de todos para a consumação deste direito. 


\section{REFERENCIAL BIBLIOGRÁFICO}

ANDRADE GRIMM, Flávia Cristina. Trajetória Epistemológica de Milton Santos: uma leitura a partir da centralidade da técnica, dos diálogos com a economia política e da cidadania como práxis. Universidade de São Paulo: Faculdade de Filosofia, Letras e Ciências Humanas. São Paulo, 2011.

BERNARDES, Adriana; ZERBINI, Adriano; GOMES, Cilene; et ali. O Papel Ativo da Geografia: um manifesto. Estudos Territoriais Brasileiros - XII Encontro Nacional de Geógrafos. Laboplan. Departamento de Geografia. Faculdade de Filosofia, Letras e Ciências Humanas. Universidade de São Paulo. Florianópolis, junho de 2000.

BERTRAN, Paulo. História da terra e do homem no planalto central: eco História do Distrito Federal: do indígena ao colonizador. - Brasília: Verano, 2000.

BOBBIO, Norberto. O futuro da democracia: uma defesa das regras do jogo /Norberto Bobbio; tradução de Marco Aurélio Nogueira. - Rio de Janeiro: Paz e Terra, 1986. Impresso no Brasil em 1997.

BONAVIDES, Paulo. Ciência Política. 10. Ed. São Paulo: Malheiros Editora, 2000.

BOTELHO, Ramon Fagundes. A Judicialização do Direito a Saúde: a tensão entre o "mínimo existencial" e a "reserva do possível" na busca pela preservação da dignidade da pessoa humana. Curitiba: Juruá, 2011.

BRASIL. Câmara dos Deputados. Estatuto da Cidade: pelos municípios e cidadãos. guia para implementação. Lei n. 10.257 de 10 de julho de 2001, que estabelece diretrizes gerais da política urbana. 2. Ed. - Brasília: Câmara dos Deputados. Coordenação de Publicações, 2002.

BRASIL. Código Civil (2002). Código civil brasileiro e legislação correlata. - 2. ed. Brasília: Senado Federal, Subsecretaria de Edições Técnicas, 2008.

BRASIL. SENADO FEDERAL. Constituição da República Federativa do Brasil. Brasília: - Senado Federal. Secretaria Especial de Editoração e Publicações (Subsecretaria de Edições Técnicas), 2010.

CÂMARA DOS DEPUTADOS. Relatório Anual Comissão de Localização da Nova Capital Federal, 1955. Comissão de Cooperação para Mudança da Capital Federal. Biblioteca Digital da Câmara dos Deputados.

CARLOS, Ana Fani Alessandri. A cidade. 9. Ed. - São Paulo: Contexto, 2011.

CASTRO, Mário Cézar de Souza. A realidade pioneira. Brasília: Edite Thesaurus, 1986.

COMPANHIA DE PLANEJAMENTO DO PLANALTO. Coletânea de informações socioeconômicas. CODEPLAN, 2007. 
COMPANHIA DE PLANEJAMENTO DO PLANALTO. Delimitação das Regiões Administrativas. CODEPLAN, 2012.

COMPANHIA DE PLANEJAMENTO DO PLANALTO. Pesquisa Distrital por Amostra de Domicílio. CODEPLAN, 2013.

CUNHA, Sérgio Sérvulo da. Dicionário compacto do Direito. 8a Ed. São Paulo: Saraiva, 2009.

DAMIANI, Amélia Luiza. Urbanização crítica na produção do espaço. Revista cidades, Vol. 6, n 10, p. 307-340, 2004.

FARIAS, Darcy Dornelas. Terras no Distrito Federal: experiências com desapropriações em Goiás (1955-1958). Instituto de Ciências Humanas. Departamento de História. Programa de Pós-Graduação. Área de concentração: História Cultural. Universidade de Brasília, 2006.

FERREIRA, Ignez Costa Barbosa; STEIBERGER, Marília. O Modelo de Gestão de Brasília e as Políticas Urbanas Nacionais. In: Cadernos Metrópole / Observatório das Metrópoles - n. 1 (1999) - ed. 14. São Paulo: EDUC, pp. 67-83, 2005.

FORTES, Paulo de Tarso Ferro de Oliveira; BARROSO, Edson Wagner de Sousa; SILVA, Maria Alice Sampaio; GUEDES, Carlos Otávio de Oliveira. Regularização fundiária em imóveis da União no Distrito Federal. Parte 1: demarcação de imóveis. Anais XIII Simpósio Brasileiro de Sensoriamento Remoto, Florianópolis, Brasil, 21-26 abril 2007, INPE, p. 5233-5240.

GIL, Antônio Carlos. Como elaborar projetos de pesquisa. $3^{a}$ ed. São Paulo: Atlas, 1991.

GOVERNO DO DISTRITO FEDERAL. SECRETARIA DE ESTADO DE DESENVOLVIMENTO URBANO E HABITAÇÃO. Diagnóstico Preliminar dos Parcelamentos Urbanos Informais no Distrito Federal. Brasília, junho de 2006.

GOVERNO DO DISTRITO FEDERAL. SECRETARIA DE ESTADO DE HABITAÇÃO REGULARIZAÇÃO E DESENVOLVIMENTO URBANO. LOUS: Lei complementar de uso e ocupação do solo do Distrito Federal. - Brasília, 2013.

GOVERNO DO DISTRITO FEDERAL. ADMINISTRAÇÃO REGIONAL DE PLANALTINA. PLANALTINA... Relatos. Brasília, Administração Regional de Planaltina, 1985. (Coleção Planaltina. Série depoimentos, 1).

GOVERNO DO DISTRITO FEDERAL. Secretaria de Estado de Habitação, Regularização e Desenvolvimento Urbano. Plano Distrital de Habitação de Interesse Social: diagnóstico da situação habitacional de interesse social. Brasília, junho de 2012.

GOVERNO DO DISTRITO FEDERAL; SECRETARIA DE ESTADO DE HABITAÇÃO, REGULARIZAÇÃO E DESENVOLVIMENTO URBANO. Processo 135.000.703/1995. Gerência da Unidade de Planejamento Territorial Norte (GENOR), 2012. 
GOVERNO DO DISTRITO FEDERAL, SECRETARIA DE DESENVOLVIMENTO URBANO E HABITAÇÃO, GRUPO EXECUTIVO DE TRABALHO. Questão Fundiária do Distrito Federal. Juvenal Antunes Pereira. Decreto ${ }^{\circ} 21.948$, de 1302-2001.

HOLSTON, James. A cidade modernista: uma crítica de Brasília e sua utopia. Tradução Marcelo Coelho. - São Paulo: Companhia das Letras, 1993.

JÚNIOR, José Cretella. Curso de Direito Administrativo. 18. ed. Rio de Janeiro, Ed. Forense, 2003.

KIST, Dario José. Fundamentos do direito penal democrático. Revista Direito e democracia / Revista de Ciências Jurídicas - ULBRA Vol. 3 - Número 2. p. 241-280. $2^{\circ}$ semestre de 2002.

MAGALHÃES, Luiz Ricardo. Sertão Planaltina: uma outra história de Brasília. - 1 . Ed. - Curitiba, PR: CRV, 2011.

MAGALHÃES, Luiz Ricardo; ELEUTÉRIO, Robson. Estrada geral do sertão - na rota das nascentes. Brasília: Editora Terra Mater Brasílis, 2008.

MALAGUTTI, Cecília Juno. Loteamentos Clandestinos no DF: legislação ou exclusão? Encontro Nacional da ANPUR (7: 1997 : Recife). Novos recortes territoriais, novos sujeitos sociais. p 148-172. Recife : UFPE, 1997. v. 1.

MARX, Karl Heinrich; ENGELS, Friedrich. O Manifesto Comunista. Edição eletrônica. Ed. Ridendo Castigat Mores, 1999.

MELO, Marcelo Augusto Santana de. Breves anotações sobre o Registro de Imóveis. Boletim IRIB em revista. São Paulo, Ed 327, julho/agosto, 2006.

MINISTÉRIO PÚBLICO DO DISTRITO FEDERAL E TERRITÓRIOS. Ação Declaratória de Nulidade de Ato Administrativo; processo 1874/93. Subprocuradoria Geral do Distrito Federal. Brasília, 19 de Setembro de 1994.

MINISTÉRIO PÚBLICO DO DISTRITO FEDERAL E TERRITÓRIOS. Dúvida; Processo 2006.01.1.090919-9. Brasília, 18 de dezembro de 2006.

MORAES, Antônio Carlos Robert. Geografia, Interdisciplinaridade e Metodologia. Mimeografado. s.n.t.

NASCENTE, Antenor. Dicionário da Academia da Academia Brasileira de Letras. Elaborado por Antenor Nascente. - Rio de Janeiro: Bloch Ed., 1988.

NOZOE, Nelson. Sesmarias e Apossamento de Terras no Brasil Colônia. Revista Economia. Brasília(DF), v.7, n.3, p.587-605, set/dez 2006.

OLIVEIRA, Rômulo Andrade de. BRASÍLIA E O PARADIGMA MODERNISTA: planejamento urbano do moderno atraso. Faculdade de Arquitetura e Urbanismo da Universidade de São Paulo. Área de concentração: Planejamento Urbano e Regional. São Paulo, 2008. 
PAGANI, Elaine Adelina. O Direito de Propriedade e o Direito a Moradia: um diálogo comparativo entre o direito de propriedade urbana imóvel e 0 direito à moradia. Porto Alegre: EDIPUCRS, 2009.

PAVIANI, Aldo. Demandas Sociais e Ocupação do Espaço Urbano. O caso de Brasília, DF. In: Cadernos Metrópole / Observatório das Metrópoles - n. 1 (1999) - ed. 21. São Paulo: EDUC, pp. 75-92, 2009.

PROCURADORIA GERAL DO DISTRITO FEDERAL. Procuradoria do Meio Ambiente, Patrimônio Urbanístico e Imobiliário: Processo 135.000.380/2011. Brasília, 26 de março de 2013.

SANTOS, Milton. A Natureza do Espaço: técnica e tempo, razão e emoção. 4. Ed. - São Paulo: Editora da Universidade de São Paulo, 2002.

SANTOS, Milton. A Urbanização Brasileira. 5 ed. - São Paulo: Editora da Universidade de São Paulo, 2005.

SANTOS. Milton. Da Totalidade ao Lugar. São Paulo: Editora da Universidade de São Paulo, 2005.

SANTOS, Milton. Espaço e método. São Paulo: Nobel, 1985.

SANTOS, Milton. Metamorfose do Espaço Habitado: Fundamentos Teóricos Metodológicos da Geografia. Milton Santos; em colaboração com Denise Elias - 6 . Ed. 1. Reimp. - São Paulo: Editora da Universidade de São Paulo, 2012.

SANTOS, Milton. Metrópole Corporativa Fragmentada: o caso de São Paulo. 2.ed. - São Paulo: Editora Universidade de São Paulo, 2009

SANTOS, Milton. O espaço do cidadão. 3를. Edão Paulo: Nobel, 1996.

SANTOS, Milton. Sociedade e Espaço: A Formação Social como Teoria e como Método. Boletim Paulista de Geografia, n 54, p.81-99, 1977.

SANTOS, Milton; SILVEIRA, Maria Laura. O Brasil: território e sociedade no início do século XXI. 5를. Edo de Janeiro, Record, 2003.

SEVERINO, Antônio Joaquim. Metodologia do trabalho científico. 23. Ed. rev. e atual. São Paulo: Cortez, 2007.

SILVEIRA, Maria Laura. O espaço geográfico: da perspectiva geométrica à perspectiva existencial. São Paulo: GEOUSP - Espaço Tempo, n 19, pp. 81-91, 2006.

SILVEIRA, Maria Laura. Território Usado: Dinâmicas de Especialização , Dinâmicas de Diversidade. Revista Ciência Geográfica - Bauru - XV - Vol. XV - (1). Pág. 04-12. Janeiro/Dezembro - 2011.

SOJA, Edward William. Geografias pós-modernas: a reafirmação do espaço na teoria social crítica. Tradução [da 2a Ed. inglesa], Vera Ribeiro; revisão técnica, Bertha Becker, Lia Machado. - Rio de Janeiro: Jorge Zahar Ed., 1993. 
SOUZA, Marcos Antônio Cardoso de. Da desapropriação indireta: análise da legalidade da exigência de precatório para o pagamento das parcelas indenizatórias. Dissertação (mestrado) - Universidade de Fortaleza, março de 2010.

SPOSITO, Eliseu Savério. Geografia e filosofia: contribuição para o ensino do pensamento geográfico. São Paulo: Editora da UNESP, 2004.

SUPERIOR TRIBUNAL DE JUSTIÇA. Conflito de Competência № 43.376 - DF 2004/0068164-4; 25 de maio de 2005.uj

SUPERIOR TRIBUNAL FEDERAL. Recurso Extraordinário n 71.385. Brasília, 26 de maio de 1971.

SUPERIOR TRIBUNAL DE JUSTIÇA. Recurso Especial № 839.131 - DF, Processo 2006/0048052-6. Relator: Ministro Herman Benjamin; 06 de agosto de 2009.

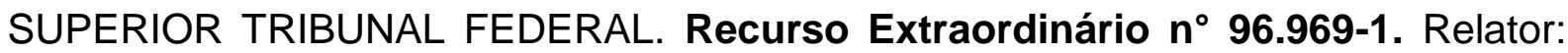
Ministro Décio Miranda, 30 de novembro de 1982.

SZMRECSÁNYL, Támas. Pequena História da Agricultura no Brasil. 4. Ed. - São Paulo: Contexto, 1998.

THÉRY, Hervé e DE MELLO, Neli. Atlas do Brasil: Disparidades e dinâmicas do território, EDUSP, 2005.

TRIBUNAL DE JUSTIÇA DO DISTRITO FEDERAL E TERRITÓRIOS. Ação Cível 2011.01.1.223930-2. Brasília, 26 de junho de 2013.

TRIBUNAL DE JUSTIÇA DO DISTRITO FEDERAL E TERRITÓRIOS. Apelação Criminal 20110510058855APR; 08 de outubro de 2012.

TRIBUNAL DE JUSTIÇA DO DISTRITO FEDERAL E TERRITÓRIOS. Ação Declaratória de Nulidade de Ato Administrativo: processo $\mathrm{n}^{\circ}$ 1.874/93. BrasíliaDF, 03 de março de 2000.

TRIBUNAL DE JUSTIÇA DO DISTRITO FEDERAL E TERRITÓRIOS. Ação Direta de Inconstitucionalidade 2009.00.2.017552-9. Procuradoria Geral de Justiça do Distrito Federal e Territórios, 27 de abril de 2010.

TRIBUNAL DE JUSTIÇA DO DISTRITO FEDERAL E TERRITÓRIOS. Agravo de Instrumento 2012.00.2.012328-5 AGI. Acórdão № 643.615. Brasília, 19 de dezembro de 2012.

TRIBUNAL DE JUSTIÇA DO DISTRITO FEDERAL E TERRITÓRIOS. Apelação Cível n 4890; Brasília,1976.

TRIBUNAL DE JUSTIÇA DO DISTRITO FEDERAL E TERRITÓRIOS. Apelação Cível 20120111018093ACJ; 18 de dezembro de 2012.

TRIBUNAL DE JUSTIÇA DO DISTRITO FEDERAL E TERRITÓRIOS. Apelação Cível. Processo 2000.01.5.006181/8. Brasília, 18 de novembro de 2002 
TRIBUNAL DE JUSTIÇA DO DISTRITO FEDERAL E TERRITÓRIOS. Apelação Cível n² 2009.01.1.149890-6. Brasília, 01 de julho de 2013.

TRIBUNAL DE JUSTIÇA DO DISTRITO FEDERAL E TERRITÓRIOS. Apelação Cível 20120110917719ACJ; 12 de dezembro de 2012.

TRIBUNAL DE JUSTIÇA DOS DISTRITO FEDERAL E TERRITÓRIOS. Conflito de Competência 1998.05.1.004297-2; 25 de outubro de 2000.

TRIBUNAL DE JUSTIÇA DO DISTRITO FEDERAL E TERRITÓRIOS. Dúvida; Processo 2006.01.1.090910-9. Vara de Registros Públicos do Distrito Federal, 14 de maio de 2007.

TRIBUNAL DE JUSTIÇA DO DISTRITO FEDERAL E TERRITÓRIOS. Dúvida; Processo 2006.01.1.090919-9. $8^{\circ}$ Ofício de Registro de Imóveis do Distrito Federal. Brasília, 25 de agosto de 2006.

VALLE, Vanice Regina Lírio do (org.). Ativismo Jurisdicional e o Supremo tribunal Federal: laboratório de análise jurisprudencial do STF. Curitiba: Juruá, 2009. 152p. - 1a Reimpressão (Ano 2012)

\section{Referências Eletrônicas}

ASSOCIAÇÃO DOS MUTUÁRIOS DE SÃO PAULO E ADJACÊNCIA. Contrato de Gaveta. In: http://www.amspa.com.br/novo/contrato-bancos/contrato-de-gaveta/; acessado em 01 de julho de 2014.

CARTILHA DE ATOS NOTARIAIS E DE PROTESTOS. In: http://www.colegionotarialrs.org.br/site/images/stories/Cartilhas/cartilha_\%20atos_e_ \%20protestos_\%202012.pdf; acessado em 05 de maio de 2014.

CENTRAL BRASILEIRA DE NOTÍCIAS. In: http://cbn.globoradio.globo.com/editorias/pais/2014/03/22/NUMERO-DE-INVASOESDE-TERRAS-PUBLICAS-NO-DF-SALTA-DE-19-PARA-25-EM-UM-ANO.htm; acessado em 12 de abril de 2014.

COMPANHIA IMOBILIÁRIA DE BRASÍLIA. In: http://www.terracap.df.gov.br/internet/index.php?sccid=281; acessado em 05 de dezembro de 2013.

DECRETO No 4.494 DE 18 DE JANEIRO DE 1922. In http://www2.camara.leg.br/legin/fed/decret/1920-1929/decreto-4494-18-janeiro-1922545132-republicacao-91197-pl.html; acessado em 19 de dezembro de 2013.

PRESIDÊNCIA DA REPÚBLICA. Constituição Brasileira de 1946. In http://www.planalto.gov.br/ccivil_03/constituicao/constituicao46.htm; acessado em 19 de dezembro de 2013. 
PRESIDÊNCIA DA REPÚBLICA. Decreto-Lei $n^{\circ}$ 58/1937. In http://www.planalto.gov.br/ccivil_03/decreto-lei/1937 1946/Del058.htm; acessado em 20 de dezembro de 2013.

PRESIDÊNCIA DA REPÚBLICA. Lei $\mathrm{n}^{\circ} 2.874$ de 1956 . In https://www.planalto.gov.br/ccivil_03/leis/1950-1969//2874.htm; acessado em 27 de dezembro de 2013.

PRESIDÊNCIA DA REPÚBLICA. LEI 6.766 de 1979. In http://www.planalto.gov.br/ccivil_03/_Ato20072010/2009/Lei/L11997.htm; acessado em 20 de abril de 2014)

PRESIDÊNCIA DA REPÚBLICA. Lei $\mathrm{n}^{\circ} 4.545$ de 1964 . In http://www.planalto.gov.br/ccivil_03/leis/L4545.htm; acessado em 29 de novembro de 2013.

PRESIDÊNCIA DA REPÚBLICA. Lei $\mathrm{n}^{\circ} 6.015$ de 1973 . In http://www.planalto.gov.br/ccivil_03/leis/L6015original.htm; acessado em 03 de janeiro de 2014.

PRESIDÊNCIA DA REPÚBLICA. Lei $n^{\circ}$ 11.997/2009. In, http://www.planalto.gov.br/ccivil_03/_ato2007-2010/2009/lei/111977.htm; acessado em 29 de novembro de 2013.

PROJETO DE LEI No $\mathrm{N}^{\circ} 671$ DE $1949 . \quad$ In http://bd.camara.gov.br/bd/handle/bdcamara/3285?show=full; acessado em 27 de dezembro de 2013.

SECRETARIA DE HABITAÇÃO, REGULARIZAÇÃO E DESENVILVIMENTO URBANO. http://www.regularizar.df.gov.br/pages/condominios/planaltina/index.php; acessado em 07 de novembro de 2013.

SUPERIOR TRIBUNAL FEDERAL. Glossário Jurídico. In http://www.stf.jus.br/portal/glossario/verVerbete.asp?letra=L\&id=184; acessado em 29 de novembro de 2013.

USINA LITERÁRIA. In: http://usinaarteliteraria.blogspot.com.br/2013/02/historia-deplanaltina-atraves-de-fotos.html; acessado em 11 de agosto de 2014.

VALPARAISO EWB. In: http://www.valparaisoweb.com.br/estudo-viavel-criacaomunicipios-entorno-df/; acessado em 17 de novembro de 2014. 


\section{Entrevistas Registradas em Áudio}

Castro.Mario César Sousa. Entrevista pessoal (áudio-gravador). Realizada em Planaltina, DF, 10 de janeiro de 2014.

ZOEHLER.Breno de Andrade. Entrevista pessoal (áudio-gravador). Realizada em Planaltina, DF, 28 de novembro de 2013. 
ANEXOS 
ANEXO 01 


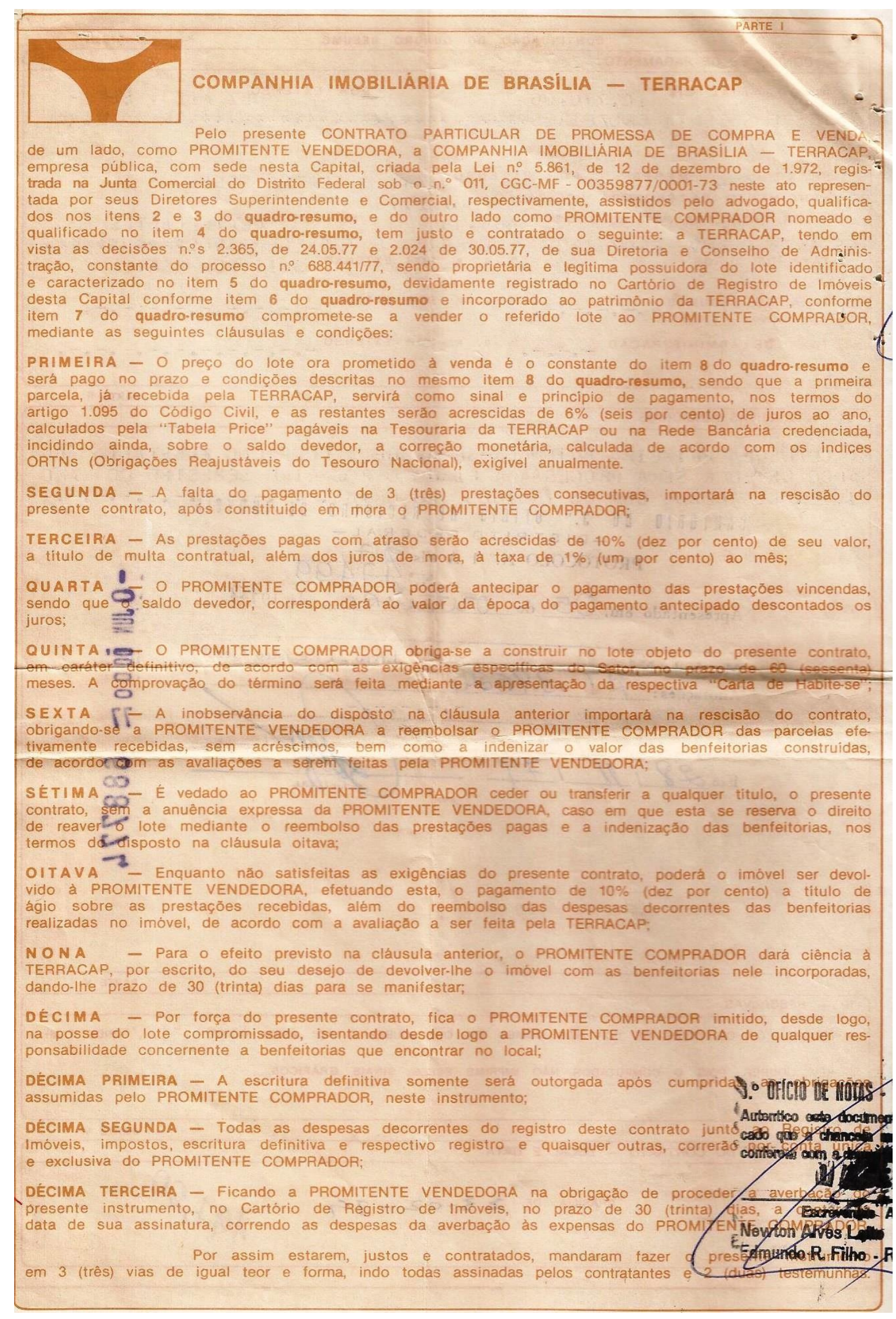


ANEXO 02 


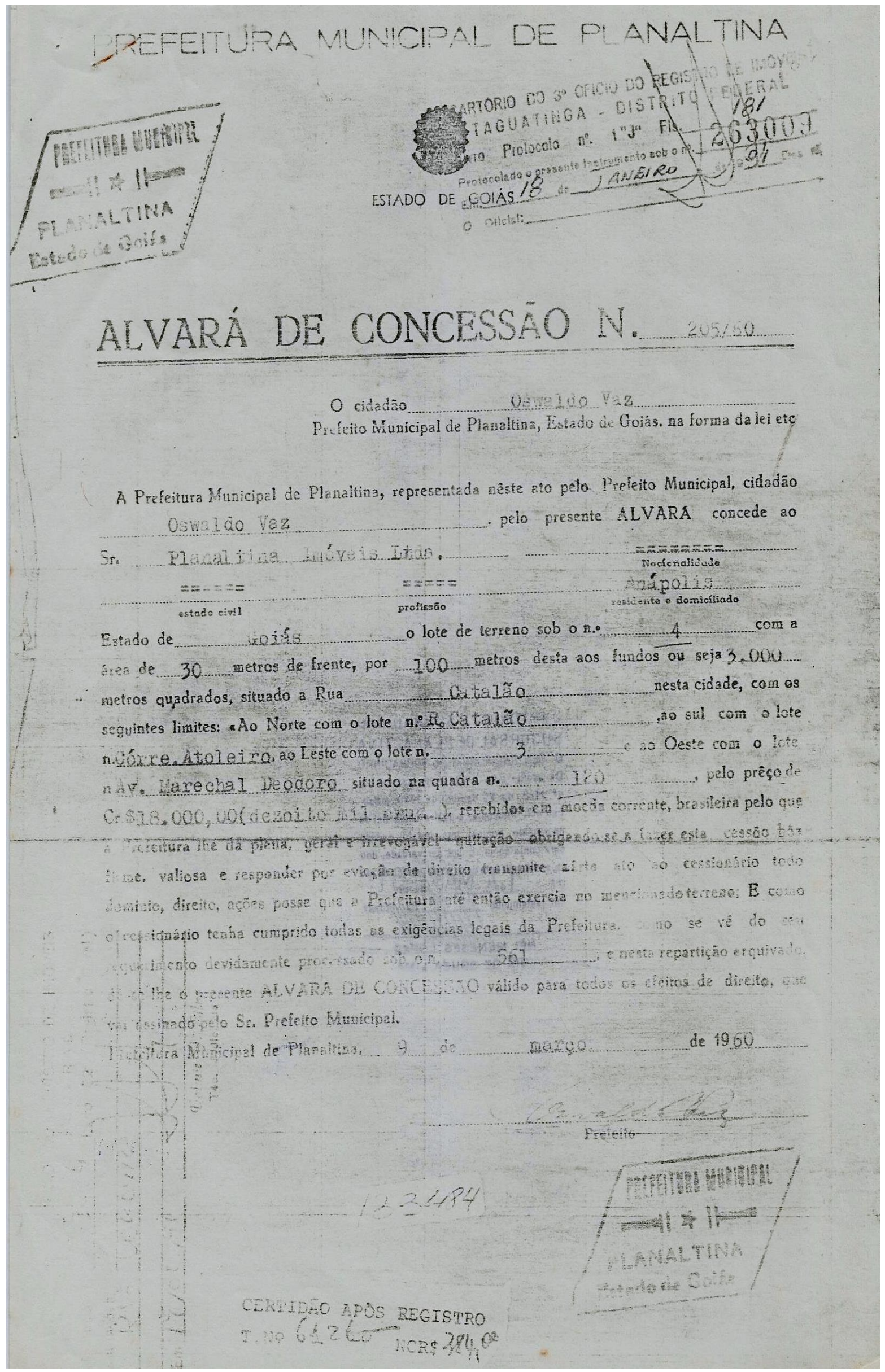


ANEXO 03 


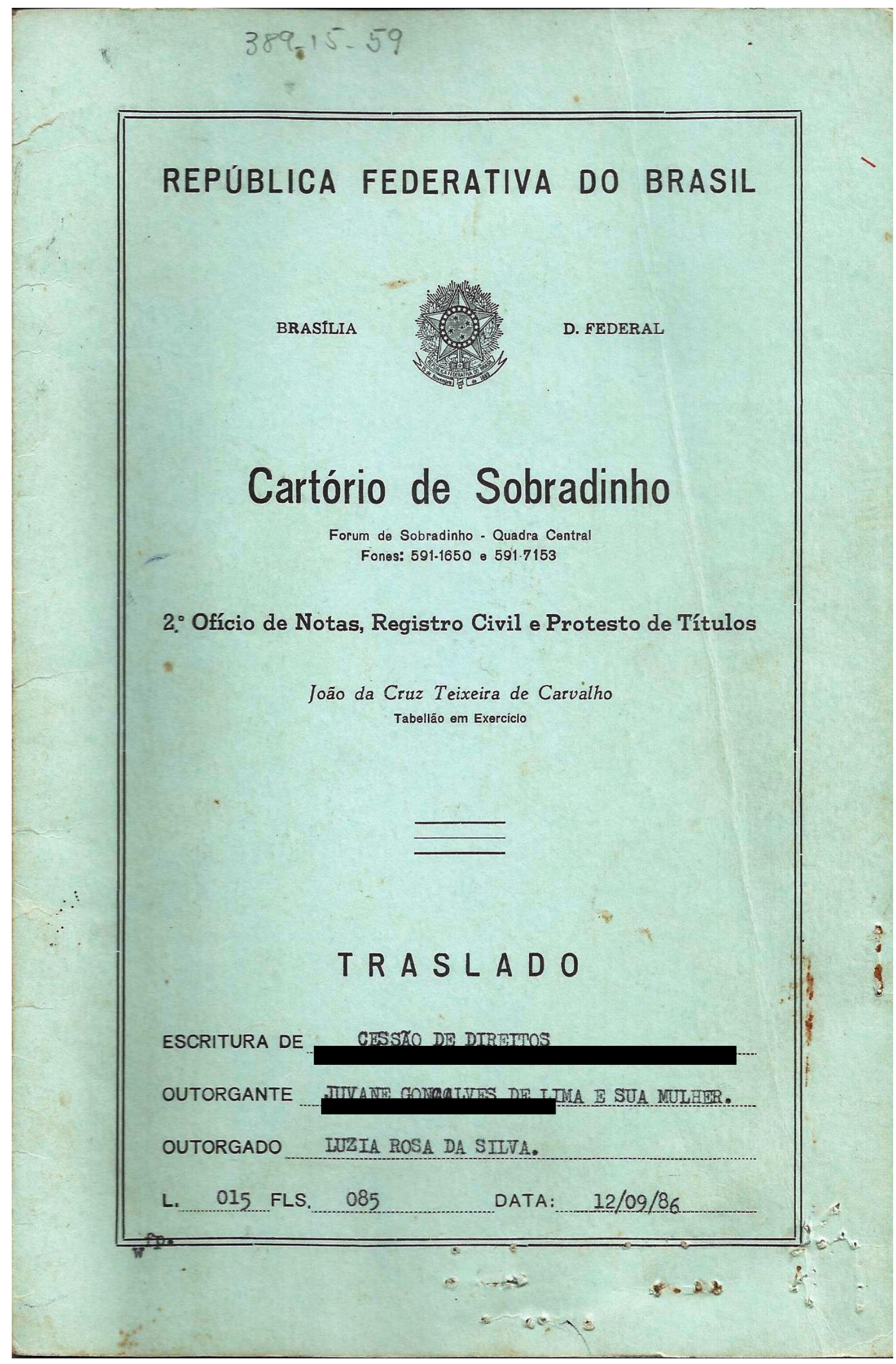




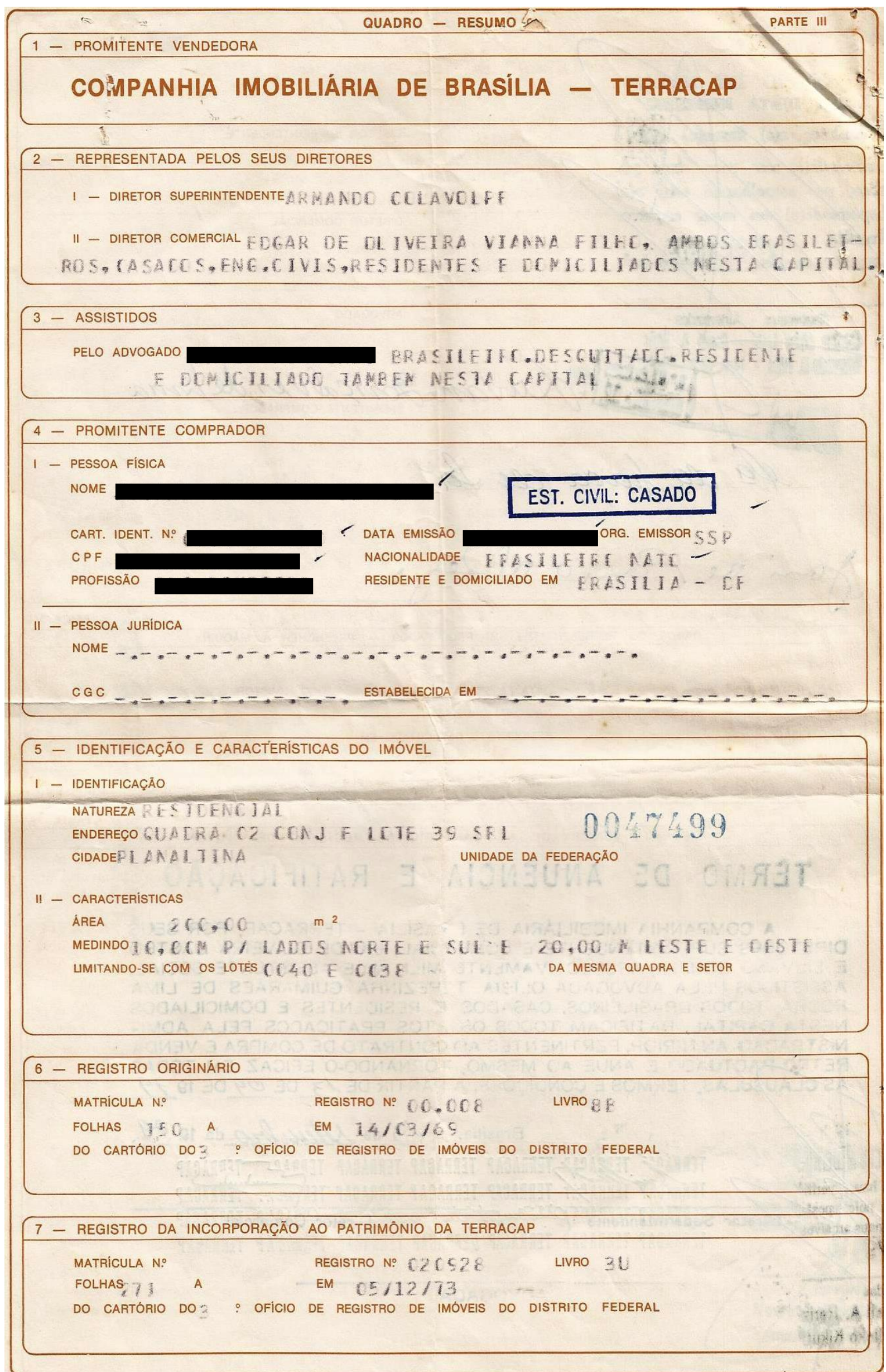




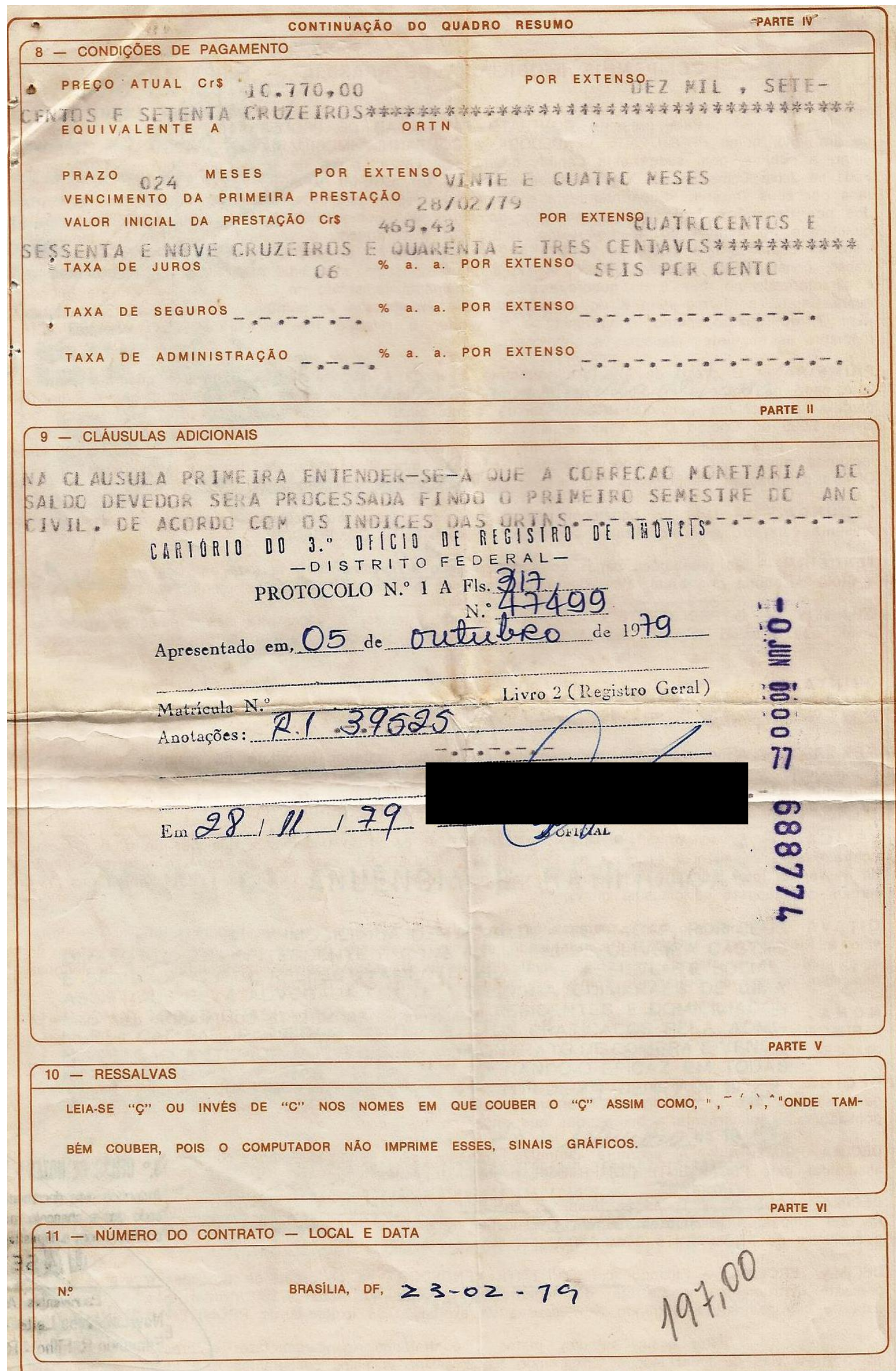




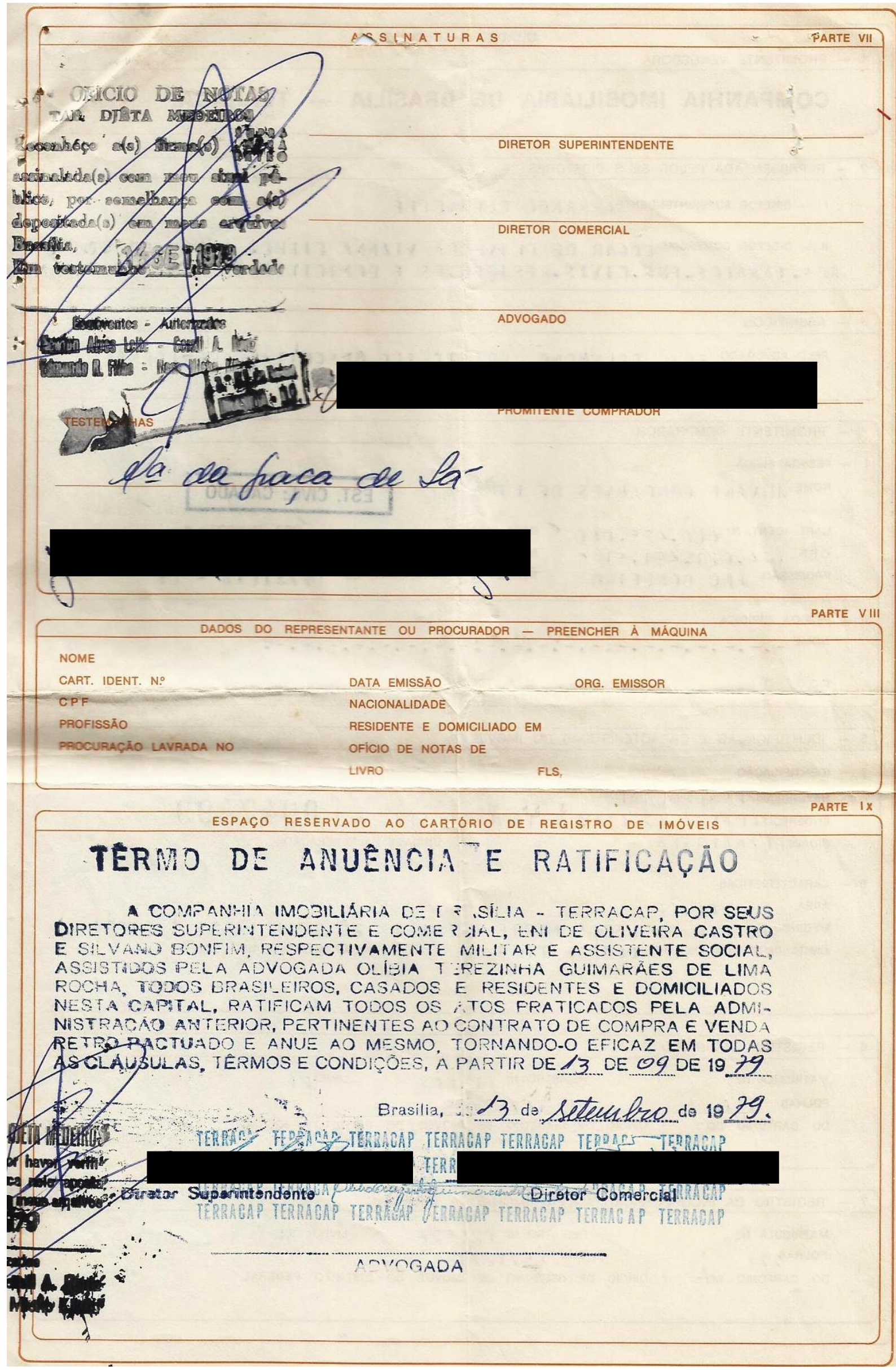




\section{Justiça do Distrito Federal}

CARTÓRIO DE SOBRADINHO

LIVRON. 015

2.0 Oficlo de Notas, Registro Civil e Protesto de Títulos de Justiça do Distrito Federal.

Quadra Central - Ed. Forum - Fones: $591-1650$ e $591-7153$

Sobradinho - $\quad$ Distrito Federal

João da Cruz Teixeira de Caroalho

Tabellão em Exercicio

$f x$

$2 x^{13^{j} \text { DOLHA } 085}$
CARTÓNO BE SORRADIMHO SUCURSAL DE PLANALTINA

Nei Marzses Repes

Escrevente Dirigente

FORUM - PLANALTINA

Fone: $596-2234$

\author{
ESCRITURA PÚBLICA DE CESSÃO DE DIREITOS \\ QUE ENTRE SI FAZEM \\ IIMA, $\odot$ SUE MULHERR \\ na forma abaixo:
}

S A I B A M quantos a presente escritura pública de cessão de direitos virem, que aos doze $\therefore$ dias do mês de setembro do ano de um mil novecentos e oltenta e $\mathrm{g}^{\text {eis. }}$ nesta cidade de Sobradinho, Distriro Federal, em Cartório, perante mim, compareceu(ram) partes entre si justas $\theta$ contratadas, a saber, de um lado, como outorgante(s) cedente(s)

dáulico, o sua mulher, ambos brasileiros, casados entre sí sob o Regime de Comunhão de Bens, residentes e domiciliados na Qua-' dra 02, Confunto F, lote 39, SRL., Planaltina, DF., portadores das cédulas de Identir dade nes

respectivamente; representados neste ato por $\mathrm{s}$ ou bastante procurador:

, brasileiro, solteiro, maior, motorista, residente na quadra 01, Conjunto I, It. 33, PlanaltinamP, portador da CI. e CIC. no final menoionado.-

6 , de outro lado, como outorgado(a)(s) cessionário(a)(s) $\quad$ brasileira, easada, com sob o Regime de Comunhão de Benø, do lax, residente e do mioiliada na Quadre 01, Conjunto I, Lote 33, SRL, Planaltina, Distrito Federal; portadora da oédula de identidade $n^{2}$

os presentes reconhecidos como os próprios por mim e pelas duas testemunhas adiante nomeadas $\theta$ assinadas, que também conheço do que dou fé, bem como de que a presente será anotada no competente Distribuidor no prazo da lei. E, perante as mesmas testemunhas, pelo(a)(s) outorgante(s) cedente(s) me foi dito que é(são) titular(es) dos direitos à compra do imóvel constituido Iote n 39 (trinta e nove), Conjunto "F", da cuadra 02" (dois), Setor Residencial Leste, Planaltina, Distrito Federal, medindo 10,00m pelos " lados norte e sul e 20,00m a leste a oeste, ou seja, 200,00m2, limitandome com os lotes 38 e 40 da mesma quadra. Adquirido da Companhia Imobiliária de Brasília TERRACAP, pelo preço de Cx\$10.770,00, conforme Contrato Partícular de Promessa de Com pra Venda, de23,02.79, registrado no Cartório do $3^{2}$ ofíoio do Registro de Imóveis, desta Capital, na matiffoula $n^{2} 39525, \mathrm{R} .1$, em 28 de novembro de 1.979.-
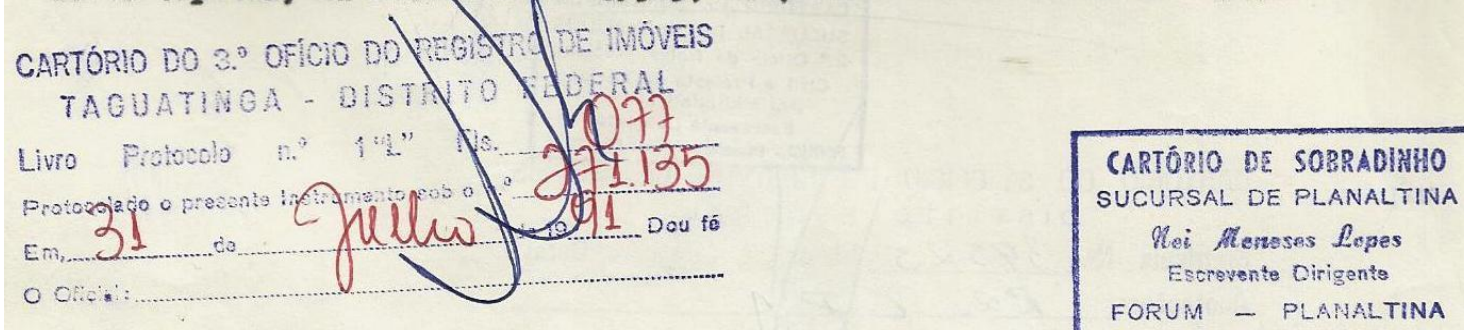
Que, pela presente escritura, $\theta$ na melhor forma de direito e pelo preço certo $\theta$ ajustado Cr\$ $30.000,00$ (trinta mil oruzados).-

importância essa que $o(a)(s)$ outorgante $(s)$ comfessa $(m)$ e declara $(m)$ já haver recebido em moeda corrente do pais da qual $\mathrm{da}(\mathrm{a} o)$ a mais plena rasa $\theta$ geral quitação, $\operatorname{cede}(\mathrm{m})$ e transfere $(\mathrm{m})$ como de fato cedido $\theta$ transferido tem, todos os sous direitos consubstanciados no aludido documento. $O(a)(s)$ outorgante(s) cedente $(\mathrm{s})$ promete $(\mathrm{m})$ por si, seus herdeiros $\theta$ sucessores a manter a presente cessão sempre boa, firme e valiosa, em todo o tempo. Pelo(a) (s) outorgado(a)(s) cessionário(a)(s) $\theta$ ante as mesmas testemunhas, me foi dito que aceita(m) esta escritura em seus expressos têrmos, ratificcando as partes contratantes todos os dizeres impressos. Foram apresentados os seguintes documentos que aqui ficam arquivados: Certidão Negativa do G.D.F. n.

105-03.747/86 expedida

em $\quad 30-05-86 \quad$ válida até $30-08-86 \quad$ Guia n. ${ }^{\circ} 113850 \quad \ldots$ do imposto de tranomissão, recolhida no valor de cr\$600,00(seiscentos cruzados), Certidão de ômas Reais expedida pelo Cartório do $3^{2}$ 0lóio do Registro de Inóveis, desta Capital, Certi dões de Feitos Ajuizados expedidas pela justiga do Distrito Federal, das quais a Oum! torgada Cessionária, tomou conheoimento. A presente Certidão Negativa do aDF, acima ' mencionada, teve seu vencimento promogado nos termos do decreto 1 ei $3.521 / \mathrm{GDF}$, Art." 46, de 28.12.76. "Bnitida D.0.I, - Declaração Sobre Operação Inobiliária, conforme , $\mathrm{IN} / \mathrm{SRF} / 090 / 85^{\prime \prime}$

$E$, de como assim o disseram, do que dou fé, me pediram lhes lavrasse esta escritura que lhes sendo lida em voz alta antes as testemunhas, aceitaram, outorgaram $\theta$ assinam com as mesma testemunhas que são: di go, antes as partes contratantes, aceitaran, outorgaram e assinan, (Dispensadas as testemunhas, nos termos da Lei 6.952 , de 06.11.81). en tempo: ressalvo entrelinhas "Orïoio". dou '

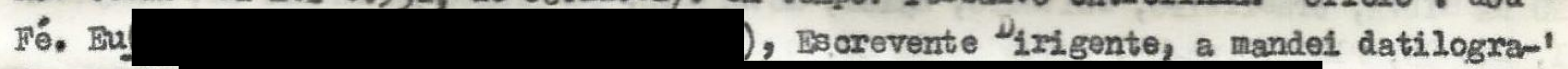
far, $\odot$ Ev D, Tabeliza 1 cio, a ubscrevo e asimo, (ata)

DA SILVA. Trasladada na neeng data. Bu vo e assino ent públ a confent, dou fé, subscre-

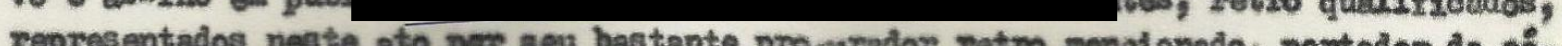

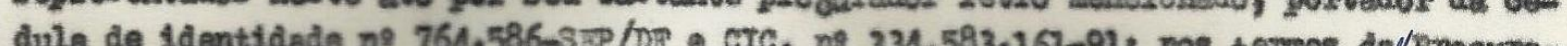

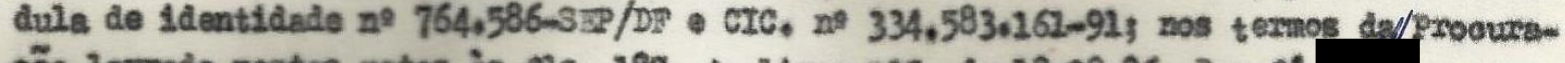
gão lavrada nestas notas às $M, 187$, do 11 vro 035, de $18,08,86$, Dour fé
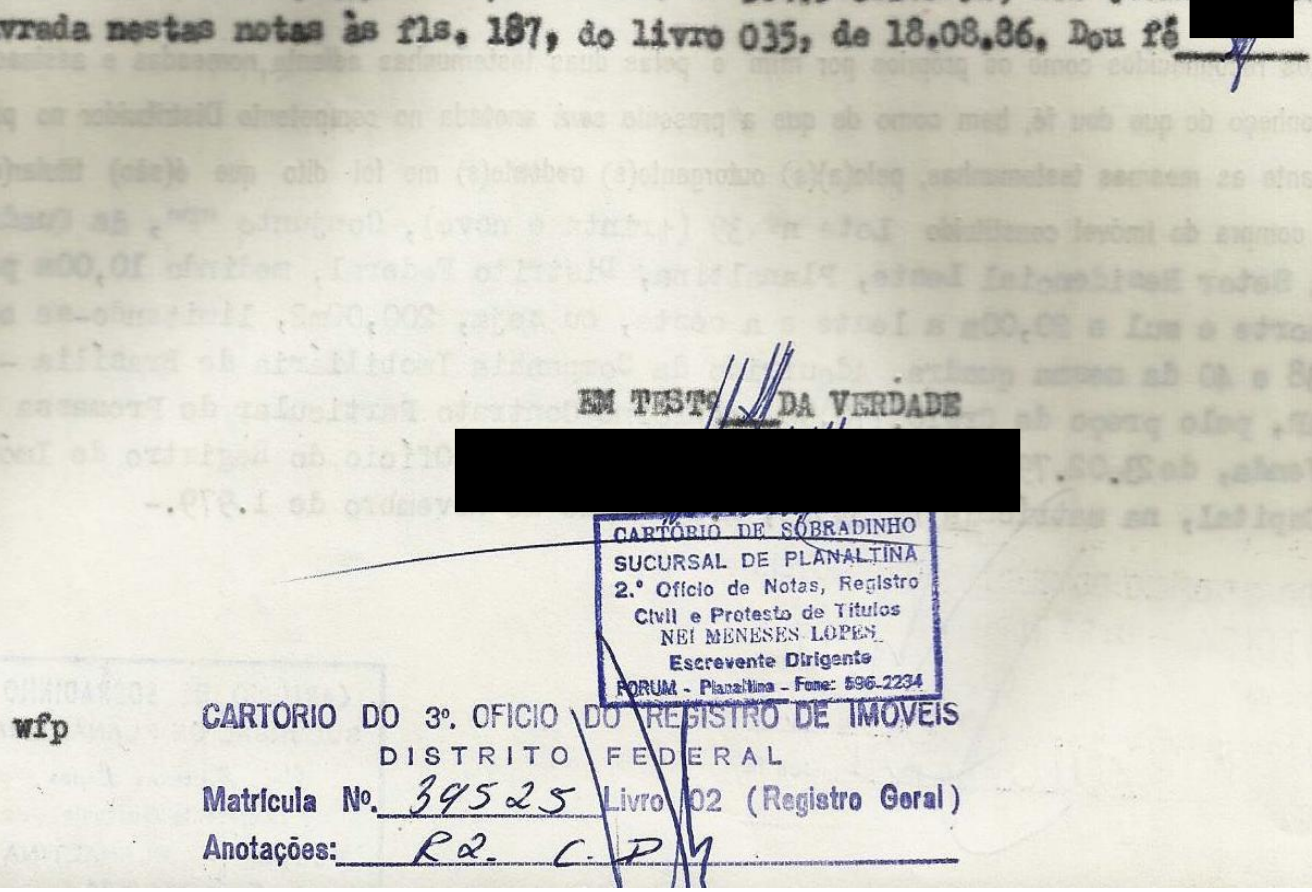


\section{REPÚBLICA FEDERATIVA DO BRASIL}

BRASÍLIA

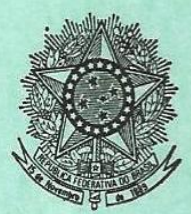

D. FEDERAL

\section{Cartório de Sobradinho}

Forum de Sobradinho - Quadra Central

Fones: $591-1650$ e $591-7153$

$2^{\circ}$ Ofício de Notas, Registro Civil e Protesto de Títulos

João da Cruz Teixeira de Carvalho

Tabellão em Exercíclo

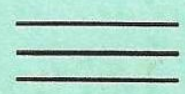

TR A S L A D O

ESCRITURA DE CESSÃO DE DIRETTOS

OUTORGANTE

OUTORGADO

L. 024

FLS

0.40

DATA, 12.07 .1991$ 


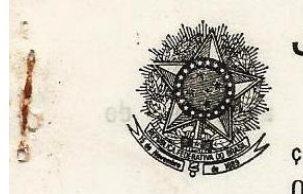

Justiça do Distrito Federal

CARTÓRIO DE SOBRADINHO

$\operatorname{lIVRON}_{\text {L }}^{8394}$

2.0 Ofício de Notas, Registro Civil e Protesto de Titulos da Justlça do Distrito Federal.

Quadra Central - Ed. Forum - Fones: $591-1650$ e $591-7153$ Sobradinhom - Distrito Federal

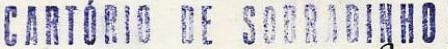

- sucursal de phahatidepão da Cruz Teixeita de Carbalho

Ed. Forum - Planiatina - DF. Tabellão em Exercicio

Fone: $596-2234$

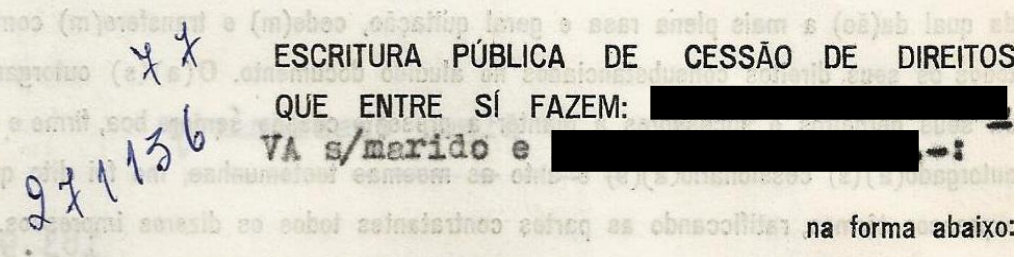

Data

FOLHA 040

na forma abaixo:

S A I B A M quantos a presente escritura pública de cossão de direitos virem, que aos DoRZ (12)

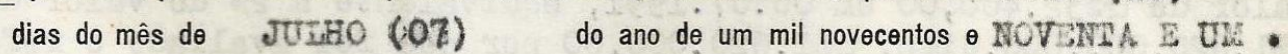

nesta cidade de Sobradinho, Distriro Federal, em Cartório, perante mim, compareceu(ram) partes entre si justas e contratadas, a saber, de um lado, como outorgante(s) cedente(s) — do lar, . portadora da.

portador da

- seu mertio

sob 0 n?

brestleiros, casados entre af polo regime de comunhão ' de bens, antes de lei $6.515 / 77$, residentes e domicliledos ns 8.01 cong.

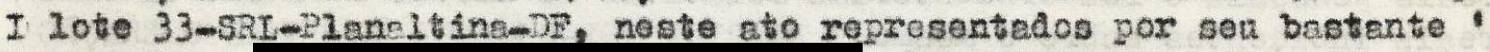
procurador, , breslle1ro, casado, conerciante, , residente e domleiliado ne Q.

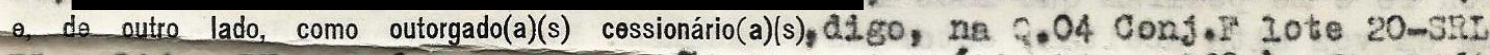
Planalt ina-DF, conforme procuraçäo deste Cextórto 11 r. 068 is Ils $105^{\circ}$ om 13.06.1991, o, de outro lado, como Outorgado cess1onár1o:
brasileiro, solteiro, maior, funcionárlo público, portador da CI
Conj. Q lote 05-SRI-PIaneIt Ine-DF. - : residents e domiciliado na 8.04

os presentes reconhecidos como os próprios por mim e pelas duas testemunhas adiante nomeadas_o assinadas _que

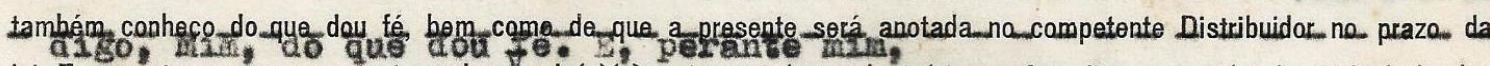
Lai. E, perante-as-mesmas Iostemunhas, Lpelo(a)(s) outorgante(s) cedente(s) me foi dito que é(sāo) titular(es) dos direitos à compra do imóvel constituido pelo lote ne 39 (trinta e nove), Conjuxito "gu", Quadra 02 (dois)-Setor Residenciel Leste-Pleneltina-Distrito Federal, medindo $200,00 \mathrm{~m} 2$ es $11 \mathrm{~m} 1$ tes e confrontações constentes de matrícula? n' 39525 do Cartório de 32 Ofício de Regletro de Imóvois local em 28.11 de 2.979 ; adquirido de $\quad$ o mwher

pelo preço de cz\$30,000,00 confoztee escritura pública de co,dío, de cessão de direitos levreda nedje ofrtório no livro ne 015 as 11 s 085 em 22.09.1986, que seré levada a regiakrg juntamente com

a presente.-:

ARTORIO DO $3^{\circ}$. OFICIO DO REEISTRO DE IMOVEIS

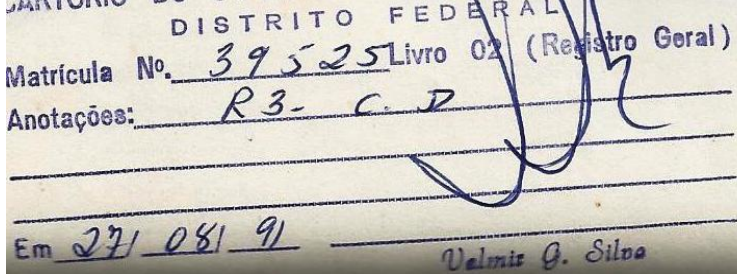

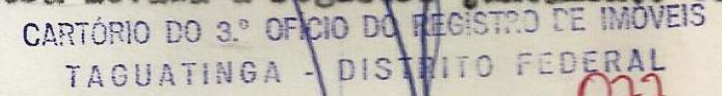

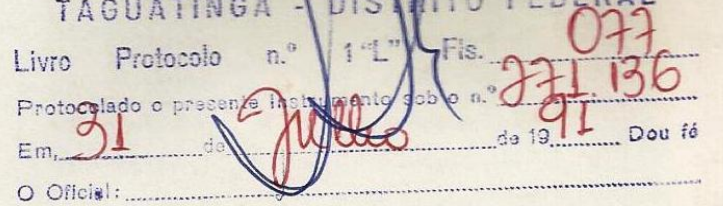

o Onicis!

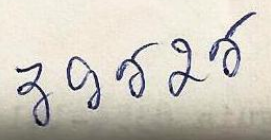


Que, pela presente escritura, e na melhor forma de direito e pelo preço certo $\theta$ ajustado de Cr\$ $1.000 .000,00$ (um milhéo de cruzeiros).-

importância essa que $o(a)(s)$ outorgante(s) comfessa $(m)$ e declara $(m)$ já haver recebido em moeda corrente do pais da qual da(ão) a mais plena rasa $\theta$ geral quitação, cede $(m)$ e transfere $(m)$ como de fato cedido $\theta$ transferido tem, todos os seus direitos consubstanciados no aludido documento. $O(a)(s)$ outorgante(s) cedente $(s)$ promete(m) por si, sous herdeiros o sucessores a mantêriagerpsentescessãnéémipo boa, firme e valiosa, em todo o tempo. Pelo(a) (s) outorgado(a)(s) cessionário(a)(s) o-ante as mesmas tostemunhas, me foi dito que aceita(m) esta escritura em seus expressos têrmos, ratificcando as partes contratantes todos os dizeres impressos. Foram apresentados os seguintes documentos que aqui ficam arquivados: Certidão Negativa do G.D.F. n.• em 29.05.1991 válida até 31.12.1991 Guiann. 018028

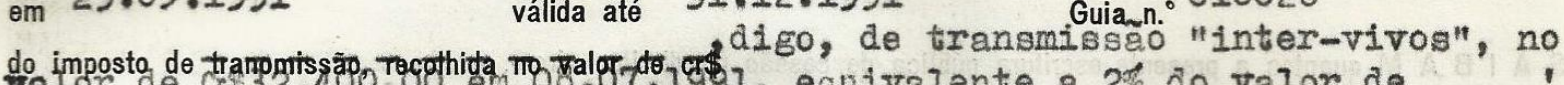

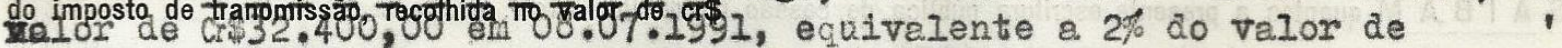
Cr\$1.620,009,000, a180, C.\$1.620.000,00 por que fol avaliado o referido imóvel, Certidão de ônus e de feitos ajuizados de que trata o Decreto' 93.240 de 09.09.1986, cujo teor o outorgado tomou conhecimento. Os ou-torgantes, via seu procuracor, decleram inexistir quaisquer açöes reais

E, de como assim o disseram, do que dou fé, me pediram lhes lavrasse esta escritura que thes sendo lida em voz

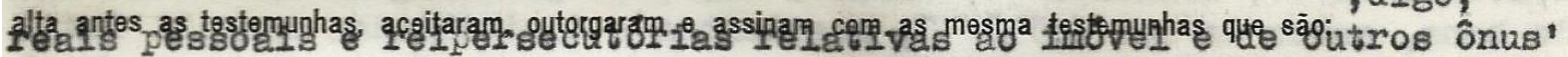
reais incidentes sobre o mesmo." EUITIDA DOI-DECLARAC ÃO SOBRE OPERAÇAO' IMOBIJIÁRIA CONFORIEE IN/SRF/090/85". E, de como assim o disseram do que dou fé e me pediram que lhes lavrasse esta escritura que lihes sendo Iida em voz alta aceitam, outorgam e assinam. Foram dispensadas es testemunitas 108 termos da lei 6.952 de 06.11.1981. Bufa.) - Técnico judiciário responsável pela sucursal, a escrevi, conferi, 11 e colhi as assinaturas, subscrevo e assino, ressalvo confirmo as entre-linhas: "digo, min, do que dou fé. S, perante mim" "digo cessionário". Dou fé. $\left(a_{*} \mathrm{z}_{*}\right)$ co fualcí́rio responsével pels sucursal, a abscrevo e assino em público e raeo.

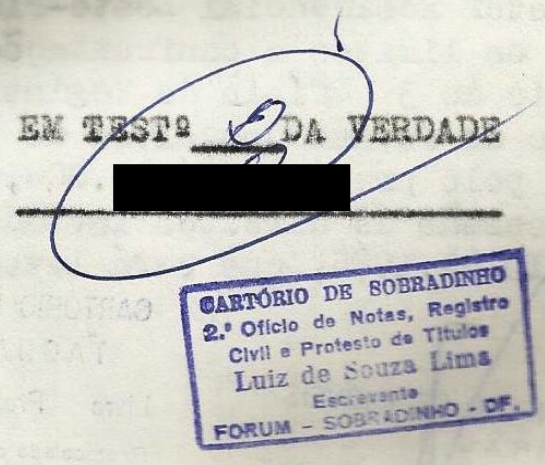

guiะ $8354-1$ s 


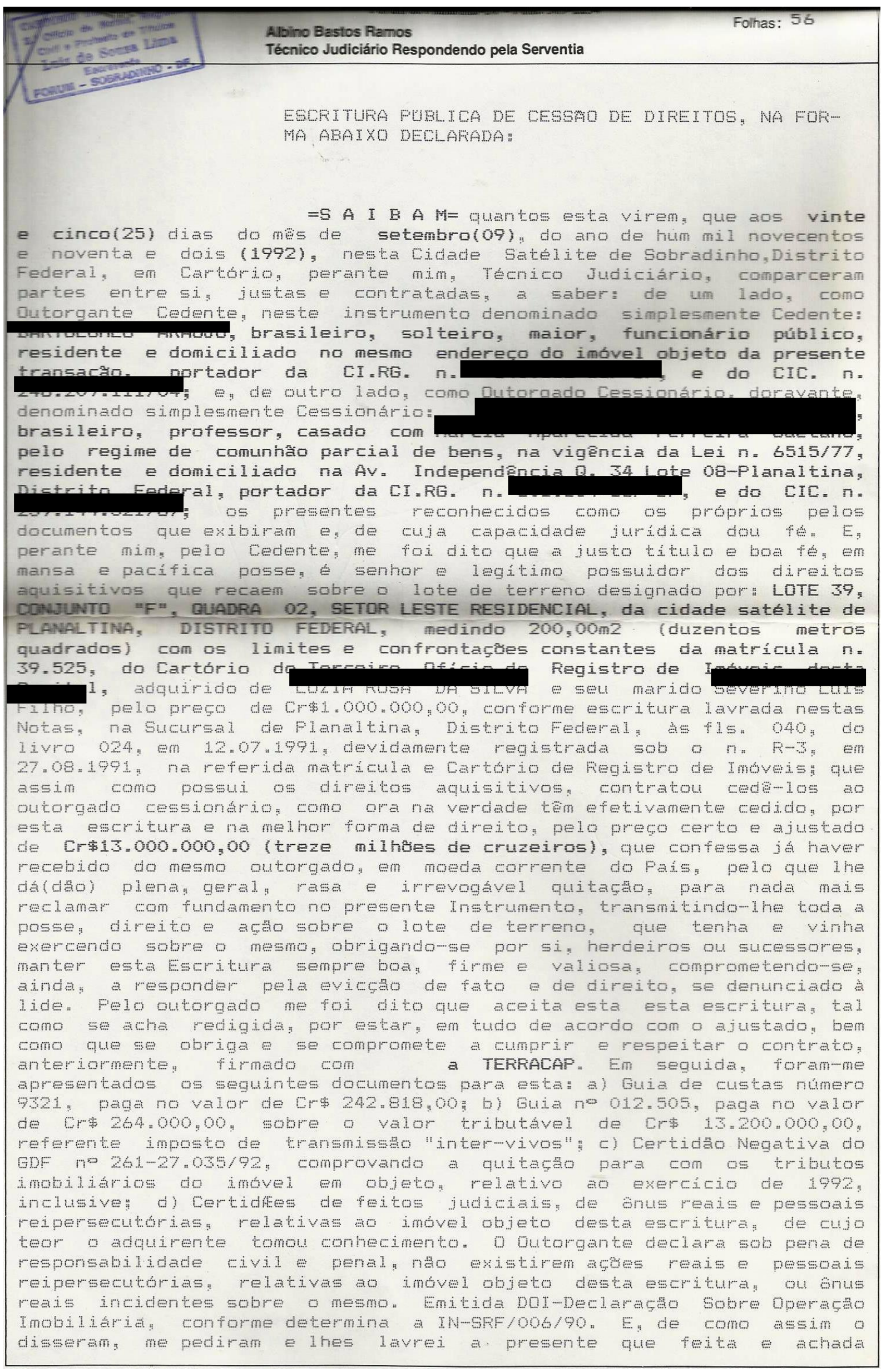




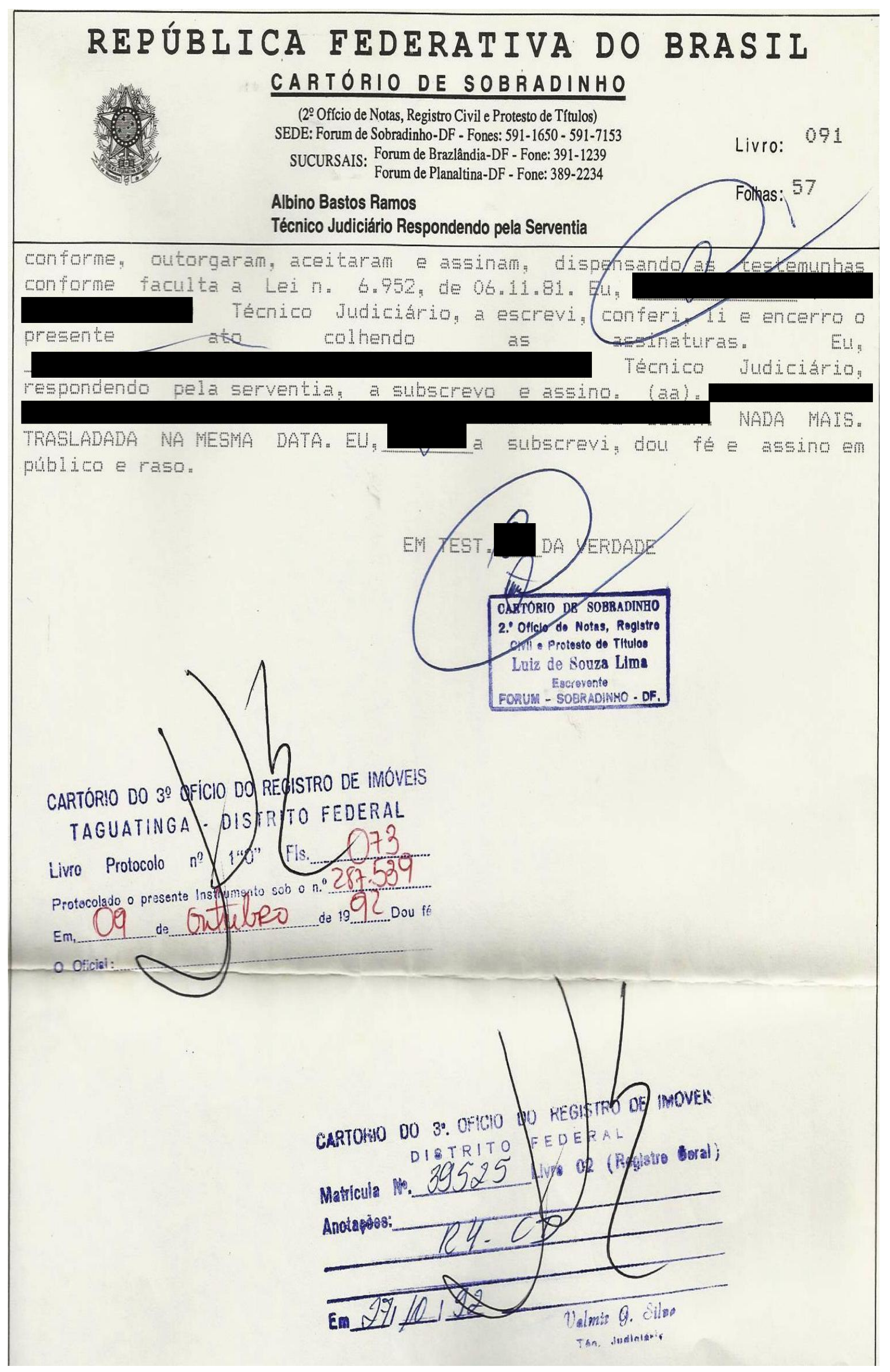




\section{REPÚBLICA FEDERATIVA DO BRASIL}

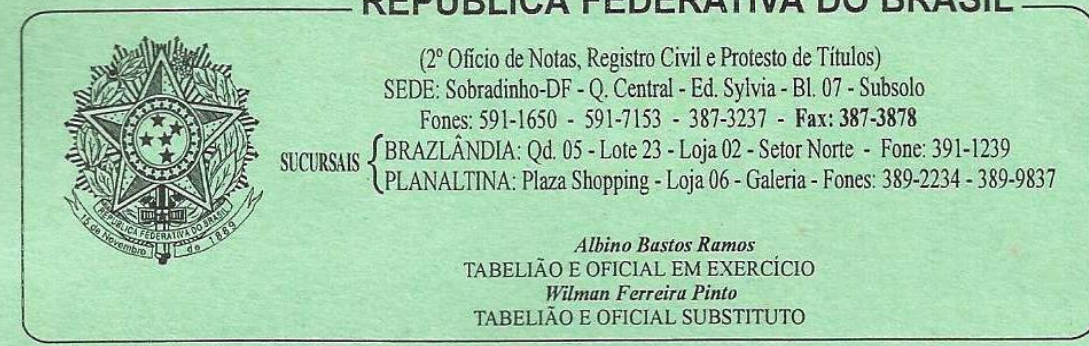

TRASLADO

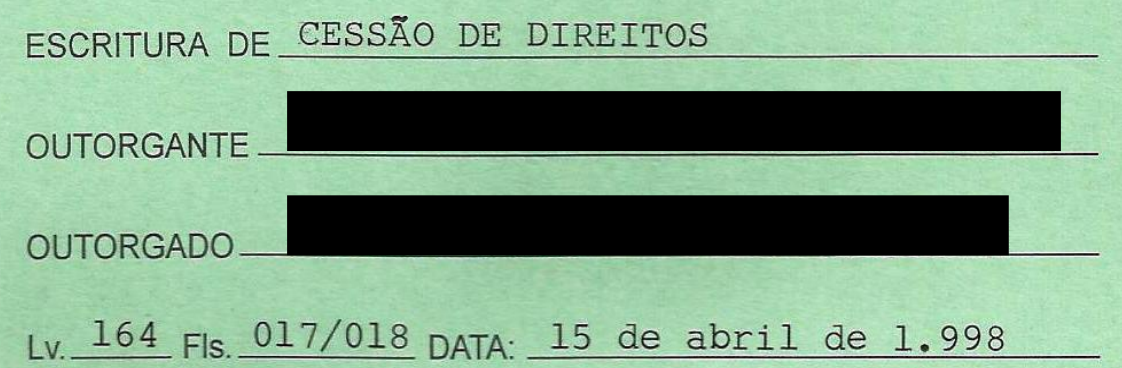




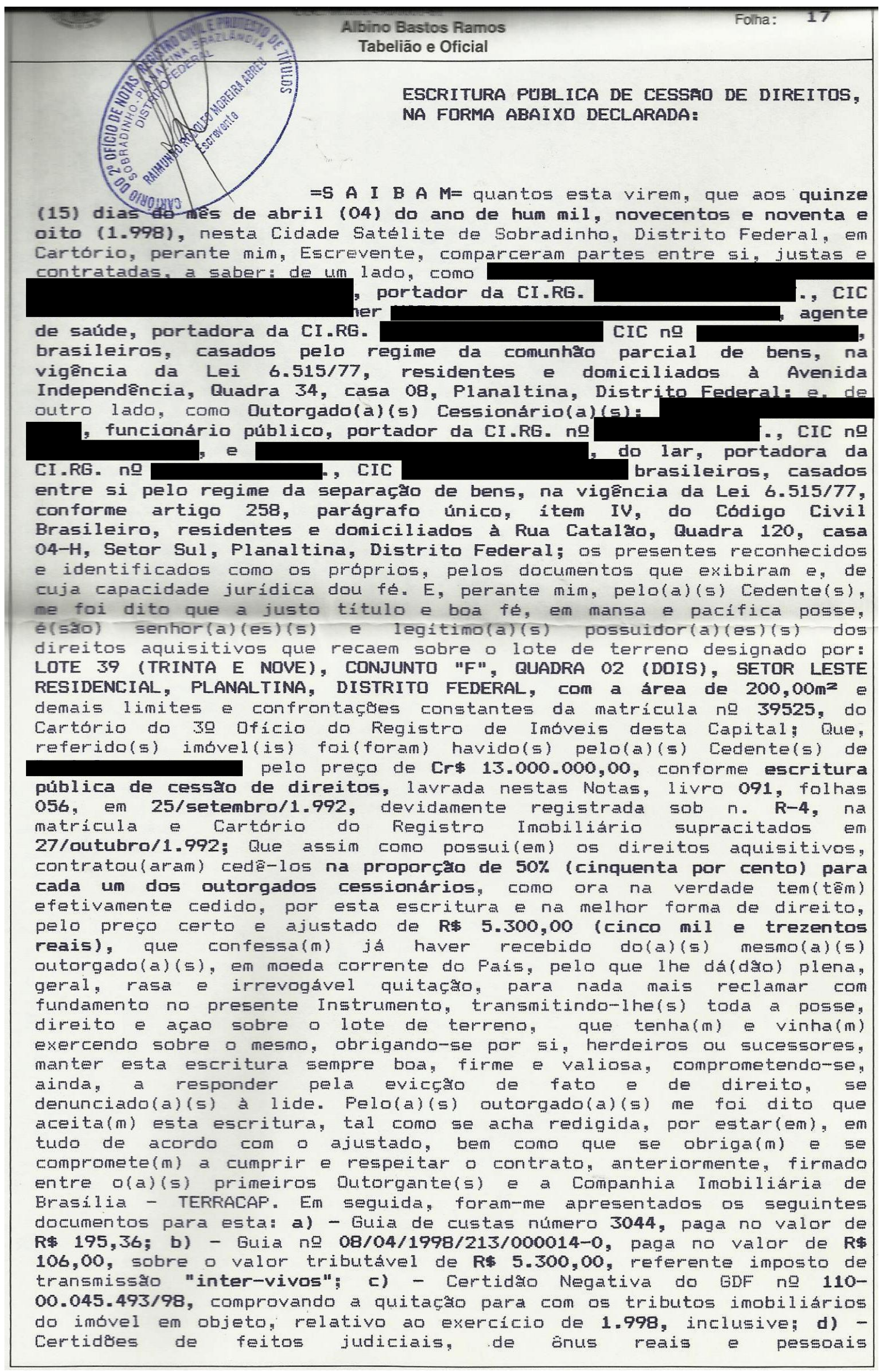




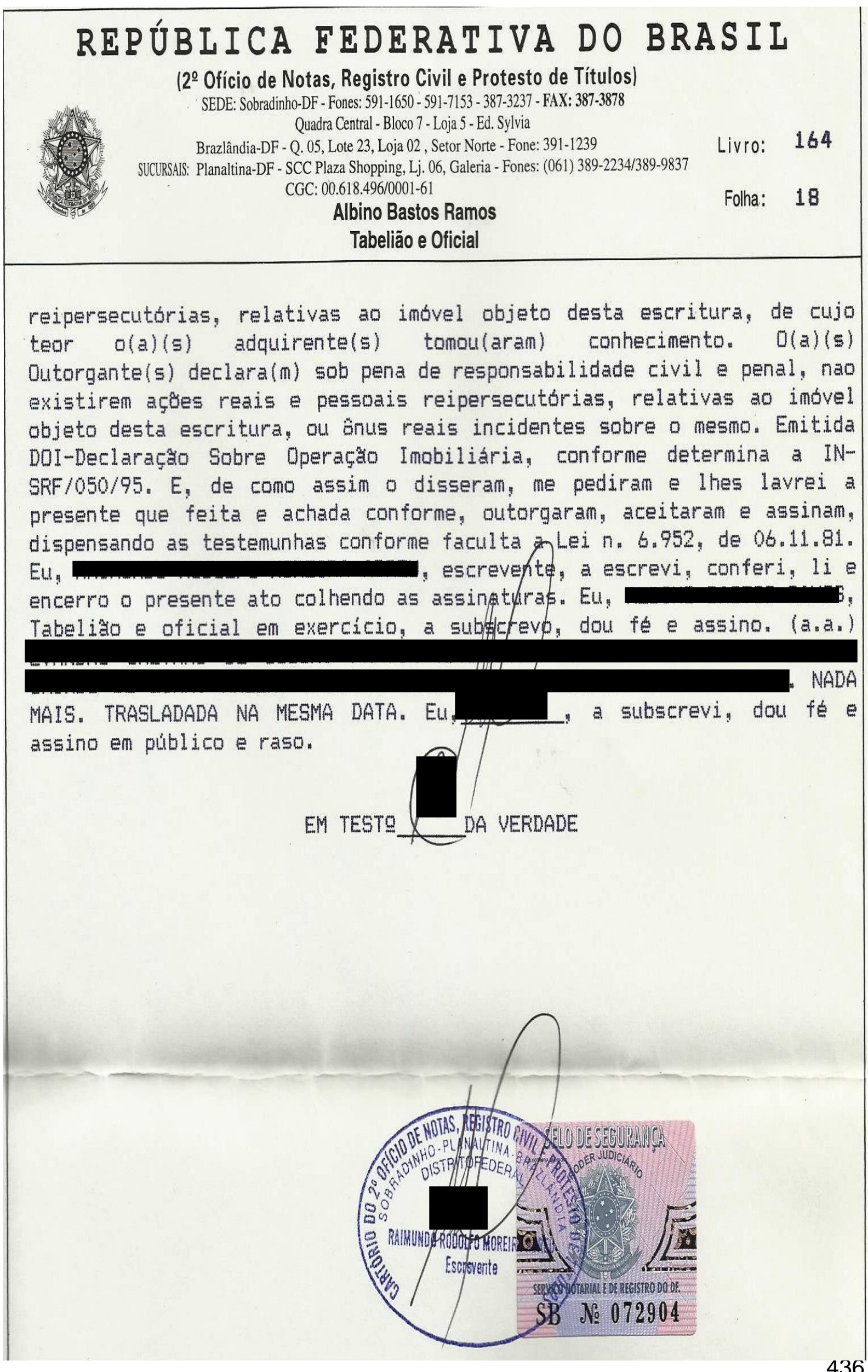


ANEXO 04 


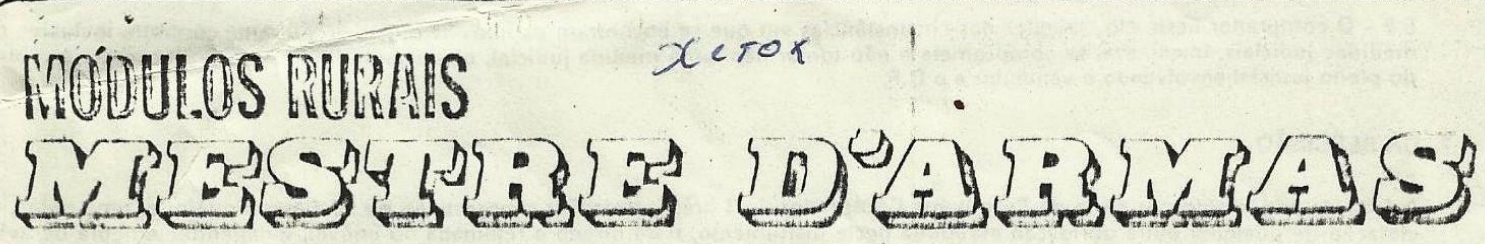

\section{CONTRATO PARTICULAR L COMPROMISSO DE COMPRA E VENDA DE FRAÇĀO 'EAL DE IMÓVEL RURAL}

\section{CONTRATO No 27}

\section{DO OBJETIVO DO CONTRATO}

PROMESSA DE COMPRA E VENDA DE FRAÇĀO IDEAL do módulo M-D5 da Gleba Rural denominada Mestre D’Armas módulos rurais localizada na fazenda Lagoa Bonita à margem da BR-020.

\section{DAS PARTES CONTRATANTES}

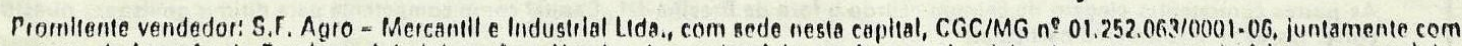
o contralo de Locaçáo de Serviços, Administraçáo e Vendas de condominio em área rural, celebrado entre o proprietário supra, aqui de. nominado PROMITENTE VENDEDOR, cujas vendas scrăo exclusivamente cletuadas por sua única vendedora, a firma SIC - Sociedade de Investimentos Comerclais LIda., ostabelecida no SDS, Ed. Miguel Badya, lojas 860 - 80 - Braslia.DF, aqui denominada CONCES. SIONARIA, o de outro lado co

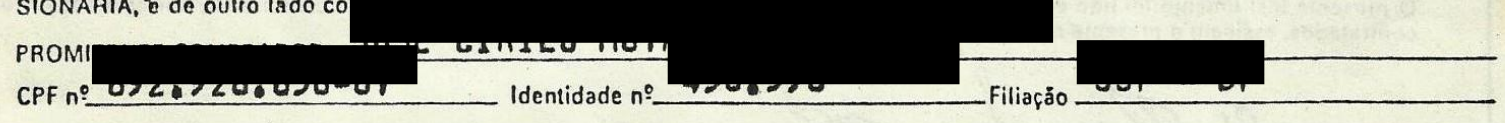

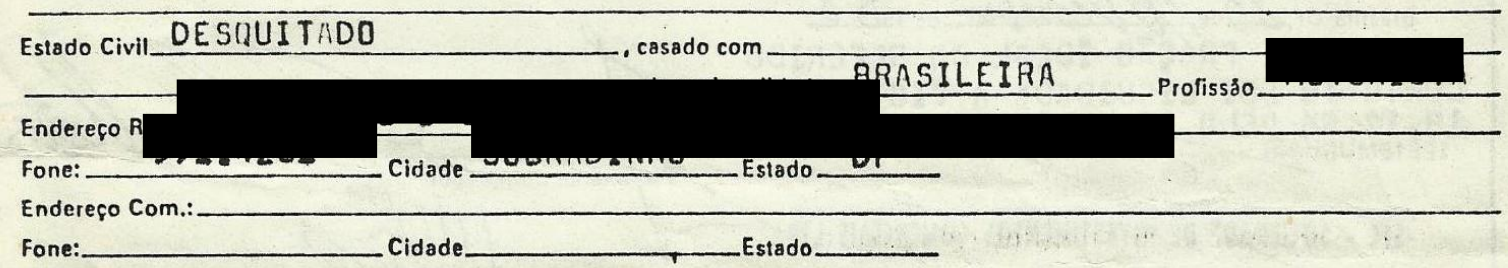

3. DO PREÇO COMDIÇÓES DO PAGAMENTO

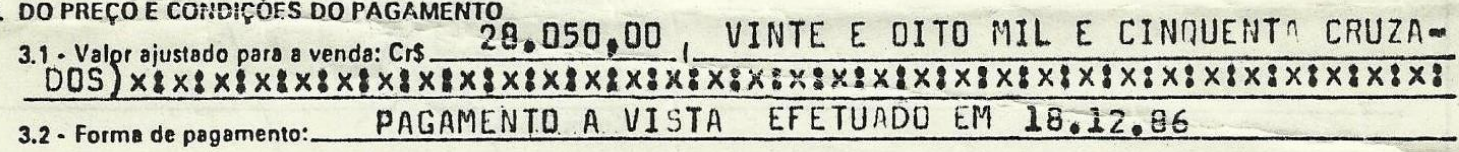

4. DA ORIGEM DOMINIAL DA GLEBA, UMITES, CONTRONTAÇÓES E HEGISTRO

Gleba de terras, havida por compra através de escritura de incorporaḉo para integralizaçáo de capital social, lavrada no cartbrio de 30 Oficio e Notas de Brasllia, no livro D. 132 fls. 088 e devidamente registrada no cartório do $3^{\circ}$ Ollicio de Registro de Imbveis do DF nas matriculas 99647 até 99668 , cujos limites e confrontaçóes encontram-se registrados isoladamente em 22 (vinte e dois) módulos distinlos, identificados de módulos " 1 " até módulo "22". Sendo todas as áreas devidamente cadastradas no INCRA, em nome de Mestre D'Armas módulos rurais.

5. DAS OBHIGAÇŌES DO PROMITENTE VENDEDOR

5.1 - Prometer vender ao Promitente Comprador, a fraçáo ideal citada no item 1 em condominio rural livre e desemberaçado de quaisquer restriçóes ao direito de propriedade, pelo preço global e forma de pagamento contidas nos itens 3.1 e 3.2 .

5.2 - Outornar a competente escritura definitiva após quitaçáo ao Promitente Comprador no prazo de 30 (trinta) dies apbs o paga. mento do últime prestaçáo do contrato, desde que pago o Imposto de Transmissbo pelo Promitente comprador.

5.3- Outorga escritura delinitiva, ou translerir direitos e vantagens e obrigaçóes a terceiros indicados pelo Promitente Vendedor, des. de que em dia com suas obrigaçóes e mediante pagamento de uma laxa de 6 OTNS, em lavor do Promitente Vendedor.

\section{DAS OBRIGAÇÓES DO PROMITEIJTE CORPRADOR}

6.1 - Pañar pontualmente nas datas de vencimento, as prestaçócs, sob pena de rescisáo contratual, independente de prévio aviso ou de interpelaráo judicial ou extra-judicial.

6.2 - Pagar todos os impostos, taxas e demais onus que incidirem sobre sua fraçáo ideal, inclusive despesas oriundas deste contrato panicular como, imnosto de transmissåo, escrituras, reg̣istros, despesas de canúrios, centióos, despachantes, e demais despesas aue vierem a ceorere en decortencia de..t contrate.

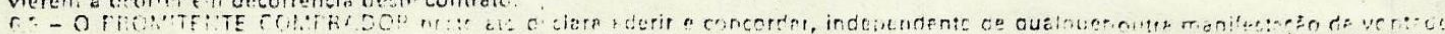

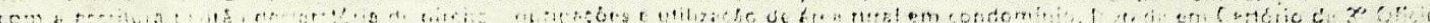
d.

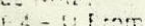

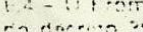

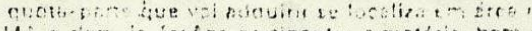

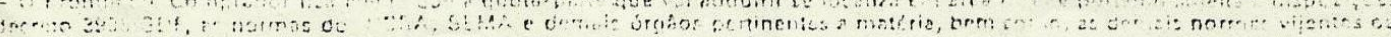

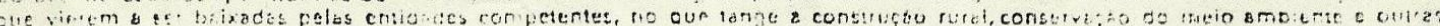

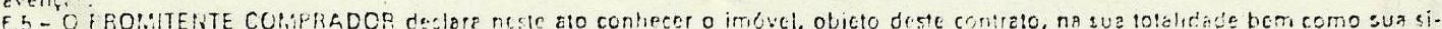

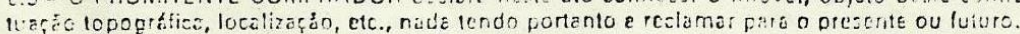

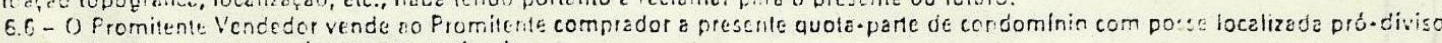
Exercitasa sobie pars-ceria, locus cena ex-fundo.

6.7 - É expressemente proibido a construft́o de barraco de madeiri ou qualquel obra que néo alcrida as normas vipentes na quota parte, sob pene de cancrlemento do presente contrato. 
6.8 - O comprador neste ato, sabedor das circunstáncias em que se encontram os imóveis objeto do presente contrato, inclusive das medidas judiciais, intentadas, se compromete a não tomar nenhuma medida judicial, objetivando ilidir a presente compra em razáo do pleito judicial envolvendo o vendedor e o D.F.

\section{DA RESCISĀO}

A lalta de pagamento por parte do Promitente Comprador de 3 (trés) prestaçōes consecutivas, ou 90 dias em qualquer uma delas, ou violaçảo de qualquer outra obrigação assumida neste instrumento, dará direito a retomada do imóvel, independentemente de aviso ou notificação judicial ou extra-judicial, implicará na rescisáo do presente instrumento, perdendo o Promitente Comprador, em favor do Promitente Vendedor, as quantias que já tiver pago, pois será considerado o Contrato em Comisso e com cláusula resolutiva expressa por eleiro de inadimplemento de obrigaçäo (art. 1.163-Código Civil Brasileiro) e será tido, por rescindido de pleno direito, ficando livre o Promitente Vendedor de qualquer obrigaça para com o Promitente Comprador inadimplente, podendo livremente cando livre o Promitente vendedor de qual

\section{DA POSSE}

O PROMITENTE COMIPRADOR, é imitido neste alo, no uso, gozo e posse provisória do imóvel comprometido vender, podendo desde já cercar a área destinada a sua utilizaçáo exclusiva, e nela só edificar atendendo aos termos da escritura pública declaratória, indicada no item 6.3, a qual adere expressamente, independente de qualquer outra manifestaçáo. Fica claro que a área objeto do presente contrato encontra-se livre e desembaraçadae fora da área compreendida pelo decreto $n^{\circ} 6.004$ de 10 de junho de 1981.

9. DO IORO

As partes contratantes elegern de comum acordo o foro de Brasllia-DF, Capital como competente para dirimir quaisquer questöes de. correntes deste instrumento particular.

\section{DA ASSINATURA}

O presente instrumento foi lido em presença das testemunhas abaixo nomeadas e assinadas, achado conforme e, por cstarem justos e contratados, assinam o presente em 3 vias de igual teor para que produzam um só eleito legal.

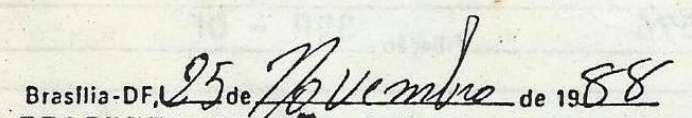
$A$ PRESENTE FRACRO IOEAL DO REFERIDO CONTR TO FOI LIIUIOROA A VISTM EM 18, 12.86 PELO 59 , KL.INGEA

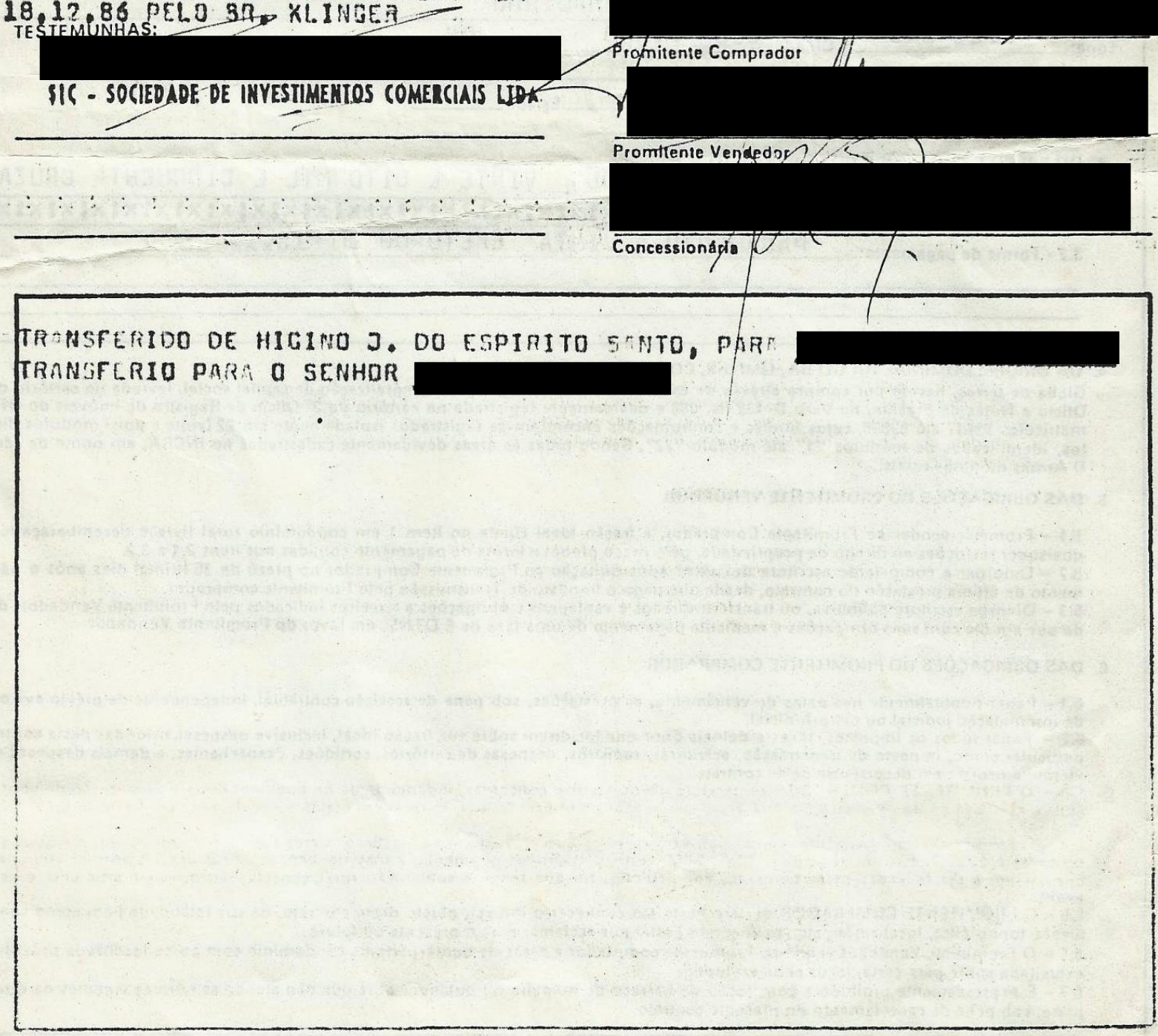


ANEXO 05 


\section{Contrato Particular de Compromisso de Compra e Venda -}

Pelo presente contrato particular de compromisso de compra e venda,

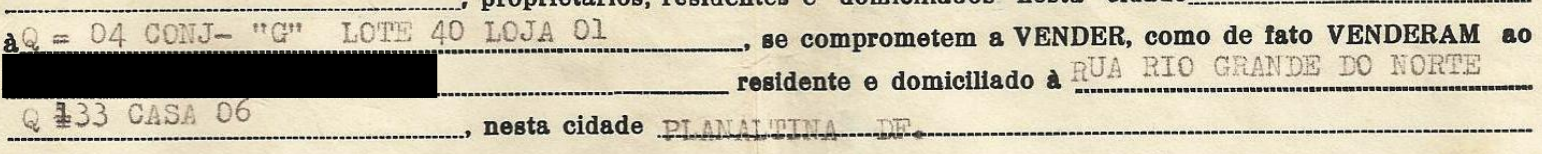

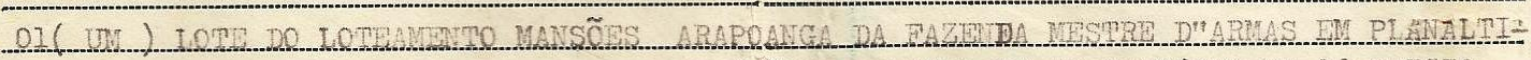
NA DISTETTO FEDRAL. REGISMRADO SOB 0 NI 99822 DO LIVRO 02 DO CARTORIO DE 30 OPTCIO DE RECISTRO DE INOVETS DO DISTRITO FEPERALE OI (UV) LOME COM $675 M 2(15 \times 45)$ DA GUADRA $7 / I$ LOTE 08 .

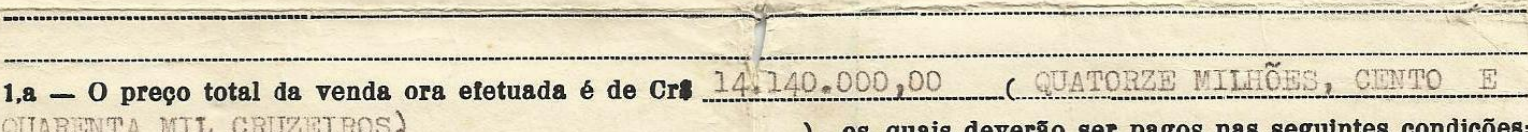
OUARINTA MIL CRUZBTROS , os quais deverão ser pagos nas

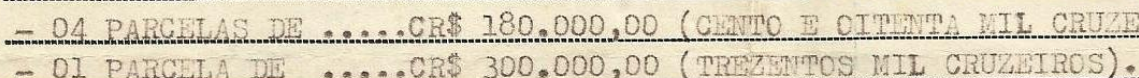

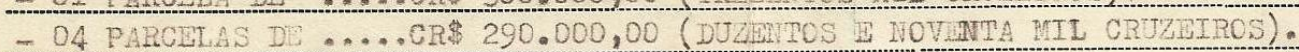
- O4 PARCHLAS DE ......CR\$ $380.000,00$ (TREZMTOS E OITEITA IIL CRUZEIROS). - O4 PARCLAS DE ......CRT $460.000,00$ (QUARROCENTOS E SESSEMTA MIL CRUZLIROS). - O4 PARCELAS DE ....CR\$ 580.000,00 (QUTMUMNOS E OITMTA MIL CRUZETROS).

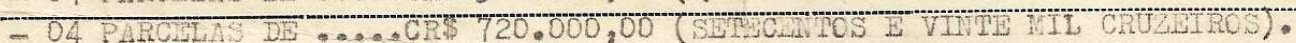
- 04 PAECH DE

2.8 - o comprador tomou posse do imóvel compromissado, podendo nele fazer toda e qualquer Benfeitoria que julgar conveniente, conservando o porém em nome dos vendedores até o pagamento final do débito que ora fica a dever

- Todos os impostos que sejam ou venham a ser lançados sobre o imóvel ora compromissado, a partir desta dats, serão pagos exclusivamente pelo comprador dentro dos respectivos vencimentos, embora sejam lançados data, serão pagos exclusivamente pelo com
em nome dos vendedores ou de terceiros.

- 0 presente contrato ficará rescindido imedlatamente e de nenhum efeito, independente de qualquer aviso on formalidade, se o comprador deixar de pagar os vendedores, tres (3) meses consecutivos, num, prazo superior a 90 (noventa) dias, as prestações a que se refere a cláusula primeira deste contrato $\Theta$, neste caso perderá o o comprador em benefíclo dos vendedores, o direito à devolução das importâncias pagas por conta do "preço gjustado, bem como as importancias dispendidas com impostos, benfeitorias, etc.

5.a - O presente contrato particular obriga em todas as cláusulas e condições, tanto as partes contratantes, como seus sucessores e herdeiros.

6. - Os vendedores se obrigam e se comprometem, por si, seus herdeiros, ou sucessores, a outorgar e assinar em favor do comprador, seus herdeiros, ou sucessores, ou ainda de pessoas pelo comprador indicadas, a respectifavor do comprador, seus herdeiros, ou sucessores, ou ainda e pasado de quaisquer ônus, uma vez que va escritura definitiva do imóvel compromissado, livre e desembaraçado de quaisquer onus, uma vez que hajam recebido do comprador, seus herdeiros, ou sucessores, a importância total que ora fica a dever bem como, no caso de recusa, ou falta de cumprimento de qualquer das cláusulas deste contrato, serem obrigados ajustado, bem como a indenização das importanclas pagas e dispendidas com benfeitorias e demais melhoramentos no imóvel compromissado, além dos prejuízos decorrentes e que serão então apurados.

7.a - Correrão por conta do comprador todas as despesas deste contrato particular de compromisso de compra e venda, bem como todas as despesas com escritura definitiva, com excesão dos impostos que, por força da lei, competirem seus pagamentos aos promitentes vendedores.

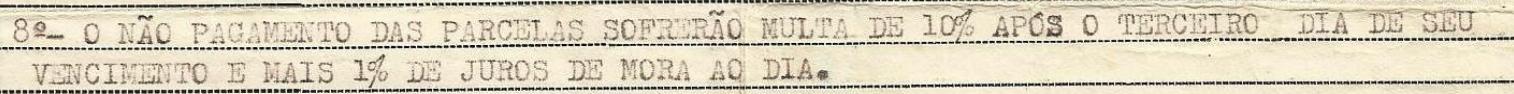

O presente contrato é passado em duas vias de igual teor e forma, estando a primeira via selada de acôrdo com a lei, 1094 DO CODIGO CIVI BRSSILETPO.

- qual fol aceito pelas partes contratantes que o assinam na presença de duas testemunhas das mesmas conhecidas.

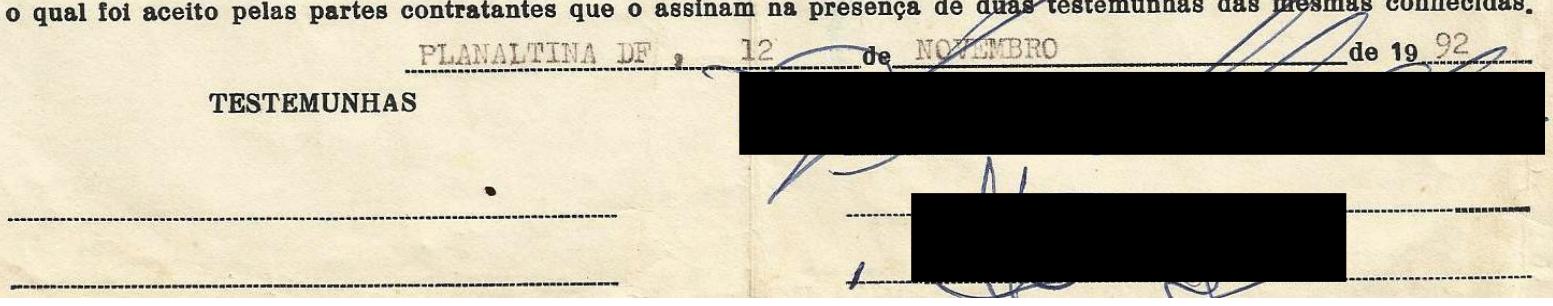




\section{- Contrato Particular de Compromisso de Compra e Venda - \\ Pelo presente contrato particular de compromisso de compra e venda,

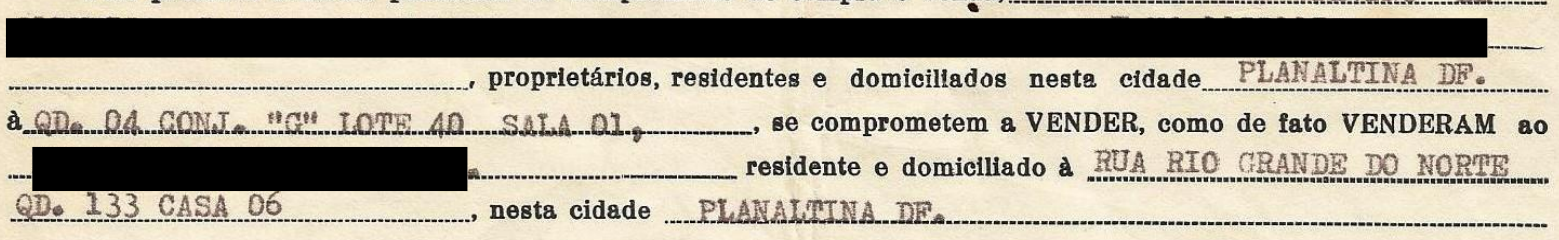 \\ - 01 (UM ) LOTE DO LOTEAMBNTO MANSÖES ARAPOANGA DA FAZFNDA UESTRE D"ARMAS BM PIAE NALTNA DF, REGISFRADO SOB O NO 99892, DO LIVRO O2, DO RECT STRO GERAL DO CARTORIO DE $3 \&$ OPICIO, DO REGISTRO CIVIL DE INOVEIS DO DISTRTW FEDRRAL. -01 (UM ) LOTE COII 675 N2 ( $15 \times 45)$ DA OUADA 07/I LOTE 08.}

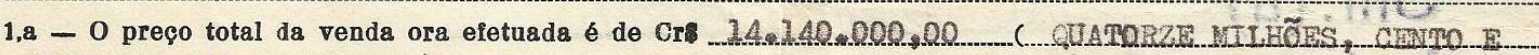
GUARENTA MIL CRUZEIROS). $\quad$ ) os quais deverão ser pagos nas seguintes condições;

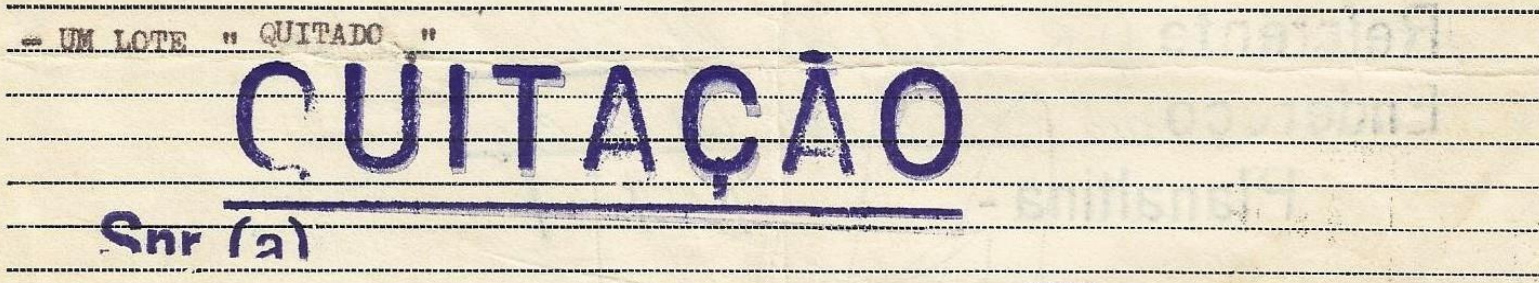

2.a - O comprador tomou posse do imóvel compromissado, podendo nele fazer toda e qualquer Benfeitoria que julgar conveniente, conservando o porém em nome dos vendedores até o pagamento final do débito que ora fica a dever

$3 . a$ - Todos os impostos que sejam ou venham a ser lançados sobre o imóvel ora compromissado, a partir desta data, serão pagos exclusivamente pelo comprador dentro dos respectivos vencimentos, embora sejam lançados em nome dos vendedores ou de terceiros.

4.a - O presente contrato ficará rescindido imediatamente e de nenhum efeito, independente de qualquer aviso ou formalidade, se o comprador deixar de pagar os vendedores, tres (3) meses consecutivos, num; prazo superio a 90 (noventa) dias, as prestações a que se refere a cláusula primeira deste contrato e, neste caso perderá o o comprador em benefíclo dos vendedores, o direito à devolução das importâncias pagas por conta do "preço ajustado, bem como as importancias dispendidas com impostos, benfeitorias, etc.

5.a - O presente contrato particular obriga em todas as cláusulas e condições, tanto as partes contratantes, como seus sucessores e herdeiros.

6.2 - Os vendedores se obrigam e se comprometem, por si, seus herdeiros, ou sucessores, a outorgar e assinar 'em favor do comprador, seus herdeiros, ou sucessores, ou ainda de pessoas pelo comprador indicadas, a respectiva escritura definitiva do imóvel compromissado, livre e desembaraçado de quaisquer ônus, uma vez que hajam recebido do comprador, seus herdeiros, ou sucessores, a importâcia total que ora fica a dever bem como, no caso de recusa, ou falta de cumprimento de qualquer das cláusulas deste contrato, serem obrigado a devolver $a 0$ comprador, em dobro, tais importâncias totais que mesmo hajam recebilo por conta do puos ajustado, bem como a indenização das importanclas pagas e dispendidas com benfeitorias e demais melhoramentos no imóvel compromissado, além dos prejuizos decorrentes e que serão então apurados.

7.a - Correrão por conta do comprador todas as despesas deste contrato particular de compromisso de compra e venda, bem como todas as despesas com escritura definitiva, com excesão dos impostos que, por força da lei, competirem seus pagamentos aos promitentes vendedores.

O presente contrato é passado em duas vias de igual teor e forma, estando a primeira via selada de acôrdo com a le1, L) 1094 DO CODICO CJVIL BRASIUEIRO.

o qual foi aceito pelas partes contratantes que o assinam na presença de duas testemunhas das mesmas conhecidas. TESTEMUNHAS

$$
\text { PLANALTIHA DE, } 21 \text { de JUNHO }
$$

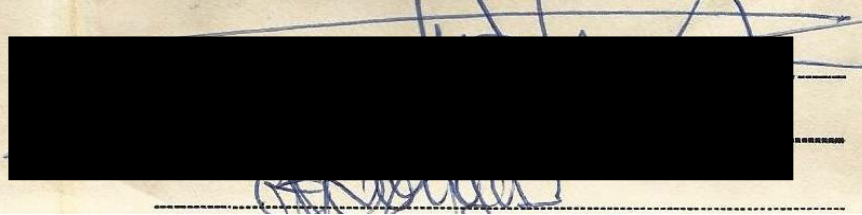


ANEXO 06 


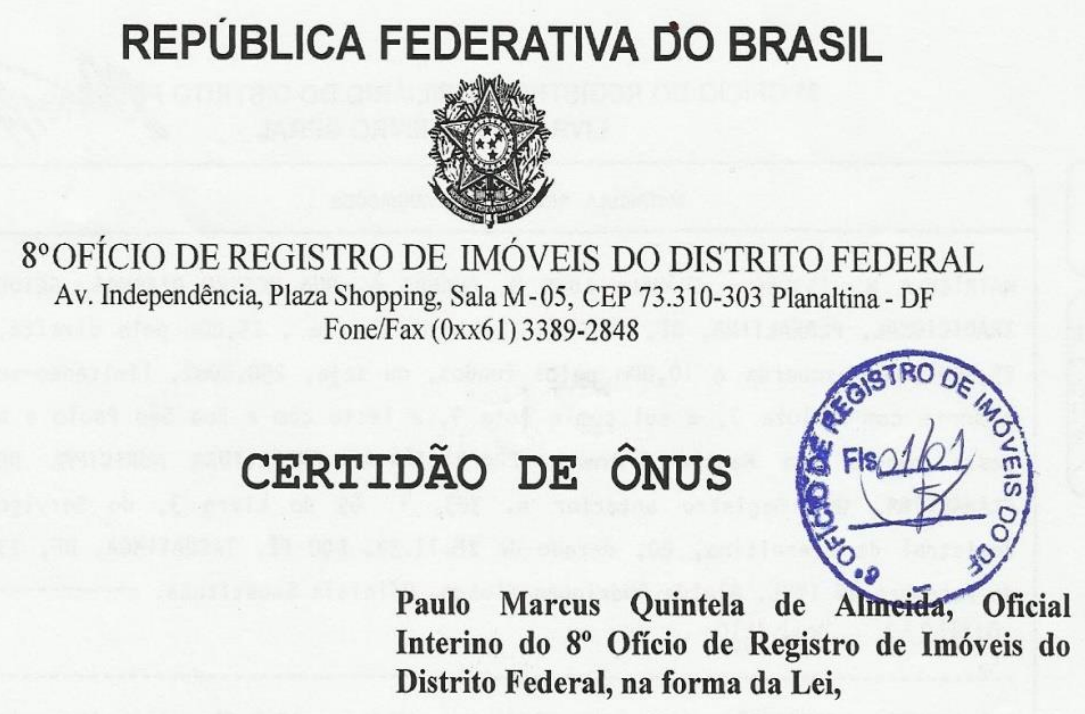

CERTIFICA que, revendo os arquivos deste serviço registral, deles não consta, na matrícula n. ${ }^{\circ} 153986$ do $3^{\circ}$ Ofício de Registro de Imóveis do Distrito Federal, nenhum ônus de qualquer natureza ou registro de citações de ações reais ou pessoais reipersecutórias relativas a ela, conforme cópias de inteiro teor extraídas por processo eletrônico na forma do art. $19, \S 1^{\circ}$, da Lei $n^{\circ}$ 6.015/73 c/c art. 41 da Lei ${ }^{\circ} 8.935 / 94$.

CERTIFICA, mais, que deverá ser apresentada Certidão do Imóvel expedida pela Administração Regional de Planaltina - DF, para fins de se constar da matrícula os limites e confrontações do imóvel.

CERTIFICA, finalmente, que as responsabilidades civil, administrativa e criminal pelos atos praticados são do Oficial Delegado Titular e/ou de seus prepostos autorizados na data da prática de cada ato, sendo esta Certidão composta por o1 (UMA) folhas devidamente rubricadas.

0 referido é verdade e dou fé.

Emol. R\$23,32

Planaltina, 28 de julho de 2014.

(1 fl.; 2 buscas; 0 fl. excedente)

Pedido: 143.394

Selo: TJDFT20140350059846PKJD

Para consultar o selo, acesse www.tjdft.jus.br. 


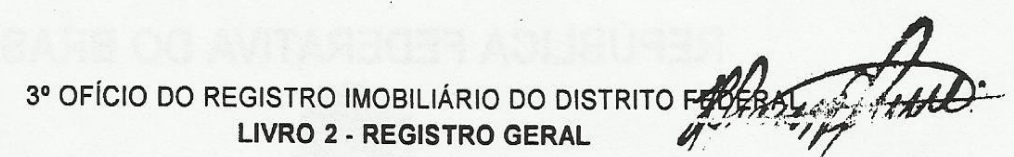

MATRÍCULA N. 153986.- IMŐVEL: LOTE 8, QUADRA 6, RUA MESTRE D'ARMAS, SETOR TRADICIONAL, PLANALTINA, DF, medindo $10,00 \mathrm{~m}$ de frente, $25,00 \mathrm{~m}$ pela direita, $25,00 \mathrm{~m}$ pela esquerda e $10,00 \mathrm{~m}$ pelos fundos, ou seja, $250,00 \mathrm{~m} 2$, limitando-se a norte com o lote 7 , a sul com o lote 9, a leste com a Rua São Paulo e a oeste com a Rua Mestre D'Armas. PROPRIETÅrIA: PREFEITURA MUNICIPAL DE PLANALTINA, 60. Registro anterior n. 303, f. 85 do Livro 3, do Serviço Registral de Planaltina, GO, datado de 28.11.32. DOU FÉ. TAGUATINGA, DF, 23 de setembro de 1996. Alaide Rodrigues Miosso, oficiala Substituta. Alarivi fonoidto

R.1.153986.- CONCESSÃo: Alvará n. 72/94, expedido em 13.9.94, subscrito pelo Prefeito Municipal José 0linto Neto, extraído do procellso n. 260/94. CONCEDENTE: a proprietária de que trata esta matrícula. CONCESSIONÅRIA:

brasileira, funcionária pública, residente e domiciliada nesta Capital, portadora da CI RG n.

, casada com e do CPF/MF $n$. cinquenta e oito reais e setenta e um centavos). Foram apresentadas e ficam aqui arquivadas a guia do recolhimento do imposto de transmissão "inter-vivus" de n. 2519/96, acompanhada do DAR n. 6010062-1, e a certidão do GDF, relativa ao IPTU, de n. 251-78.007/96, vălida até 31.12.96. DOU FÉ. TAGUATINGA, DF, 23 de setembro de 1996. Alaide Rodrigues Miosso, Oficiala Substituta. Rickdu Suñoso

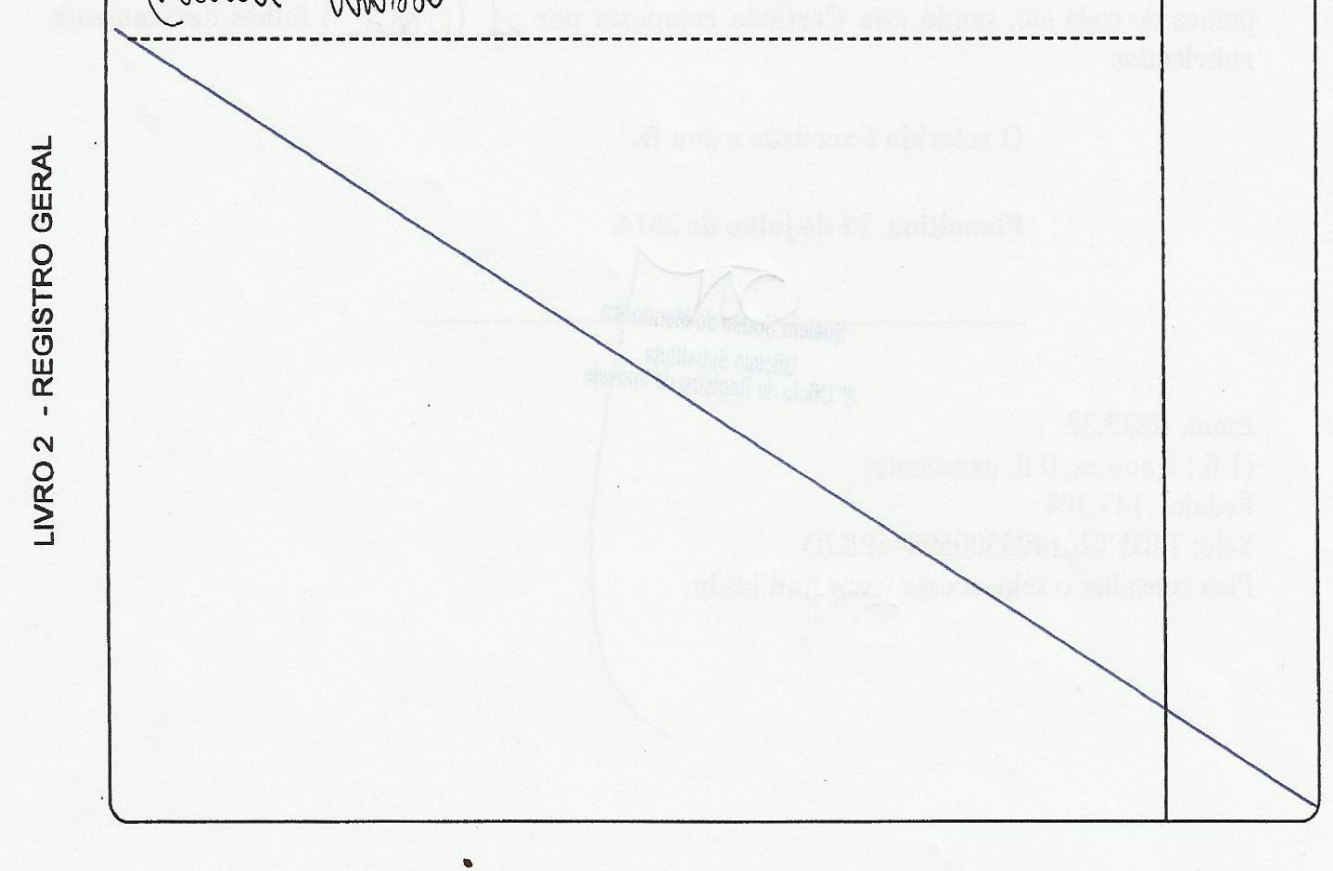




\section{REPÚBLICA FEDERATIVA DO BRASIL \\ $8^{\circ}$ OFÍCIO DE REGISTRO DE IMÓVEIS DO DISTRITO FEDERAL \\ Av. Independência, Plaza Shopping, Sala M-05, CEP 73.310-303 Planaltina - DF Fone/Fax (0xx61) 3389-2848}

\section{CERTIDÃO DE ÔNUS}

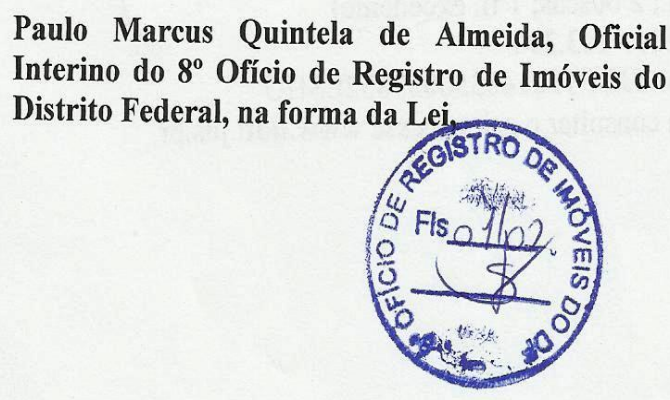

CERTIFICA que, revendo os arquivos deste serviço registral, deles não consta, na matrícula n. ${ }^{\circ} 144579$ do $3^{\circ}$ Ofício de Registro de Imóveis do Distrito Federal, nenhum ônus de qualquer natureza ou registro de citações de ações reais ou pessoais reipersecutórias relativas a ela, conforme cópias de inteiro teor extraídas por processo eletrônico na forma do art. 19, $\$ 1^{\circ}$, da Lei ${ }^{\circ}$ 6.015/73 c/c art. 41 da Lei no 8.935/94.

CERTIFICA, mais, que constam as seguintes matrículas BLOQUEADAS de lotes localizados na Quadra 07 do Setor Tradicional de Planaltina - DF: Lote 02 (Matrícula 144579 do $3^{\circ}$ Ofício); Lote 14 (Matrícula 144581 do $3^{\circ}$ Ofício); Lote 15 (Matrícula 145813 do $3^{\circ}$ Ofício); Lote 16 (Matrícula 144296 do $3^{\circ}$ Ofício); Lote 20 (Matrícula 144293 do $3^{\circ}$ Ofício); Lote 21 (Matrícula 145816 do $3^{\circ}$ Ofício); Lote 23 (Matrícula 154809 do $3^{\circ}$ Ofício); Lote 25 (Matrícula 171864 do $3^{\circ}$ Ofício); Lote 25-A (Matrícula 171865 do $3^{\circ}$ Ofício); Lote 29 (Matrícula 154806 do $3^{\circ}$ Ofício); e Lote 31 (Matrícula 154804 do $3^{\circ}$ Ofício).

CERTIFICA, finalmente, que, de acordo com Mapa fornecido pela Administração Regional de Planaltina - DF, não existe a Quadra 07 do Setor Tradicional, sendo o quadrilátero delimitado a norte pelo Córrego Buritizinho, a sul pela Rua Sergipe, a leste pela Avenida Independência e a oeste pela Rua Mestre D'Armas, correspondente a uma PRAÇA DE ESPORTES, bem público de uso comum do povo, nos termos do art. 19, I, do CC/2002 e art. 66, I, do $\mathrm{CC} / 1916$. As matrículas acima mencionadas foram indevidamente abertas, sob as responsabilidades civil, administrativa e criminal do Oficial Delegado Titular e/ou de seus prepostos autorizados, para registros de alvarás de concessão fornecidos pela Prefeitura de Planaltina - GO, que não se revestem da forma de escritura pública (art. 108 do CC de 2009; art. 134, II, do CC de 1916) nem mencionam o cumprimento das exigências legais para alienação de bens públicos (art. 17 da Lei n ${ }^{\circ} 8.666 / 93$ - avaliação prévia, autorização legislativa e licitação na modalidade concorrência). A questão deve ser solucionada perante os órgãos competentes do GDF e a Vara de Registros Públicos do DF nos autos 2007.01.1.055185-8. 
CERTIFICA, finalmente, que as responsabilidades civil, administrativa e criminal pelos atos praticados são do Oficial Delegado Titular e/ou de seus prepostos autorizados na data da prática de cada ato, sendo esta Certidão composta por $02(D \cup A S)$ folhas devidamente
rubricadas.

\section{O referido é verdade e dou fé.}

Planaltina, 24 de julho de 2014.

Emol. R\$24,81

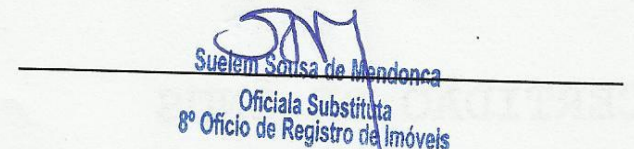

(1 fl.; 2 buscas; 1 fl. excedente)

Pedido: 143.394

Selo: TJDFT20140350059832ESHU

Para consultar o selo, acesse www.tjdft.jus.br. 
CARTÓRIO DO 3. ${ }^{\circ}$ OFICIO DO REGISTRO DE IMÓVEIS DO DISTRITO FEDERAL

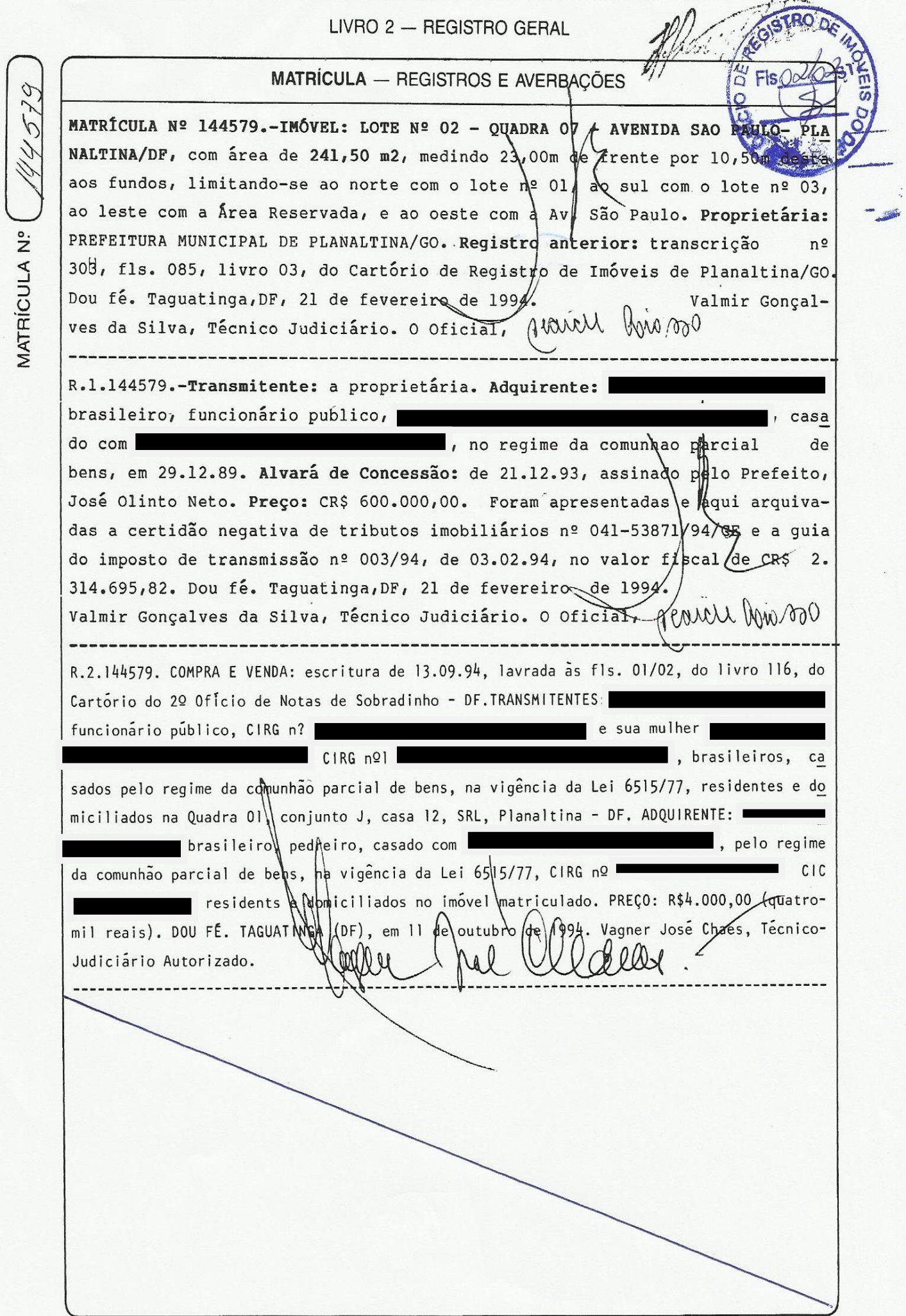



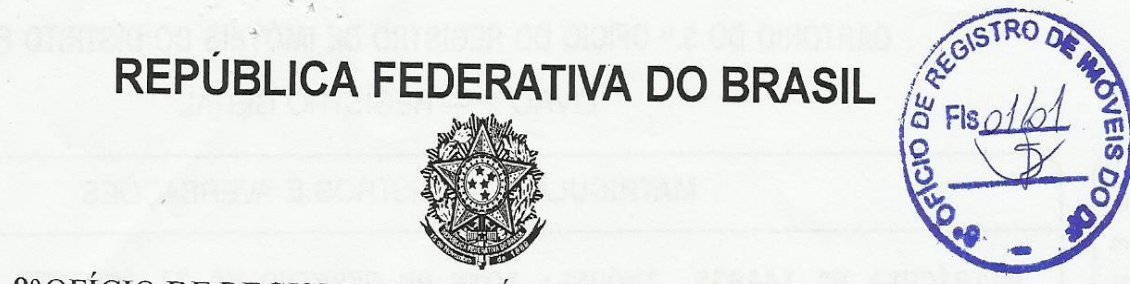

$8^{\circ}$ OFÍCIO DE REGISTRO DE IMÓVEIS DO DISTRITO FEDERAL

Av. Independência, Plaza Shopping, Sala M-05, CEP 73.310-303 Planaltina - DF

Fone/Fax (0xx61) 3389-2848

\title{
CERTIDÃO DE ÔNUS
}

\author{
Paulo Marcus Quintela de Almeida, Oficial \\ Interino do $8^{\circ}$ Ofício de Registro de Imóveis do \\ Distrito Federal, na forma da Lei,
}

CERTIFICA que, revendo os arquivos deste serviço registral, deles não consta, na matrícula n. ${ }^{\circ} 144835$ do $3^{\circ}$ Ofício de Registro de Imóveis do Distrito Federal, nenhum OUTRO ônus de qualquer natureza ou registro de citações de ações reais ou pessoais reipersecutórias relativas a ela, com exceção do BLOQUEIO mencionado na Av.2, não se podendo nela praticar qualquer ato, nem de averbação, nem de registro, ainda que de ordens judiciais de penhora, salvo com autorização da Vara de Registros Públicos do DF, conforme cópias extraídas por processo eletrônico na forma do art. $19, \S 1^{\circ}$, da Lei $n^{0} 6.015 / 73 \mathrm{c} / \mathrm{c}$ art. 41 da Lei $\mathrm{n}^{\circ} 8.935 / 94$.

CERTIFICA, finalmente, que as responsabilidades civil, administrativa e criminal pelos atos praticados são do Oficial Delegado Titular e/ou de seus prepostos autorizados na data da prática de cada ato, sendo esta Certidão composta por of (UMA) folhas devidamente rubricadas.

O referido é verdade e dou fé.

Planaltina, 22 de julho de 2014.

Emol. R\$23,32

(1 fl.; 2 buscas; 0 fl. excedente)

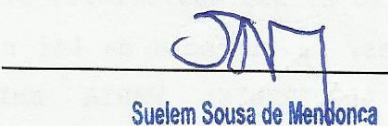

Pedido: 143.394

Selo: TJDFT20140350059846PKJD

Para consultar o selo, acesse www.tjdft.jus.br. 
CARTORIO DO 3. OFICIO DO REGISTRO DE IMÓVEEIS DO DISTRITO FEDERAL

LIVRO 2 - REGISTRO GERAL

\section{MATRICULA - REGISTROS E AVERBAÇÕES}

MATRICULA No 144835. IMÓVEL: LOTE DE TERRENO No 31 (TRINTA E HUM), QUADRA 14 (QUATORZE), RUA PARÁ, SETOR TRADICIONAL da cidade satélite de PLANALTI NA, DISTRITO FEDERAL, medindo $10,00 \mathrm{~m}$ de Arente por 30,00m desta aos fun dos, ou seja, a área de $300,00 \mathrm{~m} 2$, com os seguintes limites: ao norte com a Rua Pará, ao Sul com olote no 28, a lefte com o lote no 32; e a oeste com o lote no 30. PROPRIETARIA: PREFEITURA MUASICIPAL DE PLANALTINA - ESTA DO DE GOIÁS. RETISTRO ANTERIOR: transcricho no 303, feita às̆ fls. 085, do livro 3, de 28.11.1932, do Cartório do Reglftto de Imóveis de Planaltina, Estado de Goiás. DOU Fé. TAGUATINGA (DF), eX 6 de abrinde Iof4 vagner-

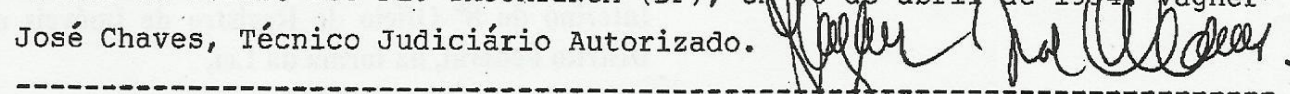

R.1.144835. ALVARA DE CONCESSAO № 025/93, datado de 13.12.93. TRANSMITEN TF: a proprietária acima. ADQUIRENTE: brpsileiro, técnico em eletrônica, مortador da casado com sob 0 reflime da comunhão parcial de bens, no dia 28.09.1988, residente e domicí lidda ta Quadra 02, Projeçã " $T$ ", Apt. 101, SRL, Planaltina - DF. PREÇO : Cr\$y $\$ 5.320,55$, pagos em 1\$.10.1985. DOU Fé. TAGUATINGA (DF), em 06 de

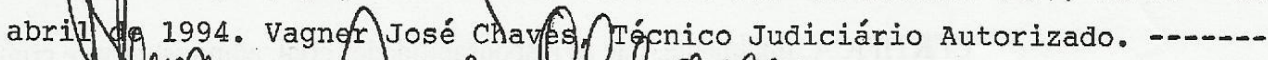

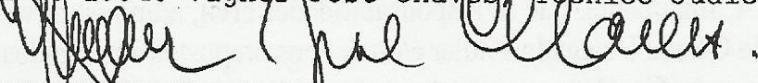

R.02.144835. - COMPRA E VENDA: escritura pública de 22.02.2001, lavrada às fls. 94-95, do Livro 235 , do $2^{\circ}$ oficio de Notas de Sobradinho, DF. TRANSMITENTE:

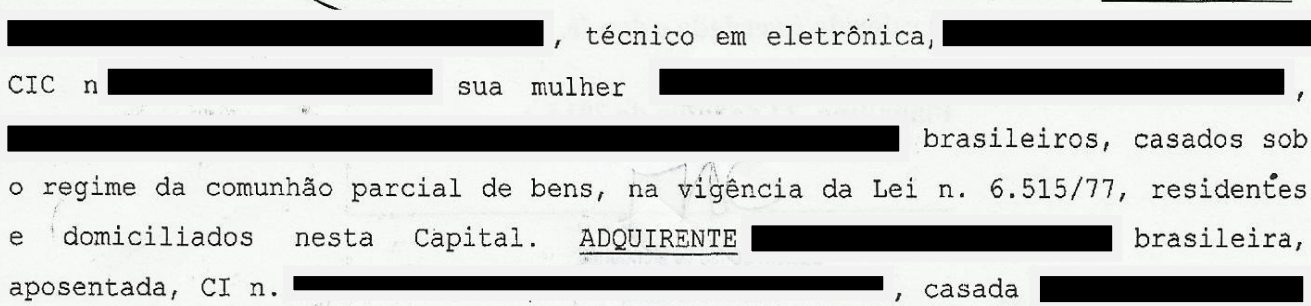

aposentada, CI n. casada

sob o regime da comunhão universal de bens, anterior à vigência da Lei n. 6.515/77, residente e domiciliada nesta Capital. PREÇO: R\$9.928,80. DOU FÉ. TAGUATINGA, DF, 28 de março de 2001.7 FRANCISCO JOSÉ DE ALENCAR ARARIPE, OFICIAL SUBSTITUTO Clluen

AV. $3 / 144835$

DATA:09 de julho de 2007.

BLOQUEIO

Conforme Decisã Interleeutória, datadła 28 de maro de 2007, acompanhada de cópia da sentença datada de 14 de maio de 2007. expedida pelo Juizo de Direito da tara de Registros Públicos do Distrito Federal, extraída dos autos do

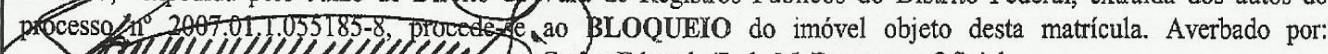

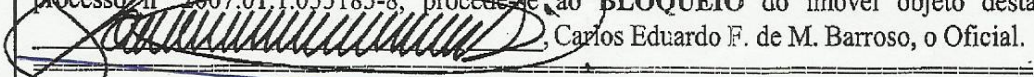




\title{
REPÚBLICA FEDERATIVA DO BRASIL

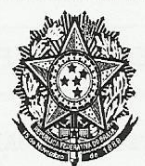 \\ $8^{\circ}$ OFÍCIO DE REGISTRO DE IMÓVEIS DO DISTRITO FEDERAL \\ Av. Independência, Plaza Shopping, Sala M-05, CEP 73.310-303 Planaltina - DF Fone/Fax (0xx61) 3389-2848
}

\section{CERTIDÃO DE ÔNUS}

\author{
Paulo Marcus Quintela de Almeida, Oficial \\ Interino do $8^{\circ}$ Ofício de Registro de Imóveis do \\ Distrito Federal, na forma da Lei,
}

CERTIFICA que, revendo os arquivos deste serviço registral, deles não consta, na matrícula n. ${ }^{\circ} 144299$ do $3^{\circ}$ Ofício de Registro de Imóveis do Distrito Federal, nenhum OUTRO ônus de qualquer natureza ou registro de citações de ações reais ou pessoais reipersecutórias relativas a ela, com exceção do BLOQUEIO mencionado na Av.2, não se podendo nela praticar qualquer ato, nem de averbação, nem de registro, ainda que de ordens judiciais de penhora, salvo com autorização da Vara de Registros Públicos do DF, conforme cópias extraídas por processo eletrônico na forma do art. $19, \S 1^{\circ}$, da Lei n ${ }^{\circ} 6.015 / 73 \mathrm{c} / \mathrm{c}$ art. 41 da Lei n ${ }^{\circ} 8.935 / 94$.

CERTIFICA, finalmente, que as responsabilidades civil, administrativa e criminal pelos atos praticados são do Oficial Delegado Titular e/ou de seus prepostos autorizados na data da prática de cada ato, sendo esta Certidão composta por 01 (UMA) follhas devidamente rubricadas.

O referido é verdade e dou fé.

Planaltina, 22 de julho de 2014.

Emol. R\$23,32

(1 fl.; 2 buscas; 0 fl. excedente)

Pedido: 143.394

Selo: TJDFT20140350059845DRGD

Para consultar o selo, acesse www.tjdft.jus.br 
CARTÓRIO DO $33^{\circ}$ OFICIO DO REGISTRO DE IMOUVEIS DO DISTRITO FEDERAL

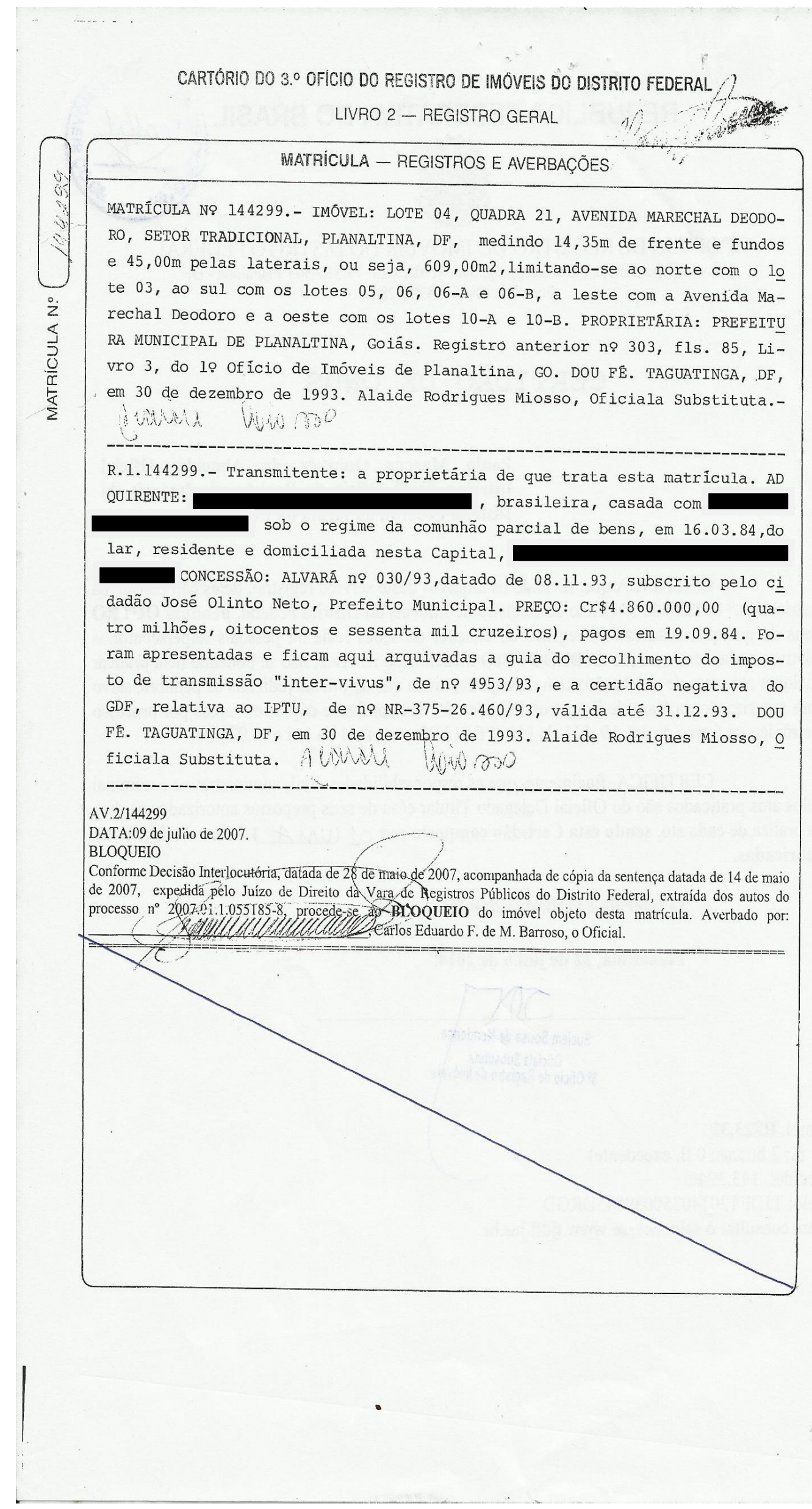




\section{REPÚBLICA FEDERATIVA DO BRASIL

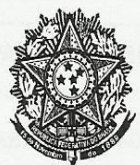 \\ $8^{\circ}$ OFÍCIO DE REGISTRO DE IMÓVEIS DO DISTRITO FEDERAL \\ Av. Independência, Plaza Shopping, Sala M-05, CEP 73.310-303 Planaltina - DF \\ Fone/Fax (0xx61) 3389-2848 \\ CERTIDÃO DE ÔNUS

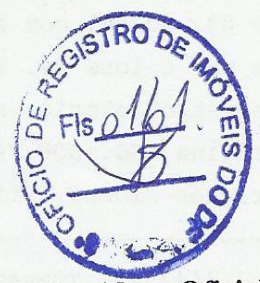 \\ Paulo Marcus Quintela de Almeida, Oficial Interino do $8^{\circ}$ Ofício de Registro de Imóveis do Distrito Federal, na forma da Lei,}

CERTIFICA que, revendo os arquivos deste serviço registral, deles não consta, na matrícula n. ${ }^{\circ} 144294$ do $3^{\circ}$ Ofício de Registro de Imóveis do Distrito Federal, nenhum OUTRO ônus de qualquer natureza ou registro de citações de ações reais ou pessoais reipersecutórias relativas a ela, com exceção do BLOQUEIO mencionado na Av.2, não se podendo nela praticar qualquer ato, nem de averbação, nem de registro, ainda que de ordens judiciais de penhora, salvo com autorização da Vara de Registros Públicos do DF, conforme cópias extraídas por processo eletrônico na forma do art. 19, $\S 1^{\circ}$, da Lei $n^{0} 6.015 / 73 \mathrm{c} / \mathrm{c}$ art. 41 da Lei $\mathrm{n}^{\circ}$ 8.935/94.

CERTIFICA, finalmente, que, de acordo com Mapa fornecido pela Administração Regional de Planaltina - DF, a Quadra 100 do Setor Tradicional não foi dividida em lotes. As matrículas acima mencionadas foram indevidamente abertas, sob as responsabilidades civil, administrativa e criminal do Oficial Delegado Titular e/ou de seus prepostos autorizados, para registros de alvarás de concessão fornecidos pela Prefeitura de Planaltina - GO, que não se revestem da forma de escritura pública (art. 108 do CC de 2009; art. 134, II, do CC de 1916) nem mencionam o cumprimento das exigências legais para alienação de bens públicos (art. 17 da Lei $\mathrm{n}^{0}$ 8.666/93 - avaliação prévia, autorização legislativa e licitação na modalidade concorrência). A questão deve ser solucionada perante os órgãos competentes do GDF e a Vara de Registros Públicos do DF nos autos 2007.01.1.055185-8.

CERTIFICA, finalmente, que as responsabilidades civil, administrativa e criminal pelos atos praticados são do Oficial Delegado Titular e/ou de seus prepostos autorizados na data da prática de cada ato, sendo esta Certidão composta por 01 (UMA) follhas devidamente rubricadas.

O referido é verdade e dou fé.

Planaltina, 24 de julho de 2014.

Emol. R\$23,32

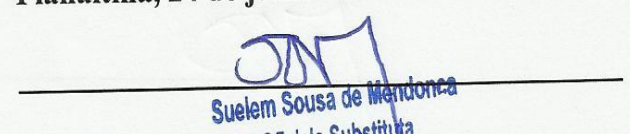

(1 fl.; 2 buscas; 0 fl. excedente)

$$
\text { Oficiala Substitute }
$$

Oficiala Substruta dimóvels

Pedido: 143.394

Selo: TJDFT20140350059834TGMY

Para consultar o selo, acesse www.tjdft.jus.br. 
CARTÓRIO DO $3 .^{\circ}$ OFICIO DO REGISTRO OE IMÓVEIS DO DISTRITO FEDERAL

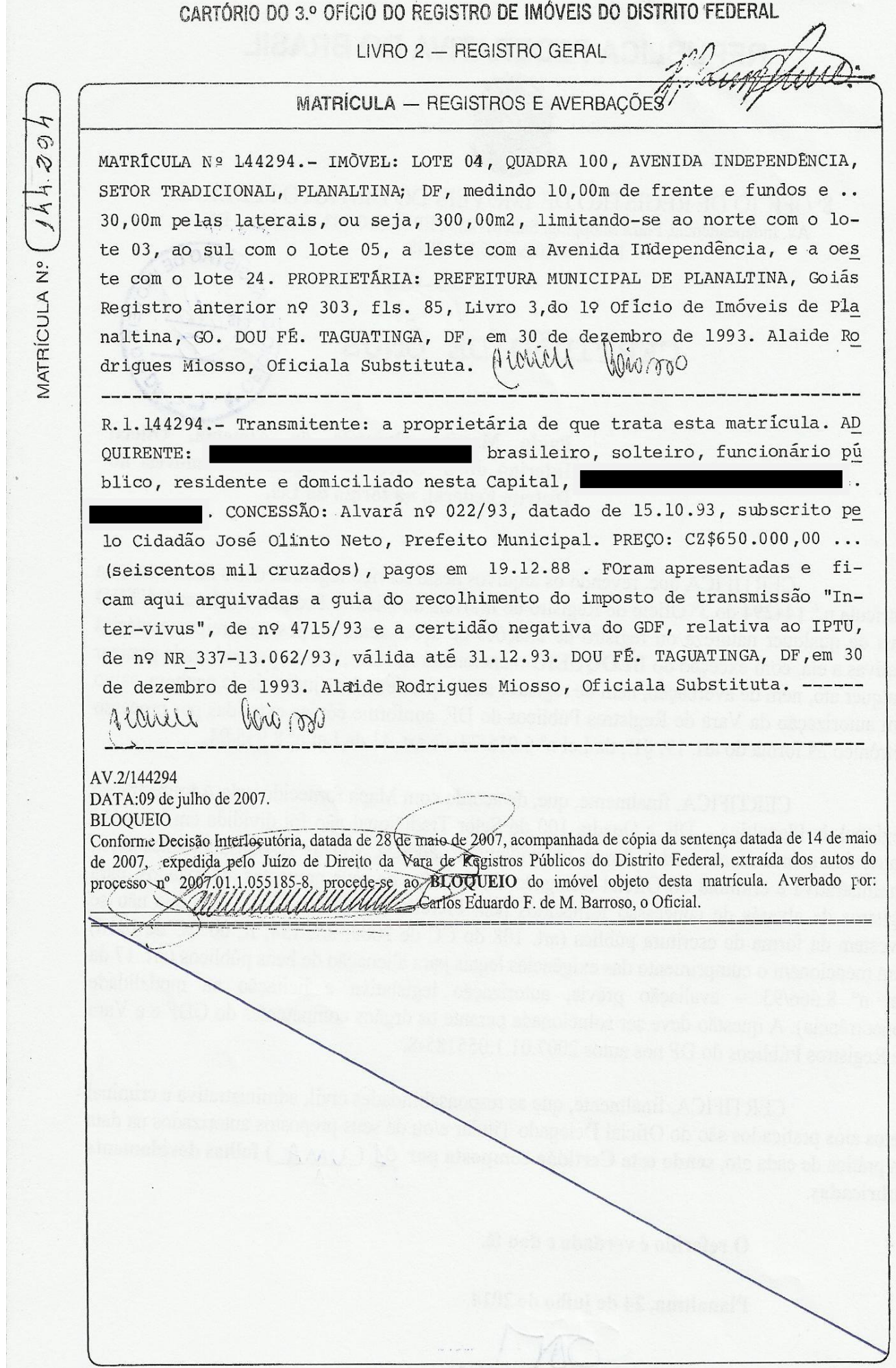




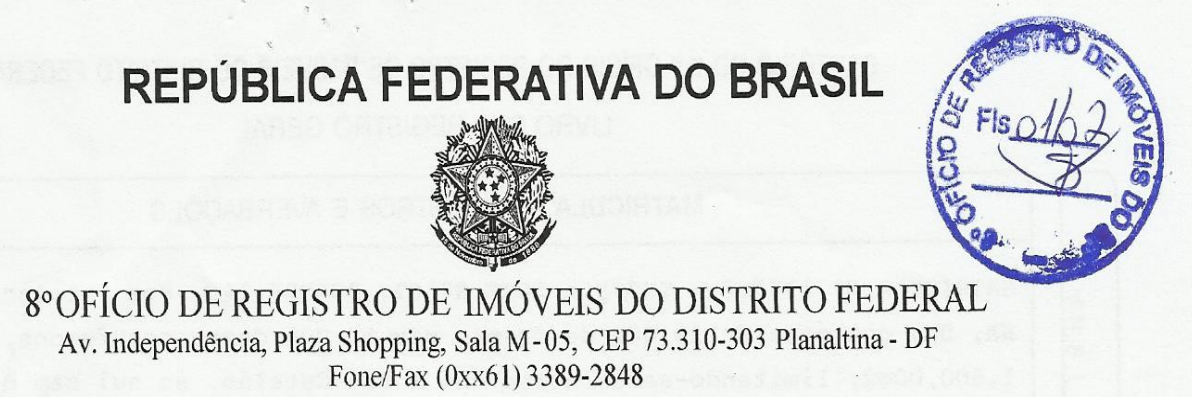

CERTIDÃO DE ÔNUS

Paulo Marcus Quintela de Almeida, Oficial Interino do $8^{\circ}$ Ofício de Registro de Imóveis do Distrito Federal, na forma da Lei,

CERTIFICA que, revendo os arquivos deste serviço registral, deles não consta, na matrícula n. ${ }^{\circ} \mathbf{1 3 3 7 6 0}$ do $3^{\circ}$ Ofício de Registro de Imóveis do Distrito Federal, nenhum OUTRO ônus de qualquer natureza ou registro de citações de ações reais ou pessoais reipersecutórias relativas a ela, com exceção do BLOQUEIO mencionados na Av.5, não se podendo nela praticar qualquer ato, nem de averbação, nem de registro, ainda que de ordens judiciais de penhora, salvo com autorização da Vara de Registros Públicos do DF, conforme cópias extraídas por processo eletrônico na forma do art. 19, §1 $1^{\circ}$, da Lei n ${ }^{\circ} 6.015 / 73 \mathrm{c} / \mathrm{c}$ art. 41 da Lei n ${ }^{\circ} 8.935 / 94$.

CERTIFICA, finalmente, que as responsabilidades civil, administrativa e criminal pelos atos praticados são do Oficial Delegado Titular e/ou de seus prepostos autorizados na data da prática de cada ato, sendo esta Certidão composta por $D 2(D / / A S)$ follhas devidamente rubricadas.

\section{O referido é verdade e dou fé.}

Planaltina, 22 de julho de 2014.

Emol. R\$24,81

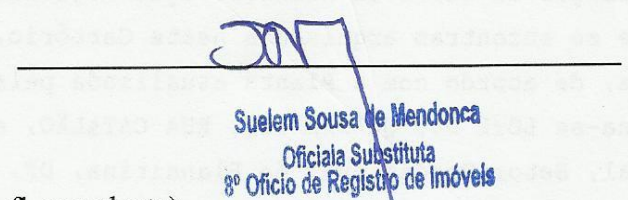

(1 fl.; 2 buscas; 1 fl. excedente)

Pedido: 143.394

Selo: TJDFT20140350059844DUHL

Para consultar o selo, acesse www.tjdft.jus.br. 
CARTÓRIO DO 3. OFICIO DO REGISTRO DE IMÓVEIS DO DISTRITO FEDERAL

LIVRO 2 - REGISTRO GERAL

MATRICULA - REGISTROS E AVERBAÇÕES

MATRfCULA № 133760.- IMÓVEL : LOTE № 01, QUADRA 115, Rua Catalão, PLANAL TI NA, DF, com área de $20,00 \mathrm{~m}$ de frente por $80,00 \mathrm{~m}$ desta aos fundos, of seja, 1.600,00m2, limitando-se ao norte com a Rua Catalão, ao sul com of chrrego' Atoleiro, ao leste com a Av. Independência e ao oeste com o loofe p2. PRoPRIETÁRIA: PREFEITURA MUNICIPAL DE PLANALTINA-GO. REGISTRO ANTERIOR/ transcrição no 303, às f1s. 85, do livro 3, do Cartório do Registro gle mêveis ' Planaltina-GO. DOU FÉ. TAGUATINGA, DF, 24 de abril de 1991.

Valmir Gonçalves da silva, Técnico Judiciário. o oficial, Aleurele 4010 sod R. R.1.1\$37\$0.- TRANSMITENTE: a proprietária. ADQUIRENTE: PLANALTINA IMOVVEIS ' LTDA, Con seđe em Formosa-GO, CGC/MF 02904142/0001-09. CONCESSÃO: Alvará no 210/\$0 expedido em 09.03.90 pelo prefeito municipal de Planaltina-GO, Oswal dp Ve. PleECO: Cr\$ 18.000,00. DOU FÉ. TAGUATINGA, DF, 24 de abril de 1991. Valmir Gonçalves da Silva, Técnico Judiciário. 0 oficial Alaver Goropo

R.2.133760.- TRANSMITENTE: a proprietária. ADQUIRENTE:

RA, brasifeirg, do comércio, casado com sob o re-

gime de copunpão de bens, antes daLei 6515/77, refidente e domiciliado nesta Capital. COMPRA E VENDA: escritura de $26\{1.990$ f1. 167, livro 020, do Cartório do 2. Ofício de Notas de Sobrajinh PR EÇO: Cr $\$ 800.000,00$. DOU FÉ. TAGUATINGA, DF, 24 de abril de 1991. Valmir Gonçalves da Silva, Técnico Judiciário. O oficiar. Alcuch lorios

Av.3.133760.- Conforme petição de 23.04.93, acompanhada da Certidão de Des membramento no 008/91, expedida em 11.10 .91 pela Divisão Regional de Licen ciamento e Fiscalização de obras da Administração Regional de Planaltina, DF, documentos que se encontram arquivados neste Cartório, o terreno objeto desta matrícula, de acordo com a Planta atualizada pela CODEPLAN-SICAD: 73.II.I.C, denomina-se LOTE 01, QUADRA 115, RUA CATALÃO, esquina com a Ave nida Independencial, setor Tradicional de Planaltina, DF, a qual foi desmembrada em 07 lotes, e mais uma áarea não edificante, conforme planta acompanhada de Memorial Descritivo, devidamente visados pelo CREA-DF e anotação de responsabilidade técnica em nome de Reginaldo pereira dos Santos, Crea-DF n\$ 908/TD, a saber: LOTE № 01, limitando-se ao norte com a Rua Ca talão, medindo 11,00 metros; ao sul, com parte do lote 01-B, medindo 11,00 metros; ao leste com o lote $01-\mathrm{A}$, medindo 22,00 metros e ao oeste, com par te do lote 01 , medindo 22,00 metros, perfazendo a área de $242,00 \mathrm{~m} 2$; LOTE no 01-A, limitando-se ao norte com a Rua Catalão, medindo 11,00 metros; ao sul com parte do lote $01-B$, medindo 11,00 metros; a leste com a Avenida In 


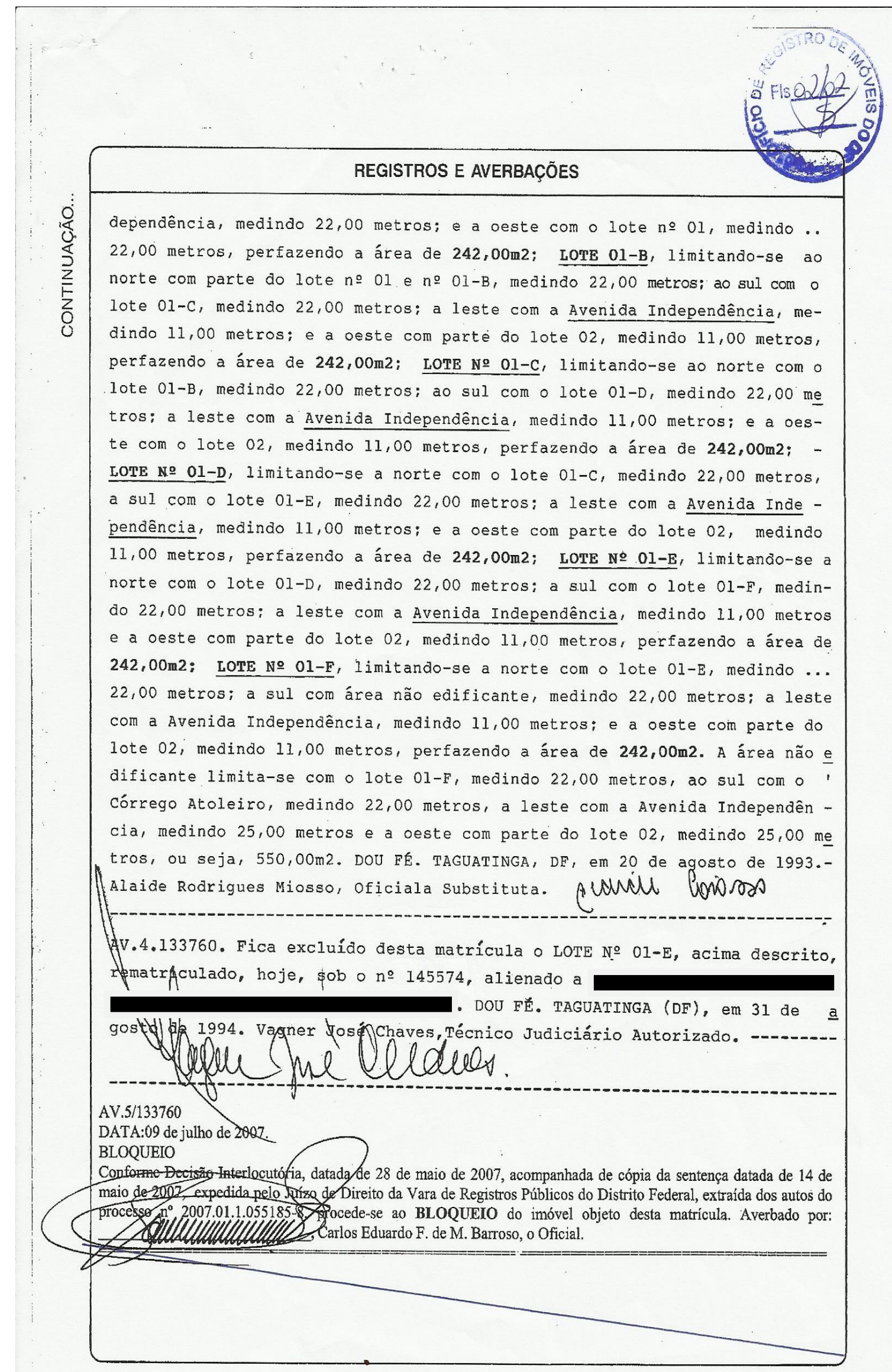


